OVNSTYPOLOGI OG OVNSKRONOLOGI

I DEN NORDISKE JERNVINNA 


\title{
OVNSTYPOLOGI OG OVNSKRONOLOGI I DEN NORDISKE JERNVINNA
}

\author{
Jernvinna i Oppland \\ Symposium på Kittilbu, 16.-18. juni 2009
}

Bernt Rundberget, Jan Henning Larsen

og Tom H. Borse Haraldsen (red.) 
(C) 2013 Portal forlag og

Kulturhistorisk museum, Fornminneseksjonen

ISBN: 978-82-92712-97-9

Grafisk design og omslag: Apostolos Spanos

Trykk: InPrint, Latvia

Font: Adobe Caslon Pro 11/13.3

Papir: MultiArt Silk $130 \mathrm{gr} / \mathrm{m}^{2}$

Forsidebilde: Jernvinne og landskap på Kittilbu. I forkant en kullgrop/fangstgrop fra middelalderen. Store slaggmengder er kastet ned terrassekanten mot Kittilbubekken. I bakkant ligger setergrenda på Kittilbu. Foto: J.H. Larsen, Kulturhistorisk museum.

Baksidebilde: Jernlupp utvunnet ved eksperimenter utført i regi av «Jernvinna i Oppland» på Kittilbu utmarksmuseum.

Foto: L. Grandin, GAL

\section{$\overbrace{\mathbf{Z}}^{\substack{\text { MIX } \\ \text { Paper from } \\ \text { responsible sources }}}$ \\ $\begin{array}{ll}\text { FSCC } & \text { responsible sources } \\ \text { muntsecosg } & \text { FSC }^{\circ} \text { C014521 }\end{array}$}

\section{Valdresmusea AS}

Alle henvendelser om denne boken kan rettes til:

Portal forlag AS

Gimlemoen 19

4630 Kristiansand

www.portalforlag.no

post@portalforlag.no

Kulturhistorisk museum

Fornminneseksjonen

Postboks 6762 St. Olavs plass

N-0130 Oslo

Norway

Tlf.: (+47) 22851900

Fax: (+47) 22851938

E-mail: postmottak@khm.uio.no

Det må ikke kopieres fra denne boken i strid med åndsverkloven eller fotografiloven eller i strid med avtaler inngått av KOPINOR, interesseorgan for rettighetshavere til åndsverk.

interesseorgan for rettighetshavere til andsverk. 


\section{FORORD}

Fra jernalderens begynnelse 500 f.Kr. og fram til våre dager har jernet vært det dominerende materialet innen produksjon av våpen og redskaper. Gjennom jernalderen og middelalderen ble det benyttet myr-, sjø- og bergmalm til å framstille jern i Norden. Den førindustrielle jernproduksjonen i Norden har gjennom jernvinna sysselsatt tusenvis av mennesker, særlig i utmarksområdene. Jernet har bidratt til ansamling av rikdom og utvikling av maktsentra i tillegg til at det har vært et vesentlig grunnlag for handel.

Symposiet «Ovnstypologi og kronologi i den nordiske jernvinna» ble arrangert som en del av prosjektet «Jernvinna i Oppland». Dette prosjektet er et samarbeid mellom Oppland fylkeskommune, den regionale kulturminnemyndigheten, Kulturhistorisk museum, Universitetet i Oslo og de opplandsbaserte museene Gudbrandsdalsmuseet, Mjøsmuseet, Randsfjordmuseene og Valdresmusea. Målet med «Jernvinna i Oppland» er å bidra til en lokal og regional kunnskapsbygging - det vil si gi nye data til bruk i forskning og forvaltning - og en bedre og mer rasjonell forvaltning av kulturarven. I tillegg er det et mål med prosjektet å framskaffe nyansert kunnskap som er egnet for verdiskaping i Oppland basert på opplevelser og aktiviteter knyttet til førindustriell jernframstilling. Det er også et mål med prosjektet å drive aktiv og levende formidling av denne kulturarven gjennom museene og dessuten bidra til at det utveksles kunnskap i nasjonal, nordisk og europeisk kontekst. Sekretariatet for prosjektet ligger under Oppland fylkeskommune.

Bakgrunnen for «Jernvinna i Oppland» er at Oppland fylke er et av de sentrale områdene for forhistorisk og tidlighistorisk jernframstilling i Norge og Norden. Det er bevart et betydelig antall synlige kulturminner og spor etter jernframstilling fra jernalderen og middelalderen i store deler av fylket. At det befinner seg så mange kulturminner i dette området, kommer blant annet av at det er så store utmarksområder her, hvor befolkningen har hatt rik tilgang til myrmalm og trevirke. Det er et tidsspenn på 2000 år mellom de eldste kjente jernframstillingsplassene i Snertingdal i århundrene f.Kr. og jernproduksjonen som er historisk dokumentert i Nord-Gudbrandsdalen og Valdres på 1800-tallet. Gjennom alle disse årene har produk- sjonsteknologien, samfunns- og eiendomsstrukturen, samferdselen og handelsveiene og dessuten styresettet endret seg, men tilvirking og bearbeiding av jern representerer like fullt en næring med kontinuitet.

Randsfjordmuseenes underavdeling Kittilbu Utmarksmuseum, som ligger i Gausdal kommune, er etablert i tilknytning til et av de sentrale områdene for forhistorisk og tidlighistorisk jernproduksjon i Norge. Det ble gjennomført omfattende arkeologiske utgravninger i området i perioden 1986-89. Bakgrunnen for utgravningene var vannkraftutbygging. De arkeologiske undersøkelsene ved Dokkfløy var banebrytende med hensyn til vår forståelse av omfang, teknologi og organisering knyttet til framstillingen av jern fra myrmalm i jernalder og middelalder, det vil si i perioden 500 f.Kr. til 1400 e.Kr. Senere har arkeologiske registreringer og undersøkelser i andre deler av fylket, som Snertingdal, Land, Toten, Tyinkrysset, Beitostølen og Gudbrandsdalen, bidratt til å øke vår forståelse av jernvinna i et nasjonalt og et regionalt perspektiv.

Oppland, med sine omfattende utmarksområder, er godt egnet for studier av jernvinna og andre utmarksnæringer fordi det her finnes store områder som er lite berørt av moderne, menneskelige inngrep og tiltak. Det giør at kulturminnene er bevart $i$ en god landskapskontekst samtidig som forskningen gis unike muligheter til å få fram en ny og bedre forståelse av menneskets økologiske og økonomiske tilpasning og dets bruk av ressurser $\mathrm{i}$ både et kort og et langt tidsperspektiv.

I løpet av middelalderen innføres masovnteknologien, og på 1400- og 1500-tallet blir jernet i Oppland i hovedsak produsert ved jernverkene. Ved overgangen til jernverkstida og masovnsteknologien forsvinner grunnlaget for de teknologiske løsningene som jernvinna er basert på. Selv om det fremdeles i avgrensete områder blir framstilt jern fra myrmalm som en tilleggsnæring til jordbruket, blir den tradisjonelle jernvinna utkonkurrert av masovnsteknologien. Masovnsteknologien ved jernframstilling kom først i bruk i Lunner kommune, ved Grua, Hadelands jernverk, som trolig omfattet flere mindre produksjonssteder, og senere ved Hakadals verk og Lesja verk, hvor det ble 
etablert jernverk på 1500- og 1600-tallet. Selv om jernverkstida markerer slutten på den århundrelange jernframstillingstradisjonen i utmarka, bidrar samtidig Hadelands bergverk og Lesja verk til å komplettere og understreke jernets betydning i utviklingen av opplandssamfunnet.

Symposiet har mottatt økonomisk støtte fra Nordisk kulturfond, Letterstedtska föreningen og Oppland fylkeskommune.
«Jernvinna i Oppland» opphørte som prosjekt 30. juni 2013 med et symposium på Kittilbu. Det er samtidig hyggelig å kjenne til at seminaret i 2009 er klargjort for trykking og vil foreligge høsten 2013.

Lillehammer, juni 2013

Ragnar Bjørnstad Prosjektleder 


\section{INNHOLD}

Forord

Innhold

Innledning

Kittilbu, Dokkfløy og norsk jernvinneforskning

Jan Henning Larsen

Blästbruk - finns det en systematik mellan tid, rum och typ?

Eva Hjärthner-Holdar, Lena Grandin och Svante Forenius

«Skovmark ovnen» fra Espevej og fra Sønder Holsted - Den tidligste jernudvinding i Danmark

Arne Jouttijärvi og Olfert Voss

Trøndelagsovnen - En studie basert på materielle levninger etter jernframstilling i Midt-Norge Lars F. Stenvik

Tidiga spår av järnhantering i norra Finland Hannu Kotivuori

Ovner med slaggrop i Sydøst-Norge - 400 BC-AD 800 - likheter og forskjeller Jan Henning Larsen

Forhistorisk jernproduksjon i Nord-Norge - få, enkeltstående eksperimenter eller toppen av et isfjell?

Roger Jørgensen

Drengsted/Scharmbeck slaggegrube ovnen i Danmark og i Skandinavien

Arne Jouttijärvi og Olfert Voss
9
Tidig järnproduktion i södra och västra Finland - några aspekter på järnframställning och ärnets funktion i samhället

Mika Lavento

Jernvinna i Gråfjell

- en metode i grenseland

Bernt Rundberget

Slaggeaftapningsovne i Danmark, udgravninger og forsøg

Henriette Lyngstrøm

Ovnene i Breiveskaret - trekk ved jernproduksjonen i vikingtiden og middelalderen i et skar ved Hovden i Setesdalen

Axel Mjærum

En brytningstid för järnhanteringen

- Kring teknik och social organisation i det medeltida samhället

Gert Magnusson

Evenstad-prosessen i tid og rom med en metallurgisk analyse

Arne Espelund

Oppsummering og veien videre Tom H. Borse Haraldsen

Program og deltakerliste

Artikkelforfattere 


\section{INNLEDNING}

Norden må på mange måter betraktes som et enhetlig område. Innenfor den arkeologiske forskningen finnes det klare paralleller i utviklingen i de nordiske landene, selv om det også eksisterer en rekke forskjeller. I studier av forhistorisk tid og middelalder opereres det med nordisk arkeologi som et eget felt sett i sammenheng med europeisk og klassisk arkeologi.

Jernvinneforskningen er ikke noe unntak i så måte. Jernvinneforskningen har i en årrekke hatt et internasjonalt tilsnitt, og det er interessant å se at de nordiske landene ofte deltar på konferanser ut fra egne premisser, som skiller seg ut fra det øvrige Europa. Denne fragmenteringen kan skyldes flere ulike faktorer. Svært sentralt her er de klimatiske, topografiske og geologiske betingelsene vi finner i Norden. Og den kanskje viktigste faktoren er at de nordiske landene, sammen med det nordlige Øst-Europa, er omtrent enerådende når det gjelder bruk av myrmalm i jernblestringen. For øvrig er det i hovedsak bergmalm som ble brukt i den tidlige jernproduksjonen.

Til tross for de store likhetene som finnes i den nordiske jernvinnehistorien, har faget etter hvert blitt fragmentert også her. Tidligere var det svenske Jernkontorets høstmøter en felles arena for nordisk kontakt, men manglende aktivitet, fravær av ildsjeler og den omfattende svenske tilnærmingen til masovnproduksjonen $\mathrm{i}$ de senere år har ført til at forumet delvis har falt bort. Jernvinneforskningen har derfor beklageligvis utviklet seg med vekt på nasjonale funn uten at noen har klart å sette disse inn i en bred nordisk kontekst. Etter vår mening er den nordiske konteksten helt sentral for å kunne forstå kontaktveier og innovasjonsprosesser. Den rent faglige bakgrunnen for symposiet på Kittilbu og den påfølgende publikasjonen er et direkte resultat av et ønske fra norsk side om å reetablere, kartlegge, sette sammen og systematisere den nordiske jernvinneforskningen til en naturlig felles enhet.

I Norge har det de siste årene vært en renessanse når det gjelder forskningen, gjennom både store forvaltningsprosjekter og grunnforskning, noe som har resultert $i$ en omfattende satsing på jernvinna. Det kommer blant annet til uttrykk ved at Kulturhistorisk museum i Oslo har utarbeidet et faglig program for jernvinneutgravninger, at jern- vinna er lagt inn som et eget forskningsprogram i det nasjonale nettverket «Forskning i Fellesskap» og at det både i Bergen og i Oslo har blitt tildelt stipendiatstillinger som har resultert i store avhandlinger basert på nyere materiale.

Også i Danmark har jernvinneforskningen fått en ny vår, gjennom nettverket «Smedens rum». I dette nettverket møtes i hovedsak danske forskere for å utveksle erfaringer og bygge kunnskap museene imellom. Tidligere har jernvinneforskningen i Danmark vært preget av noen få, men svært dyktige forskere. Gjennom nettverket har en rekke nye personer begynt å forske på den danske forhistoriske jernproduksjonen.

I Sverige er det særlig den tidlige hyttedriften i Bergslagen som har vært tema de siste årene, men også førindustriell jernutvinning har fått plass i flere prosjekter, noe som kommer til syne med prosjektene «Järnet och Riksbildningen» og «Järn i Småland», samt gjennom veiarbeider som i Halland og Skåne. Også her er det stadig flere forskere som bidrar til kunnskapsøkningen. Sentralt i Sverige står dessuten Geoarkeologiskt Laboratorium i Uppsala, som siden starten av 2000-tallet har gjort arkeometallurgiske analyser på både det svenske og det norske materialet - og i det siste også på dansk materiale.

Med bakgrunn i disse prosjektene og arbeidene har det blitt opprettet kontakt mellom forskningsinstitusjoner i Norge, Danmark og Sverige. Og det har vært bred enighet om at det er på høy tid å få i gang et vedvarende samarbeid.

Ut fra status med hensyn til kunnskap var det naturlig å ta utgangspunkt i og vektlegge ovner og ovnsutvikling for å etablere en nordisk terminologi. Det er vesentlig for de nordiske landene å utvikle en felles plattform i det internasjonale arbeidet. Flere samtaler under konferansen «Early Iron in Europe» i Østerrike høsten 2008 klargjorde hvor viktig det var med et nordisk symposium hvor temaet ovnstypologi og ovnskronolgi kunne tas opp til diskusjon. Videre så vi det som naturlig å kontakte fagpersoner i Finland og på Island for å initiere til et bredere samarbeid i den nordiske regionen. Alle disse fem landene var representert på symposiet, men det har av forskjellige årsaker beklageligvis ikke kommet med bidrag fra Island i denne boken. 
Sett i et vidt perspektiv står jern som råstoff sentralt i utviklingen av bosetning og erverv de siste 2500 årene. Produksjonen av jern henger tett sammen med konjunkturutviklingen i samfunnet, og jernet har vært en viktig endringsfaktor flere ganger i historien: Overgangen fra bronse til jern omkring år 500 f.Kr. medførte at folk ikke lenger var avhengig av leveranser av viktige råstoffer fra utlandet. Jernet ble produsert til lokale formål, og nytten av et hardt og formbart materiale var revolusjonerende $\mathrm{i}$ alle samfunnslag. Folk så også tidlig potensialet for storproduksjon, og allerede før Kristi fødsel var det etablert industriliknende foretak. Jernet ser dessuten ut til å ha vært en sentral faktor under utviklingen av de nordiske landene i middelalderen.

Det vi har vært inne på foran, viser at studien av jernvinna er et svært omfattende felt hvor det er mulig å ta utgangspunkt i en rekke forskjellige temaer. Utgangspunktet for den arkeologiske forskningen er ønsket om å nærme seg de menneskene som levde og virket i de perioder som studeres. For å få til det er det nødvendig både med empirisk grunnlagsdata som er ervervet gjennom arkeologiske undersøkelser og materialstudier, og med teoretiske refleksjoner som belyser hvordan dynamikker i for eksempel overordnede systemer, teknologisk utvikling, regionale variasjoner, organisering og styresett skal forstås. For å komme til bunns i slike problemstillinger er det nødvendig å ha en felles plattform, og det er derfor vi har valgt å ta utgangspunkt i ovner og deres typologi og kronologi. Ved først å kartlegge hva som finnes, og hvilke variasjoner som eksisterer i den nordiske regionen, og deretter å systematisere materialet, er det mulig å reflektere over og lage hypoteser for hvorfor utviklingen og variasjonen er slik som den fremstår i det arkeologiske materialet. Målsettingen med denne artikkelsamlingen er derfor nettopp å danne et grunnlag for et videre nordisk samarbeid og videre forskning, og å legge grunnlaget for å utvikle en rekke problemstillinger på bakgrunn av foredragene og, senere, de bearbeidede artiklene som finnes i denne boken.

Publikajonen er finansiert av Oppland fylkeskommune, Valdresmusea, Randsfjordmuseene, Gudbrandsdalsmusea, Mjøsmuseet, Letterstedska föreningen og Kulturhistorisk museum.

\author{
Bernt Rundberget \\ Jan Henning Larsen \\ Tom H. Borse Haraldsen
}




\title{
KITTILBU, DOKKFLOY OG NORSK JERNVINNEFORSKNING
}

\author{
Jan Henning Larsen
}

\section{INNLEDNING}

Seminaret om ovnskronologi og ovnstypologi ble lagt til Kittilbu Utmarksmuseum i Gausdal Vestfjell. Valget av sted var begrunnet med de store utgravningene ved Dokkfløy i perioden 1986-1989. Utgravningene førte til etableringen av Kittilbu Utmarksmuseum med tilhørende kultursti og rekonstruert jernvinneanlegg av middelaldertype der det gjennomføres årvisse blestringer. I denne redegjørelsen om Dokkaprosjektet vil det bli lagt særlig vekt på slaggavtappingsovner fra yngre jernalder og middelalderen.

Satsingen på og samarbeidet om prosjektet Jernvinna i Oppland (se Bjørnstad i dette bindet) var på mange måter selvsagt. Fylket har mange og godt bevarte anlegg, og tidsdybden er stor. Det er gjort flere registreringer nede i dalene, men de fleste registreringene er gjort i seterområdene. Mest kjent er Valdres for sine tallrike anlegg, og denne regionen er best utforsket på grunn av de mange utgravningene knyttet til samfunnsutbyggingen på 2000-tallet, særlig på Beitostølen og Fillefjell (Larsen 2009; Tveiten 2012). Det er ingen grunn til å tro at Gudbrandsdalen har færre anlegg, men her er det gjort få utgravninger i de senere år. Jernvinna finnes over store deler av fylket - det er bare i de sentrale jordbruksområdene at utbredelsen er usikker. Jordbruksarealene i Oppland utgjør mindre enn 3 prosent av fylkets totale areal, resten består av vann og utmark, og da særlig fjellområder.

Utbyggingen av Dokkavassdraget til kraftformål - i kommunene Nordre Land og Gausdal - utløste de inntil da største arkeologiske utgravningene på Østlandet. Utgravningene kastet nytt lys ikke bare over jernvinna i det indre østlandsområdet, men også over bruken av skogs- og lavfjellsområdene i steinalderen, særlig i senmesolittisk tid, og elgfangsten i jernalderen og middelalderen (Jacobsen og Larsen 1992). Målet her er å drøfte utgravningen og resultatene av jernvinnestudiene: Hvilke kronologiske faser ble påvist, hvordan var intensiteten i bruken av området, hvilken betydning hadde jernproduksjonen, og hvordan var virksomheten organisert? Særlig vil det bli lagt vekt på anleggene fra yngre jernalder og middelalderen.

Det er utarbeidet en omfattende presentasjon av utgravningene (Larsen 1991), og det foreligger en solid bearbeidelse av enkelte av anleggene fra middelalderen (Narmo 1996). En redegjørelse for resultatene fra alle delene av prosjektet finnes i eget bind i bygdeboken for Gausdal (Jacobsen og Larsen 1992). Her er også resultatene av undersøkelsene av kulturminner fra jernalderen og middelalderen diskutert i sammenheng. Dokkfløy-undersøkelsene har

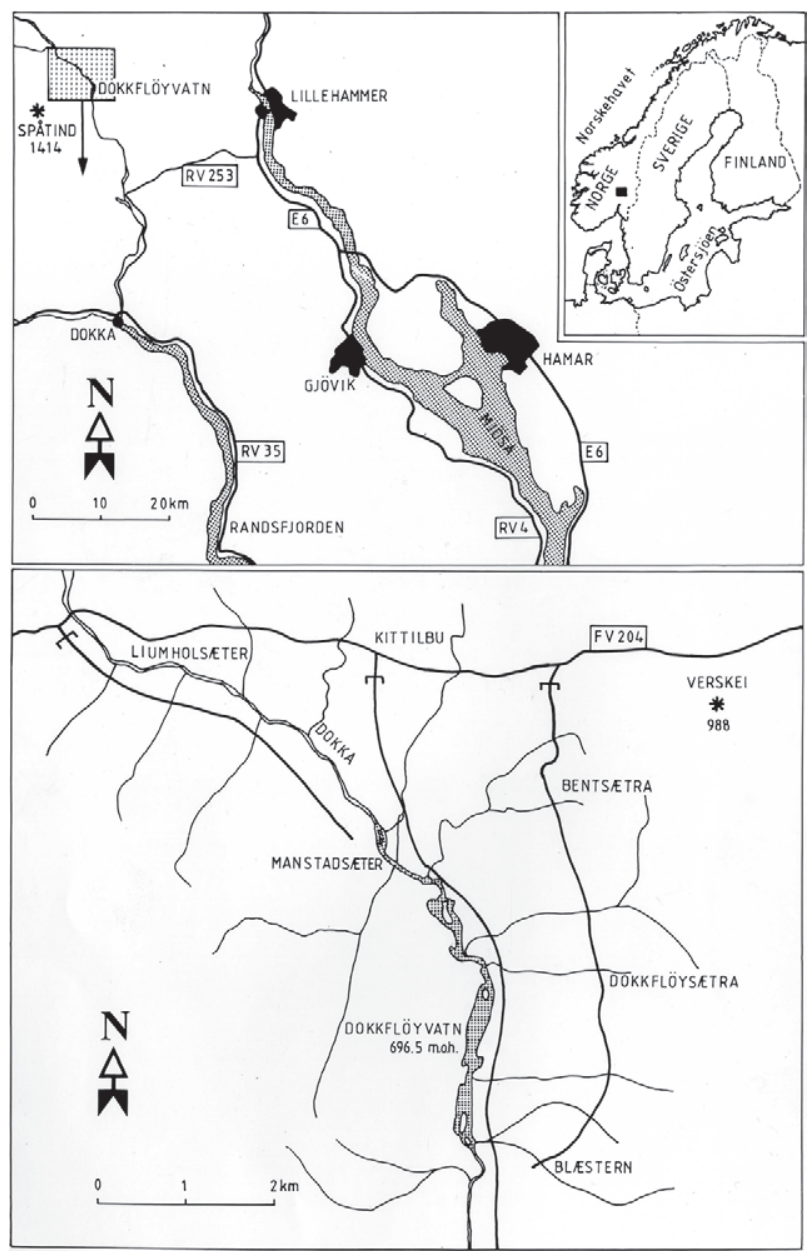

Figur 1: Dokkfloy ligger i Gausdal Vestfell cirka $35 \mathrm{~km}$ vest for Lillehammer. De fleste setrene ligger på østsiden av dalen. Vollene til setergrenda Blastern strekker seg ned mot Dokkfloy, og her lå det mange fortidsminner fra perioden AD 100-1400. Etter Larsen 1991 figur 5.

Figure 1: Dokkfloy is located in Gausdal Vestfjell, $35 \mathrm{~km}$ west of Lillehammer. Most outfield farms are located on the east slope of the valley. Between Blastern and Dokkfloy there were a lot of ancient remains of iron extraction from AD100-1400. After Larsen 1991 Figure 5. 


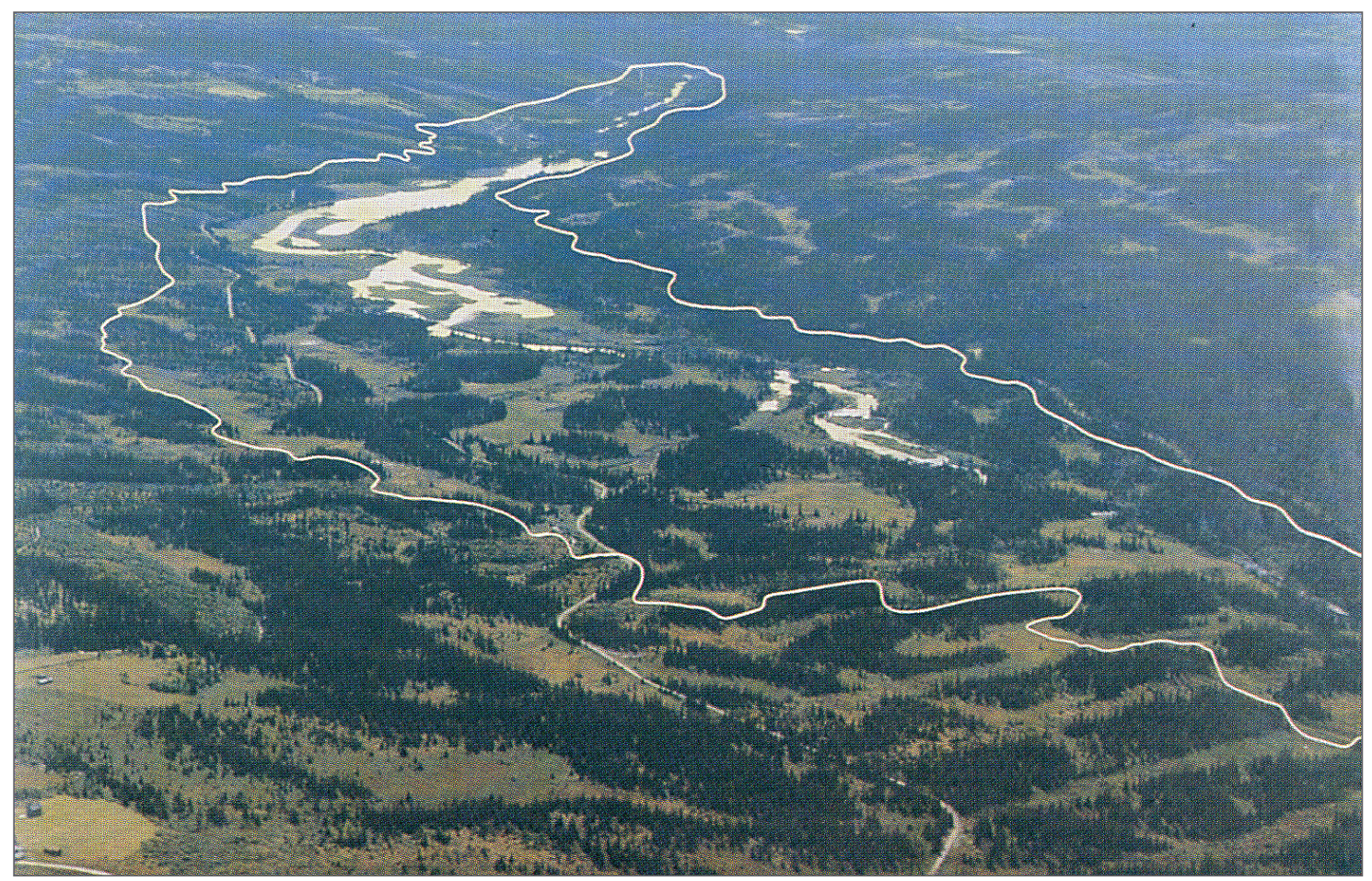

Figur 2: For utbyggingen til vannkraftmagasin bestod det nå neddemte området av myrer og partier med skog. I vår tid dominerer gran, men for jernutvinnerne $i$ middelalderen var det bjerk som var viktigst, og i jernalderen var det furu som var viktigst. I venstre billedkant ser vi Kittilbu. Foto: Fjellanger-Widerøe AS.

Figure 2: Before the hydropower development the excavation area consisted of forest and bogs. In our time spruce has become dominant. Birch was the most important for iron extraction in the Middle Ages and pine in the Iron Age. Kittilbu is at the left border of the picture. Photo: Fjellanger Widerøe AS.

en sentral plass i Kulturhistorisk museums faglige program for jernvinneundersøkelser (Larsen 2009: 125-128 et al.). I Dokkfløy startet også det eksperimentelle arbeidet med å rekonstruere ovner ut fra arkeologiske data (Jakobsen, Larsen og Narmo 1988). Arbeidet med å formidle et arkeologisk prosjekt gjennom blant annet omvisninger, kultursti, brosjyrer, publikasjoner og TV-programmer var også banebrytende.

\section{OMRÅDET OG UTBYGGINGEN}

Dokkfløy ligger i Gausdal Vestfjell på grensen mellom kommunene Nordre Land og Gausdal, 35 kilometer vest for Lillehammer (se figur 1), og her ligger også Dokkfløyvatn. Dalbunnen er demmet ned som hovedmagasin ved Dokka-utbyggingen. Før reguleringen ble iverksatt, lå vannspeilet 696 meter over havet. Bygging av en 85 meter høy dam 4 kilometer syd for vannet hevet vannspeilet med inntil 39 meter. Størrelsen på vannet økte da fra 0,5 kvadratkilometer til 9,5 kvadratkilometer.

Området er en lavereliggende fjelldal. Østsiden er slak med store myrpartier opp mot setergrender som ligger 100-150 meter høyere enn vannet (figur 2). En av disse grendene er Kittilbu, som har vid utsikt mot Dokkfløy. Analyser viser at myrene er rike på god malm. Vestsiden er brattere og mer berglendt. Setergrendene er hovedsakelig knyttet til østsiden, og det er her de fleste fornminnene finnes. Før utbyggingen var området lite berørt, og fornminnene var godt bevart (se Jacobsen og Larsen 1992; Larsen 1991).

Skogen er nå dominert av gran med noe innslag av bjerk, og det finnes også noen spredte furuer der. Pollenanalytiske undersøkelser viser at granen kom rundt Kristi fødsel, men at den er blitt dominerende først i etterreformatorisk tid (Høeg 1990). Vedartsanalyser tyder på at menneskene i jernalderen og middelalderen bare unntaksvis brukte gran. En elgstamme trekker gjennom området om våren og høsten, og elgfangsten har vært et bærende element i ressursutnyttelsen siden steinalderen.

I det neddemte området ble det kartlagt nærmere åtti steinalderlokaliteter, ett bergkrystallbrudd, én helleristning med elgfigurer, flere fangstsystemer med sperregjerder, bogesteller og groper for fangst av elg, flere hustufter fra jernalderen og middelalderen, trettitre jernvinneanlegg og trettini enkelt- 
liggende groper for fremstilling av trekull. Arbeidet med utgravningen av fornminnene ble organisert som et prosjekt, Dokkaprosjektet, og det ble engasjert tre arkeologer på heltid som i fire år, fra 1986 til 1989, hadde ansvar for henholdsvis steinbrukende tid, jernutvinning og bosetning og fangst $i$ jernalderen og middelalderen. Det ble utført pollenanalyser blant annet for å studere bosetning og vegetasjonsutvikling. I seterområdene, som ved Kittilbu, ble det påvist jordbruk tilbake til romertiden, men både husdyrhold og korndyrking går lengre tilbake i tid i Dokkfløy (Høeg 1989: 101).

\section{FORFORSTÅELSEN AV JERNVINNA I DOKKFLOY}

Den egentlige jernvinneforskningen i Norge startet med lokalhistorisk forskning i Oppland, blant annet i Lillehammer-distriktet rundt første verdenskrig (Larsen 2009: 36-37), etter at antikvarer og topografer i lang tid hadde interessert seg for både eldre og samtidig jernfremstilling. Etter en periode dabbet denne interessen av, og det ble naturvitere som kom til å føre arven videre, slik som i Danmark og Sverige (Stenvik 2003).

I Oppland var det leder av konserveringslaboratoriet ved Universitetets Oldsaksamling (nå Kulturhistorisk museum) T. Dannevig Hauge som kom til å ta fatt på det vitenskapelige arbeidet. Han deltok for første gang i utgravninger i 1936 og 1937. Senere gjennomførte han sine egne undersøkelser i Saksumdalen og nedre del av Gudbrandsdalen før han fortsatte til øvre del av Gudbrandsdalen (Ottadalen), Vågå og Vågåmo og til slutt andre fylker (Sjøvold 1991).

Hauge la først frem sine resultater fra Gudbrandsdalen med forslag til slaggtypologi (Hauge 1940: 57-58), deretter fulgte hans studie av jernvinna i Valdres (1944). Doktoravhandlingen Blesterbruk og myrjern forelå i 1946 (Hauge 1946). Senere studerte han anlegg i Nordre og Søndre Land (1952), blant annet i områder elven Dokka renner gjennom på vei til Randsfjorden.

T. Dannevig Hauge gjennomførte altså ingen undersøkelser i prosjektområdet, men i områder omkring Dokkfløy. Problemet med utgravningene hans er at dokumentasjonsmaterialet er svakt, noe som også gjelder stedfestingen, slik at det er mange av hans anlegg som ikke er blitt gjenfunnet. I tillegg oppfattet Hauge ovnene som «gryter og groper», og han mente at alle ovnene var gropovner. Senere forskning har vist at mange av de ovnene han fant, har vært andre typer ovner og til dels andre typer strukturer (Martens 1988: 74). Hauges utgravninger gav derfor ikke noe holdbart utgangspunkt for senere tiders tolkning.

Registreringene av Dokkfløy startet i 1978 og pågikk i fem sesonger, mens utgravningene ble utført i årene 1986-1989. Bearbeidelsen av kullgropene på Hovden i Aust-Agder, som riktignok bygget på Tom Bloch-Nakkeruds magistergradsavhandling, forelå trykket i 1987 (Bloch-Nakkerud 1987). Den store avhandlingen til Irmelin Martens om jernvinna på Møsstrond forelå i 1988 (Martens 1988), men hun hadde allerede omtolket «leirgryta» til sjaktovn $\mathrm{i}$ et tidligere arbeid (1972). For det indre østlandsområdet forelå det ikke nyere vurderinger enn Hauges arbeider.

\section{UNDERSØKELSESPROGRAM}

Et overgripende problemfelt for alle undersøkelsene var ressursutnyttelse $i$ en lavereliggende norsk fjelldal. De grunnleggende problemstillingene ved studiet av jernvinna var først og fremst knyttet til kronologien og organiseringen av virksomheten. Tidfesting har ikke vært mulig uten moderne naturvitenskapelige dateringer som ${ }^{14} \mathrm{C}$-metoden (selv om Hauges slutninger basert på blant annet typologi fortjener respekt). Slike dateringer var ikke vanlige innen norsk arkeologi før på slutten av 1960-tallet. Først i løpet av 1980-årene ble det publisert større serier som gjelder kullfremstilling og jernutvinning.

Registreringene viste at jernvinneanlegg med lave slagghauger knyttet til store, bolleformete kullgroper var vanlige, men at det også var enkelte anlegg der store slaggblokker med mål inntil én

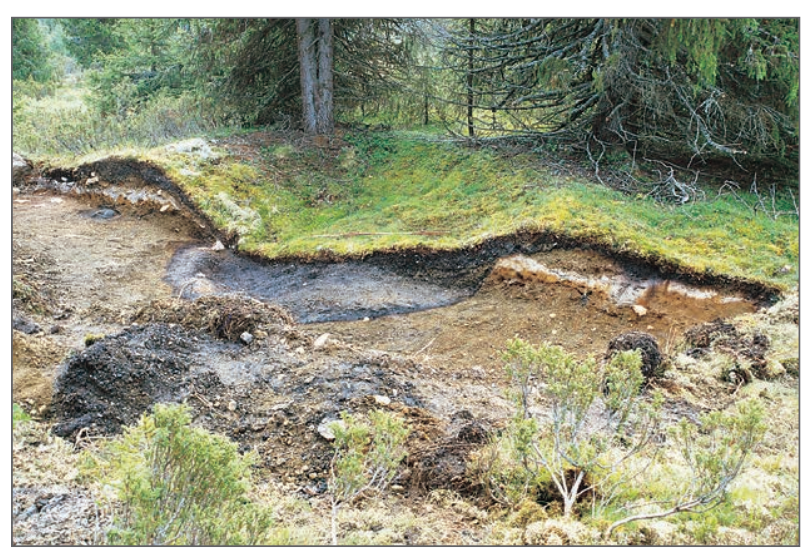

Figur 3: Kullgropene er tallrike ved Dokkfloy i middelalderen. DR 57 er delvis utgravd. Trekull av bjerk fra gropen er datert til AD 1250-1290. Foto: M. Thorleifsen, Kulturbistorisk museum.

Figure 3: Charcoal pits were common at Dokkfloy in the Middle Ages. DR 57 partially excavated. Charcoal of birch from the pit was dated to AD1250-1290.

Photo: M. Thorleifsen, Museum of Cultural History. 
meter lå i dagen. I tillegg var det en rekke kullgroper spredt rundt i terrenget. Noen få dateringer ble gjort fra kullgroper på jernvinneanlegg, og disse gav resultat høymiddelalder.

Det var uklart hvilke groper som var kullgroper, og hvilke som var fangstgroper, og Dokkaprosjektet bidrog i sterk grad til å fă frem klarer kriterier for skillet (se Narmo 1996: 24; Larsen 2009: 57-58). De fleste gropene i det indre Østland var frem til da registrert som fangstgroper. Kunnskapen om gropene var så liten at da det ved registreringene ble funnet slagg i tilknytning til enkelte av dem, ble det konkludert med at gropene var blestergroper, og at selve jernfremstillingen hadde foregått $i$ disse.

Siden det var desidert flest kullgroper, ble først enkeltliggende kullgroper undersøkt for å oppnå erfaring med denne kulturminnetypen. Deretter stod jernvinneanlegg med kullgroper for tur - svært ofte var det én til fire kullgroper, én til to slagghauger med renneslagg og én til fire ovner på hvert anlegg. Endelig, etter å ha bygget opp kompetanse, ble det tatt fatt på de fire lokalitetene som ikke hadde kullgroper integrert i anleggsstrukturen, og som hadde store slaggblokker. Anleggene lå innenfor et område på 5 kvadratkilometer der det var rikelig med myrmalm.

Undersøkelsene til Martens viste at det på Møsstrond var ulike typer anlegg. Målsetningen for utgravningene ble derfor å få grunnlag for klassifisering og å utarbeide både relativ og absolutt kronologi ved hjelp av $63{ }^{14} \mathrm{C}$-dateringer. På den tiden var dette ansett som et veldig stort antall, mens det i dagens utmarksarkeologi er å betrakte som helt utilstrekkelig. Typologi ble derfor sentralt $i$ arbeidet med kronologien.

Utgravningene på Møsstrond var gjort med håndkraft, og det var derfor bare mulig å undersøke små arealer. Ved Dokkfløy kom gravemaskinen for fullt inn i norsk utmarksarkeologi ved gravning av kullgroper og fangstanlegg, avtorving av store flater på jernvinneanleggene og avdekking av store sperregjerder til fangstanlegg i myrer. På denne tiden var gravemaskinen bare i begrenset utstrekning tatt i bruk i forbindelse med avdekking i dyrket mark. Senere har gravemaskinen vært et uunnværlig hjelpemiddel ved utgravning av fangstanlegg, kullgroper og jernvinneanlegg.

Metallurgiske undersøkelser ble fulgt opp av Sigmund Jakobsen, blant annet i samarbeid med Inga Serning og Arkeometallurgiska Institutet i Hocksberg. Men denne delen av arbeidet er ikke publisert, da forskerne falt fra - først Serning og senere Jakobsen.

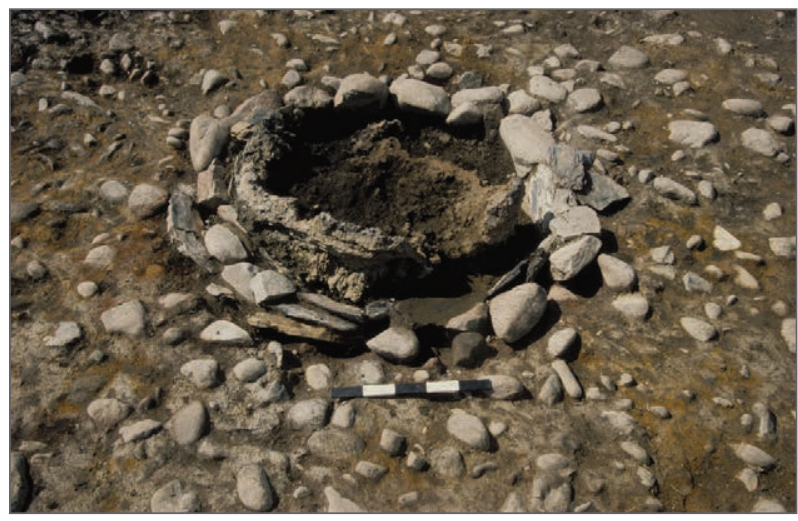

Figur 4: Jernvinneanlegg DR 307, ovn B. Den ytre diameteren er 1,6 $\mathrm{m}$. Slagget i gropen veide $365 \mathrm{~kg}$. Trekull er datert til AD 250-370. Foto: J. H. Larsen, Kulturbistorisk museum. Figure 4: Iron extraction site DR 307, furnace B. Outer diameter $1.6 \mathrm{~m}$. The slag in the pit weighed $365 \mathrm{~kg}$. Charcoal was dated to AD250-370. Photo: J. H. Larsen, Museum of Cultural History.

\section{ANLEGGENE MED STORE SLAGGBLOKKER - GRUPPE I}

I en annen artikkel i denne boken har jeg redegjort for ovnene fra eldre jernalder til merovingertid av den typen som Arne Espelund (2005) har kalt Østlandsovnen. Tre av de fire anleggene som ble berørt ved utbyggingen, lå like ved bekker mellom setergrenda Blæstern og det tidligere utløpet av Dokkfløyvatn. Det fjerde lå ved elven 4 kilometer høyere opp i vassdraget. Mange tilsvarende anlegg ligger i seterområdene høyere oppe i landskapet over Dokkfløy, blant annet finnes store avfallshauger på Kittilbu (se figur 11) ved bekken like ved utmarksmuseet. Det er et typisk trekk at anlegg fra jernalderen ligger nær setrer og/eller elver og vann, og det blir sjelden gjort utbygginger $i$ denne typen landskap (Larsen og Rundberget 2009: 46).

I Trøndelag viser pollenanalyser knyttet til vassdragsundersøkelsene ved Fjergen i Meråker at setrene først har blitt etablert etter at jernvinna gikk ut av bruk (Solem 1996: 96; Stenvik 1996: 36). Ved Dokkfløy er det spor etter jordbruk tilbake til yngre steinalder. Det er påvist pollen av havre ved Liumholseter som stammer fra omkring år $800 \mathrm{f}$.Kr. Det er påvist bygg og hvete som stammer fra henholdsvis rundt år 500 f.Kr. og år 200 e.Kr., mens det viser seg at rug først ble dyrket i vikingtiden (8001000 e.Kr.). I pollendiagrammet for Kittilbu er det bare spor etter havre fra omkring år 200 e.Kr. og rug fra perioden 1300-1550 (Høeg 1990). Det er store lokaliteter med store slaggblokker på og rundt Kittilbu (jf. figur 10), men etter alt å dømme finnes det slike anlegg ved alle setergrendene. Bare de 


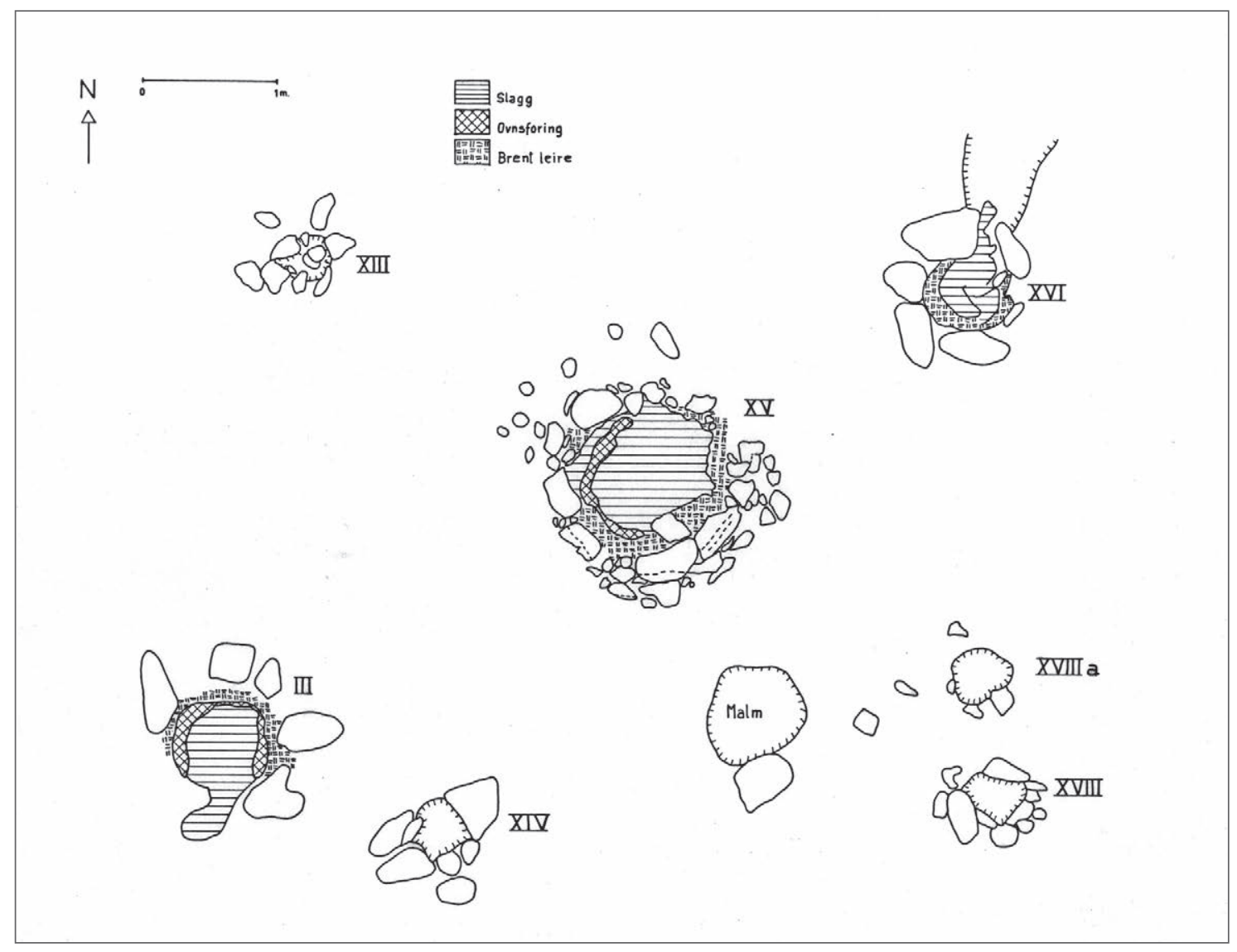

Figur 5: Jernvinneanlegget DR 75 på nedsiden av setergrenda Blestern. Struktur XV er en stor ovn fra romertiden (en Østlandsoun) med en ytre diameter på 1,7 m. Strukturene III og XVI er ovner for slaggavtapping fra yngre jernalder, mens strukturene XIII, XIV, XVIII og XVIIIa er steinskodde stolpehull. Etter Larsen 1991 figur 15.

Figure 5: Iron extrction site DR 75. Structure $X V$ is a large furnace from the Roman period ("Østlandsown»), outer diameter $1.7 \mathrm{~m}$. Structures III and XVI are slag-tapping furnaces from the 8th-9th century, while structures XIII, XIV, XVIII and XVIIIa are postholes. After Larsen 1991 Figure 15.

områdene som ble neddemmet, er systematisk registrert, og det er ikke utført utgravninger eller dateringer av jernvinna på Kittilbu. Alt taler for at jordbruket var etablert før jernvinna i Dokkfløy.

Anleggene nedenfor Blæstern lå på morenehauger der store slaggblokker lå ved foten eller var veltet utfor mot elven. På DR 75, som var et anlegg med store avfallsmasser, ble det påvist enda en ovn - struktur VI - i kanten av morenehaugen og på brinken ned mot en bekk. Avstanden mellom dem var litt over 10 meter.

De to analyserte trekullprøvene fra dette ovnsanlegget illustrerer problemene med kronologien. Den første prøven er fra kullaget rundt ovnen (struktur IV), kalibrert alder er AD 130-390, og den daterer bruken av ovnen. Den andre er fra dårlig forkullet tre i hulrommene i slaggblokken, kalibrert alder er 200-1 BC. Denne er fra siste bruksfase og skulle ha vært like gammel som eller yngre enn prøven fra kullaget.

Disse strukturene er utvilsomt rester etter slagg- roper til sjaktovner (figur 4). Størrelsen er betydelig, med en ytre diameter på inntil 1,8 meter. Innvendig diameter er på 1,1-1,4 meter, og dybden er på 0,70,9 meter (se egen artikkel om ovner med slaggroper i dette bindet).

I de tilfellene der det ble gjort undersøkelser rundt ovnene, ble det påvist steinskodde stolpehull, kanskje etter et tak eller en overbygning. Ovnen har sannsynligvis vært høy, slik at tolkningen er usikker. Dersom tolkningen om at det er satt til tørr furuved (Espelund 2005), er riktig, må flammene ha stått høyt opp.

ANLEGG FRA YNGRE JERNALDER - GRUPPE II Der det var forventet å finne et fjerde stolpehull rundt ovnen på toppen av DR 75 (figur 5), var det overraskende nok én ovn til, men av en annen og senere type. Helt inntil denne lå det en slagghaug, men her dreide det seg om renneslagg, som er typisk for vikingtidens og middelalderens jernfremstilling. 


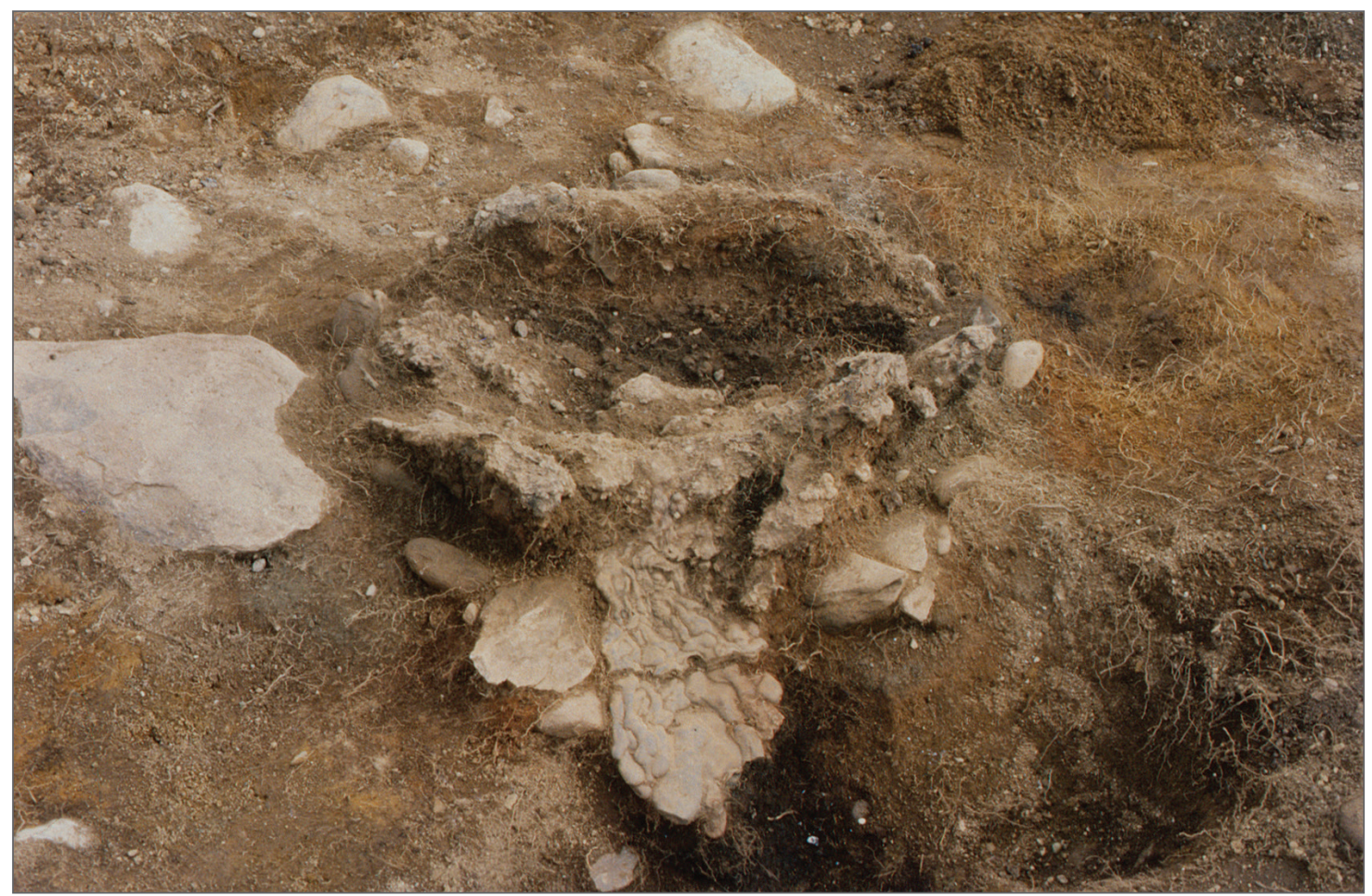

Figur 6: Slaggavtappingsovnen på DR 262 fra yngre jernalder. Sjakten var dårlig bevart. Foto: J. H. Larsen, Kulturbistorisk museum.

Figure 6: The slag-tapping furnace at iron extraction site DR 262 from the 8th-9th century. The shaft was poorly preserved. Photo: J. H. Larsen, Museum of Cultural History.

Mens avfallshaugene fra den eldre perioden gjerne er digre og inneholder mye brent jord og torv, var slagget her mye mer konsentrert. Det fantes riktignok stykker av ovner, kull, jord og stein, men mest slagg. Selve slagghaugen var avlang og ganske jevn med en lengde 5,1 meter, en bredde på 3,6 meter og en høyde på 0,3 meter.

Slagget har form som lange strenger som er brukket opp i mindre stykker. Undersiden er rund og har avtrykk av sand og grus. Oversiden, som har en bredde på inntil 12 centimeter, har ormlignende mønstre. Slagget er tappet horisontalt ut i en renne, og det kalles derfor for renneslagg, til forskjell fra tappeslagg, som er tappet vertikalt (se Hauge 1946: 39-43, Larsen 2009: 87). Bernt Rundberget (2007: 326) karakteriserer slagget i Gråfjellområdet som tappeslagg, og mener at betegnelsen renneslagg bør brukes sammen med ovner fra Dokkfløy, Møsstrond og Hovden.

Ovnen stod i en ramme av avlange steiner med største mål på inntil 35 centimeter. På undergrunnen var det lagt en 5 centimeter tykk pakning av leire og småstein som var oval og hadde målene $0,65 \mathrm{x}$ 0,75 meter. Her var det altså ingen grop under bakkenivå, men bare en 5 centimeter dyp forsenkning. I ytterkant av pakningen var det reist en sjakt av leire slik som på de eldre ovnene, men de tre som fantes i dette området, var dårlig bevart. Foran var det et hull i retning mot slagghaugen. Fra dette hullet gikk det en liten renne for slaggavtapping (figur 6).

Mens stolpehull rundt de store ovnene fra den eldste jernutvinningen fortalte om en konstruksjon, var det ikke spor etter bygning rundt de yngre ovnene ved DR 75. Men det kan godt ha vært en trekonstruksjon på bakken som ikke har satt spor etter seg. Anleggene var ganske enkle med én ovn og én slagghaug $i$ tillegg til et lag med malm.

Bare noen få dateringer foreligger siden det var lite kull å finne (på denne tiden hadde laboratoriene liten kapasitet til å gjennomføre AMS-dateringer). Dateringene fra disse anleggene peker mot tiden fra rundt år 700 e.Kr. til 900-tallet. Materialet kaster i liten grad lys over kronologien ved overgangen fra slaggropovner til slaggavtappingsovner, men så vel magasinerte prøver som bevarte anlegg over magasinområdet har potensial for nye studier.

Det har vært brukt furu til brensel. Ut fra størrelsen på ovnene å dømme har det antagelig vært brukt kull i produksjonen, men kullgroper fra denne tiden er nærmest ukjent annet enn på Fillefjell. 
Sett ut fra alle slagghaugene og restene etter den eldre virksomheten, blekner de små slagghaugene, men de vitner om at det fortsatt har foregått jernproduksjon i området. Slike slagghauger som ikke er knyttet til kullgroper, er lave og vanskelige å finne, men flere er kjent mellom Blæstern og Dokkfløysetra. Kanskje ligger anleggene fra denne tiden på et annet sted i landskapet enn nede ved Dokkfløyvatn, og kanskje er ikke det bildet som undersøkelsene har gitt, så riktig. Særlig ser det ut som om anleggene fra vikingtiden, slik som de eldre anleggene, er knyttet til elver og vann og til setrer, i områder der det sjelden gjøres utgravninger som følge av utbygging.

\section{MIDDELALDEREN}

Med middelalderen får vi et langt bedre arkeologisk kildemateriale å bygge på. I det området som ble demmet ned, var det 31 lokaliteter med totalt 35 separate anlegg, hvorav 27 var fra middelalderen. Det foreligger få dateringer fra 1000- og 1100-tallet, derimot er 1200- og 1300-tallet meget godt dekket.

\section{Kullgropene}

Kullgropene er karakteristiske for middelalderens jernfremstilling i Oppland og store deler av SørNorge. Kullet ble produsert i store, gravde groper som var runde og oftest omgitt av en voll (se figur 3). Tverrmålet med vollen kan være inntil 11 meter, og dybden kan være 0,7-1,3 meter. Selve nedgravningen kan måle 3-6 meter. Nede i gropen ble det stablet trevirke, oftest av bjerk, med en diameter på kun 10 centimeter. Vedstabelen ble dekt til med torv og jord, og det ble satt fyr på den. Lufttilførselen ble regulert ved å endre tildekkingen.
De enkeltliggende gropene avviker ikke fra dem på jernvinneanleggene med hensyn til konstruksjon og form. Alle undersøkte groper har hatt en bolleformet nedskjæring med flat bunn. Nedgravningen har vist seg å være sirkulær eller svakt oval. Avviket er imidlertid ikke større enn at gropene må kunne karakteriseres som runde. De fleste har hatt en jevn sirkulær voll, men hvor tydelig denne har vært, varierer etter terrengets hellingsvinkel. En rekke groper er også undersøkt nede i de sentrale områdene av Gausdal, og disse er nok for kull til smiing. Dateringene her strekker seg fra år 1000-1450 e.Kr.

\section{Typeinndelingen}

Ved publiseringen av materialet ble det utarbeidet en typeinndeling. Anleggene med store slaggblokker ble katalogisert som gruppe I, mens anleggene med tappeslagg uten tilknytning til kullgroper ble katalogisert som gruppe II. Larsen (1991) og Narmo (1996) har ulike betegnelser, men det som er felles for anleggene, er at det inngår kullgroper i anleggsstrukturen.

\section{Perioden 1000-1300 - blesterhus}

En mindre tallrik type anlegg (Larsen kaller dem type IIIC, mens Narmo kaller dem A-blestertuft) har ovnene inne i en tuft med slaggutkast på utsiden av tuften, og det er bare én slagghaug. Tuften har gjerne ildsted. Dimensjonene varierer, men gjennomgående er de så små at det neppe kan ha dreid seg om annet enn en verkstedsbygning. Kullgropene er en del anleggene, men organisasjonsmønsteret er ikke så klart som for den senere Dokkfløy-typen. Mest vanlig synes det å være at de ligger lavere i terrenget enn tuften. Dateringene fra anleggene ligger

\begin{tabular}{|l|l|l|}
\hline Larsen 1991 & Narmo 1996 & Karakteristika \\
\hline IIIA & (B-blester-tuft)* & $\begin{array}{l}\text { Anlegg med 1 kullgrop, 1 ovn, 1 slagghaug og hustuft. Synes å være en ikke } \\
\text { fullt utbygd utgave av gruppe IIIB. }\end{array}$ \\
\hline IIIB & B-blestertuft & $\begin{array}{l}\text { Den egentlige Dokkfløytypen. 2-3 kullgroper ligger øverst i terrenget, deretter } \\
\text { 2-3 ovner med 2 slagghauger ut til sidene. Nederst en hustuft med hellebygd } \\
\text { ildsted. }\end{array}$ \\
\hline IIIC & A-blestertuft & $\begin{array}{l}\text { Anlegg hvor ovnen(e) ligger i blestertuft. Kullgroper inngår og ligger gjerne } \\
\text { lavere i terrenget. }\end{array}$ \\
\hline IIID & - & Anlegg som ikke kan innpasses i de andre typene. \\
\hline
\end{tabular}

* Narmo definerer ikke denne typen, men typene IIIA og IIIB inneholder samme elementer. IIIA ser ut til å tilsvare et halvt IIIB-anlegg.

Tabell 1: Typeinndelingene av middelalderanleggene ved Dokkfloy.

Table 1: The classification of iron extraction sites from the medieval period. 


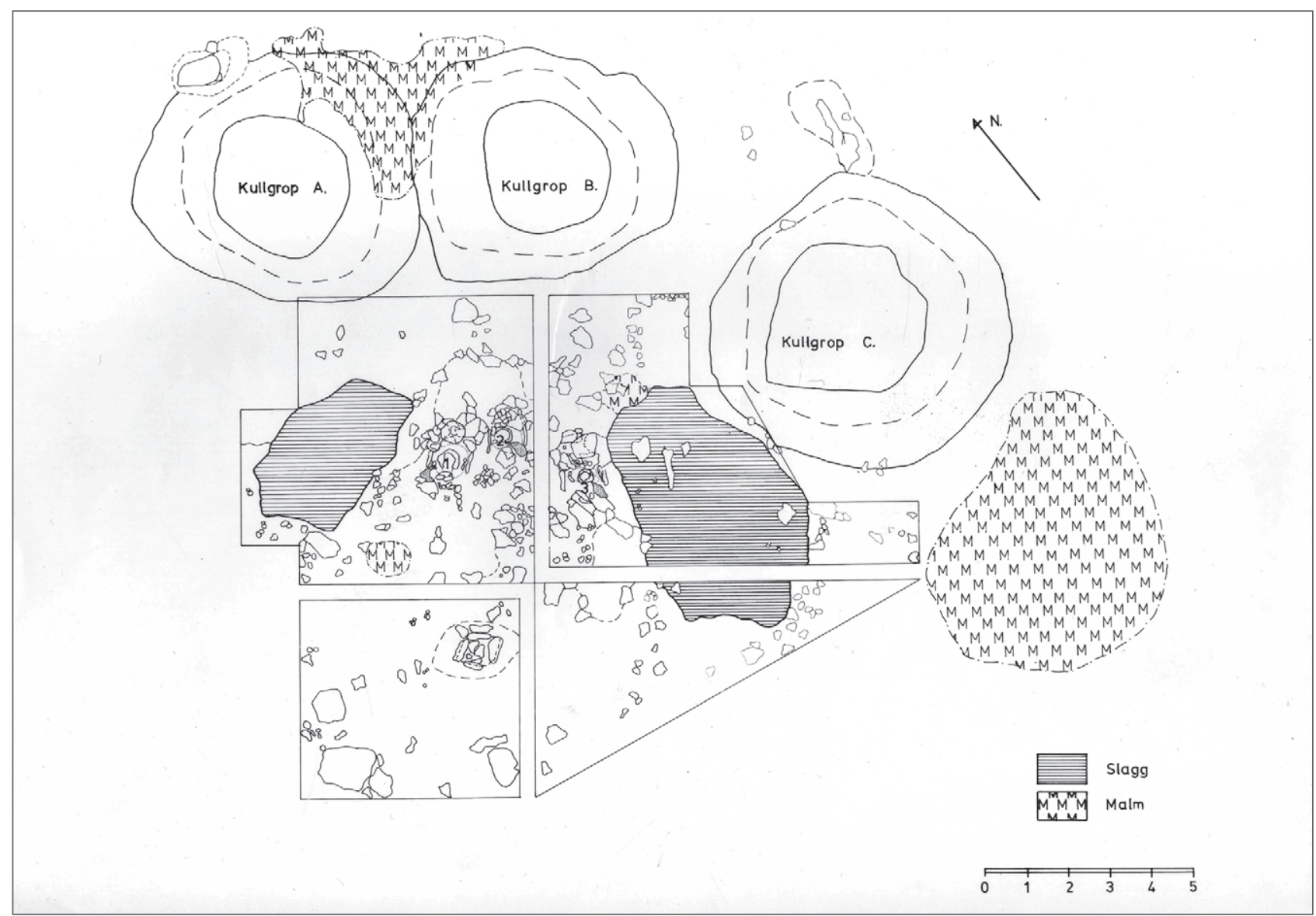

Figur 7: Jernvinneanlegget DR 69 er ${ }^{14} \mathrm{C}$-datert til perioden AD 1250-1400. Her var det tre kullgroper, tre ovner for slaggavtapping, to slagghauger og ildsted. Ildstedet har ligget $i$ en liten bygning hvor det var mulig for folk å bo mens de arbeidet på anlegget. Slaggfunn $i$ ildsteder på denne typen anlegg tyder på at det også har foregätt enklere smieaktiviteter ved anleggene. Oppmåling: $K$. Elliott,

Kulturbistorisk museum.

Figure 7: Iron production site DR 69 was ${ }^{14} \mathrm{C}$ dated to AD1250-1400. There were three charcoal pits, three furnaces for slag-tapping, two slagheaps and a hearth. The fireplace was in a small building where it was possible to stay while working at the production site. Slag finds in this type of fireplace indicate simpler smithing activities. Figure by K. Elliott, Museum of Cultural History.

i perioden AD 1000-1280 (jf. Larsen 1991: 201).

Fordi kalibreringskurvene angir lang tid, er det vanskelig å etablere en detaljert kronologi ut fra foreliggende dateringer og dateringsmetode. En enkeltdatering til perioden AD 800-1000 basert på trekull av furu plasserer neppe typen i vikingtiden. En faktor som gjør det hele mer komplisert - en faktor man ikke var tilstrekkelig oppmerksom på under utgravningene - er at et anlegg kan ha flere bruksfaser med ulik planløsning. Omrotinger kan medføre at enkeltdateringer ikke må tillegges for mye vekt.

Ovner med ramme av kuppelstein var i bruk frem til middelalderen, men senere ble sjaktene satt direkte på undergrunnen, og diameteren ble redusert. I løpet av perioden ble kraftige, vertikale skiferheller introdusert som en del av konstruksjonen rundt ovnen.

\section{Dokkfløytypen}

For å illustrere organiseringen av den vanligste typen anlegg, trekker vi frem DR 69, som var et ganske standard anlegg i dette området. Det vanligste er at anleggene ligger i slakt hellende partier med kullgropene øverst, i dette tilfellet lå de tre på linje.

DR 69 er datert til AD 1250-1400. Her stod tre ovner på rekke - ovnene 1 og 2 stod nærmest kant i kant, mens ovn 3 var plassert 1,2 meter fra ovn 2. Allerede etter at anlegget var ryddet, var det lett å lokalisere ovnene på grunn av de oppstikkende, parallelle skiferhellene. Ovnene var åpne i forkant, mens de på oversiden hadde en oppbygning, en platting, av skiferheller. Mellom kanthellene fremkom det en sjakt av brent leire med en ytre diameter på 0,5 meter og en indre diameter på 0,35 meter. Gjennomgående var tykkelsen 2-3 centimeter, men mot bunnen hvor det var forslagging, kunne tykkel- 


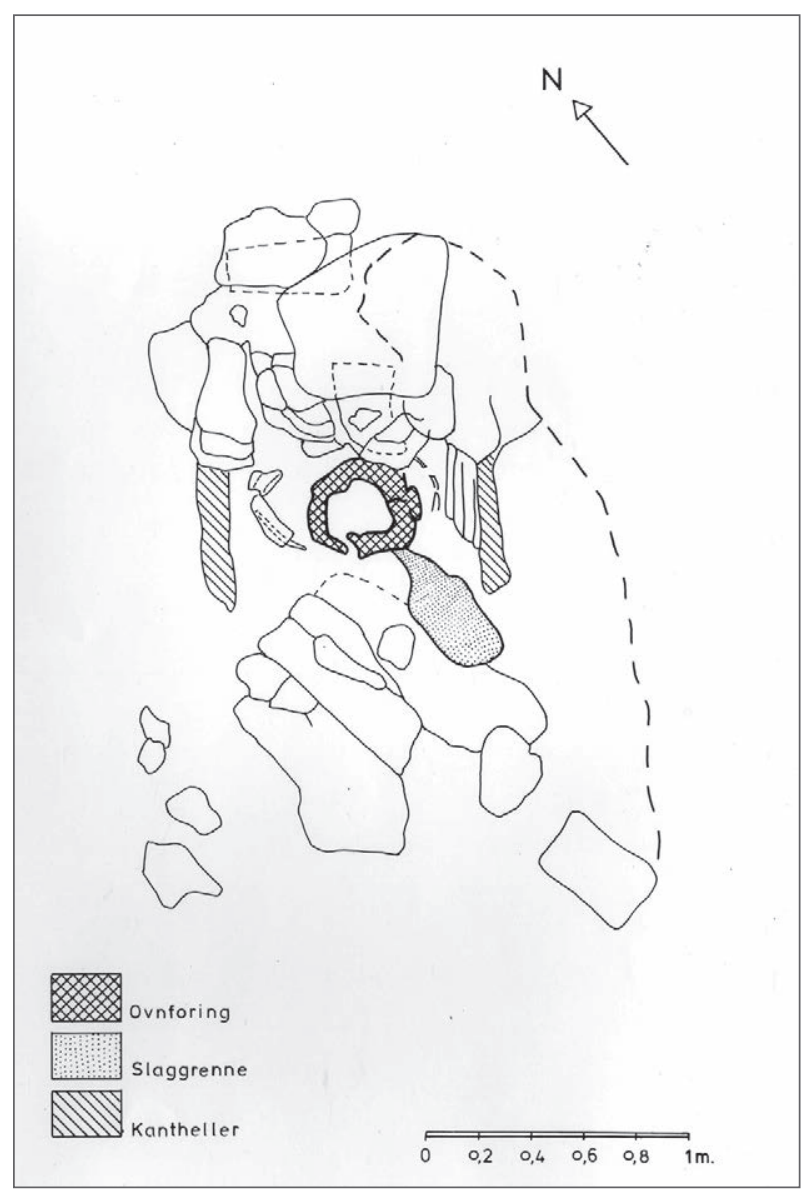

Figur 8: DR 69, ovn 2. Sjakten står mellom to kraftige sideheller. I bakkant kanskje en arbeidsplattform. Oppmåling: $K$. Elliott, Kulturhistorisk museum.

Figure 8: DR 69, furnace 2. The shaft is placed between two side slabs. At the back there was built up a construction of slabs, possibly a work platform. Figure: K. Elliott, Museum of Cultural History.

sen være opptil 0,1 meter. I bunnen lå det bunnslagg (bunnskolle) som var 5 centimeter tykt.

I høyden var sjakten bevart opp til 0,5 meter. Mellom sjakten og kanthellene var det en foring og isolasjon som bestod av jord og mindre skiferheller. I forkant ved den ene sidehellen var det slaggutløp i en renne med en dybde på inntil 0,1 meter. Slaggrennen førte i retning av den nærmeste slagghaugen. Om det har vært en vegg som isolasjon foran ovnen, er uvisst. Påfylling av malm og kull har trolig foregått fra plattformen i bakkant. Blestinntaket ble ikke påvist, men kraftig forbrenning av sjakten i bakkant tyder på at innblåsingen har vært enten rett forfra eller ved motsatt sidehelle, på et noe høyere nivå.

Sjaktene var bygget av grovt magret leire, helst lokal undergrunnsmorene. Ovn 3 på dette anlegget viste at sjakten var bygget rundt en indre forskaling.
I bunnen lå det bunnslagg som dannet avtrykk av grunnen under. Slaggrennene ved Dokkfløy ligger alltid inntil den ene kanthellen, og ikke i midten av åpningen. Disse rennene er lange og smale og sjelden mer enn 0,2 meter brede, slik at det ikke dreier seg om grøfter, men egentlige renner (for grundig gjennomgang og diskusjon, se Narmo 1996: 69-80).

Anlegget DR 36 var ganske ensartet. En prøve fra en slagghaug er datert til AD 1260-1290. Ovn 1 viste seg å være sjeldent godt bevart siden den var gjenfylt og dekket av slagg. Høyden i bakkant var 0,7 meter, og i forkant var den 0,55 meter. Bruddflater og løs ovnsforing viste at ovnen hadde vært enda høyere. Indre diameter i bunnen var på 0,35 meter. Sjakten stod inne i en ramme av 0,7 meter lange skiferheller. Mellom sjakten og rammen var det foret med jord, leire og mindre heller. Fra ovnen førte en slaggrenne mot nærmeste slagghaug.

Ovnen stod direkte på undergrunnen uten videre fundamentering. Funn av ovnsforing i konstruksjonen viste at ovnen ikke var den første på stedet. Flere steder var det spor av reparasjoner slik som på ovn 3. Rundt ovnene har det vært en hellelegning av skifer.

I alle ovnene var det i forkant ved den ene sidehellen hull for slaggavtapping. Slaggutløpet førte ut $i$ en slaggrenne med en dybde på inntil 10 centimeter. Lengden var oftest på inntil 0,5 meter, og bredden var på inntil 0,25 meter. Slaggrennen hadde alltid retning mot nærmeste slagghaug. Luftinntak fra belg(er) ble ikke funnet. Det har nok sammenheng med at sjaktene var dårlig bevart i forkant. Mellom ovnssjakten og sidehellene var det foret med skiferfliser og sand. Om det har vært en fjerde vegg foran ovnen, er uvisst.

Plattformen bak ovnene var på $0,8 \times 1,2$ meter og bestod av flere horisontalt lagte skiferheller som var inntil 0,5 meter store. Fundamentet av mindre rundstein dannet den bakre veggen i ovnene $\mathrm{i}$ form av en halvsirkelformet steinrekke. Hellene var dekket av søl av malm og trekull. Antagelig har dette vært arbeidsstedet ved påfylling i ovnene. Når det gjelder bruk og funksjon av denne ovnstypen, vises det til den redegjørelsen som er gitt i forbindelse med bygging av og forsøk med en rekonstruert ovn (Jakobsen, Larsen og Narmo 1988).

Anlegget hadde to slagghauger som var sammenlignbare med dem som kjennes fra yngre jernalder på DR 75. De lå til siden for ovnsområdet, og slaggrennene fra de to ovnene førte mot hver sin slagghaug. Ildstedet på DR 36 lå inne i en tuft som hadde en innvendig størrelse på rundt 13 kvadratmeter, altså tilstrekkelig til at det har vært mulig å 


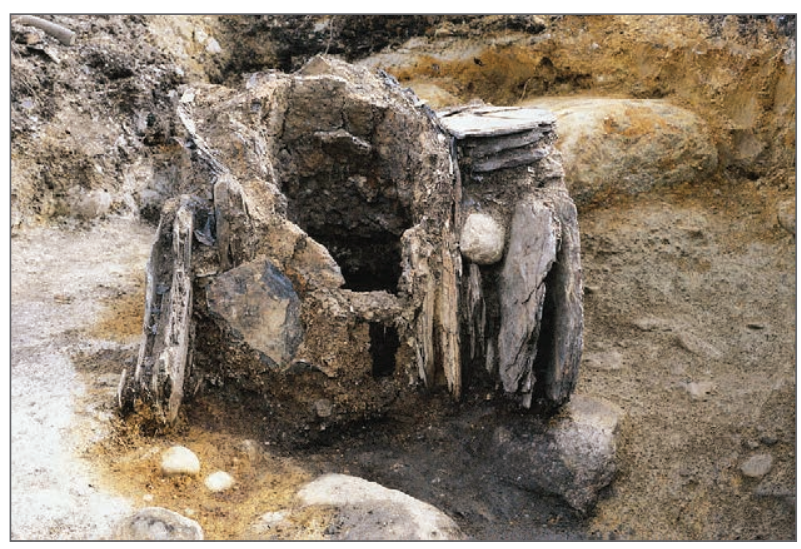

Figur 9: DR 36, ovn 1, var bevart opp til en hoyde på 0,7 m. Hull i sjaktveggen skyldes utrasing. Foto: M. Thorleifsen, Kulturhistorisk museum.

Figure 9: Furnace 1 at site $D R 36$ was preserved to a height up to $0.7 \mathrm{~m}$. The hole in front of the shaft wall was due to subsidence. Photo: M. Thorleifsen, Museum of Cultural History.

overnatte der under arbeidet, men den har neppe vært egnet som permanent bolig for en hel familie.

En variant av denne anleggsstrukturen har bare ett element av hver type og utgjør et halvt anlegg. De to variantene har samme datering og viser en intensivering av virksomheten fra 1200 -tallet.

\section{OVNSUTVIKLINGEN}

Jernutvinningen introduseres etter foreliggende data å dømme i Dokkfløy i tidlig romertid. Fra den tiden finner vi store sjaktovner med slaggroper som har vært brukt mange ganger, og ofte er det store avfallsmengder på anleggene. Ovnene som ble bygget senere, er noe mindre. Det er ikke klarlagt om det er opprenskingene som har gjort gropen uhensiktsmessig stor, eller om den store gropen er et trekk som peker mot hellegrytene i yngre jernalder.

Fra merovingertiden kjenner vi i Øyerfjella, omkring 40 kilometer øst for Dokkfløy, til hellegryter av samme type som dem vi finner på Fillefjell, Møsstrond og Hovden. Slik det er fremholdt (Larsen i dette bindet), taler mye for at hellegryta er en mindre utgave av Østlandsovnen fra Dokkfløy. Tilsvarende helleforing av gropene kjenner vi fra romertiden.

Ovn S18 på Lisætra i Øyer hadde indre mål på 41 x 43 centimeter, ytre mål på 100 x 97 centimeter og en dybde 40 centimeter. Yngre jernalders sjaktovner med slaggavtapping på Dokkfløy hadde indre mål på rundt 0,4-0,5 meter, og bunnen var utformet med pakning av leire og småstein. Disse ovnene markerer en overgang mot den følgende middelalderovnen. De eldste slaggavtappingsovnene er omgitt av kup- pelformete steiner. Senere får ovnene sideheller av skifer som gjør at de får en solid fundamentering, noe som også har gjort at mange av ovnene er godt bevart i dag. På Møsstrond og Fillefjell finnes det hellegrytelignende ovner for slaggavtapping (Martens 1988: 70-72; Tveiten 2012). Slaggavtappingsovnene fra middelalderen har en ganske ensartet utforming i store deler av Sør-Norge (for eksempel Mjærum i dette bindet og Tveiten 2012), med unntak av den spesielle tradisjonen i Hedmark (se Rundberget i dette bindet).

Kullgropen hører nå fast til. Hvordan kullfremstillingen har foregått $i$ yngre jernalder ved Dokkfløy, er uvisst. Kanskje har senere kullproduksjon utslettet eldre spor, eller kanskje har andre teknikker vært i bruk. På Fillefjell har kullgropen vært i bruk fra omkring AD 800, mens sporene etter kullbrenning er nærmest fraværende i øvrige deler av Østlandet før den senere delen av 900tallet (Larsen 2009)

På 1200-tallet får anleggene sin bestemte plan, og anleggene finnes spredt $i$ hele landskapet ved Dokkfløy - dette er «storhetstiden» for jernvinna ved Dokkføy før virksomheten legges ned omkring AD 1400. Anleggstypen er godt datert.

Den absolutte kronologien bygger på 62 ${ }^{14} \mathrm{C}$-dateringer og dessuten et par jerngjenstander. Kalibreringskurvene gjør at det er vanskelig å få en detaljert oversikt over perioden AD 700-1200. Med dagens bruk av AMS-dateringer ville resultatene ha vært mer nyanserte.

\section{DOKKFLØY OG NORSK JERNVINNEFORSKNING}

Det var Irmelin Martens (1972; 1988) som gjennom sine utgravninger på Møsstrond la grunnlaget for den arkeologiske utforskningen av jernvinna. Dokka-undersøkelsene ble den neste bærebjelken i arbeidet med å få klarhet i teknologi og kronologi og ikke minst organiseringen av arbeidet.

Utgangspunktet for de to prosjektene var vidt forskjellige. Møsstrond-undersøkelsene var et forskningsprosjekt der ikke bare jernvinna var viktig, men også utprøving av ${ }^{14} \mathrm{C}$-metoden (Martens 1979:121), noe som førte til at det ble utarbeidet en absolutt kronologi. Undersøkelsene på Møsstrond bekreftet det aksepterte bildet som viste at jernproduksjonen var særlig stor i vikingtiden og i middelalderen. De radiologiske dateringene førte til at oppmerksomheten nå også i større grad ble rettet mot jernvinna i middelalderen. Tidligere hadde man ment at jernproduksjonen i vikingtiden måtte ha vært stor på grunn av jernrikdommen i gravene. 

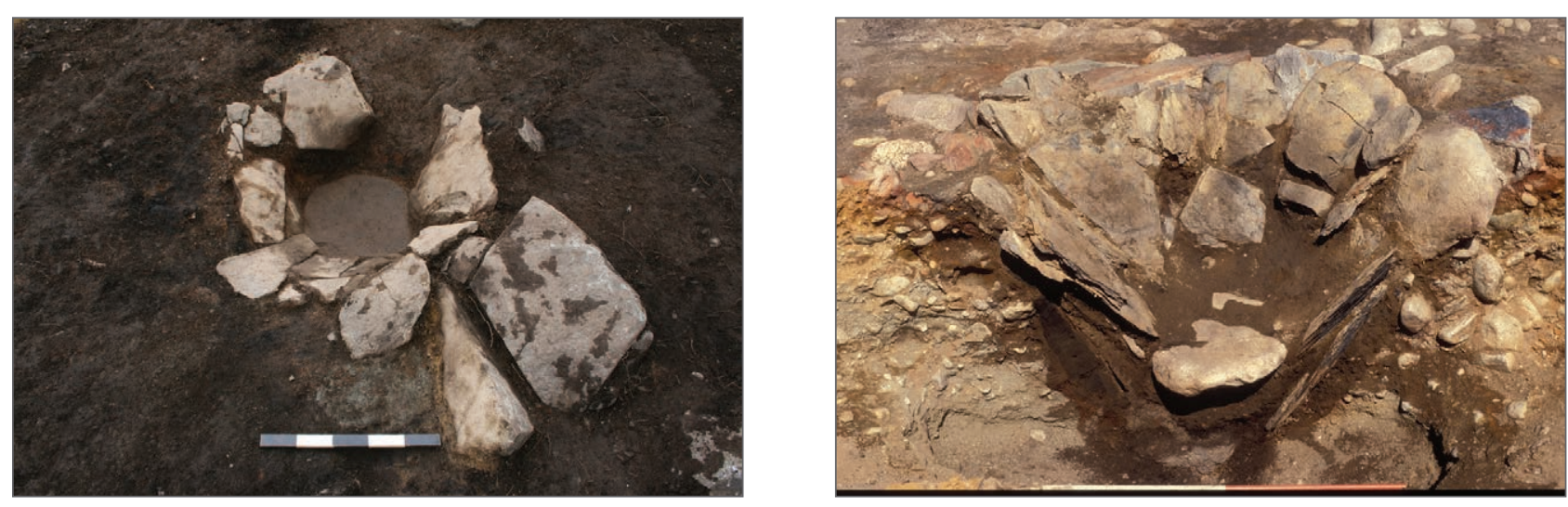

Figur 10: Størrelsen er et viktig skille mellom Østlandsovnen fra romertiden og merovingertidens hellegryte. Til venstre: Ovn struktur $X V$ ved Dokkfloy tømt for slagg. Ytre diameter: 1,7 m. Foto: Jan Henning Larsen, Kulturbistorisk museum. Til høyre: Ovn $S 18$ på Lisetra i Øyer, Oppland. Ytre mål: 1,0 × 0,97 m. Foto: S.L. Berge, Kulturbistorisk museun.

Figure 10: The size is an important distinction between the "Østlandsovn» and the Merovingian flag-lined furnace. To the left: Furnace structure XV at Dokkfloy cleared of slag. Outer diameter: $1.7 \mathrm{~m}$ Photo: Jan Henning Larsen, Museum of Cultural History. To the right: Furnace S18 on Lisetra in Øyer, Oppland. Dimensions $1.0 \times 0.97$ m. Photo: S.L. Berge, Museum of Cultural History.

Dokkaprosjektet var et rent forvaltningsprosjekt, noe som innebar at ressursene som var til disposisjon, var store, men ulempen var at utgravningene måtte begrenses til fornminner som ble berørt ved utbyggingen. Det gjorde at det ikke var mulig å forfølge problemstillingene knyttet til ressursutnyttelse og bosetning i seterområdene. Slike områder er fortsatt lite gransket i Øst-Norge.

Gravningsteknisk la Dokkaprosjektet grunnlaget for dagens utgravninger. Introduksjonen av store, flateavdekkete arealer der alle elementer ble studert i sammenheng, var spesielt viktig. Kullgropene ble undersøkt som en del av helheten, og ble sammen med ovns- og slaggtypologi sentrale elementer i oppbygningen av den relative kronologien. For første gang fikk arkeologer forståelsen av hva de store slaggblokkene representerer. Funnene av romertidens ovner har lagt grunnlaget for videre registreringer av periodens anlegg i østlandsregionen.

Som en del av Dokkaprosjektet ble det også gjennomført utgravninger av deler av fangstanlegg for elg med delvis sammenfallende dateringer og felles intensivperioder. I området har det også vært godt fiske, et godt grunnlag for å jakte på småvilt og fugl, rikelig med skog og dessuten gode beiteforhold. Var det de samme menneskegruppene som hadde husdyr, som fanget elg, og som brente jern i Gausdal Vestfjell, eller var virksomhetene spesialisert? Eller inngikk alt $i$ en annen driftsform enn den vi har i dag? Det er funnet mange hustufter, men ingen av dem peker mot gårder som har vært $\mathrm{i}$ bruk hele året. Følgelig ble slutningen at folk bare har oppholdt seg ved Dokkføy deler av året. Det ble postulert at virksomheten var organisert/drevet av bønder i de sentrale strøkene av Gausdal.

Gudbrandsdalsregionen har tre middelalderkirker av stein, og de to kirkene i Gausdal er fra midten eller siste halvdel av 1200-tallet, en periode med omfattende elgfangst og stor jernfremstilling. Siden biskopen på Hamar hadde store eiendomsinteresser i Gausdal, var det å ha en overordnet styring av utmarksbruken en nærliggende tanke (Jacobsen og Larsen 1992). Det er nok tid for å ta opp denne tanken til ny debatt. Det er påfallende at jernproduksjonen intensiveres $i$ en periode da produksjonen i Hedmark reduseres og avsluttes (Rundberget 2013). Produksjonen i Valdres og på Møsstrond tilhører hovedsakelig tiden før 1300, mens virksomheten i øvre del av Hallingdal og på Hovden øverst i Setesdal strekker seg inn på 1400-tallet. Forskjellene kan skyldes ressurstilgang, men det er mer sannsynlig at årsaken er å finne i samfunnet, slik Rundberget (2013) har vist for Hedmarks del.

\section{GAMMELT MATERIALE - NYE MULIGHETER}

Utgravningene ved Dokkfløy ble avsluttet for snart 25 år siden, men materialet har fortsatt kvaliteter som gjør det egnet for ny forskning. Den gangen lyktes man ikke i å skaffe midler til videre bearbeidelse. Det som skiller disse utgravningene fra våre dagers forvaltningsgravninger, er hovedsakelig oppmålingsteknikken, og at det $\mathrm{i}$ vår tid satses mer på naturvitenskapelige analyser.

Det foreligger omfattende prøvemateriale fra 


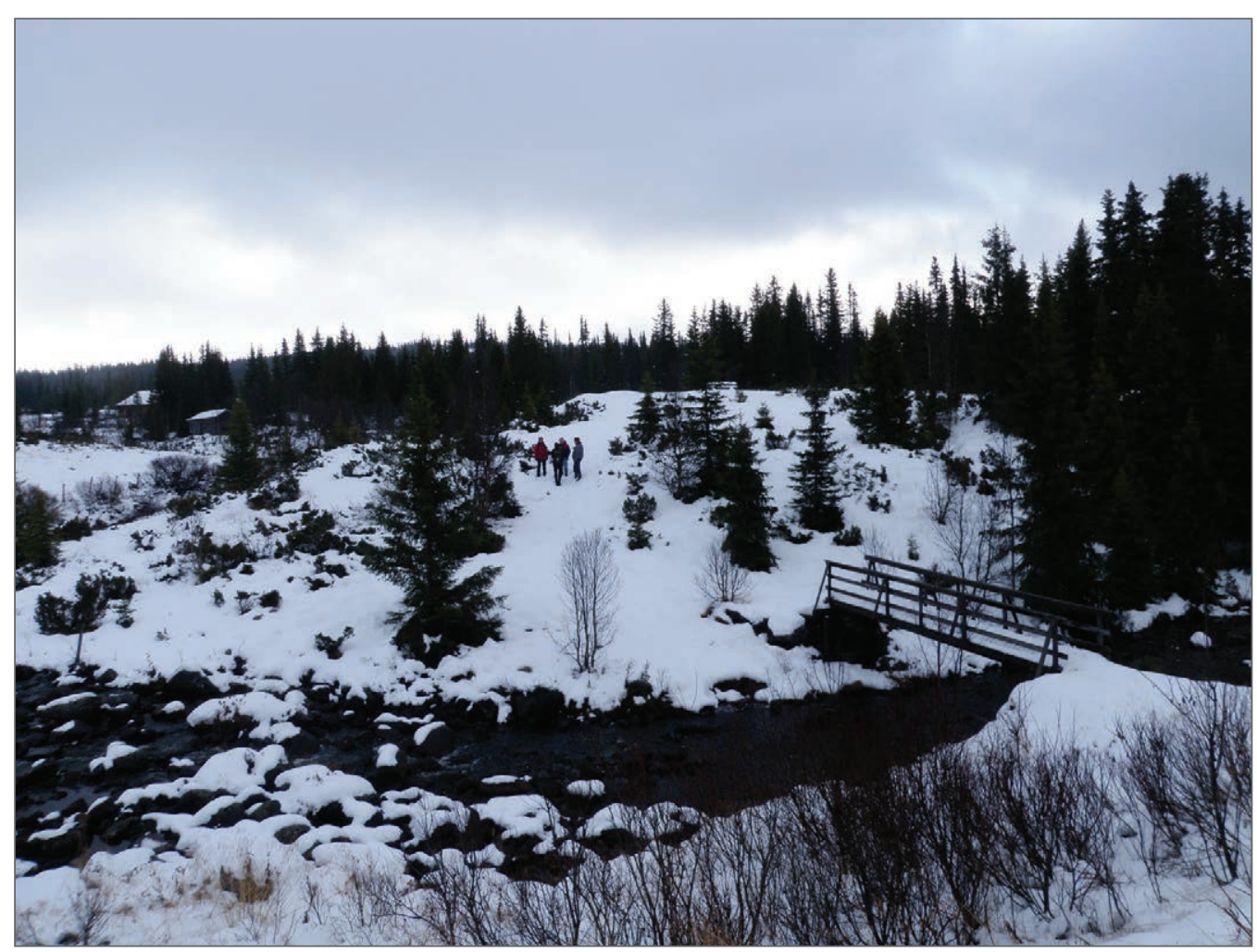

Figur 11: I seterområdene ovenfor Dokkfloymagasinet er det mange godt bevarte fornminner, sarlig jernvinneanlegg og fangstanlegg for elg. Kittilbubekken slynger seg rundt et område med fire jernvinneanlegg fra eldre jernalder og ett fra middelalderen. Kullgropene er ombygd til fangstgroper for elg og inngår $i$ et storre system. Til venstre ligger Kittilbu utmarksmuseum. Kulturstien går fra museet over området og videre ned til det nye vannmagasinet. Foto: K. Tidemansen, Oppland fylkeskommune.

Figure 11: In the mountain areas above the Dokkfloy hydropower reservoir there are many well-preserved ancient monuments, especially iron extraction sites and hunting pits for elk. The Kittilbu stream meanders through an area with four iron production sites from the Roman-Migration period and one from the Middle Ages. Charcoal pits are converted to hunting pits for elk and form part of a larger system. To the left is Kittilbu outfield museum. The heritage trail runs from the museum, passes through the area and goes down to the new water reservoir. Photo: K. Tidemansen, Oppland County.

Dokkfløy som er godt egnet til å besvare spørsmål om for eksempel kronologi, der analysemetodene gir nye muligheter (Loftsgarden et al. 2013). En rekke ovner er utgravd og godt dokumentert, og Dokkfløy er et sentralt referanseområde for studiet av ovnsteknologi i perioden fra romertiden til folkevandringstiden og i middelalderen. Utenfor undersøkelsesområdet finnes tallrike fornminner (figur 11), blant annet på Kittilbu. Mindre utgravninger kan gi svar på vesentlige spørsmål om organiseringen av virksomheten.

Mye har skjedd i norsk arkeologi på 25 år, ikke minst når det gjelder tilnærmingen til jernvinnas tilhørighet til og betydning for samfunnet (se for eksempel Tveiten 2012 og Rundberget 2013: 315-322). Disse nye måtene å tenke arkeologi på kunne ha vært interessante i studiet av Dokkfløy.

\section{SUMMARY}

The location of the seminar on Nordic furnaces for iron production at Kittilbu was based on the implementation of the large Dokka Project, 1986-1989, for hydroelectric power development. Large areas were dammed at Dokkfløy. Kittilbu is made up of outfield farms located on the east side of the project area. A lot of ancient monuments related to elk hunting and iron production are still preserved there. Kittilbu utmatksmuseum and the cultural trail down to the water, with a reconstructed iron extraction site of medieval style, result from the excavations at Dokkfløy.

35 iron extraction sites from the period $\mathrm{AD} 1$ to AD 1400 were excavated. The oldest furnaces had slag pits (see Larsen, in this volume). The first period of intensive use we find in the Roman migration period, when iron extraction sites are related 
to summer farms. Around AD 700-800 the shaft furnace with slag-tapping came into use, at first in a construction of domed stones. In the Middle Ages these were developed using a construction of slates on two sides that has led to excellent preservation conditions up to the present time.

In the Middle Ages charcoal production in large pits was a part of the iron production sites. In the 13th century the sites developed their specific plans, and the sites are scattered all around Dokkfløy. This is the «golden age» for iron extraction at Dokkfløy before the work closed down around AD 1400 . Most common are sites from AD 1250-1400 with 2-3 charcoal pits, 2-3 furnaces, slag heaps on each side of the area with the furnaces and on the lower side a house foundation with fireplace. The house is too small for permanent residents with a family, but would have been suitable for a stay while operations were going on.

There has been rapid development of the Norwegian iron extraction research and material from Dokkfløy, which has many aspects that are suitable for new discussions of its development and organization.

\section{LITTERATUR}

Bloch-Nakkerud, T. 1987. Kullgropen i jernvinna øverst $i$ Setesdal. Varia 15. Oslo: Universitetets Oldsaksamling.

Espelund, A. 2005. Bondejern i Norge. Ny, utvidet utgave. Trondheim: Arketype.

Hauge, T.D. 1940. «Jernbrenning i Gudbrandsdalen i gamle dager». Viking IV: 41-83, pl. I--IV.

Hauge, T.D. 1944. «Valdresjern». Viking VIII: 43-55, pl. IX-XII.

Hauge, T.D. 1946. Blesterbruk og myrjern. Studier $i$ den gamle jernvinna i det ostenfjelske Norge. Universitetets Oldsaksamling Skrifter III. Oslo: Universitetets Oldsaksamling.

Hauge, T.D. 1952. «Jernframstilling i Land i gamle dager». Boka om Land II: 458-479. Oslo.

Høeg, H.I. 1990. Den pollenanalytiske undersøkelsen ved Dokkfløyvatn i Gausdal og Nordre land, Oppland. Varia 21. Oslo: Universitetets Oldsaksamling.

Jacobsen, H. og J.H. Larsen 1992: Dokka-undersøkelsene. Dokkfloy fra istid til kraftmagasin. Gausdal bygdehistorie 6. Lillehammer: Gausdal kommune.
Jakobsen, S., J.H. Larsen og L.E. Narmo 1988: «Nå blestres det igjen jern ved Dokkfløy. Et forsøk på eksperimentell arkeologi». Viking LI: 87-108.

Larsen, J.H. 1991. Jernvinna ved Dokkfloyvatn. De arkeologiske undersøkelsene 1986-1989. Varia 23. Oslo: Universitetets Oldsaksamling.

Larsen, J.H. 2009. Jernvinneundersøkelser. Faglig program 2. Varia 78. Oslo: Kulturhistorisk museum, Fornminneseksjonen.

Larsen, J.H. og B. Rundberget 2009. «Raw Materials, Iron Extraction and Settlement in South-East Norway 200 BC-AD 1150». 58. Sachsensymposium in Trondheim 1st-5th September 2007. Vitark 7: 38-50. Trondheim: Vitenskapsmuseet.

Loftsgarden, K., B. Rundberget, J.H. Larsen og P. Mikkelsen 2013. «Bruk og misbruk av ${ }^{14} \mathrm{C}$-datering ved utmarksarkeologisk forskning og forvaltning». Primitive tider 15: 59-69.

Martens, I. 1972. «Møsstrond i Telemark - en jernproduserende fjellbygd før svartedauen». Viking XXXVI: 83-114.

Martens, I. 1988. «Jernvinna på Møsstrond i Telemark. En studie i teknikk, bosetning og økonomi». Norske Oldfunn XIII: 5-164. Oslo: Universitetets Oldsaksamling.

Narmo, L.E. 1996. Jernvinna i Valdres og Gausdal - et fragment av middelalderens økonomi. Varia 38. Oslo: Universitetets Oldsaksamling.

Rundberget, B. (red.) 2007. Jernvinna i Gråfellområdet. Gråfjellprosjektet I. Varia 63. Oslo: Kulturhistorisk museum, Fornminneseksjonen.

Rundberget, B. 2013. Jernets dunkle dimensjon: jernvinna $i$ sørlige Hedmark. Sentral økonomisk faktor for samfunnsutvikling c. AD700-1300. Doktoravhandling: Oslo.

Sjøvold, T. 1991. «Minnetale over hovedlærer dr. philos. Thorbjørn Dannevig Hauge». Særtrykk av Det norske videnskaps-akademis årbok 1990: 1-7. Oslo: Videnskaps-akademiet

Stenvik, L.F. 2003. «Iron Production in Scandinavian Archaeology». Norwegian Archaeological Review 36/ 2: 119-134.

Tveiten, O. 2012: Mellom aust og vest. Ein arkeologisk analyse av jarnvinna kring Langffella i yngre jarnalder og mellomalder. Doktoravhandling: Bergen. 


\title{
BLÄSTBRUK - FINNS DET EN SYSTEMATIK MELLAN TID, RUM OCH TYP?
}

\author{
Eva Hjärthner-Holdar, Lena Grandin och Svante Forenius
}

\section{INLEDNING}

Nya rön sprider nytt ljus även över tidigare undersökta järnframställningsplatser. Men hur får vi en adekvat terminologi/beskrivning av ugnarna? Vad är det som styr ugnstypen? Är det råvarorna t.ex. byggnadsmaterial och malm, funktion och/eller tradition? Hur stor inverkan har valet av malmtyp på hur man separerar slaggen från järnet och därmed också val av ugnstyp? Vilken inverkan har vår oftast ringa kunskap om antalet och storleken på ugnens blästerintag på hur vi tolkar ugnstypstillhörighet? Hur producerades järnet i t.ex. en stor ugn? Sist men inte minst viktigt - är ugnslämningens bevarandegrad tillräcklig för att tolka ugnen? Detta är frågor som vi kommer att diskutera och exemplifiera för att därefter försöka påbörja ett sätt att definiera ugnarna. Detta är ju naturligtvis inget nytt och flera forskare har under årens lopp brottats med dessa frågor. Tyvärr har man ofta hamnat i ett virrvarr av typer, betecknade med ett egennamn eller en lång rad bokstäver och siffror medan andra har sett ugnarna mer som varianter på ett tema med få egentliga typer, där en del även varnar för, för mycket terminologi och ugnstyper (se t.ex. Coghlan 1956; Cleere 1972; Serning 1979; Martens 1983; Björkenstam 1990; Narmo 1996; Englund 2002). Englund går i sin avhandling från 2002 igenom det mesta av svenskt blästbruk både vad gäller arkivalier, inventerat material och utgrävda platser. Han ställer också upp ett schema för blästugnarnas förändring under 3000 år, vilket betyder, för Sveriges del, från mellersta bronsåldern till nutid. Idag är ett mycket stort antal blästor från olika tidsperioder och miljöer undersökta i Sverige och en del är funna i större grupper och för det mesta finns flera ugnar vid ett och samma slagvarp. Slaggtappningsugnar förekommer nästan inte alls i Sverige förrän under medeltid.

Idag är det nog ingen inom nordisk järnforskning som ifrågasätter påståendet att alla våra blästugnar är schaktugnar. Idéer om att det skulle finnas ugnar som t.ex. skall betecknas som gropugnar i Skandinavien är det nog få eller ingen som håller med om idag. Begreppet gropugn har dessutom, även om beteckningen fanns med bland begreppen från början, med all sannolikhet, lite slentrianmässigt, använts av arkeologer som beteckning på i första hand den grop som finns kvar av ugnen i tron att det var hela ugnen. Istället är det fråga om slagguppsamligsgropen eller ett, till stora delar nergrävt/ingrävt, ugnsschakt med slagguppsamling nederst. En regel som kan vara användbar när man, åtminstone i Sverige, rekonstruerar ugnar är att höjden bör vara dubbla diametern över blästerhålet. Detta påstående är, som vi ser det, relaterat till malmtyp och malmens kemiska sammansättning (Björkenstam 1990:44 och anförd litt.). Dessutom har försök med bergmalm/magnetit i en blästugn, i vilken järn från myrmalm först framställts experimentellt, visat att ugnen behövde höjas ca. 25 \% för att bergmalmen/magnetiten skulle reduceras till järn (Hjärthner-Holdar 1996; Larsson et al. 1998).

En faktor som oftast är svår att få ett adekvat svar på i våra arkeologiska undersökningar är hur blästern är tillsatt eller inte tillsatt d.v.s. bläster genom naturligt drag. Det gäller dock inte bara om det är det ena eller andra utan också hur många blästerintag/formor ugnarna har haft. Vi återkommer till detta problem i samband med de stora bottenslaggerna som finns i en del ugnar och de två tunga obearbetade lupparna från Torsåker i Gästrikland (Englund 2002: 304f; Hjärthner-Holdar et al. under tryckning).

Många gånger utgör den bevarade delen av ugnen en mycket liten del av ugnens ursprungliga storlek och det är slagguppsamlingsgropen som i första hand är bevarad och direkt mätbar eller också den grop, oftast grund, som finns även i slaggtappningsugnarna. Gropen kan dock vara grund av andra orsaker, t.ex. på grund av plöjning. Detta påvisar klart vikten av att ta tillvara avfallsmaterialet och ju sämre bevarad ugn desto viktigare blir avfallsmaterialet. Slaggformer, byggnadsmaterial, bränsle och slaggavskiljningsmaterial från ugnarna avslöjar en mängd konstruktions- och processdetaljer. Det är både form och innehåll som är centralt. Men det handlar också om att en förståelse finns för vad som är tekniskt möjligt om man skall kunna tolka materialet. Det finns en mängd fantasifulla beskrivningar gjorda av arkeologer där det tydligt framgår att kunskapen om vad som är tekniskt möjligt eller omöjligt inte finns. Om vi är ense om att alla de ugnar vi finner är schaktugnar är det 


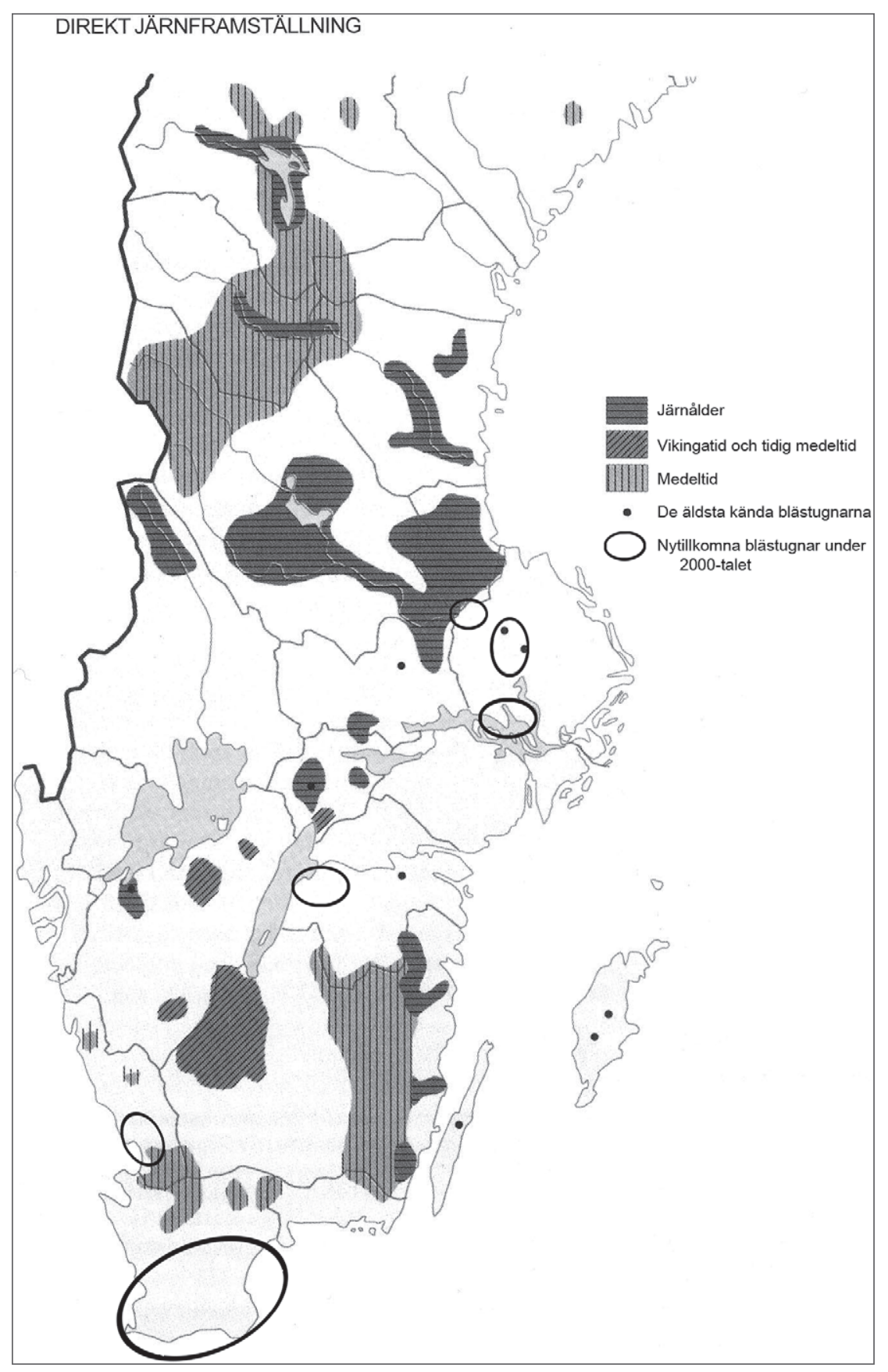

Figur 1: Karta från 1994 somvisar blästbrukets då kända utbredning, uppdelat på olika tidsperioder. Omarbetad efter Magnusson 1994b: 54, Englund 2002.

Figure 1: Map from 1994 showing the known extension of bloomery iron production at that time. Spatial distribution according to the result of the state organized survey of ancient monuments, including the beginning of the second survey (1974-1994). Revised after Magnusson 1994b: 54 and Englund 2002.

då i så fall funktion, design/konstruktion, materialval och tradition som ger skillnaden? Arkeologer ser t.ex. gärna slaggtappning som tillhörande en ugnstyp. Men vad är det som gör att det inom vissa områden utvecklas en ugnstyp eller rättare sagt en processtyp med slaggtappning och inte i andra? Vad styr valet av ugnstyp/processtyp över lag? Vi belyser dessa frågor med några exempel från olika delar av Sverige för att avslutningsvis starta en diskussion om vad som definierar en ugn - vilka är de viktiga komponenterna och faktorerna när vi talar om ugnstyper och deras förhållande till tid?

\section{REGIONALA SÄRARTER \\ - INTERREGIONALA LIKHETER}

\section{Bakgrund}

Regionaliserar vi för mycket för att vi i nutid vill markera särart? Kanske gör vi det omedvetet genom att namnge efter «upphittare», undersökare, beskrivare och genom platsnamn men även genom att finna detaljer som man inte tycker sig se någon annanstans. Är de grundlösningar järnframställaren väljer för ugnskonstruktionen regionala eller finns det ett större, interregionalt samband som vi borde utnyttja mer? Om vi börjar med 


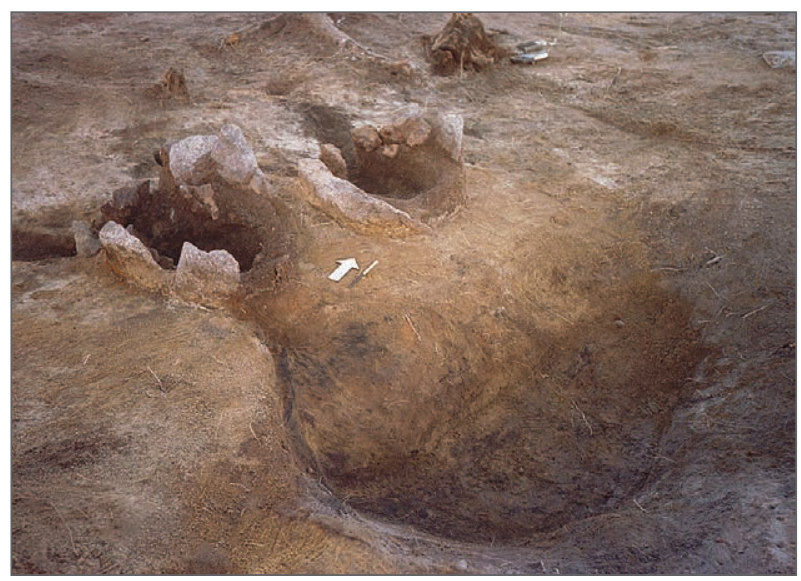

Figur 2a: Parugnar i Hedenstorp, Axamo, RÄ̈ 148, Sandseryds socken, Småland, Jönköpings län. Foto: GAL. Figure 2a: Paired furnaces during excavation, from Hedenstorp, Axamo, RAÄ 148, Sandseryd's parish, Småland, Jönköping county. Photo: GAL.

att jämföra utbredningen av järnframställningen under olika tidpunkter i Sverige, finner vi att den hela tiden förändras (figur 1). Områden tillkommer och andra tonas ner. Idag vet vi dock att vi har en järnframställning i Sverige som börjar i mitten av bronsåldern, kring ca. 1000 BC, och vars teknik delvis förändras över tid. Men det stora språnget är övergången från blästbruk till masugnsteknik och införandet av vattendrift, även om blästorna var i bruk ända fram mot 1900-talet, dock inte oförändrade. Vattendriften kom t.ex. även att nyttjas i blästbruket (Hjärthner-Holdar 1993; Buchwald 2004; Hjärthner-Holdar och Risberg 2009: 985).

Om vi nu tar några exempel på blästor i Sverige genom tiderna finner vi att det finns skillnader $\mathrm{i}$ storlek, form och val av byggnadsmaterial, med medföljande konstruktionsskillnader av t.ex. schaktet, olikheter i hur man gör med slaggen - slagguppsamling nederst i ugnen eller slaggtappning - och val av malmtyp. Men är dessa skillnader tids-, traditions- och/eller råvarurelaterade?

\section{Ugnsform/design}

Med ugnsform menas här vilket geometriskt utförande som ugnarna har. Det vi oftast har att utgå ifrån är slagguppsamlingsgroparnas form och lösa bevarade bitar av ugnsväggarna. Stenramsugnarna har en yttre form som i plan är något rektangulär under det att själva schaktet är rundat och byggt av lera innanför ramen. Det flesta schakt är rundade oavsett tid och plats men under sen vikingatid och tidig medeltid dyker det upp ugnar vars slagguppsamlingsgropar är helt kvadratiska till rek-

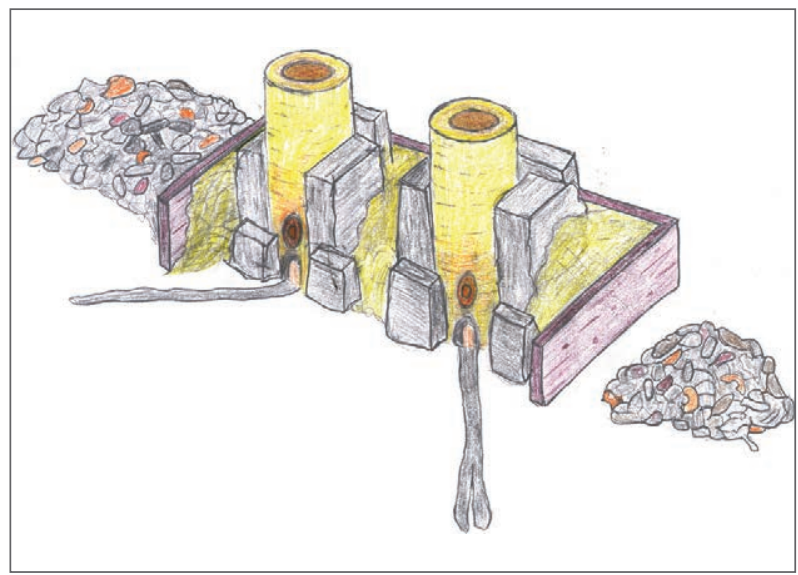

Figur 2b: Rekonstruktionsförslag for parugnarna. Teckning: GAL.

Figure 2b: Reconstructed paired furnaces. Drawing: GAL.

tangulära t.ex. i Markaryd i sydvästra Småland och Bredabäck i nordvästra Skåne. Schaktens bas är där fyrsidig men övergår i en rundad form högre upp (Forenius och Grandin 2005; Forenius et al. 2005). Detta är troligt med tanke på aerodynamiken och dess påverkan på processen och kontrollen av densamma. Sedan finns en osäkerhet om vilken geometrisk form schakten kan ha haft i profil. Är de t.ex. koniska eller cylindriska? Men det finns lokaler där man har kunnat konstatera att schakten är koniska eller svagt koniska och svängda som i fallet med ugnarna från t.ex. Bromölla i nordöstra Skåne och Ledsjö i Västergötland (Englund och Larsson 1997; Forenius et al. 2008). Möjligen har också ugnen från Söderåkra i östra Småland haft ett koniskt schakt. I dessa fall har bitar av ugnsväggar funnits i avfallet och möjliggjort en rekonstruktion (Englund et al. 1999). Detta visar hur viktigt det är att gå igenom och ta tillvara den information som finns $i$ detta material.

\section{Slaggtappning, en funktion}

För Sverige liksom för Danmark kan vi konstatera att slaggtappning är en sen företeelse och i Sverige dessutom i stort sett ett undantag under förhistorisk tid under det att det i t.ex. Norge förekommer ganska frekvent framförallt under yngre järnålder med tydlig fortsättning in i medeltid (se t.ex. Voss 1993: 206; Narmo 1996, Rundberget 2007, för en god sammanfattning Larsen 2009: 67 ff.). Vi kan också slå fast att malmerna som har använts i bl.a. Sverige ger mycket sega slagger även vid höga temperaturer och blir därmed mycket svåra att tappa. Att slagger- 

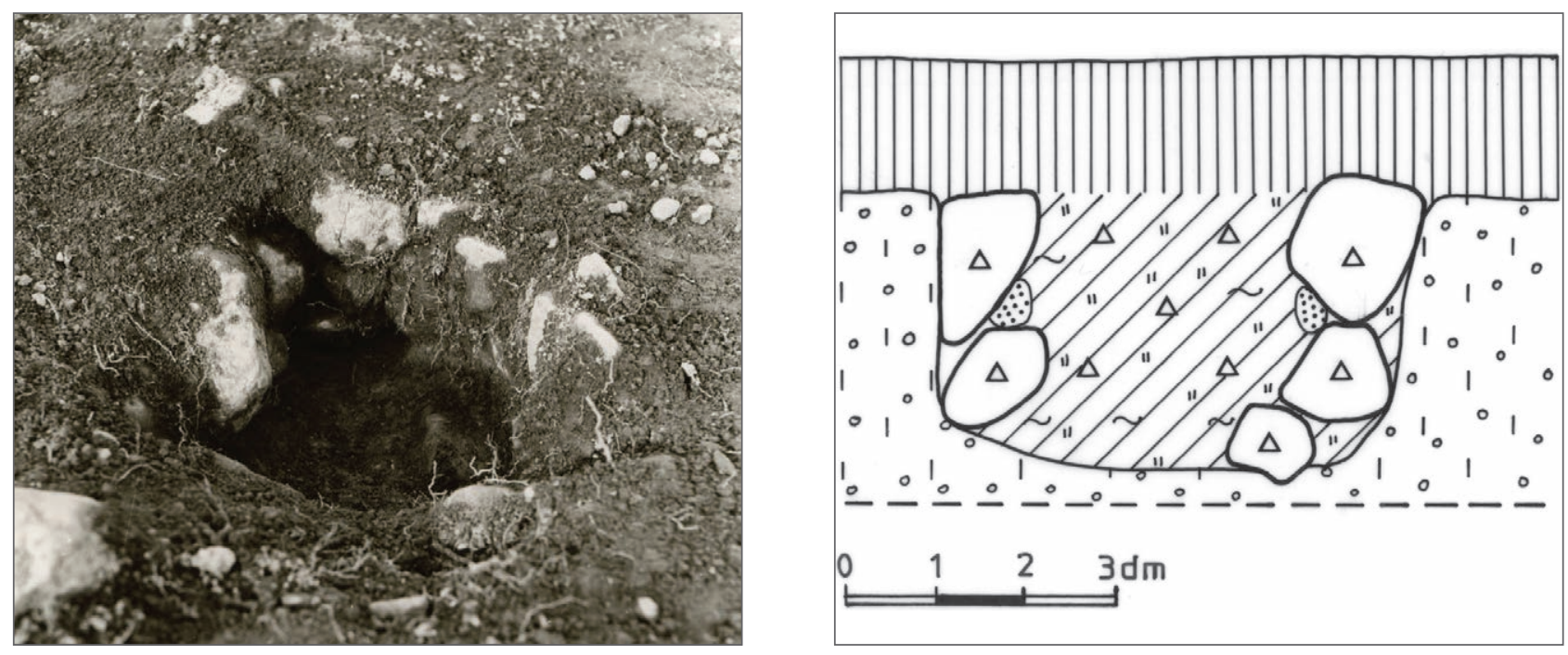

Figur 3: Blästugn från bronsåldern 1000-700 BC, Hällby Litslena socken, Uppland. Från Hjärthner-Holdar 1993.

Figure 3: Bloomery furnace during the Bronze Age, 1000-700 BC at Hällby, Litslena parish, Uppland. After Hjärthner-Holdar 1993.

na är svåra att tappa har troligen smederna vetat och det gör att innovationen att tappa slagg inte togs upp i någon större utsträckning inom nuvarande svenskt territorium. Detta påstår vi eftersom vi tror att man hade omfattande kontakter utåt och därmed tillgång till kunskapen om andra tekniker och att smederna gjorde ett val och då i huvudsak tekniken med slagguppsamlingsgrop. De parugnar som finns i sydvästra Sverige har dock tappats på slagg men man kan tydligt se att de har varit svårtappade då stora mängder slagg har fått krokas d.v.s. dras ut. Förutom tappslagg och krokad slagg bildas även en tunn bottenslagg (Englund 2002: 189 f.; Englund och Grandin 2002; Grandin 2009) (figur 2a och b). I Sverige kan vi se en viss ökning av tekniken med slaggtappning under medeltid och senare i blästugnar men ofta kan man se att slaggen är svår att tappa för att den har hög viskositet och har därför fått dras ut (Forenius et al. 2005).

\section{Ugnars och slaggers storlek/design och funktion}

Tar vi sedan och studerar ugnarnas inre diameter finner vi att storleksskillnader finns men att de inte är tydligt tidsbundna. För att med viss säkerhet kunna tidsbestämma ugnarna dateras de med ${ }^{14} \mathrm{C}$ vars kol är vedarts- och egenåldersbestämt. De äldsta mätbara ugnarna från yngre bronsålder är de minsta men dessa innermått återkommer även senare, samtidigt som vi har ugnar med stora innermått. Som exempel kan nämnas de små ugnarna från Hällby i Litslena socken i Uppland daterade till yngre bronsålder period IV, där bottenslaggernas diameter inte överstiger 0,2 meter och ugnarnas innermått troligen är ca. 0,3 meter (Hjärthner-Holdar 1993: 80 ff. och 99 f.) (figur 3a och b). Exempel på ugnar med ett litet innermått men daterade till yngre järnålder och tidig medeltid är bl.a. en ugn från Romme i Tuna socken i Dalarna där bottenskållan mätte ca. 0,3 meter i diameter under det att ugnar från Södra Järnvirke, fornl. 85, Sibbarps socken i Skåne har en innerdiameter på endast 0,2 meter (Strömberg 2004: 124). På den förstnämnda platsen, fast daterade till romersk järnålder och folkvandringstid, är ugnarna betydligt större upp mot $0,7 \mathrm{~m}$ i innerdiameter (Hjärthner-Holdar et al.1995)

Mycket näraliggande lokaler som visar att det finns en svag koppling mellan tid och storlek är några av järnframställningsplatserna vid södra änden av Vibysjön i Viby socken i Närke. Järnframställningen här är daterad från romersk järnålder till sen vikingatid och som figur 4 visar finns det en liten antydan till att de tidiga ugnarna är något mindre $\mathrm{i}$ innermått än de sena och innerdiametern varierar mellan ca. 0,35-0,9 meter. Den vanligaste innerdiametern är dock 0,5-0,6 meter. Samtidigt kan vi också notera att det finns en variation i storlek för samtida ugnar. Inte långt ifrån denna lokal i Lillkyrka socken i Närke undersöktes en ugn vars innerdiameter var ca. 0,7 meter och i slagguppsamlingsgropen fanns en väl sammanhållen bottenslagg som vägde ca. $120 \mathrm{~kg}$. Ugnen dateras till yngre romersk järnålder (Grandin och Hjärthner-Holdar 2003a: 403 ff. och 412 ff.).

De s.k. stenramsugnarna, i t.ex. i Hardemo socken i Närke, Röda Jorden i Västmanland, ugnen från 


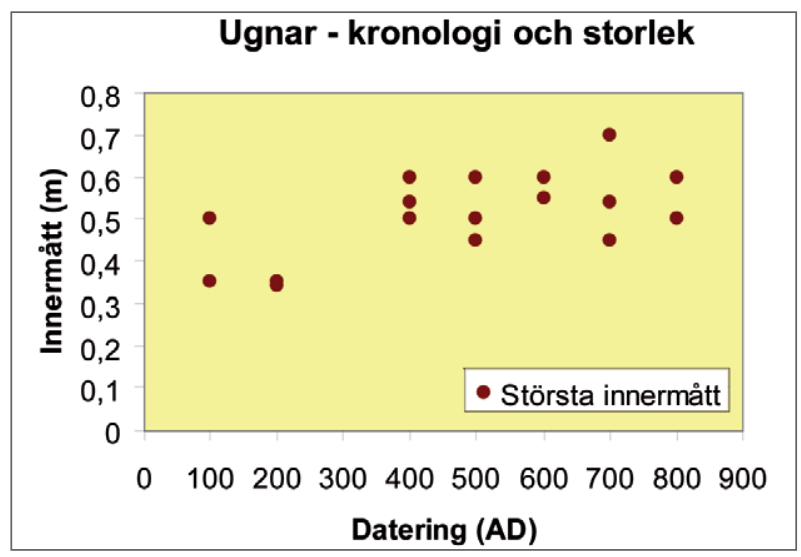

Figur 4: Innerdiametermått hos ugnar från närliggande platser $i$ Viby socken, Närke, över tid.

Figure 4: Graph presenting variations of furnace size (inner diameter) with time. Furnaces from several nearby sites in Viby parish, Närke.

Stalbo i nordvästra Uppland och Essungaugnen i Västergötland har vanligen ett innermått av $0,4 \times 0,5$ meter men $0,5 \times 0,6$ meter förekommer. Det finns en antydan till att schakten är något ovala (Wedberg 1984: 155 ff.; Magnusson 1985: 49 ff.; Hansson 1989: 86, Forenius 1990).

Ett exempel på en tidig stor ugn är ugnen från Eket i Söderåkra socken i Småland, närmare bestämt i södra Kalmar län daterad till förromersk järnålder (400-200 BC). Ugnens innermått var 0,7×0,6 meter med en slaggrop vars djup var ca. 0,9 meter (Englund et al. 1999; Magnusson och Rubensson 2001: 337 ff.) (figur 5a och b).

Stora ugnar som dateras inom tidsspannet från

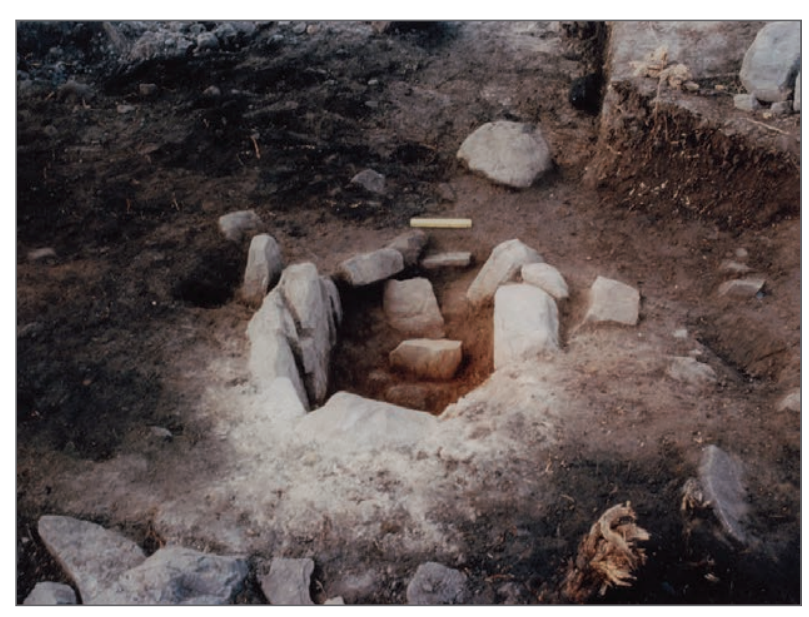

Figur 5a: Slaggrop till blästugn från förromersk järnålder, Eket, Söderåkra socken i Småland. Foto: GAL.

Figure 5a: Slag pit in the bloomery furnace from Pre-Roman Iron Age in Eket, Söderåkra parish in Småland. Photo: GAL. romersk järnålder till och med vikingatid med en innerdiameter på ca. 0,7-0,8 meter och där slagguppsamlingsgroparna är stenbyggda är t.ex. de från Valbo i Gästrikland, vilka i sin tur har gemensamma drag med Trøndelagugnen och Østlandsugnen där den sistnämnda dock ej är hästskoformad men har en innerdiameter som överstiger 1 meter i diameter (Appelgren och Broberg 1998; Stenvik 2005: 109 ff.; Forenius et al. 2007; Larsen 2009: 73 f.) (figur 6a-c).

Både i stenramsugnarna, ugnen från Söderåkra, ugnen från Stomskil och ugnarna i Valbo har stora bottenslagger bildats men också mindre bitar stearinslagg. Skillnaden ligger dock i storleken på bottenslaggerna. Stenramsugnarnas och Söderåkraugnens bottenslagger väger runt $50 \mathrm{~kg}$ under det att bottenslaggen i Stomskil, som fyllde hela utrymmet, respektive bottenslaggerna i Valbougnarna väger $120-350 \mathrm{~kg}$, figur $6 \mathrm{a}$ och $\mathrm{b}$. Bottenslaggerna i de förstnämnda var mycket välformade, täta och hållfasta till skillnad från de från Stomskil och Valbo som var lätta att bryta sönder (Englund och Larsson 1999; Englund et al. 1999; Grandin och Hjärthner-Holdar 2003a: 412 ff.; Forenius et al. 2007).

En ugnstyp med liten innerdiameter som mestadels dateras till vikingatid och tidig medeltid är de s.k. parugnarna, påträffade i t.ex. Tranemotrakten i Västergötland och i Axamo i Sanseryds socken i Småland, vars innerdiameter oftast inte överskrider 0,3 meter (Björck 1991, Nordman 1994; Englund 2002: 189 ff., Englund och Grandin 2002; Lorentzon 2008; Grandin 2009).

De ovan omtalade ugnarna är alla flergångsug-

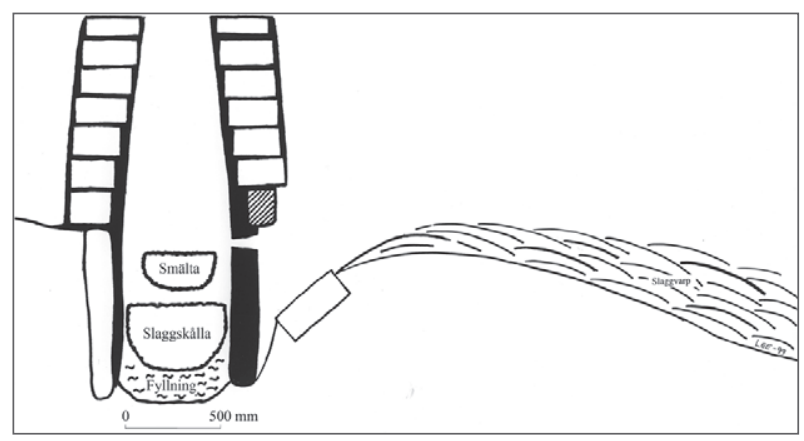

Figur 5b: Rekonstruktionsförslag på ugnen från Söderåkra. Pipmuren är byggd av huggna sandstenar och väggen har sannolikt också varit lerslammad både på ut-och insidan. Dessutom finns en sten som kan ha använts vid utdragningen av slaggblocken. Rekonstruktion och teckning: GAL.

Figure 5b: The bloomery furnace from Söderåkra reconstructed with sandstone slabs, lined with clay. The slag is interpreted to have been removed along a large sloping stone. Reconstruction and drawing: GAL. 

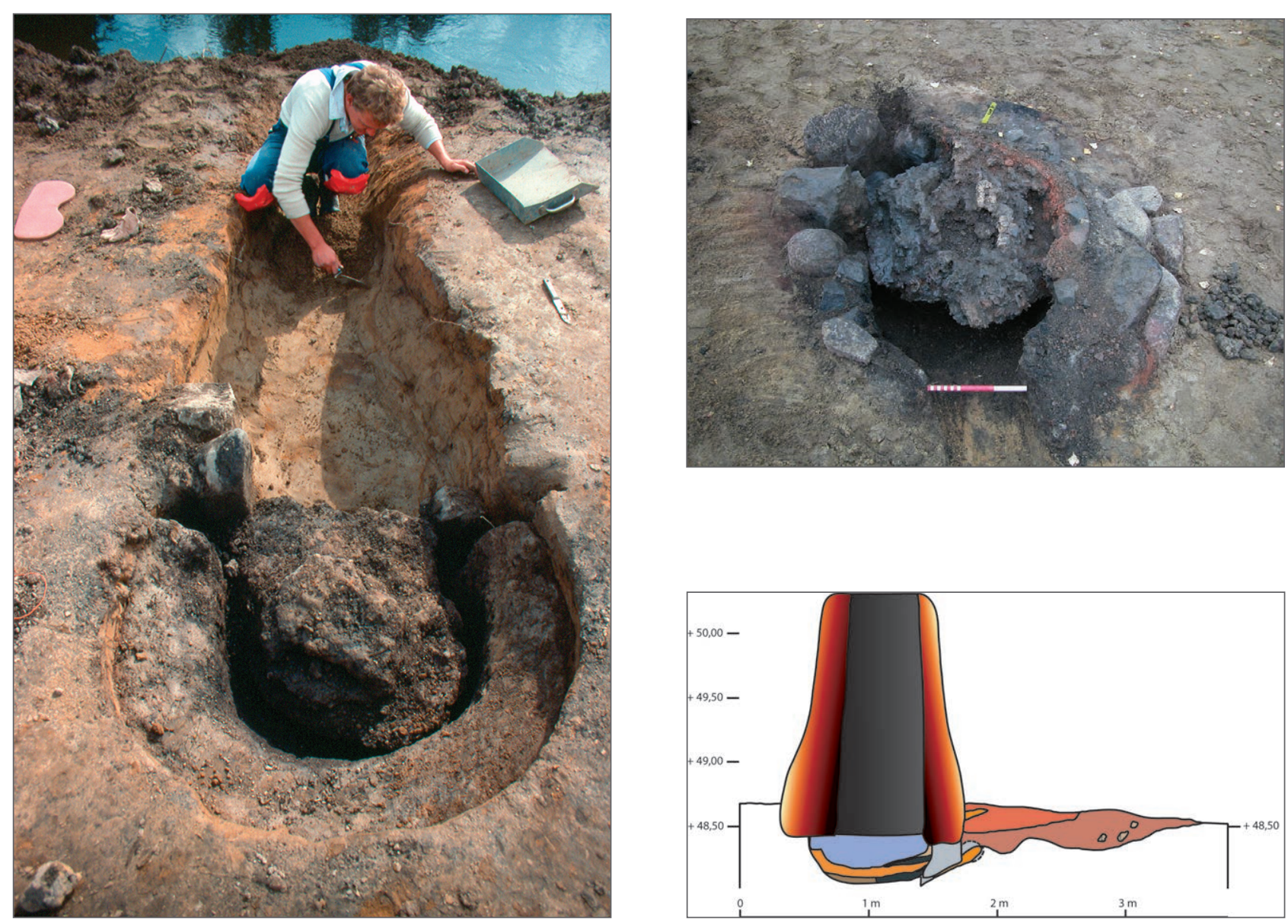

Figur 6a-c: Två exempel på större ugnar med stenbyggd slagguppsamlingsgrop med kvarlämnad slagg, från Valbo socken, Gästrikland. Ugnen i A från Åsbyggeby (Appelgren och Broberg 1998), uppvisar en tydlig bästskoform. C) Rekonstruktionsförslag på ugnen i B, från RAÄ 412 i Valbo socken. Foto och teckning: GAL.

Figure 6a-c: Two examples of large bloomery furnaces with slag pits built by stones. In both, large slag blocks were left. The furnace in $A$, from Asbyggeby, has a horseshoe shape. In C a reconstruction of the furnace in B, from RAÄ 412 in Valbo parish. Photo and drawing: GAL.

nar d.v.s. ugnar som tömts på slagg genom en öppning i nedre delen innan de återanvänts igen utan att schaktet kommit till skada. Under delvis samma tid som flergångsugnarna finns det andra typer av ugnar som tillhör typen engångsugnar d.v.s. sådana ugnar som inte återanvänts utan endast använts för en körning. Man bygger således en ny ugn för varje körning. De dateras huvudsakligen till romersk järnålder även om senare dateringar till yngre järnålder också finns. Ett bland flera exempel på sådana ugnar finns bl.a. från Ledsjö socken i Västergötland. Här påträffades ett 75-tal ugnar vilka med all sannolikhet kan definieras som engångsugnar av typen gropschaktugnar/schaktugnar med underliggande slagguppsamlingsutrymme. Innerdiametern var i marknivå ca. 0,45 meter vilken minskade uppåt $\mathrm{i}$ schaktet för att överst vara ca. 0,2 meter (Forenius et al. 2008) (figur 7). Ugnen har drag som starkt påminner om ugnstypen från t.ex. Scharmbeck i nord- västra Tyskland (Wegevitz 1957: 3 ff.). Ytterligare undersökta ugnar av i stort samma typ har påträffats i Bromölla i nordöstra Skåne. Dessa har en innerdiameter i marknivå på ca. $0,45 \times 0,7$ meter med en troligen minskande diameter uppåt $\mathrm{i}$ schaktet. Men vad som är frapperande med dessa ugnar är att de inte, som de danska och kontinentala ugnarna, producerar stora sammanhållande bottenslagger utan endast mindre bottenslagger kombinerat med stearinformade mindre slaggstycken (Englund och Larsson 1997; Pleiner 2000: 70 ff.; Englund 2002: 256 f.). Här måste man nog säga att det föreligger en annan ugnsteknologisk tradition vad gäller både konstruktion och produktionsidé i förhållande till flergångsugnarna men här finns även en skillnad gentemot de kontinentala engångsugnarna d.v.s. gropschaktugnarna vad gäller slaggbildningen.

Detta är endast ett axplock av ugnar men det framstår som om likheter i storlekar finns över större 
områden men samtidigt finns tydliga regionala skillnader och eventuellt även tidsskillnader bl.a. vad gäller bottenslaggernas storlek och form trots likhet $\mathrm{i}$ innerdiameter. Ligger således skillnaden i hur mycket man producerar per körning och eller i slaggbildningen där somliga ugnar också bildar mindre slaggstycken av mestadels stearintyp?

\section{Byggnadsmaterial}

Om vi sedan ser till byggnadsmaterial och konstruktion finner vi också skillnader, men av vilken orsak? Det finns en mängd kombinationer av tekniker och byggnadsmaterial. Om vi undersöker de ugnar som nämnts ovan där så är möjligt d.v.s. där det går att finna ut både vad schakten och slagguppsamlingsgroparna tillverkats av finner vi att översiktligt är det lera, sten och vidjor i en rad olika kombinationer som förekommer och dessutom finns vissa skillnader i hur leran, i vissa fall den grovkornigare silten, har behandlats. I norra Sverige syns avsaknaden av lera tydligt då sådan inte är vanligt förekommande i dessa trakter. Det kan också nämnas att «ugnsleran» i ugnarna från Röda Jorden definitionsmässigt sett är silt.

Men vi börjar med de äldsta ugnarna, de från Hällby i Uppland. Dessa har en slagguppsamlingsgrop som är byggd av sten, upp till ca. 0,1-0,15 meter stora, som fogats samman med lera. Schakten är uppbyggda av en grov eller osorterad siltig lera innehållande bl.a. kvarts, som hämtats alldeles intill järnframställningsplatsen. Materialet har lämpliga termiska egenskaper för de temperaturer som erfordras för järnframställning.

Går man sedan framåt $\mathrm{i}$ tiden finner vi de tidigaste stenramsugnarna, som dateras till ca. 700-talet BC, i Röda Jorden. Ugnarna är ingräv$\mathrm{da} /$ nergrävda och omges ibland av en isolerande kulle. De är uppbyggda av en något, ibland helt, rektangulär stenram av hällar med en öppning mot en arbetsgrop/bälggrop vilken flankeras av två portalstenar med överliggare. Innanför ramen är schaktet uppbyggt av ett tämligen grovt material bestående av silt som tagits från bäckkanter vilken sedan blandats både med organiskt material och med småsten av bl.a. värmetålig glimmerskiffer. Från en del schakt finns dessutom avtryck av vidjor som visar att vidjorna $e j$ varit täckta med lera mot ugnsschaktet. Leruppbyggnaden av schakten gör dem rundade. Mellan portalstenarna sätts en kraftig lerplatta/forma in med ett blästerhål ca. 0,3 meter över markytan vilket ger ett slaggutrymme på ca. 0,3 meter i höjdled. Under tiden 700 $\mathrm{BC}$ till $\mathrm{AD} 200$ sker i princip inte någon föränd-

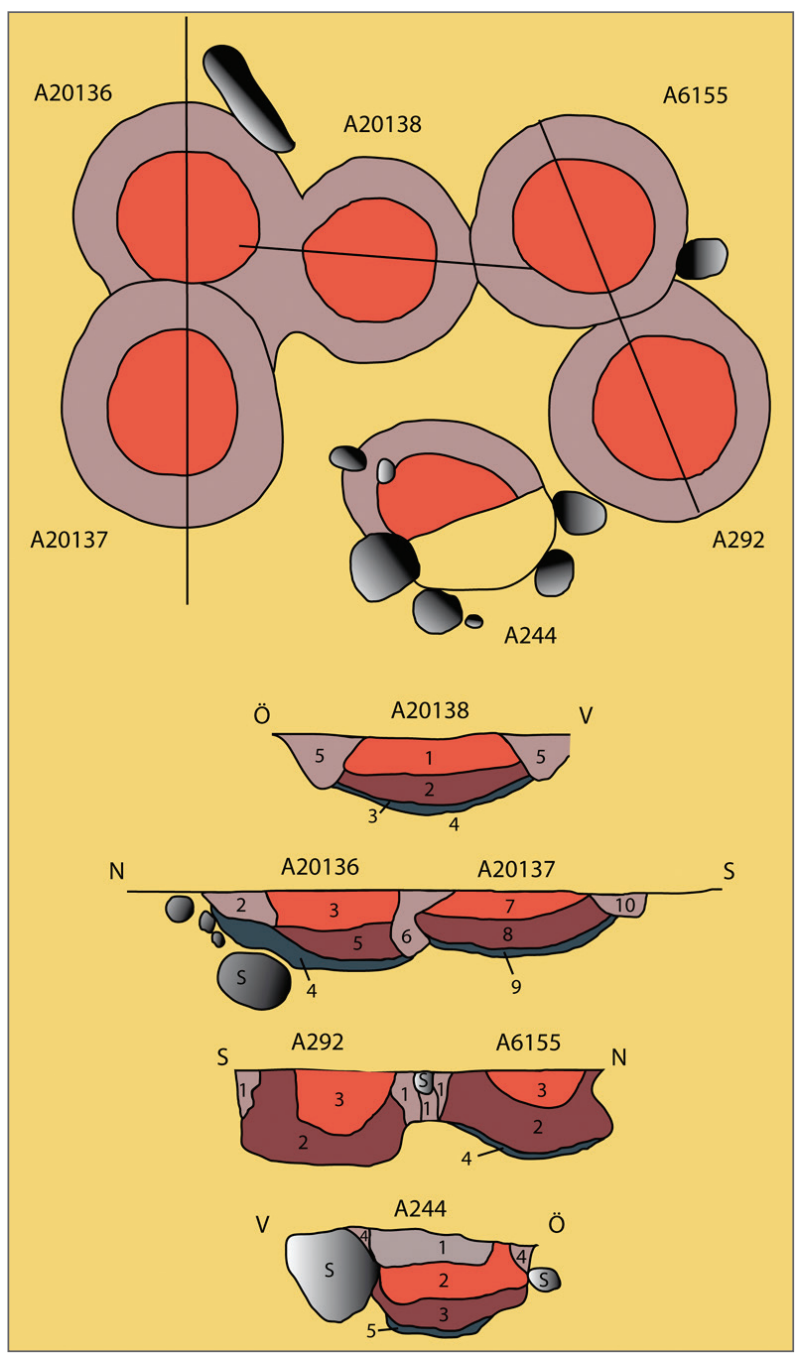

Figur 7: Grupp av slagguppsamlingsgropar till blästugnar i Ledsjö socken, RÄ̈ 150, Västergötland. Teckning: GAL. Figure 7: Cluster of slag pits in Ledsjö parish, RAÄ 150, Västergötland. Drawing: GAL.

ring av konstruktionen (Wedberg 1984: 155 ff.; Grandin och Hjärthner-Holdar 2000; Grandin och Hjärthner-Holdar 2003b: 34) (figur 8).

Ugnen från Stalbo i Uppland har i princip samma typ av konstruktion (Forenius 1990).

Jämför vi sedan med Söderåkraugnens konstruktion är den ingrävd/nedgrävd med ett något ovalt, hästskoformat slagguppsamlingsutrymme som är byggt av valda klumpstenar med en flat sida som vänts inåt $\mathrm{i}$ ugnen och som slammats med ett tunt lager lera. Här finns portalstenar för infästning av ett lerblock i vilket blästerhålet möjligen satt. Dessutom finns en sten med 45 lutning som kan ha använts vid utdragningen av slaggblocken. Schaktet är byggt av liggande huggna sandstenar och väggen har sannolikt också varit lerslammad både på ut- och insidan. Detta sätt att konstruera schaktet 


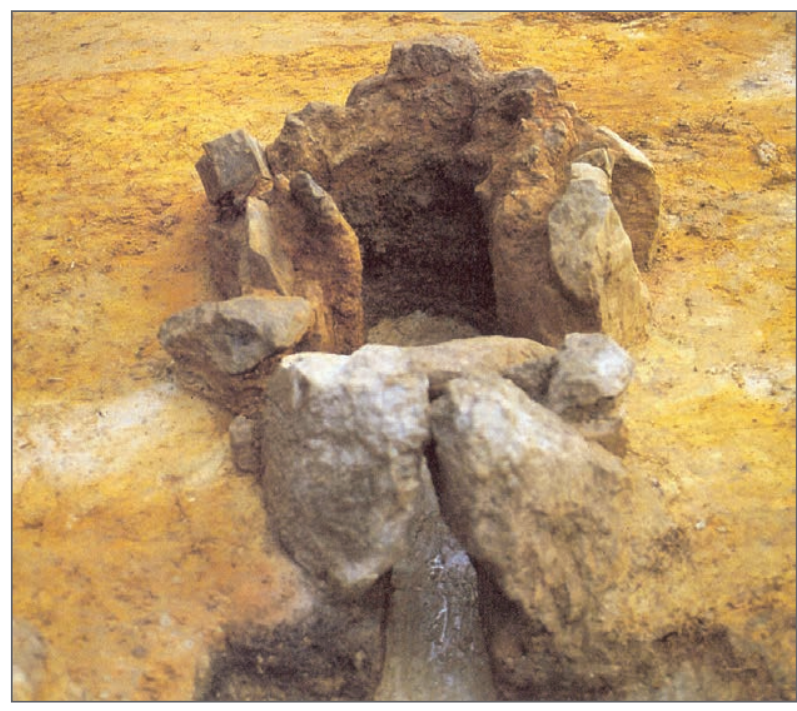

Figur 8: Utgrävd blästugn med till stor del kvarstående schakt av lera, Röda jorden, Riddarhyttan, Skinnskattebergs socken, Västmanland. Efter Wedberg 1988.

Figur 8: Excavated bloomery furnace with partially remaining shaft of clay. Röda Jorden, Skinnskatteberg's parish. Västmanland. After Wedberg 1988.

på är hittills ensamt i sitt slag i Sverige (Englund et al. 1999), figur 5a och b. Dock är också pipmuren i Stomskil byggd av större kantig sten med en fodring av lera. Möjligen har den sistnämnda även haft en timmerkonstruktion ytterst med mull mellan pipmur och timmerkonstruktionen (Englund och Larsson 1999).

Från förromersk järnålder och framåt finns det många exempel på flergångsugnar som är byggda av lera med en armering av vidjeflätning både där vidjeflätningen är förankrad i marknivå och nere i den grävda gropen för slagguppsamlingen. Ett exempel på denna konstruktionstyp från Mellansverige är de 20-tal ugnar som undersöktes i Viby i Närke där en del har en sten- och leruppbyggd slagguppsamlingsgrop med ett lerschakt $\mathrm{i}$ marknivå som armerats med vidjor och som lerklätts på båda sidor. I den andra typen börjar den vidjearmerade konstruktionen redan i den grävda gropen och omgärdar således även slagguppsamlingsgropen. Det finns ingen tydlig kronologisk skillnad mellan de båda konstruktionssätten utan under hela den tid som ugnar byggs i området d.v.s. från förromersk järnålder till och med vikingatid, har sätten växlat. Leran till schakten uppvisar olikheter som t.ex. att ugnarna på ena sidan bäcken är hår-/tagelmagrade men inte de på den andra sidan trots att de är samtida. Under sen bronsålder och förromersk järnålder fanns det också ugnar som huvudsakligen har varit stenbyggda, möjligen med en fodring av lera och som troligen helt saknar vidjeflätning. Detta kunde konstateras utifrån ugnsväggsbitar och andra byggnadsdetaljer som påträffades i avfallet. Det som fanns bevarat i de plöjda åkrarna var endast slagguppsamlingsgroparna, pinnhålen och de förkolnade resterna efter de tillspetsade lodräta vidjorna. De sistnämnda påträffades i den kolbemängda fyllningen i slagguppsamlingsgroparna (Grandin och Hjärthner-Holdar 2003a: 401 ff.) (figur 9a-f).

Ugnarna i Valbo har i sin tur, utifrån bevarade delar, kunnat konstateras ha en i stort sett likartad konstruktion från romersk järnålder till och med vikingatid och som förut påtalats uppvisar de konstruktionsmässiga likheter med Trøndelagsugnarna (Stenvik 2003: 77 f.). Möjligen är det dock så att bottenslaggerna i Valbougnarna tenderar att bli något tyngre med tiden. Däremot ser inte innerdiametern ut att ha förändras särskilt mycket över tid. De är som stenramsugnarna hästskoformade. Skillnaden mellan stenramsugnarna och ugnarna i Valbo är att slagguppsamlingsgropen i de senare är byggda av mindre stenar, tätt sammanfogade, men med i vissa fall också tydliga portalstenar precis som hos stenramsugnarna. Schakten är med stor sannolikhet cylindriska eller koniska och byggda av en lokal naturligt mellangrov till grov lera med goda termiska egenskaper. Schaktet har haft en armering av vidjeflätning. Väggens tjocklek vid basen har varierat något från 0,3 meter på sidorna till som mest 0,6 meter på motstående väggen mot arbetsgropen alternativt blåsväggen (Forenius et al. 2007).

Ytterligare ugnstyp som är viktig att diskutera omfattar de s.k. parugnarna. Dessa består av två cylindriska eller svagt omvänt koniska schakt i en stenkista. Schakten är lerfodrade med plan något lutande botten mot formvägg och slaggränna, figur 2a och b. Man skulle kunna säga att dessa ugnar inte uppvisar något egentligt släktskap med andra ugnstyper i Sverige (Englund 2002: 189 f.; Englund och Grandin 2002).

De ovan beskrivna ugnarna är alla flergångsugnar. De har alla en tämligen rustik konstruktion och är inte svåra att reparera. Men, vi avslutar med att granska hur de s.k. engångsugnarna som påträffats i Sverige är konstruerade med hjälp av exemplet Ledsjö i Västergötland. De 75 ugnarna som fanns inom exploateringsytan var i princip av samma konstruktion. De hade tunna väggar av växtmagrad lera med ett invändigt flätverk som ej täckts av lera förutom vid basen. Schakten var fristående i marknivå där även en del pinnhål efter vidjeflätningen kunde skönjas på ett inbördes avstånd av 40 millimeter. 

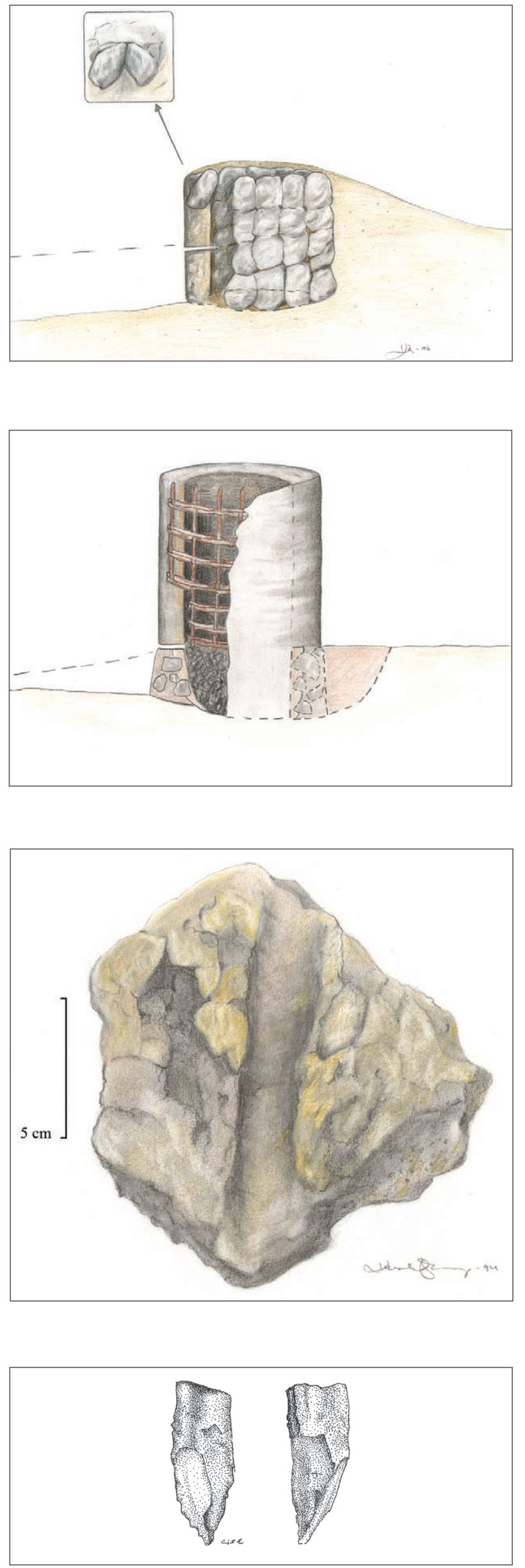

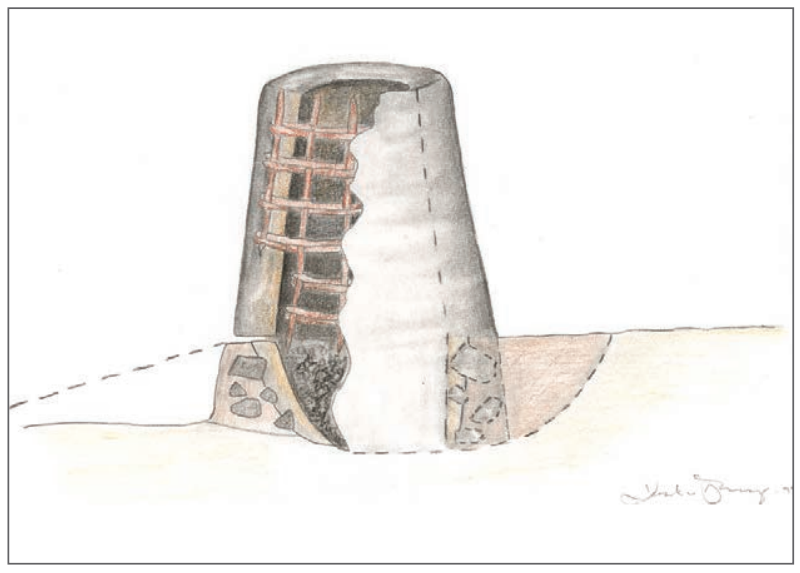

Figur 9 a-c: Några av de rekonstruerade blästugnarna från Viby socken, Närke. A) stenbyggd från förromersk järnålder, B) och C) ler-och stenbyggd från vikingatid med cylindriskt respektive koniskt schakt.

Figure 9 a-c: Three of the furnace types excavated in Viby parish, Närke. A) a reconstructed furnace dated to Pre-Roman Iron Age, B) and C) reconstructed furnace dated to the Viking Age.

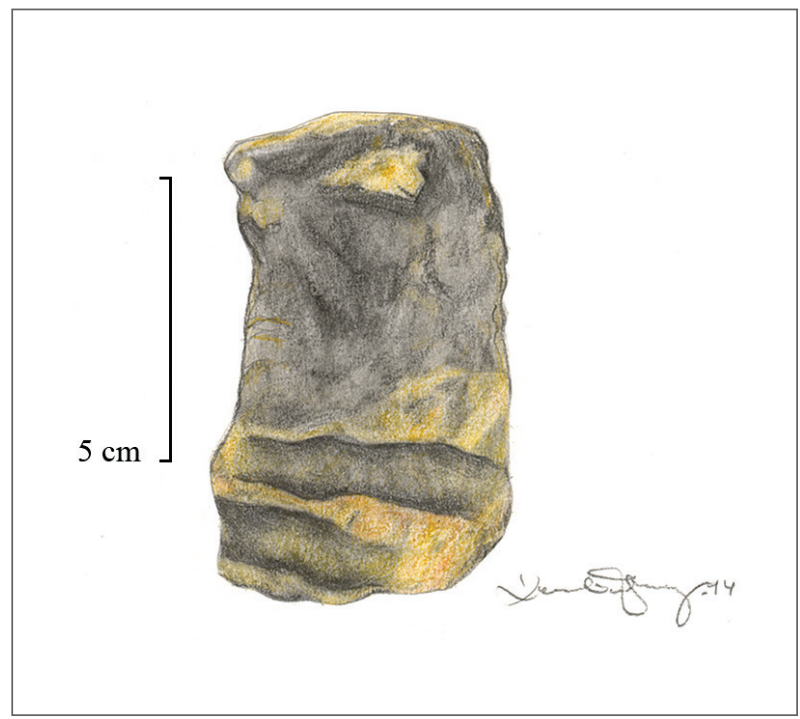

Figur 9 d-f: Konstruktionsmaterial till ugnsväggarna. D) lera frän väggen med avtryck efter lodräta vidjor, E) efter horisontella vidjor, F) nedre delen av tillspetsad vidja. Rekonstruktion GAL. Teckning K. Äberg A-E, L. Engblom F.

Figure 9 d-f: Furnace construction material. D) Fragment of furnace wall with imprints of the vertical wooden rods in the wattle, E) with horizontal imprints $F$ ) the pointed lower parts of wooden rods. Drawing K. Aberg A-E, L. Engblom F. 
Flätverket brändes av vid körningen och tillsammans med den tunna pipväggen medförde det att den eventuella rivningen av schaktet underlättades (figur 10). Konstruktionen minimerar också åtgången på byggnadsmaterial (Forenius et al. 2008).

\section{Slaggavskiljare/funktion}

Slaggavskiljare har vi konstaterat i de flesta ugnar men av helt olika slag. I ugnarna från Viby i Närke precis som i ugnarna från Valbo har man använt sig av vedkluvor av tämligen stora dimensioner (Forenius et al. 2007) (figur 11). De har endera ställts relativt tätt packade på högkant eller travats horisontellt. Prov på andra material som använts som slaggavskiljare är t.ex. vass i en ugn från Stomskil i Närke och i Ledsjö har halm och kvistar eller ris använts (Forenius et al. 2008). Avtryck i slaggen avslöjar oftast vilket avskiljningsmaterial som använts, t.ex. i Stomskil, i andra fall har vi funnit rester av materialet både $\mathrm{i}$ botten av ugnen och som avtryck i slaggen (Grandin och Hjärthner-Holdar 2003b: 415f) (figur 12). I många fall är det just slaggen som avslöjar viken typ av avskiljare man använt. I andra fall kan det finnas rester av det organiska material som utgjort slaggavskiljaren, t.ex. kvistar av hassel i ugnar från Stafsinge socken, Halland (Danielsson 2001). Återigen är det avfallsmaterialet som är viktigt för inhämtning av kunskap.

\section{Lufttillförsel/funktion}

Det svåraste att bedöma i järnframställningen är lufttillförseln. De flesta ugnslämningar är inte tillräckligt välbevarade för att vi ska kunna avgöra hur lufttillförseln har skett, eller framförallt hur många blästeringångar som en ugn har haft. Här är det återigen i avfallsmaterialet som vi finner några svar bl.a. blästeringångarnas diameter, vilken kan avslöja om det rör sig om naturligt drag eller tillförd bläster. Vanligen överstiger inte blästeringången för tillförd bläster $35 \mathrm{~mm}$. Undantag finns naturligtvis om man t.ex. haft två bälgar i samma blästeringång. Troligt är, vad gäller svenska ugnar, att de flesta har drivits med bälgar. Dessutom är det troligt att en del av schaktugnarna, med ett innermått som inte överskrider 0,5 meter och eller så länge slaggskållan inte väger mer än $50 \mathrm{~kg}$, mycket väl kan ha drivits med en bälg. Detta är naturligtvis hypotetiskt men inte helt orealistiskt. Frågan är hur ugnarna med 150-350 kg stora bottenslagger har drivits. Som utgångspunkt kan vi ta de två obearbetade luppar från Torsåker i Gästrikland som väger 25 respektive $33 \mathrm{~kg}$ (Englund 2001; Englund et al. 2001; Englund 2002: 304f; Hjärthner-Holdar 2009). Längdmåtten

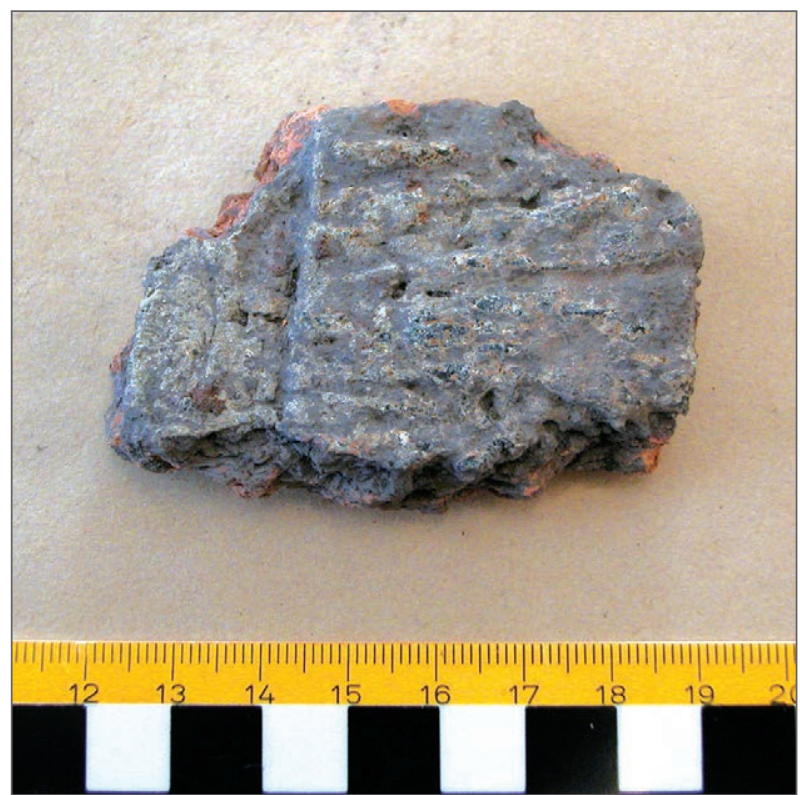

Figur 10: Ett fragment av en tunn ugnsvägg av växtmagrad lera med avtryck av ett invändigt fätverk, från en av ugnarna $i$ Ledsjö socken, RAÄ 150, Västergötland. Foto: GAL.

Figure 10: A fragment of a furnace wall from one of the furnaces in Ledsjö parish Västergötland. The clay is tempered with organic material and has imprints of wattle. Photo: GAL.

på dessa är ungefär hälften av Valbougnarnas diameter. Om man menar att bottenslagger på 150$350 \mathrm{~kg}$ härrör från ett körningstillfälle och förhållandet mellan slagg och järn är 1:1, betyder det att det borde bildas en lupp av i stort sett samma vikt. Men hur kan man hantera det? Kan det inte vara så att det istället bildas ett antal luppar vid körningen t.ex. sex luppar gånger $25 \mathrm{~kg}$. Det skulle kunna betyda att vi kan ha att göra med sex blästerintag om vi antar att det bildas en lupp vid varje intag. Detta skulle i så fall, enligt Englund (2002: 246), vara en sexima ugn. Men det gäller att vara försiktig. Mängden slagg som anges för en slagguppsamlingsgrop är ibland den totala mängden slagg. Här kan finnas fällor som t.ex. den totala slaggmängden från en av Valbougnarna. Här kunde vi konstatera att en slaggskålla från en äldre ugn delvis fått utgöra fundamentet till den nya ugnen, vilket får till följd att om vi hade räknat all slagg i uppsamlingsgropen som tillhörande en körning hade det blivit fel mått på möjlig mängd producerat järn per körning (Forenius et al. 2007).

\section{HUR KAN VI DEFINIERA UGNAR?}

Med all tydlighet visar den ovan gjorda exposén, av ugnar från olika tider, att det finns röda trådar som man kan följa för att finna ett sätt att definie- 


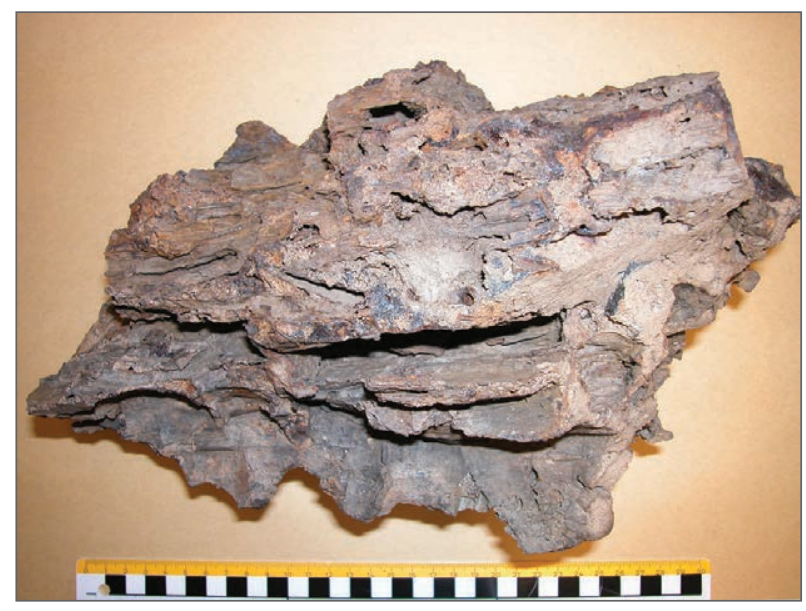

Figur 11: En del av ett av de stora slaggblocken från en av ugnarna i Valbo socken, Gästrikland, med tydliga horisontella parallella vedavtryck. Foto: GAL.

Figure 11: A part of a slag block from Valbo parish Gästrikland. A slag block with parallel horizontal wooden imprints in its lower part. Photo: GAL.

ra ugnarna/typerna. Men tidsbundna detaljer ser ut att vara svåra att belägga. Ugnars storlek verkar t.ex. inte vara en linjär funktion av tiden utan styrs möjligen av helt andra faktorer. Andra detaljer som byggnadsmaterial styrs säkert av tillgången på typer av material och möjligen tradition. Vad som uppenbarligen ger en tämligen stor skillnad i byggnadssätt är om ugnen är en flergångsugn eller en engångsugn. Engångsugnarna tycks i alla avseenden ha en lättare konstruktion än de ofta mycket stabilt byggda flergångsugnarna. En annan skillnad som är väsentlig när det gäller processen är om vi har att göra med slaggtappning eller slagguppsamling i en underliggande grop. Men vad denna skillnad beror på kan

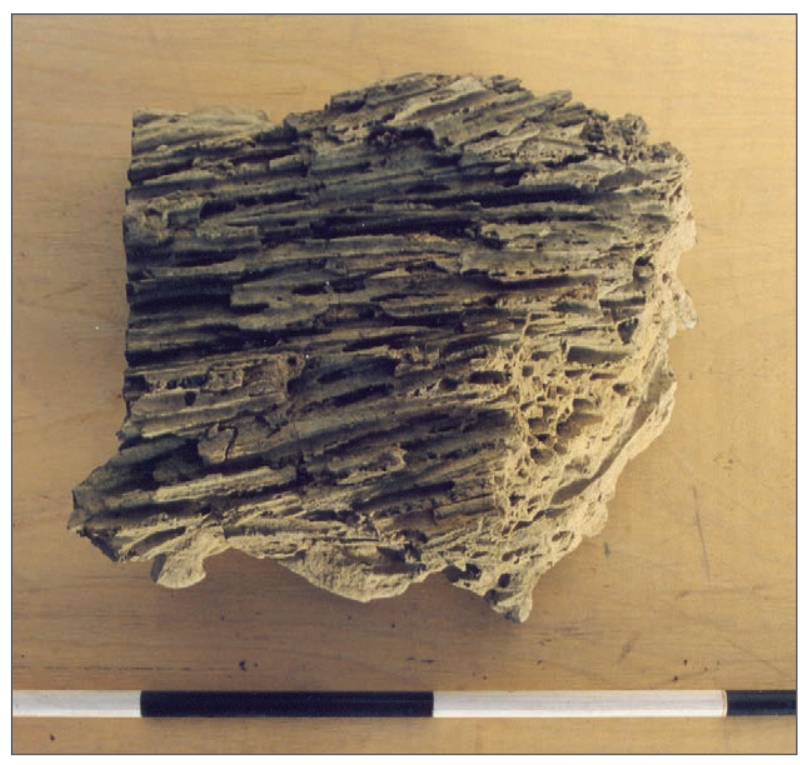

Figur 12: Slagg med tydliga horisontella avtryck efter vass. Stora delar av bottenslaggen i blästugnen i Stomskil socken, Närke, var hålig till följd av att slaggropen var mer eller mindre fylld med vass. Foto: GAL.

Figure 12: Slag with horizontal reed imprints. Most of the slag block in the bloomery furnaces in Stomskil parish, Närke, was porous due to this filling material in the slag pit. Photo: GAL.

inte sägas vara löst. Möjligen har det att göra med malmens kemiska sammansättning och därmed inte direkt med en ovilja mot att införa ny teknik utan snarare ett val som beror på råvarans art.

Med detta i bagaget kan vi börja med att diskutera vad det är som definierar en ugn/ugnstyp. Det finns forskare i det här sammanhanget som tydligt hävdar att ugnens design är en funktion av den malmtyp man valt, vilket man också enligt vår mening måste ta hänsyn till, som framgår av reso-

\begin{tabular}{|c|c|c|c|}
\hline \multicolumn{5}{|c|}{ Funktion (utifrån slaggens separation) } \\
\hline $\begin{array}{c}\text { Horisontell slaggseparation, dvs. slaggtappning } \\
\text { Platta tunna slagger } \\
\text { i ränna }\end{array}$ & $\begin{array}{c}\text { Större kägelformade } \\
\text { slagger }\end{array}$ & $\begin{array}{c}\text { Vertikal slaggseparation, dvs. uppsamling i grop under } \\
\text { ugn eller i nedre del av schakt }\end{array}$ \\
\hline \multicolumn{3}{|c|}{$\begin{array}{c}\text { Sesign } \\
\text { Rund/oval i plan }\end{array}$} & $\begin{array}{c}\text { Mindre slaggvolymer } \\
\text { (t.ex. stearinslagger) }\end{array}$ \\
\hline Koniskt schakt & Cylindriskt schakt & Koniskt schakt & Cylindriskt schakt \\
\hline \multicolumn{2}{|c|}{ Byggnadsmaterial i plan } \\
\hline Lera & Lera runt flätverk & Lera och sten & Sten (och lera) \\
\hline
\end{tabular}

Tabell 1: Exempel på varianter av funktion, design och byggnadsmaterial som kan tänkas förekomma bland blästugnar. Table 1: Examples of function, design and construction material that might occur in bloomery furnaces. 
nemang kring magnetit och myrmalm ovan (Forbes 1950: 407; Clough 1987: 27; Björkenstam 1990: 44 f.; Crew 1990: 150). Ett sådant resonemang skulle medföra att malmtypen och dess kemiska sammansättning i ett område, som skiljer sig från ett annat område, skulle ge skillnader i ugnars design och även påverka huruvida ugnen konstruerats för slaggtappning eller ej.

För att föra denna diskussion vidare har vi gjort några förenklade scheman som skulle kunna vara till hjälp. Det finns naturligtvis flera sätt att göra detta på men här har vi valt att använda oss av tre olika komponenter som alla är beroende av varandra nämligen, funktion, design och material. $\mathrm{Om}$ vi ställer upp scheman över de olika komponenterna och definierar blästugnarna efter funktion, design och byggnadsmaterial synliggörs de i komponenterna ingående storheterna (tabell 1). Uppställningen är inte komplett utan innehåller några exempel på alternativ som kan förväntas i blästugnar. Med hjälp av dessa är det dock möjligt att beskriva hur ugnen är konstruerad utan att specifikt hänvisa till någon tidigare karaktäriserad ugn. Om man sedan lägger samman komponenterna i ett schema (figur 13), kan man också lätt se olika sätt att lösa helheten. För att t.ex. se om det finns en tidsfaktor när det gäller dessa komponenter lägger vi in några av de ugnar från Viby i Närke som vi hade i diagrammet över diameter och tid. Vi finner då att det faktiskt sker något väldigt spännande eller skall vi säga «ospännande». Den enda storhet som möjligen har med tid att göra är bildandet av slaggblock, vilket dessutom sker mycket sent just i detta kluster av ugnar. Ugnar i övrigt i landskapet bildar slaggblock redan under romersk järnålder även så i Röda Jorden (Hansson 1989: 83 f.; Grandin och Hjärthner-Holdar 2000). Det är svårt att verkligen slå fast skillnader som är beroende av tid. Samma förhållande tycks finnas om vi ser till de andra ugnarna som beskrivits ovan. Det finns dock sådana som i dagsläget är unikum som t.ex. den sandstensbyggda ugnen från Söderåkra i Kalmar län. För övrigt kan man sluta sig till att många av ugnarna i grunden är byggda efter samma tekniska idé och att materialval och storlek inte med någon säkerhet kan ha med tid att göra.

Återstår att fråga om inte vissa mindre detaljer

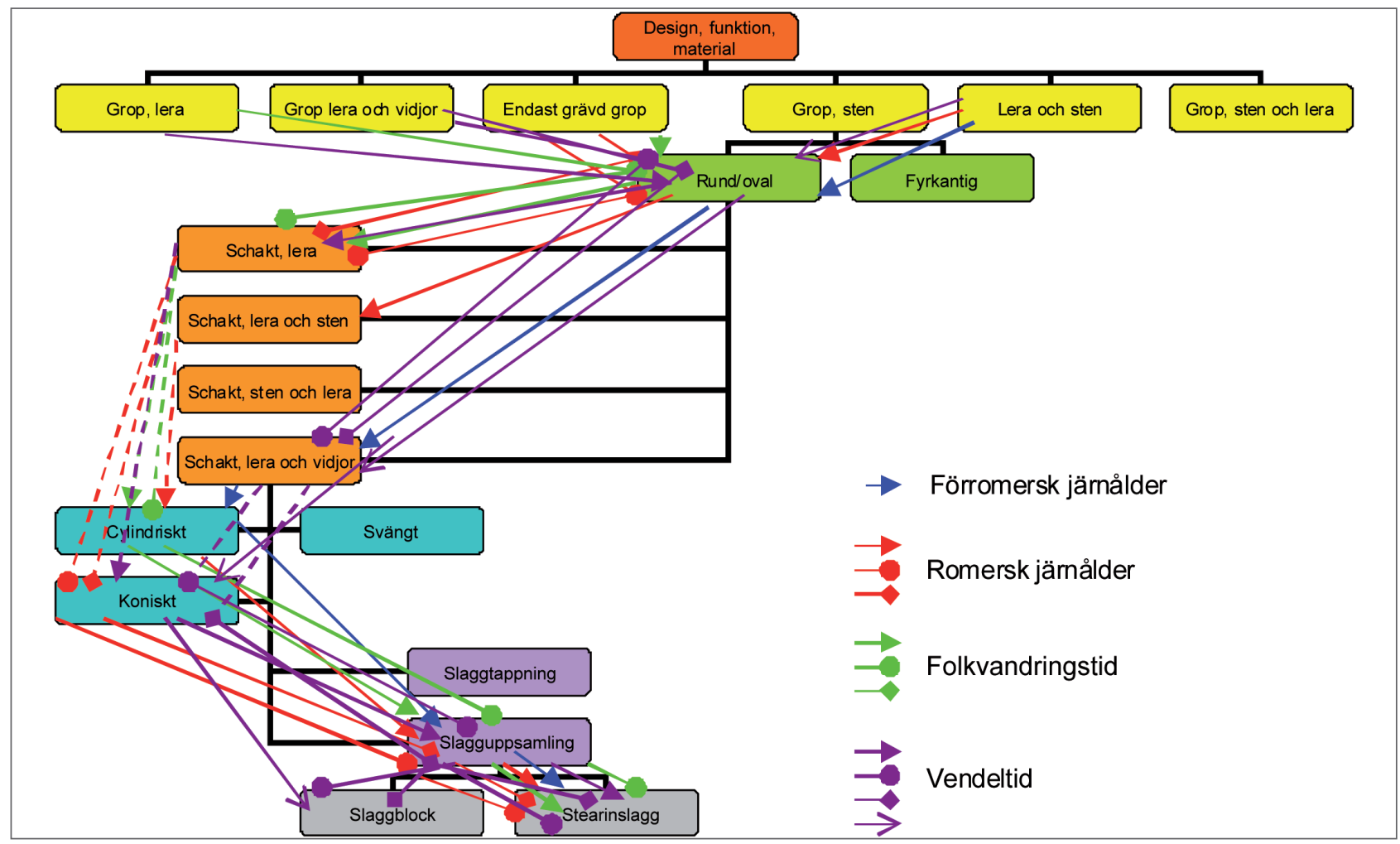

Figur 13: Schema som illustrerar den variation av ugnstyper som har förekommit vad gäller form, funktion och materialuppbyggnad. Exempel från ugnar från Viby socken, Närke, där linjer visar de varianter som förekommer under olika tidsperioder.

Figure 13: Schematic illustration of the variety of bloomery furnace types that have occurred, in terms of morphology, function and construction material. An example from Viby parish in Närke, where the lines represent various chronologies, demonstrates many possible combinations. 
tillhör områdets tradition och att storleken hör samman med behov/efterfrågan och organisation mer än de hör samman med vad processen kräver. Således finns här en humanistisk-samhällsvetenskaplig sida av problemet som kemiskt tekniska analyser endast delvis kan hjälpa oss med. Men naturligtvis finns det, som vi ovan diskuterade, just tekniska lösningar som vi ännu inte vet svaret på. Vi kan som exempel ta blästerproblematiken och slaggtappning kontra slagguppsamling. Hur många blästeringångar har ugnarna och framförallt de stora ugnarna haft? Hur blästertillförseln har skett är ibland en fråga som inte heller är helt enkel att lösa. Vi har inte heller lufttillförseln inlagd i schemat över funktion. Delvis beror det på, att vi anser att här borde kanske lite krut läggas för att om möjligt lösa denna fråga, kanske t.o.m. på ett annat sätt än att finna lösningen i fält. Slaggtappning kontra slagguppsamling i grop är också en fråga som kanske bör belysas mer än enbart som ett konstaterande och en underton av att slaggtappning skulle vara mer avancerat än slagguppsamling. Som vi tidigare påstod är slaggtappning en sällsynthet under förhistorisk tid i Sverige. Under medeltid och senare finner vi en viss ökning av användningen av tekniken med slaggtappning $\mathrm{i}$ blästugnar men ofta visar slaggen att den har varit svår att tappa - troligen för att den har hög viskositet. Är det således en kemisk skillnad mellan t.ex. norska och svenska malmer? Eller finns skillnaden i förbehandlingen av malmen (Espelund 2004: 133 ff.). Detta borde studeras närmare. Resultatet av en dylik studie skulle kunna visa om det fanns ett medvetet val av teknik hos smederna och hur det tog sig ut och vilken roll traditionen hade. Om vi till slut återgår till titeln på denna artikel kan man säga att systematiken inte är helt lättfångad och att tid inte verkar vara den avgörande faktorn.

\section{SUMMARY}

Since the birth of archaeometallurgy, scholars have described and defined various bloomery furnaces. Terminology is in truth an important tool in our understanding of the bloomery process and why furnaces were constructed as they were. However, too detailed definitions have unfortunately also created complex systematic furnace categories, with labels combined from letters and numbers, geographical designations or named after the scholar who found the furnace. In some cases the furnace types are so rare that they occur only at one site - the one that was initially described. Other scholars have suggested a more restricted terminology, in which only a few types should be defined. Currently, we discuss the latter and try to focus on the functional aspect of the furnace, in combination with access to construction material for the walls and the available iron ore and its characteristics. Our suggestions are based on a number of Swedish examples distributed in time and space. By means of process-related parameters such as slag separation technique, and size as well as shape of the furnace, a fundamental description can be made. Supplementary details can be found in furnace construction material such as stone, clay and wicker, and in what way optimal air supply was achieved. The results indicate that there are variations as well as similarities in many of these parameters at one site and between sites from various time periods. One aim is to raise the question of terminology for discussion, and in the future reach a more general approach.

\section{LITTERATUR}

Appelgren K. och A. Broberg 1998. «Gravar och ugnar vid Gavleån. Arkeologisk förundersökning och undersökning. Gästrikland Valbo socken, Sveden 1:107, Åsbyggeby 8:2 och Tolvforsskogen 2:1, RAÄ 13, 29, 35-37, 97-98». RÄ̈ UV Stockbolm, Rapport 1996:130. Stockholm.

Björck, N. 1991. Den lågtekniska järnhanteringen i södra Vätterbygden. En studie av en regions vikingatida och tidig medeltida järnhantering. Uppsats för $\mathrm{C} 1$ : Umeå.

Björkenstam, N. 1990. «Västeuropeisk järnframställning under medeltiden». Stockholm Archaeological Reports 25; Jernkontorets Bergshistoriska Skriftserie nr 26. Stockholm: Jernkontoret.

Buchwald, V.F. 2004. Om jernfremstillingspladsene nær Tvååker, Halland. I Vellev, J. (red.). Järnmollen i Halland. Arkeologiske undersogelser 1993-1995. Hikuin 31: 175-204. Højberg: Forlaget Hikuin.

Cleere, H. 1972. «The classification of early iron-smelting furnaces». Bulletin of Historical metallurgi Group, 5-2: 74-75.

Clough, R. E. 1987: «The Bloomery Process Observations on the use of rich ores and the production of natural steel». I Scott B. G. och H. Cleere (red.). The Crafts of the Blacksmith. Belfast: UISPP with the Ulster Museum.

Coghlan, H. H. 1956. «Notes on prehistoric and Early Iron in the old World». Occasional Papers on technology, 8. Oxford: Pitt Rivers Museum

Crew, P. 1990. «Late Iron-Age and Roman Iron production in North Wales». I Burnham och Davies (red.). Conquest, Co-Existence and Change. Trivium 25.

Danielsson, E. 2001. «Rapport över vedartsanalyser på material från RAÄ 195, Skrea socken, och RAÄ 
120, Stafsinge socken, Halland». I: Johansson, N., P.Nicklasson, Ch. Rosén, J. Streiffert och P.Wranning: Landskap i förändring. Teknisk rapport från de arkeologiska undersökningarna av RÄ̈ 116, 118, 120 och 122 i Stafsinge socken, Halland. Volym 3. Arkeologiska rapporter från Hallands länsmuseer 2001-5: 206-207. Hallands länsmuseer och Riksantikvarieämbetet.

Englund, L-E. 2001. Smältor och spadformade ämnesjärn. Kråknäset, RAÄ 406, Torsåkers sn, Gästrikland. Geoarkeologiskt Laboratorium, Analysrapport 19-2001. Uppsala.

Englund, L-E. 2002. Blästbruk. Myrjärnshanteringens förändringar i ett långtidsperspektiv. Jernkontorets bergshistoriska Skriftserie nr 40. Stockholm: Jernkontoret.

Englund, L-E. och L. Grandin 2002. Järnframställning i parblästa. Hedenstorp, RAÄ 186, Sandseryds sn, Småland, Kronobergs län. Geoarkeologiskt Laboratorium, Analysrapport 1-2002. Uppsala.

Englund, L-E. och L. Larsson 1997. Järnframställning i Bromölla. Skåne. Ivetofta socken. Geoarkeologiskt Laboratorium, Analysrapport 20-1997. Uppsala.

Englund, L-E. och L. Larsson 1999. Romartida järnframställning i Stomskil - en arkeologisk och analytisk studie. Lillkyrka sn, Raä 219, Närke. Geoarkeologiskt Laboratorium, Analysrapport 1-1999. Uppsala.

Englund, L-E., L. Grandin, E. Hjärthner-Holdar, P. Kresten och O. Stilborg 1999. Förromersk järnframställning i Söderåkra - en arkeometallurgisk undersökning. Söderåkra sn, RAÄ 342, Småland. Geoarkeologiskt Laboratorium, Analysrapport 12-1999. Uppsala.

Englund, L-E., L. Grandin, och E. Hjärthner-Holdar 2001. Datering av spadformat ämnesjärn och smälta. Kråknäset, Fors 27:3, Torsåkers sn, Gästrikland. Geoarkeologiskt Laboratorium, Analysrapport 13-2001. Uppsala.

Espelund, A. 2004. Jernet i Vest-Telemark - der tussane rådde grunnen. Trondheim: Arketype.

Forbes, R. 1950. Metallurgy in Antiquity. Leiden.

Forenius, S. 1990. «Stalbo - en tidig järnframställningsplats i Uppland». I G. Magnusson (red.): Förhistorisk och medeltida metallutvinning. Föredrag vid Jernkontorets Bergshistoriska utskott 24 november 1987, H 46, Forskningskommitté 9005/72. Stockholm.

Forenius, S. och L. Grandin 2005. Medeltida järnframställning på en gård i skogen. Arkeometallurgiska analyser. RAÄ 75, Markaryds sn, Småland. Geoarkeologiskt Laboratorium, Analysrapport 10-2005. Uppsala.

Forenius, S., A. Willim och L.Grandin 2005. Medeltida blästbruk vid Bredabäck. E4-projektet i Skåne, område E4:31. RAÄ 125, Värsjö 3:10, Skånes Fagerhults sn, Skåne. Geoarkeologiskt Laboratorium, Analysrapport 12-2005. Uppsala.
Forenius, S., A. Willim, D. Andersson och L. Grandin med bidrag av Stilborg, O. 2007. Romartida Blästbruk och sentida bebyggelse i Valbo. RAÄ 412 och 413, Valbo sn, Gästrikland. Geoarkeologiskt Laboratorium, Analysrapport 11-2007. Uppsala.

Forenius, S., L.Grandin och O.Stilborg 2008. Sjuttiofem blästugnar i Ledsjö. Romartida järnframställning i boplatsmiljö. Västergötland, Ledsjö socken, Kyrkebo 1:7, fornlämning 150. UV Uppsala Rapport 2008:16. Geoarkeologisk undersökning. Riksantikvarieämbetet. Avdelningen för arkeologiska undersökningar. Geoarkeologiskt Laboratorium. Uppsala.

Grandin, L. med bidrag av Stilborg, O. \& Jonsson, E. 2009. Järn för avsalu. En järnframställningsplats bland många andra i en omfattande organiserad produktion i området kring Axamo och Dumme mosse - arkeometallurgiska analyser. Småland, Jönköpings län, Sandseryds socken, Hedenstorp 1:3, fornlämning 338. UV Uppsala Rapport 2009:16. Geoarkeologisk undersökning. Riksantikvarieämbetet. Avdelningen for arkeologiska undersökningar. Geoarkeologiskt Laboratorium. Uppsala.

Grandin, L. och E. Hjärthner-Holdar 2000. Bronsålderns järnproducenter. Geoarkeologiskt Laboratorium, Forskningsrapport R11-2000. Uppsala.

Grandin, L. och E. Hjärthner-Holdar 2003a. «Högteknologisk järnframställning». I L.Karlenby (red.): Mittens Rike. Arkeologiska berättelser från Närke. Riksantikvarieämbetet Arkeologiska undersökningar Skrifter No 50: 391-424. Stockholm.

Grandin, L. och E. Hjärthner-Holdar 2003b.» Early Iron Production in the Red Earth Area, South Central Sweden». I L. Ch. Nørbach (red.): Prebistoric and Medieval Direct Iron Smelting in Scandinavia and Europe. Aspect of Technology and Science: 33-36. Aarhus: Aarhus University Press.

Hansson, P. 1989. Sambälle och järn i Sverige under järnålder och äldre medeltid - exemplet Närke. Aun 13. Uppsala.

Hjärthner-Holdar, E. 1993. Järnets och järnmetallurgins introduktion i Sverige. Med bidrag av Peter kresten och Anders Lindahl. Aun 16. Uppsala.

Hjärthner-Holdar, E. 1996. «Användning av bergmalm för framställning av järn i blästugn». Sagt och schakt, Nr 1996:3. Stockholm.

Hjärthner-Holdar, E. 2009. «The Earliest Production of Iron and Steel in Sweden». I T. Brattli (red.): The $58^{\text {th }}$ International Sachsensymposium 1-5 september 2007. VITARK 7: 26-36. Trondheim: Tapir.

Hjärthner-Holdar, E., P. Kresten och L. Larsson 1995. Slagger från Dala Airport. Dalarna, St. Tuna sn., RAÄ 382. Geoarkeologiskt Laboratorium, Analysrapport 7-1995. Uppsala. 
Hjärthner-Holdar, E. och Ch. Risberg 2009: Technology of Iron: Choices and Innovation. I Materials and Manufacturing Processes 24: 981-986. Taylor \& Francis Group, LLC.

Hjärthner-Holdar, E., S. Forenius och A. Willim in press. "A Roman Iron Age bloomery site in Gästrikland, Sweden. Evidence of a widespread trade?» I Th. Rehren och B. Cech (red.). Early Iron in Europe Prehistoric, Roman and Medieval Iron production. Symposium in Hüttenberg $8^{\text {th }}$ to $12^{\text {th }}$ september 2008. Under tryckning.

Larsen, J. H. 2009. Jernvinneundersøkelser. Faglig program Bind II. Varia 78. Oslo: Kulturhistorisk museum .

Larsson, L., P. Kresten och E. Hjärthner-Holdar 1998. Application of experimental data in archaeometallurgy. Examples from smelted siderite and magnetite ores. Geoarchaeological Laboratory, Research Report R2-1998. Uppsala.

Lorentzon,M. 2008.Järn, slagg och snö vid fornlämning 186. Undersökning av fornlämning 186, järnframställningsplats, inför byggnation inom Hedenstorp 1:3 et al. Sandseryds socken i Jönköpings kommun, Jönköpings län. Jönköpings läns museum. Arkeologisk rapport 2008:23.

Magnusson, G. 1985. Essunga kommuns förhistoria. Skara.

Magnusson, G.och L.Rubensson 2001.» Järnhanteringens etablering i Sverige». I G. Magnusson (red.). Möre historien om ett småland: 331-366. Kalmar.

Martens, I. 1983. «The Norwegian Bloomery Furnaces and their Relation to European Finds». Offa Band 40: 119-124.

Narmo, L-E. 1996. Jernvinna i Valdres og Gausdal - et fragement av middelalderens økonomi. Varia 38. Oslo: Universitetets Oldsaksamling.

Nordman, A-M. 1994. «Dubbelugnar i Axamo». Jernkontorets Bergshistoriska Utskott, $H$ 55: 69-77. Stockholm.

Pleiner, R. 2000. Iron in Archaeology. The European Bloomery Smelters. Praha: Archeologický Ústav Avčr.
Rundberget, B. 2007. «Jernframstillingsplasser i Gråfjellområdet». I Rundberget, B. (red.). Jernvinna i Gråfellområdet I. Varia 63: 39-246. Oslo: Kulturhistorisk museum.

Serning, I. 1979. «Prehistoric Iron Production». I H. Clarke (red.). Iron and Man in Prebistoric Sweden: 50-98. Stockholm: Jernkontoret, LTs förlag.

Stenvik, L. 2003. «Recent Results from Investigations of Iron Production in Northern Europe. Some Reflections on the Variation». I L.Ch. Nørbach (red.). Prehistoric and Medieval Direct Iron Smelting in Scandinavia and Europe. Aspect of Technology and Society. Proceedings of the Sandbjerg Conference 16th to 20th September 1999. Acta Jutlandica LXXVI:2. Humanities Series 75: 77-82. Aarhus: Aarhus University Press.

Stenvik, L. 2005. «Jernaldern. Et nytt metall - en ny epok». I I. Bull (red.). Trondelags historie del 1. Landskap blir landsdel fram til 1350: 107-118. Trondheim: Tapir.

Strömberg, B. 2004. «Arkeologiska undersökningar av järnframställningsplatser i Tvååkersområdet». I J. Vellev (red.). Järnmöllan i Halland. Jernkontorets Bergshistoriska Skriftserie nr 43 och bikuin 31: 105-174. Højbjerg: Hikuin, Moesgård.

Voss, O. 1993. «Jernudvindning». I S. Hvass och Storgaard B. (red.). Da klinger i muld.... 25 års arkeologi i Danmark: 206-209. Aarhus.

Wedberg, V. 1984. «Röda Jorden - rapport från ett arkeologiskt forskningsprojekt». Västmanlands Fornminnesförening och Västmanlands Museum Arsskrift 1984: 155-162. Västerås.

Wedberg, V. 1988. «Det tidigaste järnet». I Backlund, A.-C. (red.). Boken om Bergslagen - resa i levande bistoria: 50-61. Stockholm.

Wegevitz, W. 1957. «Ein Rennfeuerofen aus einer Siedlung der älteren römischen Kaiserzeit in Scharmbeck (Kreis Harburg)». Nachrichten aus Niedersachsens Urgeschichte 26: 3-25. 


\title{
«SKOVMARK OVNEN» FRA ESPEVEJ OG FRA SØNDER HOLSTED - DEN TIDLIGSTE JERNUDVINDING I DANMARK
}

\author{
Arne Jouttijärvi og Olfert Voss
}

\section{INDLEDNING}

Vor viden om fortidens jernudvindingsovne er baseret på tolkninger af de fund, som gøres ved arkæologiske udgravninger. Når man i dag gennemgår den europæiske litteratur om jernudvinding, støder man tilsyneladende på et meget stort antal forskellige typer jernudvindingsovne. Det er forfatternes opfattelse, at den store variation i højere grad skyldes variationer i de udgravende arkæologers tolkninger og forskelle i lokale traditioner, end reelle forskelle i ovntyper. Det er ofte meget svært at afgøre, hvor meget af rekonstruktionen af en ovn i en arkæologisk publikation, som kan siges at være sikkert dokumenteret i det arkæologiske materiale, og hvor meget der er en tolkning. En tolkning kan i denne sammenhæng være både en tolkning af de sete strukturer og en tolkning af de ikke bevarede dele af ovnen.

I det følgende vil der dels blive gjort status over den viden vi har om den ældste type jernudvindingsovn, som blev brugt indenfor det nuværende Danmark. Dels vil der, for at understrege tolkningens betydning for vores forståelse, blive givet en oversigt over de ændringer, som er sket i rekonstruktionen af denne ovn.

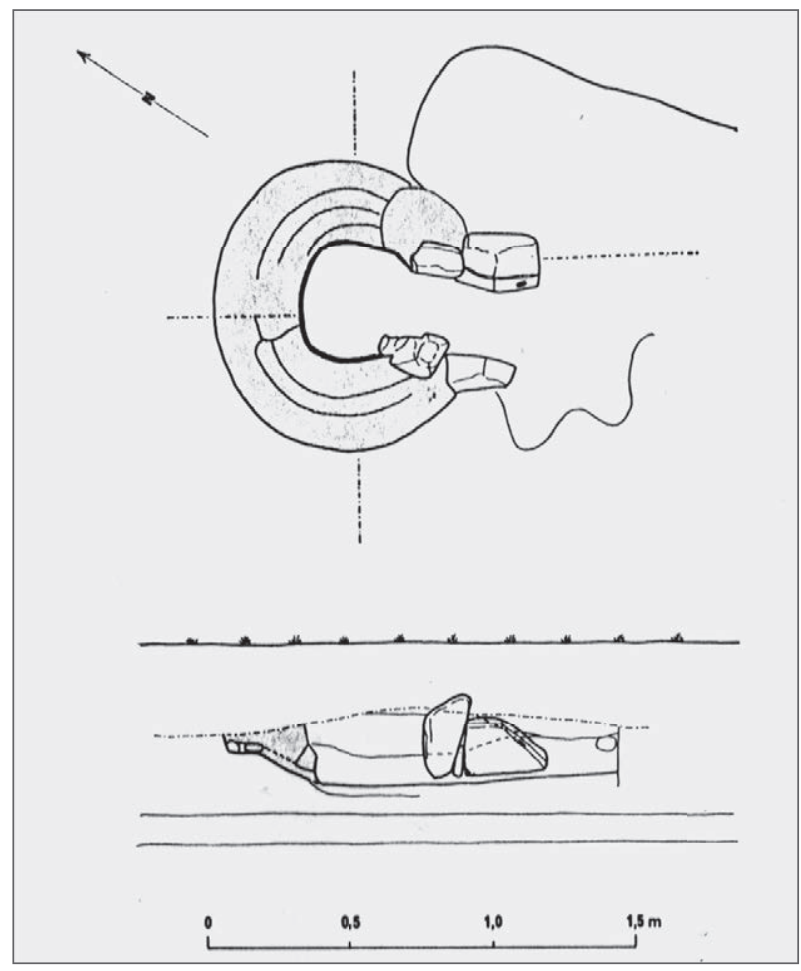

\section{DE DANSKE FUND AF OVNTYPEN}

De første fund af ovne af denne type blev giort af Olfert Voss ved Skovmark nær Ålborg i Nordjylland (Voss 1989). Kun de nederste ca. $20 \mathrm{~cm}$ var bevaret (figur 1) og viste, at ovnen havde en lerkappe på næsten $0,5 \mathrm{~m}$ i tykkelse og en stensat åbning ud mod en foranliggende arbejdsgrube.

På baggrund af dette fund blev ovnen rekonstrueret, som det er vist i figur 2. Der er her tale om en delvist nedgravet ovn med tykke vægge og, bortset fra åbningen mod arbejdsgruben, uden andre luftindtag. Den opfattedes mest som en form for ovn med slaggeaftapning, hvor slaggen tappedes ud gennem den samme åbning, som luften kom ind ad. Skønt vores opfattelse af ovnen siden er ændret kraftigt, ses denne rekonstruktion stadig i nyere litteratur.

Efterhånden som antallet af fund blev større, fremkom der også nye detaljer, som ændrede på opfattelsen af ovnens rekonstruktion. Væesentligt i denne sammenhæng var fund (i1986) af to ovne på de nærtliggende lokaliteter Espevej og Skydebjerggård ved Boeslunde i Vestsjælland (Andersen et al. 1987). Den første af disse lokaliteter er siden blevet en del af ovnens typebetegnelse.

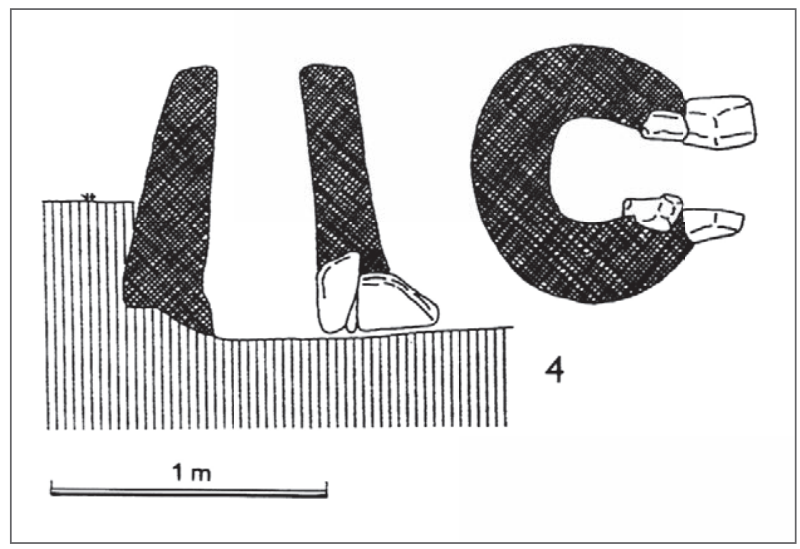

Figur 2: Rekonstruktion af ovnen, baseret på fundet fra Skovmarkqen.

Figure 2: Reconstruction of the furnace based on the find from Skovmarken.

Figur 1: Ovnen fra Skovmarken.

Figure 1: The furnace from Skovmarken. 


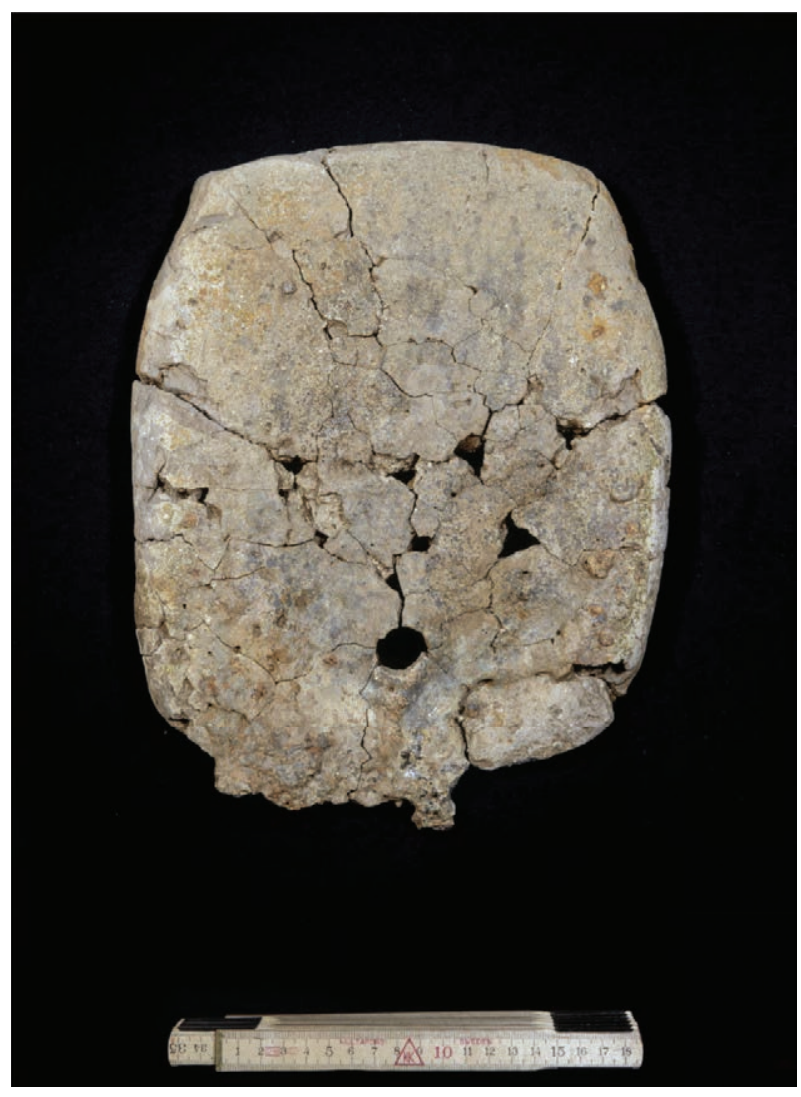

Figur 3: Dyseplade fra Espevej.

Figure 3: Tuyere from the excavation at Espevej.

Ved disse fund var næsten $40 \mathrm{~cm}$ af anlæggets nederste del bevaret, igen med en tydelig åbning ud mod arbejdsgruben. Dog var den ikke stensat, som det kunne ses på ovnen fra Skovmark og på andre ovne fundet i Jylland. Senere fund på Sjælland og Fyn viser, at der er tale om en konsekvent forskel, og at der derfor er tale om to varianter af ovnen. Det er muligt, at stensætningen har været nødvendig i den sandede jyske jord for at forhindre ovnen $i$ at skride ned $i$ arbejdsgruben, medens den $i$ den lerede østdanske jord har været tilstrækkeligt stabil uden.

Væsentligst ved fundene var dog, at der fandtes flere rektangulære lerplader, dyseplader (figur 3), som må have lukket en åbning i ovnen, medens brændingen foregik. Pladerne var ca. $5 \mathrm{~cm}$ tykke, og tæt ved underkanten fandtes et lufthul med en diameter på ca. $2,5 \mathrm{~cm}$. De var kraftigt forglasset på den ene side, og i ét tilfælde viste forglasning på begge sider, at pladen havde været brugt to gange. Efter første brænding var den blevet vendt om og brugt ved endnu en brænding.

Hidtil var der ikke fundet rester af indblæsningshuller, men i et senere fund fra Brødbæk nær

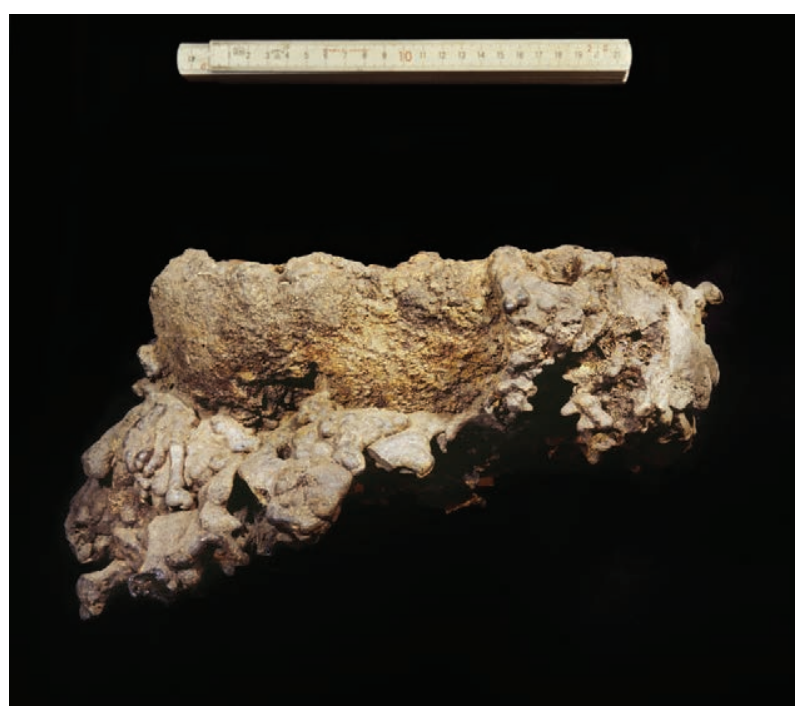

Figur 4: Slagge fra Espevej. Slaggen har hengt i overgangen mellem ounskakten og slaggedranet.

Figure 4: Slag from Esperej. The slag was deposited in the transition area between the furnace and the slag drain.

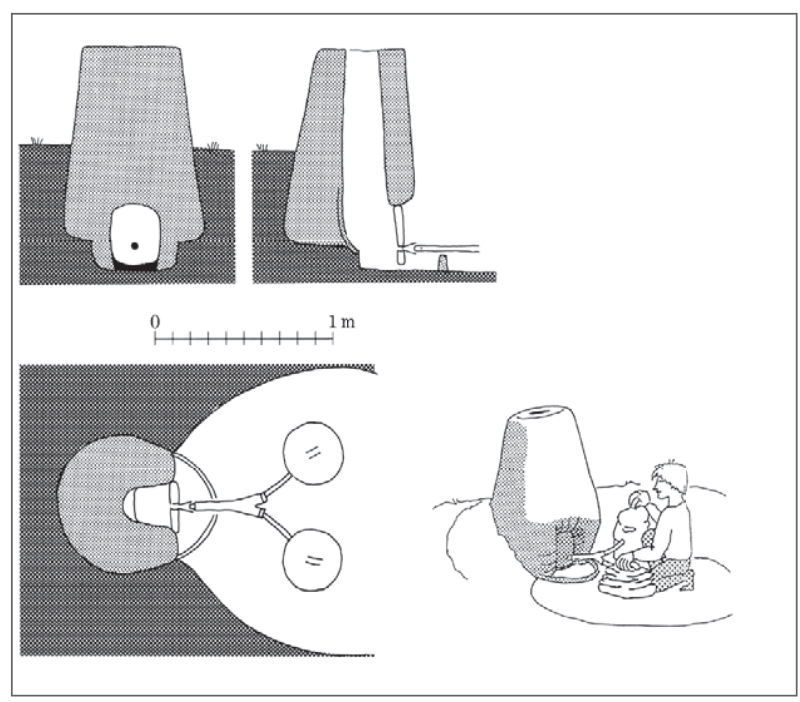

Figur 5: Rekonstruktion af ovnen baseret på fundene fra Espevej og Skydebjerggård.

Figure 5: The reconstruction of the furnace based on the finds from Espervej and Skydebjerggård.

Holstebro i Jylland fandtes mindre stykker brændt ler, som kan stamme fra tilsvarende plader. Også i disse var der spor af huller med en diameter på ca. $2,5 \mathrm{~cm}$. Siden er mere eller mindre komplette lerplader også fremkommet ved andre fund.

Også ovnene viste tydelige tegn på at være blevet repareret flere gange ved pålægning af et lag ler på 


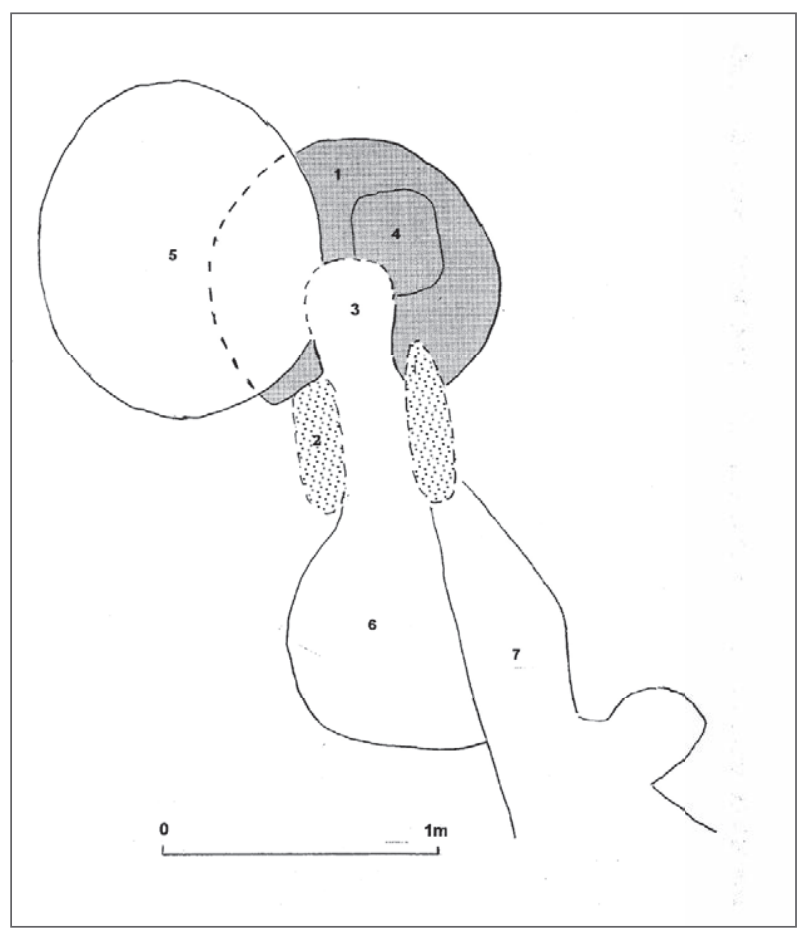

Figur 6: Plan af oonen fra Sønder Holsted.

Figure 6: Situation of the furnace from Sønder Holsted.

indersiden. Der var altså tale om en ovn, som var beregnet til at kunne bruges flere gange.

For første gang fandtes også en større, sammenhængende slagge (figur 4) som viste, at ovnen måtte have været opdelt i en øvre del, hvor processen foregik, og en nedre, hvori slaggen kunne løbe ned og bort fra det dannede jern. Jernluppen må have siddet som en porøs klump i overgangen mellem de to dele af ovnen.

Disse nye fund førte til en ændring af rekonstruktionen (figur 5). Dysepladen blev indføjet $i$ åbningen ud mod arbejdsgruben, og der blev lavet en skålformet afslutning af selve ovnskakten nederst. Herunder var der plads til at slaggen kunne løbe fra jernet, men ovnen blev stadig primært opfattet som en form for slaggeaftapningsovn, så det nederste blev ikke gjort særligt dybt. Denne rekonstruktion ses også i litteraturen og bliver ofte anvendt ved eksperimentel udvinding $\mathrm{i}$ ovntypen.

Siden blev det dog klart, at den nederste del af anlægget måtte have været væsentligt højere. Slagger fra Brødbæk nær Holstebro viste således, at der måtte have været et større rum nederst, hvor slaggen kunne opsamles og danne en mere eller mindre kompakt slagge, som under eller efter udvindingen blev brækket i stykker og fjernet gennem åbningen ud mod arbejdsgruben. I funktion nærmede ovnen sig nu mere slaggegrubeovnen, men mindre

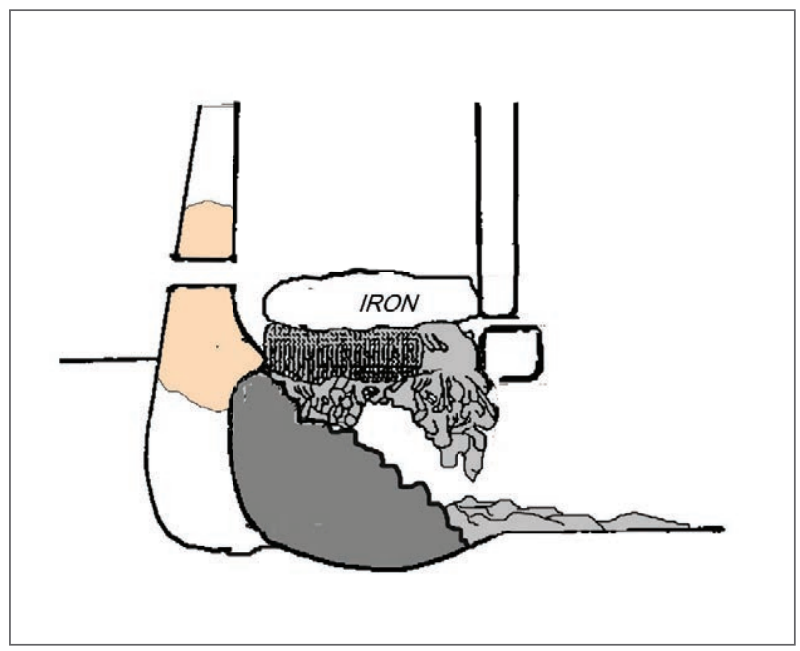

Figur 7: Rekonstruktion af den nederste del af ornen med slagge (lys grå), trekul (mork grå) og jernluppe. Baseret på fundene fra Espevej, Brodbak og Sonder Holsted. Den del af ovnvaggen, som blev fundet ved Sønder Holsted, er markeret med lyserødt.

Figure 7: Reconstruction of the lower part of the furnace and the slag drain with slag (light gray), charcoal (dark gray) and iron bloom. Based on the finds from Espevej, Brodbak and Sønder Holsted. The location of the part of the wall found at Sonder Holsted is marked in light red.

af størrelse og med en grube, som kunne tømmes og genbruges. Den nederste del af anlægget under selve ovnen, som tjente til midlertidig opsamling af slaggen, har vi valgt at betegne som «slaggedræn» for at adskille den fra slaggegruben, som jo kun bliver fyldt med slagge én gang og derefter efterladt. Navnet indikerer altså den funktionsmæssige forskel mellem ovne med slaggedræn, som kan bruges flere gange, og ovne med slaggegrube, som kun anvendes én gang. I Danmark er der også en kronologisk forskel mellem de to typer, idet ovne med slaggedræn er de ældste og i 2. århundrede bliver afløst af ovne med slaggegrube.

Et tredje fund, som gav årsag til endnu en kraftig ændring af rekonstruktionen, blev gjort ved Sønder Holsted i år 2000. Umiddelbart var fundet ret typisk: et slaggedræn bevaret i ca. $30 \mathrm{~cm}$ højde, med stensat åbning ud mod en arbejdsgrube (figur 6). Det specielle ved fundet var dog, at der også, sekundært i gruben 5 på figur 6 , fandtes et brudstykke af ler, som havde udgjort en del af overgangen mellem ovnskakten og slaggedrænet (figur 7). Stykket omfattede en del af den skålformede overgang, og det kunne ses, at der også i selve ovnvæggen havde været mindst ét hul til indblæsning af luft. Også dette stykke viste tegn på reparation og genbrug af ovnen.

På denne baggrund er ovnen nu rekonstrueret som vist i figur 8 . Det er klart, at lufthullerne, og 


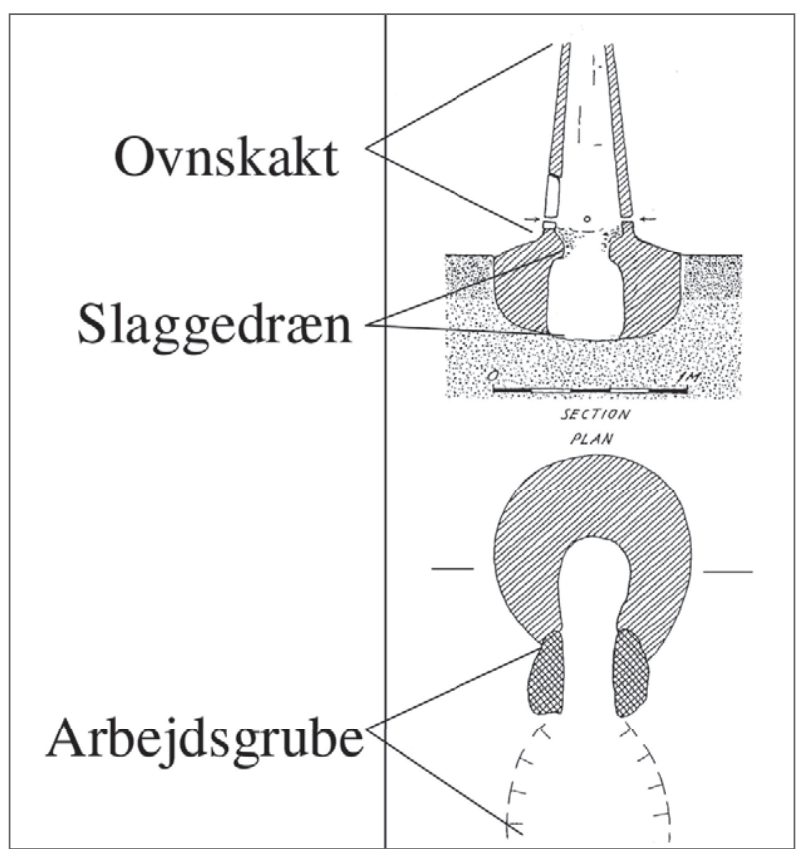

Figur 8: Rekonstruktion af udvindingsovnen efter fundet fra Sønder Holsted.

Figure 8: Reconstruction of the furnace based on the find from Sønder Holsted and earlier finds. dermed også dysepladen, må have siddet i selve ovnskakten over jordoverfladen. Hvor mange lufthuller der har været, og hvor tyk ovnvæggen har været, vides dog ikke.

Også andre fund har givet oplysninger om detaljer i ovnenes konstruktion.

En ovn fra Lysehøj ved Korsør i Vestsjælland havde næsten $40 \mathrm{~cm}$ af slaggedrænet bevaret og viste, at ovnene godt kan være opført uden den tykke lerkappe, idet lervæggen omkring slaggedrænet her kun var ca. $5 \mathrm{~cm}$ tyk. Jorden er her leret og stabil, og det er muligt, at den meget kraftige lerkappe omkring slaggedrænet har fungeret som en form for fundament under selve ovnen i sandet jord.

En særlig gruppe af de tidlige ovne findes $\mathrm{i}$ området omkring Herning. Her er jernudvindingen foregået under tag i en lille bygning, som i den ene ende rummer udvindingsovnen og $\mathrm{i}$ den anden en smedje, hvor jernet blev renset og videreforarbejdet (figur 9).

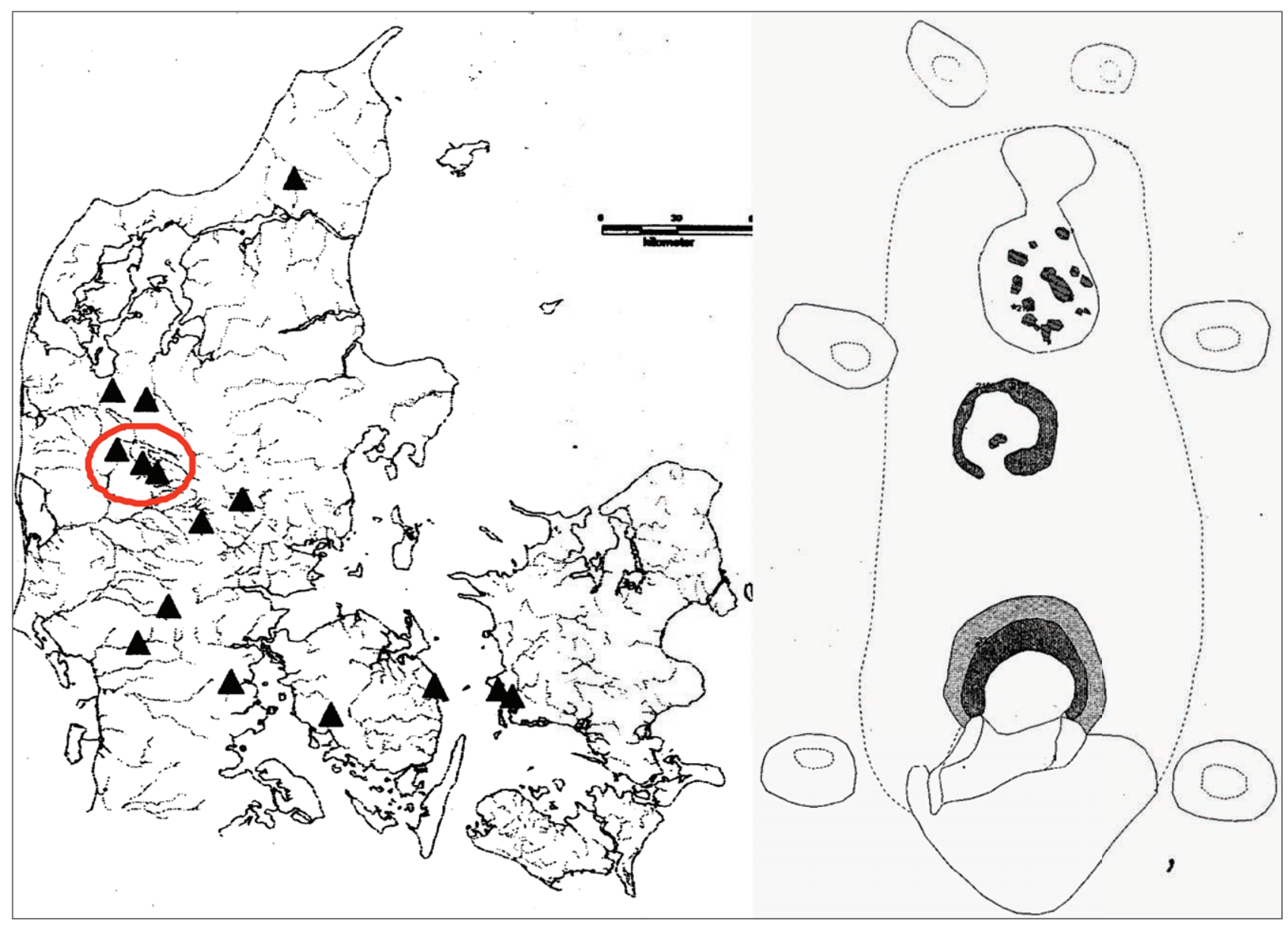

Figur 9: I et område omkring Herning er udvindingsovnene placeret inde $i$ hytter med smedje $i$ den nordlige ende. Figure 9: Around Herning the furnaces are located in small buildings equipped with a smithy in the northern part. 
Figur 10: Nogle af de cldste ovne, som kan vare forgangere for owne af Skovmark typen. 1: Baden-Württemberg (5. årh. f.Kr., Gassmann et al. 2005), 2: Engsbach og Minnerbach (5.-1. årh.f.Kr., Pleiner 2000).

Figure 10: Some of the earliest furnaces that might be predecessors of the Skovmark type in Denmark. 1: Baden-Württemberg (5th century BC, Gassmann et al. 2005), 2: Engsbach and Minnerbach (5th to 1st century BC, Pleiner 2000).

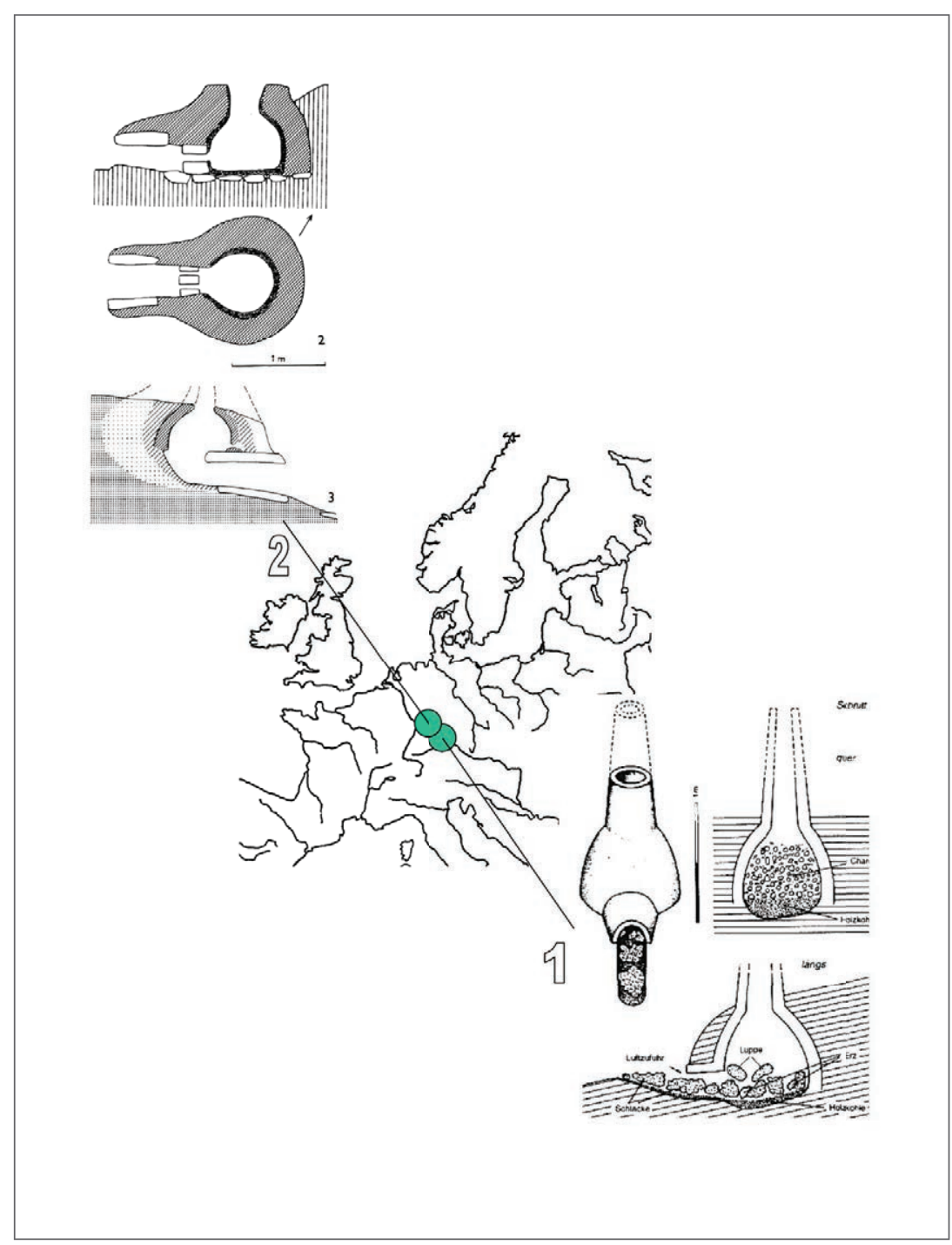

\section{KOMPARATIVT MATERIALE}

Espevej/Skovmarken ovnen kan have sin oprindelse i keltiske jernudvindingsovne, som de bl.a. er fundet i Baden-Württemberg (1) 5. årh. f.Kr. (Gassmann et al. 2005), Engsbach og Minnerbach (2) 5.-1. årh. f.Kr. (Pleiner 2000) (figur 10).

Disse ældste ovne har som Espevej/Skovmarken ovnene et nedgravet slaggedræn og en foranliggende arbejdsgrube. De er blevet fortolket som kuppelovne, men i rekonstruktionerne er det blevet antydet, at de, over jordoverfladen, kan have haft en skakt. I det tilfælde er det nærliggende at tolke den kuppelformede del af ovnen som noget, der svarer til slaggedrænet på de danske ovne. Det vides ikke, om lervæggen i det mulige slaggedræn er forglasset over åbningen, som det må forventes, hvis der er tale om egentlige kuppelovne, hvor forbrændingen foregik i den nederste del af anlægget. Det er derfor vigtigt, at der ved arkæologiske udgravninger altid dokumenteres, hvor stor graden af brænding og forglasning af leret er forskellige steder i anlægget.

I århundrederne omkring Kristi fødsel synes ovntypen at have bredt sig over et større område. I figur 11 ses således en række eksempler på jernudvindingsovne, som kan være beslægtet med Espevej/Skovmarken ovnen (1). Der er her tale om en ovn fra Fyllinge i Sverige (2), dateret til 2.-1. årh f.Kr. (Toreld \& Wranning 2005), en ovn fra Unterpullendorf, Østrig (3), dateret til 1. årh. f.Kr. (Pleiner 2000), ovne fra Dakien (4), dateret til 2. årh. f.Kr. - 1. årh. e.Kr. (Iaroslavschi 2000), ovne fra Orech, Böhmen (5), dateret til 1. årh. e.Kr. (Motyková \& Pleiner 1987) samt endelig en ovn fra Minepit Wood i Sussex (6), dateret til 1. årh. f.Kr. -1. årh. e.Kr. (Money 1974, Pleiner 2000).

Af disse er ovnene fra Unterpullendorf og Minepit Wood blevet tolket som kuppelovne, men også her kan der have været en højere ovnskakt, som kan have fungeret som den egentlige ovn. 


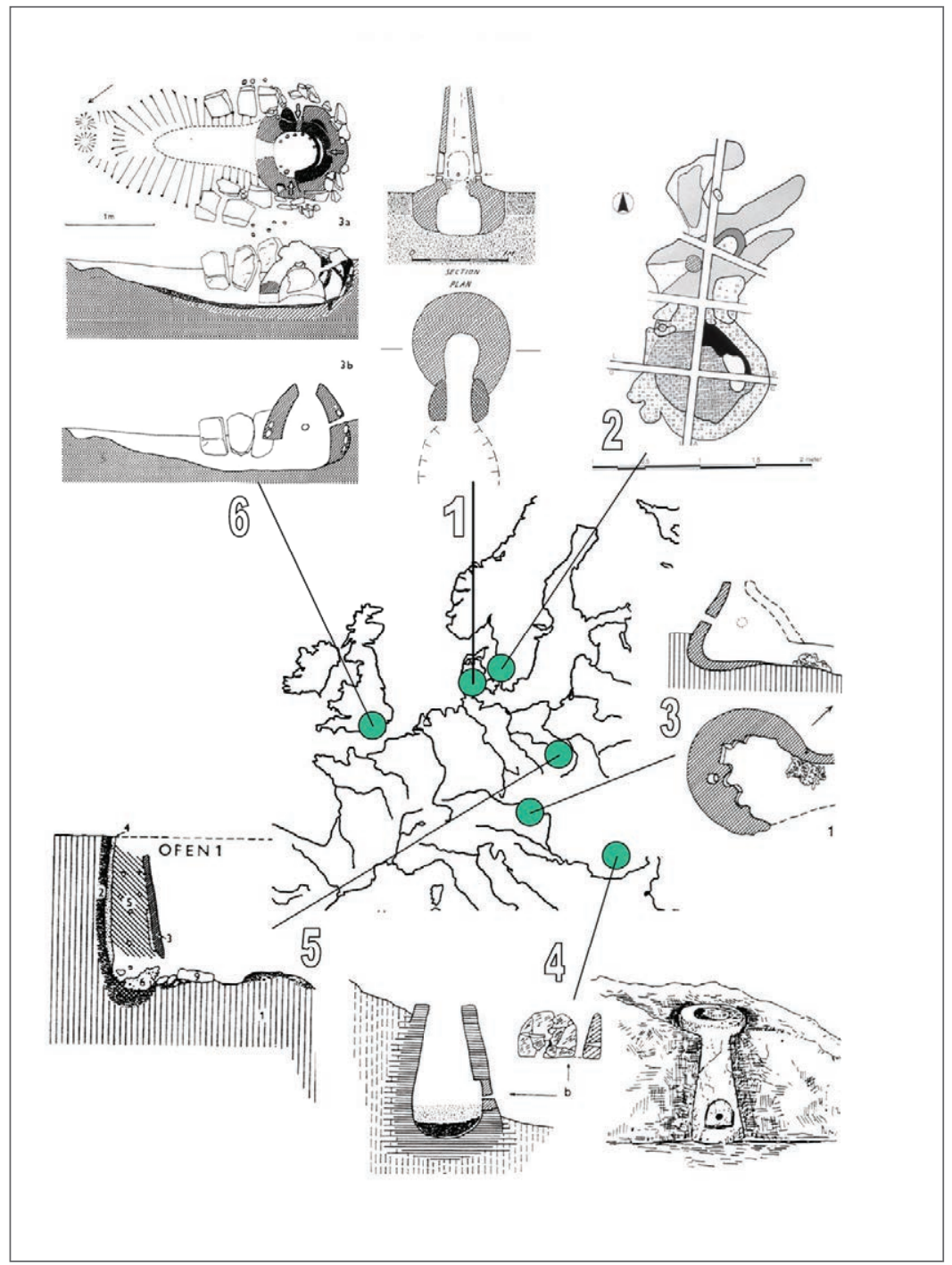

Figur 11: Samtidige ovne, som kan vere $i$ slagt med Esperej/Skovmarken ovnen (1). 2: Fyllinge i Sverige (2.-1. årh. f.Kr., Toreld E Wranning 2005), 3: Unterpullendorf, Østrig (1. årh.f.Kr., Pleiner 2000), 4: Dakien (2. årh. f.Kr. - 1. årh. e.Kr., Iaroslavschi 2000), ovne fra 5: Orech, Böbmen (1.årh. e.Kr., Motyková छ̊ Pleiner 1987), 6: Minepit Wood i Sussex (1. àrh. f.Kr. - 1. arrh e.Kr., Money 1974, Pleiner 2000).

Figure 11: Contemporary furnaces related to the Skoumarken type (1). 2: Fyllinge in Sverige (2nd to 1st century BC, Toreld E' Wranning 2005), 3: Unterpullendorf, Austria (1st century BC, Pleiner 2000), 4: Dakien (2nd century BC to 1st century $A D$, Iaroslauschi 2000), 5: Orech, Böhmen (1st century AD, Motyková E̊ Pleiner 1987), 6: Minepit Wood, Sussex (1st century BC to 1st century AD, Money 1974, Pleiner 2000).
Selv efter at Espevej/Skovmarken ovnen i Danmark i 2. århundrede er blevet erstattet af slaggegrubeovnen, kan der findes ovne, som tilsyneladende tilhører gruppen af genanvendelige ovne med underliggende slaggedræn. Eksemplerne i figur 12 er: en ovn fra Semeniskes i Litauen (1), dateret til 2.-3. årh.e.Kr. (Toreld \&Wranning 2005), en ovn fra Gera-Tinz (2), dateret til 1.-3. årh. e. Kr. (S. Dusek 1967) samt en ovn fra Altmark i Sachsen-Anhalt (3), dateret til 3. årh e.Kr. (Leineweber 1993). Også Trøndelagsovnen (4) fra Norge må være en ovn med slaggedræn, og har i driftsmåde en stor lighed med Espevej/Skovmarken ovnen. I opbygning adskiller den sig dog væsentligt fra de øvrige ovne, idet der er tale om en stenbygget konstruktion. Dette kan dog være en tilpasning til de lokale forhold, da sten i Norge vil være et væsentligt mere tilgængeligt materiale end ler.

I Danmark er skiftet fra Espevej/Skovmarken ovnene til slaggegrubeovnene tilsyneladende for- bundet med en grundlæggende ændring i organiseringen af jernudvinding. I begyndelsen var udvindingen knyttet til enkelte gårde eller landsbyer, som må formodes at have fremstillet mindre mængder jern til eget forbrug. Der er fundet spor efter jernudvinding i hele det nuværende Danmark. Med slaggegrubeovnens indførelse forsvinder den lokale jernudvinding på Sjælland, Fyn og i den nordlige del af Jylland, og produktionen af jern koncentreres på meget store udvindingspladser i det vestlige Jylland. Produktionen her har dækket mere end det lokale behov, og jern herfra er sandsynligvis blevet distribueret til det meste af Danmark.

\section{KONKLUSION}

Som det er set i det foregående, udgør ovne, som kan tolkes som værende med slaggedræn, en stor og varieret gruppe. En ikke uvæsentlig del af variationen kan, som det er vist i eksemplet med den danske Espevej/Skovmarken ovn, skyldes forskelle 
Figur 12: Senere ovne i slagt med Skovmarken typen: 1: Semeniskes i Litauen (2.-3. årh. e.Kr., Toreld E' Wranning 2005), 2: Gera-Tinz (1.-3. årh. e. Kr, S. Dusek 1967), 3: Altmark i Sachsen-Anhalt (3. årh. e. Kr Leineweber 1993).

4: Trondelagsownen, Norge.

Figure 12: Later furnaces related to the Danish Skovmarken furnace:

1: Semeniskes i Litauen (2nd to 3rd century AD, Toreld E Wranning 2005), 2: Gera-Tinz (1st to 3rd century AD, S. Dusek 1967), 3: Altmark i Sachsen-Anhalt (3rd century AD, Leineweber 1993).

4: Trondelagsounen, Norge.

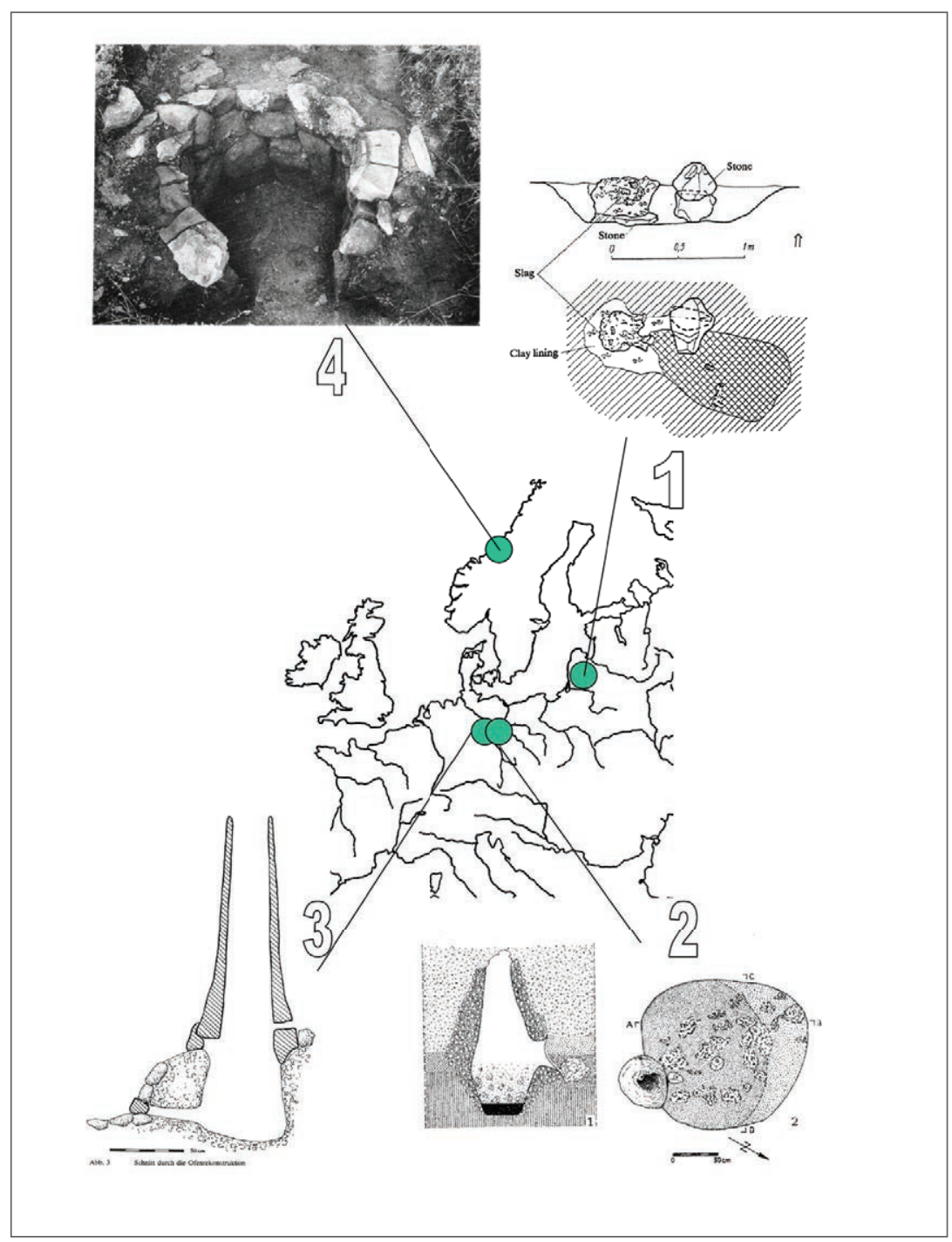

i den måde de, ofte sparsomme, arkæologiske levn af ovnene er blevet tolket. Der kan dog næppe være tvivl om, at der også i virkeligheden har været store forskelle i ovnenes udseende, selv om driftsmåden grundlæggende kan have været den samme.

At der vil være endog ganske store variationer inden for det man vil kunne betegne som én ovntype, er egentlig ganske naturligt. Hvis en smeltemester vandrede til et nyt område for at lave jern der, var han nødt til at tilpasse sig efter de råmaterialer der var til rådighed for bygning af ovnen, og de lokale ressourcer af træ og malm. Også forskelle i jordbunden kan, som i det danske tilfælde, have gjort det nødvendigt at lave forskellige konstruktioner for at bevare ovnens stabilitet.

Ud over de rent praktiske årsager til forskellene i ovnenes konstruktion, har udviklingen af lokale traditioner, som ikke nødvendigvis har haft et praktisk formål, uden tvivl også spillet en stor rolle. De mennesker, som udvandt jern i forskellige egne, har sandsynligvis ingen kontakt haft med hinanden, og har derfor gennem generationer langsomt indført ændringer i den måde de opfattede som «den rigtige» at bygge en ovn på eller udføre en jernudvinding. I denne sammenhæng vil de have været mere påvirket af andre lokale traditioner, f.eks. fra andre håndværk, end af den måde smeltemestre i fjerntliggende egne udførte deres håndværk.

Det vil derfor ikke være at forvente, at man over større områder vil kunne finde ensartede ovntyper. Snarere skal typer defineres som ovne, der har nogle grundlæggende fællestræk og en fælles driftsmåde. Derfor vil der sandsynligvis kun eksistere få egentlige typer, som derimod hver især vil udvise en rig variation i udformninger. Man kan sige, at en ovntype, på baggrund af tilpasninger og lokale traditioner, vil kunne antage alle former, hvor den grundlæggende tradition for driftsmetode er mulig. I nogle tilfælde vil man sandsynligvis kunne danne lokale undertyper, men oftest vil variationerne være 
så mange, at et forsøg på at definere typer blot vil øge forvirringen.

Denne differentiering i lokale traditioner er på nogle måder en parallel til et af de væsentligste problemer, som vi i dag står med, når det gælder tolkningen af de arkæologiske spor efter fortidens jernudvinding. Skønt der kan være tale om relativt ensartede anlæg, vil arkæologer i forskellige områder tolke dem forskelligt ud fra deres individuelle baggrund og forudsætninger. Dette vil yderligere forstærkes af, at den ofte meget fragmentariske bevaring af anlæggene levner rig mulighed for forskellige tolkninger. Den eneste måde at opnå en mere ensartet tolkning, er at arbejde tættere sammen og i videst muligt omfang besøge udgravninger uden for ens eget område, og diskutere tolkningen med de lokale arkæologer. Herigennem vil der kunne dannes baggrund for opbygningen af en bedre typologi, og dermed for en mere kvalificeret bedømmelse af, hvordan traditioner spredtes og udvikledes.

\section{SUMMARY}

The oldest iron smelting furnace in Denmark is the Skovmark type, of which the first was excavated in 1966. Since then the type has been found at several sites, but with only the underground part preserved it became the basis for different reconstruction attempts.

In 2000 during the excavation of the remains of a furnace at Sønder Holsted, in south Jutland, the base of the clay-built shaft was found in a secondary pit that had been dug into the underground part of the furnace. This showed that the smelting process had taken place in a clay-built shaft above ground. It accorded with the fact that in no case had the underground walls of clay shown signs of having been covered with molten slag.

\section{LITTERATUR}

Andersen A.H., F1. Kaul og O.Voss 1987. «Danmarks ældste jernudvindingsovne». Danmarks langste udgravning: 176-180. Herning: Poul Kristensens Forlag.

Dusek, S. 1987. «Eisenschmelzöfen einer Germanischen Siedlung bei Gera-Tinz». Alt-Thüringen 9: 95-183.

Gassmann, G. et al. 2005. «Forschungen zur keltischen Eisenverhüttung in Südwestdeutschland». Forschungen und Berichte zur Vor-und Frühgeschichte in Baden-Württemberg, Band 92.

Iaroslavschi, E. 2000. «Les fourneaux de réduction du minerai de fer chez les Daces». I Feugère, M. og M. Gus凹tin (red.). Iron, Blacksmiths and Tools. Ancient European Crafts. Acts of the Instrumentum Conference at Podsreda (Slovenia) in April 1999, Montagnac Instrumentum 12: 97-102. Montagnac: Éditions M. Mergoil.

Leineweber 1993. "Schmelzversuche zur römerzeitlichen Eisenverhüttung». Archäologie in Deutschland 1: 28-31.

Money, J. H. 1974. Iron Age and Romano-British iron-working site in Minepit Wood, Rotherfield, Sussex. Historical Metallurgy, 8/1, 1-20.

Motyková, K. og R. Pleiner 1987. «Die römerzeitliche Siedlung mit Eisenhütten in Ořech bei Prag,» Památky Archeologické 78 (1987): 371-448.

Pleiner R. 2000. Iron In Archaeology. Praha: Archeologiký ústav av čr.

Voss, O 1989. Iron Furnaces in Denmark in Archeometallurgy of Iron. Symposium Liblice 1987 Prague 1989, p. 153:1

Toreld, C. og P. Wranning 2005. Framgrävt förflutet från Fyllinge, Vol. 2. Arkeologiska rapporter från Landsantikvarien 2005:2. 


\title{
TRØNDELAGSOVNEN - EN STUDIE BASERT PÅ MATERIELLE LEVNINGER ETTER JERNFRAMSTILLING I MIDT-NORGE
}

\author{
Lars F. Stenvik
}

Siden 1980-tallet har en rekke jernframstillingsanlegg fra eldre jernalder (cirka 350 f.Kr.-500 e.Kr.) blitt registrert og undersøkt i Trøndelag. På grunnlag av arkeologisk dokumentasjon, eksperiment og metallurgisk kunnskap oppsummerer vi her det vi vet om ovnstypen som ble funnet i Trøndelag. Undersøkelsene har avslørt en ovnstype som er nokså forskjellig fra samtidige ovner i Skandinavia. Det dreier seg her om en type sjaktovn med slaggrop som kunne drives kontinuerlig. Ovnene er omkranset av groper, og i perioder kan ovnene ha vært dekket av tak som ble båret av jordgravde stolper. Flere ovner har vært i bruk samtidig, og de har vært fyrt med ved. Sjakta ser ut til å ha vært traktformet med en innsnevring på bakkenivå, og ovnene har trolig vært drevet ved hjelp av naturlig trekk. Denne ovnstypen er kjent hovedsakelig fra Midt-Norge.

\section{INNLEDNING}

Med undersøkelsene på Heglesvollen i Levanger kommune i Nord-Trøndelag som startet i 1982, dukket det opp en type jernframstillingsanlegg fra eldre jernalder vi ikke hadde sett klare paralleller til (Farbregd et al. 1984) (figur 1). I årene som fulgte, ble flere anlegg både i Nord-Trøndelag og i SørTrøndelag undersøkt (Rundberget 2002; Stenvik 2005). Undersøkelsene kunne bekrefte de observasjonene vi hadde gjort på Heglesvollen, i den forstand at restene etter ovnene var identiske med dem vi hadde funnet på Heglesvollen. I ettertid har denne ovnstypen fått navnet Trøndelagsovnen, og ovnen var et motstykke til Østlandsovnen, som stammer fra samme tidsepoke (Espelund 1999). Trøndelagsovnene er datert fra cirka $350 \mathrm{BC}$ til AD 500.

I denne artikkelen skal vi sette søkelyset på selve ovnskonstruksjonen i Trøndelagsovnen, fordi oppfatningen av den har endret seg betydelig over tid. Det gjelder særlig med hensyn til formen på selve ovnen. Kunnskapen her må nødvendigvis bygge på arkeologiske funn og observasjoner, men forståelsen må samtidig bygge på metallurgisk kunnskap. I tillegg er det en tredje faktor med i bildet, nemlig de forsøkene som er gjort med rekonstruksjoner av ovner. I Trøndelag har Arne Espelund ivaretatt det metallurgiske aspektet, Ivar Berre har vært ekspe-

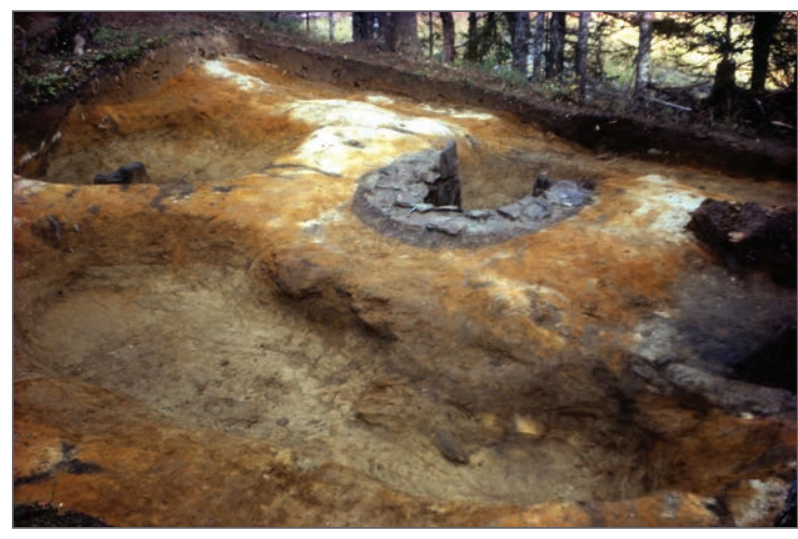

Figur 1: Jernframstillingsanlegg på Heglesvollen, Levanger, Nord-Trondelag. Foto: L.F. Stenvik, NTNU Vitenskapsmuseet. Figure 1: Iron production site at Heglesvollen, Levanger, North Trondelag. Photo: L.F. Stenvik, NTNU University museum.

rimentatoren, mens undertegnede har stått for den arkeologiske dokumentasjonen.

\section{METODE:}

\section{DET ARKEOLOGISKE UTGANGSPUNKTET}

De arkeologiske restene etter jernfamstillingsovner kan grovt sett deles inn i fire kategorier: slaggrop, sjaktmateriale, groper og stolpehull. Videre kan både slagg, trekull og ved si noe om ovnskonstruksjonen. For at vi skulle få et begrep om sjaktas form, limte vi sammen sjaktdeler for å dokumentere form, høyde og diameter. Brenningsgraden på leire som er brukt $\mathrm{i}$ ulike deler av ovnskonstruksjonen, benyttet vi til å identifisere prosessene i ovnen. Vi observerte torv, løsmasser og steiner rundt ovner og i slaggvarp, og vi antok at det var elementer som hadde fungert som isolasjon og støtte. Funn av åpninger i sjaktdeler har vi brukt til å forklare hvordan lufttilførselen foregikk. Avtrykk i slagg kan fortelle noe om formen og byggemåten når det gjelder slaggropa, og i noen tilfeller kan avtrykkene kanskje også fortelle noe om lufttilførselen. Ved utgravningene la vi etter hvert særlig vekt på overgangen mellom slaggropa og sjakta på bakkenivå, fordi vi oppdaget at det var en innsnevring der på godt bevarte rester i Stordalen i Meråker (Stenvik 1998: foto 2846/10; Rundberget 2002: 70). Vi lette 


\begin{tabular}{|l|l|l|l|} 
Ovn & Bredde & Dybde & Bredde i bakkenivå \\
\hline Heglesvollen Ø1 & 0,80 & 1.00 & \\
\hline Heglesvollen A6 & 0,78 & 0,87 & \\
\hline Heglesvollen C2a & 0,85 & 0,90 & \\
\hline Heglesvollen C5 & 0,78 & 0,80 & \\
\hline Heglesvollen C4b & Ikke målt & 0,80 & \\
\hline Vårhusvollen 1 & 0,90 & 0,88 & \\
\hline Fjergen 1 & 0,75 & 0,70 & \\
\hline Fjergen 2 & 0,80 & 0,82 & \\
\hline Fjergen 3 & 0,75 & 0,65 & \\
\hline Østrungen & 0,80 & 0,70 & \\
\hline Storbekken & 0,85 & 0,80 & \\
\hline Tovmo & 0,70 & 0,60 & \\
\hline Fossvatn 1 & $0,70-0,80$ & 0,80 & Mindre enn 0,70 \\
\hline Fossvatn 2 & $0,70-0,80$ & 0,80 & \\
\hline Stordalen 1 & 0,70 & 0,60 & 0,50 \\
\hline Stordalen 2 & 0,66 & 0,80 & 0,50 \\
\hline Stordalen 3 & 0,65 & 0,70 & 0,45 \\
\hline Stordalen 4 & 0,70 & 0,80 & 0,50 \\
\hline Børsjøtjørna & 0,80 & 0,67 & \\
\hline Høltjørnbekken & 0,80 & 0,80 & \\
\hline & & & \\
\hline & &
\end{tabular}

Tabell 1: Mål på slaggroper som er undersøkt $i$ Trøndelag med dybde, bredde og vidde på bakkenivå.

Table 1: Slag pits with depths, diameter and opening at ground level. etter luftkanaler i gropene som omga ovnene, og i restene av sjaktveggene der det var mulig.

\section{MATERIALET}

\section{Slaggropa}

Ovnene fra eldre jernalder har bestått av to hovedelement: ei sjakt over bakkenivå der selve reduksjonen har foregått, og ei slaggrop under bakkenivå der slagget ble samlet opp (figur 2). Denne gropa kan også ha hatt andre funksjoner enn å være en ren oppsamlingstank for restprodukt, men det skal vi ikke komme nærmere inn på her. Slaggropa er gravd ned i løsmasser på en terrassekant slik at slagg kunne veltes ut over kanten. Slaggropa er gjerne murt opp av vertikale og horisontale steiner med en hesteskoformet avslutning på bakkenivå. Leire er brukt som bindemiddel, og i noen tilfeller også som puss utenpå steinene i gropa. Et skråplan leder ut fra gropa, og her har det vært mulig å tømme den gjennom en åpning i siden. Slaggropa har en indre diameter på 65-90 centimeter, og den er 65-100 centimeter dyp (tabell 1). Den håndverksmessige utførelsen vitner om imponerende kunnskap ettersom konstruksjonen står omtrent uendret etter 2000 år.

I åpningen av slaggropa der slagget ble raket ut, står det gjerne to «karmsteiner» på hver side som må ha båret en bro over åpningen og samtidig støttet veggene i selve gropa. Kantsteinene måtte være solide og tåle hard medfart under opprensing av ovnen.

I de første ovnene vi undersøkte, var vi ikke tilstrekkelig oppmerksom på overgangen mellom slaggrop og sjakt. Det skyldtes nok til en viss grad at restene var dårlig bevart, og at vi konsentrerte oss om innholdet i slaggropa. I forbindelse med forsøksvirksomhet med rekonstruerte ovner hadde vi imidlertid blitt oppmerksom på at sonen mellom sjakt og slaggrop kunne ha vært viktig i temperaturstyringen inne i ovnen. Ved undersøkelsene av ovner ved Fossvatnet i Meråker i perioden 1997-98 var vi særlig opptatt av denne overgangssonen samtidig som vi konsentrerte oss om større deler av sjakta som hadde stått oppå slaggropa, $i$ håp om at vi kunne finne ut mer om formen på denne også (Stenvik 1998: 2).

På den ene ovnen ved Fossvatnet observerte vi en innsnevring av slaggropa på bakkenivå. Observasjonen ble et par år seinere bekreftet $\mathrm{i}$ forbindelse med nye utgravninger i Stordalen i Meråker. Her så vi det samme på fire nye ovner (Rundberget 2002). Det ser altså ut til at ovnene har hatt en flaskehals som bare var 45-50 centimeter vid i overgan- 


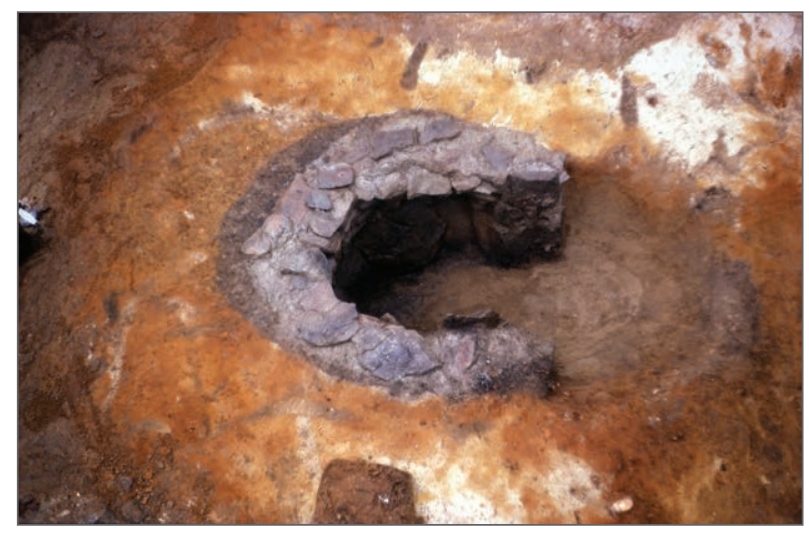

Figur 2: Slaggrop under sjakta. Heglesvollen. Foto: L.F. Stenvik, NTNU Vitenskapsmuseet.

Figure 2: Slag pit beneath a furnace at Heglesvollen. Photo: L.F. Stenvik, NTNU University museum.

gen mellom slaggrop og sjakt på bakkenivå. Selv om dette ikke er dokumentert på andre anlegg, er det fristende å tro at det har vært tilfelle der også.

Denne flaskehalsen har åpenbart hatt en funksjonell hensikt. For det første har den gjort det lettere å holde ved, trekull og røstet malm på plass inne i sjakta. For det andre har den gjort at det har vært et temperaturskille mellom sjakta og den underliggende slaggropa, slik at den veden som var i slaggropa ikke brant opp så fort. Slaggropa ser nemlig ut til å ha vært fylt med ved - ut fra vedavtrykk som er funnet på slagg i slaggropa, å dømme. Driftsmessig kan denne innsnevringen ha betydd at temperaturen på oversiden kunne bli svært høy hvis vi tenker oss at det kom trekk nedenfra. Det er det samme prinsippet vi ser på innsiden av trekken i en vedovn.

\section{Slaggfunn i slaggropene}

I de utgravningene vi har gjennomført, har vi funnet slagg fra den siste smeltekampanjen som kan avsløre detaljer om selve ovnen (tabell 2). For det første så ser det ut som om slaggmengden inne i slaggropa er konsentrert om to vektintervall. Vi finner én klynge på rundt 50 kilo og en annen på rundt 150 kilo, noe som gir forholdet $1: 3$. Det kan tyde på at vi står overfor tre ulike driftskonsept der noen anlegg har kjørt kampanjer som har vært tre ganger større enn andre (Stenvik 2005: 53).

På den annen side har noen ovner hatt forbausende små slaggmengder etter siste brenning, noe vi skal se nærmere på seinere.

Det er ellers en del interessante trekk ved det slagget som er funnet inne i slaggropa. En del slaggkaker er størknet inn mot veggene i slaggropa. Her

\begin{tabular}{|c|c|}
\hline Jernvinneanlegg & Slaggvekt \\
\hline Heglesvollen Ø1 & $46 \mathrm{~kg}$ \\
\hline Heglesvollen A6 & $54 \mathrm{~kg}$ \\
\hline Heglesvollen C2a & $55 \mathrm{~kg}$ \\
\hline Heglesvollen C5 & $20 \mathrm{~kg}$ \\
\hline Fjergen ovn 1 & $150 \mathrm{~kg}$ \\
\hline Fjergen ovn 2 & $155 \mathrm{~kg}$ \\
\hline Fjergen ovn 3 & $155 \mathrm{~kg}$ \\
\hline Fossvatn ovn 1 & $50 \mathrm{~kg}$ \\
\hline Fossvatn ovn 2 & $150 \mathrm{~kg}$ \\
\hline Vårhusvollen & $144 \mathrm{~kg}$ \\
\hline Tovmoen & $140,6 \mathrm{~kg}$ \\
\hline Storbekken & $71 \mathrm{~kg}$ \\
\hline Stordalen ovn 1 & $5 \mathrm{~kg}$ \\
\hline Stordalen ovn 2 & $25 \mathrm{~kg}$ \\
\hline Stordalen ovn 3 & $50 \mathrm{~kg}$ \\
\hline Stordalen ovn 4 & $50 \mathrm{~kg}$ \\
\hline
\end{tabular}

Tabell 2: Vekten av slagg som er funnet $i$ slaggroper på ovner som er undersøkt $i$ Trondelag.

Table 2: Slag weights measured in slag pits excavated in Mid Norway.

ser vi at veggene må ha vært kalde, og at de ikke har inngått i den delen av ovnen som var så varm at det kunne foregå en reduksjon av malm. Leira er for eksempel helt grå i slike størkningsflater. Som tidligere nevnt forteller treavtrykk at gropa må ha vært fylt med tre. Vi har også funnet spor av tjære i bunnen av gropene, noe som er et bevis på at det har vært brukt trevirke i ovnen på Fjergen.

I noen tilfeller er slaggblokkene store. På Fjergen i Meråker ble det for eksempel funnet en slaggblokk i slaggvarpet som veide cirka 120 kilo. Det må riktignok sies å være et særtilfelle. Det ble imidlertid observert fem fordypninger på overflaten av denne slaggblokken, noe Arne Espelund mener må ses i sammenheng med dannelsen av fem blåsterjern inne i ovnen. Det må $\mathrm{i}$ så fall ha passet sammen med fem luftinntak. Vi har ikke noe belegg for disse påstandene - det er så langt bare en mulighet at det var slik - men det var fem groper som omkranset noen av ovnene på stedet.

\section{Sjakta}

De observasjonene vi har gjort i slaggropa, må nødvendigvis få betydning for hvordan vi skal oppfatte formen på sjakta. Det var i denne delen av ovnen 
selve reduksjonen fant sted. Innledningsvis må det sies at vi hadde regnet med at sjakta $\mathrm{i}$ våre ovner hadde en form som mer eller mindre kunne ha lignet på en skorstein, en avkortet kjegle. Her spiller selvfølgelig formen på Scharmbeckovnen fra NordTyskland en rolle. På Heglesvollen hadde vi riktignok sett at det kunne være en relativt stor vinkel mellom sjaktvegg og bakke, uten at vi reflekterte noe mer over det.

I ettertid har vi fått en mistanke om at alle de ovnene vi har undersøkt, må ha blitt ødelagt med vilje etter bruk. Kan det være at ovnene måtte ødelegges for at man skulle kunne bevare kunnskapen om en teknologi man ikke ønsket skulle bli spredd? Eller dreide det seg om et ritual som måtte gjennomføres for at prosessen skulle lykkes, altså at det var en handling styrt av maktene? To slaggroper som ble utgravd i Stordalen i Meråker, hadde åpenbart blitt forseglet etter en smeltekampanje, som om hensikten var å lukke inne ovnens kraft (Rundberget 2002). Den ene slaggropa var samtidig tømt for slagg, noe som ellers ser ut til å ha vært uvanlig.

Ved våre undersøkelser har vi funnet sjaktrester som har vært laget av leire, stein, grus og torv. Leira er magret med sand og småstein. Vi har ikke analysert sjaktmateriale som kan fortelle mer om hva slags kjemisk, geologisk eller organisk materiale som har inngått i konstruksjonen. Vi har imidlertid sett kvistavtrykk som kan indikere at det har vært en eller annen form for armering som ble brukt inne i leira, som på Vangstadvollen i Verdal. På noen anlegg ser vi at leira har vært rullet ut i "pølser», som så har blitt klappet flate i sjaktveggen, som på Fjergen i Meråker. På sjaktbiter vi fant på Heglesvollen, ser vi at det er bygget på fire-fem nye lag med leirklining inne i sjaktveggen. På den måten må ovnens indre diameter ha blitt redusert.

Leira har deretter blitt brent i prosessen, noen ganger så hardt at den har fått en glassaktig overflate. Det er uvisst hvor ofte det var nødvendig med så omfattende reparasjoner. Ved de forsøkene vi har gjort, har sjaktene fått nokså mange sprekker etter en kampanje, og det har følgelig vært nødvendig å reparere dem. På den annen side er det nok slik at de største skadene vanligvis oppstod etter den første smeltingen, ettersom leira da ble herdet og brent. Deretter var det neppe snakk om tilsvarende krympinger av og påkjenninger for godset.

Der det har vært mulig å gjøre gode observasjoner av sjaktrestene oppe i ovnene, er det tydelig at sjakta har vært tykkest ved basis, det vil si på bakkenivå. Så har godset i sjakta åpenbart blitt tynnere oppover. Det må naturligvis ha vært viktig at sjakta var sterkest der den skulle bære tyngden av det som lå over. På bakkenivå var sannsynligvis også andre påkjenninger størst - her var temperaturen høyest, og her måtte man fra tid til annen stake opp dyser som slagget igjen. På dette nivået ble antagelig også det ferdige jernet hengende fast i sjaktveggen. På de fleste ovnene vi har undersøkt, er det en hesteskoformet avslutning av slaggropa med flate steiner som sjakta har hvilt på.

I slagghaugene nedenfor ovnene har vi funnet mye jord som vi antar at stammer fra torv som har vært brukt som isolasjon og støtte for sjaktene. Vi har imidlertid ikke funnet torv i direkte anslutning til sjaktene vi har undersøkt, så at torv ble brukt som isolasjon, er foreløpig bare en antagelse vi indirekte har sluttet oss til.

Overén av slaggropene på anlegget ved Fossvatnet i Meråker fant vi relativt store biter av selve sjakta som var laget av leire. Det gjorde det mulig for oss å lime sammen biter som hørte sammen (Berre 1997; 1998). Resultatet ga oss helt ny kunnskap om sjaktas form. For det første hadde de bitene vi fant, svært liten krumning. En sekvens vi klarte å sette sammen, viste en krumning på minst 90 centimeter. Det passet dårlig med observasjonen på bakkenivå der diameteren må ha vært rundt 50 centimeter. Følgelig må sjakta ha hatt en større diameter oppe enn nede ved bakken. I stedet for å anta at sjakta hadde en kjegleform eller en sylinderform, ble vi tvunget til å tenke oss at den hadde vært traktformet. Det er aldri funnet kanaler som kan ha ledet luft inn til slaggropa i ovnene. Hvis det har vært noen form for lufttilførsel her, må den ha kommet inn gjennom luken. Det er heller ikke funnet rør eller deler av rør («tuyere») i slaggvarp eller ovner i de undersøkelsene vi har gjennomført i Midt-Norge. På den annen side er det funnet sjaktbiter med runde hull som kan ha vært dyseåpninger i ovnene. Disse dyseåpningene har en diameter på 4-8 centimeter. Det kan bety at ovnene har vært drevet ved hjelp av naturlig trekk. Denne trekken må da ha kommet dels nedenfra, dels gjennom dyseåpninger i sidene på ovnen. Dermed kan det ha vært mange muligheter til å kontrollere temperaturen $\mathrm{i}$ ulike faser av produksjonen.

\section{Gropene}

Selv om vi ikke har funnet konkrete bevis for bruk av belger $\mathrm{i}$ våre undersøkelser, kan vi ikke utelukke at slike har vært brukt. De såkalte rosettgropene rundt ovnene kan for eksempel ha blitt brukt som belggroper. Disse gropene har ikke gitt noen klare svar med hensyn til funksjon, selv om mange av dem er gravd ut svært omsorgsfullt. Mange av gro- 
pene har sjiktninger med trekullrik jord. Slagg og ovnsrester er også vanlig. Stolpehull kan av og til stå i kanten av gropene, men aldri oppi. I ett tilfelle (Heglesvollen C2b) er en grop fylt med stein som åpenbart var ment som bygningsmateriale til en ovn. Vi har også gjettet på at gropene rett og slett kan ha vært arbeidsplattformer. Disse gropene kan ha gjort det mer bekvemt å stå når man skulle stake opp luftinntakene, som stod på bakkenivå. Dette er noe vi har erfart gjennom forsøk.

Arne Espelund har pekt på at antall groper rundt en av ovnene på Fjergen kan stemme med antall fordypninger $i$ en stor slaggblokk som ble funnet i slaggvarpet. Espelund tenker seg at det er dannet lupper ved luftinntakene, og disse luppene har i sin tur satt avtrykk i slaggblokken under.

Antall groper rundt ovnene varierer fra tre til fem. De gropene som ligger på motsatt side av åpningen i slaggropa, henger ofte sammen, slik at de danner et åttetall. Gropene er 20-40 centimeter dype, og de er gjerne 1-2 meter vide. På mange anlegg er det groper som ikke har noen direkte sammenheng med ovnene - avstanden er for stor til at de kan ha hatt noen driftsmessig funksjon. Ei slik grop er gravd ut på Heglesvollen. Denne gropa var svært tydelig, og den var noe dypere enn de gropene som lå tett inntil ovnene (Farbregd et al. 1985: figur 2). Det viste seg at denne gropa inneholdt et sjikt med leire. Det kan se ut som om leira i denne gropa har blitt eltet for bruk enten i selve ovnsbyggingen eller ved reparasjoner.

\section{Stolpehull}

På mange av anleggene vi har undersøkt, har vi funnet stolpehull. De første undersøkelsene våre, var nokså begrenset med hensyn til areal rundt selve ovnene. Etter hvert ble søkelyset satt på andre aspekt enn selve ovnskonstruksjonene, og større areal rundt ovnene ble avdekket. Dette var særlig tilfellet på Fjergen, der et større område rundt alle ovnene ble avtorvet (Stenvik 1996). Her var det mulig å se et mønster i hvor disse stolpehullene opptrådte. Rundt hver ovn var det et sett med stolpehull som så ut til å ha en funksjonell sammenheng med ovnen. I tabell 3 er målene på stolpehullene vi fant på Fjergen, listet opp:

Stolpehullene var relativt store og dype. De må ha båret eller støttet en stor konstruksjon. Vi gjettet på at det kunne ha vært et stillas som gjorde arbeidet med etterfylling av malm og ved adskillig lettere. Det forutsatte imidlertid at det eksisterte ei sjakt som var formet som en avkortet kjegle. I ettertid har vi blitt mer skeptiske til denne teorien, så vi

\begin{tabular}{|c|c|c|}
\hline Stolpehull & Diameter & Dybde \\
\hline Ovn 1, hull 1 & $0,25 \mathrm{~m}$ & $0,20 \mathrm{~m}$ \\
\hline Ovn 1, hull 2 & $0,20-0,30 \mathrm{~m}$ & $0,37 \mathrm{~m}$ \\
\hline Ovn 1, hull 3 & $0,20-0,27 \mathrm{~m}$ & $0,35 \mathrm{~m}$ \\
\hline Ovn 1, hull 4 & $0,20-0,25 \mathrm{~m}$ & $0,20 \mathrm{~m}$ \\
\hline Ovn 1, hull 5 & $0,30 \mathrm{~m}$ & $0,50 \mathrm{~m}$ \\
\hline Ovn 2, hull 1 & $0,12-0,20 \mathrm{~m}$ & $0,26 \mathrm{~m}$ \\
\hline Ovn 2, hull 2 & $0,20-0,26 \mathrm{~m}$ & $0,21 \mathrm{~m}$ \\
\hline Ovn 2, hull 3 & $0,19-0,21 \mathrm{~m}$ & $0,27 \mathrm{~m}$ \\
\hline Ovn 2, hull 4 & $0,20-0,28 \mathrm{~m}$ & $0,37 \mathrm{~m}$ \\
\hline Ovn 2, hull 5 & $0,22-0,27 \mathrm{~m}$ & $0,32 \mathrm{~m}$ \\
\hline Ovn 3, hull 1 & $0,21-0,22 \mathrm{~m}$ & $0,30 \mathrm{~m}$ \\
\hline Ovn 3, hull 2 & $0,17-0,18 \mathrm{~m}$ & $0,36 \mathrm{~m}$ \\
\hline Ovn 3, hull 3 & $0,20-0,21 \mathrm{~m}$ & $0,30 \mathrm{~m}$ \\
\hline Ovn 3, hull 4 & $0,18-0,20 \mathrm{~m}$ & $0,26 \mathrm{~m}$ \\
\hline
\end{tabular}

Tabell 3: Mål på stolpehull som er funnet rundt jernframstillingsooner.

Table 3: Diameter and depth of post holes found around furnaces.

må kanskje søke andre forklaringer på stolpehullene. Dimensjonene kan ellers stemme bra overens med stolper som har båret hustak på denne tiden. Det er imidlertid vanskelig å se for seg et tak over traktformete ovner. Strålevarmen fra disse ovnene er såpass stor at et eventuelt tak raskt ville ha tatt fyr. Under forsøk har det vist seg at flammene står svært høyt etter hver vedtilsetting. Det kan på den annen side ha vært behov for å dekke til anlegget i vinterhalvåret. I så fall ville en eller annen form for tak ha hindret at ovnene ble ødelagt før neste sesong. Det ville ha vært særlig aktuelt om man visste at det kom til å gå flere år til neste gang man hadde bruk for anlegget. ${ }^{14} \mathrm{C}$-dateringer av flere anlegg tyder på at det kan ha vært lange opphold mellom driftsperiodene.

\section{DISKUSJON}

Konklusjonene vi har trukket i denne artikkelen, hviler på relativt få undersøkelser. Utgravningene viser imidlertid at vi har med en homogen gruppe ovner å gjøre. Nå var ikke oppmerksomheten på konstruksjonsdetaljer altfor stor ved de første gravningene, men disse detaljene ble en viktig problemstilling ved de siste utgravningsprosjektene, og de må derfor tillegges særlig vekt. Det er noen motstridende funn som giør det problematisk å dra altfor bastante slutninger. Det er for eksempel funnet sjaktbiter med spor etter sirkulære hull som antas å være luftinntak. 
Vi har imidlertid ikke observert kanaler gjennom det isolerende laget som har omgitt sjakta.

Trøndelagsovnen har en del likhetstrekk med Østlandsovnen, som også er en sjaktovn med underliggende slaggrop. Østlandsovnen ble benyttet omtrent samtidig som Trøndelagsovnen, men måtte brytes ned etter hver smeltekampanje for at det skulle være mulig å ta ut jernet. Da var slaggropa fylt med slagg som kunne veie 400 kilo, 2-3 ganger så mye som det vi har observert i Trøndelagsovnen (Larsen 1991; 2009). Begge disse ovnstypene ser ut til å ha vært drevet med ved. I Trøndelag dreier det seg utelukkende om furuved. Et tjærelignende stoff $i$ bunnen av noen av slaggropene er et klart bevis på at ovnene har vært fyrt med ved. Avtrykk av ved i slagg som er funnet inne i ovnene, peker i samme retning.

Sammenliming av sjaktbiter fra en ovn i Stordalen i Meråker der det var bevart ganske store deler av sjakta, har vist at diameteren på sjakta må ha vært over 90 centimeter. Sammenholdt med dokumentasjonen av sjaktdiameteren på bakkenivå, som har vært mellom 45 og 50 centimeter i flere ovner som ble undersøkt i Meråker, må det bety at sjakta har videt seg ut over bakken. Den må ha vært traktformet (figur 3). Dette er en form vi ikke kjenner fra eldre jernalder noe sted. Høyden på ovnen har det ikke vært mulig å bestemme eksakt, men det antas at den har vært omtrent én meter over bakkenivå. Først med Evenstadovnen, som er datert til seinmiddelalderen og etterreformatorisk tid, har vi fått eksempler på denne formen. Evenstadovnen var også fyrt med ved (Evenstad 1782). Et spørsmål som dukker opp, er om det kan tenkes at det er en kontinuitet mellom Trøndelagsovnen og de ovnene Evenstad beskriver på 1700-tallet. Arne Espelund har datert noen av disse ovnene til slutten av middelalderen (Espelund 2005). De yngste daterte Trøndelagsovnene stammer fra slutten av 500-tallet e.Kr. Det er med andre ord et kronologisk gap på rundt 1000 år mellom de to ovnstypene. Det svekker tanken om en kontinuitet.

Allerede ved den første utgravningen vi gjorde på Heglesvollen i Levanger, fant vi deler av sjakta som hadde flate steiner på baksiden som ikke lå 90 grader på sjaktveggen, men dannet en stump vinkel. Det er en indikasjon på at sjaktveggen ikke har vært loddrett, men at den må ha hellet. Dette var et faktum vi ikke la spesielt mye vekt på, vi antok i stedet at sjakta hadde lignet på sjakter vi hadde kjennskap til fra litteraturen. Særlig viktig i denne sammenheng var funnet av sjakta ved Scharmbeck i NordTyskland (Pleiner 2000: 151; Wegewitz 1957). Denne sjakta ser ut som en skorstein som smalner

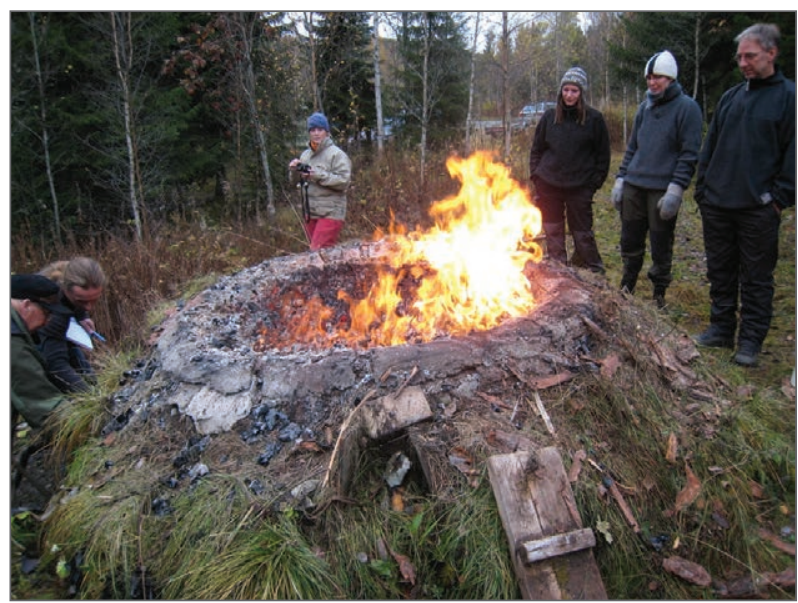

Figur 3: Forslag til rekonstruksjon av Trondelagsovnen. Foto: L.F. Stenvik, NTNU Vitenskapsmuseet.

Figure 3: A reconstruction of a 'Trondelag furnace'. Photo: L.F. Stenvik, NTNU University museum.

svakt inn mot toppen. Den vil nok fungere optimalt når man fyrer med trekull, men den blir fort upraktisk når man skal forkulle ved i den.

Vi skal ikke diskutere driftskonseptet i Trøndelagsovnen her, men vi kan slå fast at det må ha vært praktisk med en vid sjakt når man skulle forkulle ved i det første steget av prosessen.

Det er brukt leire i byggingen av sjakta. Vi har ikke analysert sammensetningen av leira eller tilsatsen av magringsstoff. Leira har vært bearbeidet før bruk, slik at den kunne bygges opp som strenger, og det er kvistavtrykk som indikerer at den har vært armert for å styrke formen. Leire har også vært brukt for å påføre steinheller i veggene i slaggropa. Det har gjort veggene i så vel sjakta som slaggropa slette, slik at innholdet i ovnen har kunnet gli nedover i takt med framdriften i prosessen.

Ovnene har vært omgitt av et sett av groper med uviss funksjon. Teoretisk kan det ha vært belggroper, men vi har ikke kunnet dokumentere luftkanaler fra dem som kan bevise det. Gropene kan ha fungert som lagergroper for materiale som trengtes under prosessen. I ett tilfelle fant vi bygningsstein som ville ha vært nyttige i forbindelse med reparasjoner. Ellers er gropene fylt med avfall som virker tilfeldig. Det kan også at dette har vært arbeidsplattformer som lettet visse operasjoner i forbindelse med framstillingen.

Det er vanskelig å finne konkrete forbilder for Trøndelagsovnen. Det er klart at den er laget over et generelt konsept med ei oppsamlingsgrop og ei sjakt der reduksjonen av malmen har foregått under tilførsel av luft. Både størrelsen på ovnen, bruken av ved 
og ikke minst omfanget av produksjonen, der opptil åtte ovner kan ha vært i drift samtidig, tyder på en avansert teknologi som bare har kunnet utvikle seg innenfor et godt organisert samfunn (Stenvik 2005). Teknologien opptrer først i førromersk jernalder på en tid som er preget av stor bosetningsekspansjon i Trøndelag (Grønnesby 2005; Rønne 2005). Like brått som teknologien kommer, forsvinner den på slutten av 500-tallet, og den etterlater seg knapt noen spor i den teknologien som blir tatt i bruk i perioden som følger. Det kan skyldes en samvirking mellom endringer i samfunnsforhold, demografisk krise og politiske faktorer. Vi vil imidlertid ikke her komme nærmere inn på årsakene til at det var slik.

\section{KONKLUSJON}

Den såkalte Trøndelagsovnen er en sjaktovn med slaggrop som føyer seg inn i en europeisk ovnstradisjon for framstilling av jern. Ovnene av denne typen har bestått av en slaggrop under bakkenivå som kunne tømmes gjennom en åpning $i$ siden. Det gjorde at ovnene kunne brukes om igjen, og smeltekampanjer kunne kjøres kontinuerlig. Mellom slaggropa og sjakta som lå over bakkenivå, har det vært en innsnevring, i alle fall i noen ovner, som har kunnet holde ved, trekull og røstet malm på plass samtidig som det har hatt effekt på temperaturen over innsnevringen. Slaggropa har vært forholdsvis kald ettersom leira i veggene her ikke er rødbrent. Sammenliming av sjaktbiter har vist at sjakta må ha vært traktformet. Dette er en uvanlig form som imidlertid er kjent fra Evenstadovnen på et langt seinere tidspunkt. Formen kan ha vært svært praktisk med tanke på at det har vært brukt ved, og ikke trekull, i prosessen. Ovnene kan ha vært drevet uten belger med lufttilførsel nedenfra gjennom innsnevringen på bakkenivå og/eller gjennom dyser i sjaktveggene. På noen anlegg har det trolig vært stolpebårne tak som har beskyttet ovnene mot nedbør. De metallurgiske implikasjonene har vi ikke gått inn på.

Takk: Deler av dette manuset har tidligere blitt presentert på et seminar i regi av Norsk Bergverksmuseum i Folldal i 2005. Jeg vil rette en særlig takk til de personene jeg har samarbeidet med i undersøkelsene av jernvinneanlegg i Trøndelag i tre tiår: Arne Espelund, Ivar Berre, Kristin Prestvold og Bernt Rundberget.

\section{SUMMARY}

Since the beginning of the 1980s several iron production sites from the Early Iron Age have been surveyed and investigated in the Trøndelag Counties in Mid Norway. Based on archaeological material, experiments and metallurgical knowledge, the shape of the furnace has been reconstructed. Our investigations have revealed a type of furnace which is different from contemporary furnaces in Scandinavia. These furnaces are known as «Trøndelag furnaces» and they are shaft furnaces with slag pits. The furnaces could be operated in continuing smelting operations. The furnaces are surrounded by a set of pits and they seem to have been protected by a roof, supported by posts, for periods. Several furnaces seem to have been operated simultaneously and they were fired with pine wood. The furnace seems to have been funnel-shaped, with a bottle neck at ground level. The furnace must have been mainly driven by natural drought. The furnace type has a distribution limited to Mid Norway.

\section{LITTERATUR}

Berre, I. 1997. Studie av sjaktmateriale frå Heglesvollen og Fossvatnet. Rapport 1.9.1997.

Berre, I. 1998. «Heglesvollomnen». Levanger Historielag. Årbok: 71-103. Levanger: Historielaget.

Espelund, A. 1999. Bondejern i Norge. Trondheim: Arketype forlag.

Espelund, A. 2005. Bondejern i Norge. Ny utgave. Trondheim: Arketype forlag.

Evenstad, O. 1782. Afhandling om Jern-Malm som findes i Myrer og Moradser i Norge og omgangsmåden med at forvandle den til Jern og Staal. København 1790.

Farbregd, O., L. Gustafson og L.F. Stenvik 1985. «Tidlig jernproduksjon i Trøndelag. Undersøkelsene på Heglesvollen». Viking 1984: 103-129.

Grønnesby, G. 2005. «Fra stolpehull til hushold. Utgravninger av hustomter på Kvenild, Trondheim 1998». M. Høgestø1, L. Selsing, T. Løken, A.J. Nærøy og L. Prøsch-Danielsen (red.). Konstruksjonnspor og byggeskikk. Masinell flateavdekking - metodikk, tolking og forvaltning. AmS-Varia 43: 97-107. Stavanger: Arkeologisk museum.

Larsen, J.H. 1991. Jernvinna ved Dokkfloyvatn. De arkeologiske undersøkelsene 1986-1989. Varia 23. Oslo: Universitetets Oldsaksamling.

Larsen, J.H. 2009. Jernvinneundersøkelser. Faglig program 2.Varia 78. Oslo: Kulturhistorisk museum.

Pleiner, R. 2000. Iron in Archaeology. The European Boomery Smelters. Praha: Archeologiký ústav av čr.

Rundberget, B.H. 2002. Teknologi og jernvinne. En teoretisk og metodisk tilnarming til jernvinna som kilde for 
menneskelig kunnskap og handling. Hovedfagsoppgave: NTNU, Trondheim.

Rønne, P. 2005. «Arkæologiske undersøgelser forud for bygningen af ny E6 gennem Melhus, Sør-Trøndelag». M. Høgestøl, L. Selsing, T. Løken, A.J. Nærøy og L. Prøsch-Danielsen (red.). Konstruksjonnspor og byggeskikk. Masinell flateavdekking - metodikk, tolking og forvaltning. AmS-Varia 43: 87-96. Stavanger: Arkeologisk museum.

Stenvik, L.F. 1996. «De arkeologiske undersøkelser av et jernframstillingsanlegg ved Fjergen, Meråker. Undersøkelser i forbindelse med kraftutbygging i
Meråker, Nord-Trøndelag». L Stenvik (red.) Rapport Arkeologisk serie 1996/1: 5-39. Trondheim: NTNU Vitenskapsmuseet.

Stenvik, L.F. 1998. Rapport fra utgravning av jernframstillingsanlegg ved Fossvatnet $i$ Meråker. Trondheim: NTNU Vitenskapsmuseet.

Stenvik, L.F. 2005. «Jernalderen». Trondelags Historie 1: 106-170. Trondheim: Tapir Akademisk forlag.

Wegewitz, W. 1957. «Ein Rennfeuerofen aus einer Siedlung der älteren römischen kaiserzeit in Scharmbeck (kreuz Harburg)». Nachrichten aus Niedersachsens Urgeschichte 26: 3-25. 


\title{
TIDIGA SPÅR AV JÄRNHANTERING I NORRA FINLAND
}

\author{
Hannu Kotivuori
}

Enligt rådande forskning är uppfinningen att använda metallföremål ett östligt eller sydöstligt fenomen i inlandet och i norra Finland. Orsaken till detta är att de gamla «stenålderstida» handelsvägarna från sjön Ladoga och Vita havet riktade sig mot nordväst. Ananinokulturen i Volga- och Kamatrakten kan vara ursprunget för denna innovation.

Bruket och tillverkningen av metallföremål började redan på stenåldern i Finland. Rent koppar påträffades redan då i naturen. Man bearbetade metallen genom hamring och tillverkade knivar och mejslar av samma utseende som stenföremålen. Det hittills äldsta verktyget av metall som påträffats i Finland, en hålmejsel av koppar, härstammar från Kukkosaari i Suomussalmi. Hålmejseln dateras till slutet av stenåldern (Huurre 1986). Föremålet antyder att norra Finland och inlandet påverkats starkt av den östeuropeiska metallkulturen, som var rådande under ett par tusen års tid.

Under tidig metallålder (ca. 1900 -1500 f.Kr. 300 e.Kr) anlände färdiga brons- och järnföremål samt kunskap om föremålens framställningsmetoder till Finland längs med gamla handelsleder från området Volga - Oka (Carpelan 1999). De böjda järndolkarna som hittats i Kosku i Savukoski i Lappland inleder fasen av självständig metallurgi (Erä-Esko 1969). Dessa dolkar, som troligen härstammar från 400-talet f. Kr, har hämtats från östra Ryssland, från Ananinokulturens område vid floden Kamas mynning (Carpelan 2003).

Bronsföremålen stöptes vanligen i formar gjorda av täljsten eller lera. Man kunde skapa en önskvärd föremålsform för gjutformen genom att använda vax, som smälte bort då man brände leran. För denna framställningsteknik talar bl.a. deglar eller kannor gjorda av grov lermassa, vilka påträffats i Neitilä i Kemijärvi och Kiikarusniemi i Sotkamo (Huurre 1986; Kotivuori 1997). Från dessa båda fyndplatser samt från Varaslampi i Joensuu känner man även till lämningar av kärl med fot, som liknar bägare. Keramiktyperna som kännetecknar tidig metallålder innehåller asbest, talk eller glimmer (lovozero-, textil-, imiterad textil- och anttilakeramik).

Kjelmøykeramiken, som var i bruk i början av tideräkningen ca. 700 f.Kr. - 300 e.Kr., är vanligen förekommande vid järnframställningsplatserna i norr (Carpelan 2003). Järnbitar har till och med blandats med keramikleran (Willemark 1989). Därför har man ibland antagit att kjelmøykeramiken spelat en roll i järnframställningen, men i praktiken håller inte kärlen en värme på drygt $1100{ }^{\circ} \mathrm{C}$. För att smälta järnet behövs $1538{ }^{\circ} \mathrm{C}$, så därför bör ett dylikt bruk av kjelmøykeramiken betraktas som hypotetiskt (jfr Hulthén 1991; Baudou 1995). Det skulle då även vara onödigt att dekorera kärlen i enlighet med den tradition som förefaller typiskt för kjelmøykeramiken.

\section{UTGRÄVNINGAR I ROVANIEMI}

På de två järnframställningsplatserna Kotijänkä och Riitakanranta i Sierijärvi i Rovaniemi som undersöktes åren 1989-1991 påträffades även skärvor av 13 olika kjelmøykärl (Kotivuori 1996). Enligt dateringen av slagg (Hela-no 14, $2410 \pm 75$; Hela-no 15, $2465 \pm 75$; Hela-no 16, $2540 \pm 80$ ) från bitarna från Kotijänkä är skärvorna troligen äldre än järntillverkningen, från ca. 700 - 400-talet f.Kr. Således representerar de ett tidigare bruk av platsen. En påträffad järnkniv av Ananinotyp kan ha tillhört dem som smält järn, eller så tillhör föremålet den litet äldre kontexten kjelmøykeramik. Vid denna tid har man tydligen framställt först och främst knivar, pilspetsar och holkyxor av järn. Från boplatsen i

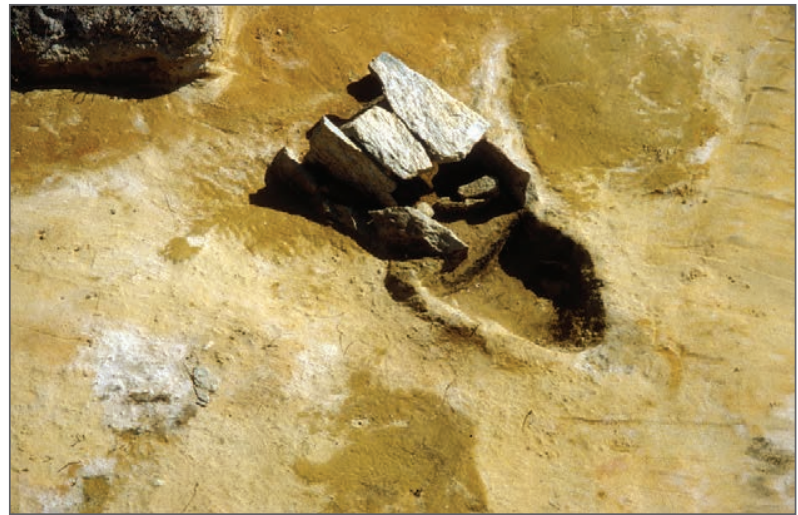

Figur 1: Järnframställningsugnen frän Riitakanranta $i$ Rovaniemi. Ugnen làg direkt under markytan. Foto: H. Kotivuori, Lapin maakuntamuseo.

Figure 1: The iron production furnace from Riitakanranta in Rovaniemi. The furnace is located well below the surface. Photo: H. Kotivuori, The Provincial museum of Lapland. 
Kotijänkä påträffades även fyra oidentifierade fragment av ett järnföremål samt ett fragment av ett föremål som påminner om en bronsknopp.

Ugnen, en låg schaktugn/gropugn, med flata stenar, som grävts direkt under markytan i Riitakanranta (figur 1), mätte ca. 50 × $25 \times 25 \mathrm{~cm}$, dvs. den håller ca. 31 liter (Hjärthner-Holdar 1993: 95, figur 84). På ugnen hade en flat, rektangulär sten med retuscherade kanter krossats, men på botten hade endast lera lagts som isolering. Slaggen hade letts ut $\mathrm{i}$ en liten jordgrop framför ugnen. I övrigt fanns ganska litet slagg i närheten av ugnen. Av slaggen var $15 \mathrm{~kg}$ järnhaltigt material och $9 \mathrm{~kg}$ bestod av en massa blandad med lera och sten. I närheten fanns dylika «väggbitar», och antagligen därför har här funnits en ugn som ursprungligen byggts på markytan men förstörts. Ugnen kunde ha varit gjord av lera och skifferstenar, formad som en liten schaktugn. Vid markytan fanns dessutom en $45 \mathrm{x}$ $20 \mathrm{~cm}$ bred och endast ca. $3-5 \mathrm{~cm}$ tjock flat sten. På stenen och på dess kant fanns in situ ett lager som bildats av små bitar av slagg. Stenen verkade inte ha varit ett underlag för tillverkningen, utan snarare en del av grunden till en ugn som byggts på markytan.

Volymen på en ugn av flata stenar i Kotijänkä (figur 2), som är mer krossad än föregående, var ca. 50 liter, eftersom ugnens storlek var ca. 40 x 50 x $25 \mathrm{~cm}$. Volymen går att anta, eftersom man för en smältningsprocess behövde ca. 8-10 kg myr- eller sjömalm (fi. hölmä, limoniitti), som var järnhaltigt och torkat genom förbränning (fi. pasutus), av vilken man kanske fick ca. 1,5-2,0 kg bearbetat järn (Kotivuori 1996). Produktionsberäkningar eller snarare produktionsvärderingen är enligt rysskan A.V. Anpilagov (1966: 180), Drevneja zelezodelatelnaja masterskaja... (Se noten Kotivuori 1996). Värderingen är förstås beroende av olika faktum/ fynd och kan inte vara exakt/motsvarande $\mathrm{i}$ alla omständigheter. Troligen kunde ugnen användas flera gånger, eftersom mängden slagg i närheten av denna ugn för finska förhållanden var betydande. Järnhatligt material av slaggen var $137 \mathrm{~kg}$ och $33 \mathrm{~kg}$ utgjordes av en massa blandad med lera och sten. På ugnen fanns cylinderformade bitar gjorda av slagg (81 st.), som verkade vara lämningar av mynningen av en bälg, tätta, (Serning 1979: 86). Diametern av insidan på bitarna är ca. endast $6 \mathrm{~mm}$ och längden åtminstone $5 \mathrm{~cm}$ (figur 3). Inga kemiska analyser har giorts på fyndmaterialet.

Även i närheten av skifferstensugnen i Kotijänkä fanns resterna av en möjlig kupolugn, på ytan av sandjorden (Serning 1979: 75; Hjärthner-Holdar 1993: 95). Möjlig kupolugn är för mig en ovanlig typ

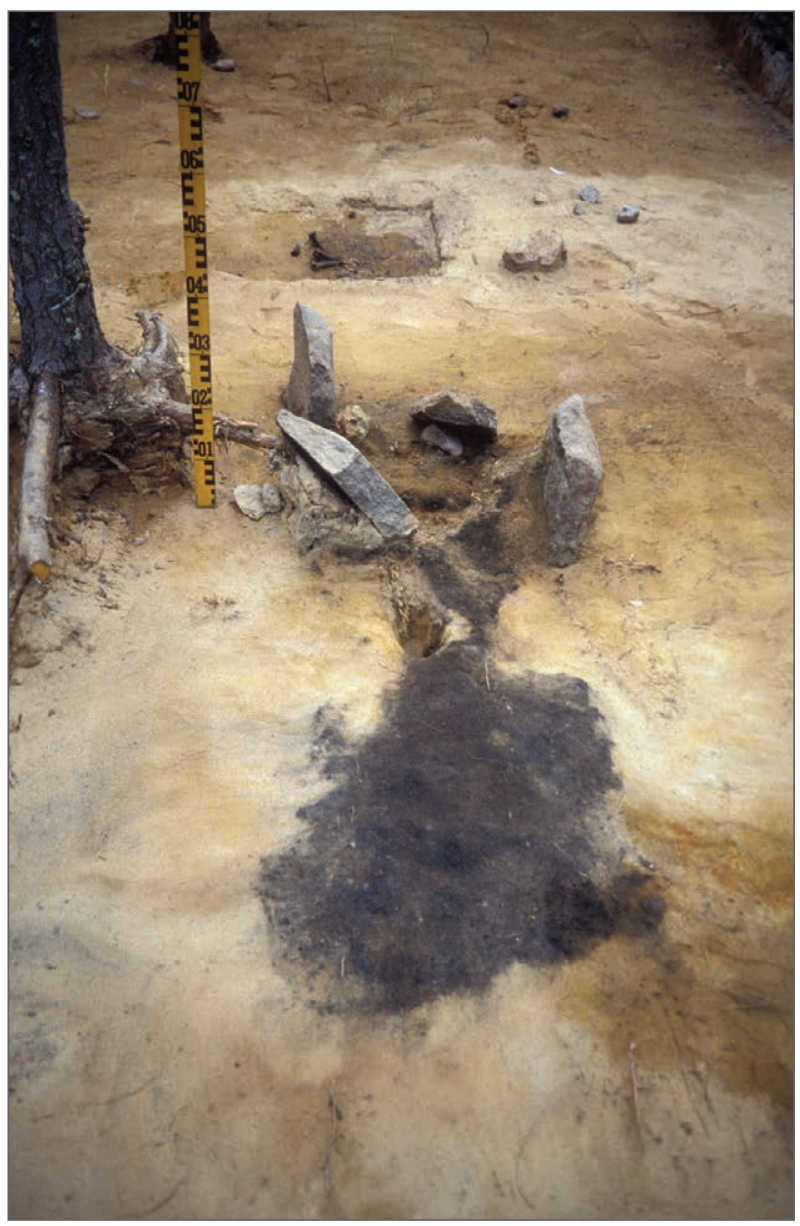

Figur 2: Järnframställningsplatsen Kotijänkä i Rovaniemi. Ugnen med flata stenar och jordgropen för slagg. Foto: $H$. Kotivuori, Lapin maakuntamuseo.

Figure 2: Iron production site Kotijänkä in Rovaniemi. The furnace was made of stone slabs and it had a pit for collecting slag. Photo: H. Kotivuori, The Provincial museum of Lapland.

av ugn eller ett «enstaka fenomen». För mig är det en fråga om en hypotes, när ugnsresterna låg ovanpå markytan. Den rundkantade anomalin var ca. 50 $\mathrm{cm}$ bred och bestod av slagg, på vilken det in situ fanns ett lager av väggbitar formade av lera och sten. Slaggen har typiskt delvis fastnat på väggbitarnas insidor. Helheten verkade rentav vara ett förstört resultat av en misslyckad smältningsprocess.

Schaktugnen/gropugnen, som byggts av flata stenar i en jordgrop i Kotijänkä, dateras med radiokol (Hel-3173, $1880 \pm$ 110), kalibrerat, till ca. 10 f.Kr. - 320 e.Kr. En radiokoldatering från Riitakanrantas skifferstensugn (Hel-2955, $2090 \pm 100)$ har kalibrerats till ca. 360 f.Kr. - 20 e.Kr. En annan datering från samma ugn (Hel-2965, $1820 \pm 110)$ motsvarar däremot kalibrerat en datering till ca. $70-340$ e.Kr. Den stora spridningen av dateringen antyder att man framställt järn ungefär vid tideräkningens bör- 


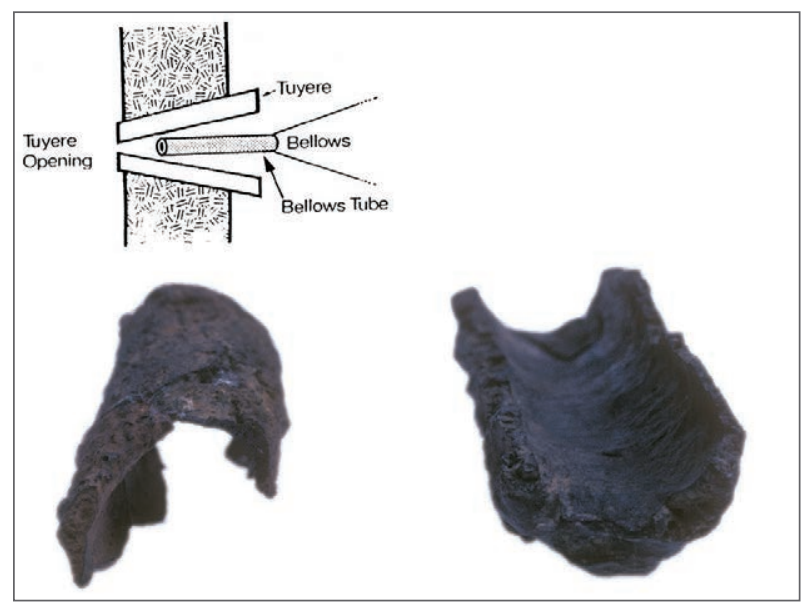

Figur 3: Cylinderformade bitar (inre mått $6 \mathrm{~mm}$ ) gjorda av slagg låg bredvid ugnen. En ritning av «bellows tube» påminner fyndena (Serning 1979:86). Foto: H. Kotivuori, Lapin maakuntamuseo.

Figure 3: Cylindrical pieces (diameter $6 \mathrm{~mm}$ ) of slag were found beside the furnace. Drawing of conjectured 'bellows tube' resembles these finds (Serning 1979:86). Photo: H. Kotivuori, The Provincial museum of Lapland.

jan. En datering från platsen kunde även tas från en eldstad (Hel-3174, $2040 \pm 100)$ och möjligen från en näverkorg som brunnit in situ (Hel-3679, $2070 \pm$ 90); båda motsvarar dateringarna från ugnarna.

\section{MOTSVARANDE FYND FRÅN FINLAND OCH ÖST-KARELEN}

I Finland har man undersökt järnframställningsplatser från tidig metallålder även bl.a. på boplatserna i Neitilä i Kemijärvi, Äkälänniemi i Kajana och Kitulansuo i Ristiina (Kehusmaa 1972; Schulz 1986; Lavento 1999). Till sin konstruktion motsvarar ugnarna i Sierijärvi fynd från Äkälänniemi, som daterats (Hel-2098, $2220 \pm$ 100; Hel-2101, $2180 \pm 90$ ) och kalibrerats till mellan ca. 400 - 120 f.Kr.

I östra Karelen har man undersökt rikligt med motsvarande skifferstensugnar, bl.a. resterna av sju ugnar på en boplats benämnd Kudoma XI i Säämäjärvi (Kosmenko och Manuhin 1999). Enligt radiokoldateringar är de dock yngre än sina nordliga motsvarigheter, från ca. 400 - 1300 e.Kr. I Finland har en motsvarande datering fătts från en skifferstensugn i Kitulansuo i Ristiina (Lavento 1999). Ugnstypen verkar på basis av detta ha fortsatt att vara i bruk från tidig metallålder till medeltid. Kronologiskt kan dateringarna av dessa ugnar inte verifiera att innovationen kommit från sydöst, men utbredningen av själva de undersökta blästerugnarna ger vid handen att så är fallet. I Öst-Karelen känner man dock till flera till sin datering osäkra järnframställningsplatser, som på basis av det övriga fyndmaterialet kan härröra sig från tiden före tideräkningens början (Kotivuori 1996; Kosmenko och Manjuhin 1999).

Järnsmältningsprocessens skeden är allmänt kända i teorin. I ugnen brändes först träkol eller hackat trä och slutligen tillsattes malmen. Slaggen rann ut genom ugnens mynning. Med hjälp av en bälg smältes den upphettade malmen, och järnet samlades slutligen till en lupp i slagsjøen på ugnsbottnen, varifrån den togs upp för ytterligare bearbetning.

Forntida järnframställningsugnar kan även i Finland indelas enligt sin konstruktion och funktion i många typer, bruket av dem har många lokala och kulturella särdrag. . På grund av det knappa materialet har man i Finland ändå inte närmare gett sig in på att klassificera olika förhistoriska ugnstyper eller definiera deras möjliga bruksperioder (Serning 1979; Hjärthner-Holdar 1993). Den mest primitiva typen företräds av olika gropugnar och ett mer utvecklat tillverkningssätt ses företrätt i schaktugnarna (Mäkivuoti 1988). Tidiga experiment hos jägar- och samlarpopulationer att tillverka järn av lokala råvaror verkar i Finland ha upphört i huvudsak på 300-talet e.Kr. En betydande orsak till detta kan antas vara att man fått tillgång till mera färdiga järnföremål från handelspartners i söder och öster.

\section{SUMMARY}

In the Early Metal Age bronze and iron objects were brought to Finland, especially from the VolgaOka area, along old trade routes. The idea of local production began to spread rapidly. In Rovaniemi, North Finland, two iron manufacturing sites were excavated by the Provincial Museum of Lapland during the years 1989-91. Radiocarbon dating of the slabstone furnaces proves that iron was manufactured there, probably only for domestic needs, at about the turn of the Christian Era. Many corresponding rectangular slabstone furnaces have been researched in Eastern Karelia and also in some places in Finland. In Scandinavia furnaces of this type are not known. Also in Finland and Eastern Karelia iron smelting furnaces can be divided into many different types which contain regional and cultural characteristics. 


\section{LITTERATUR}

Baudou, E. 1995. Norrlands forntid - ett historiskt perspektiv. Bjästa.

Carpelan, C. 1999. Käännekohtia Suomen esibistoriassa aikavälillä $5100 \ldots 1000$ e.Kr.Pohjan poluilla. Suomalaisten juuret nykytutkimuksen valossa. Bidrag till kännedom av Finlands natur och folk 153.

Carpelan, C. 2003. Inarilaisten arkeologiset vaiheet. InariAanaar. Inarin historia jä̈kaudesta nykypäivään (toim. Veli-Pekka Lehtola). Oulu.

Erä-Esko, A. 1969. Akinakeslöytö Pohjois-Suomesta. Suomen Museo 1969.

Hjärthner-Holdar, E. 1993. Järnets och järnmetallurgins introduktion $i$ Sverige. Societas Archaeologica Upsaliensis. Aun 16. Uppsala.

Hulthén, B. 1991. On Ceramic Ware in Northern Scandinavia during the Neolithic, Bronze and Early Iron Age. Archaeology and Environment 8.

Huurre, M. 1986. Esibistoria. Kainuun historia I. Kajaani. Kehusmaa, A. 1972. Neitilä 4. Pro gradu -tutkielma Suomen ja Skandinavian laudatur-arvosanaa varten. Helsingin yliopiston arkeologian laitos. Moniste n:o 3.

Kosmenko, M. G. \& Manjuhin, I. S. 1999. Ancient iron production in Karelia. Fennoscandia archaeological XVI.
Kotivuori, H. 1996. Pyytäjistä kaskenraivaajiksi. Rovaniemen asutus noin 6000 eKr-1300 jKr. Teoksessa: Veikko Kallio (toim.), Rovaniemen historia vuoteen 1721.

Kotivuori, H. 1997. Poimintoja Kemijärven Neitilän tulvalietteestä. Raito 2/1997.

Lavento, M. 1999. An iron furnace from the Early Metal Period at Kitulansuo in Ristiina, in the southern part of the Lake Saimaa Water System. Fennoscandia archaeolociga XVI.

Mäkivuoti, M. 1988. Esi- ja varbaishistoriallinen raudanvalmistus Pobjois-Suomessa. Sivu- ainelaudatur-tutkielma. Suomalainen ja vertaileva arkeologia. Turun yliopisto.

Schulz, E.-L. 1986. Ein Eisenverbüttungsplatz aus der älteren Eisenzeit in Kajaani. Iskos 6. Serning, I. 1979. «Prehistoric Iron produktion». I Clark, H. (red.). Iron and Man. Prehistoric Sweden. Jernkontoret: Stockholm.

Sundqvist, Ø. 1999. Traces of iron in prehistoric Finnmark. Fennoscandia archaeological XVI. Willemark, K. 1989. «Ödinge, en uppehållsplats genom förhistorien». Arkeologi, fäll, skog och bygd. 1. Stenålder - tidig järnålder. Uddevalla. 


\title{
OVNER MED SLAGGROP I SYDØST-NORGE - 400 BC-AD 800 - LIKHETER OG FORSKJELLER
}

\author{
Jan Henning Larsen
}

\section{INNLEDNING}

Målet med denne artikkelen er å drøfte de ulike ovnene for jernproduksjon av myrmalm som har grop for oppsamling av slagg. Dette er den typen ovner som Arne Espelund (2005) har skilt ut som type I i sitt system, en inndeling som synes å ha fått allmenn tilslutning (jf. Larsen 2009; Larsen og Rundberget 2009; Rundberget 2011). Forfatteren har tidligere gitt en bred gjennomgang av slike ovner (2009). I denne artikkelen skal vi gjennomføre en mer detaljert analyse av ovnene, og vi skal diskutere om de er reelle typer. Ovnene er også drøftet $i$ andre sammenhenger $i$ senere tid (Rundberget 2011; Larsen og Rundberget in print).

Perspektivet er at de sydøstnorske ovnene kan inngå i en felles nordisk forståelse av ovnsutviklin- gen. Den geografiske rammen for materialet avgrenser seg til det området hvor Kulturhistorisk museum har ansvar for utgravninger - fylkene fra Østfold til og med Vest-Agder.

I undersøkelsesområdet er det svært mange jernvinneanlegg. Bare en liten del av området er systematisk registrert, og her er det kjent omkring 2500 anlegg (figur 1). I enkelte områder er tidsdybden på jernvinna stor, opptil 2000 år. Mer omfattende prosjekter knyttet til samfunnsutbygging er gjennomført i flere områder, men bare ved undersøkelsene på Rødsmoen i Hedmark (Narmo 1997), Dokkfløy i Oppland (Larsen 1991) og Møsstrond i Telemark (Martens 1988) er det undersøkt ovner som her regnes for å være av typen med slaggroper. Lokalt initiativ har resultert i forskning på jernvinna i Snertingdal

Figur 1:

Jernvinneanlegg $i$ undersokelsesområdet (Sørost-Norge) ut fra kulturminneregisteret Askeladden, april 2012. De fleste anleggene er fra middelalderen. Kart: K. Loftsgarden, Kulturbistorisk museum. (Kartgrunnlag: Statens kartverk. Tillatelsesnummer NE12000-

150408SAS.)

Figure 1: Iron production sites in the study area (Southeast Norway) from the heritage register of Askeladden, April 2012. Most are from the Middle Ages. Map: K. Loftsgarden, Museum of Cultural History. (Map base: NMA, Permit number NE12000150408SAS).

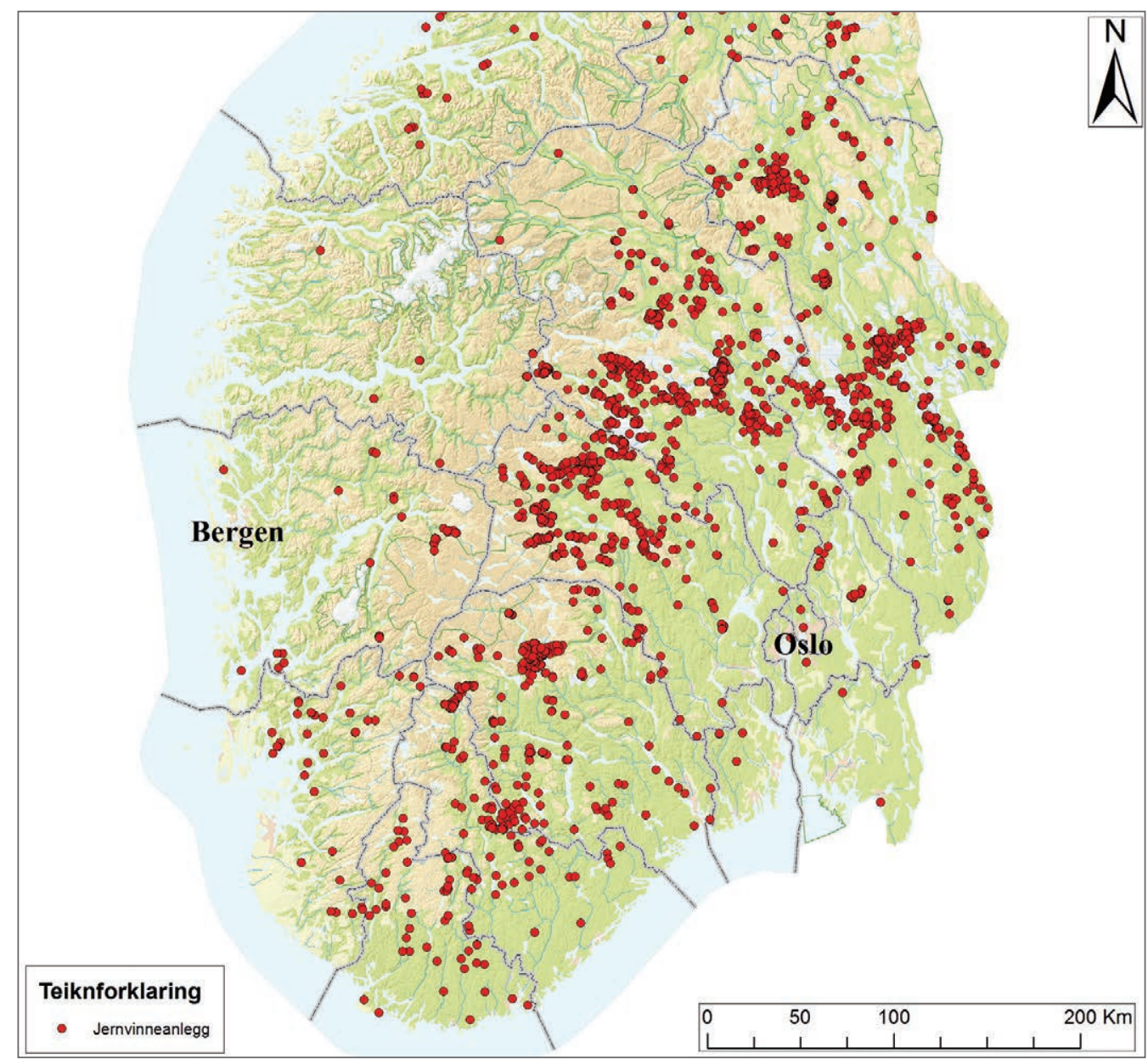


i Gjøvik kommune i Oppland, bare 30 kilometer fra Dokkfløy (Larsen 2003b; 2007; 2009). Andre kjente jernvinneområder med mange anlegg fra vikingtiden og middelalderen finnes på Beitostølen og Fillefjell i Valdres, i Ustedalen ved Geilo i Hallingdal og på Hovden, øverst i Setesdal. I disse områdene er det utført en rekke utgravninger knyttet til turistutbygging. I tillegg er det gjort et stort antall mindre utgravninger, særlig av kullgroper. Disse er knyttet til anlegg av type II (Larsen 2009) og er utenfor rammen for denne artikkelen.

Slaggavtappingsovner i Gråfjellområdet i Hedmark kan ha underliggende grop med slagg, men gropen har ikke tjent til oppsamling av slagg under produksjonen (Rundberget 2007), og den må betegnes som grop med slagg, og ikke slaggrop. Denne ovnstypen faller derfor utenfor rammen for det foreliggende arbeidet.

De aller fleste undersøkte jernvinneanleggene har ovner for slaggavtapping og er fra middelalderen, AD 1000-1400. Det skyldes først og fremst at det er langt flere anlegg fra denne perioden, men også at mange type I-anlegg ligger nær elver og vann, i landskap der det sjelden gis tillatelse til inngrep (Larsen og Rundberget in print). Produksjonen på mange av disse anleggene har vært betydelig, slik at færre anlegg ikke nødvendigvis betyr liten produksjon, men dette er et lite utforsket felt.

\section{HISTORIKK}

Jernvinneforskningen i Norge har rot i lokalhistorisk forskning i østre del av Oppland (Lillehammerdistriktet og Gudbrandsdalen) i årene omkring første verdenskrig (se Stenvik 2003; Larsen 2004; 2009: 36-37).

Naturvitenskapsmennene Rolf Falck-Muus (1927; 1931) og T. Dannevig Hauge (1946) la grunnlaget for den vitenskapelige utforskningen. Begge utførte utgravninger og utarbeidet typologi på slagg som fortsatt kan ha relevans. Hauge delte ovnene inn i fem typer som han mente var «groper og gryter».

Det ble Irmelin Martens (1988) som gjennom sine arkeologiske undersøkelser på Møsstrond i Telemark kom til å sette søkelyset på ovnsutviklingen. Før Møsstrond-undersøkelsene var alle ovner oppfattet som gropovner, slik de også var i de andre nordiske landene. Martens påviste en sjaktovn med slaggavtapping fra vikingtiden/middelalderen og en eldre hellegryte som hun oppfattet som en gropovn.

Først gjennom Dokkaprosjektets utgravninger i Gausdal Vestfjell i perioden 1986-1989 (Larsen 1991) fikk vi data om utviklingen i det indre øst-

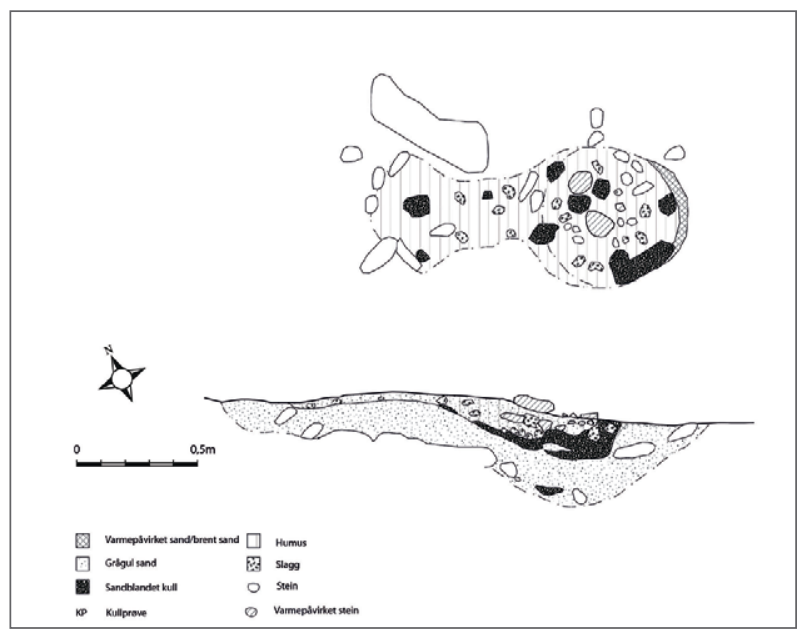

Figur 2: Ovn fra tidlig forromersk jernalder på Holen $i$ Follebu, Gausdal kommune, Oppland. Med «forkammeret» har ovnen likhetstrekk med danske ovner av Skovmarken-typen. Målestaven er 0,5 m lang. Tegning: E.M. Storrusten /K. Loftsgarden, Kulturhistorisk museum.

Figure 2: Furnace from early Pre-Roman Iron Age at Holen in Gausdal, Oppland. In structure it has similarities to Danish finds of Skovmarkentypen. Drawing: E. M. Storrusten/K. Loftsgarden, Museum of Cultural History.

landsområdet. Her ble det klarlagt at de eldste ovnene fra romertiden var store sjaktovner med underliggende slaggrop som i yngre jernalder ble avløst av sjaktovner med slaggavtapping. Forholdene er bekreftet gjennom en rekke mindre og mellomstore utgravningsprosjekter.

\section{DE ULIKE OVNSTYPENE}

I det følgende skal vi komme inn på de ulike ovnstypene, og avslutningsvis tar vi med en sammenlignende drøfting hvor også utbredelse og datering vil bli vektlagt.

\section{Tidlige slaggroper $\mathrm{i}$ innlandet}

I de senere år har det kommet for dagen jernvinneanlegg ved maskinell sjakting i jordbruksområder rundt Mjøsa som har blitt datert til tidlig førromersk jernalder. Vi skal se på et par av dem.

I 2008 ble det gjort en mindre utgravning på Holen i de sentrale delene av Gausdal, nær Follebu kirke, en steinkirke fra middelalderen. Ved registreringen i dyrket mark var det påvist to små lokaliteter med groper og litt slagg, og de var antatt å være smieplasser. Den ene ble datert til førromersk jernalder, den andre til nyere tid, og denne siste var fra en smie. Det viste seg snart at slagget fra de to var svært forskjellig, og at det fra den eldste strukturen bar preg av å være fra gammel jernpro- 


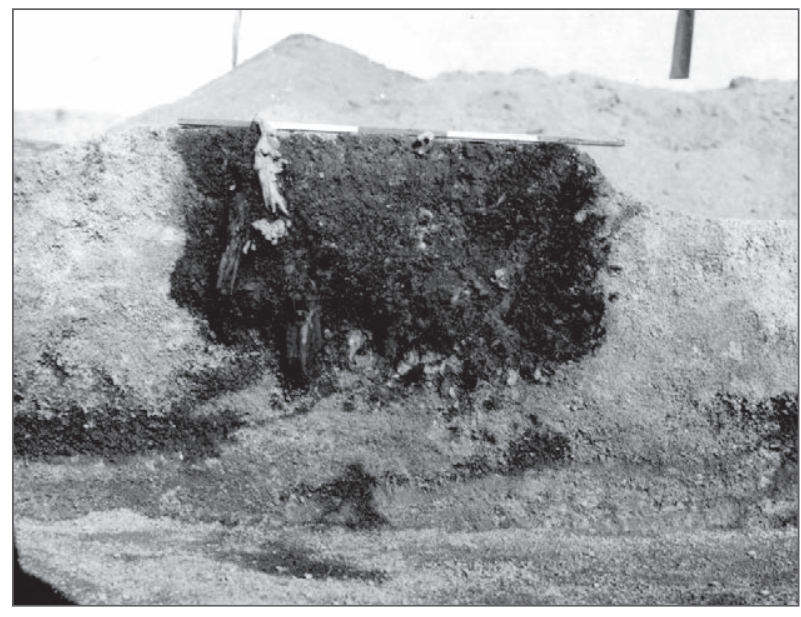

Figur 3: Slaggroper fra romertiden på Eg i Kristiansand, VestAgder. Foto: T. Bloch Nakkerud.

Figure 3: Slag pits from the Roman Period at Eg in Kristiansand, Vest-Agder. Photo: T. Bloch Nakkerud.

duksjon, noe som er bekreftet ved metallurgiske analyser.

Strukturen var en $0,4 \times 0,35$ meter vid og 0,2 meter dyp grop, delvis ødelagt ved pløyning. Innholdet var slagg, kull og rødbrent sand. Mot nordvest var det en grunnere nedgravning med en lengde på 0,5 meter og en bredde på 0,2 meter (figur 2). Det var bare mindre mengder slagg på lokaliteten, og det ble påvist noen fragmenter av sjaktmateriale, men slikt kan være vitret bort ved dyrkingen. Flere mindre steiner kan ha inngått i en konstruksjon. Videre ble det påvist et par mulige stolpehull. Det foreligger flere dateringer til 300-400-tallet f.Kr. (Loftsgarden et al. 2013: 62).

En annen undersøkelse gjaldt en ovn i Biri, i Gjøvik i Oppland. Her var det bare én grop med en diameter på 0,6 meter og en dybde på 0,13 meter. To ${ }^{14} \mathrm{C}$-dateringer ligger innenfor tidsrommet 410-250 BC. Også her var slaggmengdene små. Fra Hedmarken foreligger dessuten tidlige dateringer av slaggroper (for eksempel Risbøl 1997).

Felles for disse tidlige ovnene er at de finnes i gode jordbruksbygder og bosetningsområder i områdene rundt innsjøen Mjøsa.

\section{Ovner av Eg-typen}

Ved maskinell flateavdekking i 1977 av et boplassområde på Eg i Kristiansand i Vest-Agder ble det oppdaget syv slaggroper innenfor et areal på 10 kvadratmeter. Slaggropene var runde, med en diameter på 0,5 meter (figur 3 ), og to av dem ble ${ }^{14} \mathrm{C}$-datert til yngre romertid. Dessuten ble det funnet en samling

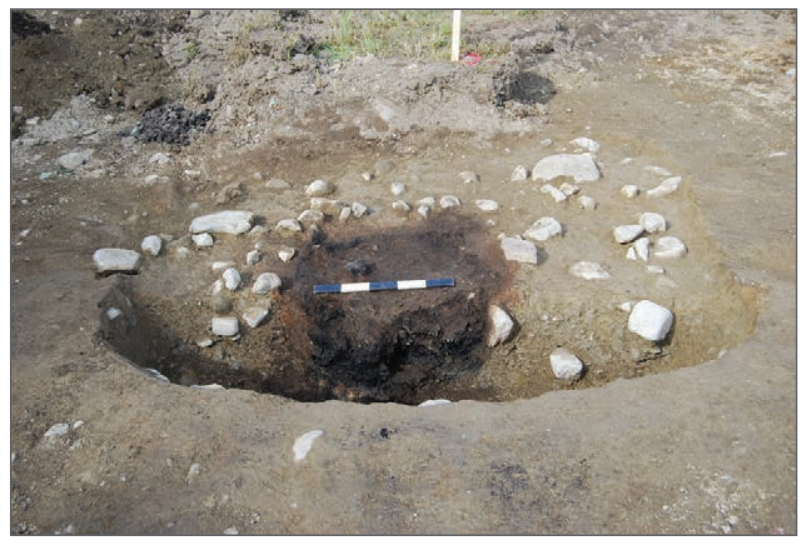

Figur 4: Slaggrop S104 ved Vardal kirke, Gjøvik i Oppland. To groper ble funnet $i$ dyrket mark med en avstand på 2,5 $m$. De ble datert til yngre romertid (bildet) og merovingertiden. Gropene var opptil dobbelt så store som gropene på Eg i Kristiansand. I størrelse ligner de på Østlandsounen, men spor etter slagghaug mangler, og slaggmengden i ovnene er langt mindre. Målestaven er 0,5 m lang. Foto: M.S. Valum, Kulturbistorisk museum.

Figure 4: Slag pit S104 at Vardal Church in Gjovik, Oppland. Two pits were found in a distance of $2.5 \mathrm{~m}$. One of them was dated to the Roman Period (figure), the other to the Merovingian Period. In diameter they are similar to the furnaces of «Østlandstypen», but without a slag heap. Photo: M. S. Valum, Museum of Cultural History.

forslagget leire, som trolig var rester av sjakten. Videre ble det oppdaget forråd av leire som kan ha vært brukt til å bygge og reparere sjakten (Nakkerud og Schaller 1979).

Karakteristisk for typen er at gropen bare er brukt én gang. Når den var full av slagg, ble produksjonen flyttet til en ny grop. Typen er påvist flere steder i Agder og Rogaland (Larsen 2003a) og er også kjent i Hedmark. Slaggmengdene i hver grop synes å ligge i størrelsesordenen 20-60 kilo. I Norge kalles disse ovnene ofte for Eg-typen, etter det første funnstedet. Ovnene i Hedmark er ifølge Risbøl (1997) fra førromersk jernalder og eldre romertid, mens ovnene fra Agder og Rogaland helst er fra romertiden. Trolig er typen mer alminnelig i Norge enn tidligere antatt, men siden den ikke kan erkjennes ved overflateregistreringer, er bare et fåtall av ovnene registrert og undersøkt. Flere slaggfunn som kan være fra ødelagte ovner, er kjent.

Det sydøstnorske materialet spriker i tid og rom. Antagelig finnes det flere varianter av slaggroper som har vært for én gangs bruk. Vi kan for eksempel nevne en undersøkelse fra 2009 i Vardal i Gjøvik, i Oppland fylke. To groper la i dyrket mark like ved kirkestedet med en avstand mellom seg på 2,5 meter. Gropene var ovale med et tverrmål på henholdsvis 0,9 og 1,1 meter 
og en dybde på henholdsvis 0,2 og 0,46 meter (figur 4). Noen biter av sjaktmateriale ble påvist. Gropene inneholdt henholdsvis 26 og 69 kilo slagg. Den ene ble datert til yngre romertid, og den andre til tidlig merovingertid. Det ble ikke påvist noen slagghaug.

\section{Østlandsovnen}

Navnet Østlandsovnen er det Arne Espelund (1999) som står bak, og navnet er gitt ut fra den geografiske fordelingen av de ulike ovnstypene. Ovnen er best dokumentert i Oppland (Larsen 1991; 2003b; 2007), og etter slaggtypen å dømme er den karakteristisk for store områder på det indre Østland, fra Hedmark til Telemark. Navnet er så godt innarbeidet at det foreløpig er liten grunn til å endre det. Anleggene finnes både nede i dalførene og oppe i fjellet (Larsen og Rundberget 2009: 39).

Det var ved Dokkfløy de første moderne utgravningene ble gjort, og det var der vi fikk de første ${ }^{14} \mathrm{C}$-dateringene til eldre jernalder på Østlandet. Ovner som hørte sammen med store slaggblokker (ovner med et tverrmål på over 1 meter), var så langt ikke erkjent (Martens 1983: 122).

Et stort materiale finnes i T. Dannevig Hauges mange utgravninger på Østlandet (1946). Det er på det rene at han undersøkte en rekke østlandsovner. For å kunne utnytte det kunnskapspotensialet som ligger i Hauges utgravninger, er det en nødvendig oppgave å ta fatt på en gjennomgang av hans

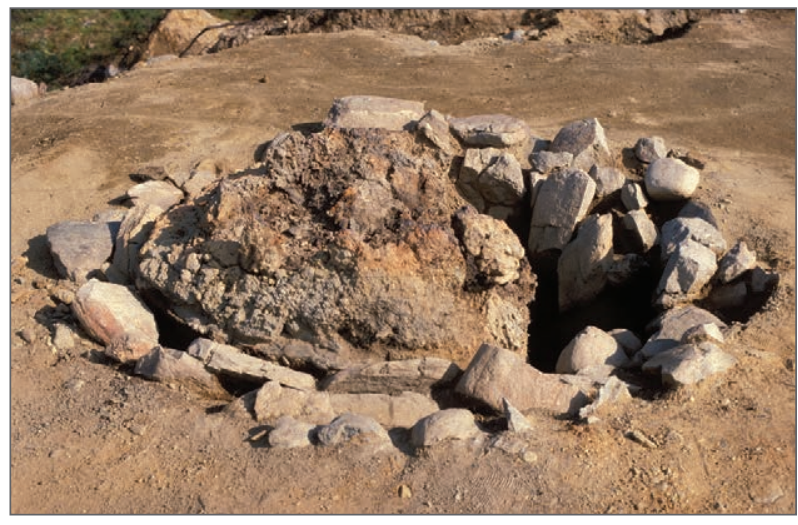

Figur 5:DR 223 ved Dokkfloy, Gausdal Vestfell i Oppland, fra yngre romertid gav svar på mange sporsmål. Sjakten var bevart opp til en hoyde på 0,25 m. Deler av den har smeltet ned over slaggblokken. Fjerning av slaggblokken var påbegynt. Den resterende delen veide omkring $300 \mathrm{~kg}$, slik at totalvekten kan ha vart nermere $400 \mathrm{~kg}$. Den indre diameteren er 1,3 m. Foto: J.H. Larsen, Kulturhistorisk museum.

Figure 5: DR 223 at Dokkfloy in Gausdal, Oppland, from the late Roman period gave answers to many questions. The shaft was raised up to a height of $0.25 \mathrm{~m}$. Part of it has melted down. Removal of the slag block in the furnace was begun. The remaining portion weighed about $300 \mathrm{~kg}$ so the total weight may have been close to $400 \mathrm{~kg}$. Inner diameter of $1.3 \mathrm{~m}$. Photo: J. H. Larsen, Museum of Cultural History.

\begin{tabular}{|l|l|l|l|l|}
\hline Ovn & \multicolumn{1}{l}{ Ytre diam. } & \multicolumn{1}{l|}{ Indre diam. } & \multicolumn{1}{l|}{ Dybde } & Slaggvekt \\
\hline DR 75, str. VI & $1,8 \mathrm{~m}$ & $1,4 \mathrm{~m}$ & $0,7 \mathrm{~m}$ & $450 \mathrm{~kg}$ \\
\hline DR 75, str. XV & $1,7 \mathrm{~m}$ & $1,5 \mathrm{~m}$ & $0,7 \mathrm{~m}$ & $243 \mathrm{~kg}$ \\
\hline DR 222, str. I** & $1,7 \mathrm{~m}$ & $1,3 \mathrm{~m}$ & $0,85 \mathrm{~m}$ & $103 \mathrm{~kg}$ \\
\hline DR 222, str. II** & & $1-1,1 \mathrm{~m}$ & $0,7 \mathrm{~m}$ & Ca $30 \mathrm{~kg}$ \\
\hline DR 223 & $1,9 \mathrm{~m}$ & $1,3 \mathrm{~m}$ & $0,7 \mathrm{~m}$ & Ca. $300 \mathrm{~kg}{ }^{* * *}$ \\
\hline DR 307, ovn B & $1,7 \mathrm{~m}$ & $1,2 \mathrm{~m}$ & $0,9 \mathrm{~m}$ & $365 \mathrm{~kg}$ \\
\hline DR 307, ovn C & $1,65 \mathrm{~m}$ & $1,2 \mathrm{~m}$ & $0,8 \mathrm{~m}$ & $390 \mathrm{~kg}$ \\
\hline Snertingdal R14 & $1,4 \mathrm{~m}$ & $0,9 \mathrm{~m}$ & Ikke undersøkt & Ikke undersøt \\
\hline Fagstad & $1,5-1,8 \mathrm{~m}$ & $1,2 \mathrm{~m}$ & $0,8 \mathrm{~m}$ & $438 \mathrm{~kg}$ \\
\hline
\end{tabular}

* Det hadde foregått ras av ovnsmasse ned i gropen slik at slaggvekten ikke er signifikant.

** Ovn 222 var ombygd og bare litt forskjøvet. Det meste av slagget var renset ut og sjakten fjernet.

**** Slaggblokken var påbegynt fjernet i romertiden.

Tabell 1: Tabellen sammenstiller enkelte data om utgravde ovner av ostlandstypen. Alle ovnene er fra Oppland. DR-nummeret forteller at ovnen lå ved Dokkfloy.

Table 1: The table compiles some data (outer and inner diameter, depth and content of slag) on excavated furnaces of "Østlandstypen». All sites are from Oppland. DR-numbers show that the furnaces were situated at Dokkfloy. 
utgravninger i felt, siden dokumentasjonsmaterialet ikke tilfredsstiller dagens krav.

Det kunne påvises at ovnene ved Dokkfløy var sjaktovner med slaggrop (Larsen 1991). I de fleste av dem lå det en slaggblokk fra siste gangs brenning i gropen. Ovnene, i alt syv stykker, ble påvist på fire anlegg som lå i nær kontakt med seterområdene og inntil en bekk eller en elv.

Karakteristisk er en vid ovn med slaggrop, med en indre diameter på 0,9-1,4 meter (figur 5). Flere av ovnene som ble funnet, hadde rester etter sjakt av brent leire, men vi har ingen indikasjoner på den opprinnelige høyden på dem. En av ovnene var bevart opp til 0,4 meter over bakken. På lokalitet DR 223 ble det funnet et stykke av en ovnsvegg med en lengde på 0,62 meter. Dette stykket hadde treavtrykk og viser at sjakten er bygd rundt en indre forskaling av treverk. På de andre anleggene er det også funnet slike stykker, riktignok litt mindre. Alle gropene viste spor etter flere gangers bruk, slik som DR 222, som er sterkt ombygd.

Det er ikke funnet spor etter luftinntak verken i sjaktmaterialet eller i slaggropene. Nivået på slagget i gropene går opp i plan med bakkenivået. På toppen av slaggblokkene var det rester av metallisk jern, sannsynligvis fra luppen.

Slagget var porøst med hulrom og store vedavtrykk, angivelig fra en form for gitter nede i gropen. Enkelte av avtrykkene er så store (inntil 0,4 meter lange) at det er vanskelig å tenke seg at de skyldes kontakt med trekull. De mange slaggblokkene viser også at hver grop kan ha vært gjenbrukt mange ganger. På DR 223 hadde noen begynt å tømme gropen, trolig for å gjøre den klar til neste gangs bruk. I gropene er det veid opp inntil 450 kilo slagg (se tabell 1). Ved flere ovner er sjakten nedsmeltet og revnet. Noe slagg kan ha rent ut slik at det også finnes stykker som ligner tappeslagg eller renneslagg. Den store mengden ovnsforing $i$ avfallshaugene tyder på at sjakten er revet for hver gang gropen ble renset opp.

Anleggstypen med store slaggblokker (figur 6) er kjent fra hele det indre østlandsområdet opp mot skoggrensen - $\mathrm{i}$ Østerdalen, $\mathrm{i}$ Gudbrandsdalen, rundt Mjøsa, i Hallingdal og i Telemark. De finnes ned til Totenåsen, Akershus, Nordmarka i Oslo og Modum i Buskerud. I enkelte områder, som Snertingdal, ligger disse anleggene tett, langt tettere enn i de gjorde i middelalderen (Larsen og Rundberget 2009: 14).

De foreliggende ${ }^{14} \mathrm{C}$-dateringene viser til perioden AD 100-700 (1 sigma) (se figur 7 med alle dateringene av ovnstypen i museumsdistriktet). Det finnes flere eldre dateringer, men siden de bygger på furu som kan ha høy egenalder, er de usikre.

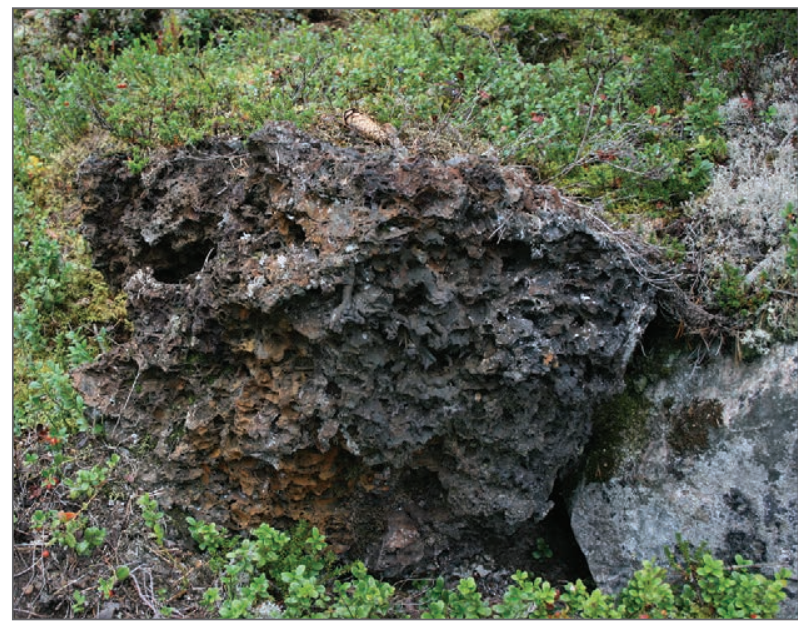

Figur 6: Slaggblokk fra Smådøla, Nore og Uvdal kommune, Buskerud. Slike blokker finnes på anlegg med ovner av ostlandstypen og kan vare opptil 1 m i tverrmål. Slagget har tydelige vedavtrykk. Foto: B. Rundberget, Kulturhistorisk museum.

Figure 6: Block of slag from Smådol, Nore and Uvdal, Buskerud. Such blocks are found on sites with "Østlandsovner» and can measure more than $1 \mathrm{~m}$. The slag has marks from wood. Photo: B. Rundberget, Museum of Cultural History.

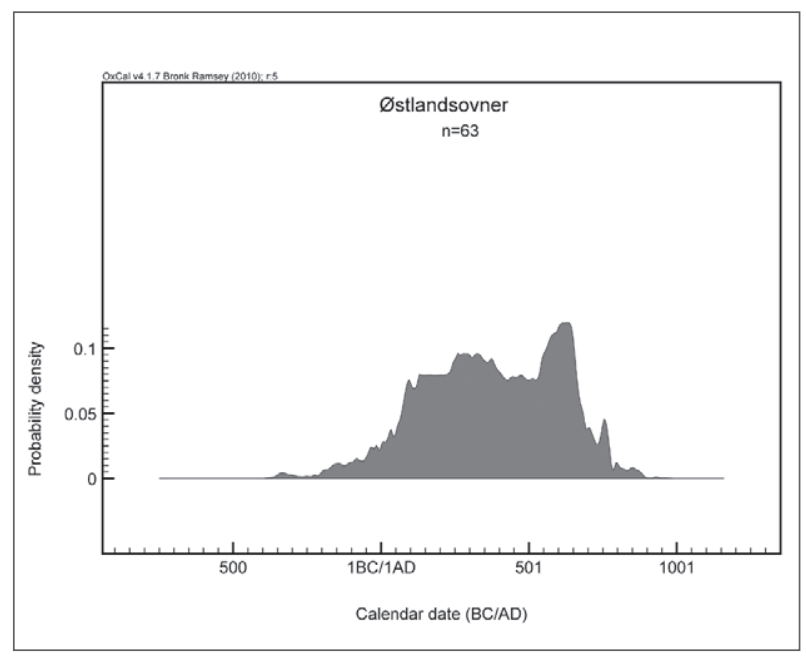

Figur 7: OxCal-diagram av 63 dateringer av anlegg med ovner av ostlandstypen fra Hedmark, Oppland og Buskerud. Det er grunn til à merke seg de mange sene dateringene. Dateringene er så tallrike at de forteller om sammenhengende bruk av ovnen $i$ det minste fra eldre romertid til den senere delen av merovingertiden. Diagram: B. Rundberget, Kulturhistorisk museum.

Figure 7: Oxcal diagram of 63 datings from sites with "Østlandsovnen» from Hedmark, Oppland and Buskerud. There is reason to note the many datings from the 6 th- 8 th centuries. The datings are so numerous that they indicate the continuous use of the furnace at least from the early Roman period to the later part of the Merovingian period. Diagram: B. Rundberget, Museum of Cultural History. 
Gjenstandsfunn er sjeldne, og viktigst er en spydspiss av jern, datert til romertiden, på DR 307 (Larsen 1991: 76).

Rundt ovnene på Dokkfløy og Fagstad på Lillehammer er det påvist stolpehull, blant annet steinskodde. Det er antatt at det dreier seg om konstruksjoner som skulle beskytte ovnsområdet, og størrelsen var på 5 x 5 meter. Det er imidlertid vanskelig å få klarhet $\mathrm{i}$ om det $\mathrm{i}$ så fall dreier seg om bare en takkonstruksjon, eller om det har vært vegger der også. Spor etter veggriller eller oppråtnet treverk er ikke påvist. Det problematiske ved tolkningen er at ovnen må ha vært høy, og ved tilsats av tørr furuved kan flammene ha stått høyt opp.

Narmo (1996: 21) har delt inn anleggene på Dokkfløy der denne typen enten har en stor slagghaug som kan være akkumulert gjennom flere århundrer, eller har flere mindre slagghauger innenfor et begrenset område. Anleggene ligger gjerne i tilknytning til setrer. Mange av dem ligger ved elver og vann (Narmo 1997: 117-118).

Inntrykket er at anleggene helst ligger på en morenehaug ved en elv eller en bekk, med ovnen på toppen og slaggutkastet på sidene og store slaggblokker i en krans ved foten. Tre av de fire anleggene ved Dokkfløy fantes på små morenehauger med den vesentligste delen av slaggutkastet mot en bekk, mens avfallsmasser er deponert rundt hele haugen. Det fjerde anlegget lå på en flat elveslette. Det er nødvendig med videre arbeid med hensyn til anleggsklassifiseringen. Anlegg kan inneholde ulike strukturer i form av ovner, stolpehull til overbygninger over ovner og hus, veggvoller, lagergroper og amboltsteiner (jf. Larsen 1991: 45-81).

Registreringsmaterialet fra Snertingdal viser at anleggene kan variere sterkt i størrelse. De kan også finnes på nærmest flat mark langt fra vann. Det underbygger at anleggene langt ifra er så enhetlige som Dokkfløy-materialet i utgangspunktet har fått oss til å mene. Materialet fra Snertingdal tyder også på at hypotesen om at slike anlegg fortrinnsvis finnes ved gamle setrer, bør testes grundigere (Larsen 2007: 152).

\section{Hellegryter}

Betegnelsen hellegryte stammer fra T. Dannevig Hauges ovnstypologi, og typen er omdiskutert. Den er best undersøkt og dokumentert på Møsstrond (Martens 1988). Som eksempel i materialet til Martens skal vi se på en ovn på Erlandsgard. Den var velbevart med en randdiameter på cirka 1 meter, en bunndiameter på 0,4 meter og en dybde på 0,4 meter. Det kan finnes flere ovner, men i regelen fin-

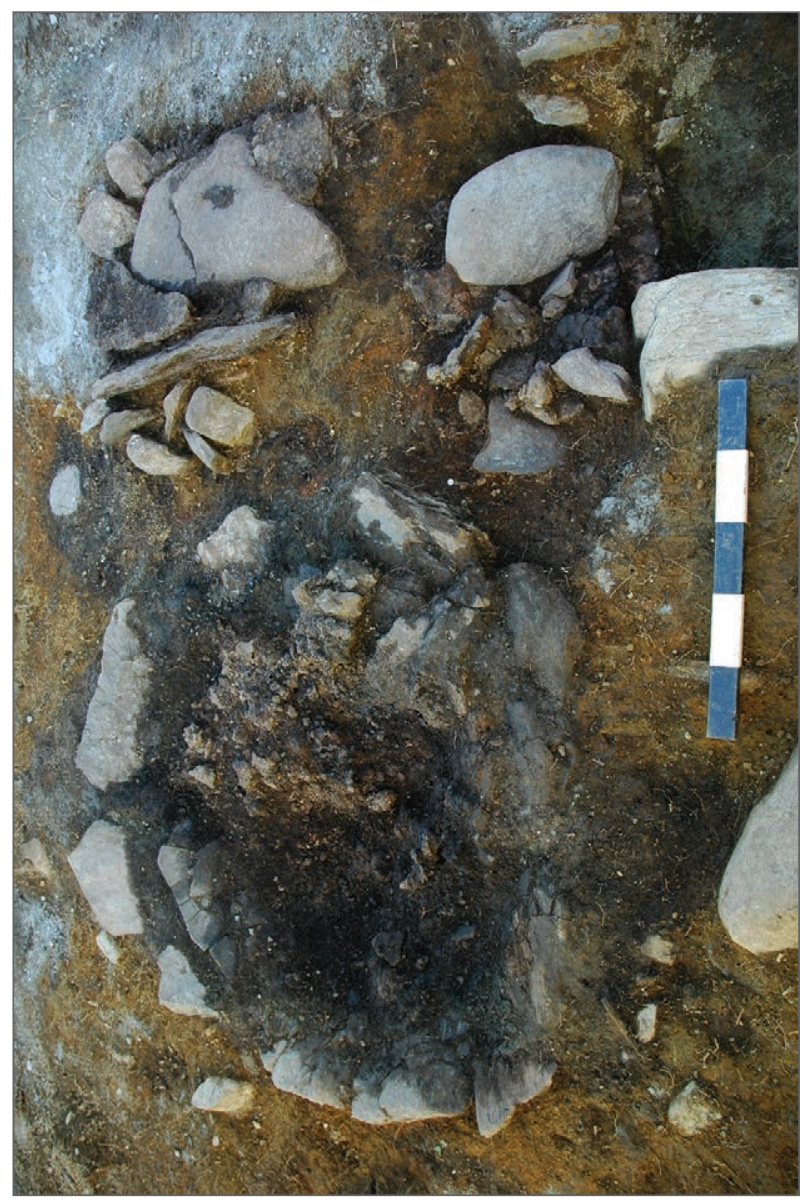

Figur 8: Hellegryte fra Gudbrandslie, Vang kommune i Oppland. Anlegget hadde flere faser, hvorav denne ovnen med tilhorende slagghaug ble datert til merovingertiden. Den ytre diameteren er 1,2 $\mathrm{m}$, den indre diameteren er 0,8-0,85 m, og dybden er 0,25 m. I gropen lå det $32 \mathrm{~kg}$ slagg. Foto: $A$. Mjerum, Kulturbistorisk museum.

Figure 8: Flag-lined furnace from Gudbrandslie in Vang, Oppland. The iron extraction site had several phases, of which this furnace with associated slag heap was dated to the Migration Period. Outer diameter $1.2 \mathrm{~m}$, inner diameter 0.8 to $0.85 \mathrm{~m}$, depth $0.25 \mathrm{~m}$. In the pit there was $32 \mathrm{~kg}$ slag. Photo: A. Mjerum, Museum of Cultural History.

nes det bare én slagghaug på hver lokalitet.

De ti hellegrytene Martens undersøkte på Møsstrond, viser store forskjeller i blant annet form. Vertikalsnittet er rektangulært eller trapesformet, mens tverrsnittet er rundt, ovalt eller avrundet firkantet, mens bunnen (herden) er konkav eller flat. Herddiameteren oppgis til å være $0,4-0,55$ meter for runde ovner og tilsvarende bredde for ovale ovner. Giktvidden - målet ved toppen - er 0,6-0,93 meter, mens høyden er 0,3-0,4 meter. Ovnene er nedgravd, og det er uavklart hvordan lufttilførselen har skjedd. Det er spor etter leirforing i enkelte hellegryter, og det er funnet forslagget ovnsforing $\mathrm{i}$ 
alle avfallshaugene. Enkelte ovner har åpning i den ene siden (én har åpning i begge sidene), og de har slaggutløp der det er påvist renneslagg. Det omtales også andre funn av hellegryter i Telemark.

Martens (1988: 74-75) tolker ovnen som en nedgravd gropovn fra perioden AD 550-800. Hun deler den inn i to undertyper: 1) lukkete ovner uten slaggutløp og 2) ovner med slaggutløp på siden. De lukkete ovnene er de egentlige hellegrytene, mens de med veggåpning oppfattes som en mellomform til sjaktovnene med slaggavtapping. Bare Martens' ovner Nystaul 7 og Erlandsgard 6 er runde, de øvrige er avlange.

Det ble gjennomført registrering i deler av utvaskingssonen langs Møsvatn i 1999. Ti anlegg med hellegryter ble påvist, og det var sjaktdeler på halvparten av anleggene. Slagghaugene var lave og oftest under 10 meter $\mathrm{i}$ diameter, og det pekes på at de kan være underrepresentert i det samlete materialet. Slagget bestod av fragmenterte slaggblokker, men det var også noe «tappeslagg» der. Den ytre diameteren på hellegrytene var omkring 1 meter, og grytene bestod ofte av flere rektangulære heller med mål 0,2-0,4 meter og en tykkelse på 3-5 centimeter (jf. Risbøl 1999: 14).

Arne Espelund har analysert slagg fra hellegryter på Møsstrond, og resultatene tyder på at slagget ikke stammer fra jernutvinning. Espelund (2004: 133135) fremsetter en hypotese om forbehandling av malm utover røsting der malmen er sintret før selve jernproduksjonen. Hellegrytene er konstruksjoner for sintring eller smelting av malm. Hellegrytene burde derfor etter Espelunds mening kalles sintregroper ut fra funksjonen.

I løpet av 2000-tallet er det fremkommet tilsvarende hellegryter blant annet på Hovden i AustAgder og på Fillefjell (figur 8) og i Øyerfjella i Oppland. De er sirkulære, helst med spor etter sjakt, og analysene, blant andre Arne Espelunds, viser normalt produksjonsslagg. Hellegrytene er så langt datert til merovingertiden.

\section{Trøndelagsovnen}

Trøndelagsovnen har også fătt sitt navn ut fra sin geografiske konsentrasjon til trøndelagsfylkene (Espelund 2005). Siden denne ovnstypen behandles av Lars F. Stenvik i denne boken, skal vi i det følgende bare ta med en mer summarisk beskrivelse av dem.

Slaggropene er gjerne godt bevart siden de er bygd av heller. På Heglesvollen, det mest kjente funnstedet i Nord-Trøndelag, var de nærmest sylinderformete med en diameter på $0,7-0,8$ meter og en dybde på 0,8-1,0 meter. Ofte ligger det igjen slagg fra siste bruksfase. Slaggvekten kan være 150 kilo (Espelund 1999: 120). Flate steiner danner basisen for sjakten, som gjerne er dårlig bevart. Ovnene står mot en skråning der det er en åpning med en bredde på 0,45-0,6 meter. Her har det vært mulig å ta ut slagg uten å ødelegge overbygningen. Et par ovner har en innsnevring toppen av gropen og er bare 0,5 meter i tverrmål, men betydelig videre lenger nede (Rundberget 2005: 67). Sannsynligvis har sjakten vært traktformet med en innsnevring i overgangen mellom slaggropen og sjakten. En slik form passer godt inn i vedovntradisjonen (Rundberget 2005: 67-69, jf. Englund 2002: 206).

En utgravning på Hillestad i Tovdal i Aust-Agder på begynnelsen av 2000-tallet gav nye opplysninger om utbredelsen av denne ovnstypen (Kallhovd og Larsen 2006). Det ble funnet slagg ved pløyning, og morfologien tydet på at dette stammet fra en ovn med slaggrop. Det ble derfor gjennomført en mindre undersøkelse for å sikre enkelte data.

Anlegget ligger ytterst på en høy og markert elveterrasse (220 meter over havet) med slaggutkast i skråningen ned mot elven. Slaggutkastet har en utbredelse på omkring $15 \times 10$ meter og en tykkelse på 0,1-0,25 meter. En maskinell flateavdekking langs ryggen av terrassen avdekket to forskjellige typer ovner, men begge hadde slaggrop. Den ene lå 4-5 meter fra terrassekanten og var sterkt skadet av dyrking. Her var det bevart en grop med slagg som var 0,5 meter i tverrmål og 0,5 meter dyp. Den kan ha vært en ovn av Eg-typen. Den andre ovnen lå ytterst på brinken og var relativt intakt. Den bestod av en hesteskoformet, steinbygd grop med indre mål på 0,8 meter og tilsvarende dybde (figur 9). Åpningen vendte ut mot skråningen, og her har det åpenbart vært en luke slik at slagget kunne renses ut. Sjakten var dårlig bevart, og gropen var renset for det meste av slagget. Inntil ovnen var det et malmlager. I bunnen av malmlageret var det en kasseformet struktur på 0,4 x 0,6 meter bygd av stående heller. De tre ${ }^{14} \mathrm{C}$-dateringene fra lokaliteten befinner seg innenfor tidsrommet AD 270-545.

Slaggfunn langs elver og vann i mellomsonen i Agder ser hovedsakelig ut til å være fra ovner med slaggroper, og de mange slaggutkastene stammer nok fra tilsvarende ovner som den i Tovdal. Følgelig må vi anta at dette var en alminnelig ovnstype i indre Agder, selv om det er gjort få utgravninger (Kallhovd og Larsen 2006: 247). Ett eksempel er ovnene ved Homstølvatn i Froland, som må være av samme type. En av disse ovnene er datert til romertiden. 


\section{Små slaggroper i Østerdalen}

På Rødsmoen ved Rena i Østerdalen er det funnet sjaktovner med små slaggroper. Produksjonsplassen R370a hadde fem slaggroper hvorav fire var ensartete med en diameter på 0,24-0,6 meter og en dybde på $0,26-0,5$ meter. Det var spor etter sjakter som hadde vært større enn slaggropene. Gropene lå i et slagglag som veide $253 \mathrm{kilo}$ og som trolig stammer fra tidligere blestringer. Slaggropene hadde vært fylt med vertikale trepinner av gran, og slagget hadde rent ned mellom pinnene og dannet små blokker med en vekt på 10,65-14,07 kilo. Dateringene strekker seg fra AD 550-660 frem til AD 890-1025. Det er knyttet amboltsteiner til gropene. Videre ble det funnet en noe større slaggrop, en ovn for slaggavtapping og et lag med slagg og dessuten flere lag med leire og malm. Anlegget var ikke synlig på overflaten.

Narmo (1997: 22-29) peker på at det ut fra slaggmengdene bare kan dreie seg om 34 blestringer over en periode på flere hundre år. Det var for lite ovnsforing til at det kunne være nok til alle sjaktene, så denne må ha vært gjenbrukt eller vitret bort. En annen slaggrop med bare 5 kilo slagg fremkom på R434. Totalt var det bare 22 kilo slagg her, men cirka 1,5 kubikkmeter malm og en grop med ukjent funksjon (Narmo 1997: 30-35). Det er vanskelig å vurdere typen før flere funn blir gjort.

\section{DISKUSJON OG VURDERING}

\section{Tidlige slaggroper}

Foreløpig er tidlige slaggroper en begrenset funngruppe fra et sentralt innlandsområde som gjennom lang tid har hatt nær kontakt med kysten. Felles for dem er at det har vært begrenset produksjon. Ovnen i Biri var dårlig bevart, mens utgravningen på Holen i Gausdal gav mer informasjon. Utvilsomme slaggroper med tidlige dateringer har vi også fra jordbruksområdene i Hedmark.

Ser vi på det danske materialet, finnes det en eldre, liten ovn - Skovmarken-typen. Den er delvis nedgravd, og det er en arbeidsgrop foran den. Dette funnet er tilsvarende det fra Holen, men vi må avvente flere funn for å få klarhet i om likheten bare beror på en tilfeldighet. Dateringen av de danske ovnene er fra 100 f.Kr til 100 e.Kr. Denne ovnstypen kan brukes flere ganger. Under brenningen er den lukket med en forplate av leire. Det produseres 2-3 kilo jern per brenning, og det går med 20-30 kilo malm og cirka 50 kilo trekull. Ovnen finnes i prinsippet over hele landet, men på «Øerne» kalles den for Espevej-typen (se artikkelen av Jouttijärvi

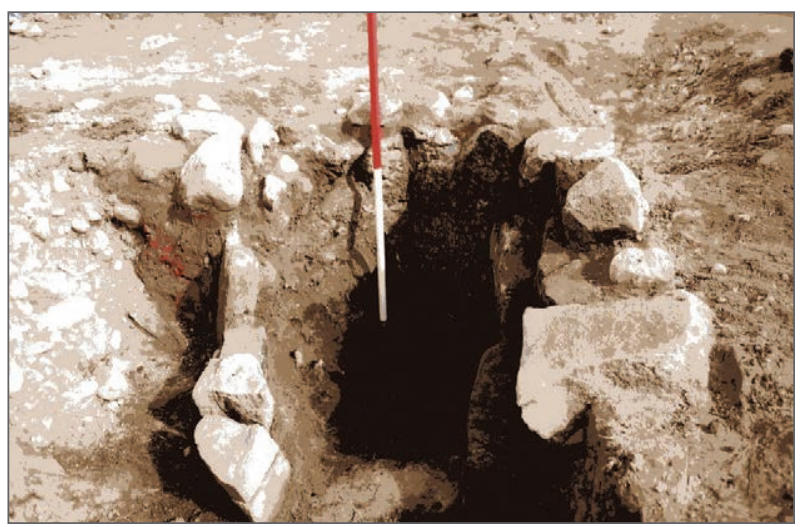

Figur 9: Hesteskoformet slaggrop på Hillestad i Tovdal, Åmli kommune, Aust-Agder. Form og mål tilsvarer Trondelagsovnen som er mer noyaktig oppmurt. Anleggsstrukturen er også forskjellig. Foto: J.H. Larsen, Kulturbistorisk museum. Figure 9: U-shaped slagpit at Hillestad in Tovdal, Amli, AustAgder. Form and dimensions correspond to the furnaces from Trondelag (Trondelagstypen), but the construction is different. Photo: J. H. Larsen, Museum of Cultural History.

og Voss i dette bindet). Brukstiden her er 300-200 BC. Ovnen er ingen slaggropovn, men oppfattes som en slaggdreneringsovn.

De eldste ovnene i Danmark er sannsynligvis for småskalaproduksjon, og de er vanskelige å typebestemme. Det er også foreslått at noen kan være gropovner (Lyngstrøm 2008: 27). Tolkningsproblemene er tilsvarende for de tidlige ovnene i Oppland og Hedmark. Vi må avvente nye funn og ikke minst sikrere dateringer, blant annet ved bruk av detaljerte vedartsanalyser (se Loftsgarden et al. 2013).

Eg-typen og andre slaggropovner med bare én bruksfase

Eg-ovnene er sammenlignet med danske slaggegrubeovne (Nakkerud og Schaller 1979), ovner av Snorup-typen eller Drengsted-typen. Disse har en grop nedgravd i sand og er brukt bare én gang. Produksjonen er deretter flyttet til en ny grop. Den innvendige diameteren er cirka 0,4 meter, med kolbeform. Halsen er trang med en halmdott ved overgang til gropen. Hele gropen kan være fylt med halm, og i noen tilfeller kan det i stedet være brukt lyng. Slaggvekten kan være omkring 200 kilo eller mer. Bare på Snorup i Sydvest-Jylland er det lokalisert mer enn 8000 ovner. Dateringen er 1.-7. århundre (Voss 1991; Jouttijärvi og Voss i dette bindet).

De danske ovnene fra førromersk jernalder og eldre romertid er nær knyttet til bosetningsområder, noe som også ser ut til å gjelde mange av de norske funnene. Enkelte utvaskete slaggforekomster langs 
elver og vann kan tilhøre slike ovner (Larsen 2003a).

Spørsmålet er om våre slaggroper er sammenlignbare med de danske funnene. Flere av de norske funnene er gryteformete nedgravninger, og bruken av halm er usikker. Det nevnes ikke funn av halmpropp i slaggropene på Eg, men de øverste delene var fjernet ved dyrking. Vekten av slagg i gropene er ikke oppgitt. Det spesielle var funnene av forkullete trestokker, som var cirka 5 centimeter i tverrmål, som var stukket loddrett ned gjennom bunnen av gropene (Nakkerud og Schaller 1979). Gropene på By i Løten er ennå ikke tilstrekkelig publisert, men regnes for å være av kontinental type. De fremkom ved maskinell flateavdekking av et boplassområde fra eldre jernalder (Risbøl 1997).

Stenvik (2003) definerer Eg-ovnene inn i den kontinentale sjaktovntradisjonen. De danske ovnene er fra romertiden og folkevandringstiden, mens det i Norge er enkelte dateringer fra førromersk jernalder, noe som kan ha sammenheng med mer presise dateringer i Danmark på halm og lyng fremfor furu, som kan ha høy egenalder (jf. Mikkelsen 2003).

Olfert Voss (1991) legger vekt på at slaggegrubeovnen har fylling av halm eller lyng, og at gropen er innsvingt. I Danmark har det kommet for dagen ovner med slaggroper som ikke tilfredsstiller kravene, som derfor er av en annen type, og som muligens kan likestilles med funnene fra $\mathrm{Eg}$. Det danske materialet er neppe så entydig som litteraturen til nå har gitt inntrykk av, noe som har kommet frem gjennom foredrag i det danske nettverket «Smedens Rum» i 2011 og 2012. André Bendix Matthissen (2012) viser til at kompakte slaggblokker bare finnes på Snorup, men ikke på for eksempel Drengsted, og at det er stor forskjell mellom de utgravde slaggropovnene på Jylland (se også Olesen 2012). Følgelig må det bli opp til fremtidige funn å avklare i hvilken grad de enklere slaggropene for «engangsbruk», slike som er blitt funnet i Agder, i Rogaland, i Telemark og på Hedmarken, er ekte slaggegrubeovner. De avviker en del fra de andre ovnene av denne typen, særlig i slaggmengde, som gropene ved Vardal kirke i Oppland. Foreløpig er funnene for få til å skille ut undergrupper. Felles for denne typen slaggroper er at de bare har vært brukt én gang, og at de gjerne er knyttet til bosetningsområdene.

\section{Østlandsovnen}

Noen inngående analyse av ovnene fra Dokkfløy foreligger ikke, sju ovner fra fire anlegg er heller ikke grunnlag nok for statistikk. Slaggropene viser forskjeller, i både form, utforming og størrelse.
Enkelte groper er fôret med heller, og kan følgelig karakteriseres som hellegryter. Slaggblokker ute i marken viser også store forskjeller i størrelse fra anlegg til anlegg, selv innen samme anlegg. Det kan kanskje ha med malmkvalitet, hvor flytbart slagget er, og frostsprengning å gjøre. Utenom ovnen fra Dokkfløy er det undersøkt en ovn på Fagstad i Lillehammer, og det er avdekket en ovn i Snertingdal, på Gjøvik - begge steder er få mil unna Dokkfløy.

$\mathrm{Vi}$ må være åpen for at det kan finnes flere varianter av den store sjaktovnen med slaggrop på Østlandet, særlig siden de utgravde ovnene er fra Oppland. Det vi her har kalt Østlandsovnen, kan ha en annen utforming andre steder. Den runde hellegryten med sjakt slik vi kjenner den fra Øyer og Fillefjell (og trolig Hovden og Møsstrond), er én variant. Her dannes det ikke store slaggblokker, og det er derfor praktisk å skille disse ovnene fra hverandre selv om teknologien ellers synes å være lik. Det er også mulig at Østlandsovnen undergår en utvikling ved at gropens størrelse reduseres (Larsen 2004: 160).

Dateringer fra Møre og Romsdal bekrefter at slaggropovner, trolig østlandsovner, er så sene som fra 600-700-tallet (Tveiten 2005: 58-60), men så langt samler dateringene av type I-anlegg seg i romertid på Vestlandet. Her ser det ut til at enkelte anlegg er gårdsnære (Bjørnstad 2003: 65, 74). Daterte slaggforekomster i Snertingdal tyder på at ovnstypen her kan ha vært tatt i bruk i løpet av de siste to århundrene f.Kr. (Larsen 2007: 148). Dateringene bygger på trekull av furu som kan ha høy egenalder. Det er derfor store tolkningsproblemer knyttet til ovnenes egentlige alder. Enkelte anlegg har ifølge dateringene svært lang brukstid, slik som anlegget på Fagstad, der ${ }^{14} \mathrm{C}$-dateringene spriker fra yngre bronsealder til merovingertiden. Med en slaggmengde på 7 tonn kan ovnen ha vært brukt under 20 ganger.

Anlegg med store slaggblokker er også kjent i Sverige, blant annet i Närke, der det foreligger dateringer særlig til perioden fra folkevandringstiden til vendeltiden. Her kalles de «grop-schaktungnar med stora slaggblokk» og oppfattes som sjaktovner med underliggende slaggrop. Det er vanskelig å finne noe utgangspunkt i Sverige for ovnstypen, og Pär Hansson viser til forbindelsen med Norge (1989: 88-89). Imidlertid blir ikke størrelsen så vesensforskjellig fra enkelte av de sydjyske slaggegrubeornene, som kan inneholde inntil 300 kilo slagg. 


\section{Trøndelagsovnen}

De trønderske anleggene ligger ofte på terrassekanter med tørr grunn. Ovnene kan finnes sammen i grupper på to til fem stykker, og slagget er veltet utfor skråningen. Rundt hver ovn kan det ligge inntil fem mindre groper, noe som har ført til at betegnelsen rosettanlegg blir brukt.

Slike strukturer er ikke kjent i Agder, og det ligger åpenbart en helt annen anleggs-organisering til grunn her. Mens trønderanleggene har slaggutkast på tvers av brinken, har anleggene i Agder slaggdeponi langs den. Selv om materialet er begrenset, er det antagelig bare én ovn, kanskje to, på hvert sted.

I Sverige er forholdene godt gransket i Jämtland (og Härjedalen) gjennom undersøkelsene til Gert Magnusson (1986). Den eldste ovnstypen som forekommer fra romertiden, og som er strandbundet, tolker han som gropovn. Den har klare paralleller til Trøndelagsovnen (Stenvik 2003: 78), og det er grunn til å slutte seg til Arne Espelunds oppfatning (1988: 54) om at dette er en sjaktovn med slaggrop.

\section{Hellegryter}

Bare Martens' ovner Nystaul 7 og Erlandsgard 6 er runde. En tilsvarende ovn ble utgravd i Gudbrandslie, i Vang kommune i Oppland. Den var datert til merovingertiden, og den hadde tydelige rester etter sjakt. Det samme var tilfellet med ovner i Øyerfjella i Oppland. Sommeren 2012 fremkom også slike ovner på Hovden i Aust-Agder. Martens mener hellegrytene i Telemark ikke har hatt sjakt, men utvaskete slagghauger ved Møsvatn inneholder sjaktmateriale, ifølge Risbøl (1999).

De øvrige hellegrytene til Martens er avlange. Disse kan ifølge Narmo (1996: 11) være hellebygde ildsteder av den typen som er kjent fra Dokkfløy og Hovden. Det bør legges til at disse gjennomgående har en senere datering. Hellegryter med veggåpning, datert til 700-tallet, beskrives med renner, og Narmo mener det kan ha vært sjaktovner med slaggavtapping der sjaktene ikke er bevart. Det er god grunn til å slutte seg til Narmos vurderinger.

Martens tar et oppgjør med Hauges syn på at ovnene med slaggavtapping («leirgryter») var gropovner, mens hun holder fast ved at hellegryta var en gropovn. Den fremstod som spesiell, og hun fant ingen parallell i det europeiske materialet.

De avlange grytene kan være strukturer tilsvarende dem til Trøndelagsovnen. Etter undersøkelsen i Tovdal er det grunnlag for å omtolke en del utvaskete strukturer i regulerte vann fra hellegryter til trøndelagsovner. Flere av disse ovnene er datert til romertiden, slik som ovnen i Tovdal, mens det som er definert som hellegryter på Møsstrond, er fra merovingertiden, uten at det skal tillegges avgjørende vekt.

Mer sirkulære «gryter» kan være slaggroper til sjaktovner, slik som ovnene på Fillefjell og i Øyerfella. Dateringen stemmer overens med hellegrytene i Telemark. Disse anleggene har ikke store slaggblokker, men mindre stykker størkneslagg. Det dreier seg følgelig om en noe mindre sjaktovn med slaggrop enn Østlandsovnen.

Det må derfor stilles spørsmål om hvorvidt hellegryta skal opprettholdes som egen ovnstype, eller om den skal omdefineres til å være den sirkulære, mindre slaggropen. Åpenbart er det behov for nye undersøkelser av den ovnstypen som ved Møsstrond kalles hellegryte, naturlig nok siden det er mer enn 30 år siden Martens' undersøkelser ble avsluttet.

\section{Små slaggroper i Østerdalen}

De små slaggropene i Østerdalen er skilt ut på grunn av de små dimensjonene og den spesielle beliggenheten. De loddrette pinnene i gropen kjenner vi fra ovnene av Eg-typen. På grunn av slagglaget kan det herske en viss tvil om hvorvidt det dreier seg om groper for én gangs eller flere gangers bruk. De skiller seg i dimensjon imidlertid ikke avgjørende fra ovner av Eg-typen, og bør nok oppfattes som en variant av disse.

\section{EN SAMLET VURDERING}

Det har vært utarbeidet flere forsøk på objektive klassifiseringsmåter for blesterovner, blant annet var det en omfattende debatt i NAR i 1978 der forskere som Irmelin Martens, Radomir Pleiner og Inga Serning engasjerte seg (Larsen 2009: 67-68 med litteraturreferanser). Utgangspunktet var et forslag fra Martens (1978) der ovnenes form, slaggbehandling, lufttilførsel, materiale og om de var frittstående eller nedgravde, ble vektlagt. Lars-Erik Englund kritiserer at utgangspunktet er bevarte rester og ikke på tolkninger av hvordan ovnene har sett ut når de har vært i bruk. Det blir lett svært mange ovnstyper, alt ettersom hvordan de enkelte elementene er bevart og tolkes. Samme ovn kan klassifiseres ulikt av ulike forskere - det har vist seg at ulike forskere har gitt samme ovn ulike betegnelser, og at åpenbart ulike ovner har fått samme betegnelse (Englund 2002: 24-28, 51 med referanser). Martens viser for øvrig til at hun mener at det $\mathrm{i}$ virkeligheten dreier seg om noen få typer ovner som har variasjoner i detaljer, og ikke om et ubegrenset antall forskjellige ovnstyper (1983: 122). Lars Erik Narmo (1996) har tatt et oppgjør med gropideen, og han mener at alle ovner er sjaktovner. 


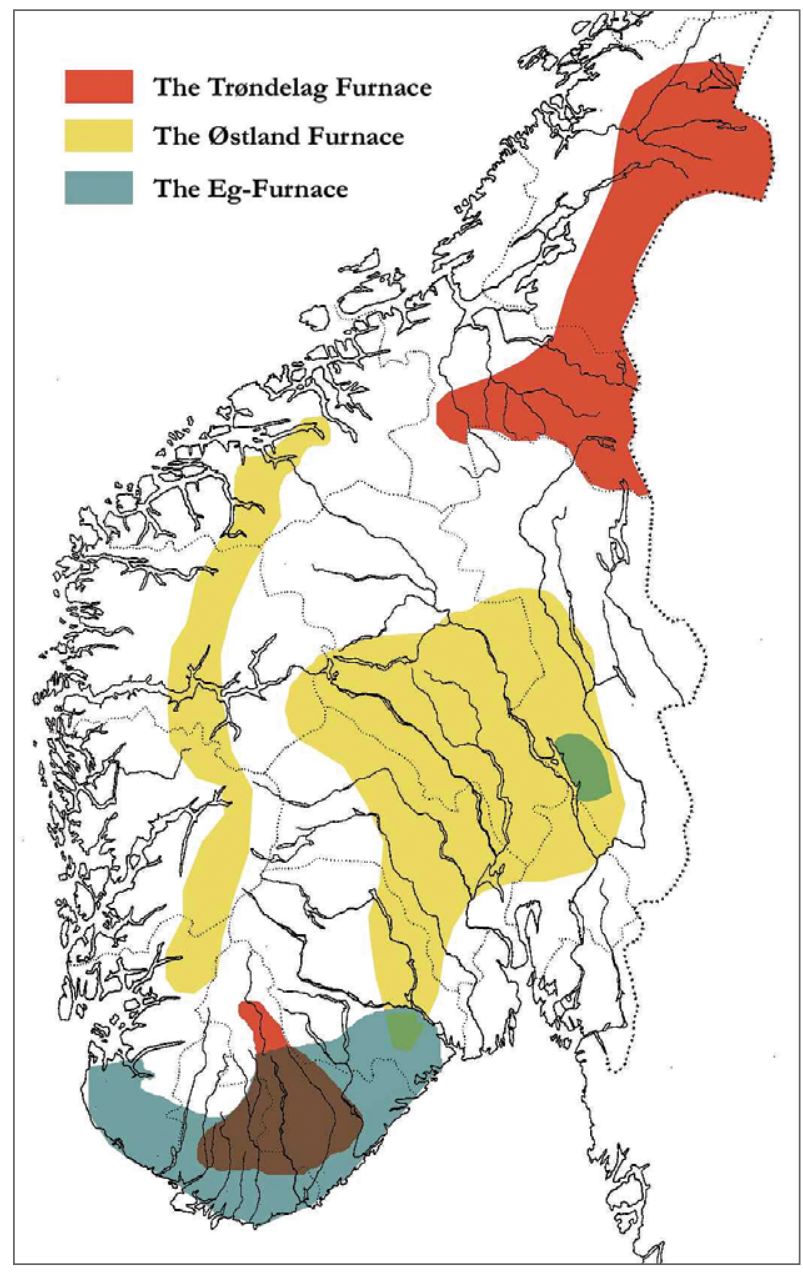

Figur 10: Den geografiske fordelingen av enkelte ovnstyper. Kart: B. Rundberget, Kulturhistorisk museum. Etter Larsen and Rundberget in press figur 11.

Figure 10: The geographical distribution of some types of furnaces. Map: B. Rundberget. After: Larsen and Rundberget in press figure 11.

Christiane Zimmermann gjennomfører sin inndeling av ovnene i Skandinavia og Schleswig-Holstein uten å bruke dette systemet. Hun mener for øvrig å finne en forholdsvis ensartet utvikling i jernfremstillingen i dette området, til tross for at intensiteten er forskjellig $(1998: 78,96)$.

Skillet mellom ovner med slaggrop og ovner med slaggavtapping fungerer godt siden dette også dreier seg om en teknologisk utvikling. Det er vist at Østlandsovnen minst må ha vært i bruk frem til $\mathrm{AD} 700$, men det utelukker ikke at slaggavtappingsovnen kan ha vært tatt $\mathrm{i}$ bruk noe tidligere enn dette, slik at de to ovnstypene i en periode har opptrådt parallelt. Dateringer av furukull kan føre til at dateringene blir for gamle, og kronologien er derfor beheftet med usikkerhet (Loftsgarden et al. 2013).
Forholdet til bruk av sjakt er vesentlig. Med noe usikkerhet når det gjelder de tidligste ovnene $\mathrm{i}$ innlandet i Oppland, har alle slaggropovnene etter alt å dømme hatt sjakt. De tidlige jernvinneanleggene er foreløpig så få at vi må avvente flere funn før det kan trekkes sikre konklusjoner.

De store slagghaugene er knyttet til anlegg med østlands- og trøndelagsovner. Her kan det dreie seg om flere titalls tonn avfall på hver lokalitet. Belegget for å konkludere med at disse ovnene har hatt sjakt, er uomtvistelig ut fra de utgravningene som har vært gjort. Både ovner i Trøndelag og den som ble gravd ut i Tovdal, hadde bevarte deler av sjakt. Ved eldre utgravninger er ikke dette forholdet vektlagt slik som hos T. Dannevig Hauge, selv om det ofte fremgår at det er påvist stykker av brent leire («leirmantel»).

Det er mulig å skille mellom slaggroper (ovner) som har vært brukt gjentatte ganger, og groper som har vært brukt kun én gang. Av de sistnevnte er Snorupovnene de som er best kjent, og her i landet blir det trolig Eg-typen som ligger nærmest. For øvrig er funnene av disse slaggropene for få til at det er mulig å danne seg noe enhetlig bilde utover at de er sjaktovner som har likhetstrekk med danske ovner. De fleste dateringene er fra perioden fra romertiden til folkevandringstiden.

På dette punktet skiller østlands- og trøndelagstypene seg ut. Slaggropene har vært brukt et stort antall ganger, og ovnsstedet har vært stabilt. Begge må foreløpig antas å være lokale tilpasninger av de europeiske sjaktovnene. Skillet mellom dem er først og fremst luken til å rake ut slagg fra slaggropen i Trøndelagsovnen. At man har måttet rive sjakten til Østlandsovnen etter hver gang den var brukt, tyder den store mengden sjaktmateriale i avfallshaugene på. Med den store dimensjonen og den større slaggmengden har det kanskje vært mest praktisk å rive sjakten. Funn av slagg som har stivnet i fri luft, viser at sjakten har vært så medtatt at det har gått hull i den. Vi skal derfor være forsiktig med å karakterisere Østlandsovnen som en mye enklere ovn enn Trøndelagsovnen. Siden ingen ennå har klart å rekonstruere og lage jern i slike ovner, vet vi lite om de driftsmessige prinsippene. Kjent utbredelse for Eg-typen, Østlandsovnen og Trøndelagsovnen fremgår av figur 10.

Hellegrytene kan neppe opprettholdes som en særegen ovnstype - det hersker usikkerhet om hva de avlange grytene representerer, mens de sirkulære åpenbart er en mindre utgave av Østlandsovnen, og bare må oppfattes som en variant av denne.

Vi kan følgelig operere med: 
1. mulige gropovner i innlandet med liten produksjon - datering: førromersk jernalder

2. ovner med slaggroper som er brukt bare én gang, og som kan ha likhetstrekk med danske ovner - datering: hovedsakelig romertid folkevandringstid

3. ovner med slaggroper som er gjenbrukt et stort antall ganger

A1. Østlandsovnen, der sjakten ikke kunne gjenbrukes - datering: $100 \mathrm{BC}-\mathrm{AD} 800$.

A2. Hellegryta (den lille Østlandsovnen) datering: merovingertiden

A3. Trøndelagsovnen, der sjakten kunne brukes flere ganger - datering i Agder: romertiden og folkevandringstiden.

Det er de siste 25 års forvaltningsgravninger som har gitt oss det materialet vi har å bygge på. Imidlertid er det anlegg fra middelalderen som dominerer i det utgravde materialet. Det beste ville ha vært å få utført flere mindre forskningsgravninger, særlig med tanke på de ovnene som inngår som hellegryter. Å få lokalisert flere av de anleggene Hauge undersøkte, $o g$ å få gjennomført nye utgravninger står sentralt.

Vi har etter hvert dannet oss et bilde av den geografiske fordelingen av disse typene ovner og jernvinneanlegg. Slike utbredelseskart må stadig revideres etter hvert som nye funn kommer for dagen. Det er flere tolkningsproblemer enn dem som er knyttet til typologi og utbredelse for slaggropovnene. Det er også tolkningsproblemer knyttet til et så viktig felt som kronologi. Kronologien bygger på ${ }^{14} \mathrm{C}$-dateringer av trekull som hovedsakelig er av furu, og som kan ha høy egenalder (Larsen 2009: 181). Detaljerte vedartsanalyser og akseleratordatering av godt daterbart materiale vil etter hvert forhåpentligvis løse problemet.

Et annet forhold gjelder ovnenes opphavsområde. Slaggropovnene føyer seg inn $\mathrm{i}$ den europeiske sjaktovntradisjonen (Pleiner 2000, 70-74). Østlandsovnen produserer store slaggblokker, og på den måten er det likhetstrekk mellom Østlandsovnen og de sydjyske ovnene. Det har vært vanskelig å peke på noe direkte opphavsområde for Østlandsovnen, slik at det kan dreie seg om lokal tilpasning til naturforholdene. Det samme kan gjelde Trøndelagsovnen. Muligheten for å tømme slaggropen uten å bryte ned sjakten har den felles med Skovmarkenovnen, men forskjellen i produksjonsmengde er for stor. Trøndelagstypen er ifølge Lars F. Stenvik ferdig utviklet så tidlig at den er eldre enn den danske.

For å komme videre med slike spørsmål om opphavs- og kontaktområder er det nødvendig å gå sterkere inn i det svenske materialet, som er svært uoversiktlig med et utall forskjellige typer. Det er tydeligvis behov for en terminologi også for de norske ovnene. For eksempel gir navnet hellegryte lite mening siden det kan assosieres med flere typer ovner.

Seminaret på Kittilbu og denne publikasjonen tyder på at ønsket om å få et enklere nordisk system og en bedre oversikt er berettiget. Det vil gi bedre grunnlag for å forstå kontaktveier og innovasjonsområder. Målet må være å koble jernutvinningen sammen med samfunnsutviklingen. Arbeidet med proveniensanalyser (Grandin et al. in print) vil gjøre det enklere å kaste lys over kontaktområder og økonomiske sentre. En av konklusjonene fra symposiet var at jernvinneforskere i større grad må oppfatte store deler av Norden som ett jernvinneområde.

\section{SUMMARY}

The article deals with the different types of furnaces with slag pits in the area where the Museum of Cultural History works, the southeastern part of Norway. Pits have been used for collecting slag under furnaces for more than 1,000 years in Norway. The oldest, from the districts around Lake Mjøsa, have been for small-scale production, and it is uncertain whether they were shaft furnaces.

Slag pit furnaces of what is called Eg-type after excavation in Kristiansand, Vest-Agder, are known from rural areas and are believed to be a parallel to the type known from Drengsted/Snorup in Denmark. These are undoubtedly shaft furnaces such as in Denmark. Slag weight is, however, different $(30-60 \mathrm{~kg})$ and the use of straw as fill in the slag pit is uncertain. There are both major and minor slag pits of this type, and they have in common that they have only been used at one time. The dating is predominantly from the Roman period.

The main production is connected to the «Østlandsovnen» and «Trøndelagsovnen». These are large furnaces where the slag pit has been reused time after time. "Østlandsovnen» are common in eastern part of Norway where they are common near rivers and lakes, particularly in mountain areas, but have probably also been used in Western Norway in Møre og Romsdal. Characteristic are large slag blocks. Slag pits can hold up to $450 \mathrm{~kg}$ of slag. ${ }^{14} \mathrm{C}$-datings centre on the period $\mathrm{AD} 100-700$ (100BC-AD800).

A variation of «Trøndelagsovnen» has been excavated in Agder where it is probably common by rivers and lakes, in the zone between the coast and the higher ground inland. The site structure is different 
than in Trøndelag. There are few ${ }^{14} \mathrm{C}$-datings from the southern part of Norway, and they centre on the Roman period.

«Hellegryte» (flag-lined furnaces) got their name from the construction of stone-slabs ( $T$. Dannevig Hauge) and were later connected to the investigations at Møsstrond in Telemark. Some of the structures are certainly slag pits, others may have been fireplaces or remains of the later furnace for slag tapping. There is reason to believe some of the flag (stone)-lined furnaces are a smaller version of «Østlandsovnen», and they represent the transition to the later furnace for slag tapping. There is no reason to see «hellegryta» as a separate furnace type.

The article concludes by stating the need to understand the furnaces on a Nordic basis.

\section{LITTERATUR}

Bjørnstad, R. 2003. Teknologi og samfunn. Jernvinna på Vestlandet $i$ jernalder. Hovedoppgave: Bergen.

Englund, L.-E. 2002. Blästbruk. Myrjärnshanteringens förändringar $i$ ett långtidsperspektiv. Jernkontorets Bergshistoriska Skriftserie, 40. Stockholm: Jernkontoret.

Espelund, A. 1988. Reviews. Gert Magnusson: Lågteknisk järnhantering i Jämtlands län. (Bloomery Iron Production in the County of Jämtland, Sweden). Jernkontorets Bergshistoriska Skriftserie N: r 22. Stockholm 1986. 437 pp., 162 figs. Norwegian Archaeological Review 21: 51-52.

Espelund, A. 2004. Jernet i Vest-Telemark - der tussane rådde grunnen. Trondheim: Arketype.

Espelund, A. 2005. Bondejern i Norge. Ny, utvidet utgave. Trondheim: Arketype.

Falck-Muus, R. 1927. «Fra noen jernvinneplasser i ÅsnesFinnskog». Norsk Geologisk Tidsskrift 1926-1927/9: 358-397.

Falck-Muus, R. 1931. «Grensetraktenes jernsaga. Et fragment». Den norske turistforenings årbok 1931: 56-72.

Grandin, L., B. Rundberget, J.H. Larsen og J. Bill in print. «Searching for the production site for iron in the Gokstad ship». J. Bill (red.). Early Medieval Monumental Graves in Northern Europe. Aarhus: Aarhus University Press.

Hansson, P. 1989. Sambälle och järn i Sverige under järnåldern och äldre medeltin. Exemplet Närke. Aun 13. Societas Archaeologica Upsaliensis. Uppsala: Uppsala universitet.

Hauge, T.D. 1946. Blesterbruk og myrjern. Studier $i$ den gamle jernvinna $i$ det ostenfelske Norge. Universitetets Oldsaksamlings Skrifter III. Oslo: Universitetets Oldsaksamling.
Jouttijärvi, A. 1995. «5. Slagger og ovnanlæg». Trabjerg. En vestjysk landsby fra vikingetiden. Holstebro Museums række. Jysk Arkeologisk Selskabs Skrifter XXXI: I: 73-77.

Kallhovd, K. og J.H. Larsen 2006. «På sporet av den eldste jernvinna i indre Agder - et sentralt produksjonsområde?» Historien i forbistorien. Festskrift til Einar Østmo på 60-års dagen. Kulturhistorisk museum Skrifter 4: 237-253. Oslo: Kulturhistorisk museum.

Larsen, J.H. 1991. Jernvinna ved Dokkfloyvatn. De arkeologiske undersøkelsene 1986-1989. Varia 23. Oslo: Universitetets Oldsaksamling.

Larsen, J.H. 2003a. «Utmarksbruk i Vest-Agder i eldre jernalder». Snartemofunnene $i$ nytt lys. Universitetets kulturhistoriske museer Skrifter 2: 167-190. Oslo: Universitetets kulturhistoriske museer.

Larsen, J.H. 2003b. «Lokalt initiativ og jernvinneforskning i Snertingdal, Gjøvik kommune i Oppland bidrag til forståelsen av jernutvinningen i eldre jernalder på Østlandet». Viking LXVI - 2003: 79-104.

Larsen, J.H. 2004. «Jernvinna på Østlandet i yngre jernalder og middelalder - noen kronologiske problemer». Viking LXVII - 2004: 139-170.

Larsen, J.H. 2007. «Jernvinneundersøkelsene i Snertingdal». Arkeologiske undersøkelser 2001-2002. Varia 62: 140-157. Oslo: Kulturhistorisk museum, Fornminneseksjonen.

Larsen, J.H. 2009: Jernvinneundersøkelser. Faglig program 2. Varia 78. Oslo: Kulturhistorisk museum, Fornminneseksjonen.

Larsen, J.H. og B. Rundberget 2009. «Raw Materials, Iron Extraction and Settlement in South-East Norway 200 BC-AD 1150». 58. Sachsensymposium in Trondheim 1st-5th September 2007. Vitark 7: 38-50. Trondheim: Vitenskapsmuseet.

Larsen, J.H. og B. Rundberget in print. «Iron production in South- and Middle-Norway 200BC-AD400». B. Chech og T. Rheren (red.). Proceedings of the conference on «Early Iron» in Hüttenberg.

Loftsgarden, K., B. Rundberget, J.H. Larsen og P. Hambro Mikkelsen 2013. «Bruk og misbruk av ${ }^{14} \mathrm{C}$-datering ved utmarksarkeologisk forskning og forvalting». Primitive tider 15: 59-69.

Lyngstrøm, H. 2008. Dansk Jern. En kulturhistorisk analyse af fremstilling, fordeling og forbrug. København: Kongelige Nordiske Oldskriftselskab. (Nordiske Fortidsminder C, 5.)

Magnusson, G. 1986. Lågtekniskjärnhantering i Jämtlands län. Stockholm: Jernkontoret. (Jernkontorets Bergshistoriska, 22.)

Martens, I. 1978. «Some reflections on the Classification of Prehistoric and Medieval Iron-smelting Furnaces». Norwegian Archaeological Review 11: 27-36. 
Martens, I. 1983. «The Norwegian Bloomery Furnaces and their Relation to the European Finds». Offa 40: 119-124.

Martens, I. 1988. «Jernvinna på Møsstrond i Telemark. En studie i teknikk, bosetning og økonomi». Norske Oldfunn XIII: 5-164. Oslo: Universitetets Oldsaksamling.

Matthissen, A.B. 2012. «Variationer af jernudvindingsovne i Sønderjylland». Produktionen. Smedens Rum 4. Arkæologiske Skrifter 11: 101-114. København: Saxo-instituttet, Københavns Universitet.

Mikkelsen, P.H.og L.C. Nørbach 2003. Drengsted. Bebyggelse, jernproduktion og agerbrug $i$ yngre romersk og aldre germansk jernalder. Højbjerg: Moesgård museum.

Nakkerud, T.B. og E. Schaller 1979. «Slaggroper på Eg, Kristiansand, Vest-Agder». Jern og jernvinne som kulturhistorisk faktor $i$ jernalder og middelalder $i$ Norge. AmS-Varia 4: 8-18. Stavanger: Arkeologisk museum i Stavanger.

Narmo, L.E. 1996. Jernvinna i Valdres og Gausdal - et fragment av middelalderens økonomi. Varia 38. Oslo: Universitetets Oldsaksamling.

Narmo, L.E. 1997. Jernvinne, smie og kullproduksjon $i$ Østerdalen. Arkeologiske undersøkelser på Rodsmoen i Amot 1994-1996. Varia 43. Oslo: Universitetets Oldsaksamling.

Olesen, M.W. 2012. «Kulstof-14-dateringer af midtjyske jernudvindingsovne fra ældre jernalder». Produktionen. Smedens Rum 4. Arkæologiske Skrifter 11: 115-134. København: Saxo-instituttet, Københavns Universitet.

Pleiner, R. 2000. Iron in Archaeology. The European Bloomery Smelters. Praha: Archeologiký ústav av čr.
Risbøl, O. 1997: «Arkeologi i vegen - om de nyere arkeologiske undersøkelsene på Engelaug og By i Løten». Lautin 1997: 7-23.

Risbøl, O. 1999: Fornyelse av reguleringskonsesjon for Møsvatn, Vinje og Tinn. Konsekvenser for automatisk fredete kulturminner. NIKU Oppdragsmelding 87. Oslo.

Rundberget, B.H. 2005. «Kunnskapen om jernvinna». Funn og forskning $i$ Trondelag. Foredrag fra to arkeologiseminarer i 2003: 65-82. Verdal: Stiklestad nasjonale kultursenter.

Rundberget, B. 2007. «Jernvinna i Gråfjellområdet». B. Rundberget (red.) 2007: Jernvinna $i$ Gråfellområdet. Gråfjellprosjektet I. Varia 63: 339-358. Oslo: Kulturhistorisk museum, Fornminneseksjonen.

Rundberget, B. 2011. «Jernproduksjon i Norge i romertid; en marginal eller sentral ressurs». På sporet av romersk jernalder. Nicolay skrifter 3: 36-49.

Stenvik, L.F. 2003. «Iron Production in Scandinavian Archaeology". Norwegian Archaeological Review 36/2: 119-134.

Tveiten, O. 2005. Utkant eller egg. Jarnutvinning $i$ Møre og Romsdal i forhistorisk tid og mellomalder. Hovedoppgave: Bergen.

Voss, O. 1991. «Jernproduktionen i Danmark i perioden 0-550 e.Kr.». C. Fabech og J. Ringtved (red.). Samfundsorganisation og Regional Variation. Norden $i$ romersk jernalder og folkevandringstid. Jysk Arkæologisk Selskabs Skrifter XXVII: 163-170. Aarhus: I kommission hos Aarhus Universitetsforlag.

Zimmermann, C. 1998. «Zur Entwicklung der Eisenmetallurgie in Skandinavien und SchleswigHolstein». Praehistorische Zeitschrift 73: 69-99. 


\title{
FORHISTORISK JERNPRODUKSJON I NORD-NORGE - FÅ, ENKELTSTÅENDE EKSPERIMENTER ELLER TOPPEN AV ET ISFJELL?
}

\author{
Roger Jørgensen
}

Forhistorisk jernproduksjon i Nord-Norge har lenge vært et forsømt forskningstema, og mangelen på fysiske strukturer som kan knyttes til jernproduksjon, har medført at dette temaet har vekket liten arkeologisk interesse i nord. Jeg vil her kort gå gjennom de senere års funn i Nord-Norge og vurdere disse opp mot forskningsstatus i resten av nordre Fennoskandia. Hele dette området skiller seg ut med en ganske beskjeden forhistorisk jernproduksjon, og jeg vil derfor avslutningsvis se på mulige årsaker til at det er slik. Kronologisk vil hovedvekten ligge på jernalderen, men fordi datagrunnlaget er ganske sparsomt, vil også et funn fra middelalderen bli trukket inn i diskusjonen.

\section{ET FORSKNINGSHISTORISK TILBAKEBLIKK}

Likhetene i materiell kultur mellom jernalderbosetninger henholdsvis i Nord-Norge og på Sørvest- og Vestlandet har ledet til en antagelse om at de germanske jernalderbosetningene i nord var blåkopier av de sørnorske. Brøgger (1931: 33,35) understreker i Nord-Norges bosetningshistorie likhetene mellom jernalderen i nord og i sør og hvordan «Oldfunnene [reflekterer] en bondekultur, hvor jernvinna og jernvirket til redskap og våben har spilt den samme rollen som i de mest utpregede bondebygder i SørNorge» (Brøgger 1931: 35). Denne forestillingen om at jernproduksjonen i Nord-Norge var en vanlig produksjonsform $\mathrm{i}$ jernalderen, har vært utbredt $\mathrm{i}$ forskningsmiljøene helt frem til i dag (Sjøvold 1962: 48, 232; Munch 1965; Bertelsen 1985: 42). Det er svært vanlig å finne små mengder jernslagg på boplasser fra jernalderen og middelalderen i NordNorge, og funnene har i mange tilfeller vært tatt til inntekt for en hypotese om at produksjon av jern til eget bruk var vanlig i Nord-Norge i jernalderen.

Slike funn av slagg er i hovedsak gjort på kystnære boplasser (figur 1, tabell 1) i området mellom Helgeland og Øst-Finnmark. Foruten likhetstrekkene med sørnorsk jernalder har antagelsene om at det foregikk en lokal jernproduksjon på disse lokalitetene vært basert på funn av moderate mengder slagg og kjemiske analyser av slagg. Bartolotta et al. (1988; 1990) gjennomførte i to omganger kjemiske analyser av til sammen 16 slaggprøver fra 7 nordnorske lokaliteter, og de konkluderte med at «All

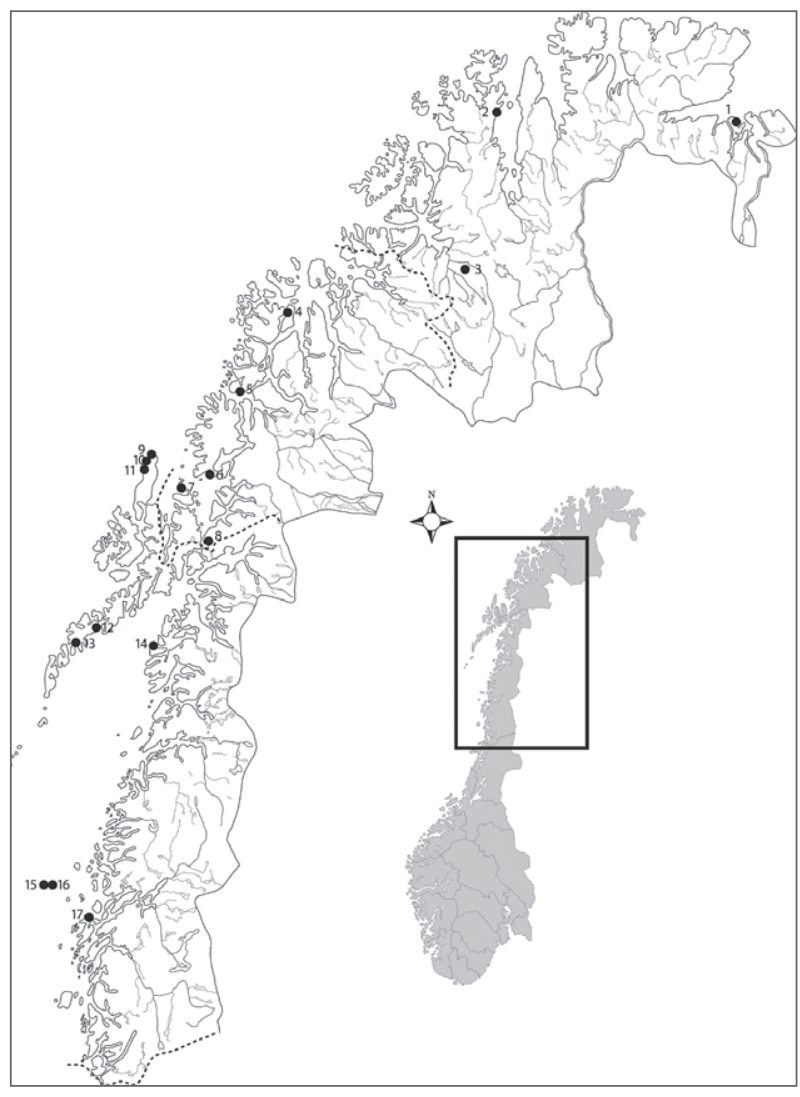

Figur 1: Boplasser med påstått jernproduksjon (2-17) og tidlig jernbruk (1). Grafikk: E. Høgtun, Tromsø Museum, Universitetsmuseet.

Figure 1: Sites with assumed iron production (2-17) and early use of iron (1). Graphics: E. Hogtun, Tromsø University Museum.

slag samples studied are interpreted as smelting slag from a bloomery process» (Bartolotta et al. 1990: 218). Arne Espelund (1989) har satt spørsmålstegn både ved analysemetodene og ved de konklusjonene som ble trukket. Han peker dessuten på at mengden slagg på disse boplassene er svært beskjeden, og at også det taler mot at slagget stammer fra jernproduksjon. På de aller fleste av lokalitetene (se figur 1) er slaggmengden altfor liten til at slagget alene kan brukes som et argument for at det skal ha funnet sted en lokal jernproduksjon.

Frem til midten av 1990-årene var alt som ble ytret om jernproduksjon i Nord-Norge, bare påstander. 


\begin{tabular}{|l|l|l|}
\hline Nr. & Lokalitet & Sør-Varanger \\
\hline 1 & Kjelmøy & Porsanger \\
\hline 2 & Indre Sortvik & Alta \\
\hline 3 & Virdnejavri & Karlsøy \\
\hline 4 & Finnby & Tromsø \\
\hline 5 & Greipstad & Tranøy \\
\hline 6 & Hofsøy & Bjarkøy \\
\hline 7 & Øvregården & Skånland \\
\hline 8 & Stauran & Andøy \\
\hline 9 & Toften II & Andøy \\
\hline 10 & Bleik & Andøy \\
\hline 11 & Storslettneset, Bleik & Vestvåøy \\
\hline 12 & Moland & Vestvågøy \\
\hline 13 & Leknes & Steigen \\
\hline 14 & Bø & Træna \\
\hline 15 & Hellarvikjæ House I & Træna \\
\hline 16 & Røsnesvalen & Dønna \\
\hline 17 & Glein & \\
\hline
\end{tabular}

Tabell 1: Boplasser med påstått jernproduksjon (2-17) og tidlig jernbruk (1).

Table 1: Sites with assumed iron production (2-17) and early use of iron (1).

Ingen anlegg for produksjon av jern hadde tidligere blitt dokumentert. Denne a priori troen på en nordnorsk jernproduksjon må forstås ut fra både materielle likheter med sørnorsk jernalder og manglende kunnskap om og dermed manglende evne til å gjenkjenne spor etter jernproduksjon. Etter at den første jernvinna ble registrert i 1994, har ytterligere to anlegg blitt registrert og utgravd.

\section{TRE NORDNORSKE JERNVINNER}

Til sammen er det nå kjent tre produksjonsanlegg for jern i Nord-Norge (figur 2). Rognlivatnet ble som det første registrert av Bjerck og Stenvik i 1994, mens anleggene på Flakstadvåg og Hemmestad Nedre ble registrert og utgravd av forfatteren i perioden fra 1997 til 2002.

\section{Rognlivatnet}

Anlegget ved Rognlivatnet ligger på cirka 400 meter over havet, inne på fjellet ved tettstedet Misvær i Salten i Nordland. To til tre små slagghauger er synlige på markoverflaten, men selve ovnen er ikke påvist. Haugene, som består av røstet malm iblan-

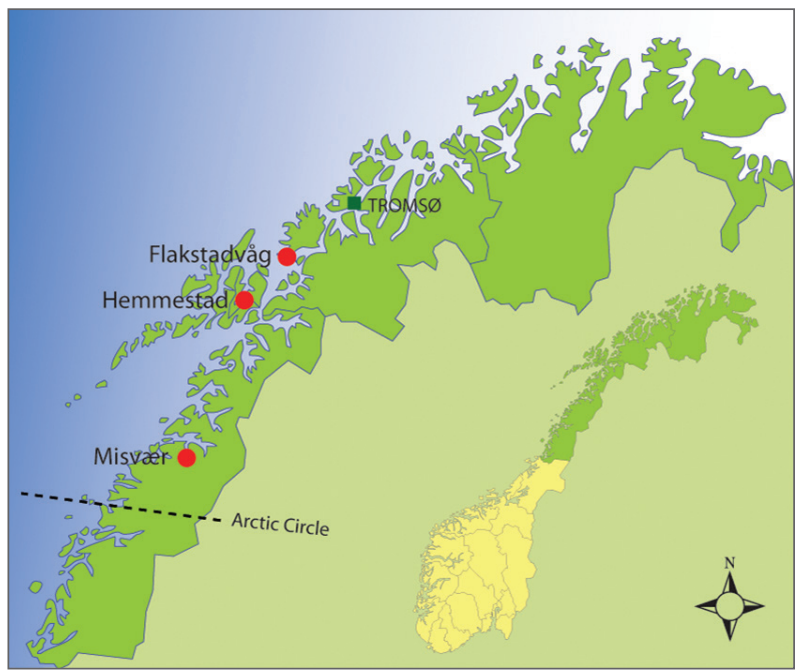

Figur 2: Steder med jernproduksjon i Nord-Norge. Grafikk: E. Høgtun, Tromsø Museum, Universitetsmuseet. Figure 2: Iron production sites in North Norway. Graphics: E. Hogtun, Tromsø University Museum.

det slagg, viser likevel at dette utvilsomt er deler av et anlegg for produksjon av jern. Like ved er det registrert to store trekullmiler på henholdsvis 6,3 og 12,2 kubikkmeter (Johansen 2000: 64). Koplingen mellom jernslagg og kullgroper indikerer en datering til sen jernalder eller middelalderen, noe som er bekreftet av ${ }^{14} \mathrm{C}$-dateringer. Bjerck og Stenvik (1994) ${ }^{14} \mathrm{C}$-daterte en av haugene med røstet malm og slagg til 800 pluss-minus 35 BP (T-11811), hvilket gir en kalibrert datering innenfor to standardavvik mellom AD 1175 og 1277 (Bronk Ramsey 2001; OxCal 3.10 2005). Senere ${ }^{14} \mathrm{C}$-dateringer av de to kullgropene støtter opp under denne dateringen, og det er sannsynlig at anlegget var i virksomhet en gang på 1200-tallet.

Haugene med slagg og røstet malm er ganske små, og det er lite som tyder på at anlegget har vært i bruk over lengre tid. Selv om mye slagg kan ligge skjult i slaggroper nede i bakken, gir de synlige strukturene ingen indikasjoner på at det har funnet sted noen omfattende eller langvarig produksjon på stedet (Jørgensen 2010: 48). 
Flakstadvåg

Anlegget i Flakstadvåg ligger sør på Senja i MidtTroms, cirka 2 kilometer fra sjøen og 31 meter over havet (Jørgensen 1998; 1999a). Før utgravningen var de eneste synlige sporene etter virksomheten noen store, inntil 7 kilo tunge slaggklumper og en delvis erodert, traktformet grop. Denne lå på toppen av en skråning ned mot en bekk som delvis hadde gravd ut bakken nedenfor gropen og forårsaket at deler av den var rast ut. Bevarte sjaktfragmenter viser at det har stått en sjaktovn på stedet, og at dette var restene etter den underliggende slaggropen. To ${ }^{14} \mathrm{C}$-dateringer tidfester anlegget til romertiden, mest sannsynlig til 300-tallet e.Kr. (Jørgensen 2010: 44).

Mengden slagg (117 kilo) og sjaktmateriale (19,8 kilo) tyder ikke på at det har vært noen omfattende jernproduksjon på stedet. Ovnsgropen målte cirka 1 meter i diameter ved markoverflaten, og den var 0,8 meter dyp. Mengden slagg sett i relasjon til ovnsgropens størrelse indikerer at ovnen har vært i bruk én eller høyst to ganger, hvilket ville ha gitt en forholdsvis begrenset mengde produsert jern.

Anleggets beliggenhet gir assosiasjoner til romertidsanleggene i Nord-Trøndelag, som ofte har samme plassering i terrenget. De ligger gjerne på et tørt område ute i en myr, på toppen av en skråning over et vann, en elv eller en bekk (Stenvik 1990: 210). Selv om utgravningen av anlegget resulterte $i$ få funn som kunne gi innsyn i teknologiske aspekter ved produksjonen, medfører likhetene med anleggene i Nord-Trøndelag at det er mulig å hente kunnskap derfra om noen av de teknologiske løsningene.

\section{Hemmestad Nedre}

Anlegget inne i Kvæfjorden i Sør-Troms ligger på et jorde som første gang ble oppdyrket rundt 1950 (Jørgensen 1999a; 1999b). Bonden avdekket da noen kull- og slaggroper, og utgravninger i 1999 og 2002 avdekket to nær identiske ovner. Disse lå på et forholdsvis flatt jorde, 10 meter over havet og cirka 150 meter fra sjøen. Dette var små sjaktovner - med en diameter på bare 30 centimeter - som hadde vært plassert midt i hver sin leirfylte grop i bakken. I bunnen av ovnene var det åpninger som var markert av reiste steinheller mot hver sin slagghaug, som bestod av ganske små slaggklumper. Jordet hvor ovnene nå ligger, har vært pløyd og harvet gjentatte ganger, slik at slagg og sjaktmateriale er spredt over hele det 20 mål store oppdyrkede området. Det er derfor ikke mulig å beregne hvor mye jern som har vært produsert her, basert på mengden produsert slagg. Kun 28 kilo slagg og 16 kilo sjaktmateriale ble funnet, men en uviss mengde ligger fortsatt spredt i pløyelaget rundt omkring på jordet. Mengden slagg som ble funnet i umiddelbar nærhet av ovnene og gjenfunnet rundt omkring på jordet, tyder likevel ikke på at det har vært noen omfattende produksjon her.

${ }^{14} \mathrm{C}$-dateringer av ovnene og en av de tilhørende slagghaugene plasserer anlegget i yngre bronsealder eller førromersk jernalder. Dateringenes tyngdepunkt indikerer at anlegget mest sannsynlig var $\mathrm{i}$ drift i første del av førromersk jernalder.

Konstruksjonsmessig ser ovnene ut til å ha mange fellestrekk med anlegg i Sør-Skandinavia. Ovner med liten diameter som har vært plassert i leirfylte groper, er konstruksjonsmessige trekk som er å finne over store deler av Sør-Skandinavia, men ovnene på Hemmestad er eldre enn de fleste sammenlignbare anleggene i sør (Stenvik 2005; Larsen 2009).

\section{Oppsummering av de nordnorske anleggene}

De tre anleggene for produksjon av jern som til nå er funnet i Nord-Norge, er kronologisk spredt fra tidlig førromersk jernalder til tidlig høymiddelalder. Hvert enkelt anlegg ser ut til å ha hatt en ganske begrenset funksjonstid, produksjonen har vært ganske liten, og bare tre anlegg i drift over en periode på omkring 1200 år har ganske opplagt ikke hatt noen betydning for den generelle jernforsyninga i landsdelen. Et viktig spørsmål når vi skal vurdere betydningen av den nordnorske jernvinna, er om disse tre anleggene utgjør toppen av et isfjell, det vil si om det finnes en rekke, uoppdagede anlegg i landsdelen, eller om den nordnorske jernproduksjonen var liten, ubetydelig og nærmest ikke-eksisterende, slik at jern ble skaffet til veie på andre måter.

For bedre å forstå den nordnorske jernvinna og den konteksten den inngikk i, kan det være nyttig å se på forskningsstatus i tilstøtende geografiske områder.

\section{JERNPRODUKSJON PÅ NORDKALOTTEN}

Nord-Norge hadde i jernalderen, som i senere perioder, en sammensatt befolkning, både etnisk og kulturelt. Ytterkysten nord til Nord-Troms ser ut til å ha hatt en germansk gårdsbosetning som til en viss grad var basert på fehold og åkerbruk, mens den samiske bosetningen i innlandet, NordTroms og Finnmark i større grad levde av jakt og fangst. Denne kulturelle dikotomien kan spores tilbake til yngre steinalder, men utvikler seg i siste årtusen f.Kr. til det som senere fremstår som germansk og samisk etnisitet (Jørgensen og Olsen 1987; 1988; Olsen 1994: 215-217; Hansen og Olsen 2004: 40). Disse etniske kategoriene knyttes 
gjerne til forskjellige geografiske områder, med samer i nord og øst og germanere i sør og vest, men en slik geografisk grenseoppgang basert på etnisitet gir et forenklet og til dels feilaktig bilde av de demografiske skillelinjene. Selv om den germanske gårdsbosetningen i sør og vest i hovedsak har vært geografisk adskilt fra flertallet av den samiske befolkningen i nord og øst, indikerer historiske kilder og arkeologiske funn samisk tilstedeværelse også i kjerneområdene for den germanske bosetningen, og motsatt. Anleggene på Hemmestad Nedre og Flakstadvåg, som begge er datert til jernalderen, ligger i kjerneområdet for de germanske bosetningene i Nord-Norge, mens Rognlivatnet kanskje kan knyttes til den samiske bosetningen innerst i fjordene og i innlandet. I hele Finnmark og Nord-Troms, som til sammen dekker et område på rundt 63000 kvadratkilometer, det vil si 1,5 ganger Danmarks areal, finnes det ingen spor etter jernutvinning. Befolkningen har likevel hatt tilgang på jern, og jernbruken i Finnmark går tilbake til omkring år $600 \mathrm{f} . \mathrm{Kr}$, noe som er blant de eldste sporene etter bruk av jern i Nord-Norge. Dersom vi fra Finnmark ser østover mot Russland, er det heller ikke registrert spor etter jernproduksjon på Kolahalvøya. Sør for Kola, i Karelen, er det imidlertid registrert en rekke produksjonsanlegg for jern (Kosmenko og Manjuhin 1999).

Forskning på forhistorisk jernproduksjon i Finland har ikke vært prioritert like høyt som i resten av Norden, og forholdsvis lite har vært gjort for å utforske denne virksomheten, særlig sør i Finland. I Øst- og Nord-Finland har imidlertid flere anlegg blitt registrert og utgravd (Schulz 1986; Mäkivuoti 1987; Kotivuori 1996; Lavento 1999). Teknologisk viser den finske jernproduksjonen nært slektskap med virksomheten i Karelen og også med den baltiske produksjonen (Peets 2003).

I området rundt Storsjön i Jämtland er det registrert et betydelig antall anlegg for produksjon av jern som dateres til jernalderen og middelalderen (Magnusson 1986). Dette var også det nordligste kjente produksjonsområdet for jern i Sverige frem til registreringen av et jernvinneanlegg ved Sangis i Kalix sogn i 2009 (e-post fra C. Bennerhag av henholdsvis 9. og 13. november 2009). Anlegget som bestod av en ovn, ble utgravd sommeren 2010, og dette er det hittil nordligste anlegget for produksjon av jern i Sverige (Norrbottens museums hjemmeside).

Hvis vi sammenligner Nord-Norge med resten av nordre Fennoskandia, skiller ikke landsdelen seg ut verken med en spesielt liten jernproduksjon og få jernvinneanlegg eller med en større produksjon enn i naboområdene. I Norge og Sverige finner det sted en omfattende jernproduksjon i sør, mens jernvinna er svært sparsomt representert i de nordligste landsdelene. Når det gjelder status på forskningen i Finland, er den noe forskjellig fra den i Norge og Sverige, da de fleste finske anleggene er funnet i øst og nord. De få anleggene som er funnet i NordNorge, føyer seg inn i det bildet som er skapt av de senere års forskning av en svært begrenset forhistorisk jernproduksjon på Nordkalotten. De tre nordnorske jernvinnene ligger riktignok lenger nord enn de nordligste anleggene i nabolandene, men jernvinna er ukjent i de nordligste og østligste delene av Nord-Norge. Det er ikke funnet belegg for å påstå at det har vært produsert jern verken på Kolahalvøya eller i den nordligste delen av Finland, nord for Rovaniemi.

\section{ER FORSKJELLENE FORSKNINGSSKAPTE?}

Kun en håndfull anlegg for produksjon av jern som er datert til jernalderen og middelalderen, er funnet på Nordkalotten - i Nord-Norge er det funnet tre anlegg, i Nord-Sverige nord for Jämtland er det funnet ett anlegg, og i Lapplands län i Finland er det utgravd tre produksjonsanlegg. Hva forteller det om den forhistoriske jernproduksjon på Nordkalotten? De nåværende funnene indikerer at jernproduksjonen i Fennoskandia i regelen var avgrenset til Sør- og Midt-Norge og Sør- og MidtSverige, mens jern kun sporadisk ble produsert i de nordlige landsdelene. Denne beskrivelsen av stor produksjon i sør og liten produksjon i nord passer i mindre grad med det finske materialet, der jernproduksjonen i nord synes å være noe større enn i nabolandene. Forskningen omkring den tidlige jernproduksjonen i Finland har imidlertid ikke vært like omfattende som i Norge og Sverige, og jernvinnas omfang og betydning som økonomisk og sosial faktor i de ulike delene av landet er derfor ikke like tydelig.

De store forskjellene mellom nord og sør når det gjelder den forhistoriske jernproduksjonen i Norge og Sverige, kan ha flere forklaringer. En av dem kan være at det dreier seg om forskningsskapte forskjeller, det vil si at forhold ved dagens forskning har skapt disse forskjellene, mens en annen kan være at disse forskjellene er reelle og avspeiler en historisk realitet. Forskningens finansiering og organisering og hva som til enhver tid har vært populære forskningstema, er svært viktig for hvilke perioder og tema som tiltrekker seg oppmerksomhet, ressurser og forskere. Det er imidlertid liten grunn til 
å tro at slike faktorer har virket forskjellig i nord og i sør. Forskningsmiljøene i sør har imidlertid alltid vært flere og større enn dem i nord, og det samlede antallet forskere har dermed vært betydelig større i sør enn i nord. Det har gjort det mulig å få til en større tematisk spredning av forskningen i sør. Og kanskje minst like viktig er funn som ble gjort tidlig på 1900-tallet, som har medført at den tidlige jernvinna fikk så stor oppmerksomhet. Oppmerksomheten rundt den tidlige jernvinna hadde en selvforsterkende effekt som gjorde at de nye funnene ledet til økt oppmerksomhet fra flere forskere, som igjen samlet større ressurser, som igjen førte til nye funn. Mangelen på funn, frem til midten av 1980-tallet i Nord-Finland, frem til midten av 1990-tallet i Nord-Norge og frem til 2009 i Nord-Sverige, har medført at forskersamfunnet har vært lite oppmerksomt på den tidlige jernproduksjonen i nord. Forskningsmiljøene i nord har følgelig ikke hatt samme mulighet som dem i sør til å bygge kompetanse på å søke etter og gjenkjenne anlegg hvor jernproduksjon har funnet sted.

Få og små fagmiljøer, få forskere og få funn kan være en del av, men neppe hele, forklaringen på hvorfor så få produksjonsanlegg for jern er funnet i nordre Fennoskandia. I så fall forutsetter det at jernproduksjon var mer omfattende enn det de få registrerte anleggene indikerer, og dermed at potensialet for mange, nye funn er til stede.

En annen forklaring på at så få anlegg for forhistorisk jernproduksjon er funnet i nordre Fennoskandia, er at det reflekterer en historisk realitet, det vil si at den forhistoriske jernproduksjonen i nord har vært lav og produksjonsstedene få, og at det er derfor så få anlegg er registrert. Nedenfor skal vi se nærmere på noen mulige bakenforliggende årsaker til den tilsynelatende begrensede jernproduksjonen i nord.

\section{HVORFOR VAR JERNPRODUKSJONEN SÅ LITEN I NORD?}

De arkeologiske funnene indikerer at det i forhistorisk tid og i middelalderen over store deler av Nordkalotten var liten eller ingen jernproduksjon. Det er all grunn til å tro at produksjonen var større enn det tilgjengelige data tyder på, fordi det vil være urimelig å tro at vi har funnet alle anleggene som en gang var i drift. Det er imidlertid svært usikkert hvor omfattende den lokale jernproduksjonen var, og om den noen gang fikk et omfang som gjorde de nordlige samfunnene uavhengig av tilførsler av jern utenfra.

Dersom jernproduksjonen i nordre Fennoskandia har vært så lav som funnene kan tyde på, vil det være nødvendig å se bak funnene for å finne årsaker til at det er slik. Nordkalotten, det vil si nordre Fennoskandia og Kolahalvøya, var gjennom jernalderen og middelalderen bebodd av ulike etniske grupper med forskjellig kulturell tilhørighet og forskjellig økonomi og dessuten ulike eksterne forbindelser.

Mangel på - eller fravær av - naturressurser vil kunne forklare mangelen på produksjon av jern i nord. For å produsere jern er det først og fremst nødvendig å ha tilgang til jernmalm som har riktig kjemisk sammensetning, dernest er det nødvendig à ha byggematerialer til ovnen og brensel til prosessen. Brensel og byggematerialer har neppe vært minimumsfaktorer, men det er mer usikkert hvordan tilgangen har vært på god jernmalm med riktig kjemisk sammensetning. Det finnes, så vidt vi vet, ingen samlet oversikt over myrmalmforekomster på Nordkalotten, men i forbindelse med feltarbeider i Nord-Norge er det gjort en rekke funn av myrmalm. Malm fra noen av disse lokalitetene har blitt analysert, og det viser seg at det dreier seg om malm som har en kjemisk sammensetning som er velegnet for den teknologien som jernproduksjonen var basert på i jernalderen og i middelalderen (tabell 2). Disse

\begin{tabular}{|c|c|c|c|c|c|c|c|c|c|c|c|c|c|}
\hline & $\mathrm{FeO}$ & $\mathrm{Fe} 2 \mathrm{O} 3$ & $\mathrm{MnO}$ & $\mathrm{SiO} 2$ & $\mathrm{Al} 2 \mathrm{O} 3$ & $\mathrm{P} 2 \mathrm{O} 5$ & $\mathrm{CaO}$ & $\mathrm{MgO}$ & $\mathrm{BaO}$ & $\mathrm{TiO} 2$ & $\mathrm{~K} 2 \mathrm{O}$ & Sum & $\mathrm{R}$ \\
\hline $\begin{array}{l}\text { Hemmestad } \\
\text { Nedre }\end{array}$ & & 84.16 & 2.0 & 7.96 & 3.26 & 0.394 & 0.51 & 0.56 & 0.02 & 0.09 & 0.31 & 99.24 & 8.12 \\
\hline Flakstadvåg & & 95.44 & 0.03 & 1.59 & 1.49 & 0.039 & 0.07 & 0.11 & $<0.01$ & $<0.01$ & 0.04 & 98.81 & 45.0 \\
\hline Dverberg & & 92.63 & 1.08 & 4.60 & 0.44 & 0.051 & 0.12 & 0.13 & 0.03 & $<0.01$ & 0.04 & 99.12 & 17.0 \\
\hline Altevann & & 83.19 & 5.06 & 4.90 & 2.94 & 0.249 & 0.58 & 0.21 & 0.25 & 0.07 & 0.23 & 97.68 & 13.5 \\
\hline Børselvfjellet & & 94.09 & 0.45 & 3.35 & 0.31 & 0.045 & 0.05 & 0.25 & $<0.01$ & 0.01 & 0.08 & 98.24 & 23.8 \\
\hline
\end{tabular}

Tabell 2: Analyser av myrmalm fra Nord-Norge (Espelund 2005).

Table 2: Analyses of bog iron ore found in North Norway (Espelund 2005). 
få funnene er ikke et resultat av en systematisk gjennomgang og systematiske søk etter myrmalm, så når disse malmforekomstene synes å være velegnet for tidlig jernproduksjon, vil det være rimelig å anta at det i dag finnes myrmalm med riktig kjemisk sammensetning mange steder på Nordkalotten, og at det samme var tilfellet også $i$ jernalderen. Det at jern har vært produsert noen få steder, viser at ressursene var til stede og kjent, i det minste enkelte steder på Nordkalotten.

Dersom den beskjedne jernproduksjonen på Nordkalotten ikke kan forklares ut fra manglende naturressurser, vil det være nærliggende å se på sosiale årsakssammenhenger. Det vil si at sosioøkonomiske forhold gjorde at menneskene i disse områdene avstod fra jernproduksjon selv om naturressursene var tilgjengelige og teknologien var kjent. Slike sosioøkonomiske faktorer kan ha vært av intern karakter, men de kan også ha vært koplet til befolkningens eksterne relasjoner. Årsakene til at den forhistoriske jernproduksjonen på Nordkalotten har vært så beskjeden, kan altså være å finne i interne forhold i befolkningene eller i befolkningenes relasjon til eksterne aktører, eller de kan være å finne $i$ en kombinasjon av de to forannevnte elementene. Nedenfor er det listet opp noen mulig elementer som kan ha bidratt til at jernproduksjonen i nord fikk et så lite omfang.

\section{Liten etterspørsel etter jern}

Kan etterspørselen etter jern ha vært så lav at det ikke var bryet verdt å etablere en egen produksjon? Det er ingenting i det arkeologiske materialet som tyder på at etterspørselen etter jern var mindre i nord enn i sør. Det ser ut til at jernredskaper ble tatt i bruk like tidlig i Nord-Norge som i Sør-Norge, og jernbruken ut over i jernalderen var omfattende. Det er grunn til å tro at jern var et ettertraktet råstoff gjennom både jernalderen og middelalderen, og vi ser at jern så sent som på 1700-tallet var et ettertraktet og kostbart råstoff. I Karlsøy i Nord-Troms kostet en jerngryte på den tiden 1-5 daler, mens en fiskers årlige inntekt bare var på 15 daler (Bratrein 1989: 498-99). Dessuten var det vanlig praksis å hugge løs jernplater, bolter og lignende fra treverket i strandede skip for å selge jernet på markedene (Bratrein 1990: 181).

Det er imidlertid ikke nødvendigvis noen sammenheng mellom etterspørsel og pris på jern i århundrene etter middelalderen og forsyningssituasjonen i tidligere perioder, fordi handelsforbindelser og bytteforhold endret seg kanskje gjennom århundrene. Eksemplene over er trukket frem for å vise at selv etter århundrer med langvarige og tet- te handelsforbindelser mellom nord og sør var jern likevel en etterspurt og verdifull vare så sent som på 1700- og 1800-tallet.

\section{Forsyninger utenfra}

I Midt- og Sør-Skandinavia ble det gjennom store deler av jernalderen og middelalderen produsert jern i mengder som i høy grad oversteg den lokale etterspørselen, og handel med disse områdene ville langt på vei kunne ha tilfredsstilt etterspørselen i nord. De nordlige bosetningene hadde tilgang på varer som var ettertraktet på markedene både sør i Skandinavia og på kontinentet, og en form for byttehandel ville derfor ha vært mulig.

Kan det være at bytteforholdet mellom jern og de varene «nordlendingene» kunne tilby, var så gunstig at de nordlige bosetningene av den grunn avstod fra selv å produsere jern?

\section{Manglende tilgang på teknologisk kunnskap}

Den lite utviklede jernproduksjonen i nord kunne skyldes manglende tilgang på teknologisk kunnskap. Lars Stenvik (2003: 80-81) har sammenlignet de sørnorske jernprodusentene med moderne selskaper som hegner om forretningshemmeligheter. Han ser den lille nordnorske jernproduksjonen som et resultat av at jernprodusentene i sør gjennomførte en kunnskapsembargo for å unngå at markedene i nord ble selvforsynte med jern, noe som ville ha medført bortfall av de nordlige markedene.

Et problem med denne modellen er at det er påvist flere tilfeller av jernproduksjon i nord, om enn i liten skala. De tre anleggene vi har funnet, dokumenterer at teknologien var kjent. Men hvorfor ble ikke denne kunnskapen vedlikeholdt og spredt, noe som ville ha resultert i en mer omfattende produksjon?

\section{Etnisk arbeidsdeling}

Etnisk arbeidsdeling har vært fremhevet som en viktig årsak til at vi ikke finner spor etter jernproduksjon i Nord-Troms og Finnmark, altså i de samiske kjerneområdene. Produksjon av jern var noe «de», det vil si den germanske befolkningen, drev med, ikke jakt-og-fangst-folket. «... the production of iron should be seen as part of the agricultural and sedentary ethnic 'label'» (Sundquist 1999: 55-56), og å involvere seg i jernproduksjon ville innebære å krysse etniske skillelinjer. En slik virksomhet ville ha vært et brudd med etniske tradisjoner, noe som kunne medføre at det ble satt spørsmålstegn ved gruppens etniske identitet.

Etnoarkeologiske studier har dokumentert at 
etnisitet i visse sammenhenger kan ha vært en avgjørende faktor for hvorvidt nye råstoffer og ny teknologi ble sosialt akseptert (Eliade 1978: 99; Hedeager 2001: 486). Det er imidlertid et åpent spørsmål hvorvidt etnisitet hadde noen relevans for de nordnorske bosetningenes aksept for og bruk av den nye teknologien.

En gjennomgang av skiftesaker og dødsbo i Vesterålen og i Karlsøy kommune viser at smedutstyr i det 18. og 19. århundret hovedsakelig opptrer i samisk kontekst (Bratrein 1990: 198; Borgos og Torgvær 1998: 105). Smedutstyr opptrer så sjelden i norske skifter og dødsbo at det ser ut til at det på denne tiden eksisterte en tilnærmet etnisk arbeidsdeling i Vesterålen og Nord-Troms. Det er imidlertid usikkert om dette er en type arbeidsdeling som var vanlig i hele Nord-Norge, eller om den var et resultat av en forholdsvis moderne utvikling, eller om arbeidsdelingen har røtter tilbake i middelalderen og kanskje også jernalderen.

Dersom vi ser isolert på Nord-Troms og Finnmark, som tidligere hadde en overveiende samisk befolkning, kan forslaget om en etnisk arbeidsdeling synes rimelig. Men hvis vi hever blikket og tar inn et større geografisk område, ser vi at anleggene for produksjon av jern som er funnet $i$ Nord-Finland og Nord-Sverige, trolig ble etablert og operert av folk som etnisk og kulturelt stod nær befolkningen i Nord-Troms og Finnmark. Denne modellen kan heller ikke forklare hvorfor jernproduksjonen var fraværende også i store deler av det germanske bosetningsområdet.

\section{Den sosiale organiseringen}

Et samfunns sosiale organisering vil kunne både fremme og motvirke aksept og bruk av ny teknologi. I et tidligere arbeid (Jørgensen 2010) har jeg argumentert for at den interne organiseringen av de germanske bosetningene i nord og dessuten relasjoner til jernproduserende grupper i sør sammen motvirket utviklingen av en mer omfattende jernproduksjon i Nord-Norge. Stenviks hypotese (2003: 81-82) om at jernprodusentene i sør sikret seg markedene i nord gjennom å hindre at folk i nord fikk tilgang til produksjonsteknologien, kan i denne sammenheng ha noe for seg. Det er imidlertid neppe slik at denne kunnskapsembargoen kunne opprettholdes effektivt over tid, noe som også dokumenteres av de få jernvinnene som er funnet i nord, men en allianse mellom nordnorske stormenn som trolig kontrollerte handelen, og jernprodusenter i sør kan ha medvirket til at den nordnorske jernproduksjonen ble holdt nede (Jørgensen 2010: 198-204).

\section{ER FUNNENE I NORD BARE TOPPEN AV ET ISFJELL?}

Vi kan med stor grad av sikkerhet anta at de tre anleggene for produksjon av jern som til nå er funnet i Nord-Norge, kun er de første i en rekke av flere som vil bli funnet $\mathrm{i}$ årene som kommer. Det er imidlertid høyst usikkert hvor stort omfang den nordnorske jernproduksjonen hadde i jernalderen og middelalderen. Etter hvert som kunnskapen om jernvinna øker og det blir tatt i bruk registreringsmetodikk som er spesielt utviklet for å finne spor etter jernproduksjon, vil utvilsomt flere anlegg bli avdekket. Det er imidlertid lite sannsynlig at vi vil komme til å gjøre registreringer $\mathrm{i}$ et så stort omfang som det har vært gjort i Midt- og Sørøst-Norge. Dersom den forhistoriske jernproduksjon i Nord-Norge har hatt tilnærmet samme omfang som den i sør, ville det være sannsynlig at flere enn tre anlegg hadde vært funnet etter 135 års arkeologisk virksomhet i landsdelen. De anleggene som til nå er funnet, er derfor neppe toppen av et isfjell som vil bli avdekket $\mathrm{i}$ årene som kommer, men heller de første av flere funn som viser at jern til en viss grad ble produsert i landsdelen både i jernalderen og i middelalderen, men at omfanget var ganske lite (Jørgensen 2011).

Tidligere forskere som har vært opptatt av problemstillingen, har i hovedsak sett mot sør og jernproduksjonen som fant sted i de germanske bosetningene i Midt- og Sør-Skandinavia. Siden midten av 1980-tallet har imidlertid anlegg for jernproduksjon blitt registrert og utgravd også i Nord-Finland, særlig ved Kemijärvi og i nærheten av Rovaniemi (Schulz 1986; Mäkivuoti 1987; Kotivuori 1996; Lavento 1999), og i Nord-Sverige, ved Sangis i Kalix (Norrbotten museums hjemmeside). Både det nordsvenske og de nordfinske anleggene ser ut til å tilhøre en østlig tradisjon, en tradisjon som skiller seg fra den vi ser lenger sør i Sverige og Norge. Denne produksjonsteknologien er det heller ikke funnet spor etter i Nord-Norge. Kulturelle kontakter mellom øst og vest har lange tradisjoner på Nordkalotten, noe som også underbygges av arkeologiske funn. Det vil derfor ikke være overraskende om vi, kanskje særlig i Nord-Troms og Finnmark, finner lave, rektangulære ovner som er bygd av steinheller (figur 3), lik dem som er funnet i NordSverige og Nord-Finland.

Befolkningen i Nord-Norge var gjennom jernalderen og middelalderen sosialt, kulturelt og økonomisk svært sammensatt. Dersom vi aksepterer at det ikke var mangel på naturressurser, men sosiale faktorer som begrenset jernproduksjonen, vil et sentralt spørsmål være hvordan det kunne skje. Hvilke 
sosiale mekanismer kunne bidra til at ulike folkegrupper som var spredt over hele Nord-Norge, i stor grad avstod fra jernproduksjon gjennom både jernalderen og middelalderen? Det er mulig at de sosiale mekanismene som bidro til å holde jernproduksjonen nede, var mange, og at de var kulturelt og etnisk spesifikke, det vil si at årsakene til at jernproduksjonen var beskjeden i jakt-og-fangst-miljøene, var forskjellig fra mekanismene som medvirket til å holde jernproduksjonen nede i de germanske miljøene. En annen mulighet er at de samme mekanismene virket på tvers av etniske skillelinjer, altså at de ulike etniske gruppene i landsdelen inngikk i relasjonelle system som medførte at de samme mekanismene som hemmet jernproduksjon i en befolkningsgruppe, også bidro til å holde produksjonen nede i andre grupper.

Selv om befolkningen i landsdelen var etnisk, sosialt og økonomisk sammensatt, er det grunn til å tro at den inngikk i interetniske, sosioøkonomiske relasjoner. Den historisk kjente «finnehandelen» er et eksempel i den forbindelse, men det er uvisst hvor lange historiske røtter den har. Arkeologiske funn indikerer at fangstbefolkningens eksterne relasjoner $i$ det første årtusenet e.Kr. først og fremst var å finne blant kystbefolkningen i sørvest og vest (Hansen og Olsen 2004: 72-73, 75). Fangstbefolkningen i nord og øst inngikk dermed i et større utvekslingssystem som inkluderte den germanske befolkningen langs kysten av Nord-Norge og jernprodusentene i sør. En allianse mellom sørnorske jernprodusenter og nordnorske stormenn som kontrollerte handelen med jern, sikret jernprodusentene tilgang på prestisjevarer som hvalrosstenner, pels og jaktfalker og dessuten store kvanta av hval og selolje og tran fra fiskelever. I Nord-Trøndelag er gjort en rekke funn av importgjenstander som er datert til romertiden, da jernproduksjonen i Trøndelag var på det største (Stenvik 1987: 111; 2005). Det er sannsynlig at den velstanden som disse gravfunnene dokumenterer, ikke bare var basert på salg av jern direkte til markeder i sør, men også på en videreformidling av produkter fra Nord-Norge. En allianse mellom jernprodusentene i sør og de nordnorske stormennene ville ha vært nyttig for begge parter. Jernprodusentene fikk tilgang til ettertraktede produkter fra nord, og de nordnorske stormennene styrket sin maktbase i nord gjennom kontroll av jerntilførselen. En lokal, nordnorsk jernproduksjon ville følgelig ikke ha vært i verken de sørnorske jernprodusentenes eller de nordnorske handelsmennenes interesse, snarere tvert imot. Begge parter ville ha hatt all interesse av å undertrykke tilløp til en lokal, nordnorsk jernproduksjon.

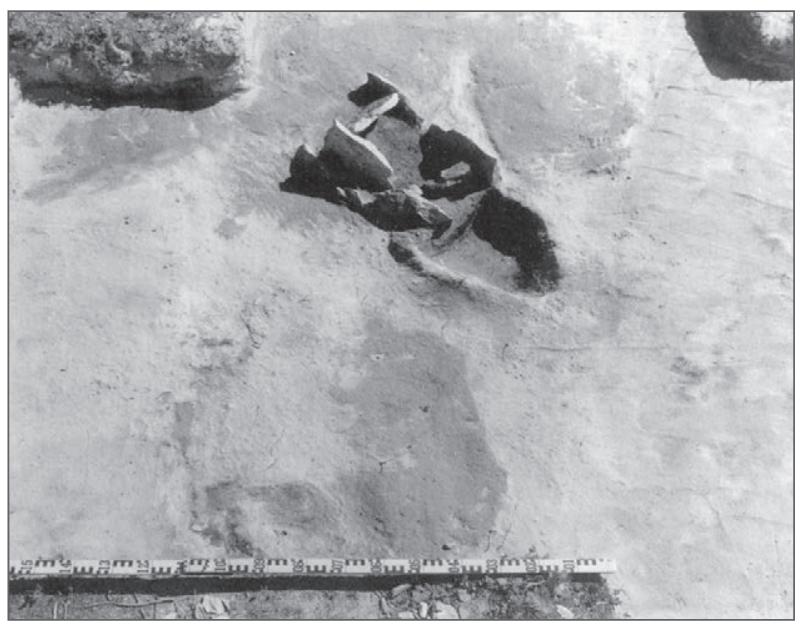

Figur 3: Steinrammeovn ved Sierijärvi ved Rovaniemi i Finland. Foto: H. Kotivuori (1996:109).

Figure 3: Stone box furnace at Sierijärvi, Rovaniemi, in Finland. Photo: H. Kotivuori (1996:109).

Jernproduksjonen var generelt liten i hele nordre Fennoskandia i jernalderen og middelalderen, og de sosioøkonomiske mekanismene som motvirket utviklingen av en nordnorsk jernproduksjon, kan ikke forklare den beskjedne jernproduksjonen i hele dette området. Selv om de nordnorske stormennene kunne undertrykke lokale entreprenørers forsøk på å få i gang en lokal nordnorsk jernproduksjon, er det lite sannsynlig at deres innflytelsessfære dekket hele Nordkalotten. Andre mekanismer som hindret utviklingen av en større jernproduksjon, må derfor ha vært virksomme i disse områdene.

\section{SUMMARY}

Research into early iron production has long traditions in Central and South Norway and numerous sites have been discovered and excavated. Iron production seems to have been comprehensive, especially in the counties of Trøndelag and in southeast Norway. It seems periodically to have exceeded local demand and iron is believed to have been an important commodity.

Prior to the mid-1990s, no iron production site had been found in North Norway. However, North Norwegian Iron Age farming settlements were an integrated part of the southern cultural sphere and it has thus generally been accepted that iron also was produced in the north.

Till now, three iron production sites have been found in North Norway, two dated to the Iron Age and one to the medieval period. Does this small number of sites mirror the scope of the production, or are a large number of sites expected to be found 
in the years to come? The few sites found during a period of archaeological research of more than 100 years indicate that iron production never was comprehensive in the north. If this was the case, what was the reason for this? Was the need for iron satisfied through trade rather than by local production?

\section{LITTERATUR}

Bartolotta, K.N.A., P.J. Bush,J.C. Fountain, D.Wellspeak, E.Zubrow, K.Allen og A. Pelcin 1988. «Slag as evidence for Early Iron Production in Arctic Norway». Acta Borealia 5 (1-2): 22-33.

Bartolotta, K.N.A., P.J. Bush, J.Fountain, E.Zubrow, K.Allen, S. Fie og A. Pelcin 1990. «The Analysis of Bloomery Slag from Arctic Norway». Acta Archaeologica 61: 212-219.

Bertelsen, R. 1985. «Fra den eldste tida til ca. 1500». Lofoten og Vesterålens historie. Stokmarknes: Publisert av kommunene i Lofoten og Vesterålen.

Bjerck, H. og L. Stenvik 1994. Rapport fra befaring 12.7.1994 $i$ forbindelse med nyoppdaget jernvinneanlegg, Rognlivatnet, Skjerstad, samt pressemelding med ${ }^{14} \mathrm{C}$ datering, 17.08.1995. Bodø: Nordland fylkeskommune, Kulturavdelingen.

Borgos, J. og T. Torgvær 1998. «Samer og båtbygging». Människor och båtar i Norden. Sjöbistorisk årbok 19981999: 104-115. Stockholm: Föreningen Sveriges sjöfartsmuseum.

Bratrein, H.D. 1989. Karlsøy og Helgøy Bygdebok I. Hansnes: Karlsøy kommune.

Bratrein, H.D. 1990. Karlsøy og Helgøy Bygdebok II. Hansnes: Karlsøy kommune.

Bronk Ramsey, C. 2001. «Development of the Radiocarbon Program OxCal». Radiocarbon 43 (2A): 355-363.

Brøgger, A.W. 1931. Nord-Norges bosetningshistorie. En oversikt. Oslo: Instituttet for sammenlignende kulturforskning. (Instituttet for sammenlignende kulturforskning, C, II-4.)

Eliade, M. 1978. The Forge and the Crucible: The Origins and Structures of Alchemy. The Chicago: University of Chicago Press.

Espelund, A. 1989. «Comment on the paper Slag as evidence for early iron production in arctic Norway» av Bartolotta et al. i Acta Borealia 1988, Vol. 5 (1-2). Acta Borealia 6 (1):98-99.

Espelund, A. 2005. Undersøkelser av prover fra NordNorge. Upublisert rapport, topografisk arkiv. Tromsø: Tromsø Museum, Universitetsmuseet.

Hansen, L.I. og B. Olsen 2004. Samenes historie fram til 1750. Oslo: J.W. Cappelens Forlag. Hedeager, L. 2001. «Asgard reconstructed? Gudme a 'central place' in the North». M. De Jong, F. Theuws og C. Van Rhijn (red.). Topographies of Power in the Early Middle Ages. The Transformation of the Roman World 6: 467-507.

Johansen, G.A. 2000. Trekullproduksjon på Vestrågøya $i$ perioden 1100-1700. - Et bidrag til diskusjonen omkring temaet nordnorsk jernvinne og smieaktivitet. Hovedoppgave: Universitetet i Tromsø.

Jørgensen, R. 1998. «Jernvinna på Flakstadvåg - NordNorges første kjente jernproduksjon». Arbok for Senja 27: 48-57. Stonglandseidet: Laget.

Jørgensen, R. 1999a. «Den tidligste jernutvinning i NordNorge». Ottar 225/2-1999: 39-47.

Jørgensen, R. 1999b. «Jernvinna på Hemmestad». Årbok for Kvafjord 13: 2-7. Borkenes: Kvæfjord Historielag.

Jørgensen, R. 2010. Production or Trade. The Supply of Iron to North Norway during the Iron Age. Doktorgradsavhandling: Universitetet i Tromsø.

Jørgensen, R. 2011. «Prehistoric Iron Production in North Norway». Acta Archaeologica 82: 97-128.

Jørgensen, R. og B. Olsen 1987. «Asbestkeramikk i Nord Norge». Finskt Museum 1987: 5-39.

Jørgensen, R. og B. Olsen 1988. «Asbestkeramiske grupper i Nord-Norge 2100 f.Kr.-100 e.Kr». Tromura: Kulturbistorie 13. Tromsø: Tromsø Museum.

Kosmenko, M.G. og I.S. Manjuhin 1999. «Ancient iron production in Karelia». Fennoscandia Archaeologica XVI: 31-46.

Kotivuori, H. 1996. «Pyytäjistä kaskenraivaajiksi. Rovaniemen asutus noin 6000 e.Kr». M. Saarnisto et al. (red.). Rovaniemen historia vuoteen 1721: kotatuliota savupirtin suojaan: 34-125. Jyväskylä.

Larsen, J.H. 2009. Jernvinneundersøkelser. Faglig program 2. Varia 78. Oslo: Kulturhistorisk museum.

Lavento, M. 1999. «An Iron Furnace from the Early Metal Period at Kitulansuo in Ristiina, in the Southern Part of the Lake Saimaa Water System». Fennoscandia Archaeologica XVI: 75-80.

Magnusson, G. 1986. Lågtekniskjärnhantering i Jämtlands län Stockholm: Jernkontoret. (Jernkontorets Bergshistoriska Skriftserie, 22.)

Mäkivuoti, M. 1987. «An Iron Age Dwelling site and burial mounds at Rakanmäki, near Tornio». Fennoscandia Archaeologica V: 35-45.

Munch, J.S. 1965. «Jernaldergården». Ottar 46:18-26.

Olsen, B. 1994. Bosetting og samfunn i Finnmarks forhistorie. Oslo: Universitetsforlaget.

Peets, J. 2003. The Power of Iron: iron production and blacksmithy in Estonia and neighbouring areas in prehistoric period and the Middle Ages. Tallin: Tartu University.

Schulz, E.-L. 1986. «Ein Eisenverhüttungsplatz aus der Älteren Eisenzeit in Kajaani». Iskos 6: 169-173.

Sjøvold, T. 1962. «The Iron Age Settlement of Arctic Norway. A study in the expansion of European Iron 
Age culture within the Arctic Circle I, Early Iron Age». Tromsø Museums Skrifter 10:1. Trømsø: Tromsø museum.

Stenvik, L.F. 1987. «Tidlig jernproduksjon i MidtNorge». K. Julku (red.). Nordkalotten i en skiftande värld-kulturer utan gränser och stater över gränser. Studia bistorica septentrionalia 14:1: 99-119. Rovaniemi: Pohjois-Suomen historiallinen yhdistys.

Stenvik, L.F. 1990. «Jernvinna i Midt-Norge». Heimen 27: 209-218.

Stenvik, L.F. 2003. «Recent Results from Investigations of Iron Production in Northern Europe. Some Reflections on the Variation». L.C. Nørbach (red.). Prehistoric and Medieval Direct Iron Smelting in Scandinavia and Europe. Acta Jutlandica LXXXVI:2, Humanities Series 75: 77-82. Aarhus: Aarhus University Press.
Stenvik, L.F. 2005. «Et nytt metal - en ny epoke». Trondelags historie 1. Landskapet blir landsdel. Fram til 1350: 107-120. Trondheim: Tapir Akademisk Forlag.

Sundquist, Ø. 1999. «Traces of Iron in Prehistoric Finnmark». Fennoscandia Archaeologica XVI: 47-57.

\section{Artikler på nettsider}

Norrbottens museum, hjemmeside (09.2010). http://arkeologipnorrbottensmuseum.blogspot. com/2010_06_01_archive.html

OxCal v. 3.10, 2005 (01.2008). http://c14.arch.ox.ac.uk/ oxcal.php 


\title{
DRENGSTED/SCHARMBECK SLAGGEGRUBE OVNEN I DANMARK OG I SKANDINAVIEN
}

\author{
Arne Jouttijärvi og Olfert Voss
}

\section{SPREDNINGEN AF JERNTEKNOLOGIEN}

Hvilke forhold er det, der har haft indflydelse på den geografiske og tidsmæssige spredning af jernteknologien?

Som vist af Pleiner (1980) blev jernet først introduceret $\mathrm{i}$ et område som et importeret materiale. Det blev smedet lokalt og mest anvendt til mindre genstande, først og fremmest smykkenåle. De meget tidlige fund af smedeslagger må stamme fra denne virksomhed.

Senere kom jernudvindingsteknologien frem til området med jernsmeltere, der ikke alene kom for at sælge deres jern, men tillige for at undersøge, om der var jernmalm, ler og træ på stedet, der kunne gøre det muligt at udvinde jern i samarbejde med lokale smede.

En hjemlig jernproduktion har næppe fundet sted, hverken i Skandinavien eller i andre dele af Europa, uden i et samarbejde med besøgende jernsmeltere.

Man må derfor regne med, at ovntyperne må ligne hinanden, men med variationer, der kan skyldes forskellig malm, men også andre geologiske og topografiske forhold. Ovntyperne afspejler dermed også eksisterende handels- og kulturforbindelser.

Den langsomme spredning af jernteknologien i Europa ses af, at mens der er jernproduktion i Grækenland allerede o. år 1000 f.Kr., kommer der først en produktion i Danmark, der næppe går længere tilbage end 4. årh. f.Kr.

Der er relativt sikre tegn på, at jernudvindingen begyndte i Danmark i løbet af 4. årh. f.Kr., altså samtidig eller lidt senere end den tidligste udvinding i den nordlige del af Kontinentaleuropa (Jouttijärvi og Voss: Skovmarkovnen, dette bind). Fund af udvindingsovne kendes først fra omkring 200 f.Kr. Der er derfor ingen tegn på, at udvindingen kan have startet allerede i 8. århundrede f.Kr., som det muligvis kan have været tilfældet i Sverige (Hjärtner-Holdar 1993).

De tidlige jernudvindingsovne var relativt små, men kunne anvendes flere gange og var knyttet til landsbyer eller gårde. Der var øjensynligt tale om mindre produktion til eget forbrug. De erstattedes af ovne med slaggegrube (Drengsted/Scharmbeck ovne), som var væsentligt større, og hvori der

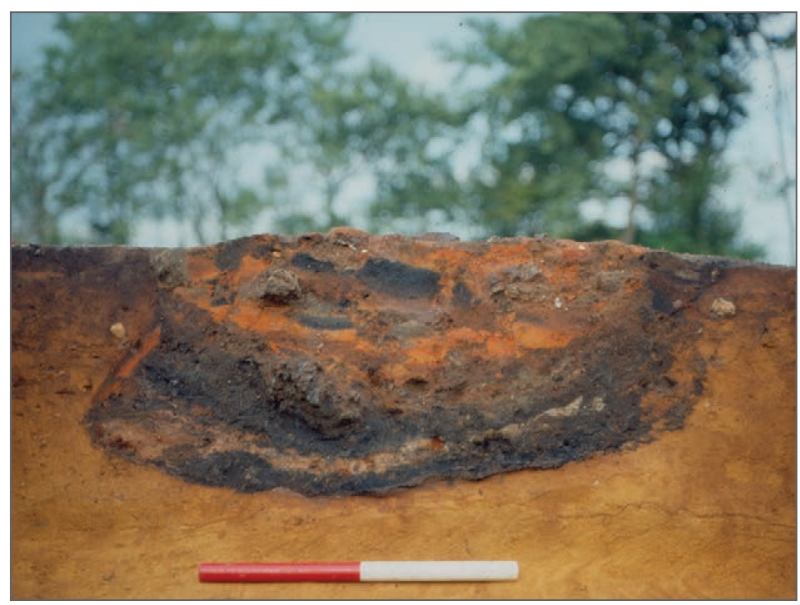

Figur 1: Snorup. Lodret snit gennem en slaggegrube, der er blevet opbrudt efter brendingen og fyldt igen med hovedsagelig. rodbrendte brudstykker af oonskakten. I venstre side er bevaret slaggegrubens underskärne side, mens hojre side er forstyrret ved opbrydningen af gruben. Målestok $40 \mathrm{~cm}$. Foto: O. Voss.

Figure 1: Snorup. Vertical section through a slag-pit that has been broken up after the smelt and then filled mainly with the charred fragments of the shaft. At the left side, a part of the undercut side of the pit is preserved. Scale $40 \mathrm{~cm}$. Photo: O. Voss.

sandsynligvis kunne produceres et overskud af jern, som kunne sælges videre indenfor et større område.

\section{DRENGSTED/SCHARMBECK OVNEN}

Drengsted/Scharmbeck ovnen er i Danmark ${ }^{14} \mathrm{C}$ dateret til tiden 150-600 e.Kr. (Rasmussen, Rahbek og Voss 2006: 127). Ved de udgravninger, der er gennemført siden 1950, er det kun den nederste del af ovnen, slaggegruben, der har kunnet undersøges in situ, figur 1-3. Gruben er gravet kolbeformet, ca. $80 \mathrm{~cm}$ dyb og $80 \mathrm{~cm}$ i diameter ved bunden. Den har en ca. $25 \mathrm{~cm}$ bred og $25 \mathrm{~cm}$ høj forbindelse op til ovnskakten, der står på jordoverfladen.

Slaggegrube ovnen, der af (Pleiner 2000: 159) er kaldt Drengsted/Scharmbeck typen, er muligvis afledt af de keltiske jernudvindingsovne, som G. Gassmann (2005) har udgravet i BayernWürttemberg. De er ${ }^{14} \mathrm{C}$ dateret til 380-170 f.Kr. og rekonstrueret som vist på figur 7 .

De tidligste slaggegrube ovne i Polen og Tyskland er dateret til sen La Tène, 1. årh. f.Kr., mens de 
ældste i Jylland er fra 2. årh. e.Kr. Det har således taget mere end hundrede år for kendskabet til denne ovntype at nå frem til Jylland, hvor man i tiden omkring Kristi fødsel udvandt jern i Skovmark ovne.

I Danmark er der udgravet næsten et par tusind slaggegrube ovne med forkullet halm, men af disse er kun 73 fra 11 forskellige jernudvindingspladser indtil nu blevet ${ }^{14} \mathrm{C}$ dateret. Dateringerne viser, at slaggegrube ovnen blev brugt i Jylland fra o. 150 til 600 e.Kr. Dette beskedne antal dateringer er dog ikke tilstrækkeligt til, at ovnens anvendelsesperiode i Danmark kan anses for at være endelig fastlagt (Rasmussen et al. 2006).

Ingen af de fundne jernudvindingspladser er blevet fuldstændig udgravet, men inden for et areal på ca. $100 \mathrm{~km}^{2}$ nord for Varde har Dr. Tatiana Smekalova foretaget magnetisk kortlægning af otte jernudvindingspladser. Denne viser, at der i dette område har været op mod 10.000 ovne, der med o. 2000 tons slagge kan have produceret 400 tons jern i løbet af de 450 år, hvor slaggegrube ovnen var i brug her.

På pladsen i Snorup, figur 8, der dækker et område på 900 x 600 meter, fremgår det af det magnetiske kort suppleret med mindre udgravninger, at der har været 4-5000 slaggegruber, og på pladsen i Yderik, figur 9, der dækker 800 x 600 meter, må der have været mindst 1200 slaggegruber.

Hvis man kan gå ud fra, at de øvrige jyske jernudvindingspladser er af samme størrelsesorden som pladserne ved Varde, kan der have været mere end 100.000 ovne i Jylland med 20.000 tons slagge svarende til 4000 tons jern. Dette mangler vi dog at kunne sandsynliggøre gennem en magnetisk kortlægning af flere af de 140 jyske jernudvindingspladser.

Denne kortlægning skal imidlertid foretages meget snart, idet bevaringsforholdene for slaggegruberne bliver stadig ringere, fordi Danmark er så opdyrket, at $2 / 3$ af landet er under plov. Inden for få år vil det derfor ikke længere være muligt ved en magnetisk kortlægning at belyse størrelsen af den jyske jernproduktion i tiden 150-600.

Siden 1950erne er landbruget blevet mekaniseret, der er blevet pløjet dybere. Ved at der er foretaget en hyppigere jordbehandling kombineret med vind- og vanderosion, er der sket en udjævning af landskabet, som har fjernet store dele af mange slaggegruber. Resultatet af denne udvikling kan ses af, at mens der i 1960erne ved udgravningen i Drengsted var 24\% velbevarede slaggeblokke, så var der i 1990erne kun $6 \%$ af de udgravede slaggeblokke i Snorup, der var ubeskadigede, og denne udvikling fortsætter.

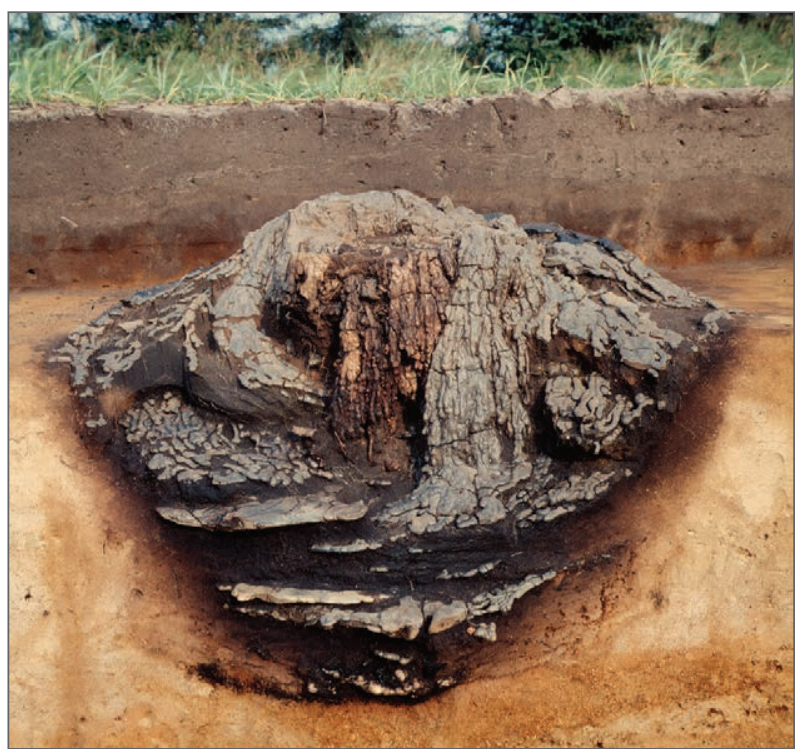

Figur 2: Drengsted. Slaggegrube BV, hvis øverste del er skredet sammen, fordi sand fra grubens sider er lobet ind $i$ den og har delt slaggen op $i$ lag. Ved bunden af gruben kan man se de svage spor af den gravede grube, der er ca. $80 \mathrm{~cm}$ i diameter. Billedets bredde er 1 meter. Foto: O.Voss.

Figure 2: Drengsted. Slag-pit BV, of which the upper part has collapsed because sand from the inward-curving sides has run into the pit and split the slag up in layers. At the bottom, the faint traces of the bottom of the pit, which is about $80 \mathrm{~cm}$ in diameter, can be seen. The width of the picture is 1 meter. Photo: O.Voss.

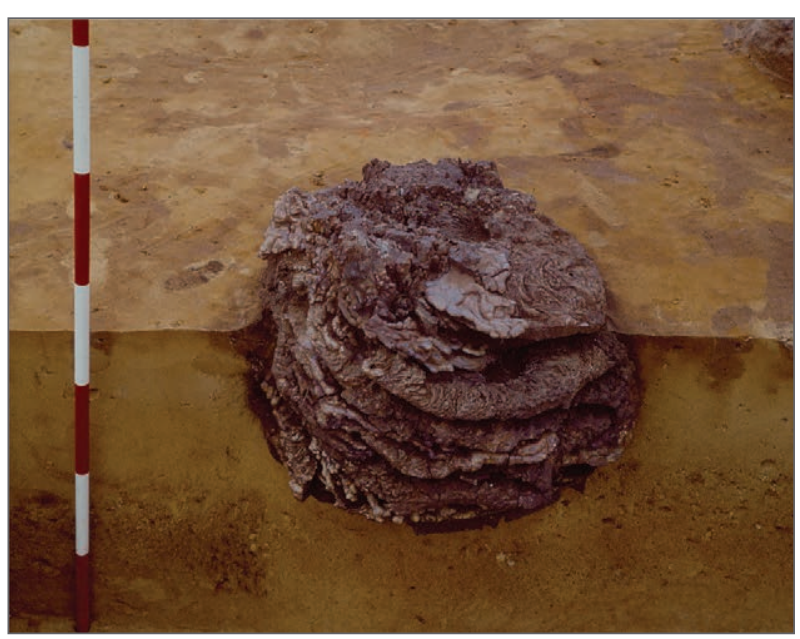

Figur 3: Drengsted. Slaggeblok, hvor slaggen er blevet opdelt $i$ lag ved at tort sand fra grubens sider jevnligt under processen blev aflejret i gruben oven på den allerede storknede slagge. Det aflejrede sand er ved udgravningen blevet delvis fernet med en svag vandstråle således, at slaggens struktur blev synlig. Målestokkens inddeling er $20 \mathrm{~cm}$. Foto: J. Bruun.

Figure 3: Drengsted. Slag-block where the slag is divided into different layers due to the fact that dry sand from the side of the pit has come down into the pit during the smelting process, on top of already solidified slag. During the excavation, this sand has been partly renoved by a fine jet of water to show the structure of the slag. The scale of the units is $20 \mathrm{~cm}$. Photo: J. Bruun. 


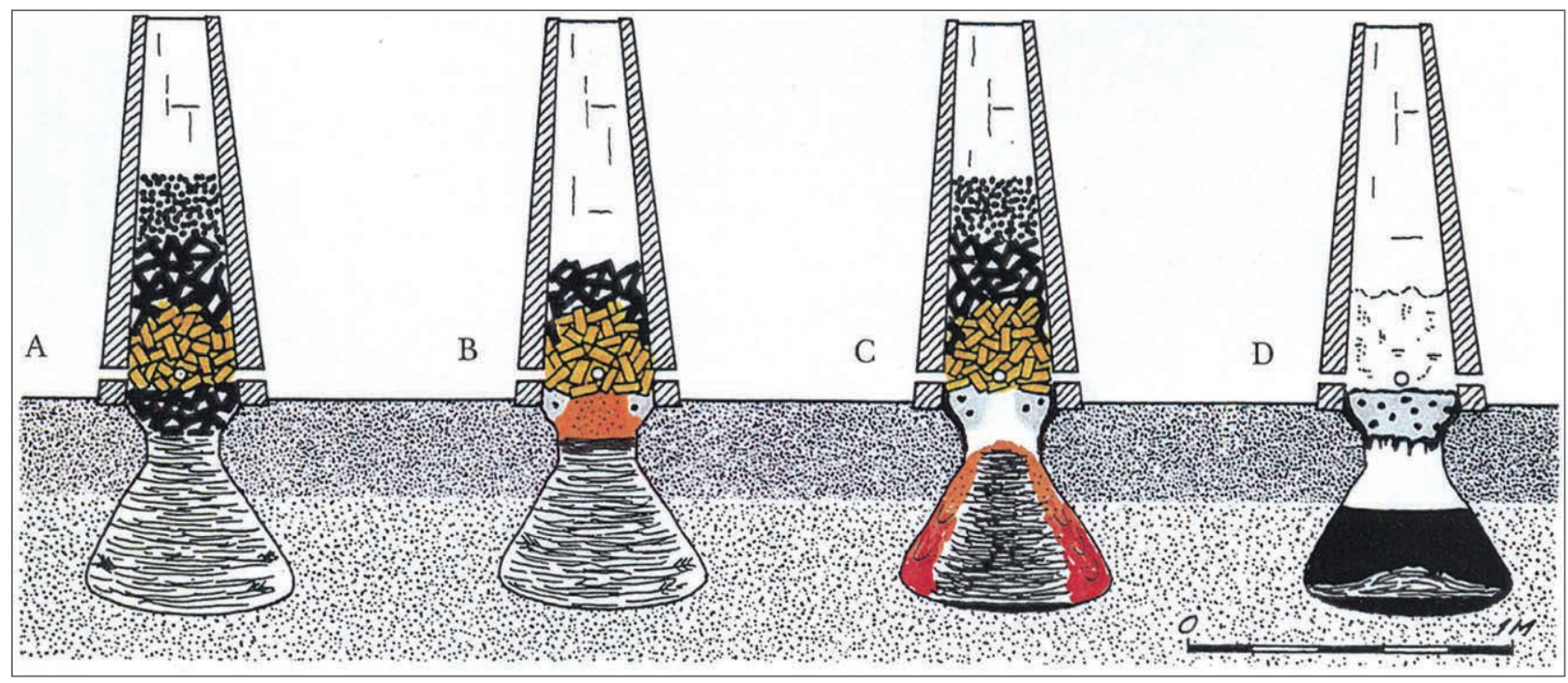

Figur 4: Rekonstruktion af slaggegrube ovnen med fire stadier af jernudvindingsprocessen:

A. Slaggegruben var det forste, der blev gravet. Den blev fyldt med halm, og derefter blev ovnskakten bygget op af halvt torrede lersten. Den fardige ovn blev fyldt med trakul, der blev antandt gennem lufthullerne forneden. När ovnen var blevet tilstakkelig varm, blev den fyldt med skiftende lag af ristet myremalm og trakul. Det brandende trakul udviklede kuliltegas (CO), der fernede en del af ilten fra myremalmen, hvorved der blev dannet partikler af metallisk jern i en struktur, der kan sammenlignes med en svamp, hvor mellemrummene er fyldt af slagge.

B. Når disse porose stykker jern kom ned $i$ det $12-1300^{\circ}$ varme område lige over lufthullerne, smeltede slaggen helt og løb ned $i$ bunden af ovnen. Den forste slagge storknede straks oven på den kolde halmfyldning - vist med den vandrette sorte streg oven på halmfyldningen - og sparrede dermed for den slagge, der fortsat blev produceret i ovnen.

C. Men efter at mere flydende slagge kom til, smeltede bunden på denne slaggebeholder atter, og hele den opsamlede slagge løb ned på bunden af slaggegruben, bvor den størknede i en centimetertyk plade.

D. Samtidig hermed blev gruben opvarmet så meget, at den efterfolgende slagge undgik at størkne overst $i$ gruben. Jernsvampen, luppen, opbyggedes efterhainden neden for lufthullerne.

Hele processen har strakt sig over mere end 2 dogn, bvor der skiftevis blev fyldt trakul og malm i ovnen. Til fremstilling af ca. $60 \mathrm{~kg}$ luppejern blev der brugt $0.300 \mathrm{~kg}$ trekul og $0.300 \mathrm{~kg}$ ristet myremalm.

For at smede medens jernet var varmt, er der straks ved afslutningen af processen slået bul i siden af ovnen, så jernet kunne trekkes ud $i$ glodende tilstand for at blive bearbejdet af smeden.

Det $30 \mathrm{~cm}$ tykke plojelag er vist med en tettere signatur, og det kan ses, at i et dyrket område er det kun selve slaggeblokken, der har mulighed for at forblive uforstyrret.

Figure 4: Reconstruction of the slag-pit furnace showing four stages of the iron smelting process:

A. The slag-pit was the first part of the furnace to be dug. It was filled with straw and then the shaft was built from half-dried clay bricks. Then the furnace was filled with charcoal and ignited and, when it was hot enough, about half of the volume of the shaft was filled with a charcoal to bog iron-ore ratio of 1:1 by weight. The burning charcoal produced carbon-monoxide (CO) which removed some of the oxide from the ore, thereby producing particles of metallic iron with a spongy structure where the pores were filled with slag. $B$. When this iron sponge came into the 12000 zone above the air inlets, the slag melted and ran to the bottom of the furnace, where it solidified on top of the cold filling of straw. The soldified slag is shown by the horizontal black line at the top of the straw. This solidified slag prevented the in-coming slag from entering the pit. Instead, it had time to penetrate into the sides above the solidified slag. C. After more hot fluid slag came down from the shaft, the solidified slag on top of the straw re-melted, causing all of the retained slag to run down to the bottom of the slag-pit, where it then solidified.

D. Because of this molten slag, the whole pit was heated sufficiently so that the incoming slag did not solidify in the upper part of the pit. The produced sponge of iron became stuck below the air inlets.

The whole process took longer than 48 hours, during which the furnace was charged with about $300 \mathrm{~kg}$ of charcoal and $300 \mathrm{~kg}$ of roasted iron ore. This could have resulted in output of an iron sponge of about $60 \mathrm{~kg}$.

In order to forge the iron while it was still hot, a hole was probably made in the shaft which allowed the bloom to be removed and forged on the spot.

The $30 \mathrm{~cm}$ thick top soil is shown with a denser signature. It is clear that in a cultivated area it is only the slag block which might still be preserved. 


\section{OVNTYPENS INDFØRELSE OG BETYDNING}

Slaggegrube ovnen er fundet på o. 140 fundpladser i Jylland og alle syd for en linje mellem Lemvig og Randers, et område på $18.000 \mathrm{~km}^{2}$.

Det er denne del af Jylland, som Ringtved (1988) udskilte som en selvstændig kulturgruppe, Sydgruppen, ud fra bl.a. gravskik, husenes udformning og lerkarrenes form og dekoration.

Jernsmelterne med slaggegrube ovnen kan være indvandret fra Nordtyskland engang sidst $\mathrm{i}$ ældre romersk jernalder, figur 10. De har udgjort en økonomisk betydningsfuld del af befolkningen i den sydlige del af Jylland. Når denne teknologi ikke nåede videre til Nordjylland og Øerne, kan forklaringen være, at herskerne i denne del af Jylland ikke ønskede, at andre skulle få kendskab til denne nye jernudvindingsovn.

Noget tyder på, at herskerne her også havde magt til at holde andre ude fra deres territorium, og at dette har ført til kampe i Østjylland mod indtrængende hære. Samtidig med at der foregik en omfattende jernproduktion i Vest - og Midtjylland, var der således gentagne våbenofre $\mathrm{i}$ en række østjyske moser som Hedelisker, Illerup, Porskær, Dallerup Sø, Vingsted, Tranebær, Ejsbøl, Nydam og Thorsbjerg. Inden for den samme periode blev der også udført store forsvarsværker som søspærringerne i Haderslev Fjord og i Gudsø Vig ved Kolding, der suppleret med langvolde og ringvolde i de samme områder har udgjort et forsvarssystem mod indtrængende fjender (Jørgensen 2003). Våbenfundene i moserne viser, at nogle af invasionsstyrkerne må være blevet nedkæmpet i nærheden af de moser, hvor deres våben er blevet ofret.

Oliver Grimm spørger i artiklen «Angrep nordmenn Jylland ret etter 200 e.Kr.? Hvad kæmpede man om?» (Grimm 2008).

Det er vores teori, at det var den store jyske jernproduktion, der fik fremmede hærstyrker til gentagne gange at forsøge at invadere Jylland. Dette skete $\mathrm{i}$ en periode, hvor vi ikke har sikre spor efter jernudvinding hverken på Fyn eller på Sjælland, og hvor der kun er kendskab til en begrænset jernproduktion i Norge og Sverige. Heller ikke analyser af slaggeindeslutninger af jerngenstande tyder på, at der har været en jernproduktion på Fyn og Sjælland.

Gennem Jørgen Ilkjærs analyser (Ilkjær 2003) af det personlige udstyr, der er ofret sammen med våbnene i Illerup og Ejsbøl Mose, er det vist, at de invaderende hærstyrker kan være kommet dels fra det sydlige Norge og dels fra Sverige.

Det er næppe alle invasionsforsøg, det er lykkedes at slå tilbage. Derfor kan der flere gange

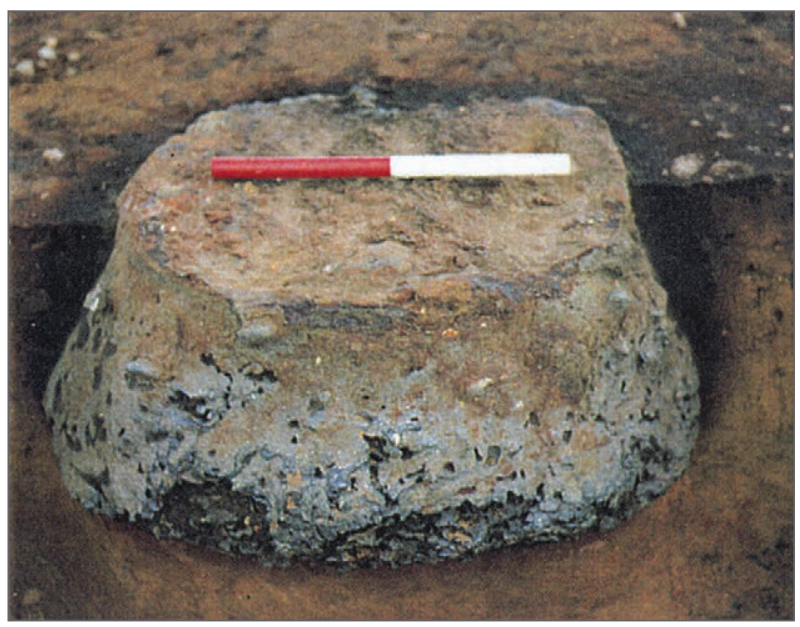

Figur 5: Snorup. Slaggeblok på $290 \mathrm{~kg}$. Den er bredest forneden og har helt udfyldt den gravede grube. Målestok $40 \mathrm{~cm}$. Foto: O. Voss.

Figure 5: Snorup. Slag-block weighing $290 \mathrm{~kg}$. Its width is biggest at the bottom. It has filled out the entire pit. Scale $40 \mathrm{~cm}$. Photo: O. Voss.

været blevet røvet både jern og bortført smeltere fra jernudvindingspladserne, der alle var uden noget forsvarsværk. De var dermed helt afhængige af den beskyttelse, som lokale høvdinge eller en kongemagt kunne give.

Man må derfor antage, at landsbyerne med jernudvinding har været underlagt en eller flere høvdinge eller en konge, der med en stående hær kunne beskytte dem mod overfald samtidig med, at de har kontrolleret produktionen og også stået for administrationen af handelen med jernet.

Den jernudvinding, som har efterladt de forekomster af store slaggeblokke og slaggegruber, der er fundet i det østlige Norge (Larsen og Rundberget 2009), kan måske være indført af indvandrede eller tvangsflyttede smeltere fra Jylland. Det er fundene af slaggegruber/blokke som Eg i Vest-Agder, i Rogaland, Fet i Sysendalen, i Hordaland, i Oppland (Snertingdal og Dokkfløy). De norske fund af store slaggeblokke er ${ }^{14} \mathrm{C}$ dateret til romersk jernalder og folkevandringstid (Larsen 2007), men nye ${ }^{14} \mathrm{C}$ dateringer i forbindelse med de seneste undersøgelser $\mathrm{i}$ Snertingdalen har overraskende placeret flere anlæg i førromersk jernalder. Kommende udgravninger på pladser med store slaggeblokke vil forhåbentlig kunne bringe en afgørelse vedrørende de store slaggeblokkes datering i Norge.

Forekomsten af store slaggeblokke i Närke i Sverige fra folkvandringstid-vendeltid (Hansson 1989: 88), og måske også i Ryd, Västergötland (Särlvik 1976), kan ligeledes være produceret af 


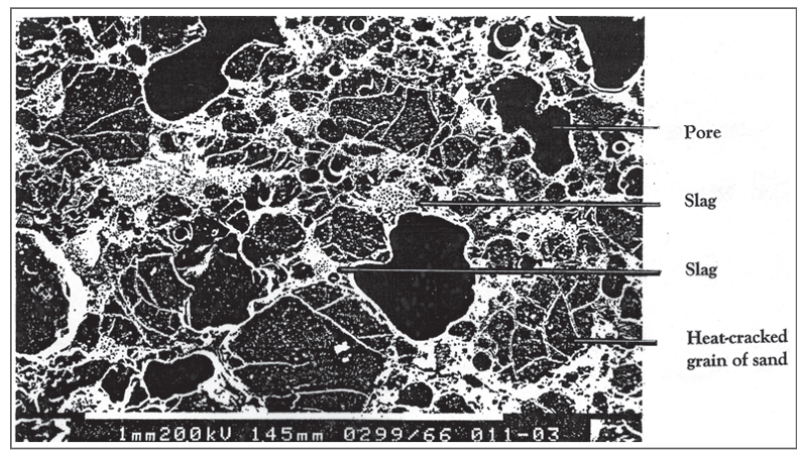

Figur 6: Drengsted. Mikrofoto af tvarsnit af den lodrette jordvag $i$ det cylindriske rum oven over halmfyldningen. Strukturen består af ildskornede sandskorn, der er kittet sammen afflydende, varme slagge. Den bvide bjalke oven over teksten i billedets underkant er 1 millimeter lang. Foto: A. Jouttijärvi.

Figure 6: Drengsted. Microphoto of the section of the vertical wall of earth in the cylindrical space above the straw filling of the pit. Grains of sand have been heat-cracked by the hot slag penetrating the earthern wall. The white bar above the text at the bottom of the picture is 1 millimeter long. Photo: A. Jouttijärvi.

indvandrede smeltere fra Tyskland eller Jylland.

De fremmede smeltere, der har begyndt en jernproduktion i Norge eller i Sverige, har måttet tilpasse deres slaggegrube ovn til de forhold og de muligheder, der var på det sted, hvor de nu arbejdede (Larsen 2003; 2007, Larsen og Rundberget 2009).

\section{UDVINDINGSOVNENS DRIFT}

På grundlag af de iagttagelser, der er gjort ved udgravningen af næsten 2000 slaggegruber, er ovnen og forløbet af jernudvindingsprocessen blevet rekonstrueret som vist på figur 4 .

Man begyndte med at grave den kolbeformede grube, der blev fyldt med stråene fra en næsten moden kornmark med byg og/eller rug. Forkullet halm eller aftryk af halm er fundet i så mange tilfælde, at man må regne med, at jernudvindingen almindeligvis er foregået sidst på sommeren (Mikkelsen 2003, Henriksen 2003).

Formålet med halmfyldningen $\mathrm{i}$ gruben var at holde ladningen af trækul og myremalm oppe i skakten, hvor reduktionen og afsmeltningen af slaggen fandt sted. Slaggen indeholder som regel $60-65 \% \mathrm{FeO}$ og $25 \% \mathrm{SiO}_{2}$, og den er ved $1200-$ $1300^{\circ}$ flydende som vand. Det metalliske jern blev dannet direkte i fast form i en jernsvamp, en luppe, neden for lufthullerne.

Når den første flydende slagge nåede ned til toppen af halmfyldningen, brændte den lidt af halmen, men størknede straks på den kolde overflade. Derved

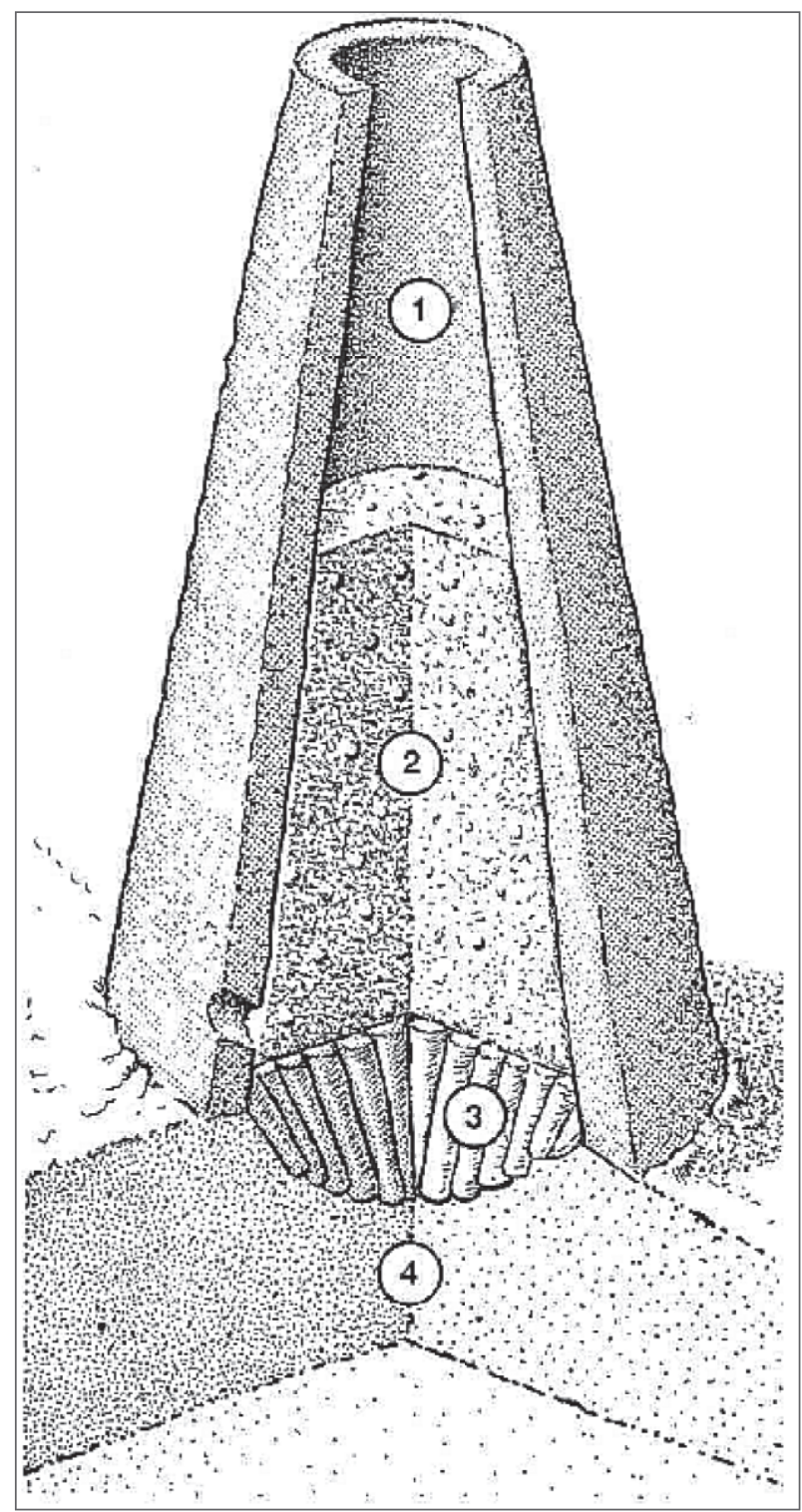

Figur 7: Schliengen-Liel. Gassmanns rekonstruktion af ornen for brandingen. 1. Skakten, 2. Blanding af malm og trakul, 3. Slaggegruben fyldt med trestykker, 4. Undergrund af ler. (Efter Gassmann 2005).

Figure 7: Schliengen-Liel. Gassmann's reconstruction of the furnace before the smelt. 1. The shaft, 2. A mixture of ore and charcoal, 3. The slag-pit filled with wood, 4. Subsoil of clay. (after Gassmann 2005).

blev den snævre forbindelse mellem ovnskakten og slaggegruben lukket med et lag af størknet slagge. Derfor blev den efterfølgende flydende slagge for en tid holdt tilbage i rummet oven over.

Senere, når der var kommet mere varm slagge ned i dette cylindriske rum, blev slaggens temperatur her så høj, at bunden i denne «beholder» igen smeltede, hvorefter hele den opsamlede slagge, dvs. flere liter, løb ned på bunden af gruben på en gang. Her dannede slaggen en slaggeplade eller 


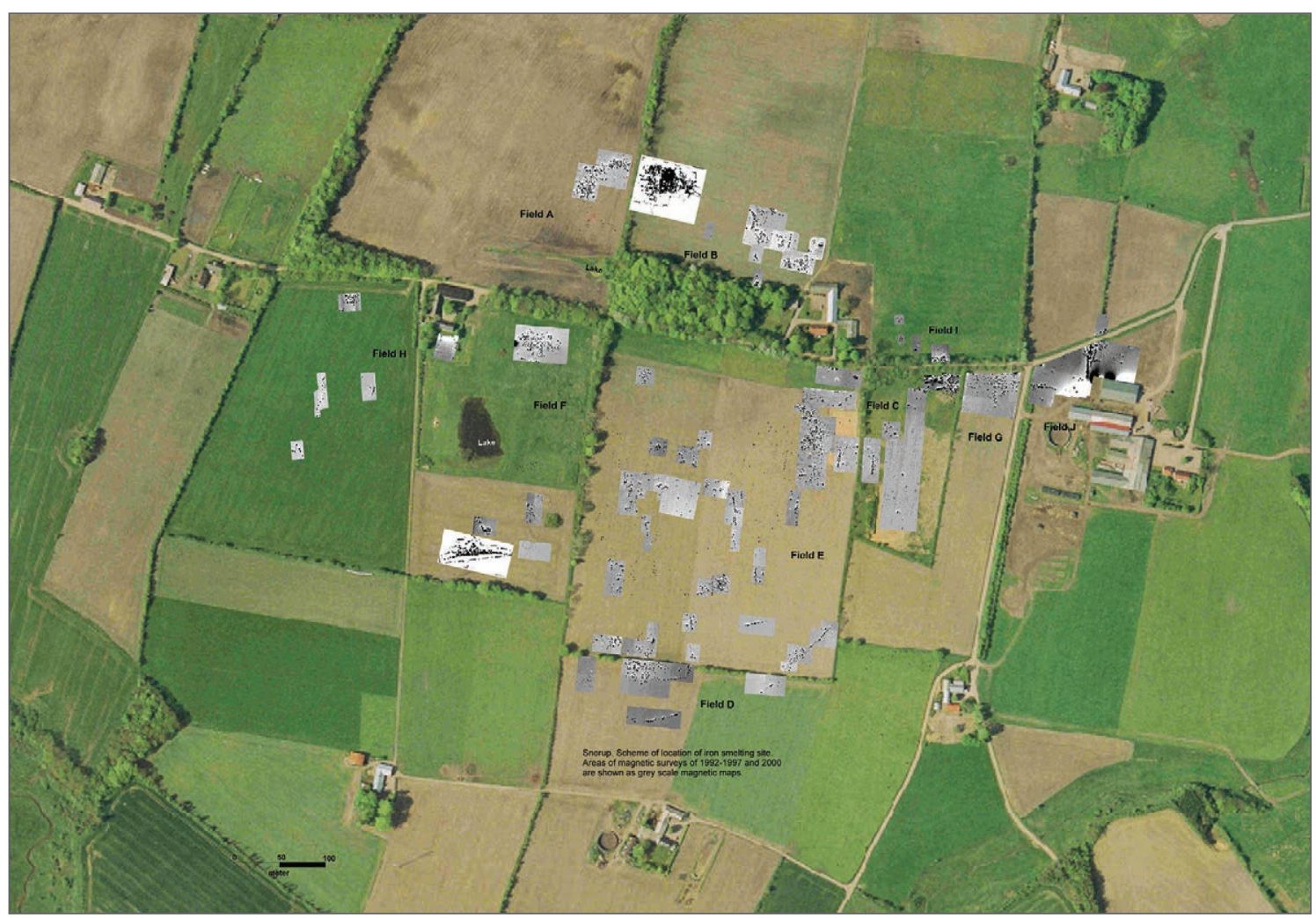

Figur 8: Snorup. De magnetisk kortlagte områder af jernudvindingspladsen er lagt ind på et luftfoto. Pladsen er 900 $m$ fra vest til øst og $600 \mathrm{~m}$ fra syd til nord og består af 4-5.000 slaggegrube ovne. De to hvide felter viser totalt udgravede klynger med slaggegruber. Kortlagt af T. Smekalova.

Figure 8: Snorup. The magnetically surveyed areas of the iron smelting site shown on an aerial photo. The site is 900 meters from west to east and 600 meters from south to north. It consists of 4-5,000 slag-pits. The two white areas show excavated clusters of slag-pits. Surveyed by T. Smekalova.

bundslagge. Samtidig blev hele gruben opvarmet så meget, at den følgende slagge kunne løbe helt ned på bunden af gruben uden at størkne på vejen.

Slaggeblokkens vandrette overflade, figur 5 , viser, at slaggen har været flydende som vand, da den kom ned i gruben. Dette betyder, at den jernsvamp, der var dannet nederst i ovnen, kun kan have indeholdt en mindre mængde slagge i porerne.

Vi mener, at det må være dette procesforløb, som jernsmelterne med deres erfaring har ønsket at opnå.

Ved gennemskæringen af en slaggeblok fra Grimstrup, udgravet 1928, har det da også vist sig, at den er næsten uden metallisk jern.

Halmfyldningen i gruben brændte, så længe der var tilstrækkelig ilt, oxygen, og resten blev forkullet. Det er dette materiale, der er brugt til ${ }^{14} \mathrm{C}$ dateringerne, og derfor er slaggegrubens alder den samme som halmens.

Mens den varme slagge stod i det cylindriske rum oven over halmfyldningen, trængte den ind i den omgivende jord, og der blev dannet en op til 2 $\mathrm{cm}$ tyk, solid væg, som det ses på tværsnittet, figur 6, hvor de ildskørnede sandskorn er omgivet af størknet slagge. I enkelte tilfælde varede afkølingen op til jordvæggen så længe, at der her blev dannet større slaggekrystaller.

\section{UDVINDING EFTER DRENGSTED/ SCHARMBECK OVNEN}

Ophøret af jernudvindingen i slaggegrube ovnen skete i løbet af en kort periode o. 600. e. Kr. En årsag er sandsynligvis, at den jyske egeskov, der leverede træ til ovnene, var blevet udpint. Der kunne derfor ikke længere skaffes tilstrækkelig med træ til at fremstille det trækul, der skulle til for at gennemføre den årlige jernudvinding.

Vi ved ikke, hvor Danmark fik sit jern fra efter 600 e. Kr., men proveniensbestemmelser af slaggeindeslutninger $\mathrm{i}$ jerngenstande fra tiden efter $600 \mathrm{e}$. Kr. vil sandsynligvis kunne give svar på dette spørgsmål. De analyser, der er foretaget af genstande fra vikingetid tyder på, at der stadig er mindre hjemlig produktion af jern.

Her i landet er der i gamle skove og i enge kun 


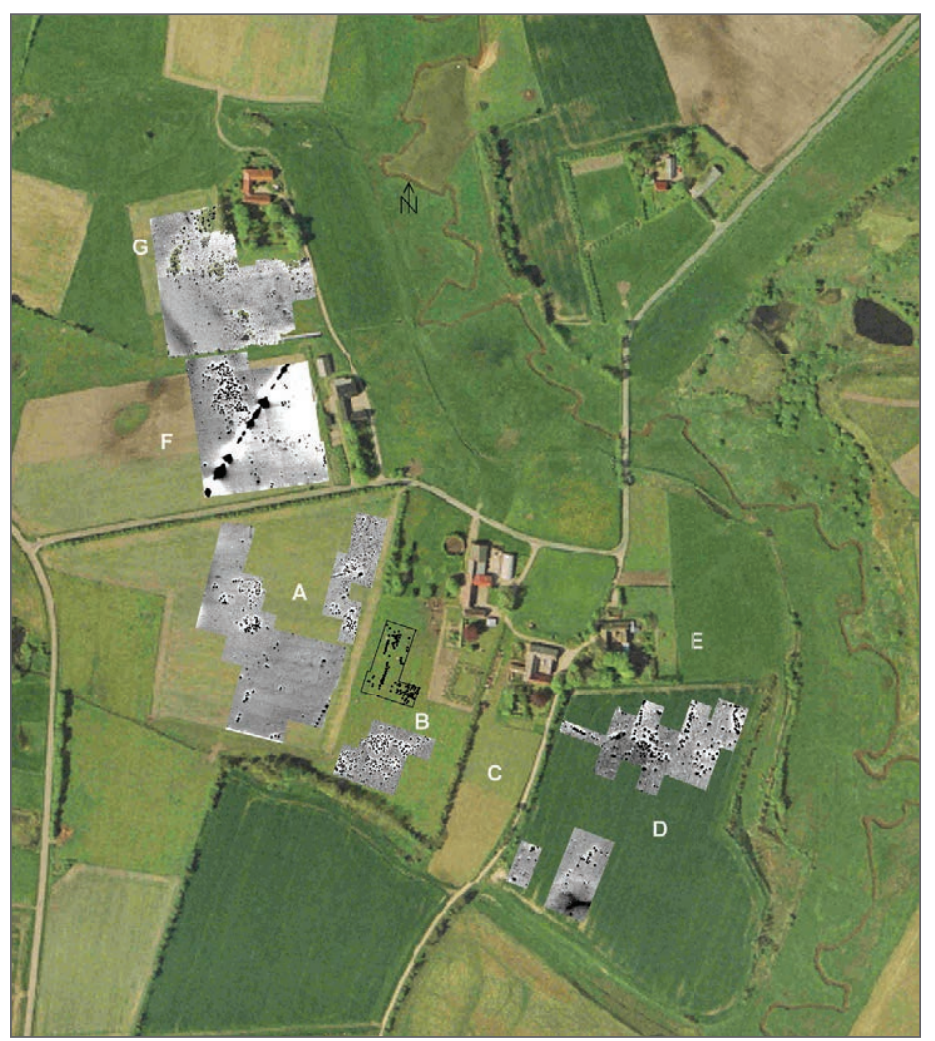

Figur 9: Yderik, $2.5 \mathrm{~km}$ syd for Snorup. De magnetisk kortlagte områder af jernudvindingspladsen er lagt ind på et luftfoto. Pladsen dakker 800 meter fra syd til nord. En enkelt klynge slaggeggruber $i$ felt $B$ er vist med sort. Felt $F$ er delvis forstyrret af en nedgravet naturgasledning, og $i$ den hvide ostlige del af feltet er magnetfeltet forstyrret af bygninger af mursten. Ud fra den magnetiske kortlagning anslàs antallet af slaggegruber at vare 0.1200, men da der ikke har kunnet måles mellem felt $A$ og $E$, hvor der ligger tre gårde, har antallet sikkert varet storre. Kortlagt af T. Smekalova.

Figure 9: Yderik, $2.5 \mathrm{~km}$ south of Snorup. Magnetically surveyed areas of the iron smelting site shown on an aerial photo. The site is 800 meters from south to north. One cluster of slag-pits in area $B$ is shown in black. Area F has been partly destroyed by a natural gas pipeline. The eastern part of the white area shows where the magnetic field has been disturbed by neighboring brick buildings. From the magnetic survey, it is estimated that the number of slag-pits is about 1,200, but because it was not possible to survey between areas $A$ and $E$ where three farms are situated, the number of slag-pits might have been more numerous. Surveyed by $T$. Smekalova.

bevaret nogle få slaggedynger, der alle er dateret til middelalder. Der kan have være mange flere, men de er for længst blevet fjernet, fordi de lå i vejen for dyrkningen.

\section{OVNSTYPOLOGI}

Allerede Coghlan 1956 foretog en opdeling af jernudvindingsovne i:

1. Grubeovne, 2. Skaktovne og 3. Kuppelovne. Denne opdeling blev i 1970erne anvendt af Inga Serning (1976; 1978) og af Irmelin Martens (Martens 1978). I 1986 gav Gert Magnusson (Magnusson 1986) sin egen version af Sernings og Martens typologi. Alle tre er de påvirket af Mats Malmers typebegreb (Malmer 1963), som Magnusson dog har en vis reservation overfor (Magnusson 1986: 243).

I 2002 beskrev Lars-Erik Englund en lang række ovne til jernudvinding fra Europa og Afrika. De blev også opdelt i grubeovne, skaktovne og kuppelovne som hos Coghlan 1956, men inden for hver af disse grupper gjorde Englund rede for, hvordan luften blev tilført, hvordan skakten var opbygget samt den måde, hvorpå man har skilt sig af med slaggen. Englund (2002: 227) omtaler forskellige former for opsamlingen af slagge, hvoraf følgende tre er fundet på nordisk område:

Ovnen, hvor slaggen drænes ned i en grube, der er åben forneden, så slaggen kan fjernes ud til en arbejdsgrube.

Slaggegrube ovnen, hvor slaggen drænes ned i en lukket grube under ovnskakten.

Ovnen, hvor slaggen tappes ud på jordoverfladen fra et hul på siden af ovnen.

Denne opdeling af ovnene er foretaget på grundlag af de iagttagelser, som det er muligt at gøre ved en udgravning, og den er derfor mere operationel.

Det er i ovnskakten, reduktionsprocessen foregår. Skakten stod på jordoverfladen, og den kendes derfor kun fra fragmenter, der ikke ligger in situ. Den bedst bevarede skakt er fra Scharmbeck ved Hamborg (Wegewitz 1957). I Danmark er der fundet mindre, men betydningsfulde fragmenter af skakten på flere pladser (Voss 1993).

I skakten foregår reduktionen af malmen ved den kulilte, der fremkommer ved afbrændingen af trækul i en reducerende atmosfære. Ved en temperatur på $12-1300^{\circ}$ smelter slaggen og frigøres fra det dannede netværk af metallisk jern, hvis smeltepunkt er højere end slaggens. Jernsvampen bliver fastholdt ved bunden af skakten, mens tyngdekraften fører den flydende slagge bort. Den process, der finder sted i ovnen, må stort set have været den samme for alle ovntyper, mens disse er forskellige i den måde, slaggen blev drænet bort fra den dannede jernsvamp (luppen). 


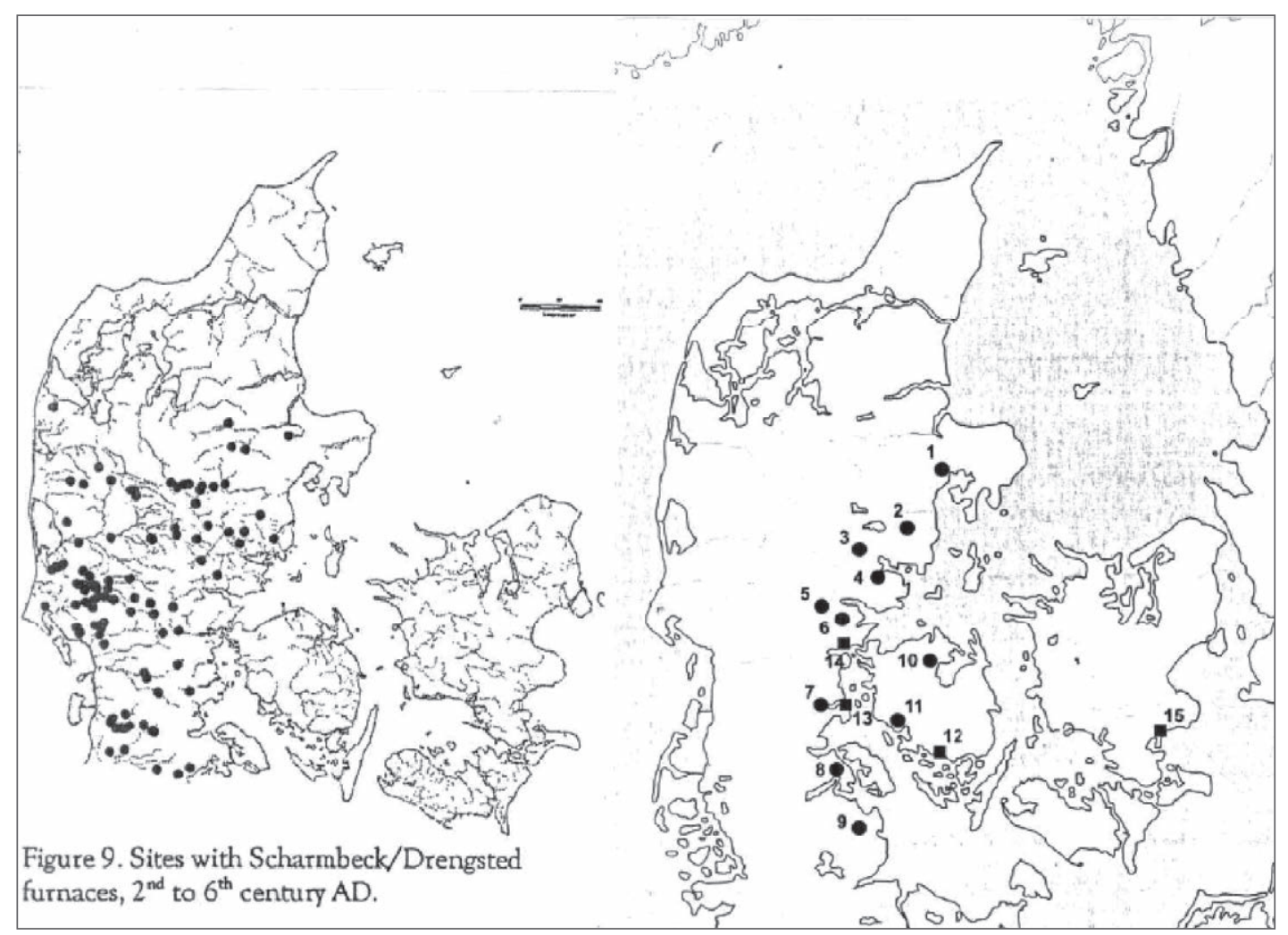

Figur 10: Kortet til venstre viser forekomsten af slaggegrube ovne i Jylland, mens kortet til hojre viser placeringen af våbenofferfundene: 1. Hedelisker, 2. Illerup, 3. Porsker, 4. Dallerup Sø, 5. Vingsted, 6. Tranbar, 7. Ejsbol, 8. Nydam, 9. Thorsbjerg, 10. Vimose, 11. Kragehul, og af søsparringerne: 12. Nakkebølle Fjord, 13. Haderslev Fjord, 14. Gudsø Vig, 15. Jungshoved Nor. (efter Ilkjer 2003, fig. 17; Nørgaard Jørgensen 2003, fig. 4).

Figure 10: The map to the left shows the distribution of slag-pit furnaces in Denmark. The map to the right shows the bogs with weapon sacrifices: 1. Hedelisker, 2. Illerup, 3. Porskar, 4. Dallerup Sø, 5. Vingsted, 6. Tranebar, 7. Ejsbol, 8. Nydam, 9. Thorsbjerg, 10. Vimose, 11. Kragehul, and the Sea blockades: 12. Nakkebolle Fjord, 13. Haderslev Fjord, 14. Gudsø Bay, 15. Jungshoved. (after Ilkjar 2003, fig. 17 and Nørgaard Jørgensen 2003, fig. 4).

I Danmark kender vi følgende tre ovntyper:

Den ældste, der kan dateres til tiden 3. årh. f.Kr. til 2. årh. e.Kr. er Skovmark/Sønder Holsted oonen (Jouttijärvi og Voss 2010), hvor den flydende slagge drænes ned i et o. $40 \mathrm{~cm}$ dybt afløb, der forneden er åben ud til en arbejdsgrube. Herfra blev den størknede slagge taget op og efterladt $i$ en dynge tæt ved ovnen. I forbindelse med den senere dyrkning af området er disse slaggedynger blevet fjernet uden at efterlade nogen spor. Det er den samme ovntype, der er udgravet i Trøndelag (Stenvik 2003) og i Eket i Kalmar Län (Rubenson 2000). Det er en ovn, der kan anvendes flere gange, og den producerede slagge er efterladt ved siden af eller neden for ovnen som i Trøndelag. Denne ovn har kunnet bruges til flere brændinger i modsætning til Drengsted/Scharmbeck ovnen, der er dateret til tiden 150-600 f.Kr. Her drænes hele slaggen ned i en lukket grube, der i gennemsnit har rummet $0.200 \mathrm{~kg}$. I de tilfælde, hvor slaggen endnu er bevaret in situ, vil det være muligt at beregne, hvor meget jern der blev produceret på den enkelte plads.

Slaggegrube ovnen er fundet $\mathrm{i}$ hele området fra Ukraine til Holland og fra Tyskland til Jylland. Engang i 1000-årene eller senere kommer ovnen, bror slaggen drenes ud af siden ved bunden af skakten ud til en lav grube på jordoverfladen. Her størkner slaggen hurtigt, og også her er slaggen efterladt på jordoverfladen i en dynge, der sammen med ovnskakten er blevet fjernet af eftertidens dyrkning. Derfor er der i Danmark fundet meget få af disse slaggedynger, der nu kun er tilbage i gamle skove og udyrkede enge (Nielsen 1924).

\section{HVORDAN OPNÅR VI EN FÆLLES NORDISK TERMINOLOGI OG TYPOLOGI FOR OVNE TIL DIREKTE JERNUDVINDING?}

Som objekt eksisterer jernudvindingsovnen kun under udgravningen, ganske som det også er til- 
fældet med bl.a. hustomter og gravanlæg. Dette stiller særlige krav til dokumentationen, for efter udgravningens afslutning eksisterer ovnen kun i form af fotografier, slaggeprøver samt tegninger og en beskrivelse. Udformning af denne dokumentation er helt afhængig af udgraverens erfaring og dennes viden om jernudvindingens teknologi, og af om udgravningen og beskrivelsen er udført sammen med en metallurg.

Ved beskrivelsen af de gjorte observationer mangler man en fælles terminologi, og dette gør det vanskeligt at formidle iagttagelserne til andre arkæologer. Ved tegninger af rekonstruktioner savnes der som oftest en særlig angivelse af den del af ovnen, der har kunnet dokumenteres ved udgravningen af anlægget.

En vej til en forbedret beskrivelse af udgravningsresultaterne og til mere informative rekonstruktioner af jernudvindingsanlæg kunne være, at gennemføre fælles nordiske udgravninger med deltagelse af både arkæologer og metallurger. Herigennem ville man kunne nå frem til at udforme en fælles terminologi og fælles standarder for dokumentationen af ovne til jernudvinding, og dermed også til udformningen af mere forståelige typebeskrivelser. Selv om et tættere samarbejde om udgravninger først på længere sigt vil kunne føre til en mere ensartet sprogbrug, vil det allerede på kort sigt kunne give en værdifuld forståelse for forskelle i arbejdsmetoder, tankegange og fortolkninger. På den måde vil det blive væsentligt lettere for den enkelte arkæolog at «oversætte» udgravninger i de øvrige nordiske lande til sin egen begrebsverden.

Man kunne begynde med at invitere interesserede til at deltage i igangværende udgravninger på jernudvindingspladser, selv om det betyder, at dette kommer til at ske uden en planlægning. Det vil derfor være vanskeligt for arkæologer fra andre museer og andre lande at kunne udnytte muligheden for at deltage, men det vil måske være den mest realistiske måde at begynde et samarbejde på.

Når alle har e-mail adresser, kan man let informere om, hvad der udgraves, og om hvilken tidsramme der er for udgravningen. Hertil kommer praktiske oplysninger om udgravningslederens mobil nr., overnatningsmuligheder og kørselsvejledning. Rejse- og opholdsudgifter må i de fleste tilfælde dækkes af de besøgende arkæologer.

\section{SUMMARY}

Iron was first introduced to the regions as an import and forged by the local smith. Later, foreign smelters came in to sell their iron and, at the same time, to look for possibilities with the local smith of starting iron production in slag-pit furnaces.

The slag-pit furnace in Denmark has been dated to within the period 150-600 AD. It has only been found in Jutland, south of Lemvig-Randers, where by now about 140 sites with these furnaces have been located.

In Denmark, more than 2,000 slag-pits have now been excavated at different sites: about 1,000 are at the Snorup site, $10 \mathrm{~km}$ north of Varde, and 240 at the Drengsted site, $17 \mathrm{~km}$ north of Tønder.

From these excavations it has been possible to produce a reconstruction of the furnace and gain information on the smelting process, figure 4.

Magnetic surveys have been carried out at eight iron smelting sites within a $100 \mathrm{~km}^{2}$ area around Snorup. They showed that there were almost 10,000 slag pits in that area alone.

The sacrifices of weapons in the bogs in East Jutland might have belonged to Scandinavian invaders who had tried to gain possession of the iron produced in Jutland. The iron smelting here was controlled by a military leadership that also protected the iron smelting villages.

The slag blocks found in Norway and Sweden could have come from slag-pit furnaces introduced by smelters coming from Jutland.

To achieve a common Nordic terminology and typology for iron smelting furnaces, it is necessary to achieve closer collaboration between the Scandinavian metallurgists and archaeologists in the documentation process of the excavations in the field.

\section{LITTERATUR}

Coghlan, H. H. 1956. "Notes on Prehistoric and Early Iron in the Old World». Occasional Papers on Technology, 8. Oxford: Oxford University Press.

Englund, L.-E. 2002. Blästbruk. Jernkontrets Bergshistoriska Skriftserie nr. 40. Stockholm: Jernkontoret.

Gassmann, G. et al. 2005. "Forschungen zur keltischen Eisenverhuttung in Südwestdeutschland». Forschungen und Berichte zur Vor- und Frübgescbichte in Baden-Württemberg, Band 92, 2005.

Grimm, O. 2008. «Angrep nordmenn Jylland rett etter 200 e.Kr.?» Viking 2008: 71-102.

Hansson, P. 1989. Sambälle och järn i Sverige under järnåldern och äldre medeltiden. Societas Archaeologica Upsaliensis 1989. Uppsala. 
Henriksen, P. S. 2003. «Rye cultivation in the Danish Iron Age - some new evidence from iron-smelting furnaces». Veget. Hist. Archaeobot. 2003/12: 177-185.

Hertz, E., A. Jouttijärvi og O. Voss 2010. «Jernudvindingsovnen fra Sønder Holsted». Sønderskov bogen 2010.

Hjärtner-Holdar, E. 1993. Järnets och järnmetallurgins introduktion $i$ Sverige. Societas Archaeologica Upsaliensis. Uppsala.

Ilkjær, J. 2003. «Danske krigsbytteofringer». I Jørgensen, L. et al. (red.). Sejrens Triumf: 44-64. København: Nationalmuseet.

Jørgensen, A. N. 2003. «Befæstning og kontrol af færdsel til lands og til vands i førromersk og romersk jernalder». I Jørgensen, L. et al. (red.). Sejrens Triumf: 194209. København: Nationalmuseet.

Jørgensen, A. N. 2009. "Jernalderen i Nordeuropa, Porskjær Mosefund».Jysk Arkeologisk Selskab. Aarhus.

Larsen, J. H. 2003. «Lokalt initiativ og jernvinneforskning i Snertingdal, Gjøvik kommune i Oppland». Viking 2003: 79-104.

Larsen, J. H. 2004. «Jernvinna på Østlandet i yngre jernalder og middelalder - noen kronologiske problemer». Viking 2004: 139-170.

Larsen, J. H. og B. Rundberget 2009. «Raw Materials, Iron Extraction and Settlement in South-East Norway 200 BC-AD 1150». 58. Sachsensymposium in Trondheim 1st-5th September 2007. Vitark 7: 38-50. Trondheim: Vitenskapsmuseet.

Magnusson, G. 1986. Lågtekniskjärnhantering i Jämtlands län. Jernkontorets Bergshistoriska Skriftserie Nr 22. Stockholm: Jernkontoret.

Malmer, M. P. 1963. «Metodproblem inom järnålderens konsthistoria». Acta Archaeologica Lundensia, Series in 8, nr. 3. Lund: Gleerup.

Martens, I. 1978. «Some reflections on the Classification of Prehistoric and Medieval Iron-smelting Furnaces». Norwegian Archaeological Review. Vol. 11: 27-36.

Mikkelsen, P. H. 2003. «Det arkæobotaniske indhold i jernudvindingsovne». I Mikkelsen, P. H.og L.C. Nørbach 2003. Drengsted. Bebyggelse, jernproduktion og agerbrug i yngre romersk og aldre germansk jernalder. Højbjerg: Moesgård museum.

Nakkerud, T. B. og E. Schaller 1979. «Slaggroper på Eg,
Kristiansand, Vest-Agder». Jern og jernvinne som kulturbistorisk faktor $i$ jernalder og middelalder i Norge. AmS-Varia 4: 8-18. Stavanger: Arkeologisk museum i Stavanger.

Näsman,U.2006. «Danerne og det danske riges opkomst». Kuml 2006: 205-241.

Nielsen, N. 1924. Studier over Jernproduktionen i Jylland. København: Arnold Buscks boghandel.

Pleiner, R. 1980. «Early iron metallurgy in Europe». I Wertime, T. A . og J. D. Muhly (red.). The Coming of the Age of Iron: 375-415. New Haven: Yale University Press

Pleiner, R. 2000. Iron in Archaeology. The European Bloomery Smelters. Praha: Archeologiký ústav av čr.

Rasmussen, K. L., U. Rahbek og O. Voss 2006. «Radiocarbon dating of the iron production in slagpit furnaces in Jutland». Journal of Danish Archaeology, Vol.14: 127-138.

Ringtved, J. 1988. «Jyske gravfund fra yngre romertid og ældre germanertid». Kuml 1986: 95-231.

Rubensson, L. 2000. Mörejärnet. Meddelande från Kalmar läns hembygdsförbund och Stiftelsen Kalmar läns museum, Årgang 84. Kalmar.

Serning, I. 1976. «Tidig järnframställning Skandinavien». När järnet kom. Göteborg: Göteborgs Arkeologiska Museum.

Serning, I. 1978. "Comments on I. Martens: Some reflections on the Classification on Prehistoric and Medieval Iron-smelting Furnaces». Norwegian Archaeological Review.Vol 11/1.

Stenvik, L. F. 2003. «Iron Production in Scandinavian Archaeology». Norwegian Archaeological Review, Vol. 36/2: 119-134.

Särlvik, I. 1976. «Järnframställning i Ryd». Västergötlands fornmines förenings tidskrift 1975-76. Skara.

Voss, O. 1962. «Jernudvinding i Danmark i forhistorisk tid». Kuml 1962: 7-32.

Voss, O. 1993. «Snorup. Et jernudvindingsområde i Sydvestjylland». Nationalmuseets Arbejdsmark 1993: 97-111.

Wegewitz , W. 1957. «Ein Rennfeuerofen aus einer Siedlung der älteren Römerzeit in Scharmbeck». Nachrichten aus Niedersachsens Urgeschichte, Nr. 26. Hildesheim. 


\title{
TIDIG JÄRNPRODUKTION I SÖDRA OCH VÄSTRA FINLAND - NÅGRA ASPEKTER PÅ JÄRNFRAMSTÄLLNING OCH JÄRNETS FUNKTION I SAMHÄLLET
}

\author{
Mika Lavento
}

\section{INLEDNING}

Liksom många andra fenomen i Finlands förhistoria, uppstod också järnhantering som ett resultat av inflytande från väster, söder och öster. I ljuset av det arkeologiska materialet, som vi känner från boplatser idag, kan vi spekulera om när, var och varför möjligheter till själva tidiga järnproduktionen skapats. I östra Finland och södra Lappland har vi påträffat boplatser där järnframställningen, enligt ${ }^{14} \mathrm{C}$-dateringarna, har börjat redan ca, $400 \mathrm{BC}$. Men det är även möjligt, att den började litet tidigare.

Vid kusten, i de södra och västra områdena i Finland, kan järnproduktionen ha börjat antingen samtidigt som $\mathrm{i}$ inlandet, eller redan under 500-talet BC. Dateringarna är oklara där eftersom boplatser med smältugnar inte hittills påträffats. Järnföremål och slagg har ändå hittats på många platser. Även om detta kunde vara ett bevis på lokal järnproduktion, några övertygande fornlämningar och dateringar har vi inte fram tills nu . Jag är speciellt intresserad av södra och västra Finland och kan därför ge en översikt över området enligt den nuvarande forskningssituationen som är bristfällig. Det är också orsak till varför jag inte kan berätta mycket om processen för järnframställning.

\section{ARTIKELNS FRÅGESTÄLLNING}

I denna artikel strävar jag efter att granska hur de tidigaste faserna av järnproduktion avspeglas i det arkeologiska materialet i södra och västra Finland. Mitt syfte är också att diskutera skillnaden mellan järnhanteringens två olika traditioner som uppstod i landet $\mathrm{i}$ början av den förromerska järnåldern och som kanske uppkom under järnåldern i olika delar av Finland. Finländska arkeologer har inte glömt grannområdenas roll i frågorna kring järnproduktionens ursprung och utveckling. Överhuvudtaget har de närliggande områdena utgjort viktiga utgångspunkter till kulturella förändringar $i$ vårt land. De har varit väsentliga källor för olika traditioner $i$ järnframställningsmetoder och därför försöker jag ta hänsyn till det geografiska perspektivet då det gäller södra och västra Finland (figur 1).

I praktiken kommer jag koncentrera mig på att fundera vilken roll Skandinavien och Estland har spelat i det finska kustområdet då de första stegen inom järnframställning togs. Det är också mycket viktigt att diskutera den influens som förorsakade processerna som ledde till att järnframställningen började i östra och norra Finland. Som ett exempel på den östliga traditionen kommer jag att presentera en järnframställningsplats i Ristiina, som ligger i södra delen av Saimens sjösystem i sydöstra Finland. Ugnens struktur i Ristiina liknar järnugnarna på vissa boplatser vid Ule älv och i Kemi älvs sjösystem. Därmed antar jag att de skulla kunna representera samma tradition, som i sin tur skiljer sig från traditionen i södra och västra Finland. Det arkeologiska materialet för den västliga traditionen är dock mera komplicerat att presentera.

Jag kommer även att diskutera var de första järn-

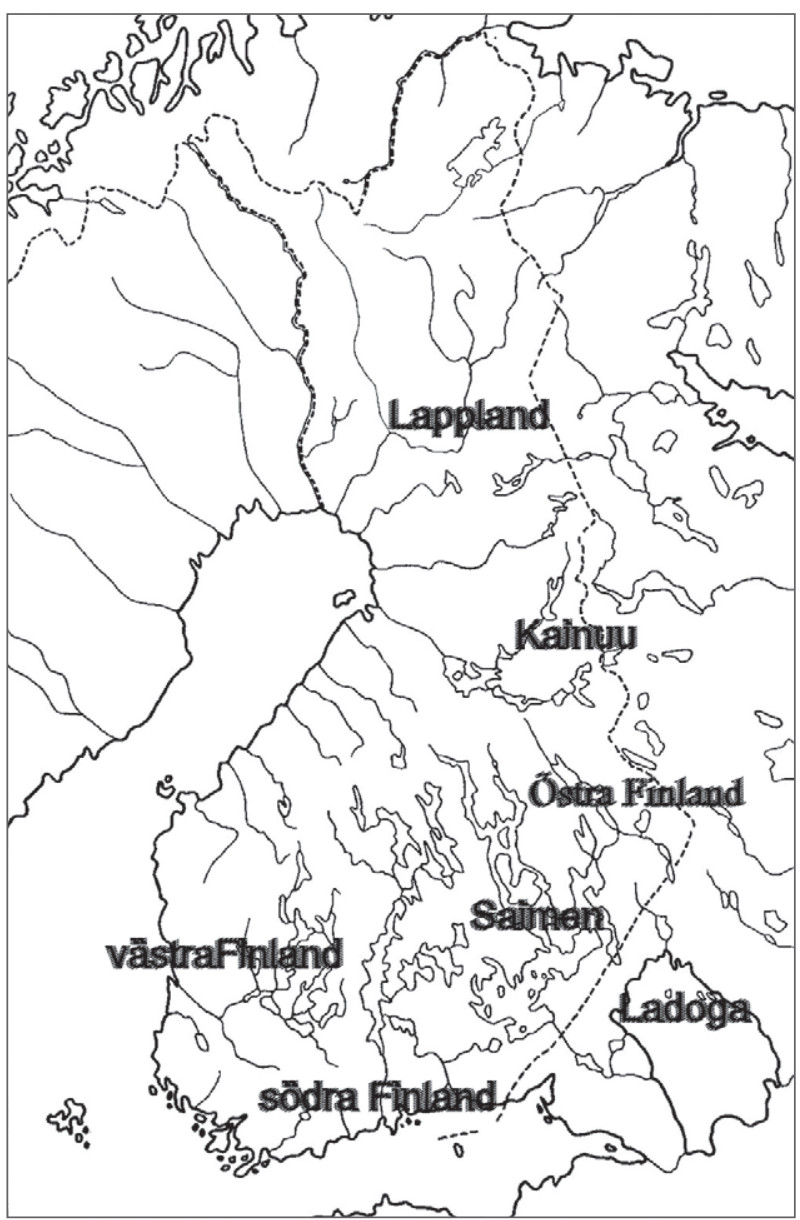

Figur 1: Olika områdena i Finland.

Figure 1: The main regions in Finland. 
hanteringsplatserna kan ha legat i södra och västra Finland (se Kotivuori 2010) men jag kommer även att tangera östra och norra järnframställningen som en hjälp för läsaren att se möjliga skillnader. Därtill vill jag beskriva hur de tidigaste järnugnarna ser ut då de påträffas vid arkeologiska utgrävningar. Slutligen diskuteras i korthet var boplatser och gravplatser, som vittnar om järnproduktion, ligger och vilka slags material vi har påträffat där. En viktig roll i arkeologiska tolkningar spelar järnslagg. Slaggen bevisar att järnet har haft väsentlig betydelse i järnålderssamhället. Därtill kan man ställa frågan om hur det är möjligt att diskutera järnframställning i breda kulturella sammanhang, fastän frågan inte är central i denna artikel. Saken har senast behandlats i Anna Wessmans (2010) doktorsavhandling.

\section{DE TIDIGASTE METALLFÖREMÅLEN I FINLAND}

Om man vill lita på typologiska dateringar kan man anta att de tidigaste järnföremålen i Finland har påträffats i Lappland (Jørgensen 2010). Det är oväntat, men indikerar ändå att järnet har varit ett utbytesmaterial i det norra barrskogsområdet från Uralområdet till Skandinavien. De allra tidigaste föremålen av järn i Finland är två Akinakesdolkar från Sillankorva i Savukoski i östra Lappland. De är nästan identiska, böjda och har daterats till ca. 700-600-talen BC. Med andra ord har de tillverkats under en period som motsvarar Ananinokulturen i norra barrskogsområdet. Motsvarande fyndtyper har inte hittats någon annanstans i Finland. När man försöker lokalisera proveniensen för fynden verkar det mest sannolikt att de har importerats till Lappland från Kamaområdet (Erä-Esko 1969;
Carpelan 2003: 56-57). På fyndplatsen i Savukoski finns ingen boplats och depåfynden kan därför tolkas som skattfynd.

Depåfynd är ett av de viktigaste tecknen på järnets betydelse i samhället även i södra Finland strax innan vår tideräknings början. Till exempel holkyxan från Otaniemi i Kannonkoski som ligger i Mellersta Finland har daterats till ca. 500 BC. Problemet med depåfynd är att man inte får några exakta dateringar för metallerna, på grund av att kontexter inte existerar. Därmed har finländska arkeologer svårigheter med att utreda frågan om när järnåldern egentligen började. Vad vi kan göra är att datera föremål typologiskt och följa den skandinaviska eller baltiska kronologin (Tallgren 1931; Kivikoski 1961).

Den knappa inhemska informationen om metallhantering lämnar mycket rum för spekulationer, men det är dock sannolikt att järn har tagits i bruk mer eller mindre under den förromerska tiden. Arkeologiska kontexter ger inga exempel på lokal järnhantering, på grund av att vi överhuvudtaget känner till få boplatser från denna period i södra och västra Finland. Järn togs i bruk, men frågan om hur processen skedde har fram tills nu förblivit obesvarad.

Till de tidigaste järnfynden hör depåfyndet från Malmsby i Pernå vid Finska viken (100 BC- AD 50 ) i södra Finland som innehåller åtta tappyxor, åtta spjutspetsar, två skäror, tre lieblad och en hålyxa med öra. Enligt Torsten Edgren (1992: 157-158) härstammar tappyxorna från Lettland, medan hålyxan hör till en skandinavisk tradition. Unto Salo (1992: 104) antar att de flesta yxorna har tillverkats i Finland, men man borde ändå inte utesluta möjligheten att det är fråga om importföremål (se också Salo 2008).

\begin{tabular}{|l|l|l|l|l|l|}
$\begin{array}{l}\text { Perioder i } \\
\text { Södra Finland }\end{array}$ & $1025-1200$ & Korstågstid & $1025-1300$ & $\begin{array}{l}\text { Rektangulara } \\
\text { härdarnas tid }\end{array}$ & $800-1400$ \\
\hline Korstågstid & $800-1025$ & Vikingatid & $800-1025$ & & Kronologi \\
\hline Vikingatid & $600-800$ & Merovingertid & $600-800$ & Samisk järnålder & $800-$ \\
\hline Merovingertid & $400-600$ & Folkvandringstid & $400-600$ & Samisk järnålder & \\
\hline Folkvandringstid & $1-400$ & $\begin{array}{l}\text { Folkvandringstid } \\
\text { Tidig metaltid }\end{array}$ & $\begin{array}{l}250- \\
-250\end{array}$ & $\begin{array}{l}\text { Samisk järnålder } \\
\text { Tidig metaltid }\end{array}$ & $\begin{array}{l}250- \\
-250\end{array}$ \\
\hline $\begin{array}{l}\text { Den romerska } \\
\text { järnåldern }\end{array}$ & Tidig metaltid & & Tidig metaltid & \\
\hline Förromersk järnålder & $500-1$ & Tidig metaltid & 1800 & Tidig metaltid & 1900 \\
\hline Bronsåldern & $1600-500$ & & &
\end{tabular}

Tabell 1: Kronologin för periodiseringen av järnåldern i Finland.

Table 1: Chronology and different periods of the Iron Age in Finland. 
Tidiga yxor i Finland är grova till sin karaktär, som är ett drag som tyder på att de eventuellt har tillverkats lokalt. Det är sannolikt att de första yxorna är importvaror även om antalet förromerska järnföremål är lågt i Finland, antyder det ändå att man redan då hade lärt sig att smälta myr- och sjömalm. De första möjliga dateringarna för smältningsugnar i norr är ca. 400 f.Kr., men i södra och västra Finland dateras de första till romersk järnålder. Tabell 1 visar kronologin för periodiseringen av järnåldern i Finland. Landet har delats i tre olika områden. Denna artikel behandlar landets södra och västra del.

\section{JÄRNHANTERINGENS BÖRJAN I FINLAND}

Unto Salo påstår att järnhanteringen började vid kustområdet och i södra Finland i början av den förromerska tiden. Han har tolkat processen så, att teknologin spreds från Skandinavien eller de baltiska länderna till den finska kusten och snart därefter började en lokal järnframställning vid kusten. Mellan 500 - 300 BC hade kunskapen att framställa järn adopterats i inlandet (Salo 1992: 104106). Hans tolkning baserar sig på depåfynd och på järnslagg som påträffats på boplatser. På boplatser förekommer vanligtvis mycket sparsamt med järnmaterial. Dessutom argumenterar Salo att järnframställningen i östra och norra Finland knappast har sitt ursprung i Ryssland. Salos argument kan ändå kritiseras.

I jämförelse med förromerska metallföremål är järnslagg en mer allmän fyndkategori i Finland. Hittills har slagget daterats enbart på basis av kontext, med hjälp av keramik. Det går också att datera laborativt (Oinonen et al. 2009). Men varken slaggen eller järnfyndens typologi ger dateringar till förromersk järnålder på inlandets boplatser. I inlandet känner vi inte till en enda boplats som skulle kunna höra till denna period. Vid kusten dateras de tidigaste kända boplatserna från metallåldern till tidig romersk järnålder. Information om järnframställningen och dess datering kan inte fås, eftersom man på kustens förromerska boplatser och gravar påträffat ett så ringa antal järn. En grov kronologi kan dock presenterats med hjälp av landhöjningen. Ju närmare vi kommer till vår tid, desto osäkrare blir strandförskjutningsmetoden i södra Finland. Den viktigaste orsaken till detta är långsammare takt för strandförskjutningen.

Inalles är fynden mycket få ändå till början av den romerska järnåldern, eftersom järnsmältningsugnar (blästerugnar) inte har påträffats (och inte grävts ut) i södra Finland. Fast man påträffat både järnmaterial och bitar av järnslagg i olika kontexter, kan man inte utan vidare säga när och var järn framställts. Det är den lokala råvaran, sjömalm och myrmalm, som har möjliggjort spridningen av järnhantering och smedens yrke. På några ställen smältes det myr- eller sjömalm, men en stor del av de tidiga järnföremålen har troligen varit bytesvaror.

Under den romerska järnåldern ökar antalet järnföremål i kustzonens gravar. Tidigare tolkade arkeologerna denna process som finnarnas invandring från Estland, men numera har hypotesen om en märkbar migration övergivits. Ändå har kontakterna över havet troligen varit livliga. Vissa järnföremålstyper härstammar från baltiska länder, andra från södra Skandinavien.

Det är ändå anmärkningsvärt att påpeka att enligt ${ }^{14} \mathrm{C}$ dateringarna började järnhanteringen först i östra och norra Finland (se nedan). Trots att järnframställningsugnar påträffats i Finland har vi svårigheter att peka på några järnföremål som med säkerhet tillverkades av exakt detta lokala järn. Det är intressant att flera stenföremålstyper ännu var i bruk under bronsåldern, men strax efter järnframställningens början ersattes brons och sten slutgiltigt med järn. Detta hjälper oss förstå varför vi känner till ett så ringa antal fynd från folkvandringstid och merovingertid från inlandet. En möjlighet är att brons och keramik ersattes med trä och ben, som på grund av sitt låga $\mathrm{pH}$-värde inte har bevarats $\mathrm{i}$ den finska jorden. Men också en stor del av järnet som använts fattas från fyndmaterialet. En orsak kan ha varit återanvändning av järnet.

En föremålsgrupp som också hör till järnåldern, men som är nästan outforskad, är gjutformar. De ha använts först och främst för gjutning av bronsföremål från tidig järnålder till medeltid (Edgren 1958). De ingår i fyndmaterialet från många järnålderboplatser och indikerar framställning av olika föremålstyper, fastän arkeologer i Finland inte har diskuterat deras roll i järnålderssamhälle i någon större omfattning (se ändå Korosuo 1946). Gjutformar har påträffats på många boplatser i olika områden i Finland, men vi vet inte, under vilken tid på järnåldern som traditionen började. Här måste jag betona att deras roll i framställningen av järnföremål innebär att man borde forska mera kring dem än vad arkeologer hittills gjort.

\section{TIDIGA UGNSTYPER I NORRA OCH SYDÖSTRA FINLAND}

I Finland känner vi till två ugnstyper som har använts för smältning av sjö- och myrmalm. De kallas för lådugn och blästerugn. Därtill har vi påträffat gropar 
som eventuellt är lämningar av ugnar som inte kan klassificeras väl.

Lådugnen har blivit mera utforskad än någon annan tidig ugnstyp i Finland. Strukturen för denna typ är mycket enkel. Den är en rektangulär låda som har konstruerats av skifferstenar. Lådan har använts för utvinning av järnmalm. Utbredningen av denna typ ligger i Finlands östra och norra delar. Den tidigaste kända lådungen har hittats i Äkälänniemi i Kajana (Schulz 1986). I Rovaniemi känner vi till två likadana strukturer belägna i Riitakanranta och Sierijärvi (Kotivuori 1996). Typen har också påträffats i Karelen, Ryssland (Lavento 1999; Kosmenko och Manjuhin1999). Det är ugnstypen som har varit känd även i norra Sverige. I Finland har vi inte påträffat sådana ugnar vid kusten, vilket kan visa på att deras ursprung är inlandet, kanske i Karelen. Ugnarna i Rovaniemi har kopplats ihop med Kjelmøykeramiken som har just detta östliga utbredningsområde. Ett exempel av typen känner man till i Ristiina i södra delen av Saimen sjö (se nedan).

En blästerugn var hittats i Riitakanranta i Rovaniemi, södra Lappland. Också den utgörs till sin nedre del av en stenlåda, men den övre delen av konstruktionen är kupolformad. En viktig poäng är att den högre, övre delen gör luftcirkulationen effektivare i jämförelse med den i lådugnen. Luft har blåsts till ugnens hjärta med tuyiére - pipor, som man har hittat fragment av i närheten av ugnarna vid utgrävningar. Tyvärr är ugnarnas storlek och form bara mycket fragmentariskt känd i Finland. Här har för närvarande ett exempel grävts ut, i södra Lappland (Kotivuori 1996).

Det är sannolikt att också andra ugnstyper har utnyttjats under den förromerska tiden och under tidig järnålder, men vårt arkeologiska material är fram tills nu så bristfälligt att en rekonstruktion av en typ inte är möjlig. Till exempel verkar det som om man på boplatsen Neitilä 4 i Kemijärvi i södra Lappland har använt någon slags gropugn, men ugnens lämningar är så fragmentariska att det är nästan omöjligt att tolka hur den har byggts (Kehusmaa 1972). I södra och sydvästra Finland är det även mer problematiskt att på basis av olika ugnslämningar avgöra deras ursprungliga strukturer.

\section{JÄRNSLAGG OCH JÄRNFRAMSTÄLLNING I SÖDRA OCH SYDVÄSTRA FINLAND}

Följaktligen kommer jag att göra en kort översikt om järnframställningsungarnas forskningsläge såväl i sydvästra och västra Finland som i insjöområdena Päijänne och Saimen men också vid kustområden

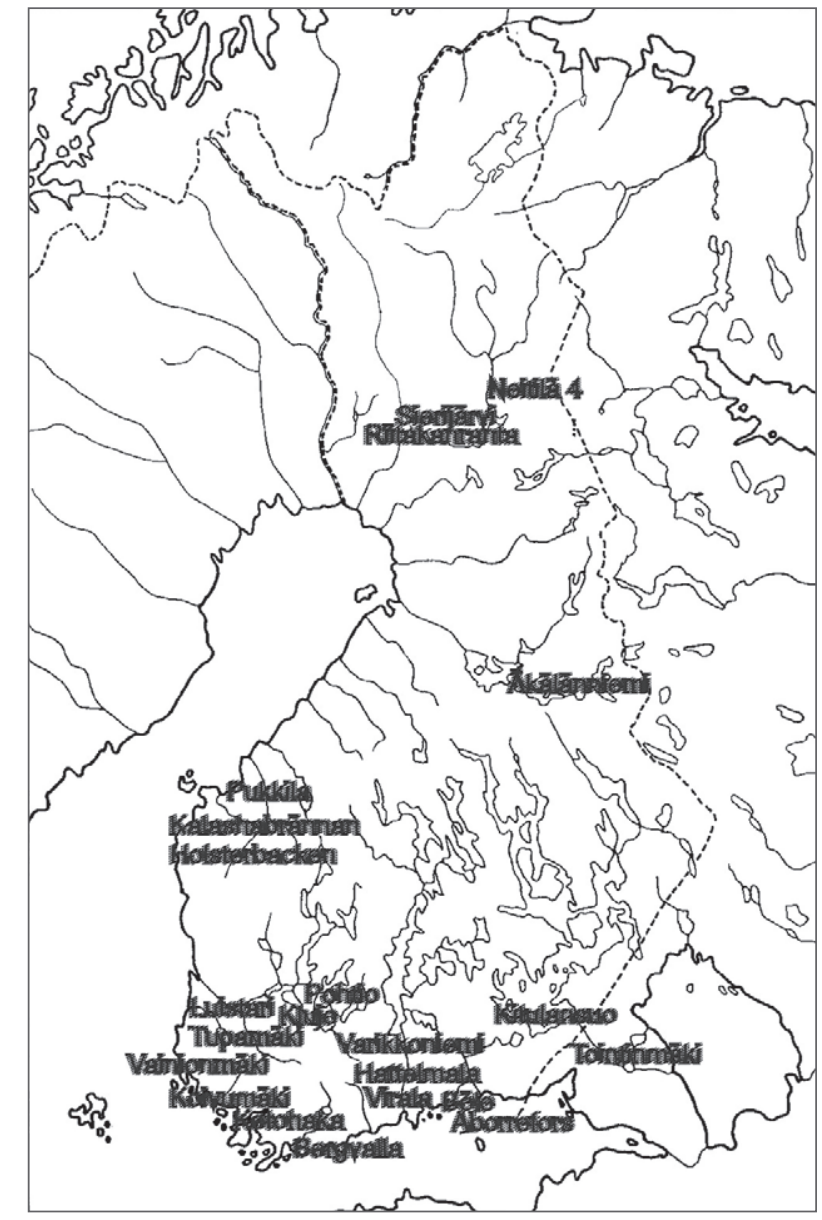

Figur 2: Tidiga boplatser med järnhantering och järnslagg $i$ Finland.

Figure 2: Early settlement with finds of iron production and iron slag in Finland.

(figur 2). Det är intressant att man känner till inalles över 60 boplatser som innehåller järnslagg från tidig metallålder eller från järnålderns senare perioder. Järnhantering har inte påträffats på många boplatser. Bara några enstaka lämningar av klent bevarade ugnar har grävts ut av arkeologer och därför är det inte lätt att säga varför de sistnämnda lämningarna är så få till antalet. Men även detta material ger många möjligheter till tolkning (Lavento 1999).

\section{Lådugnen i Saimeområdet i sydöstra Finland}

I sydöstra Finland har alla kända järnframställningsugnar ungefär samma struktur som ugnar i norra Finland och södra Lappland. En av dem ligger i Kitulansuo i Ristiina kommun i södra Savolax, i den sydvästra delen av Saimens sjösystem. Ugnen dateras till ett lång tidsintervall, ca. AD 1-500, men den kan väl jämföras med de ugnar som hör till den tidigaste fasen av järnframställningens his- 
toria i Kajana, Rovaniemi och Karelen (se ovan). Järnframställningsplatsen i Kitulansuo påträffades vid utgrävningen av en textilkeramisk boplats, där den hittades genom magnetometrisk kartläggning. Ugnen framträdde som en anomali på boplatsen och visade sig inte bara vara en vanlig stensättning, utan en rektangulär ca. $70 \mathrm{~cm}$ lång och $50 \mathrm{~cm}$ bred stenlåda. Strukturen var byggd av stenplattor som inte var större än ca. 20-40 cm i diameter. Omkring ugnen hittades $9 \mathrm{~kg}$ järnslagg. Några järnföremål påträffades inte. (Lavento 1996: 77-79)

Fyndmaterialet på boplatsen utgiordes huvudsakligen av textilkeramik, men det hittades också ett litet antal asbestoskeramik av Luukonsaarityp från äldre metallåldern. Det som är viktigt för tolkningen var att Luukonsaarikeramiken låg närmast järnframställningsugnen. Koncentrationen av textilkeramik var ca. $10 \mathrm{~m}$ från ugnen, på en förhistorisk strandlinje. Att göra den mest trovärdiga dateringen för ugnen har varit problematiskt. Enligt nuvarande ${ }^{14} \mathrm{C}$ dateringar hör den samman med den senare fasen av Luukonsaarikeramiken, som dateras från de sista århundradena före Kristi födelse eller de första århundraden e.Kr. Det är möjligt är att ugnen fortvarande använts så sent som ungefär $\mathrm{AD} 500$ (Lavento 1999).

Om vi lät lämningar av en järnframställningsugn vara det enda kriteriet för att bekräfta järnhantering på en järnåldersboplats, skulle antalet boplatser med egen järnproduktion vara mindre än tio, under över tusen år av förhistoria i hela Finland. Kitulansuo ligger i södra Finland, men hör ihop med de östliga ugnstyperna som har påträffats $\mathrm{i}$ östra och norra Finland och södra Lappland. Det är hittills den enda, kända boplatsen med en ugn av detta slag som påträffats i sydöstra Finland.

\section{Järnslagg på boplatser i södra och västra Finland}

På olika järnåldersboplatser har det påträffats slagg, som indikerar att järnframställning förekommit i detta område. Det stora utgrävningsområdet i Luistari i Eura i Satakunda är ett exempel. Platsen är känd som en stor merovinger- och vikingatida gravplats, men i dess omedelbara närhet ligger även en boplats som dateras till övergångsfasen mellan sen bronsålder och tidig förromersk järnålder (Lehtosalo-Hilander 1973: 31-36; 1982: 176-177). På boplatsen har Pirkko-Liisa Lehtosalo-Hilander hittat en järnkniv - och järnslagg. Några spår av en järnframställningsugn har inte observerats. På Luistari gravfält som ligger nära boplatsen har man påträffat en grav nummer 245 med en gjutform som gravgåva (LehtosaloHilander 1973: 30-31).
På en annan boplats men också i Eura kommun, Tupamäki i Säkylä by, dateras järnframställningen tidigast till folkvandringstiden, till början av 400-talet AD. Kronologin på boplatsen är oklar och platsen var bebodd fram till medeltiden (tabell 2).

Från Koivumäki i Nousis kommun, som inte ligger längre än $25 \mathrm{~km}$ nordväst om Åbo, har järnslagg påträffats i stora mängder. Flera järnföremål hittades, tyvärr är de dock odefinierbara. Torsten Edgren anser att lerkliningen på boplatsen härstammar från järnframställningsugnar, trots att några klara lämningar av ugnar inte påträffades. Enlig Edgren (1992: 156) har det producerats järn på boplatsen redan i början av järnåldern.

Järnhantering kan ha förekommit ganska tidigt i Kalashabrännan i Malax, södra Österbotten. Någon ugn eller några välbevarade lämningar av en sådan har inte påträffats, men $1,2 \mathrm{~kg}$ järnslagg plockades upp under utgrävningarna där. Det är också viktigt att påpeka att man påträffade flera fragment av gjutformar, som hade använts för bronsföremål (Kotivuori 1992: 62-64).

På boplatsen Holsterbacken som också ligger i Malax socken hittades järnslagg i bränd lera (Miettinen 1988). ${ }^{14} \mathrm{C}$-dateringar antyder att boplatsen var i bruk under den yngre romerska järnåldern (tabell 2). Enligt Hannu Kotivuori har dessa två boplatser mycket gemensamt. Kalaschabrännan kan vara mer eller mindre samtida med Holsterbacken. Textilkeramiken i Kalaschabrännan hör troligen till en fas då järn ännu inte var i bruk där.

På boplatsen Ketohaka 1 i Salo i Egentliga Finland, hittades några bitar järnslagg (Uino 1986: 83-84). Även en närastående litet gravröse innehöll samma typ av slaggbitar (Hirviluoto 1977: 7-9). På boplatsen Bergvalla i Karis socken i västra Nyland, från romersk järnålder, påträffades järnslagg men inga lämningar av ugnar eller några andra tecken på järnframställning observerades.

På boplatserna Pohtio III och IV i Kangasala socken, i Birkaland (nära Tammerfors) ingår järnslagg i fyndmaterialet, men tecken på järnhanteringsugnar har inte påträffats där (Lavento 2001: 265-266). Boplatserna är en del av Sarsa fyndkomplex, där bosättningen har varit kontinuerlig från tidig neolitikum till början av järnåldern. Det är ju sannolikt att järnslagg har kommit till boplater från en annan framställningsplats.

Järnhantering har känts till också i Tavastland. Ett exempel är boplatsen Hattelmala i Tavastehus, där några få lämningar av järnframställningsgropar har hittats. Strukturen på järnhanteringsplatsen kunde inte avgöras under utgrävningen, men bitar 
av slagg som var fastnat $i$ bränd lera indikerade järnhantering. Totalt $1,2 \mathrm{~kg}$ järnslagg hittades också. Tyvärr kan man inte säga mera om järnhanteringens detaljer på denna boplats, som har daterats till sen järnålder och tidig medeltid (Schulz, H.-P.: 1994). Järnframställningsgroparnas struktur har inte diskuteras, men det är troligt att typen påminner om dem som kan förknippas med blästerugnar.

En annan järnhanteringsplats från järnålderns slut ligger på ett näs mittemot Tavastehus slott. På boplatsen Varikkoniemi hittades järnföremål av olika typ; verktyg, ca. $17 \mathrm{~kg}$ järnslagg och många andra slags spår av järnhantering (Schulz och Schulz 1990: 79). På Varikkoniemi har det troligen funnits en smedja. Tolkningen har gjorts på basis av vissa verktyg och slagget (Schulz och Schulz 1992: 69-70) (dateringar tabell 2). Överhuvudtaget har Varikkoniemi dock visat sig vara en mycket problematisk plats för arkeologer eftersom området har använts från senare hälften av järnåldern fram till vår tid.

Virala i Janakkala i Tavastland var i slutet av järnåldern en liten by. Vid utgrävningar har man påträffat lämningar av järnframställning där, till och med en smedsässja (Schulz H.-P.: 1994). Det hittades också material som ansluter sig till gjutning av bronsföremål. Fyndmaterialet på boplatsen är daterat till en lång period, från merovingertid till medeltid (tabell 2).

På boplatsen Böle i Borgå har det påträffats järnmalm och järnslagg, som visar att järnhantering möjligtvis skett också vid havskusten i östra Nyland under förromersk järnålder. Dateringarna har publicerats av C. F. Meinander (1954: 161-165) men de kan inte anses vara exakta.

Ganska nyligen har järnugnar påträffats i sydöstra Finland, vid kusten av Finska viken. En koncentration av tre ugnar är nu känd från Abborrfors och Merikoski i Pyttis, vid flodmynningen av Kymmene älv (figur 3). Ugnar har också hittats nära staden Fredrikshamn. Det är inte uteslutet att några av ugnar vid Aborrefors kan dateras till början av järnåldern. Men för tillfället pekar ${ }^{14} \mathrm{C}$ och strandförskjutningsdateringar på att nästan alla ugnarna här varit $\mathrm{i}$ bruk under senare hälften av järnåldern eller under historisk tid. Tyvärr har de nya fyndplatserna ännu inte grävts ut, vilket lämnar kronologierna osäkra tillsvidare. Enligt nuvarande information kan de äldsta järnhanteringsplatserna vid den södra sjökusten dateras mellan AD 400-1000.

Gällande Finska viken väntar många frågor på svar genom ny forskning i framtiden. Man kunde till exempel belysa närmare på vilket sätt järnfram-

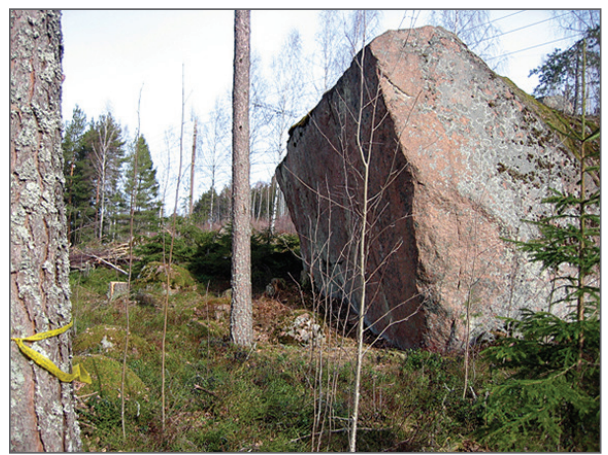

Figur 3: Järnhanteringsplats från Abborrefors $i$ Pyttis, vid flodmynningen av Kymmene älv. Figure 3: Remains of the iron smelting furnace at Abvenkoski in the estuary of River Kymi.

ställningen, som började i Estland, kan ses i kontakterna mellan norra Estland och södra Finland under järnåldern. Kontakterna från Kymmenedalen söderut och kontakterna från kusten till sjöområdena $\mathrm{i}$ södra Saimen kan ha existerat även om vi för närvarande inte ännu har hittat dem i det arkeologiska materialet. Vi vet att järnframställningen började även i Estland under förromersk tid (Peets 2003). Samma slags blästerugnar som var i bruk i södra Skandinavien användes där.

På Karelska näset har man inte hittat tidiga järnframställningsugnar från järnåldern fastän det är troligt att det har hanterats järn där också. Ändå är det intressant att redan 1888 grävde etnologen och arkeologen Theodor Schvindt ut en smedja i Tontinmäki på Hovinsaari ö i Räisälä kommun (ry. Mel'nikovo) (Schvindt 1993: 70-81). Smedjan innehöll mycket exceptionellt material med verktyg m.m. och den har senare utforskats av finländska och ryska arkeologer. Jorma Leppäaho (1949) daterade smedjan till korstågstiden. På Karelska näset har järnslagg påträffats på över femton boplater och lämningar av någon typ av metallurgisk aktivitet från olika perioder har hittats på tio boplatser (Uino 1997: 75-76).

Enligt forskningsdata kan järnet ha tagits i bruk nästan samtidigt $i$ södra och norra Finland men produktionen av järnet började enligt nuvarande information först i norra och östra Finland. Hela processen tog inte mera än 200 till 400 år. Järnhanteringen började under tidig metallålder $\mathrm{i}$ östra och norra Finland, i början av förromersk tid, och järnfynd i södra Finland antyder motsvarande kronologi. Bruket av lokalt järn började tidigt, kanske redan under ca. 400-talet f.Kr., men man har också påträffat material som antyder att de första 
järnföremålen var importerade. Både de typologiska och ${ }^{14} \mathrm{C}$ dateringarna bekräftar denna hypotes. Relationerna riktade sig inte bara till syd och väst, fastän järnimport från Skandinavien fortsatte under romersk tid (Mäkivuoti 1988). Tidigare och senare viktiga relationer hade varit till öst (Erä-Esko 1969, Carpelan 2003).

Under järnålderns gång ökade antalet järnfynd och slagg på boplatser, men antalet ugnar förblev lågt. Många boplatser var i bruk under långa perioder och en exakt datering av järnhanteringslämningar är ofta problematisk. Således finns det mycket vi borde undersöka närmare gällande järnhantering på boplatser på alla håll i Finland.

\section{NÅGRA ORD OM JÄRNETS ROLL I JÄRNÅLDERSSAMHÄLLET}

Forskarna har ofta betonat att järnet har haft stort värde i det förhistoriska samhället. Orsaken till detta var järnteknologins mångsidighet och den knowhow som krävs, då man producerar järn och olika järnföremål. Smeden åtnjöt stor uppskattning i samhället - detta har också antropologer observerat i olika delar av världen. Smeder har varit viktiga personer i lokalsamhällena. Deras höga status betonas i flera arkeologiska undersökningar, där folkloristiskt material ingår (t.ex. Salo 1992). Det är dock svårt att säga hur stor roll en egen järnframställning spelade hos fiskar- och jägargrupper i den tidigaste fasen.

Vad smeden gör - även om det enbart skulle vara att framställa järn - har laddats med betydelser, som troligen har förknippats med religiösa föreställningar. Etnografiska analogier gällande smedens sociala position i ett lokalt samhälle måste användas med största försiktighet (Peets 2003). I Finland ger nationaleposet Kalevala lockande möjligheter till tolkningar. Den mytologiska smeden Seppo Ilmarinen var en stor hjältefigur som sägs spegla samhälle för nästan tvåtusen år sedan. Smeden innehade en kunskap som bara några få kände till. (Salo 2008; Siikala 2012.)

Om järnet hade ett magiskt värde för smeden, kan järnslagg ha varit det samma för de andra människorna i samhället. Slagg har gett kraft inför en kommande odlings- och jaktsäsong. Järnframställningsoch järnhanteringsprocesser innehåller många steg som alla haft sin egen mening och ett värde i forntidens samhälle. Det är inte så svårt att föreställas sig en metaforisk betydelse som järnslagg har haft $i$ begravningsritualer och dess värde i byarnas gravfält (Wessman 2010).

Inom den finländska arkeologin har tolkningar av smedens och järnets position gjorts med hjälp av järnslagg på grund av att ugnar eller andra slags järnhanteringsplatser varit dåligt kända. Detta förorsakar en mängd problem. Järnslagg har haft flera olika betydelser redan under järnåldern. Ju oftare man hittar järnslagg utan några strukturer eller andra fynd som skulle förevisa praktisk järnframställning på samma ställe, desto mera problematiska blir arkeologiska tolkningar. Kanske hör inte allt järnslagg till järnframställningen?

I ett av Finlands mest berömda skelettgravfält i Luistari i Eura har det också hittats järnslagg, men Lehtosalo-Hilander (1982: 41) ansåg att det kan ha haft någonting att göra med boplatsen som ligger bredvid gravfältet. Det finns gravfält i Finland där man påträffat mellan $2-5 \mathrm{~kg}$ järnslagg. På Vainionmäki A i Laitila i Satakunda fann man mycket slagg (Söyrinki-Harmo 1996: 79) och i

\begin{tabular}{|l|l|l|l|}
\hline Sted & Lab. referanse & BP alder & Cal. alder BC/AD \\
\hline Säkylä, Tupamäki & Hel-2789 & $1350 \pm 110$ & $\begin{array}{l}\text { AD 560-810 (67.0\%) } \\
\text { AD 840-860 (1.2\%) }\end{array}$ \\
\hline Säkylä, Tupamäki & Hel-2790 & $1600 \pm 110$ & AD 340-600 (68.2\%) \\
\hline Holsterbacken, Malax & Hel-2549 & $1680 \pm 110$ & $\begin{array}{l}\text { AD 240-470 (58.6 \%) } \\
\text { AD 480-540 (9.6\%) }\end{array}$ \\
\hline $\begin{array}{l}\text { Abb. 26. Hämeenlinna, } \\
\text { Varikkoniemi }\end{array}$ & Hel-3063 & $940 \pm 90$ & AD1010-1190 (68.2\%) \\
\hline Janakkala, Virala & Hel-2860 & $1010 \pm 90$ & $\begin{array}{l}\text { AD 900-920 (5.0\%) } \\
\text { AD 960-1160 (63.2\%) }\end{array}$ \\
\hline Janakkala, Virala & Hel-2861 & $1280 \pm 100$ & AD 660-880 (68.2\%) \\
\hline Janakkala, Virala & Hel-2862 & $840 \pm 90$ & $\left.\begin{array}{l}\text { AD 1060-1090 (9.3\%) } \\
\text { AD 1120-1140 (5.9\%) }\end{array}\right)$ \\
\hline
\end{tabular}

Tabell 2: Konventionella ${ }^{14} C$-dateringar från järnåldersboplatser i Satakunda, södra Österbotten och Tavastland. ( Hel = Helsinki dating laboratory). Table 2: Conventional ${ }^{14} \mathrm{C}$ dating from Iron Age settlements in Satakunta, southern Pohjanmaa and Häme. (Hel = Helsinki dating laboratory). 
vissa gravfält i sydvästra Finland är slaggmängden många gånger större. Så här mycket slagg innebär sannolikt en järnframställningsplats.

Julius Ailio tolkade depåfyndet i Hattelmala Kirkkovuori i Tavastehus som ett metallager för en smed. Fyndet innehöll bronssmycken, ett runt spänne, ett kräftformat spänne, ett hästskoformat spänne och olika slags bronsbitar. Det som gör depån speciellt intressant är att alla föremål hade brunnit och de kanske hade samlats där från några andra fyndställen. Ailio antog att smyckena redan under järnåldern hittats från enstaka gravar eller de hade tagits till depån från ett gravfält som inte hade använts under en lång tid (Ailio 1928).

Det är möjligt att järnåldersmänniskorna påträffade metall på ställen som tidigare varit gravfält fastän de inte visste detta. Brandgravfält under flat mark är en gravtyp som kan leda till ett sådant misstag. Om den orala traditionen bröts var det lätt för en senare förhistorisk population att se stället bara som en källa till värdefull metall som kunde användas på nytt. J.-P. Taavitsainen (1991) påstår att många fornlämningar som arkeologer tolkat som gravfält i själva verket skulle vara ställen där smeder samlat metall till återanvändning. Vi får hålla i minnet att det ofta ligger en järnåldersboplats i närheten av brandgravfält under flat mark.

Det motsatta argumentet (Söyrinki-Harmo 1979: 92-99) är det att traditionerna i byarna var starka. Detta har fătt stöd i observationer som visar att järnslagg hittats vid utgrävningen av gravar. Enligt dessa tolkningar hade järnet också värde i livet efter detta. Även om hypotesen är intressant, är den mycket svår att verifiera. Theodor Schvindt (1893: 70,79) hittade slaggbitar i gravar på Karelska näset och Alfred Hackman (1938) påträffade slagg när han grävde ut båtgraven i Pukkila i Storkyrö kommun i Sydösterbotten. Hackman ansåg att järnslagg har kommit fram i brandgravar från folkvandringstid till vikingatid i sydvästra Finland så ofta, att man kan anta det vara gravgåvor: «dass man berechtigt ist sie Grabbeigaben zu betrachten, besonders wenn sie wie in dem älteren Kriegergrabe in grösserer Menge auftreten» (1938: 59). Det är väsentligt att förfädernas brandgravfält hade stort värde för människorna från generation till generation. Minnesmärken, gravfält eller enstaka föremål höll traditionen levande. De hade långa historier och stort värde för människor och släkter (Wessman 2009).

Hypotesen att järnslagg har haft magiskt värde för avlidna personer har presenterats relativt tidigt inom den finländska arkeologin, men man hade inte mycket att säga om dess betydelse. Finländska arkeologer har dock fört tanken vidare. Nils Cleve - när han grävde ut skelettgravfälten på Kjuloholm i Kjulo - konstaterade att järnslagg var förorsakad av «någon husliknande bålkonstruktion som har använts vid likbränningen, eller från ett bålunderlag av lera» (1943: 56-57). Han tyckte också att man borde separera två kontexter för slaggen; den som ligger i graven kan tolkats som gravgåva, men annat slagg är en avfallsprodukt, «som sådan knappast tänkbar som gåva åt den döde» (Cleve 1943: 55). Cleve (1943: 55) ansåg att slaggen «på grund av sitt samband med eld har haft en apotropeisk betydelse.»

Orsaken till en stor mängd material har även diskuterats tidigt. C.F. Meinander noterade att «Det är säkerligen mera än en tillfällighet att spår av smedjor ofta anträffas på våra järnåldersgravfält, där de helgade krafter likbegängelsen skänkt platsen, utnyttjats av den magiskt beroende smideskonsten» (Meinander 1943: 46). Han tyckte således att gravfälten var förknippade med metallhantering. Det är viktigt att boplatser och gravfält ligger nära varandra och det har funnits en kontakt mellan de två som kunde vara antingen andlig, praktisk eller både och.

Beträffande utgrävningarna på gravfält med järnslaggfynd, har materialet vanligen varit omöjligt att basera pålitliga tolkningar på. Järnslagg, några bitar av keramik eller benbitar är inte mera än en början. Redan de första arkeologerna i Finland lade märke till problemet, men frågan har inte blivit lättare att förstå för vår tids arkeologer, som kan använda vår tids metodologi (t.ex. Edgren 1992; Raike och Seppälä 2005).

Vi måste också ta hänsyn till att skilda bitar av järnslagg kanske inte har någonting att göra med varken boplatser eller gravar. Slaggfynd utan kontext är knappast daterbara. Slagg kan ibland bara ha kastats bort av en eller flera personer som antingen bodde på en plats eller besökte den säsongsvis. Det räcker med ett ögonblick för en person att lämna bakom sig skräp eller spår som senare blir viktigt forskningsmaterial för arkeologer. Samma kulturlager kan ha både flera bosättningsfaser och spår efter sporadiska forntida visiter på platsen. Varje arkeologisk tolkning är bara en hypotes som kan ifrågasättas. Till exempel kan ett forntida slaggfynd förbli oförståeligt för moderna människor.

Jag har här presenterat några hypoteser om järnslaggets forntida betydelser. De är möjliga förklaringar, men samtidigt kastar de ljus över ett av arkeologins grundproblem. 


\section{NÅGRA SLUTSATSER}

I Finland har det varit intressant att å ena sidan se hur lämningar av den tidigaste järnsmältningen med ugnar tillsvidare har koncentrerat sig till norra och östra delen av landet. $\AA$ andra sidan har man i södra och västra Finland påträffat sådana depåfynd av järnföremål och järnslagg, som kan dateras till förromersk tid. Tidiga ugnar har inte grävts ut i södra Finland, men däremot järnslagg och järnföremål, som indikerar att järnhantering troligen förekommit, är känd redan under den förromerska järnåldern. Skillnaden mellan öst och väst antyder kulturella kontakter åt olika håll. I södra Finland har kontakterna varit starka till Estland och Skandinavien, vilket kan ha frambringat de första järnföremålen till kustområdet ganska tidigt. Under järnåldern har vi påträffat boplatser i södra och västra Finland som möjligtvis har använts redan under den förromerska tiden.

De första lämningarna av järnframställning i Satakunda och Tavastland är påträffade på boplatser som dateras till romersk järnålder. Järnframställningen har absorberats till området från syd och väst men vårt ringa material gör tolkningen bara hypotetisk. Det är viktigt att skilja mellan två eller möjligtvis flera ugnstraditioner, även om man ännu inte har hittat lådugnar av samma slag på västra delen av Bottenviken, i Sverige, som i Finland. I Norge känner man inte heller till ugnar av denna typ ännu. Enligt Jüri Peets (2003) har den arkaiska traditionen av lådugnar påträffats $i$ Finland, Estland, Lettland och nordöstra Ryssland.

Järnframställningen kan ha spritt sig under förromersk tid nästan samtidigt till norra och södra Finland. Enlig Unto Salo har processen framskridit från kusten till inlandet, men problemet är att bevisa detta. Järnframställningsugnar som kunde dateras så tidigt, har inte fram tills nu påträffats i södra Finland. Järnslagg har påträffats där på några boplatser i samband med Morbykeramiken. I östra och norra Finland är keramiken som hittats tillsammans men järnugnar antingen av Luukonsaari- eller av Kjelmøytyp. Enligt nuvarande fyndmaterialet ser järnsmältningstraditionen ut att ha etablerats tidigare där än i södra och västra Finland.

Kronologiska frågor är viktiga, men också komplicerade när arkeologer försöker förstå järnframställningens historia i Finland. I södra och västra Finland har boplatser med järnslagg påträffats, och kontinuiteten från förromersk tid till vår tid är uppenbar. I östra och norra Finland slutar järnframställningen efter det femte århundradet efter Kristi födelse. Ugnarna försvinner liksom även boplats- erna. Enlig ryska arkeologer fortsätter järnproduktionen i Karelen (Kosmenko och Manjuhin 1999). De menar att lokala skillnader är viktiga och dessa bättre borde förstås innan man kan berätta mera om järnets historia i Finland.

För att lära oss mera om ugnarnas struktur måste vi göra nya fältarbeten och forska på ugnar genom utgrävningar. Möjliga ugnslämningar är dock inte lätta att känna igen under en utgrävning. Lämningarna kan vara fragmentariska, och postdepositionella processer kan har påverkat de ursprungliga strukturernas synlighet, «visibility.»

Arkeologer har hittat järnslagg både på olika gravfält eller boplatser. Det indikerar järnets viktiga betydelse för människor, men det innebär inte bara järnhantering. Samtidigt berättar det mycket om dåtidens samhälle, smedens roll i detta och t.ex. i världsbild och mytologi. Dessa betydelser är inte lätta att tolka, men de har stort värde när arkeologer försöker förstå tidig järnframställning och dess påverkan på livet under tidig järnålder.

\section{SUMMARY}

The article discusses the beginning of the iron production in southern and western Finland. Although the earliest dating of the iron furnaces are known to be in the region of the northern rivers Oulujoki and Kemijoki in Finland, it is possible that iron production took place at the same point in time in western and southern parts of Finland. The earliest probable dates of finds in southern and western Finland are as early as the $6^{\text {th }}$ century $\mathrm{BC}$ and local iron production was possibly known in most areas since the beginning of our era. In Finland, the origin of iron making can be looked for in the east, south and west.

This article presents the most important iron making sites in southern and western Finland. In addition, finds of a noteworthy amount of iron slag are listed. The meaning of iron in the society has been considered in the light of the grave finds and remains of blacksmithing at the dwelling sites. The process of iron making has also been discussed, although the early iron smelting furnaces have not been well preserved and excavated in southern and western Finland. 


\section{LITTERATUR}

Ailio, J. 1928. «Hattelmalan rautakautinen kätkölöytö». Suomen Museo 35: 51-54.

Carpelan, C. 2003. Inarilaisten arkeologiset vaiheet. Inari: Inarin historia jääkaudesta nykypäivään = Aanaar / kirjoittajat: Samuli Aikio ... [et al.] / toimittanut: VeliPekka Lehtola. Inari: Inarin kunta: 28-95.

Cleve, N. 1943. «Skelettgravfältet på Kjuloholm i Kjulo I. Den yngre folkvandringstiden». Finska Fornminneföreningens Tidskrift XLIV:1.

Edgren, T. 1968. «Zu einem Fund von Gussformen aus der jüngeren Eisenzeit in Finnland». Suomen Museo 75: 37-51.

Edgren, T. 1992. «Den förhistoriska tiden». I Edgren, T. och L. Törnblom (red.). Finlands Historia 1:11-270. Esbo: Schildt.

Erä-Esko, A. 1969. «Akinakeslöytö Pohjois-Suomesta». Suomen Museo 76: 85-93.

Hackman, A. 1938. «Das Brandgräberfeld von Pukkila in Isokyrö». Finska Fornminneföreningens Tidskrift XLI.

Hirviluoto, A.-L. 1977. «Kaivaus Isonkylän muinaismuistoalueella». Hakastarolainen n:o 11:7-9. Salo-Uskelan Seura.

Jørgensen, R. 2010. Production or Trade? The supply of iron to North Norway during the Iron Age. Doktorgrad: Tromsø.

Kehusmaa, A. 1972. «Neitilä 4. Pro gradu -tutkielma Suomen ja Skandinavian laudatur-arvosanaa varten». Helsingin yliopiston arkeologian laitos. Moniste n:o 3.

Kivikoski, E. 1961. «Suomen esihistoria». Suomen historian I osa. Porvoo: WSOY.

Korosuo, O. 1946. "Gjuttekniken under järnåldern i Finland». Finskt museum 53: 5-30.

Kosmenko, M. G. och I. S. Manjukhin, 1999. «Ancient iron production in Karelia». Fennoscandia archaeologica XVI: 95-147.

Kotivuori, H. 1992. «Dwelling-site finds from the Middle Iron Age fieldwork at Kalaschabrännan in Maalahti, Southern Ostrobothnia 1987-1989». Fennoscandia archaeologica IX: 57-74.

Kotivuori, H. 1996. «Pyytäjistä Kaskenraivaajiksi». I Kallio, V. (red.). Rovaniemen historia. Kotatulilta savupirtin suojaan vuoteen 1721: 34-125. Jyväskylä.

Kotivuori, H. 2013. «Tidiga spår av järnhantering i norra Finland». Denna publikation.

Lavento, M. 1996. «Varhaista raudanvalmistusta Ristiinassa - muutamia huomiota Kitulansuon raudansulatusuunista ja siihen liittyvästä keramiikasta». Sibti 4: 64-75. Savonlinna: Savonlinnan maakuntamuseo.

Lavento, M. 1999. «The Iron Furnace from the Early Metal Period at Kitulansuo in Ristiina, southern part of Lake Saimaa Water System». Fennoscandia archaeologica XVI: 75-80.
Lavento, M. 2001. «Textile ceramics in Finland and on the Karelian Isthmus. Nine Variations and Fugue on the Theme of C. F. Meinander». Finska Fornminneföreningens Tidskrift 107.

Lehtosalo-Hilander, P.-L. 1982. «Merkillisiä kiviesineitä Euran Luistarista». Suomen Museo 1977: 26-36

Lehtosalo-Hilander, P.-L. 1982. «Luistari I. The Graves». Finska Fornminneföreningens Tidskrift 82:1.

Leppäaho, J. 1949. «Räisälän Hovinsaaren Tontinmäen paja, sen langanvetovälineet ja langanvedosta (vanutuksesta) yleensäkin». Suomen Museo 56: 44-93.

Meinander, C. F. 1943. «Några forngravar i Laihela». Finskt Museum 50: 32-47.

Meinander, C. F. 1954. «Die Bronzezeit Finnlands». Finska Fornminneföreningens Tidskrift 54.

Miettinen, M. 1988. «Järnåldersbosättningen kring Storsjön, Malax sc, i ljuset av arkeologiska fynd och pollenanalys». Föredrag vid det 17. nordiska arkeologimötet i Åbo 1985. Iskos 7: 197-200.

Mäkivuoti, M. 1988. «An Iron-Age dwelling site and burial mounds at Rakanmäki, near Tornio». Fennoscandia archaeologica: 35-45.

Oinonen, M., G. Haggrén, A. Kaskela, M. Lavento. V. Palonen, and P.Tikkanen, 2009. «Radiocarbon Dating of Iron: A Northern Contribution». Radiocarbon, Vol. 51, Nr. 2: 873-881.

Peets, J. 2003. The power of iron: iron production and blacksmithy in Estonia and neighbouring areas in prehistoric period and the Middle Ages; Raua vägi: raua tootmine ja sepatöö Eestis ja naaberpiirkondades muinas- ja keskajal. Muinasaja teadus 12. Tallinn: Teaduste akadeemia kirjastus.

Raike, E. och S.-L. Seppälä, 2005. «Naarankalmanmäki. An Iron Age Complex in Lempäälä, Southern Finland2. Fennoscandia archaeologica XXII: 43-78.

Salo, U. 1992. «Raudan synty: rautatekniikan varhaisvaiheita Suomessa. Sananjalka». Suomen kielen seuran vuosikirja 34: 103-122.

Salo,U.2008.«Ajan ammoisen oloista: Satakunnan ja naapurimaakuntien esihistoriaa. Helsinki». Suomalaisen Kirjallisuuden Seuran toimituksia 1175. Helsinki.

Schulz, E.-L. 1986. «Ein Eisenverhüttungsplatz aus der älteren Eisenzeit in Kajaani». Iskos 6: 169-173.

Schulz, E.-L. och Schulz, H.-P. 1990. «Varikkoniemi in Hämeenlinna - a Trading Site from the Viking Period». Fenno-Ugri et Slavi 1988. papers presented by the participants in the Finnish-Soviet archaeological Symposium «Studies in the material Culture of the Peoples of Eastern and Northern Europe» 10-16 May 1988 in the national Museum of Finland. Iskos 9:75-80.

Schulz, E.-L. och Schulz, H.-P. 1992. «Hämeenlinna Varikkoniemi: eine späteisenzeitliche - frühmittela- 
1terliche Kernsiedlung in Häme: die Ausgrabungen 1986-1990». Suomen Museo: 41-85.

Schulz, H.-P. 1994. «Frühmittelalterliches Metallhandwerk in der Provinz Häme, Finnland». FinnishRussian Archaeological Symposium Pre-historic Economy and Means of Livelihood (1992). FennoUgri et Slavi 1992: prehistoric means of livelihood. Helsinki, Museovirasto, 1994. Museoviraston arkeologian osaston julkaisuja n:o 5: 124-145.

Schvindt, T. 1893. «Tietoja Karjalan rautakaudesta». Finska Fornminneföreningens Tidskrift XIII.

Siikala, A.-L. 2012. «Itämerensuomalaisten mytologia». Suomalaisen Kirjallisuuden Seuran Toimituksia 1388/ Tiede. Hämeenlinna: Kariston kirjapaino Oy.

Söyrinki-Harmo 1979. Haubon, Pälkäneen ja Kangasalan merovingi- ja viikinkiaikaisten polttokalmistojen vertailua. Pro gradu -työ, Suomen ja Skandinavian arkeologia. Helsingin yliopisto.

Söyrinki-Harmo, L. 1996. "Tools and implements». I Purhonen, P. (red.). Vainionmäki - a Merovingian period Cemetery in Laitila, Finland, National Board of Antiquities: 63-80.
Taavitsainen, J.-P. 1991. «Cemeteries or refuse heaps?» Suomen Museo 98: 5-14.

Tallgren, A. M. 1931. «Suomen muinaisuus». Suomen historia 1 . WSOY.

Uino, P. 1986. «An Iron Age Community at Ketohaka in Salo and other Remains of Metal Period Buildings in Finland. Iron Age Studies in Salo». Finska Fornminneföreningens Tidskrift 89:2: 25-201.

Uino, P. 1997. «Ancient Karelia. Archaeological studies». Finska Fornminneföreningens Tidskrift 104.

Wessman, A. 2009. «Reclaiming the past: Using old Artefacts as a Means of Remembering». Interachaeologia 3. Papers from the Third Theoretical Seminar of the Baltic Archaeologists (BASE), held at the University of Latvia, October 5-6, 2007. Memory, Society, and Material Culture: 71-88.

Wessman, A. 2010. «Death, Destruction and Commemoration. Tracing ritual activities in Finnish Late Iron Age cemeteries (AD 550-1150)». Iskos 18. 


\title{
JERNVINNA I GRÅFJELL - EN METODE I GRENSELAND
}

\author{
Bernt Rundberget
}

\section{INNLEDNING}

At det har vært en omfattende jernproduksjon etter den direkte metoden i det sørøstlige Norge, nærmere bestemt i Hedmark sør for Alvdal kommune, har vært kjent i flere hundre år. Av tidlig litteratur er Ole Evenstads kildeskrift fra 1782 det mest kjente. I tillegg finnes det en rekke beretninger om fordums jernproduksjon. Vi kan nevne Capatain Oppen (1777), som også beskriver myrmalmens behandling i Østerdalen. Videre trekker sogneprest Axel S. Smith (1784) fram en storstilt produksjon i Trysil, og sogneprest Christen C. Kiær (2004 [1743]: 120) beskriver funn av jernslagg i Stor-Elvdal og påpeker at produksjonen var viktig for bøndene i området. Sogneprest Paul B. Hammer (2004 [1743]: 88) beretter om jernmyrer mange steder i Solør, og han viser til funn av slagg som vitner om blestring i eldre tider. Gerhard Schøning (1980 [1775]: 32) så for seg en omfattende jernproduksjon i Vang da landskylden delvis ble regnet $\mathrm{i}$ «Bolløxer» (jf. Larsen 2009). Utover på 1900-tallet kom det en rekke artikler og bygdebøker om emnet, uten at vi skal gå nærmere inn på disse (se Rundberget 2007; 2013; Larsen 2009).

Likevel må vi trekke fram én person, nemlig Rolf Falck-Muus. I sin gjennomgang av de geologiske forholdene i Solør kom han over en rekke jernframstillingsplasser. Han fattet interesse for jernutvinning, og da spesielt faktorer knyttet til slaggtypologi og prosess. Gjennom egne undersøkelser og kontakt med lokalbefolkningen kartla han en rekke anlegg. Han publiserte flere artikler om emnet (f.eks. Falck-Muus 1927; 1931), og han må sies å være en av pionerene i den moderne jernvinneforskningen (Espelund 1995; Rundberget 2002; 2013). Av senere sentrale resultater må utmarksregistreringene til Hedmark fylkeskommune (f.eks. Bårdseng 1996; Holm 1998) og registreringene og utgravingene på Rødsmoen og i Gråfjellområdet nevnes spesielt (Narmo 1997; 2000; Risbøl et al. 2002; Rundberget 2006; 2007; 2012; 2013). Dagens kunnskap bygger på disse undersøkelsene, og følgende presentasjon av ovnstype og organisering i hedmarksområdet er tolket hovedsakelig ut fra Gråfjellområdet.

\section{KULTURMINNER OG JERNFRAMSTILLING I GRÅFJELLOMRÅDET}

Undersøkelsene i Gråfjellområdet hadde sin bakgrunn $\mathrm{i}$ utbyggingen av et nasjonalt skyte- og treningsfelt for det norske forsvaret. I et område på omkring 200 kvadratkilometer påviste NIKU et stort antall kulturminner. I alt ble det gjort 2994 registreringer. Av disse er 2191 automatisk fredede kulturminner, mens 803 er etterreformatoriske (Risbøl et al. 2002: 15-17). Under utgravingsprosjektet ble også et stort antall røsteplasser registrert (Smekalovs 2006; Rundberget 2007). Kulturminnene er mangeartede: Det er funnet steinalderlokaliteter, kulturminner knyttet til fangst, tjære- og jernframstilling, seteranlegg med rydningsrøyser, hustufter og brønner, men også graver, veger og bruer. Kulturminnene reflekterer en stor og spredt aktivitet over en periode på 10000 år (H. Amundsen et al. 2003; Stene et al. 2005; Rundberget 2007; T. Amundsen 2007).

Kulturminner som kan knyttes til jernproduksjon, er i stort flertall. I alt ble det registrert 115 jernvinneanlegg, i underkant av 1800 kullgroper og mer enn 300 røsteplasser (Risbøl et al. 2002). Og denne omfattende distribusjonen går igjen i store deler av søndre og midtre Hedmark. De store skog- og fjellområdene på det indre Østland er et ressursrikt område når det gjelder tilgang på trevirke og myrmalm. Området har blitt utnyttet til produksjon av jern i over 1500 år, fra eldre jernalder og opp til nyere tid. Jernframstillingen har skiftet karakter ettersom metodene har endret seg. I eldre jernalder og i etterreformatorisk tid, helt fram til 1800-tallet, ble det i området produsert jern i relativt begrenset grad, noe de forholdsvis fă registrerte anleggene vitner om. Fra siste del av yngre jernalder og fram til slutten av høymiddelalderen (AD 950-1300) var karakteren en helt annen. Overalt i skogene i Hedmark, i et belte som strekker seg over mer enn 200 kilometer fra nord til sør, finnes det utallige spor etter denne omfattende produksjonen. Hovedparten av sporene finnes i form av kullgroper hvor tømmer ble brent til kull til jernproduksjonen. Men også jernvinneanlegg og områder hvor myrmalmen er røstet, er tallrike. 


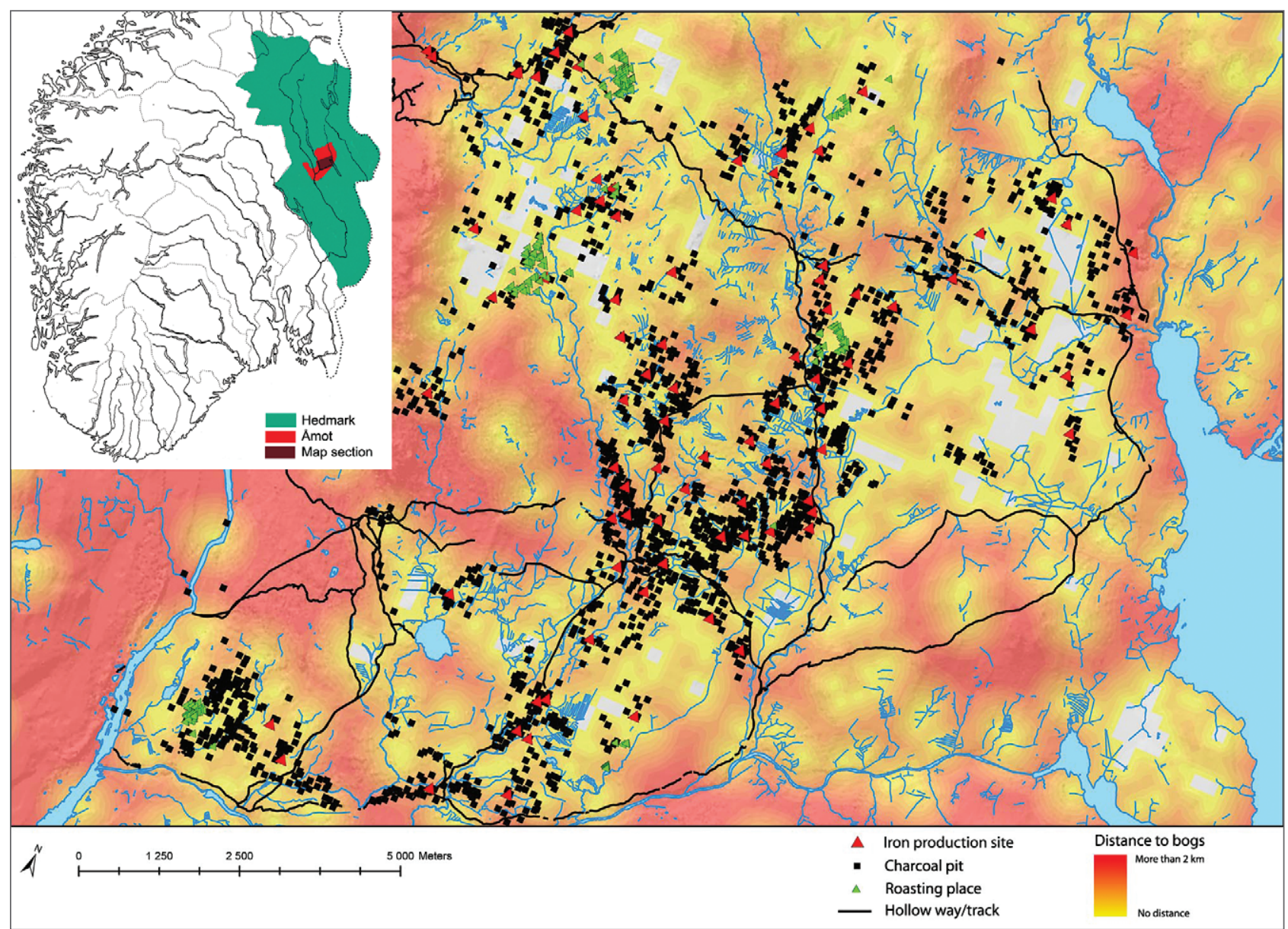

Figur 1: Jernframstillingsplasser, kullgroper og rosteplasser i Gräfellområdet. Legg merke til veisystemene som i mange tilfeller ligger i klar kontekst til jernvinneanleggene. Kart: D. Hill / B. Rundberget, Kulturhistorisk museum. (Kartgrunnlag: Statens kartverk. Tillatelsesnummer NE12000-150408SAS.)

Figure 1: Map showing production sites, charcoal pits and roasting places in the Gräfell area. Notice the road and track-system, which is often near to the production sites Map: D. Hill/B. Rundberget, Museum of Cultural History. (Map base: NMA, Permit number NE12000-150408SAS).

De arkeologiske undersøkelsene

Under utgravingene i Gråfjellområdet ble et stort antall jernframstillingsplasser (39), kullgroper (250) og røsteplasser (30) undersøkt (Rundberget 2007; 2013). Alle de undersøkte foruten ett, datert til merovingertid, var fra vikingtid/middelalder (figur 1). I denne artikkelen skal vi ikke diskutere de organisatoriske delene av produksjonen, men for å oppsummere veldig kort kan vi ved å se på de enkelte produksjonsplassene i detalj klart postulere at produksjonen var basert på et felles organisatorisk og teknologisk konsept. Lokalisering av ovner, malm- og kullagre og dessuten slagghauger på de enkelte produksjonsplassene følger alltid et felles mønster, selvfølgelig med mindre innbyrdes variasjoner anleggene imellom (Rundberget 2007: 241-246, 356; 2013). Det som først og fremst skiller anleggene fra hverandre, er størrelsen heller enn formen. De minste produksjonsplassene har produsert under 1000 kilo jern, mens de største kan ha produsert over 100 tonn. Det samme bildet viser kullgropene. Form, størrelse og organisering som en sverm rundt de enkelte jernvinneanleggene vitner om en felles tradisjon som er spesifikk for denne regionen. Når det gjelder røsteplassene, vitner deres lokalisering og distribusjon i landskapet, sett i sammenheng med produksjonsplassene og kullgropene, om at felles malmkilder ble benyttet av jernblestrerne. Det betyr at selv om alle jernvinneanleggene mer eller mindre hadde en sirkumferens med hensyn til tømmerresurser, var malmressursene en delt ressurs. Ingen hadde eksklusive rettigheter til disse kildene, noe som vitner om samarbeid heller en konkurranse om ressursgrunnlaget. 


\section{SJAKTOVNEN MED SLAGGAVTAPPING}

Temaet for symposiet på Kittilbu var typologi og kronologi på blesterovner. Innholdet i denne artikkelen bygger på en typologisk tilnærming. Kronologisk sett finnes det i Gråfjellområdet kun ett anlegg fra eldre jernalder, og dette anlegget ligger i et område hvor vi ikke finner jernvinneanlegg fra vikingtiden eller middelalderen. Anlegget fra eldre jernalder er ikke utgravd, men organisering, slaggtypologi og datering til 400-tallet (Risbøl et al. 2002: 53-54) tilsier at anlegget er av typisk østlandstype (se Larsen i denne boken). I tillegg er det undersøkt et anlegg som er datert til merovingertid (Jfp. 18 i Rundberget 2007). Typologisk er anlegget problematisk, da dårlig bevaringsgrad gjør det vanskelig å tolke typen. Slagget er av typen tappeslagg, og store mengder varmepåvirket leire tilsier at produksjonen har foregått $i$ en leirovn. Rett vest for skytefeltet, nord for Deset, er det også påvist et Evenstadanlegg. Anlegget er ikke undersøkt, men typologisk bestemt ut fra slagg.

Sjaktovnen med slaggavtapping er enerådende i Gråfjellområdet hvis vi ser bort fra de ovennevnte, kjente unntakene. For Rødsmoprosjektet på midten av 1990-tallet var imidlertid situasjonen en annen. Her ble det funnet jernvinneanlegg fra merovingertid med små slaggroper (Narmo 1997). Disse skiller seg fra Jfp. 18, og formen har klare likhetstrekk med den eldre groptradisjonen. Et spørsmål jeg tok opp på Nordic TAG i 2009, var om disse ovnene utgjør en form for forbindelse mellom de to hovedtradisjonene (Rundberget 2012; 2013). For meg ser de ut til å inneholde elementer som tilsier at det har skjedd en hybridisering fra to kronologisk atskilte tradisjoner, et utviklingsledd som har ledet fram til den ovnstypen jeg skal presentere i det følgende.

Ovnene i Gråfjellområdet er bygd opp av to hovedkomponenter: en leirsjakt over bakkenivå og en nedgravd isoleringsgrop. Ofte er isoleringsgropene anlagt $\mathrm{i}$ en oval/avlang nedgravning som løper parallelt med en slagghaug. Ovnene og slagghaugene ligger tett inntil hverandre, ingen ovner er påvist mer enn 1,5 meter fra slagghaugene. Konteksten mellom ovn og haug er derfor lett å kartlegge. Under følger en beskrivelse av ovnen på bakgrunn av de arkeologiske undersøkelsene i Gråfjellområdet. Gjennomgangen er i hovedsak generell, men jeg viser også til spesifikke ovner på noen av jernframstillingsplassene (Jfp.). (For en mer inngående analyse, se Rundberget 2007).

\section{LEIRSJAKTENE - KONSTRUKSJON OG FORM}

Ovnssjaktene var konstruert av leire. Leirsjaktene var ikke intakte da de ble funnet, men i noen tilfeller var den nedre av dem delen bevart. Det skyl- des, som jeg senere vil komme tilbake til, at det $\mathrm{i}$ mange tilfeller lå igjen tykke slagglag rundt ovnene. Slagglagene har beskyttet sjakten fra nedrasing og erodering. Tykke lag av rødbrent leire ble i mange tilfeller påvist i nærheten av ovnens opprinnelige plassering. Det har sammenheng med at den siste sjakten enten kun har blitt revet og ikke fjernet eller har blitt etterlatt etter avsluttet produksjon. Lag med sjaktmateriale ble $\mathrm{i}$ flere tilfeller også påvist som tydelige sjikt i slagghaugene eller som lag av brent leire inne på produksjonsområdet. I de tilfellene hvor sjaktmateriale ble påvist som tydelige sjikt i slagghaugene, antas det at ødelagte sjakter har blitt kastet på avfallsdynga. Mens i de tilfellene hvor det ble funnet leirlagre inne på produksjonsplassen, tolkes det som om det har vært lagre av brent leire for gjenbruk til magring i nye sjakter, da godset i mange tilfeller ser ut til være satt sammen av fint stoff magret med brent leire. Lokaliseringen tyder også på en intensjonell deponering. Keramiske analyser har imidlertid ikke vist tegn til at brent leire har vært benyttet til magring (Andersson et al. 2006). I tre tilfeller kom det derimot fram at knust leirstein var brukt til dette formålet. Leirskiferen har store morfologiske likheter med brent leire i både form og farge. Om brent leire ble benyttet til sjaktproduksjon, må derfor, nå i ettertid, sies å være usikkert. Men det kan ikke utelukkes at det var tilfellet, da det kun er utført keramiske analyser på enkeltfragmenter fra syv anlegg.

I flere tilfeller ble det funnet større stykker av sjaktveggene, enten i slagghauger eller ved ovnsområdene. Her kan form og størrelse tolkes i rimelig grad. De fleste har en krummet form som antyder at sjakten var sirkulær. I noen tilfeller er det riktignok påvist større stykker som tilsynelatende ikke har noen krumming. Disse fragmentene har likhetstrekk med det som på Rødsmoen ble tolket som rette ovnsvegger (Narmo 1997). På anlegg hvor deler av ovnssjaktene er bevart, har formen uten unntak vært krummet, og graden av krumming viser at sjakten har vært sirkulær heller enn oval. Den best bevarte sjakten ble funnet på Jfp. 3, ovn 2 (figur 2). Her kunne både sjaktens sirkulære form og sjaktens tykkelse studeres. I sjaktveggen var også ett tappehull bevart. Tappeslagg, såkalte tappepalter, lå mot undergrunnen på utsiden av sjakten. Disse viste at det var blitt tappet $\mathrm{i}$ to retninger. På innsiden av sjaktveggen sto deler av en bunnskolle igjen. Denne lagde sammen med tappeplatene gode bevaringsforhold for den nedre delen av sjakten. Sjaktens indre diameter ble målt til 38 centimeter. Leire hadde skallet av på utsiden, og den ytre diameteren ble målt til 55 cen- 


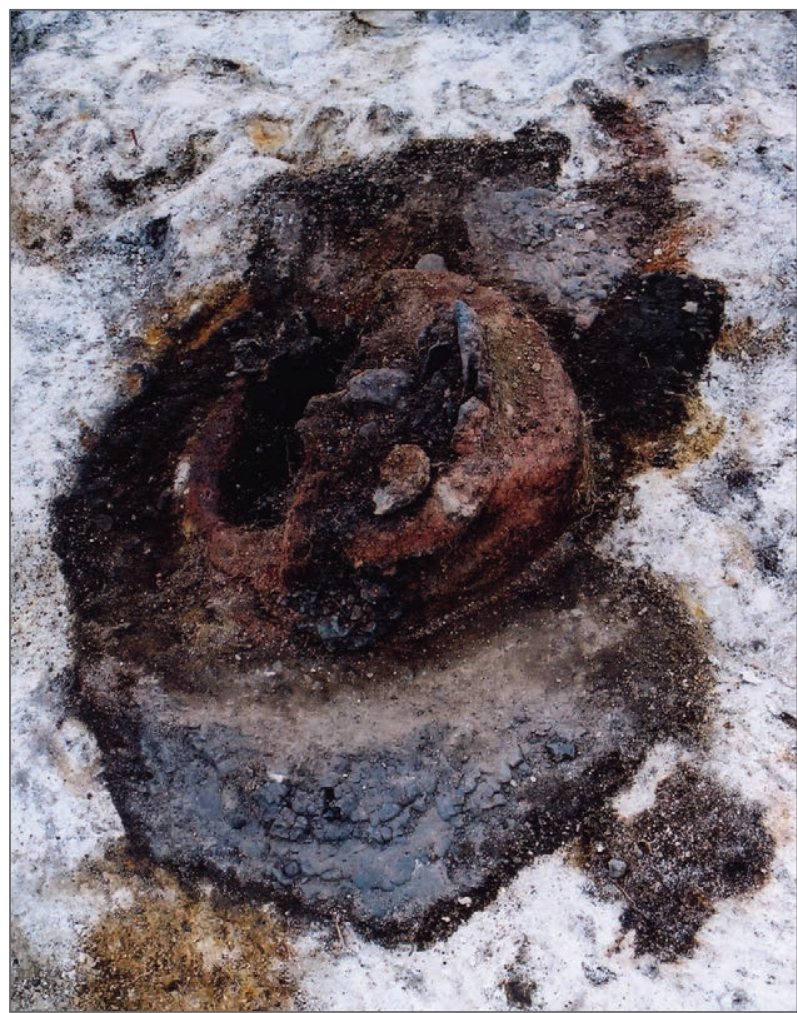

Figur 2: Jfp.3, ovn 2 med bevart leirsjakt og tappeplater i forog bakkant Foto: B. Rundberget, Kulturhistorisk museum. Figure 2: Furnace 2 from Jfp. 3 with preserved clay-built shaft and tapped slag, both in front and behind the furnace. Photo: B. Rundberget, Museum of Cultural History.

timeter, men den har trolig opprinnelig vært 60-65 centimeter. Når det gjelder sjaktens høyde, var det bare de nederste 25 centimeterne som var bevart, og opprinnelig høyde er ukjent. Ved en rekonstruksjon av blesterovnene er man nødt til å støtte seg til tidligere undersøkelser og eksperimenter. 70 centimeter er anslått som tilstrekkelig høyde i sjaktovnene med slaggavtapping på Dokkfløy (Jacobsen et al. 1988; Narmo 1996: 77). Ut fra dimensjonslikhet i sjaktenes diameter har høydemålet trolig overføringsverdi også til Gråfjellområdet. Et generelt trekk er også at sjaktens høyde skal være omtrent to ganger indre diameter (Grandin og Hjärthner-Holdar 2003: 403).

Også på andre jernframstillingsplasser ble deler av ovnssjaktene påvist in situ. Både form og størrelse ser ut til å samsvare godt med Jfp.3. Den indre diameteren varierer fra 32 til 45 centimeter, og i de tilfellene der det er mulig å måle den ytre diameteren, ligger denne på mellom 55 og 75 centimeter. Verdiene for ytre diameter er minimumsverdier, da det i de fleste tilfeller tydelig kan påvises avskalling.

\section{KERAMISKE ANALYSER AV SJAKTMATERIALET}

Keramiske analyser er utført av Ole Stilborg ved Lunds Universitet og presentert i GALs analyserapporter (Grandin et al. 2005; Andersson et al. 2006). Sjaktmaterialet er undersøkt okulært, på tynnslip med mikroskop, og det er utført totalkjemiske analyser (Andersson et al.2006). Materialet er ikke leire i egentlig forstand, men fin masse av lokal art - den er trolig funnet i myrene ved jernvinneanleggene. Rare earth elements-mønsteret (REE-mønsteret) i de totalkjemiske analysene viser også at leiren er lokal. Det kommer blant annet til utrykk i identiske prøver av leire og sjaktmateriale fra Jfp.29, og dessuten gjennom likhet mellom malmer og leire. Godsets egenskaper er derfor varierende, men det finnes enkelte fellesnevnere. Sjaktmaterialet fra de østlige områdene består av en grov masse, og magring har ikke vært nødvendig. På anlegg Jfp.32 er godset så grovt at det trolig har vanskeliggjort konstruksjonen. På to anlegg i den sørlige og vestlige delen av området består godset av noe mindre korn. Godset er her også magret med noe leirstein/skifer. Ett anlegg skiller seg ut. Jfp. 8 hadde sjakter bestående av svært finkornet masse. Det blir tolket til å ha sammenheng med at massen er tatt ut ved nærliggende vannkilder hvor leiren er vannsortert. Valg av leire har ført til at sjakten har hatt dårlige termiske egenskaper. Det har blestrerne vært klar over, og for å øke kornstørrelsen har de magret materialet med 27-40 prosent knust leirstein. Problemet her er at også magringen har tilsvarende dårlige termiske egenskaper, noe som kommer fram om vi ser på målinger av smeltetidspunket. For den østligste gruppen ligger dette på $>1350{ }^{\circ} \mathrm{C}$, for de sørlige og vestlige anleggene på $<1350{ }^{\circ} \mathrm{C}$, mens på Jfp. 8 smeltet ovnsveggen allerede ved $<1250^{\circ} \mathrm{C}$. Når da temperaturen $\mathrm{i}$ ovnene noen steder har vært oppe $\mathrm{i}$ over $1400{ }^{\circ} \mathrm{C}$, har sjaktene kollapset. Følgelig er det antydet at temperaturen ikke burde ha oversteget $1100{ }^{\circ} \mathrm{C}$ på dette anlegget (Andersson et al. 2006: 23), men ut fra kjent kunnskap om reduksjonsprosessen må den generelle temperaturen, i hvert fall stedvis i ovnen, ha vært noe høyere. Interessant er det at på nettopp Jfp. 8 hadde sjakten på ovn 3 smeltet ned og slagget hadde strømmet utover bakken og også ned i den underliggende gropen. Det må ha vært et stort trykk i ovnen siden slagg hadde rent mer enn én meter før den størknet i den kalde lufta (figur 3). Ovnene ble aldri reparert - blestrerne flyttet heller produksjonen noen meter mot vest (Damlien 2007: 92-96). 


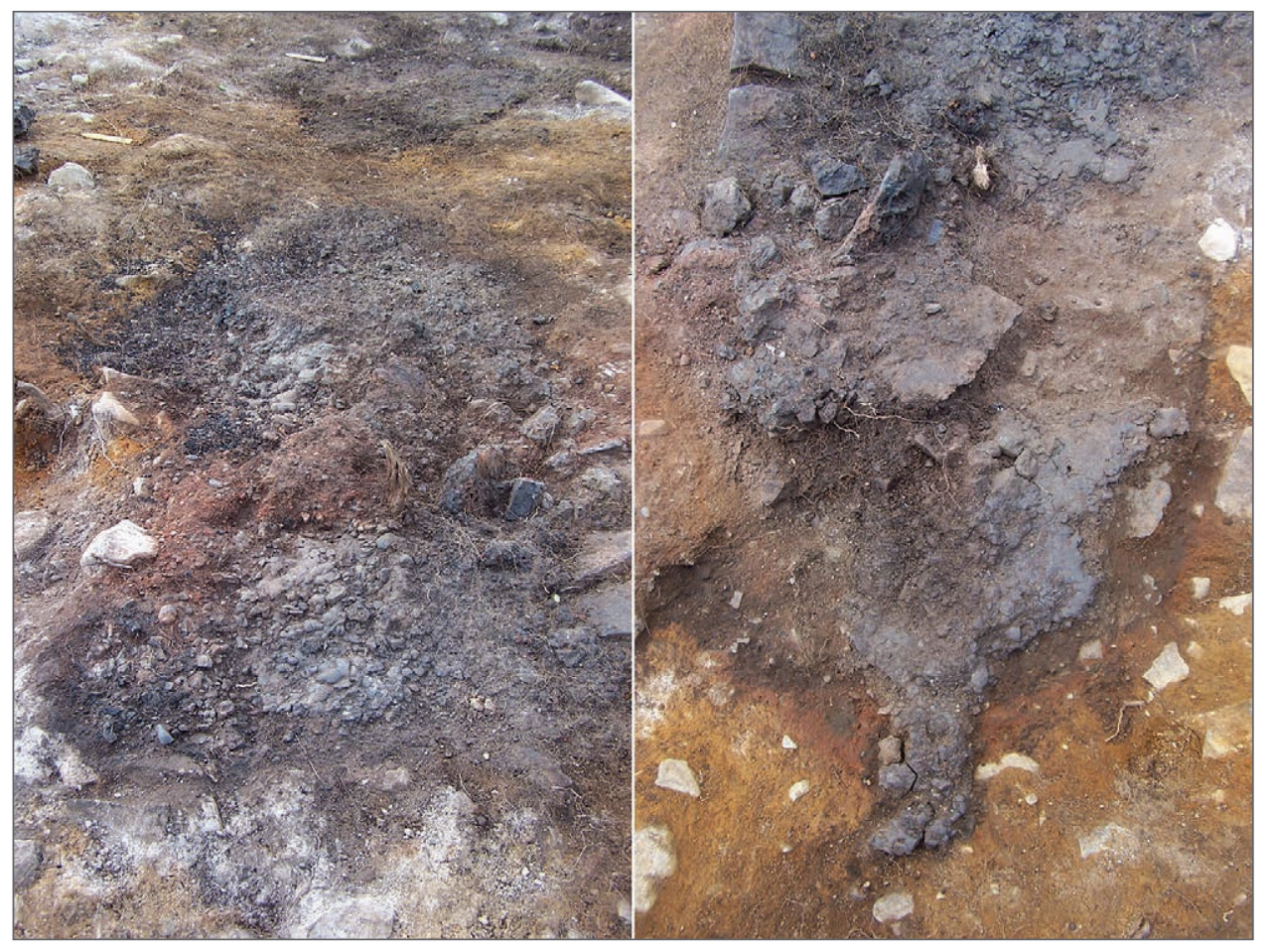

Figur 3: Jfp. 8, ovn 3. Til venstre sees ovnen $i$ midten og med uttapping i to retninger. Til hoyre ser vi et nerbilde av det nederste tappelaget som har strekt seg 1 m fra ovnen. Undergrunnen er tydelig varmepåvirket. Foto: H. Damlien, Kulturbistorisk museum. Figure 3: Furnace 3 from Jfp.8. From the left: The furnace can be seen in the centre with tapping in two directions. To the right, close up of the lowest tapped layer that has spread out over $1 \mathrm{~m}$ from the furnace. The ground shows clear indication of having been heated. Photo: H. Damlien, Museum of Cultural History.

\section{YTRE FORSKALING OG ISOLASJON}

På utsiden av leirsjaktene, mot bakkenivå, ble det i flere tilfeller påvist en tynn vegg av forkullet treflis eller bark. Flisveggen kunne observeres inn mot produksjonsområdet eller ut mot slagghaugen, men ble ikke påvist i de områdene hvor uttappingen har funnet sted. Tykkelsen på flisene varierte fra 2 til 5 millimeter, og veggen var satt sammen av kvadratiske eller rektangulære stykker i flere lag. I to tilfeller lå det tynne sandlag mellom flislagene. Best bevart var flisveggen rundt sjakten til ovn 2 på Jfp.8. Her kunne det skilles ut tre lag med treflis. Disse var flettet med trevirkets fiberretning vertikalt-horisontalt-vertikalt. De vertikalt stilte flisene var rektangulære og spisset mot bakkenivå, mens de horisontalt liggende flisene var kvadratiske. Høyden på flisveggen var på det meste 8 centimeter. Utenfor flisveggen ble det påvist et tynt trebånd av bøyelig kvist, som sannsynligvis hadde som funksjon å holde den tynne flisveggen på plass. Flisvegger som omslutter andre ovner, har samme oppbygning, og bark er foretrukket i flere tilfeller.

Jeg antar at flisveggen har omsluttet hele leirsjakten og fungert som sen forskaling under oppbyggingen av ovnssjakten. At det ikke finnes rester etter en slik vegg i tappeområdene, er naturlig, da det flytende slaggen har brent opp dette tynne trevirket. Andre former for foring eller ytre isolering av ovnssjakten er ikke påvist. Det finnes heller ingen tegn på sandmasser eller steinheller rundt ovnene. Ved ovnene hvor tappeslagg er funnet in situ, ligger også slaggen tett inntil leirsjaktene. Ovnssjakten tolkes av den grunn til å ha vært sirkulær og frittstående, med en veggtykkelse på 15-20 centimeter.

\section{ISOLERINGSGROP}

Under leirsjakten var det gravd ned og utforet en sirkulær grop. Kun med to unntak ble slike groper observert. Ovn 6 på Jfp.12 hadde steinfundamentering på bakkenivå, og funn av en bunnskolle med samme særtrekk som andre ovner tilsier at det kan ha vært en form for oppbygd grop. Den tidligere nevnte Jfp.18 fra merovingertid har en noe annen konstruksjonsform. Men også her tyder bunnskoller og et tykt lag med brent leire på at ovnen har hatt et rom under uttappingsnivået.

Gropkonstruksjonen var i hovedsak lik ved alle de utgravde ovnene. Nedgravningens vegger besto av en sirkulær steinforing. I tillegg til å hindre veggene fra å kollapse har steinkonstruksjonen trolig vært et fundament for leirsjakten som var reist direkte på denne. Utenfor steinforingen og mellom steinene var det i bunnsjiktet påfylt masser av sand og grus. Mot bakkenivå var det derimot hulrom mellom steinene, noe som ofte førte til at slagg ved uttapping hadde rent ned mellom steinene. Direkte innenfor steinforingen var det konstruert et lagg av omhyggelig tilhogde staver. Disse hadde et rektangulært eller kvadratisk tverrsnitt. Lagget har nesten alltid sirkulær form, kun én rektangulær konstruksjon er 


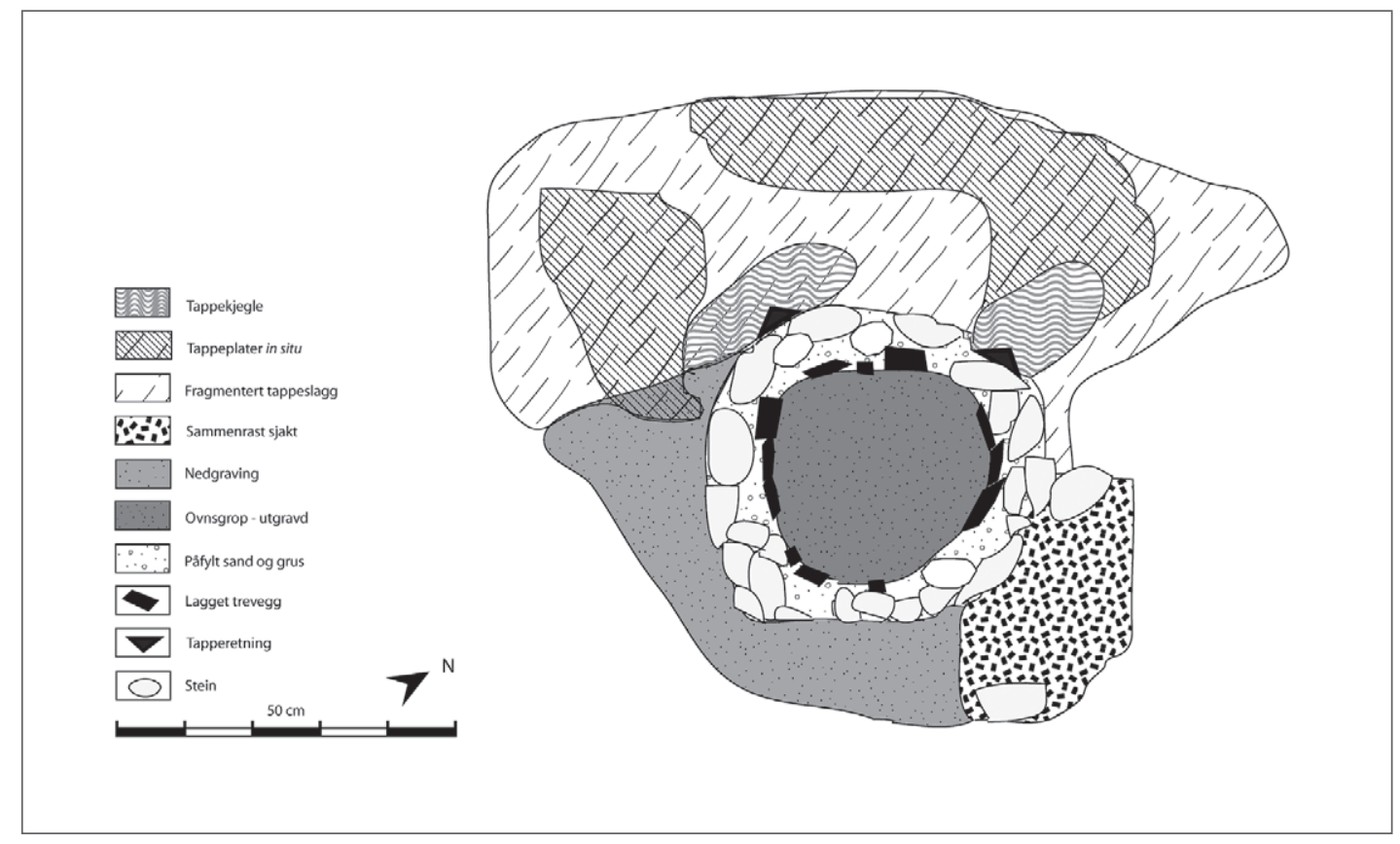

Figur 4:Jfp.11, ovn 2. Isoleringsgropen er tomt. Gropen er bygd opp av steiner og lagg av trevirke. Tappekjegler og tappeplater viser retningen for uttapping. Sjakten har rast sammen eller blitt revet mot sorost. Illustrasjon: $H$. Damlien / B. Rundberget, Kulturbistorisk museum.

Figure 4:Jfp.11, furnace 2 after emptying the isolation pit. Wall is covered by stones and a lagg of wood. Tapping cones and plates of tapped slag indicate direction of tapping. Drawing: H. Damlien/B. Rundberget, Museum of Cultural History.

påvist (Jfp.3, produksjonsplass 2, ovn 3). Hver stav var spisset $\mathrm{i}$ enden og stukket ned $\mathrm{i}$ undergrunnen under bunnen av gropen. Lagget fulgte hele gropens dybde og stakk også noe opp i leirsjakten. Hvor høyt treveggen har gått opp i sjakten, er vanskelig å si sikkert, men i ovn 2 på Jfp. 3 er det tydelig at denne strakk seg til godt over bakkenivå.

Lagget er konstruert med stor grad av presisjon, og arbeidet har vært tidkrevende. Sett ut fra dette perspektivet må vi påregne at gropen har hatt en sentral funksjon under reduksjonsprosessen. Når trevirket har brent opp eller blitt gjennomforkullet, har et nytt lagg blitt konstruert. Det viser at lagget ikke kun har vært et element ved konstrueringen av gropen. Et viktig prinsipp med lagget er at stavene skal stå tett sammen - det har ikke bare blitt satt opp av vilkårlig nedsatte trepinner. Det kommer sannsynligvis av at ikke noe skal komme ut eller inn i gropen. Ut fra ovnens konstruksjon og funksjon er det tenkelig at veggen hadde som funksjon å hindre slagg i å renne inn i gropen (figur 4). Ved uttapping rant altså slagget ofte ned i steinforingen og inn mot isoleringsgropen. En rekke ganger ble det observert at slagg har rent ned porsjonsvis og størknet mellom treveggen og steinforingen. Veggen har blitt forkullet, men den har holdt stand, og slagget har stoppet mot denne. Tappeslagg er ikke påvist på innsiden av lagget, bortsett fra i enkelte tilfeller der stavene tydelig har kollapset. Her er det åpenbart at slagg har strømmet inn i gropen fra utsiden. I ett ekstremt tilfelle, nevnte Jfp.8, ovn 3, ser vi at gropen har blitt fylt opp av tappeslagg. Ovnen ble forlatt etterpå. Grunnen til at vi kan si dette med sikkerhet, er at løperetningen på renne- og størknestrukturen på slagget går inn fra sidene og ikke vertikalt ned.

I tillegg til å ha som funksjon å forhindre slaggen $\mathrm{i}$ å innta gropen, ser det ut som om den øvre delen av lagget, i overgangen mellom sjakt og grop, har hatt til oppgave å perforere bunnskollene. Bunnslaggen som akkumuleres under framstillingsprosessen, kan få en tykkelse på over 20 centimeter. Skollene omgir lagget ut mot veggene, og det dannes her et porøst slagg som vil være forholdsvis enkelt å ta opp etter endt produksjon.

Lagget kan også ha hatt en forskalingsfunksjon ved oppmuring av ovnssjakten. I ett tilfelle er det påvist spor etter trevirke på innsiden av et sjaktfragment. Som oftest er imidlertid innsiden påvirket av sterk varme og forslagget, slik at trevirket ikke kan observeres. Lagget som går opp i ovnssjakten på Jfp.3, er, foruten sjaktfragmentet med treavtrykk, 
den eneste sikre indikatoren på at lagget har hatt en forskalingsfunksjon.

Isoleringsgropene i Gråfellområdet har i motsetning til det som omtales som slaggroper i eldre jernalders jernproduksjon (se Larsen i denne boka), ikke hatt som funksjon å samle opp slagg under brenningen. Det kommer til utrykk på flere måter. For det første er dette slaggavtappingsovner, og behovet for en underliggende grop for slaggansamling har ikke vært til stede. Det er heller ikke påvist groper som er gjenfylt, eller funnet slaggblokker som er typiske for oppsamling i grop. Lagget er også et element som tilsier at en slik prosess ikke har funnet sted, da lagget er konstruert for å stenge slaggen ute fra gropen.

I overgangen mellom grop og sjakt har det dannet seg et slagglag som betegnes som bunnskolle (figur 5). Bunnskollen danner bunnsjiktet i den delen av ovnen hvor reduksjonen har foregått. De er tung, har stor tetthet og har mørke fargenyanser, ofte også med innslag av mindre rustrøde partier med jern. Bunnskollene er formet etter ovnsveggens innside. På oversiden er den fra bolleformet til tilnærmet flat. I de fleste tilfeller er det som nevnt også treavtrykk fra lagget i bunnskollens sider. Arkeometallurgiske undersøkelser av bunnskoller viser et entydig resultat med hensyn til form og oppbygning. Fellesnevneren er en grovkornet homogen slagg som er dannet og størknet over tid (Grandin et al. 2004). Spredd i skollen finnes jern i mindre kon- sentrasjoner, ofte rundt kullstykker som er innkapslet i slaggen. I bunnsjiktet av skollen finnes innslag av kvarts, kull, slaggfragmenter og røstet malm. Dette er en sammensintret masse fra den underliggende gropen som ofte består av kull, malm, grus, sand og slagg. De metallurgiske analysene viser at denne porøse sammensintrede massen er resultatet av to prosessledd. I første omgang er slagg dannet i form av uttapping og/eller i ovnen. I en senere kjøring har den samme slaggen blitt gienbrukt i en tidlig fase, før dannelsen av bunnskollen. Reduksjonsprosessen har ennå ikke kommet skikkelig i gang, men slaggen har sintret seg sammen med andre bestanddeler som sand, kull og røstet malm, og i noen tilfeller også sjaktfragmenter av brent leire.

Isoleringsgropen har hatt en viktig funksjon i framstillingsprosessen. Det kommer tydelig fram gjennom den omhyggelig oppbygde konstruksjonen. Jeg har ikke funnet paralleller i det europeiske materialet, og funksjonen må naturlig nok ha hatt en sammenheng med denne spesifikke metoden. Trolig har isoleringsgropen hatt flere oppgaver under driften. Et forslag er at den fungerte som en fuktsperre (Espelund og Nordstrand 2003). Imidlertid er anleggene i Gråfjellområdet som oftest lagt på tørre morenerygger med god drenering og lite tilsig av vann. Problemer med høyt grunnvann forekommer sjelden. Behovet for en grop for oppsamling av vann ser følgelig ikke ut til å være til stede. Slik jeg ser det, er det også lite sannsynlig at gropene ville ha vært

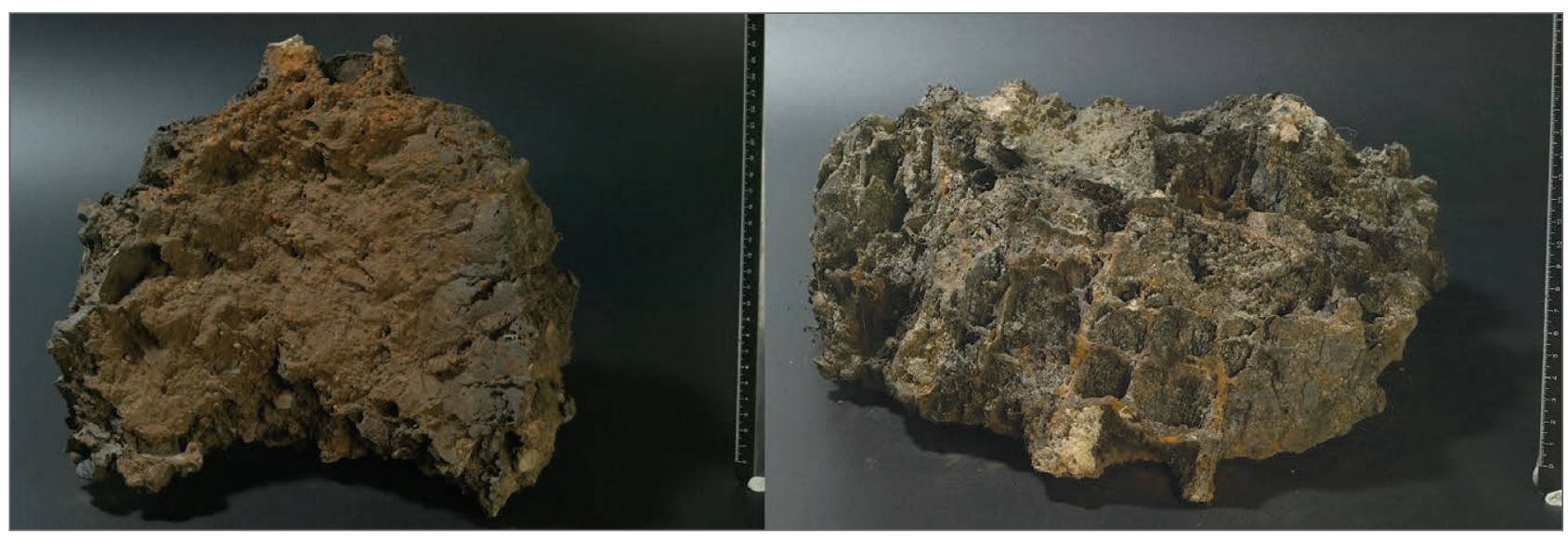

Figur 5: En nesten fullstendig bunnskolle fra Jfp.36 formet etter den sirkulere sjaktveggen. Til venstre ser vi oversiden av bunnskollen hvor jernluppen har blitt dannet. Mot utsiden kan vi skimte avtrykk av trevirke fra den laggede treveggen. Øverst $i$ bildet ser vi avtrykk etter blesteråpningen. Til høyre ser vi undersiden på bunnskollen. Slaggen har klare avtrykk av treveggen, og den skifter karakter fra å vare kompakt til à bare preg av mindre varmepävirkning der reduksjonene er i en tidlig fase. Foto: M. Teigen, Kulturbistorisk museum.

Figure 5: Nearly complete bottom crust from Jfp.36 formed in the circular shaft wall. Left: the top of the crust where the bloom was shaped. An impression of the wood from the wall of the shaft can be seen at the outside. A circle formed by the tuyere is seen at the top. Right: bottom of the crust The slag has a clear impression of the wood wall and changes character from being compact to exhibiting more modest signs of heating as the reduction phase would have been in an early stage. Photo: M. Teigen, Museum of Cultural History. 
konstruert så omhyggelig og identisk om oppsamling av vann var deres hovedfunksjon.

En annen forklaring kan dreie seg om behovet for isolering både under prosessen i leirsjakten og under slaggavtappingen. Som nevnt er det ikke påvist noen form for isolering utenfor leirsjaktene. Formen og plasseringen til de uttappede slaggen tilsier også at det ikke har vært noen form for ytre foring bortsett fra flis-/barkveggen, som på sin side ikke kan ha hatt noen isolerende funksjon. En underliggende grop kan i en slik sammenheng ha en underisolerende effekt for å unngå at bunnslaggen «fryser» for raskt. En varm grop kan også ha bidratt til god avrenning ved slaggavtapping. Etter at slaggen har blitt tappet ut i kald, fri luft, vil den størkne raskt, men den flytende tilstanden vil bli forlenget ved at bakken rundt ovnen holder en viss temperatur.

Isolering kan likevel ikke ha vært gropenes eneste funksjon. Lagget har hatt som en funksjon å unngå at gropene ble fylt med slagg, sannsynligvis for ikke å måtte ødelegge gropene ved opptak av gropslagg. Da treveggen er tolket som en sperre for tappeslagg. som har rent ned langs yttersiden av gropveggen, må rommet innenfor ha vært forbeholdt noe annet. En mulig hypotese er at gropen har en sammenheng med oppvarmingsfasen der kull og malm passerer gjennom sjakten uten at reduksjonen tar fatt. Men varmen har like fullt vært så stor at det har vært en begynnende slaggdanning. I massen fantes det imidlertid ofte også noe fragmentert slagg fra tidligere brenninger. Hvorfor denne slaggen er gjenbrukt, vet vi ikke sikkert. En annen mulighet er at det er fylt på masse i gropen før sjakten har blitt anlagt.

Så vidt meg bekjent finnes det ingen kjente paralleller til denne typen isoleringsgrop i det europeiske jernvinnematerialet, men nyere metoder som ble utviklet i renessansen, har benyttet en tilnærmet lik isoleringsmetode (f.eks. Karsten 1831). Og også innen tidlig koppersmelting er fenomenet kjent (pers.med. Hans-Gert Bachmann).

En parallell finnes også i den japanske Tatarateknologien (f.eks. Inoue 2010). Disse jernutvinningsovnene har røtter tilbake til yngre jernalder og består av runde eller firkantede ovnssjakter i tillegg til en underliggende grop fylt med kull (kalt kullbad), hvor funksjonen er å isolere og å unngå fukt. Som i Gråfjellområdet tappes slaggen fra noe høyde, og under driften er slaggen svært lettflytende. Jeg ser ingen sammenheng mellom ovnstypene, men teknologien kan være mer utbredt, om enn i en noe annen form. På Tæbring på Mors har Olfert Voss og Arne Jouttijärvi gravd ut en ovn fra 700-tallet som trolig er en slaggavtappingsovn (pers.med. Jens Jørgen Olesen, 19.03.2012). Under ovnssjakten ble det påvist et tykt kullag i en mindre forsenkning. Tolkningen på strukturen er at det har vært et kullbad, som i Tatara-prosessen, som isolasjon mot den kalde bakken. Massen i isoleringsgropene i Gråfjellområdet kan dermed tolkes i retning av å være et slikt kullbad.

\section{SLAGGAVTAPPING}

Slaggavtappingen i Gråfjellområdet og på Rødsmoen avviker fra det som er kjent fra øvrige utgravinger (Rundberget 2007; Larsen 2009). Enkle slaggstudier ved registreringer gjør det mulig å skille ut den sørøstlige delen av Hedmark som en tradisjon (vi kaller den her for Hedmarkstradisjonen, etter dens hovedsakelige geografiske utstrekning, jf. Narmo 2000), mens slaggen fra det øvrige landet har en mer eller mindre lik karakter (Rundberget 2007; 2008). Det må her påpekes at det finnes variasjoner i organiseringen også mellom andre regioner i Norge (f.eks. Narmo 2000; Larsen og Rundberget 2009), men når det gjelder ovnens oppbygning og prosess, er likhetene store. Det vanlige i slaggavtappingsteknologien, både i Norge og i Europa for øvrig (f.eks. Pleiner 2000), er at det er konstruert en smal renne på bakkenivå som løper ut fra et uttappingshull i ovnen. Ved uttappingen får slaggen dermed form som slaggstrenger (f.eks. Martens 1988; Narmo 1996; Larsen 2004; Rundberget 2008). I etterkant av Dokkaprosjektet ble det utarbeidet kriterier for definisjonen av denne typen tappeslagg (Narmo 1996: 84-87), hvor hovedkriteriet går på at slaggen skal ha en overside med rennestruktur og en underside der sand og grus fra rennen har størknet fast til slaggen.

Slaggen i Gråfjellområdet har en annen karakter. Det kan ha flere fasonger, men kjegleformen er den grunnleggende, da slaggen har rent vertikalt ned langs ovnsveggen og størknet. Begrepet planfotslagg ble tatt i bruk på Rødsmoen (Narmo 1997: 119-120), da noe av tappeslaggene fikk en form som minner om en fot. Slaggtypen er tidligere beskrevet som slaggdryppkjegle på grunn av den karakteristiske kjegleformen med en overflate som minner om størknet stearin (Falck-Muus 1927).

Renneslagg er en annen benevnelse som også blir brukt for å beskrive slaggen fra slaggavtappingsovner (Falck-Muus 1927; Hauge 1946; Martens 1988). Det er et naturlig begrep å bruke, da slaggen som blir tappet ut på bakkenivå, blir ført bort fra ovnen $i$ en konstruert hellende renne. Lars Erik Narmo har påpekt at prosessleddet er det samme, uansett 

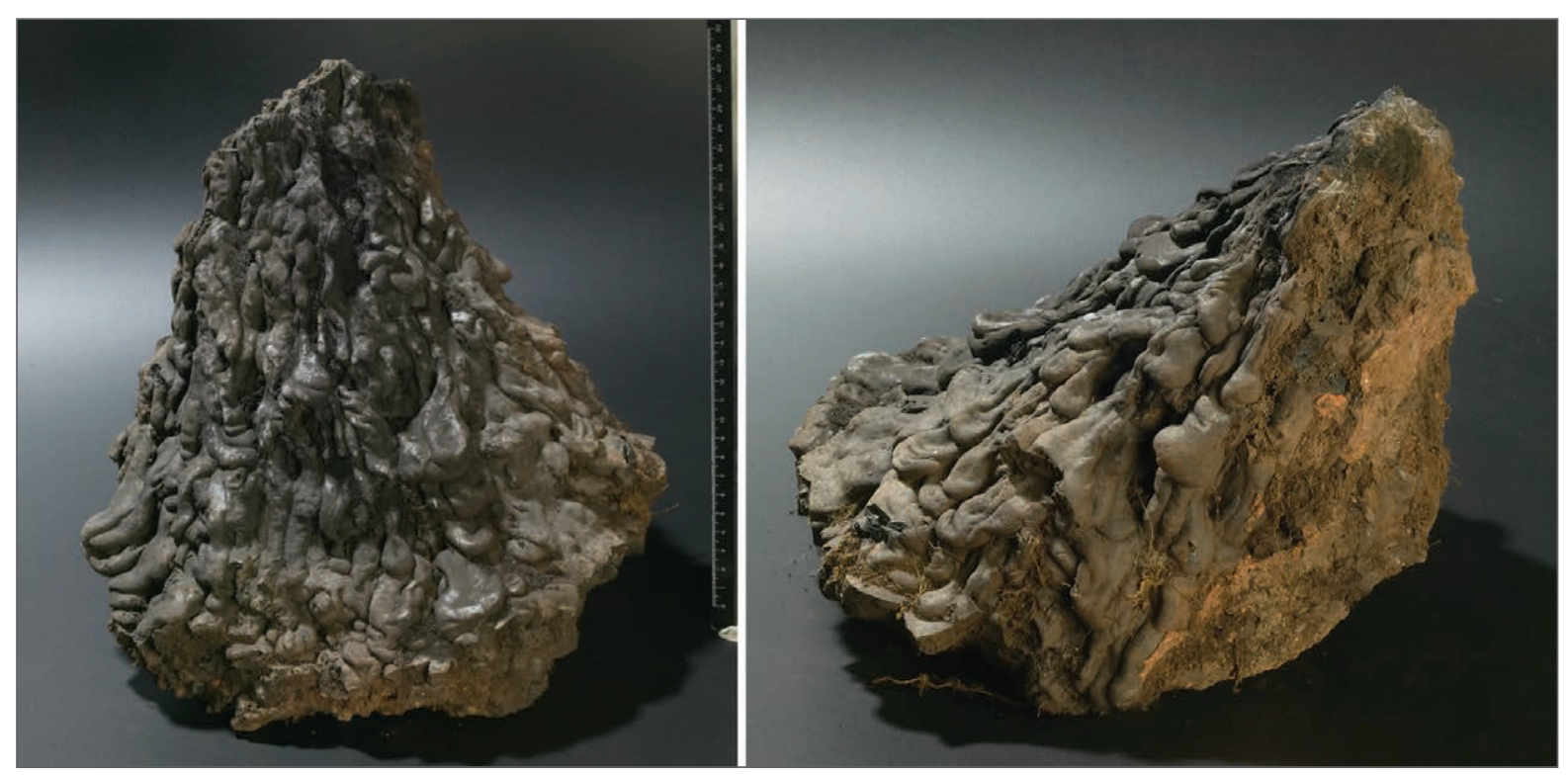

Figur 6: Tappekjegle med en høyde på $23 \mathrm{~cm}$. Til venstre ser vi overflaten som viser at det har vart en stadig flom av slaggstenger. Til hoyre ser vi baksiden med klare avtrykk etter leirsjakten. Foto: M. Teigen, Kulturhistorisk museum.

Figure 6: Slag-tapping cone with a height of $23 \mathrm{~cm}$. Left: surface showing evidence of continual dripping of slag. Right: back of the same slag cone showing the impression from the clay shaft. Photo: M. Teigen, Museum of Cultural History.

metode, og han har argumentert for at tappeslagg bør benyttes som felles begrep (Narmo 1996). Med bakgrunn $\mathrm{i}$ at produksjonsmetodene i Hedmark avviker fra det øvrige norske materialet, bør det diskuteres hvorvidt det skal benyttes en felles term. Slaggen på jernvinneanlegg på blant annet Dokkfløy, Hovden og Møsstrond renner ut horisontalt. Ved å benytte det gamle begrepet renneslagg i forbindelse med disse ovnene vil vi få et klarere begrepsmessig skille ut fra variasjoner i produksjonsmetoder (Rundberget 2007: 326)

På bakgrunn av hva som er avdekket om ovnstypen, bør tappeslagg derimot benyttes som en fellesbenevnelse på den uttappede slaggen i Hedmarkstradisjonen. Felles for dette området er at slaggen ble tappet fra en viss høyde ned langs sjaktveggen i flere etapper, og slaggen har helt eller delvis størknet mellom tappingene. Flere tilfeller viser også at tappingen har skjedd under høyt trykk, slik at treffpunktet på bakken ligger flere centimeter ut fra sjaktveggen. Resultatet er det jeg vil karakterisere som tappekjegler (figur 6). Tappekjeglene kan ta to former: som en halv kjegle om slaggen har rent langs sjaktveggen, og som en hel kjegle om den har rent ut under høyt trykk. Funn av slaggkjegler på mer enn 60 kilo antyder at én enkelt produksjon har foregått over et langt tidsrom, og at jernlupper må ha blitt tatt ut flere ganger under prosessen.

En annen form er de nevnte tappeplatene. Dette er tappekjeglenes forlengelse på flat mark. De har en flytestruktur som ofte er tykkere, bredere og mer utflytende enn slaggkjeglene. I enkelte tilfeller er overflaten helt glatt. Tappeplater er de restene etter produksjonen som oftest ligger in situ (jf. Jfp.3, figur $3)$.

Som allerede nevnt lå isoleringsgropene i mange tilfeller $i$ en avlang eller oval nedgravning orientert $i$ samme retning som slagghaugene. Nedgravningen er tilpasset produksjonsmetoden med slaggavtapping fra en viss høyde, og blir her omtalt som tapperenner. Tapperennene kan se ut som om de er en kombinasjon av å være konstruert før produksjonen og et resultat av langvarig drift. De er bredest, dypest og lengst på anlegg med store slagghauger, noe som må antas å ha sammenheng med en langvarig drift med et stort antall uttappinger. Ved opprensing og oppkasting av slagg har også undergrunnsmasser blitt med. Sammenhengen mellom lengden på haugene og tapperennene støtter opp om dette. Haugene er påbygd i lengderetningen, og slaggen har trolig blitt fjernet ved at tapperennene også har blitt benyttet til transport, ved at slagg ble raket bort fra ovnene og ut mot endene før den ble deponert på haugene.

Et annet trekk som indikerer en gradvis utgraving av tapprennene, er tappekjegler med varierende høyde på de samme produksjonsplassene. Fallet blir høyere med en dyp renne, og korte tappekjegler relateres til tidlige produksjonsfaser. Det har tilsyne- 
latende ikke vært noen intensjon å ha en fast tappehøyde, da det ikke er påvist påfylte sandlag $\mathrm{i}$ bunnen av rennene. Et sentralt poeng med dype tapperenner er ønsket om å kjøre produksjonen over lange tidsintervaller uten å måtte fjerne slaggen. Det ble ved flere anledninger påvist en rekke fortløpende uttappinger med så lange tidsintervaller at hver slaggflom har rukket å størkne. På tappeslaggen fra rennen ved ovn 2 på Jfp. 9 ble det påvist 18 separate uttappinger. Metallurgiske analyser bekrefter dette (Grandin et al. 2004), men her kan vi også se at den påfølgende slaggflommen noen ganger har blitt tappet med en slik tidsavstand at den har trengt igjennom en størknet hinne og inn i en fortsatt flytende kjerne fra den tidligere tappingen.

I noen tilfeller er det ikke påvist slike nedgravninger. Det finnes varierende metoder for slaggavtapping på disse anleggene. Det kan da være tappet i den sirkulære eller ovale skråskårne nedgravingen hvor isoleringsgropen er anlagt (f.eks. Jfp.13). Andre steder er det også konstruert mindre tappegroper rundt ovnen (f.eks.Jfp.29). En tredje metode er at naturlige forsenkninger og helling $i$ terrenget har vært brukt for å lede bort slaggen (f.eks. Jfp.3, produksjonsplass 2). De to siste variantene hører til unntakene, mens bruk av ytre del av isoleringsgropen som tappegrop forekommer forholdsvis hyppig i materialet. I alle disse tilfellene har gropene blitt fylt opp raskt, og slaggen har rent ut over opprinnelig bakkenivå.

\section{OVNEN - EN SAMMENFATNING}

Ovnstypen i Gråfjellområdet kan trolig plasseres i gruppen Radomir Pleiner omtaler som små, frittstående, tynnveggede sjaktovner (2000: 173). Men ovnene har i tillegg den karakteristiske isoleringsgropen med flerdelt funksjon, hvorav isolering er den mest sentrale. Jeg har av den grunn definert ovnstypen til å være en frittstående, tynnvegget, underisolert sjaktoon med slaggavtapping (Rundberget 2013: 114). Samtidig har gropen muligens hatt en funksjon tidlig i blestringen, nemlig å samle opp avfallsmateriale som ikke inngår i slaggdannelsen og/eller å utgjøre et eget prosessledd der massen bevisst er påtenkt å gå gjennom en delvis reduksjon for gjenbruk. Uttappingen foregikk fra en viss høyde og ned i en tapperenne eller en annen form for nedgravning. Dette har bakgrunn i et ønske om en langvarig drift uten unødig produksjonsstans (figur 7).

Lufttilførselen har skjedd ved hjelp av blåsebelger, noe funn av et munnstykke av jern til en blåsebelg på Jfp.39 vitner om. Tappehullet på en ovn på Jfp. 3 er allerede nevnt, og i sjakten på ovn
2 på Jfp.28 ble det også påvist en kanal gjennom sjaktrestene. Denne hadde samme form og dimensjon som munnstykket, og plasseringen inn mot produksjonsområdet antyder at kanalen er et spor etter blesterhullet. På flere av jernframstillingsplassene var det også spor etter blåsebelgene i form av sand- og steinfundamenter. Det er ikke funnet spor etter stolpehull og konstruksjonen for belgopphenget har vært lagt direkte på bakken. Da det i mange tilfeller har vært en samtidig drift $i$ to ovner, har det også vært behov for en mobil konstruksjon. På Jfp. 23 ble det ved ovn 1 funnet en jernring og en jernstang som besto av to ledd. Stangen hadde vært festet til ringen i den ene enden. Det ytre leddet hadde en krok ytterst. Funnkonteksten tilsier at den kan ha vært en del av et leddet oppheng til en blåsebelg, der ringen kan ha vært tredd på en tverrgående overliggende stokk. På flere jernfram-

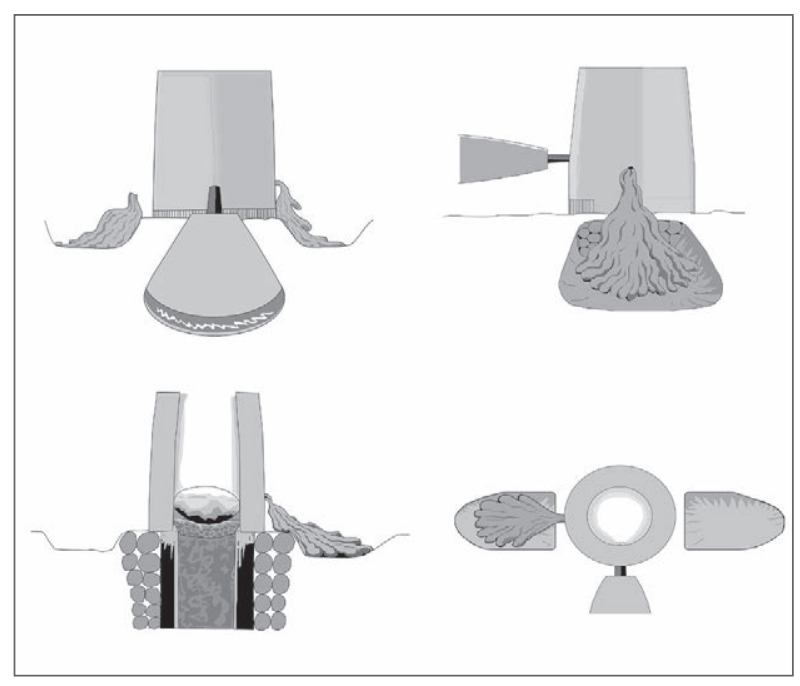

Figur 7: Blesterovnen rekonstruert etter gjennomsnittsmål og tolkninger av morfologi og drift. Øverst til venstre er ovnen sett fra produksjonsområdet med blàsebelgen i front. Tappingen har foregätt vekselvis i to renner/groper. Øverst til hoyre er ovnen sett fra siden med tappehull og tapperenne. Figuren nederst til venstre viser et snitt gjennom ovnen sett fra produksjonsplassen. Figuren viser oppbyggingen og relasjonen mellom sjakt og grop. I bunnen av sjakten ser vi bunnskollen og jernluppen. Nederst til hoyre er ovnen sett ovenfra. Illustrasjon: R. Borvik.

Figure 7: Reconstruction of a furnace using average dimensions together with interpretations of morphology and process. Above left: the furnace seen from the production area with the bellows in front. It is tapped alternately into two gutters/pits. Above right: the furnace seen from the side, with a tapping hole and gutter. Below left: section through the furnace seen from the production site. The figure shows how it was constructed in relation to the shaft and the pit. The bottom crust and bloom can be seen in the base of the shaft. Below right: the furnace from above. Drawing: $R$. Borvik. 


\section{Teknologiske og organisatoriske forskjeller}

\begin{tabular}{|c|c|c|c|}
\hline Komponenter & Elementer & Sørøstnorsk tradisjon* & Hedmarkstradisjonen \\
\hline Ovner & Overbygning & $\begin{array}{l}\text { Sirkulær/oval leirsjakt isolert } \\
\text { med steiner/heller, sand og } \\
\text { muligens tømmerkasse }\end{array}$ & Sirkulær sjakt, ingen isolering \\
\hline Ovner & Underkonstruksjon & $\begin{array}{l}\text { Ingen grop, av og til en mindre } \\
\text { forsenkning i bakkenivå }\end{array}$ & $\begin{array}{l}\text { Grop anlagt under sjakta, vegge- } \\
\text { ne oppbygd av steiner og lagg av } \\
\text { trevirke. Isolering som funksjon, } \\
\text { masse - «kullbad» }\end{array}$ \\
\hline Ovner & Støtte & $\begin{array}{l}\text { Tynnveggede sjakter støttet av } \\
\text { steinheller, tømmerkasser eller } \\
\text { de er gravd inn i en morenevegg }\end{array}$ & Frittstående sjakt, ingen støtte \\
\hline Ovner & Slaggavtapping & Små renner i bakkenivå & $\begin{array}{l}\text { Hevet } 20-30 \mathrm{~cm} \text { fra bakkenivå } \\
\text { eller i dype vide groper/renner }\end{array}$ \\
\hline Ovner & Slaggterminologi & Renneslagg & Tappeslagg \\
\hline Kullgroper & Form & $\begin{array}{l}\text { Hovedsakelig sirkulære, firkan- } \\
\text { tede forekommer }\end{array}$ & $\begin{array}{l}\text { Kun firkantede, hovedsakelig kva- } \\
\text { dratiske, rektangulære forekommer }\end{array}$ \\
\hline Kullgroper & Storrelse & $\begin{array}{l}\text { Ofte små og grunne, Større } \\
\text { groper er ikke uvanlig }\end{array}$ & $\begin{array}{l}\text { Mer eller mindre fast størrelse, } \\
\text { både i areal og dybde. Store og } \\
\text { dype forekommer }\end{array}$ \\
\hline Kullgroper & Antall & $\begin{array}{l}\text { Sjelden mer enn 3-4 tilhørende } \\
\text { hvert anlegg }\end{array}$ & $\begin{array}{l}2->30 \text { groper knyttet til anleg- } \\
\text { gene }\end{array}$ \\
\hline Kullgroper & Organisering & $\begin{array}{l}\text { Utvikling fra spredt i terrenget } \\
\text { mot å bli en integrert del av } \\
\text { produksjonsplassen, ligger da } \\
\text { gjerne på rekke. }\end{array}$ & $\begin{array}{l}\text { Spredt i terrenget rundt anleggene, } \\
\text { distanse opp til } 600 \mathrm{~m}\end{array}$ \\
\hline Produksjonsplassen & Skala & $\begin{array}{l}\text { Ofte småskala eller middel- } \\
\text { skalaproduksjon, 2-5 tonn slagg } \\
\text { på hvert anlegg }\end{array}$ & $\begin{array}{l}\text { liten, }<1 \text {, til storskala, > } 80 \text { tonn } \\
\text { slagg på hvert anlegg. Store anlegg } \\
\text { i klart overtall }\end{array}$ \\
\hline Produksjonsplassen & Organisering & $\begin{array}{l}\text { Vanlig i mindre bygninger, ett } \\
\text { til flere rom. En til to ovner } \\
\text { samtidig. Malm lagret under } \\
\text { tak, kull lagret under tak eller i } \\
\text { kullgropene }\end{array}$ & $\begin{array}{l}\text { Ikke spor etter blesterhus. Nesten } \\
\text { alltid to ovner drevet parallelt, delt } \\
\text { kull- og malmlager. En slagghaug } \\
\text { er knyttet til hver ovn }\end{array}$ \\
\hline Produksjonsplassen & Opphold & $\begin{array}{l}\text { Oppholdsrom i to eller fle- } \\
\text { reromshus. Med ildsted }\end{array}$ & $\begin{array}{l}\text { Små ettromsbygninger rett utenfor } \\
\text { fremstillingsplassen. Med ildsted }\end{array}$ \\
\hline
\end{tabular}

*) Den sørøstnorske tradisjonen sprer seg fra Oppland i øst til Setesdal i Aust-Agder i sørvest. Det må påpekes at dette ikke er en helhetlig tradisjon men at det på tvers av jernproduksjonsregionene er store likheter til forskjell fra Hedmarkstradisjonens egenart.

Tabell 1: Teknologiske og organisatoriske forskjeller mellom de sørøstnorske tradisjonene og Hedmarkstradisjonen $i$ vikingtiden og $i$ middelalderen. Etter B. Rundberget 2011: 195.

Table 1: Technological and organizational differences in the southeastern traditions and the Hedmark tradition in the Viking Age and Medieval Period. After B. Rundberget 2011: 195. 


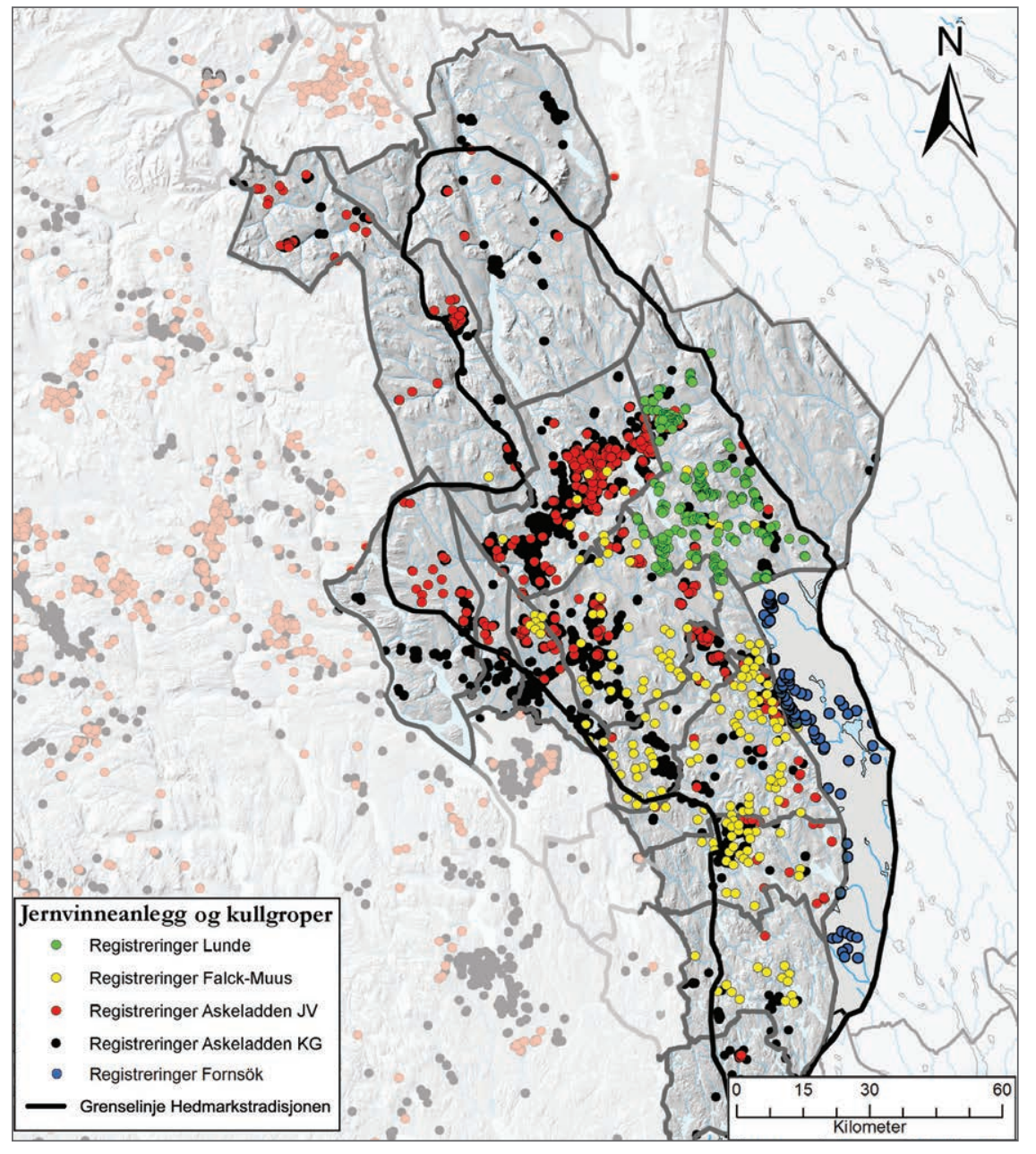

Figur 8: Utbredelse av Hedmarkstradisjonen med angitte grenser. Punktene med forskjellige farger representerer forskjellige registreringer. Også kullgropene er angitt. Grensen må ikke anses som statisk og fastlagt, men som dynamisk og $i$ endring. Etter B. Rundberget 2013: 204. Figure 8: Spread of the Hedmark tradition, with indicated borders. Dots with different colors represent different surveys. Charcoal pits are also included. The border must not be regarded as static and fixed, but dynamic and changing. After B. Rundberget 2013: 204. stillingsplasser er det funnet hengsler, eller beslag, med usikker funksjon. Felles for gjenstandene er at de har kroker eller ringer i begge ender. Flere har også sømhull. Muligens har disse hatt en sammenheng med blåsebelgkonstruksjonene.

I det arkeologiske materialet finnes det få spor etter selve blåsebelgen, men vanlige tolkninger er at det ble brukt spissbelger. Typen er kjent gjennom flere samtidige eller tidligere framstillinger, som på Hylestadportalen. Ut fra normalt plassbehov på framstillingsplassene og utstrekningen på fundamenter som er påvist, er sannsynligheten størst for at det ble benyttet én dobbeltvirket spissbelg, uten at det kan sies med sikkerhet. Fundamentering og funn av oppheng for en større belg kan imidlertid være indikatorer som peker i retning av at det var slik. Belgen var plassert mellom råstofflagrene, og det var arbeidsplass på begge sider av belgopphenget.

\section{EN METODE I GRENSELAND?}

Resultatene fra de arkeologiske undersøkelsene i Gråfjellområdet og på Rødsmoen viser tydelig at vi her har å gjøre med en «ny» tradisjon. Jeg har i et tidligere arbeid sett på forskjeller i teknologi og variasjoner mellom Hedmark og resten av Sør- og Midt-Norge (Rundberget 2012). Hovedtrekkene er grovt sammenfattet $\mathrm{i}$ tabellen under (for mer detaljer om den vanligste ovnstypen, se Narmo 1996, Larsen 2009 og Mjærum og Larsen i denne publikasjonen).

Registreringer viser at Hedmarkstradisjonen strekker seg fra Stor-Elvdal i nord til Eidskog i sør. Mot øst følger skillet mer eller mindre fylkesgrensen til Oppland, men det er observert enkelte anlegg av Dokkfløytypen på vestsiden av Glomma. Det gjelder både i Atnadalføret og i Imsdalen. Mot øst ser det ut til at Trysilelva danner en klar grense. Øst for denne er det ikke påvist anlegg av Hedmarkstypen i Norge. Heller ikke kullgroper er påtruffet her. Går vi over grensen og til Sverige, er ett anlegg av Hedmarkstypen arkeologisk undersøkt og datert i Lima, Dalarne (Carlsson og Magnusson 1999). I et belte øst for grensen i Torsby, i Vämland, er det derimot påvist flere titalls anlegg av denne typen (Svensson 1998; Myrdal-Runebjer 1999; Rundberget 2013). Anleggsstruktur, ovnstype og slaggfunn peker helt klart mot at dette er et anlegg 
av Hedmarkstypen. Et bilde som dermed kommer fram, er at det ikke er selve landegrensen som dannet grensen for tradisjonen, men elveløpene til Glomma og Trysilelva/Klarälv.

Det anlegget som ligger lengst sør av alle de kjente anleggene, befinner seg i Eidskog og er utgravd av Irmelin Martens (1980). Det er vanskelig å tolke ovnen, men det er ut fra rapporten og bilder klart at det er selve isoleringsgropen som ble undersøkt. Funn av karakteristiske slaggkjegler bekrefter at anlegget i Eidskog er av samme type som anleggene i Gråfjellområdet. Ytterligere fem anlegg i Eidskog som ligger innenfor et lite område, er trolig også av samme type. For øvrig er det få kjente anlegg helt sør i Hedmark. Det er blant annet ikke påvist ett eneste sikkert anlegg i Kongsvinger. Tettheten avtar også tydelig ved Grue Finnskog. Sør for denne grensen finnes det kun spredte anlegg, og store områder er funntomme, men her gjenfinnes det altså en rekke anlegg på svensk side.

Ut fra opplysningene over anslår jeg derfor hovedområdet til å strekke seg fra Koppang i nord til Eidskog i sør. Interessant er det som nevnt at vassdragene Glomma og Trysilelva kan se ut til å danne en form for skille. Det er mellom disse elvene det absolutte flertallet av anleggene ligger. Foruten hovedområdet har metoden kjente utstikkere i Lima. Går vi inn i Oppland, er det derimot ikke påvist ett eneste anlegg av denne karakteren. Spesielt interessant er det derfor at jernproduksjonen i Hedmark i slutten av vikingtid og i middelalder hadde en særegenhet med klare grenser. I både tid og rom finner vi elementer som viser at produksjonen her skiller seg fra den øvrige jernproduksjonen. Vi kan spørre hvorfor bildet er slik. Artikkelen har ikke disse problemstillingene som hovedtema, og det er ikke rom for en dypere diskusjon av temaet her, men faktorer som sen ekspansjon og bosetning med utvikling av egne produksjonsformer og ideer, landskap og ressurser, råstoff, styringssett og råderett, produksjonsvolum og distribusjonskanaler er alle aktuelle forklaringsmodeller (jf. Rundberget 2012; 2013).

\section{SUMMARY}

The investigation of iron extraction sites in Gråfjell, County of Hedmark, has revealed an intensive production at the end of the Viking Period and early Medieval times (c. AD 950-1300). Altogether 115 iron production sites, almost 1,800 charcoal pits and more than 300 roasting places were surveyed. Excavations included 39 production sites, more than 200 charcoal pits and 25 roasting» places. The results are important as regards the furnace type; morphology, technology and method were clearly typological, unlike contemporary production areas in Norway. And in addition, organization as well as distribution in the landscape also differs from other areas. As part of the production is also charcoal burning in pits, here both shape and process distinguishes this region from the others.

This particular furnace type and organization has also been excavated at Rødsmoen, just southwest of the Gråjell area, and the tradition is known in large parts of Østerdalen and Solør, from Koppang in the North to Eidskog in the South. To the West, the tradition ranges almost to the agricultural areas beside Lake Mjøsa, and to the East to the river of Trysil/ Klarälv (Värmland, Sweden). In this paper the aim is mainly to present and discuss furnace type and technology. However, distribution, organization and differences to other regions are also themes, albeit to a lesser extent.

\section{LITTERATURLISTE}

Amundsen, H.R., O. Risbøl og K. Skare (red.) 2003. Pa vandring i fortiden. Mennesker og landskap $i$ Gråfell gjennom 10000 arr. NIKU Tema 7. Oslo: Norsk institutt for kulturminneforskning.

Amundsen, T. (red.) 2007. Elgfangst og bosetning $i$ Gråffellområdet. Varia 64. Oslo: Kulturhistorisk museum, Fornminneseksjonen.

Andersson,D.,L. Grandin, O. Stilborg og A.Willim 2006. Järnframställning på Gråfellet. Arkeometallurgiska analyser av 2005 års undersökningar, Gräfellområdet, Ämot Kommune, Hedmark, Norge. Analysrapport nummer 7-2006. Uppsala: Avdelingen för arkeologiska undersökningar, UV GAL.

Bårdseng, L. 1996. Utmarksregistrering i Hedmark 1996. Topografisk arkiv. Hamar: Hedmark fylkeskommune.

Carlsson, E., E. Kettis og G. Magnusson 1999. «ärnhandtering och bebyggelse i Lima och Transtrand». Lima och Transtrand. Ur två socknars historia 4: 191-244. Malung: Malungs kommun.

Damlien, H. 2007. «Jernframstillingsplasser i Gråffellområdet». B. Rundberget (red.) 2007. Jernvinna $i$ Gräfellområdet. Gräfellprosjektet I. Varia 63: 88-96. Oslo: Kulturhistorisk museum, Fornminneseksjonen.

Espelund, A. 1995. «Fra Rolf Falck-Muus sitt virke i Nord-Østerdalen». Nord-Østerdalen: Arbok for NordØsterdalen 1994/95: 46-54.

Espelund, A. 2005. Bondejern i Norge (ny utgave). Trondheim: Arketype forlag.

Espelund, A. og E. Nordstrand 2003. Metallurgiske undersokelser av jernvinneanlegg $i$ Gräfellet àr 2003. Trondheim: Institutt for materialteknologi, NTNU. 
Falck-Muus, R. 1927. «Fra noen jernvinneplasser i ÅsnesFinnskog». Norsk geologisk Tidsskrift: 358-397.

Falck-Muus, Rolf 1931. «Grensetraktenes jernsaga. Et fragment». Den norske turistforenings Ärbok 1931: 56-72.

Grandin, L. og E. Hjärthner-Holdar 2003: «Högteknologisk järnframställning». L. Karlenby (red.). Mittens Rike. Arkeologiska berättelser från Närke. Riksantikvarieämbetet Arkeologiska undersökningar Skrifter 50: 391-424. Stockholm: Riksantikvarieämbetets förlag.

Grandin, L., S. Forenius og E. Hjärthner-Holdar 2004. Järnframställning på Gråfellet. Arkeo-metallurgiska analyser, Gråfellet, Amot Kommune, Hedmark, Norge. Analysrapport nummer 2-2004. Uppsala: Avdelingen för arkeologiska undersökningar, UV GAL.

Grandin, L., A. Willim, S. Forenius og O. Stilborg 2005. Järnframställning på Gråfellet. Arkeometallurgiska analyser av 2004 års undersökningar, Gråfjellområdet, Amot Kommune, Hedmark, Norge. Analysrapport nummer 9-2005. Uppsala: Avdelingen för arkeologiska undersökningar, UV GAL.

Hammer, P.B. [1743] 2004. "Grue prestegjeld». Norge i 1743 2: 87-96. Oslo: Kristin S. Røgeberg.

Hauge, T. Dannevig 1946. Blesterbruk og myrjern. Studier $i$ den gamle jernvinna i det ostenfelske Norge. Universitetets Oldsaksamling Skrifter III. Oslo: Universitetets Oldsaksamling.

Holm, I. 1998. Utmarksregistreringer i Hedmark 1998. Rapport. Hamar: Hedmark fylkeskommune.

Inoue, T. 2010. "Tatara and the Japanese sword: The science and technology». Acta Mechanica 214/ 1-2: $17-31$.

Jacobsen, S., J.H. Larsen og L.E. Narmo 1988. «Nå blestres det på Dokkfløy. Et forsøk på eksperimentell arkeologi». Viking LII: 87-108.

Karsten C.J.B. 1831. System der Metallurgie - geschichtlich, statistisch, theoretisch und technisch. Berlin: G. Reimer.

Kiær, C.C. [1743] 2004. «Åmot prestegjeld». Norge i 1743 2: 120-121. Oslo: Kristin S. Røgeberg.

Larsen, J.H. 1991. Jernvinna ved Dokkfloyvatn. De arkeologiske undersøkelsene 1986-1989. Varia 23. Oslo: Universitetets Oldsaksamling.

Larsen, J.H. 2004. «ernvinna på Østlandet i yngre jernalder og middelalder - noen kronologiske problemer. Viking LXVII: 139-170.

Larsen, J.H. 2009. Jernvinneundersøkelser. Faglig program 2. Varia 78. Oslo. Kulturhistorisk museum.

Larsen, J.H. og B. Rundberget 2009. «Raw materials, iron extraction and settlement in South-eastern Norway 200BC-AD1150». Vitark 7, The 58th Sachsensymposium, 1.-5. September 2007: 38-50. Trondheim: Tapir.
Martens, I. 1980. Undersøkelse av jernvinneplass ved Hallbekken. Skotterud gnr. 53, Eidskog kommune, Hedmark. Rapport. Topografisk arkiv. Oslo: Kulturhistorisk museum.

Martens, I. 1988. «Jernvinna på Møsstrond i Telemark. En studie i teknikk, bosetning og økonomi». Norske Oldfunn XIII: 5-164. Oslo: Universitetets Oldsaksamling.

Myrdal-Runebjer, E. 1999. «A cultural heritage management view of the forest». A. Gustafsson og H. Karlsson (red): Glyfer och arkeologiska rum - en vänbok till Jarl Nordbladh. GOTARC Series A, bind 3: 633-642. Göteborg: Göteborgs Universitet.

Narmo, L.E. 1996. Jernvinna i Valdres og Gausdal - et fragment av middelalderens økonomi. Varia 38. Oslo: Universitetets Oldsaksamling.

Narmo, L.E. 1997. Jernvinne, smie og kullproduksjon $i$ Østerdalen. Arkeologiske undersøkelser på Rødsmoen $i$ Amot 1994-1996. Varia 43. Oslo: Universitetets Oldsaksamling.

Narmo, L.E. 2000. Oldtid ved Amotet: Østerdalens tidlige bistorie belyst av arkeologiske utgravinger på Rødsmoen i Amot. Rena: Åmot historielag.

Oppen, C. 1777. Beskrivelse over den Norske Jern-MybrMalms Optagelse, Tilberedelse og Smeltning, udendertil at bekoste, nogen Huuse, Bygning eller andskaffe Kuul; Ligesom i Reendablens Prestegieldog Østerdablens Fogderie brugeligt. Opsloe ved Christiania den 25de January 1777: Det KongeligeLandhuusholdnings Selskab.

Pleiner, R. 2000. Iron in Archaeology. The European Bloomery Smelters. Praha: Archeologiký ústav av čr.

Risbøl, O., T. Risan, R. Bjørnstad, S. Fretheim og B.H.E. Rygh 2002. Kulturminner og kulturmiljø $i$ Gräfell, Regionfelt Østlandet, Amot kommune i Hedmark. Arkeologiske registreringer 2001, fase 4. Oppdragsmelding nr. 125. Oslo: Norsk institutt for kulturminneforskning.

Rundberget, B. 2002. Teknologi og Jernvinne. En teoretisk og metodisk tilnarming til jernvinna som kilde for menneskelig kunnskap og handling. Hovedoppgave: Trondheim.

Rundberget, B. 2006. «Perspektiver på jernproduksjon i Gråfjellområdet». META, Medeltidsarkeologisk tidsskrift 2: $15-32$.

Rundberget, B. (red.) 2007. Jernvinna i Gräfellområdet. Gråfjellprosjektet 1. Varia 63. Oslo: Kulturhistorisk museum.

Rundberget, B. 2008. «Et kort omriss av jernvinna i Sør-Norge». B. Rundberget og F.A. Stylegard (red.). Jernvinna på Agder. Jernvinneseminaret $i$ Sirdal 25.-26. oktober 2007. Rapportserie No. 5: 16-33. Kristiansand-Oslo:Vest-Agder fylkeskommune og Kulturhistorisk museum. 
Rundberget, B. 2012. «Iron production in Østerdalen in Medieval Times ? A consequence of regional technological change?» R. Berge, M. Jasinski og K. Sognes (red.). N-TAG TEN. Proseedings of the 10th Nordic TAG conference at Stiklestad, Norway 2009. BAR international series 2399: 191-204. Oxford: Archaeopress.

Rundberget, B. 2013. Jernets dunkle dimensjon. Jernvinna $i$ sørlige Hedmark, sentral økonomisk faktor og premiss for samfunsutvikling c. AD 700-1300. Doktoravhandling: Oslo.

Schøning, G. [1775] 1980. Reise giennem een Deel af Norge. Gudbrandsdalen og Hedmarken. Trondheim.
Smekalovs T. og S. 2006. Magnetic Survey in Gråfjell, Regionfelt Østlandet, Amot kommune, Hedmark, Southern-Eastern Norway in 2000, 2001, 2002, 2004 and 2005. Final report. St. Petersburg: Physical Institute of St. Petersburg State University.

Smith, A.C. [1784] 1895. Beskrivelse over Trysild Prestegjeld i Aggershuus Stift i Norge. Christiania.

Stene, K., T. Amundsen, O. Risbøl og K. Skare (red.) 2005: «Utmarkens grøde». Mellom registrering og utgraving $i$ Gråfellområdet, Østerdalen. Varia 59. Oslo: Kulturhistorisk museum.

Svensson, E. 1998. Människor i utmark. Lund Studies in Medieval Archaeology 21. Lund: Lunds universitet. 


\title{
SLAGGEAFTAPNINGSOVNE I DANMARK, UDGRAVNINGER OG FORSØG
}

\author{
Henriette Lyngstrom
}

Mange danske udgravninger, teoretiske diskussioner og eksperimentel-arkæologiske forsøg har taget sigte på at afgrænse jernudvindingsovnens kronologiske og typologiske udvikling.

Vi ved, at bønder i Danmark har udvundet jern af myremalm helt fra den tidligste jernalder, men det arkæologiske materiale fra ældre førromersk jernalder er begrænset til slagger, ristet myremalm og genstande af jern. Selve jernudvindingsovnen er kun kendt fra perioden mellem yngre førromersk jernalder og frem i ældre germansk jernalder - samt igen fra den tidlige middelalder. I disse to kronologiske forløb kan der identificeres tre typologisk forskellige ovne: Espevejovne, Drengsted-ovne og slaggeaftapningsovne, der alle tilhører gruppen af vesteuropæiske skaktovne, mens de i den centraleuropæiske typologi er repræsentanter for henholdsvis skaktovne og aftapningsovne.

På seminaret Ovnskronologi og ounstypologi i den nordiske jernvinna, Kittilbu 2009 blev de få danske fund af slaggeaftapningsovne vurderet og diskuteret, ligesom der blev gjort rede for, hvordan disse ovne fungerer i eksperimentel-arkæologiske jernudvindingsforsøg. Der blev også argumenteret for en nuancering af de definerede ovntyper og for, at «typerne» ikke kun varierer i tid, men også i rum.

\section{PROBLEMER I DEN DANSKE OVNSKRONOLOGI OG OVNSTYPOLOGI}

Også i Danmark indtager jernudvindingsovnen en helt central plads i den arkæologiske jernforskning. De danske bønder udvandt jern af myremalm fra den tidligste jernalder, men det arkæologiske kildemateriale fra år 500 til år 200 f.Kr. er begrænset til slagger, ristet myremalm og genstande af jern. Selve jernudvindingsovnen er i Danmark kun kendt fra omkring år 200 f.Kr. til år 550 e.Kr., samt igen fra 1100 til 1300 e.Kr.

Det er i disse to tidsforløb arkæologen Olfert Voss med forbilledlig klarhed har identificeret og dateret tre typologisk forskellige ovne: Espevej-ovne, Drengsted-ovne og slaggeaftapningsovne (Voss 1993: 206). Og hans illustrative oversigt, hvor de numeriske værdier for Espevej-ovne og Drengstedovne siden er væsentligt forøget, er gengivet i adskillige sammenhænge og står som printet på alle danske arkæologers nethinder (figur 1).

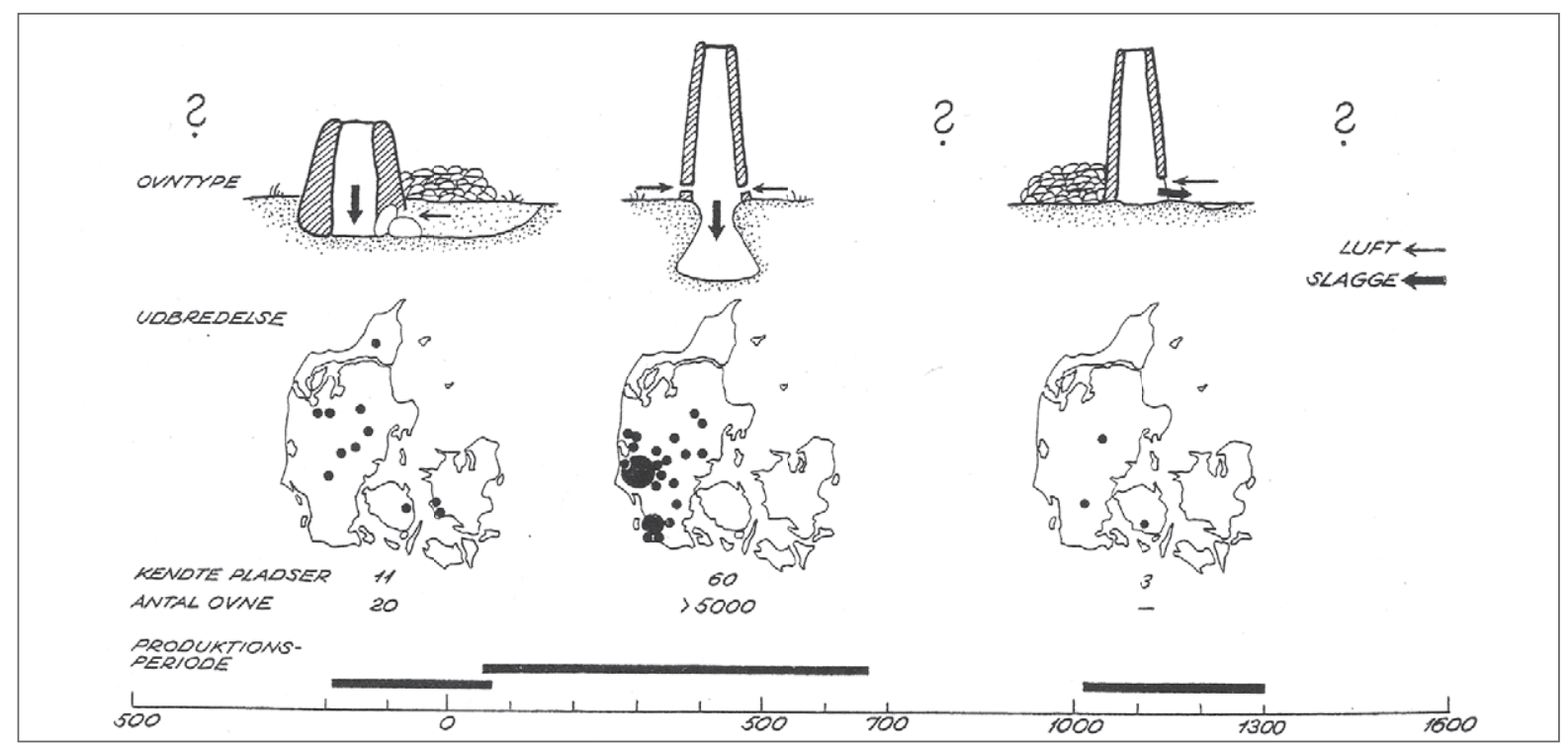

Figur 1: De tre forskellige typer jernudvindingsanleg $i$ Danmark og deres udbredelse i tid og rum. Olfert Voss' forbilledlige fremstilling fra 1993. Efter Voss 1993: 206.

Figure 1: The three different kinds of iron smelting furnaces found in Denmark and their distribution in time and space. Olfert Voss's fine figure from 1993. After Voss 1993: 206. 
Gennemgangen af det arkæologiske materiale af jernudvindingsovne fra Danmark forleder da også til opfattelsen af et enstrenget typologisk udviklingsforløb. Fra endnu ukendte ovne i tidlig førromersk jernalder til Espevej-ovne i sen førromersk jernalder og ældre romersk jernalder, knyttet til gården og den lokale smeltemester; frem til de større, vestjyske landsbyer og enkeltgårde med Drengstedovne, hvor kyndige bønder i yngre romersk jernalder og ældre germansk jernalder producerede betydelige mængder jern; og videre til en sandsynlig slaggeaftapningsovn i middelalderen - en ovn, der endnu kun er fundet ganske få steder, men som meget vel kan repræsentere et teknologisk højdepunkt i den danske jernudvinding.

Der er ingen tvivl om, at dette må være hovedlinjerne i den typologiske udvikling (Lyngstrøm 2002: 18f). Men betragter man etnografiske paralleller og det arkæologiske materiale fra landene omkring os, så er der ingen tvivl om, at det enstrengede forløb skal modificeres og de opstillede typer bør nuanceres.Vigtigt er det, at jernudvindingen i hele Europa kontinuerligt - gennem jernalder og middelalder - synes at være organiseret omkring gården og landsbyen og som sådan er integreret $\mathrm{i}$ bebyggelsens helt centrale sociale og økonomiske strukturer. Men parallelt med landsbyens produktion af jern til nærområdet, så eksisterede der i perioder store jernudvindingspladser med adskillige, samtidige ovne, hvor produktionen må have været afhængig af interregionale mekanismer og sandsynligvis også af en højt specialiseret efterspørgsel på bestemte jernkvaliteter. Den efterspørgsel kan være kommet fra smedjer, der var knyttet til eliten og til militæret og hvor jernet dermed blev et element $\mathrm{i}$ blandt andet den våbenteknologiske udvikling.

I den forbindelse kan det vestjyske, ganske fosforholdige myremalmsjern (ofte nær $0,9 \% \mathrm{P}$ ), have spillet en central rolle. Fosforjern er hårdt, sprødt og glinsende gråt. Men det kan ikke hærdes og er næsten umuligt at opkulle. Mens «jern» er betegnelsen for et grundstof, er «stål» betegnelsen for et materiale. Myremalmsjernets kemiske sammensætning svarer ikke til den i moderne materialer, og derfor er det i denne artikel valgt at anvende benævnelsen «kulstofjern» og «fosforjern» om det jern, der indeholder mellem 0,1 og 0,9\% kulstof/fosfor.

Æggen på en kniv af fosforjern flosser nemt og kan være svær at holde skarp. Og tynde emner splintrer som glas, hvis de tabes på et hårdt underlag. I nutidens jernproduktion er fosfor et uønsket legeringselement, men i jernalderen synes smedene at have foretrukket fosforjern til en del opgaver.

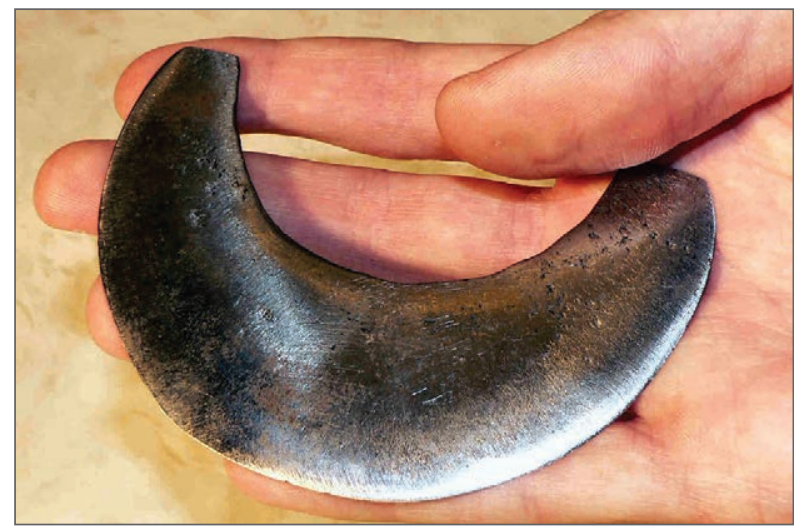

Figur 2: Rekonstruktion af halvrund kniv affosforjern. Foto: M. Nielsen.

Figure 2: Reconstruction of a semi-circular knife of phosphorous iron. Photo: M. Nielsen.

Et eksempel er de halvrunde knive, der i århundrederne omkring Kristi fødsel blev smedet af to stykker stærkt fosforholdigt jern og hvor svejsningen med stor sikkerhed er lagt i knivens midterlinje. Det var velsmedede, sarte redskaber (figur 2). Fosforjern blev også kombineret med det rene jern i økser (Thomsen 1966: 906) og knive (Lyngstrøm 2008: nr. 46), hvor det kunne erstatte eller supplere kulstofjern. $\mathrm{Og}$ i våbensmedjerne var fosforjern sandsynligvis efterspurgt til de mønstersmedede sværd. Mønstersmedning er teknisk forholdsvis let at udføre i fosforjern, og resultatet fremstår smukt sølvfarvet på sværdenes ætsede og polerede klinger (Thomsen 1994: 283).

Fosforjern er endnu ikke behandlet fyldestg $\varnothing-$ rende i en nordisk eller i en europæisk kontekst, men det er sikkert, at fosforjern besad et overordentligt stort potentiale, som vi i dag endnu ikke forstår det fulde omfang og de fulde konsekvenser af. Men sikkert er det, at den smeltemester, der kunne fremstille stabile leverancer fosforjern af sin myremalm, havde en særdeles købedygtig kundekreds. Den må fortrinsvis have bestået af erfarne smede tilknyttet specialiserede værksteder.

Som arkæologer må vi derfor være opmærksomme på, at den enkelte jernudvindingsovn og den enkelte gård eller landsby med jernudvindingsovne, kan repræsentere andet end blot et stadie i en kronologisk-teknologisk udvikling. Sikkert er det, at jernudvindingsovnens udformning - eller rettere: smeltemesterens valg af «ovntype» - afspejler råstoffernes tilgængelighed og især deres beskaffenhed. Men smeltemesterens håndværksmæssige formåen, hans ekspertise og den tradition han var oplært i og arbejdede i, må ligeledes have haft stor indflydelse 


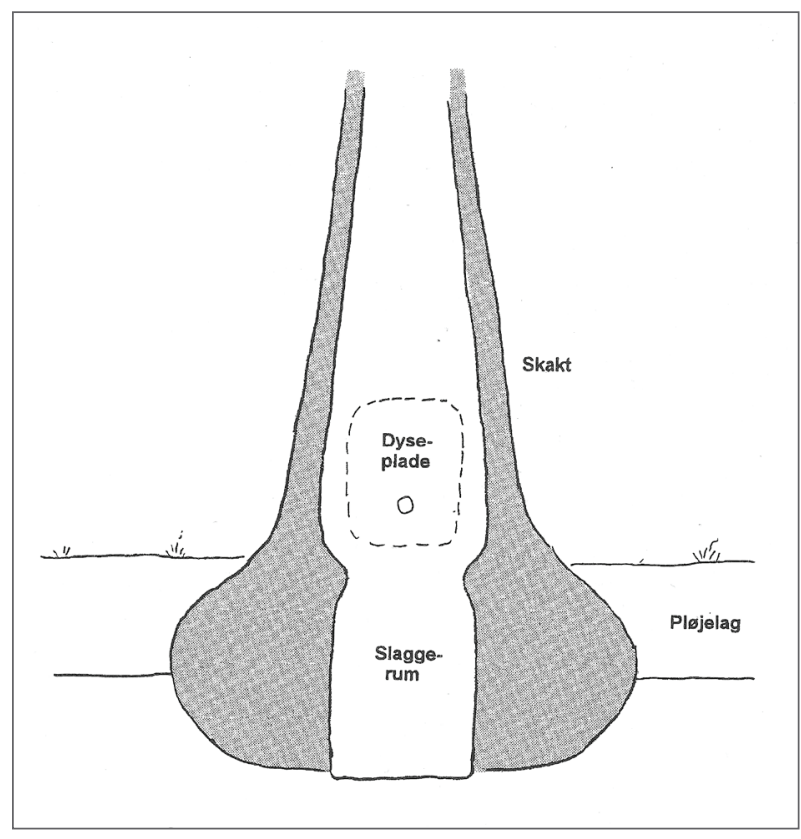

Figur 3: Ovnen fra Sønder Holsted, forslag til rekonstruktion. Efter Voss 2002: 141.

Figure 3: The furnace from Sønder Holsted, a proposal for a reconstruction. After Voss 2002: 141.

på hans valg. Videre kan man tænke sig den mulighed, at «ovntypen» også afspejlede specifikke konsumentbehov, så en øget efterspørgsel og en øget produktion ikke alene behøvede at have resulteret i flere ovne og mere slagge, men også i ovne af et andet udseende og derfor også i slagge størknet i en anden form. For selvfølgelig kan en øget jernproduktion komme til udtryk i det arkæologiske materiale som større udvindingspladser, men den kan jo også finde sted som en omlægning af ressourceudnyttelsen. Det sker blandt andet i Jämtland og Dalarna i 400-tallet (Magnusson 1991: 156) og i 700-tallet i Østnorge (Johansen 1979: 89), hvor der findes spredte jagtredskaber og gravfund i ellers ubeboede fjeldstrøg. Og en ressourceomlægning til fordel for jernproduktion behøver ikke udelukkende have været et spørgsmål om at kunne overleve. Den kunne måske også udspringe af et ønske om at etablere og/eller fastholde en kulturform, som var almindelig i centrale og økonomisk stærke områder af det nuværende Danmark. Ser vi igen mod nord til Norge, så var det måske derfor, at jernudvinding og dyrehold blev sidestillede aktiviteter i vikingetid og tidlig middelalder på Møsstrond (Rosenqvist 1983: 134; Martens 1988: 123). En væsentlig del af arbejdskraften fra gården kunne her, alt efter årstidens andre arbejdsopgaver, investeres i en produktion af jern udover egetforbruget. De samme for- hold er iagttaget på Heglesvollen, hvor mellem ti og 15 mand i perioder var beskæftiget med jernproduktionen i fire værkstedsområder (Stenvik 1987: 5). Denne sæsonmobilitet med rejse og ophold i udmarken kendes endnu ikke fra Danmark, hvor jernudvinding, rensning af jernsvamp og smedning altid synes at have været præget af nærhed og derfor er fuldt integreret i bebyggelsen. Men derfor kan mobilitet godt have haft stor betydning for den danske jernproduktion. Det iagttages blandt andet i Sydvestjylland, hvor etableringen af jernproduktionen i ældre germansk jernalder sættes i forbindelse med en regulær kolonisering af området (Smekalova og Voss 2001: 19).

\section{Ovnen i Sønder Holsted - en ny ovntype, en} undertype eller en lille del af mangfoldigheden? Etablering af kronologier på baggrund af identificerede typer hører til arkæologens helt basale arbejdsmetoder. Det gælder, hvad enten det involverer fibler, lerkar, huse eller jernudvindingsovne. Og ovnskronologi og ovnstypologi er helt klart et brugbart redskab i arkæologien. Men desværre sker det alt for tit, at arkæologen - med typologien printet på nethinden - alene udgraver det forventelige.

Anderledes var det, da Olfert Voss og Ejvind Hetz i 2000 undersøgte en jernudvindingsovn på et bopladsområde fra ældre romersk jernalder (Kristi fødsel til år 150/60 e.Kr.) umiddelbart vest for Holsted Rådhus i Vestjylland. Ovnen blev udgravet på en lokalitet, hvor der såvel tidligere (1996) som senere (2002) er lokaliseret jernudvindingsovne. Ovnene fra Sønder Holsted synes at være forholdsvis ensartede anlæg, hvor specielt den ene var så velbevaret, at det kunne give adskillige oplysninger i forhold til en rekonstruktion (figur 3). Her var ovnens slaggerum nemlig bevaret til ca. $30 \mathrm{~cm}$ over bunden, og åbningens sider var forstærket med sten, hvor den sten, der vendte mod nord, var 35 $\mathrm{cm}$ høj og tydeligt varmepåvirket på siden ind mod ovnrummet. I en senere forstyrrelse (plantegningen nr. 5) blev fundet skaktdele, der kunne sættes sammen til et stykke af skaktens væg, der har dækket et område fra omkring $12 \mathrm{~cm}$ under til $15 \mathrm{~cm}$ over jordniveau (Voss 2002: 140). Arbejdsgruben foran ovnen (nr. 6) var nogenlunde cirkulær, næsten $1 \mathrm{~m} \mathrm{i}$ diameter og placeret ca. $30 \mathrm{~cm}$ under den oprindelige jordoverflade. Gruben var skålformet og indeholdt mørkt fyld med mange små slaggestykker og få, ganske små, stykker trækul. Fyldet i slaggeafløbet (nr. 3) var nogenlunde det samme, men her fandtes også en del større slaggestykker. Nogle slagger var flade og havde en tydelig løbstruktur, men 
ingen havde aftryk af trækul. Der var tilsyneladende ikke fremstillet en særlig bund i slaggeafløbet, for afgrænsningen mod undergrunden viste sig kun i form af rødbrændt sand.

Ovnen tilhører måske gruppen af tidlige ovne i Danmark: Espevej-ovnen, som blev anvendt i århundrederne omkring Kristi fødsel. Men det usædvanlige ved ovnen i Sønder Holsted er, at der aldrig tidligere er fundet ovndele med forslagget inderside ved udgravninger af Espevej-ovne. Det kunne altså tyde på, at der enten var tale om en ny type eller, som Voss foreslår, at de tidligere rekonstruktioner af Espevej-ovnen skal revideres. Problemet er, at det i Sønder Holsted ser ud som om «ovnrummet» i virkeligheden ikke var det sted, hvor reduktionen skete, men det sted, hvor slaggen løb hen: her havde temperaturen ikke været høj nok til, at ovnvæggen blev forslagget - den blev kun rødbrændt. Selve slaggesmeltningen - og dermed formodentlig også det sted, hvor lufttilførslen til ovnen skete - må være foregået højere oppe, et stykke over jordniveau. Med hensyn til konstruktionen af ovnen, så forestiller Voss sig, at

\section{der blev gravet en $40-45 \mathrm{~cm}$ dyb, fladbundet grube med en diameter på ca. $100 \mathrm{~cm}$, der blev fyldt med ler. I mid- ten blev der så udsparet en cylinderformet grube, ca. 30 $\mathrm{cm}$ i diameter med en ca. $25 \mathrm{~cm}$ bred grube ud til en større fladbundet grube. Siderne af åbningen er mellem den centrale grube og arbejdsgruben forstærket med 1-2 flade sten. Den indsnævring, der er mellem selve ovnskakten og slaggerummet må, som det ses på stykket fra Sønder Holsted, sidde mindst $30 \mathrm{~cm}$ over bunden af slaggerummet og lige under jordoverfladen (Voss 2002: 140).}

Diameteren i ovnens nederste del har højst været $35 \mathrm{~cm}$. Ovnskaktens højde over jorden kendes ikke, men den er på rekonstruktionstegningen ført op i ca. $1 \mathrm{~m}$ højde.

Vi har prøvet at følge Voss' anvisninger og er i gang med at rekonstruere ovnen fra Sønder Holsted i fuld skala. Endnu er vi langt fra færdige med forsøget, men vi har udgravet en $45 \mathrm{~cm}$ dyb, cirkelformet grube med en diameter på $1 \mathrm{~m}$ og foret den med ler. Foran gruben har vi gravet ud til en fladbundet 30 $\mathrm{cm}$ dyb arbejdsgrube. Den er næsten cirkelformet med en diameter på $1 \mathrm{~m}$. Mellem slaggerummet og arbejdsgruben er der gravet en $35 \mathrm{~cm}$ lang forbindelse (figur 4). Vi har brugt 230 liter undergrundsler æeltet med vand og strå - og gravning af huller (med moderne spader), opgravning og æltning af ler samt bygning af ovnen har hidtil taget 24 arbejdstimer. Endnu er vi ikke nået til en rekonstruktion

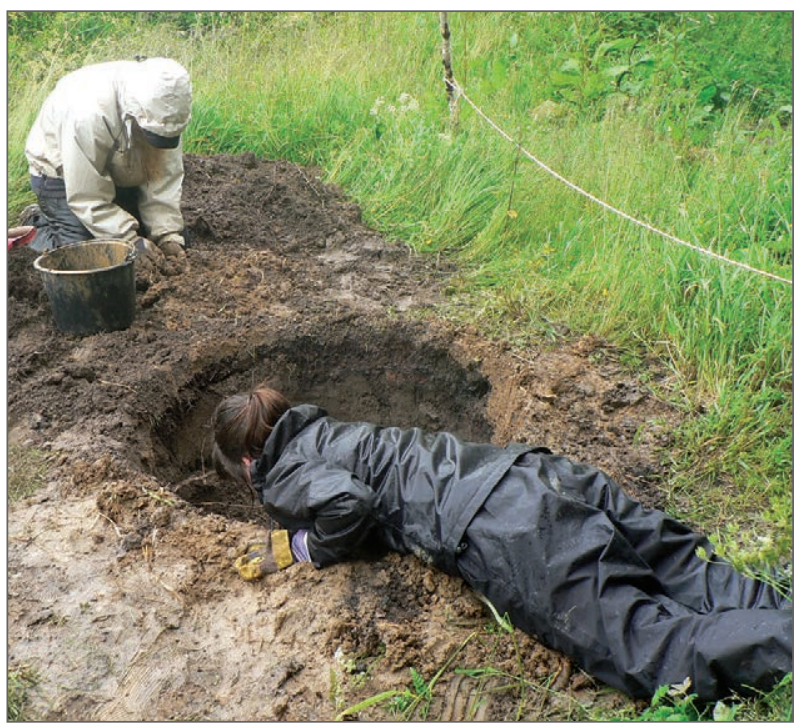

Figur 4: Rekonstruktion af ovnen fra Sønder Holsted, Lejre 2009. Foto: H. Lyngstrom.

Figure 4: The reconstruction of the furnace from Sonder Holsted, Lejre 2009. Photo: H. Lyngstrom.

af ovnskakten, men vores diskussioner om ovnens nederste del har været særdeles frugtbare. For er det «Espevej-typen», der skal revideres? Er ovnen fra Sønder Holsted en helt ny type jernudvindingsovn? Eller er ovnen udtryk for en dygtig smeltemester, der har evnet at tilpasse ovnens form til de råstoffer han disponerede over og den ekspertice han besad: en lille del af den store mangfoldighed. Og er det så en ny «ovntype»?

De foreløbige eksperimentel-arkæologiske erfaringer med ovnen fra Sønder Holsted er yderst perspektivrige, og målet er at bygge den færdig, bruge den, udgrave den og sammenligne materialet med det originale. Forsøget er et godt eksempel på, hvordan eksperimentel arkæologi kan bidrage til en konstruktiv diskussion af ovnstypologien og dermed også af ovnskronologien.

\section{SLAGGEAFTAPNINGSOVNE I DANMARK}

Et vanskeligt dilemma for jernforskningen i Danmark er samfundets tilsyneladende stærkt øgende forbrug af jern gennem yngre germansk jernalder og vikingetid (år 550 til år 1000 e.Kr.) sammenholdt med den fuldstændige mangel på fund af samtidige jernudvindingsovne (Jensen 1999: 44ff). Teoretisk kunne forbruget alene have været baseret på jern indhandlet fra andre områder, men med den omfattende og almindelige produktion kort tid forinden, synes argumentet ikke holdbart (Voss 1993: 209). Mange smeltemestre og smede må på 
overgangen mellem ældre og yngre germansk jernalder have besiddet en højt udviklet indsigt i de jernteknologiske processer. Denne indsigt må snarere - også under stabile politiske, økonomiske og sociale forhold - have resulteret i udvikling til ny og mere avanceret teknologi end i et stop for produktionen. Herkomstbestemmelse af jern på baggrund af jernets slaggeinklusioner $\mathrm{i}$ knive dateret til yngre germansk jernalder og vikingetid tyder da også på, at der stadig er produceret jern af den danske myremalm (Lyngstrøm 2008: tabel 14). Men hvorfor er der så ingen spor af jernudvindingsovne dateret til perioden mellem år 550 og 1100 e.Kr.? Årsagen kan være, at man har anvendt ovne, der var så lidt nedgravede, at de kun undtagelsesvist vil være bevaret. Slaggeaftapningsovnene står kun svagt i det materielle levn fra Danmark, men kan være en af de ovne, der i fremtiden vil supplere det arkæologiske kildemateriale for perioden yngre germansk jernalder, vikingetid og den tidligste middelalder. Ovnen synes at være eksponent for en driftssikker ovn med stor kapacitet, hvis anvendelse ikke nødvendigvis behøver at være knyttet til de store forekomster af myremalm i Vestjylland. Forsøg har vist, at den kan genbruges adskillige gange og at den er forholdsvis enkel at styre reduktionsprocessen i. Men den efterlader næsten intet arkæologisk kildemateriale i et intensivt opdyrket kulturlandskab som det danske. Hovedparten af de danske slaggeaftapningsovne er identificeret gennem slaggebunker fundet i skove. En systematisk gennemgang af områder dækket af gammel skov vil sandsynligvis kunne resultere i fund af flere ovne. Ved udgravningerne af hallerne i Gl. Lejre på Midtsjælland blev der i et stolpehul fundet et større slaggestykke, der kan være en udvindingsslagge. Den er, ud fra trækul indesluttet i slaggen, ${ }^{14} \mathrm{C}$-dateret til omkring år 600 e.Kr. Og på en bebyggelse fra 900-tallet på Mikkelsbakke på Limfjordsøen Mors er der udgravet en fuldstændigt bevaret slaggeblok, der là lige under pløjelaget. Den er 30-35 cm i diameter og vejer $12,5 \mathrm{~kg}$ (Voss 2002: 143f.). Måske er disse slagger dannet i slaggeaftapningsovne.

Fra den tidlige middelalder foreligger der skriftlige kilder om jernproduktionen. Som det gavebrev, ærkebiskop Absalon i 1197 udstedte til Sorø kloster. Heri omtales en landsby i Halland, Tvååker, hvor man kunne fremstille jern af jorden. Desuden nævnes flere teknologiske elementer som en molendino ubi fabricatur ferrum - en mølle, hvor jernet forarbejdes (Vellev 2004: figur 38). Dette er udlagt som indicium på, at vandkraft blev udnyttet i produktionen, men arkæologiske udgravninger har vist, at billedet er mere komplekst og også omfatter små ovne med et indhold svarende til 30 liter. Ovnene er slaggeaftapningsovne, og flere skaktdele har små, cirkulære huller - formodentlig beregnet til tuden af en blæsebælg (Strömberg 2004: figur 18-19; Vellev 2004: figur 14-15). Udbyttet af en brænding anslås til 7-8 kg jernsvamp. Jernsvampen blev formodentlig løftet ud af ovnskakten med lange tænger, således at anlægget kunne genbruges. Ovnene i Tvååker er ${ }^{14} \mathrm{C}$-dateret til tiden omkring gavebrevets udstedelse.

Få ovne med slaggeafløb er professionelt undersøgt, og det arkæologiske kildemateriale efter dem er oftest registreret som slaggepletter eller slaggedynger. De er kun bevaret i gamle skovområder (Voss 1986a: 29), og der har endnu ikke været resurser til at opspore alle de lokaliteter, som de gamle jernforskere Niels Nielsen (1924) og Rasmus Mortensen (1940) omtaler. Derfor har de tilhørende ovne heller ikke kunnet bestemmes eller dateres.

Et eksempel på en arkæologisk undersøgelse stammer fra Jels Skov i Sønderjylland. Det er en halv meter høj slaggedynge, der oprindeligt blev lokaliseret af Rasmus Mortensen, men siden er udgravet af Haderslev Museum i 1989. Det arkæologiske materiale fra Jels Skov omfatter såvel aflange aftapningsslagger, plankonvekse slagger som keramikfragmenter (Voss 1986a: 29). En prøve af det trækul, der lå mellem slaggerne blev ${ }^{14} \mathrm{C}$-dateret til år 1030-1220 e.Kr. (Voss 1995: 28).

Aftapningsslagger og plankonvekse slagger er også fundet i Nyvænge Skov på Sydvestfyn. I bunken, der var $6 \mathrm{~m}$ i diameter, fandt H.C. Frydendahl (1928: 61) også nogle få keramikfragmenter, der senere har kunnet dateres til 1300-årene. Han iagttog ingen spor af ovn- eller essekonstruktioner på stedet. Og i Løgager Skov i Midtjylland har Olfert Voss efter Niels Nielsens beskrivelse lokaliseret en slaggedynge med aftapningsslagger. I 1924 dannede slaggepletten

en skarpt afgrænset Højning. Da Marken henlaa i vedvarende Græsning, var Plettens Bevaringstilstand bedre end de øvrige Silkeborgpletters. Dimensio-nerne var ret betydelige, største Tværmaal $9 \mathrm{~m}$, mindste $6 \mathrm{~m}$; største tykkelse $86 \mathrm{~cm}$ Dyngens Volumen var i hvert Fald ikke under $20 \mathrm{~m}^{3}$, med en vægtfylde på 3,5 vil den altsaa veje mindst $70.000 \mathrm{~kg}$ (Nielsen 1924: 83).

Aftapningsslagger er aflange slaggestykker, ofte med en brudflade i hver ende. De er karakteriseret ved en glat overside, hvor slaggen er størknet $i$ løbstruktur, som stearin fra et lys, og på undersiden er der ofte fastsmeltet sand- eller gruskorn (figur 5). Det er slagge, der er størknet i ovnens afløbsrender. 


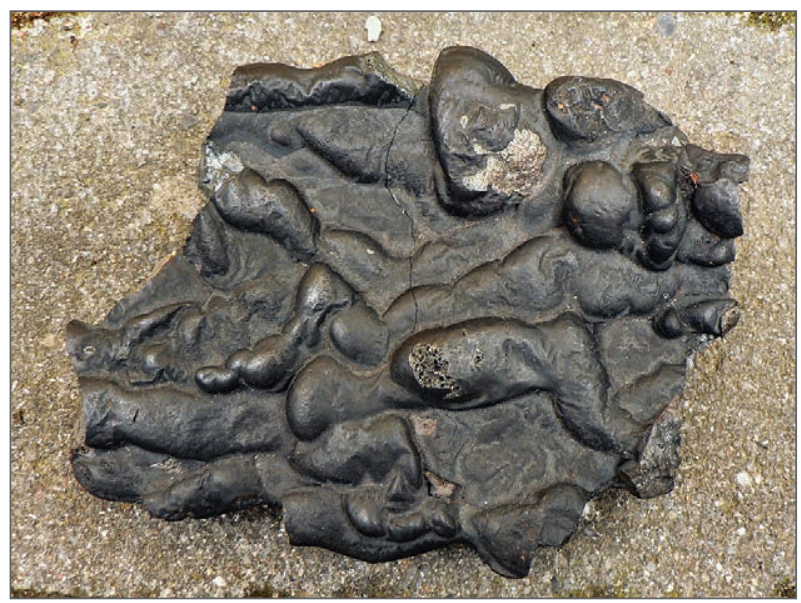

Figur 5: Fragment $(21 \mathrm{~cm})$ a aflang aftapningsslagge fra forsog med udvinding i slaggeaftapningsovn, Lejre 1994. Foto: M. Nielsen.

Figure 5: Fragment $(21 \mathrm{~cm})$ of a long tapslag from one of the experiments with iron production in a slag-tapping furnace, Lejre 1994. Photo: M. Nielsen.

Og slaggeaftapningsovnen er da også, som navnet siger, en gruppe ovne, hvor slaggerne ikke, som i de fleste andre ovne, samler sig inde i ovnen, men ledes ud. Under indtryk af det øvrige skandinaviske materiale og af eksperimentel-arkæologisk arbejde må det empiriske materiale fra ovnen netop forventes at være karakteriseret af slagger størknet $\mathrm{i}$ «løb» på deres vej ud af ovnen.

Men på grund af den ødelæggelse af slaggedynger, som har fundet sted gennem tiderne og stadig finder sted $\mathrm{i}$ et intensivt opdyrket kulturlandskab som det danske, er det meget vanskeligt at belyse omfanget af jernproduktionen i slaggeaftapningsovne. Måske vil en genregistrering og undersøgelse af de tilbageværende dynger af slagger kunne føre til en nærmere beskrivelse af de ovne, de blev dannet i forbindelse med.

\section{Slaggedyngen i Vattrup - en anden ovntype eller aftapningsslagger størknet i en anden form?}

Slaggedyngen i Vattrup i Midtjylland er «den betydeligste Slaggeforekomst» af de 91 lokaliteter, Niels Nielsen registrerede for snart hundrede år siden. Det skete i forbindelse med doktordisputatsen Studier over Jernproduktionen i Jylland (Nielsen 1924). Dengang var bunken i Vattrup

en ellipseformet Forhøjning, 20 x 10 m stor. Slaggelagets Tykkelse er i Midten $1 \mathrm{~m}$ og derfra jævnt aftagende ud mod Randene. Dets Volumen er i hvert Fald over $50 \mathrm{~m}^{3}$, og hvis Slaggernes Vægtfylde sættes til 3,5, bliver Vægten af det nuværende Slaggeindhold ca. 170,000 kg.
Men Nielsen samlede også efterretninger om, at en stor del af den allerede var fjernet inden opmålingen, og han gravede flere prøvehuller samt et $10 \mathrm{~m}$ langt og $3 \mathrm{~m}$ bredt snit igennem den:

Dyngens Indhold var næsten udelukkende Jærnslagger, af ret smaa Dimensioner, i Regelen under 10 $\mathrm{cm}$; imellem Slaggerne fandtes lidt sort og stærkt sværtende Jord, samt enkelte Lerklumper, Smaasten og Myremalmsklumpe (Nielsen 1924: 71f).

Allerede Nielsen arbejdede med forskellige ovntyper: herdgruber og lergryder. Og slaggerne i Vattrup, der var små og størknet i tyndtflydende tilstand, karakteriserede han som et resultat af en udvinding i lergryde. De plankonvekse slagger så han som dannet i lergrydeovnens bund, $15-25 \mathrm{~cm}$ i diameter, og de mange «krumme Flager af magret Ler» tolkede han som den øverste del af lergryden, $40-50 \mathrm{~cm}$ i diameter. Til lergrydeovnen hørte endvidere «ejendommeligt formede Lerindretninger, der maa tydes som en Tud, der førte Luften fra Blæsebælgen ind i Ovnen»(Nielsen 1924: 146). Dem fandt han 92 af.

Interessant er det, at slaggebunken i Vattrup er genudgravet af Olfert Voss og Viborg Stiftsmuseum i 1992. Gravningen bekræftede til fulde Nielsens iagttagelser, idet der i det nu meget nedslidte anlæg blev fundet de samme kalotformede slagger, de samme krumme randstykker og de samme aftryk af blæsetude. Udgravningen blev suppleret af Robert Thomsens analyser af et tværsnit af randstykkernes slaggelag, og det viste sig, at det metalliske jern her udgjorde op imod $50 \%$ af slaggelaget. Thomsen udførte også en analyse af det materiale, der havde sat sig omkring blæsetudene, der formodentlig har raget ind i ovnen. Også dette materiale indeholdt en ganske stor mængde metallisk jern. Randstykker og tude kan altså udmærket stamme fra samme anlæg. Vigtigt var det også, at Voss indsamlede trækul mellem slaggerne. Det blev ${ }^{14} \mathrm{C}$-dateret til år 1305-1380 e.Kr. (Voss 1995: 31).

Men ganske bemærkelsesværdigt er det, at hverken Nielsen eller Voss fandt aflange aftapningsslagger som dem, der blev fundet i Jels, Nyvænge og Løgager Skov. Måske er slaggerne i Vattrup ikke dannet i en slaggeaftapningsovn. Eller måske er de, som Voss åbner mulighed for, tappet - ikke i render - men i fordybninger foran ovnen (Voss 1995: 34). Hvis det er tilfældet, er ovnene i Vattrup så en undertype af slaggeaftapningsovnen? Eller er de blot det materielle udtryk for en lille del af de mangfoldige måder, smeltemestrene kunne arbejde på? 


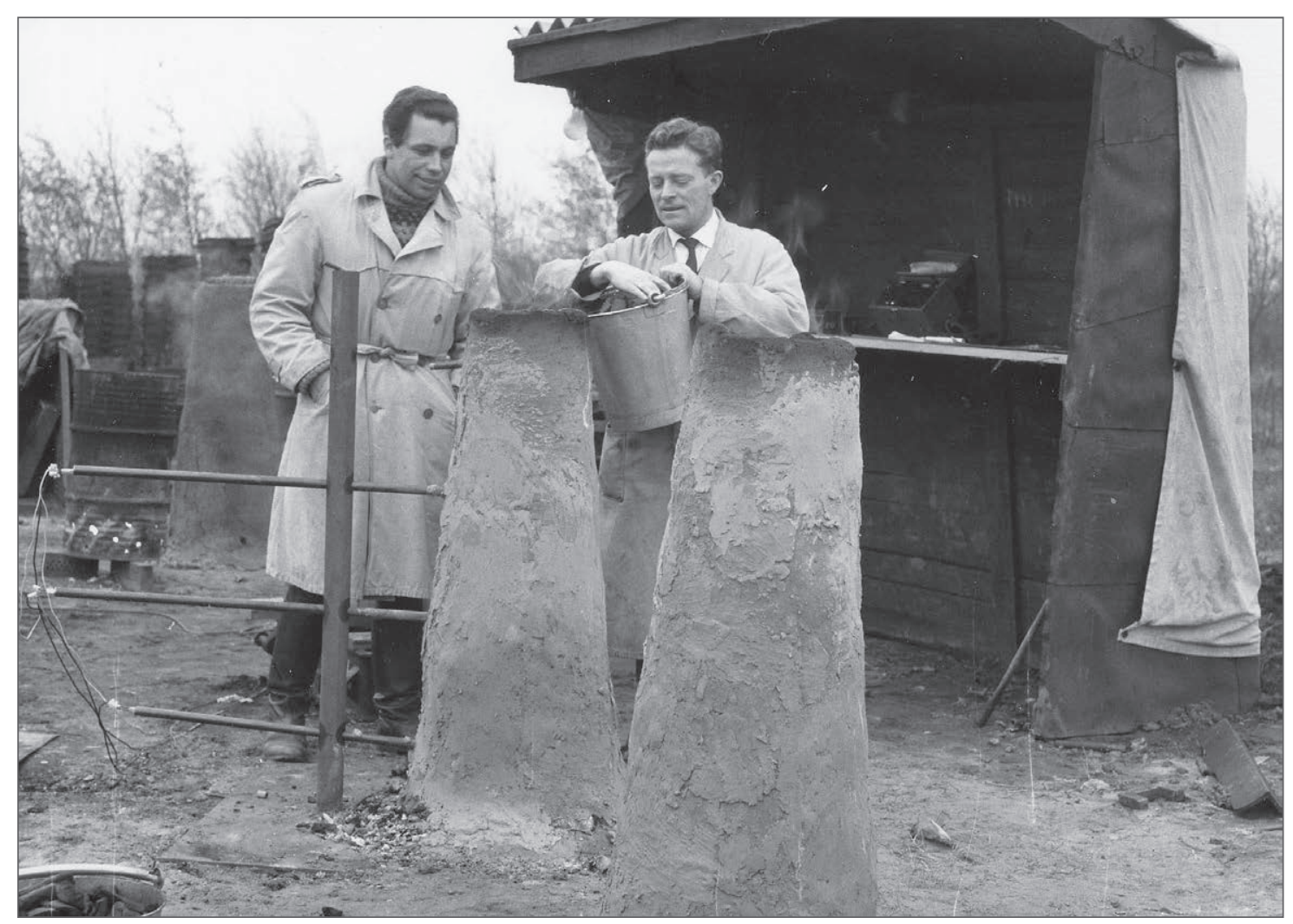

Figur 6: Olfert Voss og Robert Thomsen (til højre) ved forsøg med jernudvinding på A/S Varde Staalvark 1963. Foto: Varde Lokalhistoriske Arkiv.

Figure 6: Olfert Voss and Robert Thomsen (right) during the experiments with iron production at A/S Varde Staalvark 1963. Photo: Varde Lokalhistoriske Arkiv.

\section{FORSØG MED SLAGGEAFTAPNINGSOVNE}

I Danmark er der foretaget adskillige forsøg ikke alene med slaggeaftapningsovne, men også med flere andre forskellige ovne. De tidligste egentlige eksperimentel-arkæologiske jernudvindinger fandt sted i 1963, da Robert Thomsen fra A/S Varde Staalværk besøgte en arkæologisk udgravning. Thomsen besigtigede udgravningerne på Drengsted i Sønderjylland på opfordring af Olfert Voss, der i begyndelsen af 1960'erne havde afdxkket massive spor af jernudvinding på en bebyggelse fra ældre germansk jernalder (Voss 1986b; Mikkelsen og Nørbach 2003). Og under indtryk af de mange udvindingsslagger, havde Voss rekonstrueret et par ovne med en grube under jorden og et lerrør - inspireret af det bemærkelsesværdige fund fra Scharmbeck (Wegewitz 1957) - over jorden (Voss 1962). Dernæst havde han inviteret ledelsen fra Varde Staalværk til at overvære et forsøg med at forvandle den lokale myremalm til jern.

$\mathrm{Da}$ Thomsen så de rekonstruerede ovne, mente han nok, at det ville være muligt at fremstille jern i dem. Men han mente også, at Voss havde brug for mere avancerede måleinstrumenter, hvis det skulle lykkes. Og dem havde Thomsen hjemme på stålværkets laboratorium. Så han gik op til stålværkets direktion og bad om $4000 \mathrm{kr}$. til et jernudvindingsforsøg. Og det fik han. Stålværkets murermester gravede slaggegruber og byggede ovne inde på værkets område, og myremalmen hentede Thomsen, efter først at have analyseret den og fundet den velegnet, på mangansulfatfabrikken i Bolderslev. Den kostede ikke noget. I det hele taget mødte Thomsen en stor interesse for forsøgene. Mange mennesker bidrog med arbejdskraft og ekspertise - også Danmarks Radio fandt vej til Sydvestjylland og producerede fjernsynsudsendelsen Højornen på mosebund, der i programomtalen for 27. oktober 1963 blev beskrevet som «et forsøg, der skulle efterprøve en teori om, hvordan jernaldermennesket smeltede jern i Danmark» (figur 6).

For Thomsen og Voss blev rekonstruktionen af ovnene fra Drengsted begyndelsen til et langvarigt og frugtbart samarbejde om blandt andet eksperimentel jernudvinding, hvor resultaterne af deres forsøg besvarede to helt centrale spørgsmål for 1960'ernes akademiske diskussion om jernalderens jernudvinding: 
For ja - det var muligt at udvinde jern af myremalm $\mathrm{i}$ en ovn rekonstrueret på baggrund af et arkæologisk materiale. Det lykkedes nemlig Thomsen at vedligeholde reduktionsprocessen kontinuerligt i 60 timer og at reducere $46 \mathrm{~kg}$ ristet myremalm og 110 $\mathrm{kg}$ trækul til $5 \mathrm{~kg}$ jernsvamp. Af jernet smedede han 15 pilespidser, af samme form og størrelse som dem, der var udgravet i det store våbenofferfund i Ejsbøl Mose.

Og ja - reduktionsprocessen forløb anderledes, end man hidtil havde forestillet sig. Det var nemlig Thomsen og Voss, der som de første så, hvordan jernet i de rekonstruerede ovne dannede sig som en fast jernsvamp over den flydende slagge og ikke, som man ellers havde ment, som flydende jern under en flydende slagge. Derved kom slaggen til at ligne den, man fandt ved de arkæologiske udgravninger, og de kunne konkludere, at langt hovedparten af slaggeblokkene i Drengsted lå, som de var efterladt efter udvindingen - og ikke var væltet om, som man ellers antog dengang for 50 år siden.

Thomsens arbejde kom til at trække et betydningsfuldt spor gennem dansk jernforskning. Op gennem 1970'erne og 1980'erne besøgte han udgravninger, museer og symposier for at samle komparativt materiale. Først til sine forsøg, senere til sine mange metallurgiske analyser af forhistoriske jerngenstande. Thomsen var en pioner inden for den eksperimentelle jernforskning, og hans arbejder viste eksperimentets fulde potentiale for den humanistiske videnskab og understregede betydningen af et kontinuerligt tværvidenskabeligt samarbejde (Lyngstrøm 2002a).

I Danmark er forsøgsarbejdet fortsat med rekonstruerede Espevej-ovne, Drengsted-ovne, slaggeaftapningsovne og grubeovne. Mange forsøg er udført af spejdere, aftenskolehold eller af personale på landets mange oplevelsescentre, hvor jernudvinding og smedning er aktiviteter, der trækker et stort besøgstal (Egeberg 1998: 11). Egentlige videnskabelige eksperimenter er udført på Danmarks Tekniske Universitet (Buchwald 1991), på Aarhus Universitet, Moesgård (Lund 1988; Lund og Jouttijärvi 1999) og på Historisk-Arkæologisk Forsøgscenter i Lejre, der fra 2009 hedder Sagnlandet Lejre (Lyngstrøm 2002a: 51ff).

Først ristes malmen på et åbent bål, ganske som beskrevet af Ole Evenstad (Evenstad 1790). Ved ristningen gennemgår myremalmen en række fysiske og kemiske ændringer, der er til gavn for den efterfølgende reduktionsproces. Således fordamper vandet, og alle organiske bestanddele forkuller. Derved øges porøsiteten. Ristet myremalm knuses let i de små stykker, der er den mest hensigtsmæssige størrelse i ovnen, og myremalmens kemiske sammensætning ændres fra en dårligt defineret mineralblanding til en relativt veldefineret blanding af hæmatit, goethit og magnetit (Buchwald 1991: 2). Ristet myremalm er mørk rødbrun, porøs, let og magnetisk. Samtidigt forvarmes ovnen. Derefter fyldes den med trækul samt myremalm, og temperaturen øges ved kunstig eller naturlig blæst. Når temperaturen er steget til nær $1200^{\circ} \mathrm{C}$, begynder slaggen at flyde. Der fyldes trækul og ristet myremalm $\mathrm{i}$ ovnen gentagne gange - ofte i vægtforholdet 1/2/2:1 eller 1:1. Processen varer mellem $10 \mathrm{og} 30$ timer, afhængig af forsøgets målsætning og processens forløb.

Ved de danske forsøg med jernudvinding er det sket, at ovnen ikke er blevet tilstrækkelig, eller for ujævnt, varm og slaggen derfor er størknet oppe i skakten. Man har derfor eksperimenteret med forskellige størrelser trækul, måder at fylde ovnene på og med udformningen af halmproppen i Drengstedovnen. Der er desuden eksperimenteret med anvendelsen af træ i stedet for trækul, med tilførslen af luft, med ovnskaktens højde og med fyldningsrytmen.

Skønt tilsvarende forsøg er udført i blandt andet Norge (Jakobsen et al.1988; Berre 1985; Larsen 2009: 22ff), Sverige (Englund 2002), Tyskland (Leineweber og Lychatz 1998), England (Cleere 1990; Crew 1990), Estland (Peets 2003: 131ff), Polen (Nosek 1992), Tjekkiet (Pleiner 1991) og Ungarn (Souchopova \& Stransky 1990), så er Danmark stadig centralt placeret $\mathrm{i}$ den eksperimentel-arkæologiske udforskning af jernudvindingsprocessen.

På baggrund af de få danske slaggefund og med blik for de samtidige norske ovne, har man forsøgt at konstruere en skaktovn med slaggeafløb. Skakten blev her bygget over en lav fordybning i jorden, ikke mere end $10 \mathrm{~cm}$, og ovnen blev med fordel placeret på et let skrånende terræn. Der giver et naturligt aføb for slaggen. Omkring fordybningen bygges en knap en meter høj lerskakt, der i faldretningen forsynes med et hul i jordniveau. Under udvindingen løber slaggen gennem hullet ud i en rende og videre ned i en lille fordybning foran ovnen. På den måde dannes såvel aflange og plankonvekse aftapningsslagger, der, efterhåndensom processen skrider frem, brydes op for at give plads til ny slagge. Ovnskakten kan bruges flere gange, da kun en lille del af skakten slås i stykker efter brændingen og jernsvampen fjernes gennem hullet. Inden næste brænding repareres ovnen nemt (Lyngstrøm 2002a: 47). I det følgende skal omtales to forsøgsrækker, der er udført i Lejre, 2008 og 2009. 


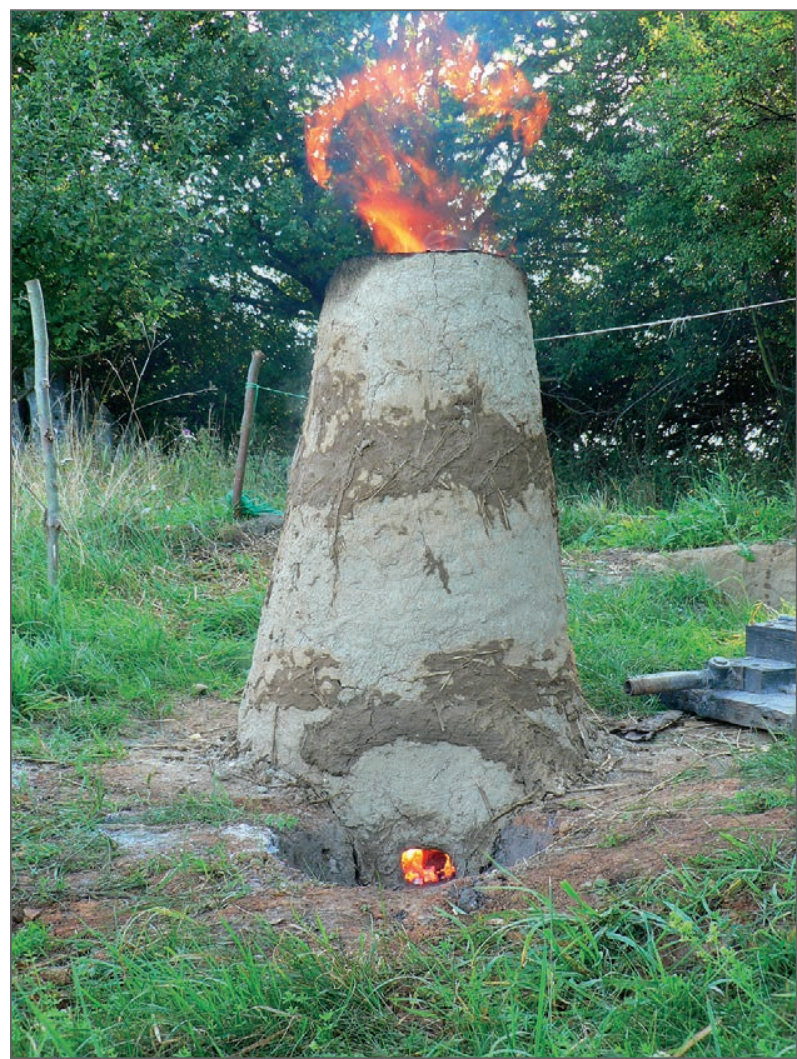

Figur 7: Slaggeaftapningsovn i anvendelse, Lejre 2009. Foto: H. Lyngstrom.

Figure 7: Slag-tapping furnace in use, Lejre 2009. Photo: $H$. Lyngstrøm.

Forsøg med slaggeaftapningsovne i 2008 og 2009 Forsøgene i 2008 (HAF j.nr. 17/08) og 2009 (HAFF j.nr. 04/09) blev begge udført på baggrund af tidligere forsøg i Historisk-Arkæologisk Forsøgscenter (fra 2009 Sagnlandet Lejre), hvor det primære mål var at dokumentere en mulig sammenhæng mellem den kemiske sammensætning i jernets slaggeinklusioner i det færdige redskab og den kemiske sammensætning i udvindingsslaggerne (Blakelock et al. 2009). Der blev derfor ikke alene udvundet jern ved forsøgene, men jernsvampene blev også renset til jernbarrer og barrerne smedet til redskaber, hvis slaggeinklusioner blev analyseret. Det sekundære mål med forsøgene var at karakterisere forskellene geografisk.

Målet for udvindingen var således ikke at producere så meget jern som muligt, men 1) at producere en moderat mængde jern til a) videreforarbejdning og til b) metallurgisk analyse af slaggeinklusionerne som referenceramme for et større arbejde med herkomstbestemmelse af dansk myremalmsjern; og 2) at producere en slagge, der såvel morfologisk som kemisk kunne fungere som komparativ reference- ramme i forhold til forhistoriske og tidligt historiske slagger.

Forsøgene med jernudvinding blev foretaget $\mathrm{i}$ slaggeaftapningsovne alene af den grund, at det er den ovn, vi har størst erfaring med, og fordi den ved tidligere forsøg har vist sig som en meget driftssikker ovn (figur 7).

Begge år blev der bygget to slaggeaftapningsovne. I 2008 fordi vi ville prøve at drive to ovne samtidigt, i 2009 fordi ovnen blev udsat for hærværk og måtte genopføres. Ovnene blev bygget på en sydvestvendt skråning ned mod en sø tæt udenfor jernalderlandsbyen i forsøgscenteret. Området har tidligere været anvendt til jernudvinding. Den første ovn i 2008, anvendt til brændingerne 2008:I og 2008:II, blev bygget som slaggeaftapningsovn uden forplade af 90 liter ler gravet ud af skrænten bag smedjen i værkstedsområdet. Leret blev æltet med tre bundter (diameter ca. $15 \mathrm{~cm}$ ) langt, vissent græs og vand hentet fra søen. Skakten blev bygget over en $10 \mathrm{~cm}$ fordybning og havde en indre bunddiameter på $40 \mathrm{~cm}$. Dens vægge var $8 \mathrm{~cm}$ tykke og dens højde var $90 \mathrm{~cm}$. Den indre diameter i toppen var 30 $\mathrm{cm}$. Ovnen var forsynet med to indblæsningshuller, der var placeret under hensyntagen til bælgenes placering $\mathrm{i}$ terrænet og $5 \mathrm{~cm}$ over jordniveau. På den første arbejdsdag blev ovnen bygget op i $50 \mathrm{~cm} \mathrm{høj-}$ de og dækket til med presenning. Fire dage senere blev ovnen bygget færdig og der blev gravet ud til ristningsbål.

Den anden ovn i 2008, anvendt til brændingen 2008:II, blev bygget som slaggeaftapningsovn uden forplade af 85 liter ler gravet ud af skrænten bag smedjen i værkstedsområdet. Leret blev æltet med fire bundter (diameter ca. $15 \mathrm{~cm}$ ) langt, vissent græs og vand hentet fra søen. Skakten blev bygget over en $10 \mathrm{~cm}$ fordybning og havde en indre bunddiameter på $35 \mathrm{~cm}$. Dens vægge var $8 \mathrm{~cm}$ tykke og dens højde var $95 \mathrm{~cm}$. Den indre diameter i toppen var $30 \mathrm{~cm}$. Ovnen var forsynet med to indblæsningshuller, der var placeret under hensyntagen til bælgenes placering $\mathrm{i}$ terrænet og $5 \mathrm{~cm}$ over jordniveau. På den første arbejdsdag blev ovnen bygget op i $40 \mathrm{~cm}$ højde og dækket til med presenning. Syv dage senere blev ovnen bygget færdig.

De dage, hvor vi brændte, begyndte vi tidligt med at forvarme ovnen og riste myremalmen. Ovnene blev forvarmet med kløvet brænde af løvtræ, og til ristningen anvendtes brænde i større dimensioner, men ligeledes løvtræ. Ved selve brændingen anvendte vi specialbrændte kul af bøgetræ, der blev sorteret til en mindste størrelse på $5 \mathrm{~cm}$ længde.

I 2008 omfattede forsøgene tre udvindinger med 
Lejre 12.08.08 Myremalm fra Guldforhoved

\begin{tabular}{|l|l|l|l|l|l|l|l|l|l|l|}
\hline Trækul & 18 & 7 & & $41 / 2$ & & 4 & & 4 & & $371 / 2$ \\
\hline Ristet malm & & 10 & & 11 & & 8 & & 7 & & 36 \\
\hline Blæst & & & $\mathrm{x}$ & & $\mathrm{x}$ & & $\mathrm{x}$ & & $\mathrm{X}$ & $\mathbf{4}$ \\
\hline Tid & 0 & $2: 05$ & $2: 10$ & $3: 20$ & $3: 40$ & $4: 10$ & $5: 25$ & $5: 55$ & $7: 10$ & $\mathbf{7 : 4 5}$ \\
\hline
\end{tabular}

Tabel 1: Udvinding 2008: I, hvor der af $36 \mathrm{~kg}$ ristet myremalm fra Guldforhoved blev udvundet en jernsvamp på $5 \mathrm{~kg}$. Jernsvampen blev renset til 455 g jernbarrer.

Table 1: Iron smelting 2008: I, where $36 \mathrm{~kg}$ of roasted bog ore from Guldforhoved were smelted to create a $5 \mathrm{~kg}$ iron bloom. The bloom was forged into a $455 \mathrm{~g}$ bar of iron.

\begin{tabular}{|l|l|l|l|l|l|l|l|l|l|}
\hline Lejre 11.10.08 & 10 & 10 & 8 & & $101 / 2$ & & 10 & & $\mathbf{4 8} 1 / 2$ \\
\hline Trækul & & & 3 & & 10 & & 7 & & $\mathbf{2 0}$ \\
\hline Ristet malm & & & & x & & x & & x & $\mathbf{3}$ \\
\hline Blæst & 0 & $1: 25$ & $1: 55$ & $2: 40$ & $3: 25$ & $5: 25$ & $6: 40$ & $7: 05$ & $\mathbf{7 : 4 5}$ \\
\hline Tid
\end{tabular}

Tabel 2: Udvinding 2008: II, hvor der af $20 \mathrm{~kg}$ ristet myremalm fra Gødsvang blev udvundet en jernsvamp på $4 \mathrm{~kg}$. Table 2: Iron smelting 2008: II, where $20 \mathrm{~kg}$ of roasted bog ore from Gødsvang was smelted into a $4 \mathrm{~kg}$ iron bloom.

\begin{tabular}{|l|c|c|c|c|c|c|}
\hline Lejre 11.10.08 & Myremalm fra Usserød \\
\hline Trækul & 10 & 11 & & 9 & & $\mathbf{3 7 1} \mathbf{2}$ \\
\hline Ristet malm & & 6 & & 5 & & $\mathbf{1 1}$ \\
\hline Blæst & & & $\mathrm{x}$ & & $\mathrm{x}$ & $\mathbf{2}$ \\
\hline Tid & 0 & $1: 40$ & $2: 35$ & $4: 00$ & & $\mathbf{7 : 4 5}$ \\
\hline
\end{tabular}

Tabel 3: Udvinding 2008: III, bvor $11 \mathrm{~kg}$ ristet myremalm fra Usserod brendte.

Table 3: Iron smelting 2008: III, where $11 \mathrm{~kg}$ of roasted bog ore from Usserod was burned.

myremalm gravet op i henholdsvis Guldforhoved (i Midtjylland), Gødsvang (i Sydvestjylland) og Usserød (i Nordsjælland), hvoraf de to første forløb tilfredsstillende og der blev fremstillet henholdsvis 5 og $4 \mathrm{~kg}$ jernsvamp. Den tredje slaggeaftapningsovn, den med myremalmen fra Usserød, brændte sammen.

Til brænding 2008:I og 2008:II anvendtes samme ovn. Vi blæste begge gange diskontinuerligt og ovnen blev hurtigt ensartet varm. Efter anden blæsning begyndte slaggen at løbe. Ovnen kunne godt have været anvendt til flere brændinger, da vi kontinuerligt reparerede den med en opslemmet lerblanding.

Brænding 2008:III mislykkedes primært for- di vi var for uopmærksomme og nok også fordi vi havde for mange uerfarne på holdet den dag. Heldigvis var omstændighederne ved sammenbrændingen de bedst mulige: den skete i skumringen, netop som en familie fra den rekonstruerede jernalderlandsby og Lejres fotograf var på besøg på pladsen. Fotografen fik et par fine stemningsbilleder af en jernalderdragtklædt familie samlet om den gnistrende ovn med søen og landsbyen som baggrund (figur 8 ).

Jernsvampen 2008:I blev efterfølgende renset til jernbarrer og smedet til genstande. I rensningsprocessen var målet at 1) producere en jernbarre egnet til videreforarbejdning og 2) at karakterisere rensningsslaggen (såvel esseslaggen som amboltslaggen) 


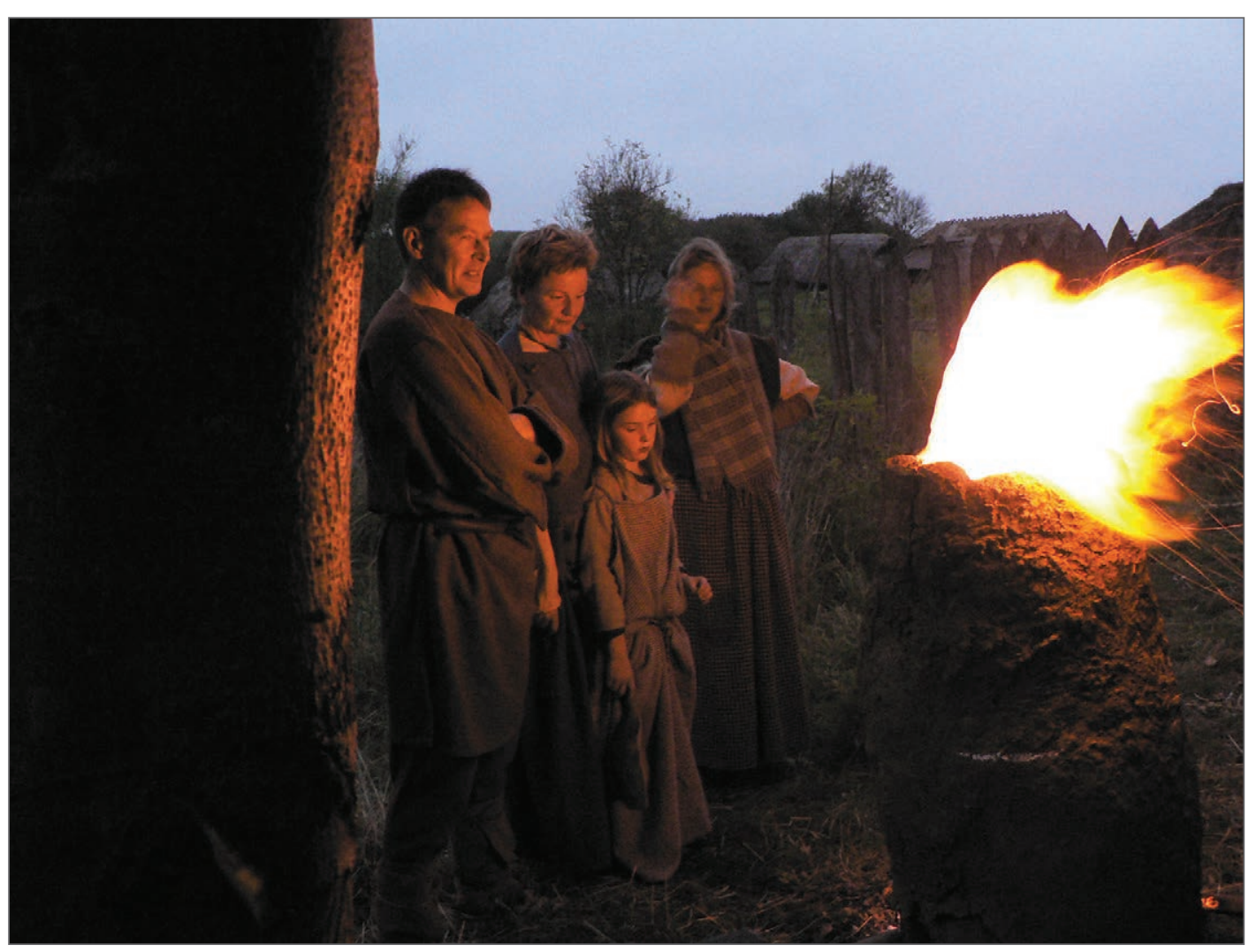

Figur 8: Jernet brender i slaggeaftapningsoun 2008:III, Lejre 2008. Foto: M. Nielsen.

Figure 8: The iron burns in the slag-tapping furnace 2008:III, Lejre 2008. Photo: M. Nielsen.

morfologisk og metallurgisk. I smedeprocessen var målet at 1) efterligne og reflektere over forhistoriske og tidligt historiske smedeprocesser og 2) at karakterisere smedeslaggen (såvel esseslaggen som amboltslaggen) morfologisk og metallurgisk.

Jernet i de $5 \mathrm{~kg}$ jernsvamp var ikke sammenhængende, men der blev udvalgt $3975 \mathrm{~g}$ jernsvamp fordelt på syv stykker. De blev renset til i alt $455 \mathrm{~g}$ jernbarrer. Efter rensningen blev der opsamlet $1007 \mathrm{~g}$ frasprængte stykker jernsvamp, slaggeflager og slaggekugler. Amboltslaggen blev indsamlet og beskrevet zone for zone og prøver udtaget til metallurgiske analyse. I essen lå en slagge på $359 \mathrm{~g}$.

Derefter smedede smedene Jokum Lind Jensen og Aron Hvid 13 emner af disse jernbarrer og af jern udvundet af myremalm fra St. Dyrehave (i Nordsjælland, HAF j.nr. 12/00) og af en anden jernsvamp af myremalm fra Guldforhoved (HAF j.nr. 07/01). De fleste af emnerne var kopier af knive, der er fundet i de sen førromerske jernaldergrave på Lønhøjgårdsvej i Vestjylland. Men der blev også smedet genstande, der ikke var kopier, men alene blev smedet for at prøve myremalmsjernets egenskaber i forbindelse med smedning af snoede og meget tynde emner (skafter, fiskekroge og nåle) (figur 9). De fleste genstande var kopier af førromerske knive og derfor smedet af ét lag jern med lavt indhold af kulstof. Rensning og smedning blev udført i en «moderne» smedje.

I 2009 blev ovnene bygget på den samme sydvestvendte skråning i Lejre. Den første, anvendt til brændingen 2009:I, blev bygget som slaggeaftapningsovn med forplade af 100 liter ler gravet ud af skrænten bag smedjen i værkstedsområdet. Leret blev æltet med en balle snittet halm og vand hentet fra søen. Skakten blev bygget over en $10 \mathrm{~cm}$ fordybning og havde en indre bunddiameter på $49 \mathrm{~cm}$. Dens vægge var $9 \mathrm{~cm}$ tykke forneden og $5 \mathrm{~cm}$ tykke foroven. Skaktens højde var $98 \mathrm{~cm}$. Den indre diameter i toppen var $45 \mathrm{~cm}$. Forpladen var $30 \mathrm{~cm}$ bred og dens maksimale højde var $25 \mathrm{~cm}$. Ovnen var forsynet med to indblæsningshuller, der var placeret under hensyntagen til bælgenes placering $\mathrm{i}$ terrænet og $4 \mathrm{~cm}$ over jordniveau. Huller til temperaturmålinger var placeret hhv. $30 \mathrm{og} 60 \mathrm{~cm}$ over jordniveau. På den første arbejdsdag blev ovnen bygget op i 50 $\mathrm{cm}$ højde og dxkket til med presenning. To dage senere blev ovnen bygget færdig og der blev gravet ud til ristningsbål.

Da denne ovn blev ødelagt af hærværk, blev der 


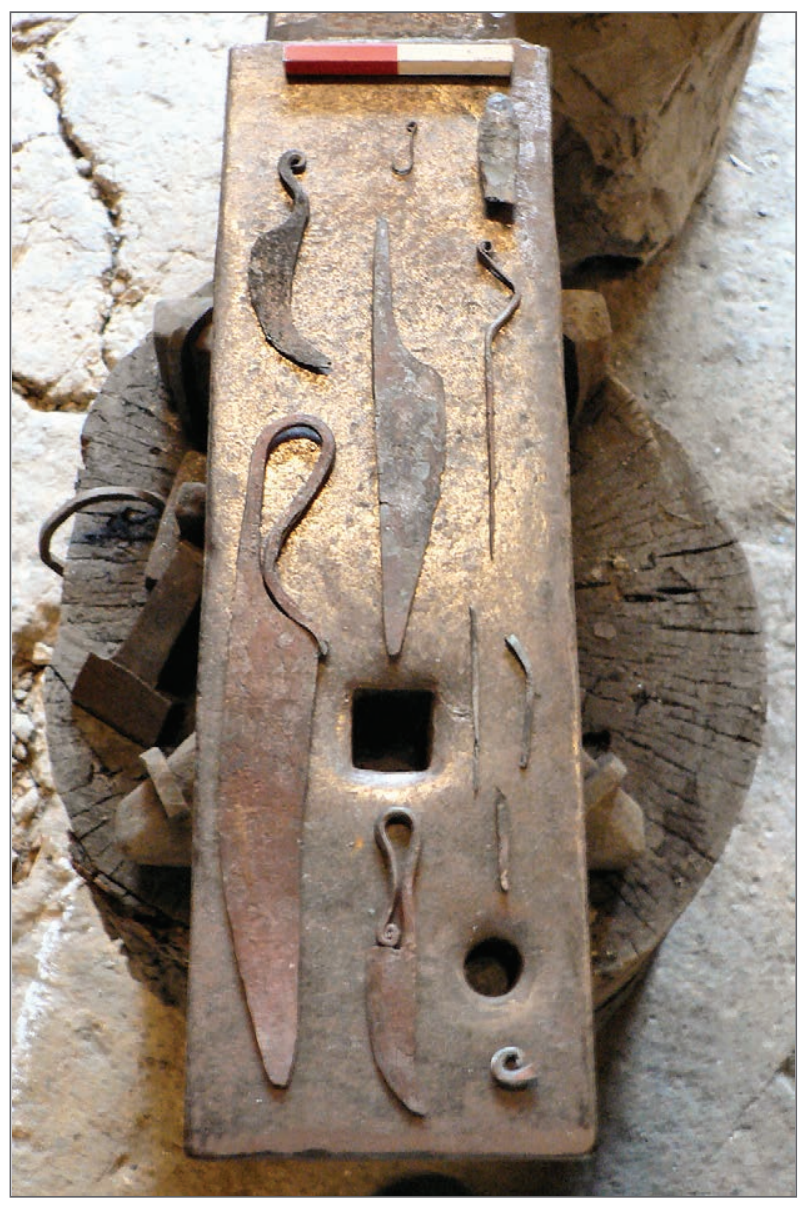

Figur 9: Genstande smedet af myremalmsjern udvundet $i$ slaggeaftapningsoune, Lejre 2008. Foto: H. Lyngstrom. Figure 9: Artefacts forged of bog ore iron from a slag-tapping furnace, Lejre 2008. Photo H. Lyngstrom.

bygget en ny til 2009:II. Også den blev bygget som slaggeaftapningsovn med forplade af 100 liter ler gravet ud af skrænten bag smedjen i værkstedsområdet. Leret blev æaltet med en balle snittet halm og vand hentet fra søen. Skakten blev bygget over en $23 \mathrm{~cm}$ fordybning og havde en indre bunddiameter på $47 \mathrm{~cm}$. Dens vægge var $9 \mathrm{~cm}$ tykke forneden og $7 \mathrm{~cm}$ tykke foroven. Skaktens højde var $115 \mathrm{~cm}$. Den indre diameter i toppen var $25 \mathrm{~cm}$. Forpladen var $30 \mathrm{~cm}$ bred og dens maksimale højde var $25 \mathrm{~cm}$. Ovnen var forsynet med to indblæsningshuller, der var placeret under hensyntagen til bælgenes placering $\mathrm{i}$ terrænet og $4 \mathrm{~cm}$ over jordniveau. Huller til temperaturmålinger var placeret hhv. 30 og $60 \mathrm{~cm}$ over jordniveau.

På den første arbejdsdag blev ovnen bygget op i $50 \mathrm{~cm}$ højde og dækket til med presenning. To dage senere blev ovnen bygget færdig og der blev gravet ud til ristningsbål.

De dage, hvor vi brændte, begyndte vi tid- ligt med at forvarme ovnen og riste myremalmen. Ovnene blev forvarmet med trækul, og til ristningen anvendtes brænde af løvtræ i store dimensioner. Ved selve brændingen anvendte vi igen specialbrændte kul af bøgetræ, der blev sorteret til en mindste størrelse på $5 \mathrm{~cm}$ længde.

I 2009 omfattede forsøgene to udvindinger med myremalm gravet op i henholdsvis Rønkilde og Guldforhoved (begge Midtjylland). Begge forløb tilfredsstillende og der blev fremstillet henholdsvis $1 / 2$ og $1 \frac{1}{2} \mathrm{~kg}$ jernsvamp.

Efterfølgende blev der fra 2008: II udtaget 1,5 $\mathrm{kg}$ jernsvamp og $3,4 \mathrm{~kg}$ slagge. $0,5 \mathrm{~kg}$ af jernsvampen blev renset til $300 \mathrm{~g}$ jernbarre, mens slaggen blev karakteriseret, udvalgte stykker gemt og prøver udtaget til metallurgisk analyse. Det var blandt andet $63 \mathrm{~g}$ af dette jern, der blev anvendt i forsøg. med trækning af myremalmsjern.

Udvindingerne i 2008 og 2009 producerede en sværm af prøvemateriale, der nu opbevares på SAXO-instituttet, Københavns Universitet. Analyser af myremalm, slagge fra rensning og slagge fra smedning fra de klart definerede lokaliteter vil kunne bidrage til at sandsynliggøre en kemisk sammenhæng mellem udvindingsslaggen og slaggeinklusionerne i forhistoriske genstande af jern. Og slaggeaftapningsovnen viste sig som en pålidelig leverandør af jernsvamp.

\section{OVNSKRONOLOGI OG OVNSTYPOLOGI}

Det er vigtigt, at vi som arkæologer fastholder, at ovnskronologi og ovnstypologi alene er et redskab for udforskningen af den tidlige jernteknologi. Ikke målet i sig selv. Den enkelte jernudvindingsovn og den enkelte gård eller landsby med jernudvindingsovne repræsenterer andet end blot et stadie $\mathrm{i}$ en kronologisk-teknologisk udvikling. For smeltemesterens valg af «ovntype» afspejler råstoffernes tilgængelighed og beskaffenhed. Men den afspejler også hans håndværksmæssige formåen, hans ekspertise og den tradition han var oplært i og arbejdede i. Det er muligt, at valget af «ovntype» ligeledes afspejlede specifikke konsumentbehov: en øget efterspørgsel - eller en efterspørgsel efter jern i bestemte kvaliteter.

De hidtidige fund af slaggeaftapningsovne i Danmark er få og næsten udelukkende identificeret på slaggerne. Ảrsagen kan være, at det var ovne, der var så lidt nedgravede, at de kun undtagelsesvist vil være bevaret $i$ et intensivt opdyrket kulturlandskab som det danske. Men ovnen synes at være eksponent for en driftssikker ovn med stor kapacitet, hvis anvendelse ikke nødvendigvis behøver at 
Lejre 21.06.09 Myremalm fra Rønkilde

\begin{tabular}{|l|l|l|l|l|l|l|l|l|l|l|l|}
\hline Trækul & 10 & 20 & $5 \frac{1}{2} 2$ & 6 & 5 & 5 & $3 \frac{1}{2}$ & 5 & 10 & $\mathbf{6 0}$ \\
\hline Ristet malm & \multicolumn{8}{|l|}{ Kontinuerligt } \\
\hline Blæst & & $1 \frac{1}{2} 2$ & $1 \frac{1}{2}$ & $1 \frac{1}{2}$ & $1 \frac{1}{2}$ & $1 \frac{1}{2}$ & $1 \frac{1}{2}$ & & 9 \\
\hline Tid & 0 & $3: 25$ & $4: 45$ & $5: 25$ & $5: 55$ & $6: 25$ & $6: 40$ & $7: 45$ & $8: 10$ & \\
\hline
\end{tabular}

Tabel 4: Udvinding 2009: I, hvor der af $9 \mathrm{~kg}$ ristet myremalm fra Rønkilde blev udvundet en jernsvamp på 1/2 $\mathrm{kg}$. Table 4: Iron smelting 2009: I, where $9 \mathrm{~kg}$ of roasted bog ore from Ronkilde was smelted into a $1 / 2 \mathrm{~kg}$ iron bloom.

Lejre 22.08.09 Myremalm fra Guldforhoved

\begin{tabular}{|l|l|l|l|l|l|l|l|l|l|l|}
\hline Trækul & 5 & 25 & 6 & & 6 & & 6 & & 6 & $\mathbf{5 4}$ \\
\hline Ristet malm & & & 4,4 & & 4,3 & & 4,3 & & 1,5 & $\mathbf{1 4 1} \mathbf{2}$ \\
\hline Blæst & & $\mathrm{x}$ & & $\mathrm{x}$ & & $\mathrm{x}$ & & $\mathrm{x}$ & & $\mathbf{4}$ \\
\hline Tid & 0 & $1: 30$ & $2: 15$ & $3: 25$ & $4: 05$ & $5: 55$ & $6: 30$ & $8: 25$ & $8: 50$ & $\mathbf{9 : 2 0}$ \\
\hline
\end{tabular}

Tabel 5: Udvinding 2009: II, hvor der af 141/2 $\mathrm{kg}$ ristet myremalm fra Guldforhoved blev udvundet en jernsvamp på 11/2 kg. Table 5: Iron smelting 2009: II, where 141/2 kg of roasted bog ore from Guldforboved was smelted into a 11/2 $\mathrm{kg}$ iron bloom.

være knyttet til de store forekomster af myremalm i Vestjylland. Forsøg har vist, at den kan genbruges adskillige gange og at den er forholdsvis enkel at styre reduktionsprocessen $\mathrm{i}$.

\section{SUMMARY}

Many Danish excavations, theoretical discussions and experimental archaeological studies have aimed to identify the chronological and typological changes in the iron smelting furnace. This is a difficult task, especially when it comes to the furnaces from the Viking Age and from the early Medieval times. We know that farmers in Denmark produced iron from bog iron ore right from the earliest Iron Age, but the archaeological material from the older Pre-Roman Iron Age is limited to slag, roasted bog iron ore and needles and knives made of iron. The iron smelting furnace itself is only known from the time between the late Pre-Roman Iron Age and the early Migration Period - and again from the late Viking Age and the centuries after. The archaeologist Olfert Voss has identified three typologically different furnaces in Denmark: Espevej-furnaces, Drengsted-furnaces and slag-tapping furnaces. They all belong to the group of Western European shaft-furnaces.

In this paper attention is drawn to the almost unknown Danish slag-tapping furnace. As seen from experimental archaeology, this furnace seems to be easy to build and operate, but it leaves almost no trace in a landscape as intensively cultivated as Denmark's. That may be the reason why they are so few in numbers and almost exclusively identified due to small heaps of slag and to small fragments of furnace wall found between the slag. All slag heaps are, when possible, dated to the late Viking Age and to a couple of centuries after this period. But experiments have shown that the slag-tapping furnace seems to have a large capacity and that it is easy to control the reduction in it - especially compared to the Espevejfurnace and to the Drengsted-furnace. Its shaft may even be re-used several times. Metallurgical and historical records shows that iron was produced in Denmark between AD 1000 and 1500 and these small, and yet almost unknown, slag-tapping furnaces may have been the furnaces used. And their use is not necessarily linked to the large deposits of bog iron ore in Western Jutland. Maybe many slag-tapping furnaces are still waiting to be excavated. Judging from this work, the empirical material from this furnace may be expected to be characterized by long tap slags - and perhaps planoconvex slags - where the surfaces are marked by run-off. 


\section{LITTERATUR}

Blakelock, E., M. Martinón-Torres, H.A. Veldhuijzen og T. Young 2009. «Slag inclusions in iron objects and the quest for provenance: an experiment and a case study». Journal of Archaeological Science 36 (2009): 1745-1757.

Berre, I. (red.) 1985. Frå malm i myra til stål $i$ smia. Namsos.

Buchwald, V.F.1991. «Dansk järnframställning». Forntida Teknik 1991/1: 49-60.

Cleere, H. 1990. «Iron Smelting Experiments: Towards a Systematic Policy for Internation Cooperation». Archéologie Expérimentale: 45-47.

Crew, P. 1990. «Experimental Iron Smelting and Bloom Smithing, linked to archaeological evidence from two sites in North Wales». Archéologie Expérimentale: 160-164.

Egeberg, T. 1998. «Smedens spådom». FRAM: 9-14.

Englund, L.-E. 2002. Blästbruk. Stockholm: Järnkontoret.

Evenstad, O. 1790. Afhandling om Jern-Malm som findes i Myrer og Moradser i Norge, og Omgangsmaaden med at forvandle den til jern og Staal. (= Det Kgl. Danske Landhuusholdnings-Selskabs Skrifter D3). København. Frydendahl,H.C.1928. «n Undersøgelse af fortidens Jernudvinding paa den fynske Øgruppe». Fynsk Hjemstaon 1: 58-62.

Jakobsen, S., J.H. Larsen og L.E. Narmo 1988. «Nå blestres det igjen jern ved Dokkfløy'. Et forsøk på eksperimentell arkeologi». Viking LI: 87-108.

Jensen, P.H. 1999. «Hvordan gjorde de?» Brudstykker fra Blicheregnen. Årsskift Blicheregnens Museumsforening 1999: 44-50. Thorning.

Johansen, A.B. 1979. «Livbergingsmåter i fjelldalene». Jern og jernvinne som kulturbistorisk faktor $i$ jernalder og middelalder i Norge. AmS Varia 4. Stavanger: Arkeologisk museum Stavanger.

Larsen, J.H. 2009. Jernvinneundersøkelser. Varia 78. Oslo: Kulturhistorisk museum.

Leineweber, R. og B. Lychatz 1998. «Versuche im Rennofen - eine Bilanz 2. Jahresschrift für mitteldeutsche Vorgeschichte 80: 263-304.

Lund, J. 1988. «Eksperimentel arkæologi - resultater, muligheder og perspektiver». I Madsen, T. (red.). Bag Moesgårds Maske. Århus.

Lund, J. og A. Jouttijärvi 1999. «Jernudvindingsforsøg på Moesgård». I Høiris, O., H.J. Madsen, T. Madsen \& J. Vellev (red.). Menneskelivets mangfoldighed. Arkcologisk og antropologisk forskning på Moesgård: 193-202. Moesgård.

Lyngstrøm, H. 2002a: «Myremalmens Mestre. Ved jernalderbonden ovn og esse». Forsøg med Fortiden 8. Lejre.

Lyngstrøm, H. 2002b. «Thomsen, slaggerne og den eksperimentel-arkæologiske metode». Drik - og du vil leve skønt. Festskrift til Ulla Lund Hansen på 60-årsdagen. Publications from the National Museum PNM Studies in Archaeology \& History 7: 131-138. København.

Lyngstrøm, H. 2008. Dansk jern - en kulturbistorisk undersogelse af fremstilling, fordeling og anvendelse. Nordiske Fortidsminder, serie C, nr. 5. København: Det Kongelige Nordiske Oldskriftselskab.

Magnusson, G. 1991. «Järnproduktion och järndistribution i Östersjöområdet». I Fabech C. \& J. Ringtved (red.). Samfundsorganisation og Regional Variation: 153-161.

Martens, I. 1988. Jernvinna på Møsstrond i Telemark. En studie i teknikk, bosetning og økonomi. Norske Oldfunn XIII. Oslo: Oldsaksamlingen.

Mikkelsen, P.H. og L.C. Nørbach 2003. Drengsted. Bebyggelse, jernproduktion og agerbrug $i$ yngre romersk og eldre germansk jernalder. Jysk Arkæologisk Selskabs Skrifter 43. Aarhus.

Mortensen, R. 1940. Jysk Jærn. Jyske Samlinger 5:IV.

Nielsen, N. 1924. Studier over Jernproduktionen i Jylland. København: Arnold Buscks boghandel.

Nosek, E.1992. The Polish smelting experiments in furnaces with slag pits. I. Craddock P.T \& M.J. Hughes (red.). Furnaces and Smelting Technology in Antiquity: 165-177.

Peets, J. 2003. The Power of Iron. Tallinn: Universitetet i Tartu.

Pleiner, R. 1991. «Bemerkungen zu einigen Schmelzversuchen in frühmittelalterlichen Rennöfen in der Tschechoslowakei». Experimentelle Archäologie Bilanz 1991. I Fansa, M. (red.). Archäologische Mitteilungen aus Nordwest-Deutschland 6. Oldenburg.

Rosenqvist, A.M. 1983. "Report on Chemical and Mineralogical Analyses of Norwegian Ores, Slags and Iron». Offa 40. Neumünster. 129-137.

Smekalova, T. og O. Voss 2001. «Snorup-området - jernproduktion i Vestjylland». Mark og Montre: 7-20. Ribe.

Souchopova, V. og K. Stransky 1990. «Versuchsschmelzen in Rekonstruktionen von Rennöfen aus der Umgebung von Blasko». Archéologie Expèrimentale: 149-155.

Stenvik, L. 1987. Gammel jernframstilling i Trøndelag. Spor, 1987/1: 4-7.

Strömberg, B. 2004. «Arkeologiska undersökningar av järnhanteringsplatser i Tvååkersområdet». Hikuin 13: 105-174.

Thomsen, R. 1966. "Metallographic Studies of an Axe from the Migration Age». Journal of the Iron and Steel Institute 204: 905-909.

Thomsen, R. 1994. «Metallografiske undersøgelser af sværd og spydspidser fra mosefundene i Illerup og Nydam. Summary». Aarbøger for nordisk Oldkyndighed og Historie 1992 (1994): 281-310. 
Vellev, J. 2004. «Om «Sorø Klosters Gavebog» - og om produktion af jern og salt i Halland». Hikuin 13: 37-66.

Voss, O. 1962. «Jernudvinding i Danmark i forhistorisk tid». Summary. Kuml: 7-32.

Voss, O. 1986a. «Jernudvindingsanlæg i Danmark fra forhistorisk og historisk tid». Arkeologiske Udgravninger i Danmark 1985: 25-30.

Voss, O. 1986b. «Drengsted». Reallexikon der germanischen Altertumskunde: 177-180.

Voss, O. 1993. "Jernudvinding». I Hvass S. \& B. Storgaard (red.). Da Klinger i Muld. 25 års arkcologi $i$ Danmark: 206-209. Århus: I kommission hos Aarhus Universitetsforlag
Voss, O. 1995. Arkæologiske spor efter middelalderens jernudvinding i det nuværende Danmark. In: S.-O. Olsson (red.) Medeltida danskt järn. 27-35. Halmstad: Centrum för sydsvensk kulturmiljöforskning, Högskolan i Halmstad.

Voss, O. 2002. «Jernproduktionen i Danmark i oldtid og middelalder - status og fremtid». Drik - og du vil leve skønt. Festskrift til Ulla Lund Hansen på 60-årsdagen. Publications from the National Museum PNM Studies in Archaeology \& History 7: 139-148.

Wegewitz, W. 1957. «Ein Rennfeuerofen aus einer Siedlung der älteren Römerzeit in Scharmbeck (Kreis Harburg)». Nachrichten aus Niedersachsens Urgeschichte 26: 3-25. 


\section{OVNENE I BREIVESKARET \\ - TREKK VED JERNPRODUKSJONEN I VIKINGTIDEN OG MIDDELALDEREN I ET SKAR VED HOVDEN I SETESDALEN}

\section{Axel Mjarum}

Det er anslått at det i perioden fra 900 til 1400 e.Kr. ble det produsert minst 4000 tonn jern i Hovdentraktene øverst i Setesdalen (Rolfsen 1992: 84; Larsen 2009: 106). Kunnskapen om denne jernblestringen har gått tapt, men på Hovden ligger det fremdeles mange produksjonsplasser med ovner og kullgroper som vitner om virksomheten. I 2006 undersøkte Kulturhistorisk museum tre blestertufter med ovner i dette området. Utgravningene frembrakte et rikt materiale som kaster nytt lys over den om lag 1000 år gamle ovnsteknologien som ble benyttet.

Blesterovnen er et helt avgjørende elemen- tet i prosessen som omskaper myrmalm til smibart jern. Ovnene kan imidlertid vanskelig forstås isolert. De bør derfor settes inn i en helhet med andre bevarte spor etter jerntilvirkningen, både i og utenfor produksjonsplassene. Av den grunn, og ut fra at detaljer knyttet til jernvinneanleggene på Hovden tidligere i liten grad har vært gjenstand for vitenskapelig publisering, legges det her vekt på å presentere ovnene $\mathrm{i}$ en noe bredere sammenheng. Ovnsfunnene, og konteksten de opptrer i, vil danne et grunnlag for å forstå noen av de trekkene som preger ovnene og blestringen i Hovden-traktene sent $\mathrm{i}$ vikingtiden og $\mathrm{i}$ middelalderen.
Figur 1: Hovdenområdet med Breive. Utarbeidet av A. Mjerum,

Kulturhistorisk museum (Kartgrunnlag: Statens kartverk. Tillatelsesnummer NE12000-150408SAS.).

Figure 1: The Hovden area with Breive (Map base: NMA, Permit number NE12000-150408SAS).

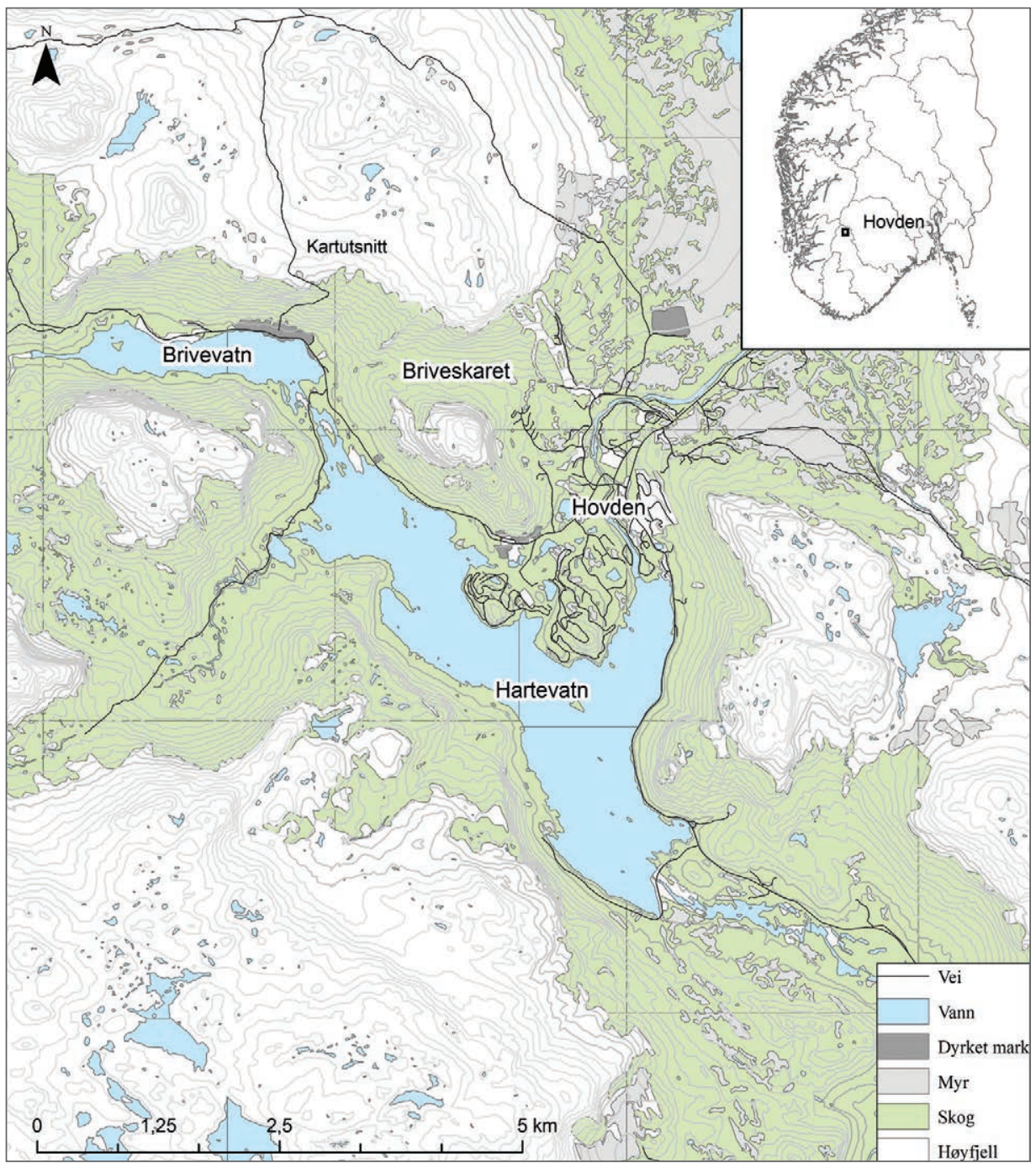




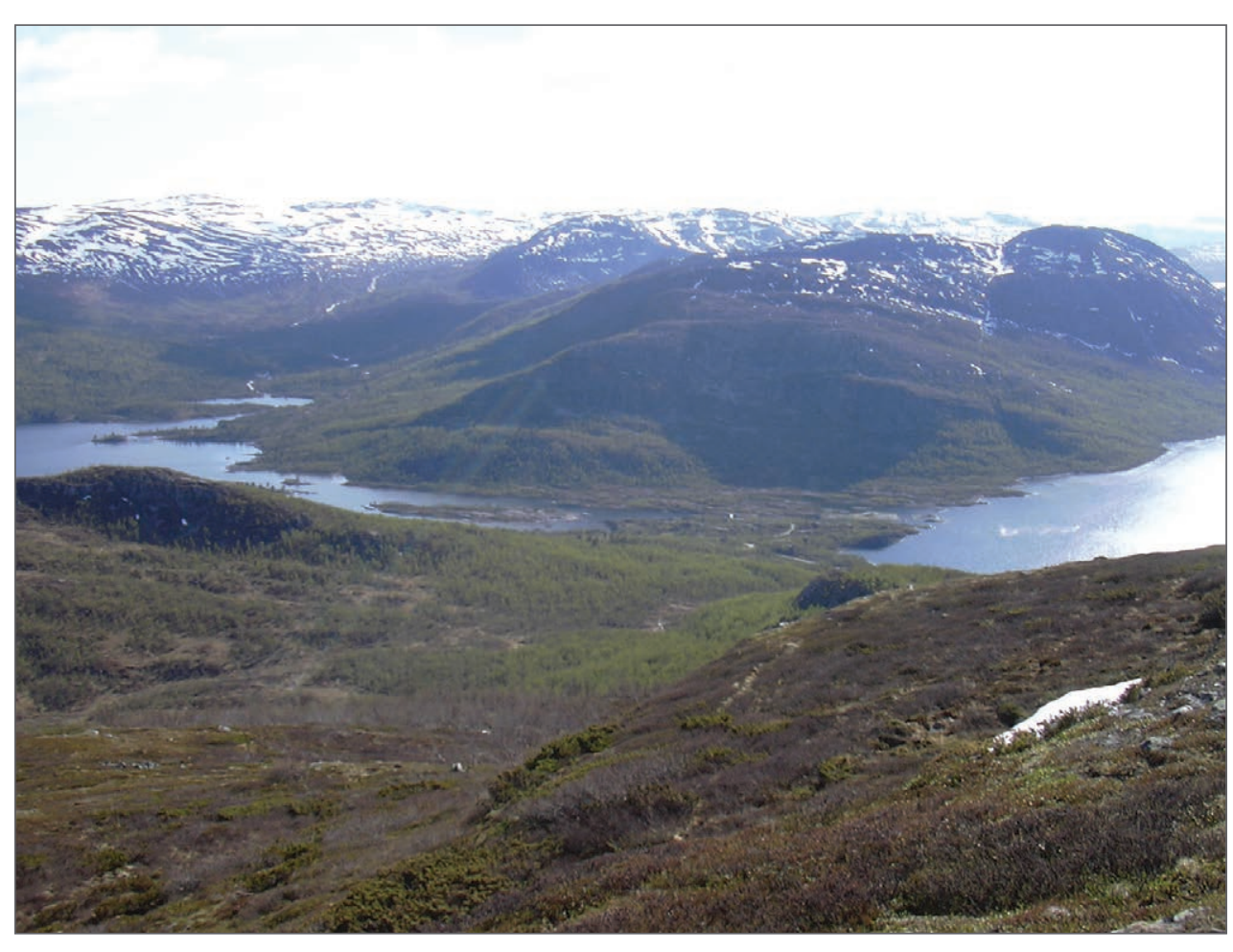

Figur 2: Østdelen av Breiveskaret med Hartervatn (t.v.) og Breivevatn (t.h.) i bakkant. Bildet er tatt fra Storenos. Foto: A. Mjarum, Kulturhistorisk museum. Figure 2: The eastern part of the small Breive valley, Lake Hartevatn (left) and Lake Breive (right). Seen from the Storenos mountain. Photo: A. Mjerum, Museum of Cultural History.

\section{HOVDEN-OMRÅDET}

Hovden ligger i Bykle kommune i Aust-Agder, på stedet hvor Setesdalen vider seg ut før den strekker seg opp mot høyfjellet. Tettstedet er lokalisert 750-850 meter over havet, og er sentralt plassert i fjellområdene sør for Hardangervidda. Elven Otra renner gjennom bygda, som i dag er et utbygd turistog skisportssenter med hytter, hoteller og skianlegg.

Naturressursene har vært et viktig utgangspunkt for stedets kulturhistoriske utvikling. Høyfjellet har gitt gode muligheter for jakt, sanking og fiske. I tillegg har det blitt drevet husdyrhold og til en viss grad åkerbruk i bygda. Hovden har videre i lang tid vært et krysningspunkt for ferdsel over fjellet fra vest til øst. Det har vært mindre ferdsel sørover langs den lange og kronglete Setesdalen (Gjerden 1993: 436).

På Hovden og de nærliggende Breive-gårdene er de eldste kjente kultursporene fra den innledende delen av jernalderen (Mjærum 2011: 19). Ved gården Skarg i østenden av Bossvatn i Bykle har det videre blitt undersøkt to gravhauger fra 400-500-tallet e.Kr., og på samme sted har det blitt gravd ut en hustuft datert til tidsrommet 500-1100 e.Kr. (Rolfsen 1977). Det har også blitt gravd ut en tjæremile på Hovden datert til 1300-1600 e.Kr. (Rolfsen 2002). Langt de fleste kulturminnene i denne bygda kan allikevel knyttes til jernblestringen.

Fra slutten av 1970-tallet har arkeologer gjennomført omfattende utgravninger av jernproduksjonsplasser i Hovden-traktene. Gjennom forskningsprosjekter (Bloch-Nakkerud 1987) og forvaltingsundersøkelser (Rolfsen 1992) knyttet til vannkraftutbygging og oppbygging av Hovden som et vintersportssenter har det blitt fremskaffet kunnskap om denne intensive aktiviteten. Det har blitt anslått at det har ligget så mye som 1000 jernvinneanlegg og 14000 kullgroper ved Hovden og i traktene sør for Haukeligrend, og radiologiske dateringer viser at anleggene $\mathrm{i}$ hovedsak var i bruk i perioden 900-1450 e.Kr. (Rolfsen 1992: 79, 83).

\section{FASE II-OVNENE - VIKINGTIDENS OG MIDDELALDERENS OVNSTEKNOLOGI}

På bakgrunn av en rekke utgravninger i innlandsområdene i Sør-Norge har den lavteknologiske jernproduksjonen og blesterovnene blitt delt inn i tre hovedfaser (Larsen 2004; Larsen 2009: 67-86; Espelund 2005: 87; Rundberget 2008: 24-27). De forskjellige hovedfasene ser ut til å avløse hverandre i tid, og de kan deles videre inn i ulike underfaser. Det henvises imidlertid til andre artikler i denne publikasjonen for en nærmere diskusjon av de ulike fasene og den kronologiske utviklingen.

Ovner med underliggende slaggroper, fase I-ovner, er kjent både fra Hovden og fra andre deler av Setesdalen (Larsen 2009: 168; Kile-Vesik og Glørstad 2013). En svært dominerende del av ovnene på Hovden er imidlertid sjaktovner med slaggavtapping - fase II-ovner (Bloch-Nakkerud 1987: 60; Rolfsen 1992: 82). Fase II-ovnene i de sentrale 


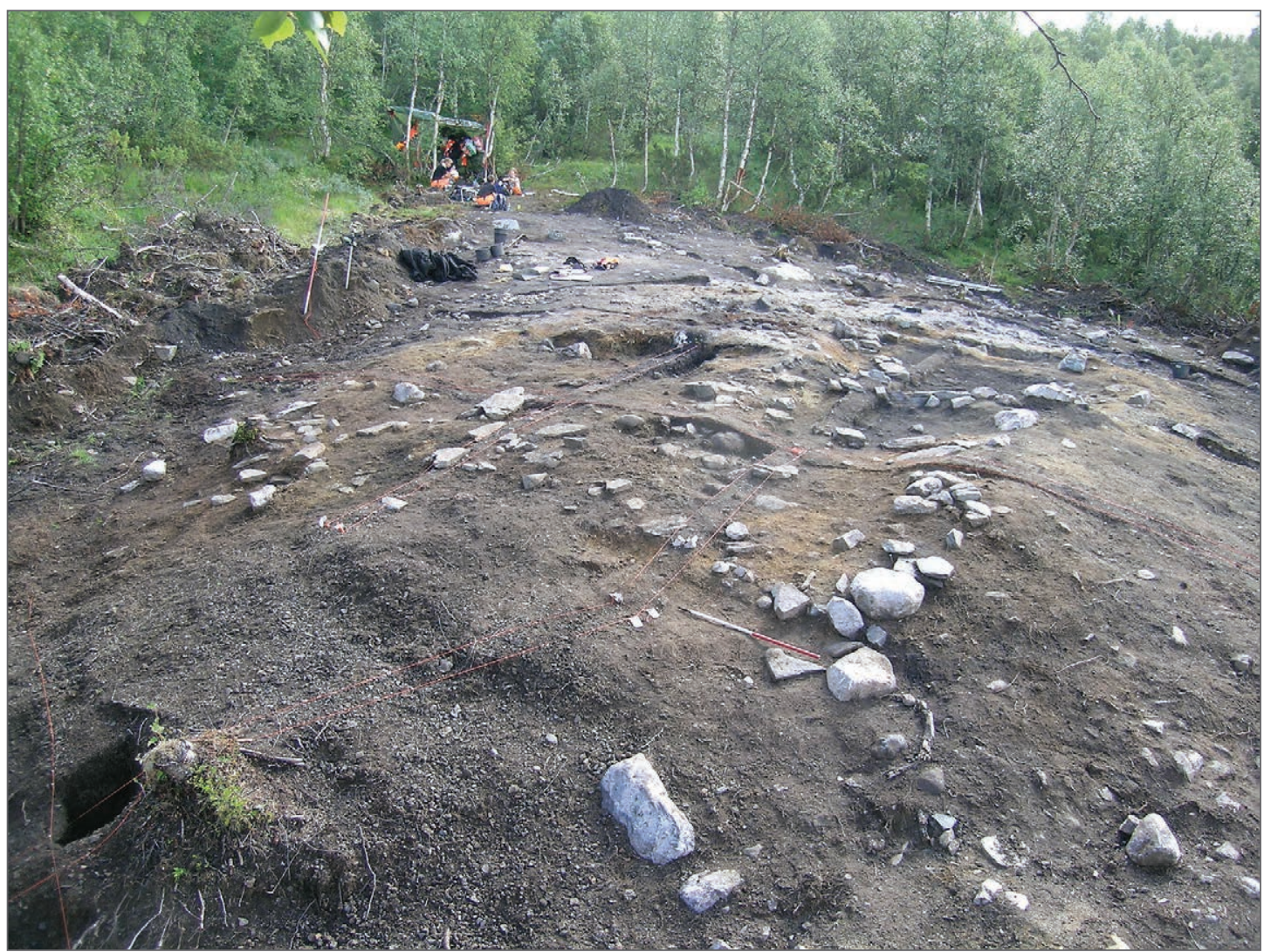

Figur 3: Fireromstuften under utgraving mot sørøst. Tuften hadde veggfundamenter av jord og stein. Til venstre $i$ tuften ligger produksjonsdelen, mens de ovrige rommene ligger på rekke til hoyre i bildet. I nedre venstre bildekant ser vi deler av slagghangen. Foto: A. Mjerum, Kulturhistorisk museum.

Figure 3: Excavation of the multi-room house ground floor (photo facing southeast): The building had a wall base of earth and stones. The furnace area is visible on the left, with other rooms to the right. Part of the slag heap can be seen, below left. Photo: A. Mjarum, Museum of Cultural History.

innlandsområdene i Sørøst-Norge kjennetegnes ved at det flytende slagget har blitt tappet ut giennom et hull på siden av ovnen og ned i en slaggrenne.Jernet, den såkalte luppen, har blitt liggende igjen, og man har kunnet ta det ut med en krok eller en tang (Larsen 2009: 77-85; se også figur 9). Uttappingen av slagget har resultert $i$ at en del av slaggavfallet har fătt en tydelig og lett gjenkjennbar rennestruktur. Type II-ovnene ble trolig tatt i bruk på 700-tallet, eller kanskje rundt år $800 \mathrm{i}$ sentrale og vestlige innlandsområder i Sør-Norge (Larsen 2004: 157), og de gikk ut av bruk i senmiddelalderen (Larsen 2004: 162-163).

\section{JERNVINNEPLASSENE I BREIVESKARET}

Fra ytterkanten av Hovden sentrum strekker det om lag to kilometer lange Breiveskaret seg i vestlig retning mot Breivevatnet. Henholdsvis nord og sør for skaret ligger de to markerte fjelltoppene Storenos og Hovdenuten. Toppen av Storenos ligger 1198 meter over havet, mens Hovdenuten er noe lavere. Bunnen av skaret befinner seg på 800-900 meters høyde og er i hovedsak bevokst med tett bjørkeskog. Langs sidene av den lille dalen blir skogen gradvis mer glissen, og det er snaufjell over om lag 1025 meters høyde. I bunnen av dalføret ligger det enkelte morenerygger med sand og grus. Mellom disse områdene er det myrpartier med varierende størrelse. Opp langs sidene av skaret finnes det også partier med blokkmark og fjell i dagen, se figur 2 .

Med utgangspunkt i planene om å utvide Hovden Skisenter har det ved flere anledninger blitt registrert kulturminner i det lille dalføret. På grunn av det arbeidet som har blitt nedlagt, er det i dag kjent 10 jernvinneanlegg, 242 kullgroper og 5 røsteplasser. Jernvinneanleggene ligger uten unntak i bunnen av skaret og ned mot Breivevatnet, mens det har blitt funnet kullgroper opp langs sidene av skaret, helt opp til dagens tregrense. Det har blitt diskutert hvilke implikasjoner denne omfattende jern- 
fremstillingen har hatt for skogen (Bloch-Nakkerud 1987: 152-154; Rundberget 2013: 317). Antallet groper, funn av groper i bratte lier og groper langt fra kjente produksjonsplasser viser også at behovet for brensel har vært stort i Breiveskaret, og tidvis har det trolig vært knapt med trevirke. Tilgangen på kull kan derfor ha vært begrensende for produksjonen på de enkelte anleggene (jf. Martens 1988: 126).

Det har også blitt søkt med magnetometer i det lille dalføret (Smekalova 2006). Ved hjelp av dette instrumentet, som måler avvik (anomalier) i magnetismen i jordens magnetfelt, fremkom det fem røsteplasser. To av lokalitetene lå i umiddelbar nærhet til tidligere kjente jernvinneanlegg. De tre øvrige samlingene var anlagt på høydedrag ved myrer, uten tilknytning til de kjente jernproduksjonsplassene.

Mye av jernproduksjonen i Hovden-traktene har foregått innomhus. I løpet av sommeren 2006 undersøkte ansatte ved Kulturhistorisk museum tre blesterhus på to ulike steder i Breiveskaret (Mjærum 2011). Det ene anlegget lå ved Heibekken, i stigningen opp fra Breivevatnet. Den andre produksjonsplassen lå ved Godtstøylbekken, lenger vest.

\section{JERNFREMSTILLINGEN VED HEIBEKKEN}

Anleggene ved Heibekken befant seg i den vestre delen av Breiveskaret, med utsyn over Breivevatn. Produksjonsplassen var lagt nær et bekkedrag med vannføring i nedbørsrike perioder. Ved Heibekken fremkom det rester etter to bygninger som hadde blitt brukt til jernproduksjon.

\section{Fireromstuften}

Den største av tuftene var vinkelformet og hadde fire rom, se figur 3. Lengden var om lag 12,5 meter, bredden var 10,3 meter, og bygningen var reist i hellende terreng. Det var bevart tydelige veggvoller, og enkelte av gulvflatene var skåret over 0,5 meter ned i terrenget, noe som gjorde tuften tydelig, også før utgravningen.

På toppen av veggvollene lå det stein, delvis i rekker. Steinene har dannet et underlag for trebygde vegger. I den nordlige delen, mellom produksjonsdelen med ovnene og slagghaugen, manglet det steinfundamenter. Behovet for utlufting og stadig tilog utførsel av råstoff, brensel og avfallsmasser kan ha gjort det hensiktsmessig å ha en stor åpning i denne delen av bygningen (Narmo 1996: 111).

De fire rommene var tilpasset ulike funksjoner og behov. I den sørlige delen lå det et bakrom som i den første tiden hadde tjent som et lager for kull. På et senere tidspunkt hadde rommet blitt bygd om, og det hadde blitt etablert et ildsted inn mot den ene

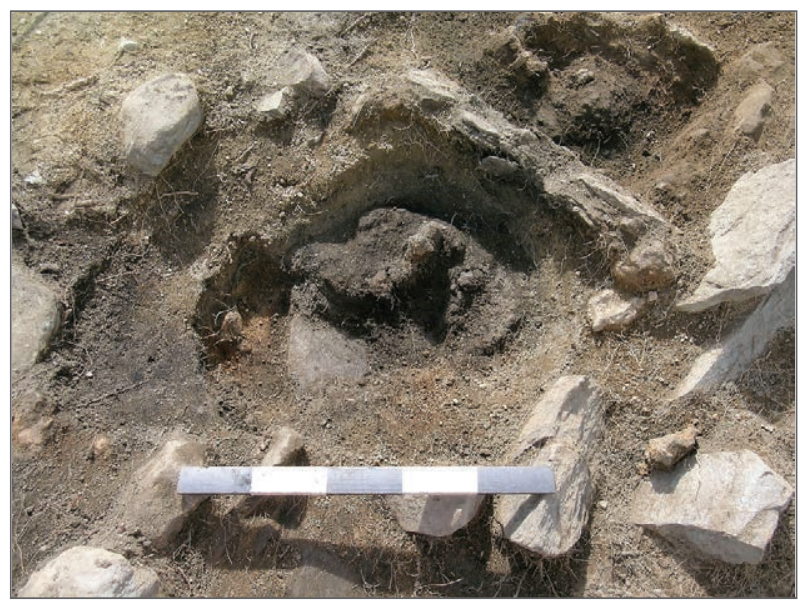

Figur 4: De to sjaktornene i fireromstuften har ligget tett ved hverandre. I forkant ser vi ovn 2 med bunnslagg. Ovnen er omsluttet av heller og annen stein. I bakkant ser vi ovn 1 med sjaktmaterialet bevart in situ. Foto: A. Mjarum, Kulturbistorisk museum.

Figure 4: The two furnaces in the multi-room house area. Furnace 2 with framing-stones is visible in front and furnace 1 with fragments of the clay wall behind. Photo: A. Mjarum, Museum of Cultural History.

veggen. Slike bakrom med ildsteder er kjent i blestertufter fra ulike deler av Sør-Norge, og rommet kan ha blitt brukt som oppholdsrom for dem som fremstilte jernet. I midten og i den nordre delen lå det to mindre rom. Det har vært vanskelig å avgjøre funksjonen til det ene av disse, mens et malmlag taler for at det andre ble brukt til lagring av røstet malm (jf. Martens 1988: 77-78).

Selve jerntilvirkningen har foregått i det største rommet, i en del av bygningen som hadde en gulvflate på 4,5 x 3,9 meter. Ved den åpne gavlveggen var det reist to jernvinneovner, se figur 4 . Begge ovnssjaktene var dårlig bevart. Ovn 1 var uten in situ sjaktmateriale, mens ovnssjakten i ovn 2 var delvis intakt opp til 5-10 centimeters høyde. Under de sentrale delene lå det lag med porøst bunnslagg over bunnheller som målte 0,25 og 0,43 meter i tverrmål. Mellom ovnene og slagghaugen som tilhørte dette anlegget, sto det et mindre antall kantstilte heller som var inntil 0,5 meter store. En helle av tilsvarende størrelse var også plassert mellom de to sjaktovnene.

Ut fra fyllskifter i området ser det ut til at ovnssjaktene har vært tilnærmet sirkulære, og at de har hatt en indre diameter på om lag 0,35 meter. Det ble ikke påvist noen entydige slaggrenner i tilknytning til dem, men renneslagg som lå mellom ovnene og slagghaugen, tyder på at slagget ble tappet ut i denne retningen. Den store mengden stein som lå 
spredt i ovnsområdet, vitner om gjentatte reparasjoner og en lang brukstid.

I produksjonsrommet var det også anlagt et kulllager, et mulig malmlager og et ildsted bygd av steinheller med en tilnærmet kvadratisk form. Denne sistnevnte konstruksjonen hadde en tydelig fyringsbunn på om lag 0,5 meter som delvis var omsluttet av en steinkarm. Et tilsvarende ildsted ble påvist ved Godtstøylbekken, se figur 7, og typen er ellers kjent fra flere andre jernvinneanlegg på Hovden (BlochNakkerud 1987: 60; Kile-Vesik og Glørstad 2013). Ut fra nærheten mellom ildstedene og ovnene er det rimelig å knytte ildstedene i produksjonsrommene til selve jerntilvirkningen. Det fremkom også noe malm knyttet til dem, noe som kan indikere at disse særegne strukturene har hatt sammenheng med malmbearbeiding. Ut over dette fremstår de hellebygde strukturene på Hovden som et lokalt særdrag, og ikke minst som en gåte.

Slagghaugen lå like nedenfor ovnsområdet. I haugen lå det et opptil én meter tykt avfallslag med slagg, kull, malm, ovnsrester og annet materiale fra jernfremstillingen. Oppmålinger og beregninger gir grunnlag for å anta at det var så mye som 28 tonn avfall i haugen, hvorav om lag 18 tonn var jernslagg. Vi har ingen sikker kunnskap om forholdet mellom mengden produsert jern og mengden avfallsstoffer (Larsen 2009: 106-107). Det har imidlertid i de senere år blitt foreslått et utbytte på 0,5-0,9 kilo jern per kilo slagg (Rundberget 2013: 250). Om vi legger et utbytte på 0,7 kilo til grunn, har den samlede jernproduksjonen vært 12,6 tonn.

Slaggstykkene var i hovedsak under 0,1 meter store, og mange stykker hadde en overflate med en tydelig flytestruktur. Slagget kan følgelig betegnes som renneslagg (Larsen 2009: 87). Slagget har blitt tappet ut av en åpning på siden av ovnen, se figur 9. Det lå også opptil 0,15 meter store, delvis porøse stykker med mer ujevn overflate i haugen. Dette slagget tilsvarte det som lå bevart $\mathrm{i}$ bunnen av ovnene. Det ble imidlertid ikke funnet noen bunnskoller, det vil si store kompakte, runde slaggstykker fra bunnen av ovnene. Slike store bunnskoller er kjent fra andre områder, deriblant Valdres (Narmo 1996: 83-86). Avfallet vitner i sin helhet om omfattende produksjon, og om at det har foregått et vedvarende vedlikehold med reparasjoner og utskiftinger av ovnsdeler.

De eldste ${ }^{14} \mathrm{C}$-dateringene som kan knyttes til jernproduksjonen i Breiveskaret, er fra fireromstuften. Syv dateringer herfra taler for aktivitet på lokaliteten på 900-tallet. Tuften ser deretter ut til å ha vært i bruk til utpå 1100-tallet, eller til rett etter år 1200 e.Kr.

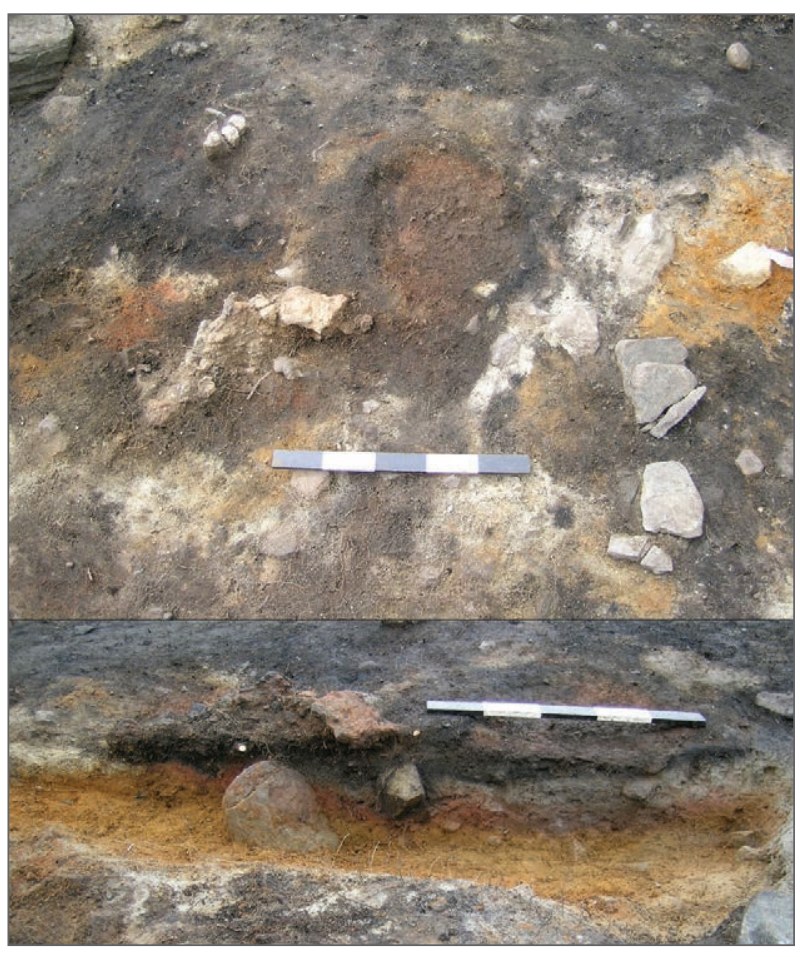

Figur 5: Ovnen uten spor etter steinfôring $i$ ettromstuften på Heibekken. Øverst ser vi ovnen i plan med den nedsmeltede ounssjakten med rodbrent leire og en slaggfylt renne. Nederst ser vi et tverrsnitt av ovnen og slaggrennen. Foto: A. Mjerum, Kulturhistorisk museum.

Figure 5: Furnace without traces of framing-stones in the single-room house. Top: plan of the furnace with the melted clay wall and the drain through which slag was removed. Bottom: section of the same furnace and the drain. Photo: A. Mjorum, Museum of Cultural History.

\section{Ettromstuften}

I den sørøstlige delen av lokaliteten var det rester etter en mindre, nær kvadratisk, svakere markert ettroms blestertuft. Denne tuften målte $6,8 \times 5,8$ meter og var markert av lave veggvoller bygd av sand og noe avfall fra tidligere jernproduksjon. På toppen av vollen lå det en del spredte stein som trolig har tjent som veggfundamenter. Både i den sørlige og $\mathrm{i}$ den nordlige kortveggen var det spor etter 0,8 meter brede inngangspartier.

En dårlig bevart sjaktovn med sideavtapping av slagg var anlagt innenfor det sørlige inngangspartiet, se figur 5. De ugunstige bevaringsforholdene har trolig sammenheng med at det i liten grad var benyttet stein til å støtte og isolere ovnssjakten. Ovnen var kun bevart som et lag med rester etter ovnssjakten og et opptil 4 centimeter tykt sjikt med bunnslagg, sjaktmateriale og malm i en grunn forsenkning. Dette bunnsjiktet hadde en oval form i plan og målte 0,44 x 0,28 meter. Samlet gir fyll- 


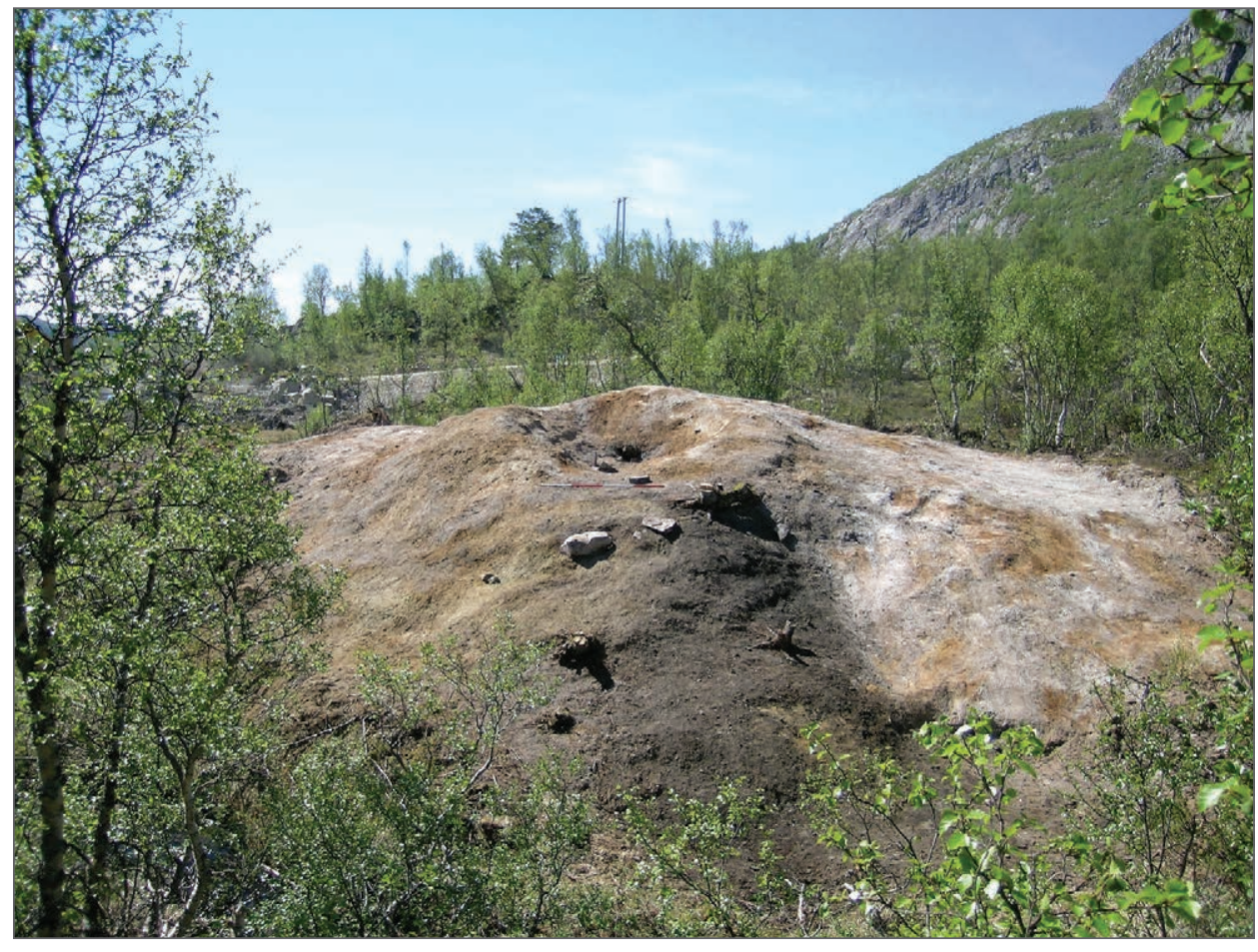

Figur 6: Lokaliteten Godtstoylbekken. Tuften sees som en grop sentralt $i$ bildet. Slaggutkastet ligger $i$ forkant av bygningen. Foto: A. Mjarum, Kulturhistorisk museum.

Figure 6: The

Godtstøylbekken site with the house area. A small slag heap can be seen in the front. Photo: A. Mjorum, Museum of Cultural History. skiftene grunnlag for å antyde at ovnssjakten har hatt en indre diameter på rundt 0,4 meter. Mot sørøst, i retning av inngangspartiet, påviste vi renneslagg som hadde størknet på stedet. Slagget lå i en opptil 0,1 meter dyp og 0,6 meter lang renne, se figur 5 .

Omkring 0,25 meter sørvest for ytterkanten av ovnen var det gravd et lite stolpehull med enkelte mindre skoningstein. Lignende stolpehull har tidligere blitt funnet i tilknytning til sjaktovner (Narmo 1996: 102-103), og det kan muligens knyttes til en blåsebelg som har vært benyttet $\mathrm{i}$ forbindelse med blesterovnen.

Innenfor den vestre veggen til den lille tuften var det også etablert et ildsted som var bygd opp av steinheller. I ildstedet, og på den omliggende gulvflaten, fremkom hoveddelen av de brente beinene som ble funnet på lokaliteten. Det er identifisert bein av sau eller geit, rein, klovdyr og hønsefugl og dessuten reingevir (Hufthammer 2007). Knokkelfunnene representerer sikre spor etter både husdyrhold og jakt.

I den nordlige delen av tuften lå det i tillegg et kullager, og utenfor ettromstuftens sørlige kortvegg var det kastet produksjonsavfall som minnet om det som fremkom ved den store tuften. Avfallshaugen har blitt beregnet til å veie omtrent 1,9 tonn, hvorav cirka 1,2 tonn er slagg. Jernproduksjonen kan ut fra dette grovt anslås til 0,85 tonn (jf. Rundberget 2013: 250).
Ettromstuften på Heibekken hvilte på avfallslag fra tuften med fire rom. I samsvar med det antyder seks ${ }^{14} \mathrm{C}$-dateringer at driften $\mathrm{i}$ ettromstuften ble påbegynt mot slutten av vikingtiden, om lag hundre år etter at fireromstuften ble anlagt. Tidspunktet for driften av ettromstuften har, blant annet gjennom en radiologisk datering av hasselnøttskall fra ildstedet, blitt belagt til AD 1015-1035 (990 \pm 25 BP, TUa-6323). Stratigrafien indikerer at bruken av ettromstuften opphørte samtidig med resten av anlegget på 1100-tallet, eller muligens rett etter 1200 e.Kr. Den begrensede slaggmengden knyttet til bygningen tyder imidlertid på at selve jernproduksjonen foregikk innenfor et kortere tidsrom.

\section{JERNFREMSTILLINGEN VED GODTSTØYLBEKKEN}

Et annet jernvinneanlegg lå ved Godtstøylbekken, om lag 1,6 kilometer øst for Heibekken og kun 1,3 kilometer fra Hovden sentrum. Selve blesterbygningen var skåret inn i en markert morenehøyde, se figur 6. Rett på andre siden av Godstøylbekken, utenfor undersøkelsesområdet, var det flere spor etter aktivitet, det har blant annet blitt funnet en vinkelformet tuft, slagg og en slåttemark som kan ha vært drevet langt tilbake i tid.

Blestertuften var gravd opptil 1,6 meter ned i terrenget, se figur 6 og figur 8. Nedskjæringene tilknyttet gulvflaten og inngangspartiet bidro til at bygningsresten fikk et hesteskoformet preg. En 


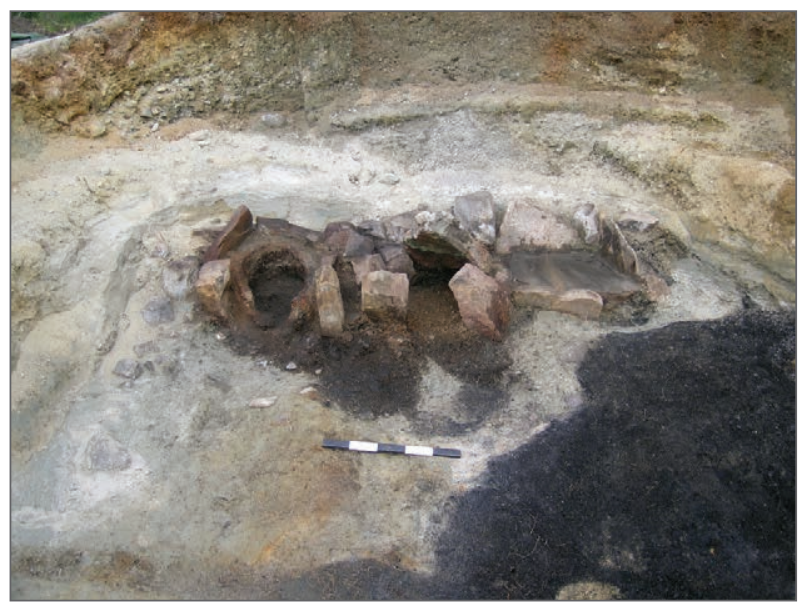

Figur 7: Ovnområdet innerst i tuften på Godtstøylbekken. Den velbevarte oun 1 var anlagt til venstre, den dårligere bevarte oun 2 ligger sentralt $i$ bildet, og ildstedet ligger til hoyre. I forkant av ovnene ser vi slaggrenner, og foran til hoyre ser vi deler av et kullager. Foto: A. Mjerum, Kulturhistorisk museum.

Figure 7: The area with furnaces at the bottom of the excavated house area at Godtstoylbekke. From left to right: the best preserved furnace, a more poorly preserved furnace and a hearth. In front of the two furnaces the drain through which slag was removed is visible, as well as parts of the charcoal depot. Photo: A. Mjorum, Museum of Cultural History.

mindre del av de utgravde massene var brukt som veggvoller, men hoveddelen lå $\mathrm{i}$ skråningen nedenfor huskonstruksjonen. Da utgravningen begynte, var gulvflaten dekket av et opptil 0,5 meter tykt lag med innraste masser. Når disse massene ble fjernet, fremkom det en gulvflate med slagg, kull og annet avfall. Gulvet hadde en nær kvadratisk form, og det målte 3,4 x 3,4 meter. I tillegg har bygningen hatt et lite inngangsparti. Innenfor veggene var det små stolpehull med en avstand på 0,3-0,4 meter. Stolpene har vært med på å bære taket.

Inn mot tuftens sørlige gavlvegg lå det tre strukturer på rekke. Det var to sjaktovner med sideavtapping av slagg og et ildsted bygd av steinheller, se figur 7. De tre konstruksjonene var plassert tett inntil hverandre. Sjaktovnen med sideavtapping av slagg, ovn 1, var den østligste. Kantstilte steiner rundt ovnssjakten og de innraste massene har bidratt til å beskytte ovnen frem til utgravningen. Sentralt i strukturen var det reist en oval til sirkulær sjakt bygd av magret, brent leire. Den var pipeformet med en indre diameter på 0,35 meter og en ytre diameter på opp mot 0,47 meter. Den bevarte høyden var 0,4 meter. Konstruksjonen hadde en åpning ut mot gulvflaten. Her må det ha vært en blesteråpning for tilkobling av blåsebelgen, og i tillegg må uttap- ping av slagget ha foregått i denne delen av ovnen, se figur 9. Kantstilte steinheller har bidratt til å støtte opp ovnssjakten. Utenfor hellene var det plassert stein som var opptil 0,3 meter i diameter. Disse har holdt de kantstilte steinene på plass. Under ovnen var det et lag med 66 kilo slagg og en kraftig, kuleformet stein.

Ovn 2 var også en sjaktovn, men denne var dårligere bevart. Allikevel var det tydelig at den var bygd etter de samme overordnede prinsippene som ovn 1. Ovnen var omgitt av stein, og sentralt lå det rester av en kollapset ovnssjakt. Det var en grop og enkelte små heller under ovnen, men ingen bunnstein av samme type som under ovn 1 .

Den vestligste av strukturene var et ildsted bygd opp av steinheller, se figur 7 og figur 8 . Sentralt var det lagt en stor trapesformet steinhelle rett på undergrunnsmassen. Steinen hadde en plan overflate, målte knapt 0,5 meter i tverrmål og hadde en tykkelse på om lag 0,2 meter. Rundt denne hellen hadde det blitt reist mindre steiner. I forkant av strukturen var det en 0,2 meter bred åpning. Mellom steinene i strukturen lå det hardpakket leire. Det ble ikke påvist rene malmmasser i tilknytning til steinhellene.

I den nordvestre delen av tuften befant det seg et kullager. Denne beliggenheten tilsvarer plasseringen av kullagrene som ble påvist ved undersøkelsene av de to blestertuftene ved Heibekken. Utenfor inngangspartiet var det et lite slaggutkast. Totalvekten av avfallet ble beregnet til kun å være i underkant av 1,2 tonn, hvorav nær 0,6 tonn var slagg. Jernutbyttet må følgelig ha begrenset seg til noen få hundre kilo (jf. Rundberget 2007: 353-354).

Slagget samsvarte med det som fremkom ved Heibekken, med små stykker av slagg med rennestruktur og enkelte biter av slagg som trolig har størknet inne i ovnene. Det fremkom imidlertid ikke større, kompakte bunnskoller. Slaggmengden tilsier at anlegget har hatt en kort brukstid.

De radiologiske analysene viser at jernfremstillingen ved Godtstøylbekken tok til en stund etter at anleggene ved Heibekken ble nedlagt . Åtte dateringer faller alle innenfor tidsrommet 1245-1445 e.Kr. Fem av disse er videre kalibrert til tidsrommet cirka $1300-1400$ e.Kr. ${ }^{14} \mathrm{C}$-dateringene gir med dette et godt grunnlag for å aldersbestemme anlegget til høy- og senmiddelalder.

\section{OVNENE OG OVNSUTVIKLINGEN I BREIVESKARET}

Alle de fem utgravde ovnene i Breiveskaret kan karakteriseres som gropsjaktovner med sideavtap- 


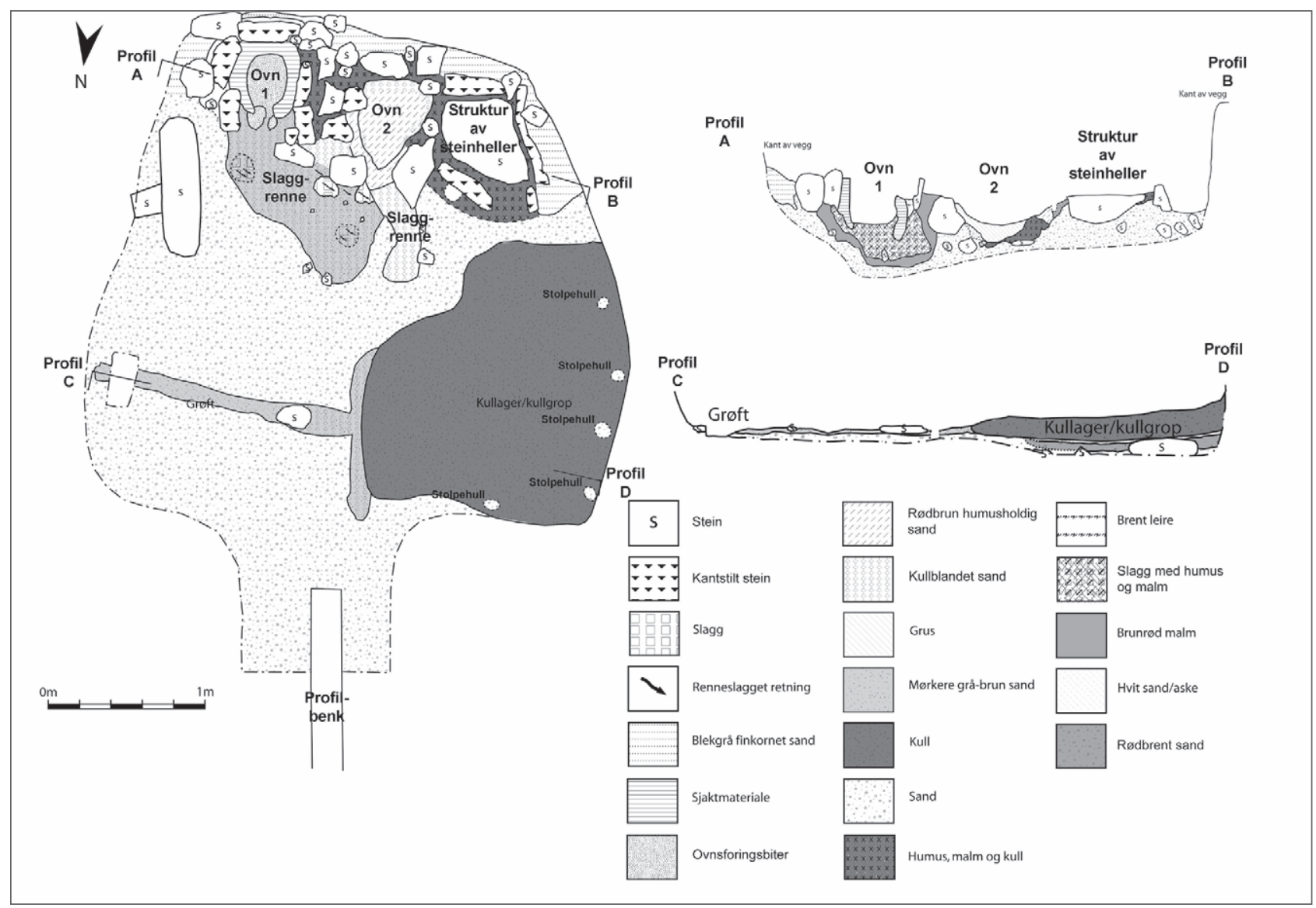

Figur 8: Plan-og profiltegninger av tuften ved Godtstoylbekken. Illustrasjon: T. Wikstrom, Kulturbistorisk museum. Figure 8: Plan- and profile drawings of the house area at Godtstoylbekken. Illustration: T. Wikstrom, Museum of Cultural History.

ping av slagg, og de er følgelig jernvinneovner av type II. Det ble ved samtlige ovner funnet spor etter leirebygde, nær sirkulære sjakter. Den indre diameteren på ovnene ble målt til om lag 0,35 meter, noe som samsvarer med det som tidligere har blitt observert på Hovden (Rolfsen 1992: 82), og på Østlandet for øvrig i vikingtiden og middelalderen (Larsen 2009: 78-80). På Godtstøylbekken var en av leirsjaktene bevart opp til en høyde på 0,4 meter. Ut fra undersøkelser og eksperimenter antas det imidlertid at høyden for ovner med slaggavtapping trolig var om lag 0,7 meter (Jakobsen et al. 1988; Larsen 1991: 148-149; Narmo 1996: 77; Rundberget 2013: 104). Disse vurderingene av høyden kan trolig også overføres til sjaktovnene på Hovden.

Det har blitt pekt på at det har vært en forholdsvis stor variasjon blant de eldste fase II-sjaktovnene (Tveiten 2012: 187). Det finnes blant annet eksempler på tidlige type II-ovner med steinforede groper under ovnssjaktene, et trekk som trolig er en arv fra eldre teknologi. I tillegg ser det i begrenset grad ut til ha blitt benyttet steinheller til å støtte opp og isolere ovnssjaktene på de eldste type II-ovnene (se for eksempel Martens 1988; Tveiten 2012: 184185). Den manglende bruken av stein i de øvre delene av konstruksjonen har medført at enkelte av vikingtidsovnene er forholdsvis dårlig bevart (jf. Larsen 2009: figur 57). Ovnen i ettromstuften på Heibekken var ikke omsluttet av en steinkasse, noe som gjør at fraværet av stein kan være et tidlig trekk ved denne oven.

Det er videre holdepunkter for at det har skjedd en standardisering av ovnsteknologien i løpet av 1000-tallet vest for Mjøsa (Tveiten 2012: 187). Utformingen fikk da et mer funksjonelt preg. Samtidig ble stein, steinheller og løsmasser i større grad benyttet for å støtte opp og isolere ovnssjakten. Slike tydelige, og tidvis velbevarte, konstruksjoner, har blitt undersøkt en rekke steder (Martens 1988; Larsen 1991: 97-202; Larsen 2009; Narmo 1996: 69-80; Mjærum 2007: 182; Tveiten 2012: 187). De to ovnene i fireromstuften på Heibekken føyer seg inn i denne sene fase II-tradisjonen. Både steinen og hellene rundt ovnssjaktene, steinhellene rundt 


\begin{tabular}{|c|c|c|c|c|c|c|c|c|c|}
\hline \multirow[t]{2}{*}{ Anlegg } & \multirow[t]{2}{*}{ Ovn } & \multirow{2}{*}{$\begin{array}{l}\text { Kant- } \\
\text { heller }\end{array}$} & \multicolumn{3}{|c|}{ Leiresjakt } & \multicolumn{3}{|l|}{ Ovnsgrop } & \multirow[t]{2}{*}{ Datering } \\
\hline & & & $\begin{array}{l}\text { Indre } \\
\text { diameter }\end{array}$ & $\begin{array}{l}\text { Ytre } \\
\text { diameter }\end{array}$ & $\begin{array}{l}\text { Tykkelse } \\
\text { sjaktvegg }\end{array}$ & Diameter & Dybde & $\begin{array}{l}\text { Bunnstein/ } \\
\text {-helle }\end{array}$ & \\
\hline \multirow{2}{*}{$\begin{array}{l}\text { Heibekken, } \\
\text { fireromstuft }\end{array}$} & 1 & Ja, delvis & 0,35 & - & - & 0,35 & $5-10$ & Helle & \multirow{2}{*}{$\begin{array}{l}900-1200 \\
\text { e.Kr. }\end{array}$} \\
\hline & 2 & $\mathrm{Ja}$, delvis & 0,35 & 0,42 & 5 & - & - & Helle & \\
\hline $\begin{array}{l}\text { Heibekken } \\
\text { ettromstuft }\end{array}$ & 1 & Nei & Ca. 0,4 & - & - & 0,44 & $<10$ & $\mathrm{Nei}$ & $\begin{array}{cccc}1 & 0 & 0 & 0 \\
12 & 0 & \mathrm{e} . \mathrm{Kr}\end{array}$ \\
\hline \multirow{2}{*}{$\begin{array}{l}\text { Godtstøyl- } \\
\text { bekken }\end{array}$} & 1 & $\mathrm{Ja}$ & 0,35 & 0,47 & $6-8$ & 0,7 & 0,35 & Stein & \multirow{2}{*}{ 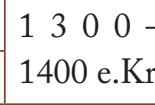 } \\
\hline & 2 & $\mathrm{Ja}$ & - & 0,45 & - & 0,5 & 0,28 & Små heller & \\
\hline
\end{tabular}

Tabell 1: Sentrale observasjoner og mål for de fem undersøkte jernvinneovnene i Breiveskaret.

Table 1: Observations and measurements related to the five excavated iron furnaces in Breiveskaret.

ovnene, størrelsen og formen til leirsjaktene samsvar godt med det som ellers er kjent.

Ovnene ved Godtstøylbekken ligner også på et overordnet plan på det som er kjent av type II-ovner i sentrale og vestlige innlandsstrøk. Konstruksjonen er imidlertid omsluttet av svært kraftige, kantsatte steiner, og den er mer forseggjort enn det som er vanlig i jernvinneområdene fra middelalderen. Kombinasjonen med ovner og et steinsatt ildsted er heller ikke kjent $i$ andre jernvinneområder. Tilsvarende kraftige ovner og nærliggende hellelagte ildsteder har også fremkommet ved en nylig avsluttet undersøkelse på Hovden (Kile-Vesik og Glørstad 2013), og de har likhetstrekk med ovner fra området som har blitt beskrevet tidligere (Bloch-Nakkerud 1987: 60; Rolfsen 1992: 82). De kraftige ovnene ved Godtstøylbekken ser derfor ut til å være en del av en tradisjon som var etablert øverst i Setesdalen.

\section{OVNENE OG JERNVINNETRADISJONEN PÅ HOVDEN}

Selv om jernproduksjonen i vikingtiden og middelalderen bygger på de samme overordnede teknologiske prinsippene $\mathrm{i}$ de sentrale og vestlige jernvinnebygdene i Sør-Norge, finnes det store variasjoner. Både brenningen av trekullet, organiseringen av jernvinneanleggene og etableringen av blestertuftene har foregått på ulikt vis (Martens 1988; Larsen 1991; Narmo 1996; Mjærum 2007; Larsen 2009; Rundberget 2013; Tveiten 2012). Undersøkelsene i Breiveskaret og på Hovden for øvrig viser at fremstillingen av jern øverst i Setesdalen kjennetegnes av tydelige bygningsspor, og at kull og malm i stor grad ser ut til å ha blitt lagret innendørs. Funn av hellebygde ildsteder i produksjonsområdene er også særegent, og de indikerer at noe av malmbearbeidingen har foregått etter lokale tradisjoner. Bunnslagget $\mathrm{i}$ ovnene var videre forholdsvis porøst, og de dannet ikke kompakte, store bunnskoller slik vi kjenner det fra enkelte andre middelalderanlegg (Narmo 1996: 83-86). Denne forskjellen taler for at det også har vært teknologiske ulikheter i selve produksjonsprosessen.

Et siste trekk som synes å kjennetegne enkelte av fase II-anleggene på Hovden, er at de har forseggjorte ovner med kraftige steinkonstruksjoner. Disse oppbygningene vitner om at det har blitt investert betydelige ressurser i etableringene av ovnene. Det er imidlertid ikke bare ovnene på Hovden-anleggene som vitner om en slik omfattende ressursbruk. Enkelte av blestertuftene er også sjeldent tydelige, selv før utgravninger har funnet sted (BlochNakkerud 1987: 29-57). Blestertufter av tilsvarende størrelse som den største ved Heibekken har tidligere kun blitt undersøkt nord i Setesdalen (BlochNakkerud 1987: 58-60; Rolfsen 1992: 81-82) og i Vest-Telemark (Martens 1988) i Sørøst-Norge. Ovns- og tuftkonstruksjonene taler for at det har blitt lagt ned mye arbeid for å legge til rette for jernproduksjonen ved enkelte av anleggene. Den samlede produksjonen ved Heibekken viser dessuten at det tidvis har vært et betydelig utbytte av aktiviteten. Produksjonsomfanget kan sammenlignes med det som er kjent fra Vest-Telemark (Martens 1988: 102) og områdene øst for Mjøsa (Narmo 1997, figur 77; Rundberget 2007, tabell 59).

Sammenfallet i de overordnede konstruksjonsprinsippene i Sør-Norge og en synkron teknologisk utvikling taler totalt sett for en omfattende kunnskapsutveksling mellom ulike jernvinneområder. Det har medført at ovnene på Hovden følger den samme overordnede utviklingen som andre deler av regionen. Samtidig har det vært særdrag både ved ovnene og 


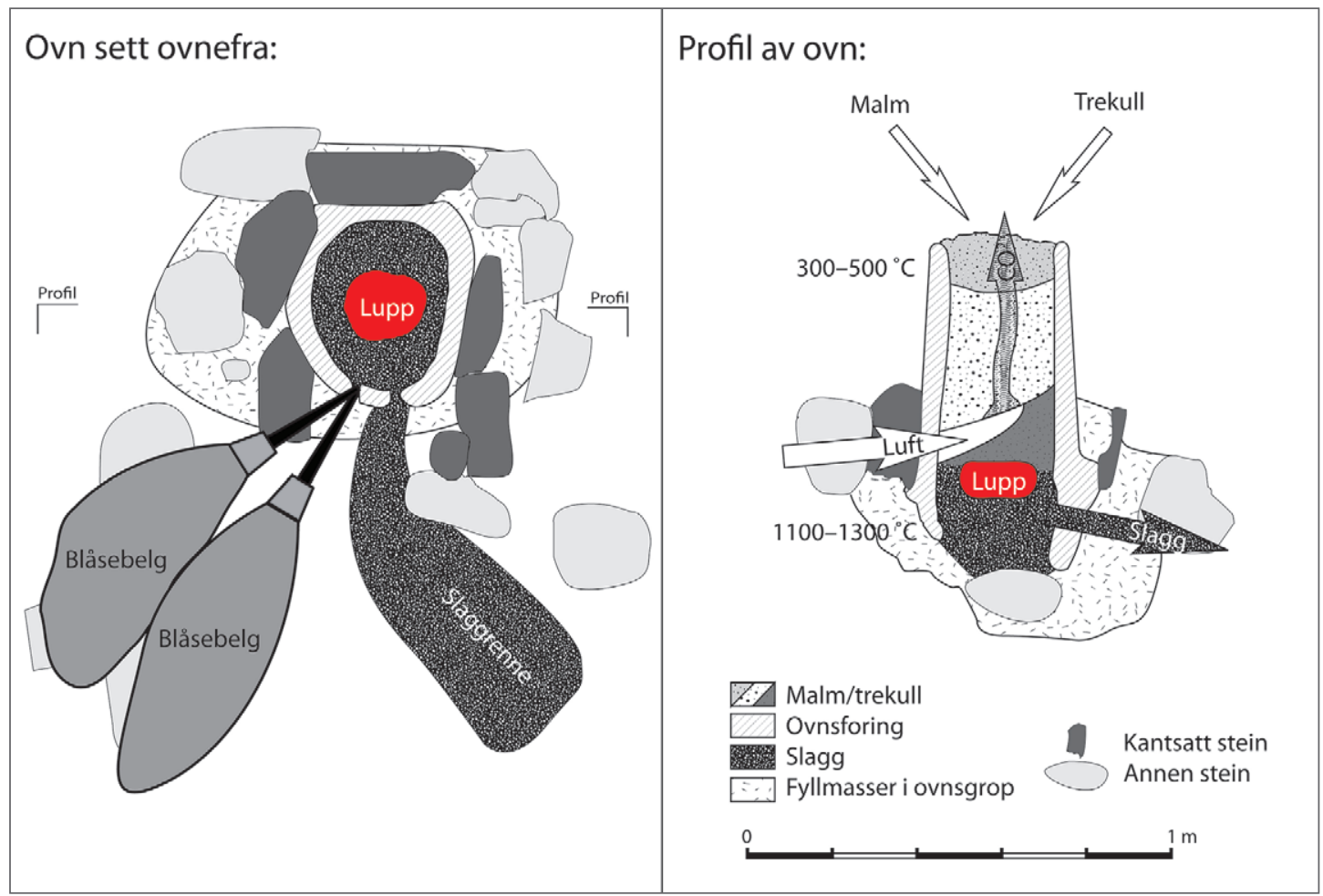

Figur 9: Prinsippskisse av sjaktovnen med sideavtapping av slagg med utgangspunkt i ovn 1 ved Godtstoylbekken. Selve jernproduksjonen har foregått i en minst 0,7 meter høy, pipeformet leirsjakt som har vart cirka 0,4 meter i tverrmål. Ovnen har blitt varmet opp til 1100-1300 ${ }^{\circ} \mathrm{C}$ i forbindelse med reduksjonsprosessen. Luft har blitt tilfort med én eller to bläsebelger (Jakobsen et al. 1988: 93-94; Rundberget 2012: 112). Det ubearbeidede jernet (luppen) samler seg i nedre del av ovnen, og slaggstoffene tappes ut på siden. Skissen er delvis utarbeidet på bakgrunn av Jacobsen og Larsen 1992: 71. Illustrasjon: A. Mjarum, Kulturhistorisk museum.

Figure 9: Iron production furnaces at Hovden: schematic drawing of a furnace with slag channel, based on one of the furnaces at Godstoylbekken. The iron formation took place in a clay shaft, at least 0.7 meter high and approximately 0.4 meters across. The furnace was heated to $1100-1300^{\circ} \mathrm{C}$ relative to the reduction process. Ventilation was provided through one or two bellows. The unworked iron (bloom) gathered in the lower section of the furnace while the slag was drained through the side. Illustration: A. Mjerum, Museum of Cultural History.

andre sider av jernproduksjonen på Hovden, slik som $\mathrm{i}$ andre jernvinnebygder. Enkelte av disse egenartede trekkene har vedvart gjennom flere hundre år, mens andre trekk kan ha oppstått og forsvunnet. Materialet som så langt har blitt publisert fra den øvre delen av Setesdalen, gir uansett grunnlag for å snakke om en egen Hovden-tradisjon, en tradisjon som ble etablert i yngre jernalder, og som eksisterte gjennom store deler av middelalderen.

\section{SUMMARY}

During the Viking and Medieval periods bog-iron was produced in the outfield of inland Norway. In some areas, such as at Hovden, in the upper part of Setesdalen, the production had nearly industrial dimensions. Several production sites and a large number of large charcoal production pits have been excavated in the Hovden area. Both large building sites with multiple internal partitions and smaller sites are known, all with small shaft furnaces.

The furnaces at Hovden are in many aspects representative of the technology in use in the central and western parts of inland Norway from around AD 800 to after 1450 . They belong to a second phase of furnace technology, where an approximately 0.7 meter high and 0.4 meter wide clay shaft was the key element. The slag was drained through a channel in front of the furnace shaft. This production also required bellows and charcoal produced in nearby pits.

Even if the iron production in many aspects was unified in large parts of Southern Norway, excavations prove that there were changes through time and some regional variations. This information shows that the producers at Hovden were local, but open to input and new innovations. 


\section{LITTERATUR}

Bloch-Nakkerud, T. 1987. Kullgropen i jernvinna øverst $i$ Setesdal.Varia 15. Oslo: Universitetets Oldsaksamling.

Espelund, A. 2005. Bondejern i Norge. Ny utgave. Trondheim: Arketype.

Gjerden,K.1993.Byklekultursoge. Bykle: Bykle kommune.

Hufthammer, A.K. 2007. Analyse av beinmaterialet fra utgravningene på lokalitet Heibekken, C55677 og C55678. Bergen: De naturhistoriske samlinger, Zoologisk museum, Universitetet i Bergen.

Jakobsen, S, J.H. Larsen og L.E. Narmo 1988. «Nå blestres igjen jern ved Dokkfløy. Et forsøk på eksperimentell arkeologi». Viking LI: 87-108.

Kile-Vesik, J. og S.T. Glørstad 2013. Rapport fra utgravning. Jernvinneanlegg og kullgroper. Hovden 2/1, Bykle, Aust-Agder. Oslo: Kulturhistorisk museum.

Larsen, J.H. 1991. Jernvinna ved Dokkfløy. Varia 23. Oslo: Universitetets Oldsaksamling.

Larsen, J.H. 2004. «Jernvinna på Østlandet i yngre jernalder og middelalder - noen kronologiske problemer». Viking LXVII: 139-170.

Larsen, J.H. 2009. Jernvinneundersøkelser. Faglig program 2. Varia 78. Oslo: Kulturhistorisk museum.

Martens, I. 1988. Jernvinna på Møsstrond i Telemark. En studie i teknikk, bosetning og økonomi. Norske oldfunn XII. Oslo: Universitets oldsaksamling.

Mjærum,A.2007. «Jord ogjern-Jernvinna på Beitostølen i middelalderen». Arbok for Valdres 2007: 176-188.

Mjærum, A. 2011. «Blestringen i Breiveskaret - To jernvinneanlegg fra vikingtid og middelalder ved Hovden i Setesdalen». Agder Historielag Ärsskrift 87: 19-45.

Narmo, L.E. 1996. Jernvinna i Valdres og Gausdal - et fragment av middelalderens økonomi. Varia 38. Oslo: Universitetets Oldsaksamling.

Narmo, L.E. 1997. Jernvinne, smie og kullproduksjon $i$ Østerdalen. Varia 43. Oslo: Universitetets Oldsaksamling.
Rolfsen, P. 1977. «En fjellgård fra jernalderen i Bykle». Viking XL: 79-128.

Rolfsen, P. 1992. "Iron production in the upper part of the valley of Setesdal, Norway». A. Espelund (red.). Bloomery ironmaking during 2000 years. Seminar in Budalen 1991 II: 79-88. Trondheim.

Rolfsen, P.2002. «Tjæremiler i Norge -med utgangspunkt i en tjæregrop på Hovden i Bykle». E.H. Hofseth (red.). UKM - En mangfoldig forskningsinstitusjon: 255-265. UKM Skrifter nr. 1. Oslo: Universitetets kulturhistoriske museum.

Rundberget, B. 2007. Jernvinna i Gråfellområdet. Gråfellprosjektet I. Varia 63. Oslo: Kulturhistorisk museum.

Rundberget, B. 2008. «Et kort omriss av jernvinna i Sør-Norge». B. Rundberget og F.-A. Stylegar (red.). Jernvinna på Agder. Jernvinneseminaret i Sirdal 25.-26. oktober 2007. Artikler utgitt $i$ anledning Jan Henning Larsens 60-årsdag: 16-33. Kristiansand og Oslo: Vest-Agder fylkeskommune, Regionalavdelingen og Kulturhistorisk museum.

Rundberget, B. 2013. Jernets dunkle dimensjon. Jernvinna $i$ sørlige Hedmark. Sentrale okonomiske faktorer og premiss for samfunnsutvikling c. AD700-1300. Doktorgradsavhandling: Universitetet i Oslo.

Smekalova, T. 2006. Magnetic survey in Hovden, Norway in June 2006. A report. St. Petersburg: Physical Institute of St. Petersburg University.

Tveiten, O. 2012. Mellom aust og vest. Ein arkeologisk analyse av jernvinna kring Langfella i yngre jernalder og middelalder. Doktorgradsavhandling: Universitetet i Bergen. 


\title{
EN BRYTNINGSTID FÖR JÄRNHANTERINGEN - KRING TEKNIK OCH SOCIAL ORGANISATION I DET MEDELTIDA SAMHÄLLET
}

\author{
Gert Magnusson
}

Den svenska järnhanteringens historia började under 500- eller 600-talet f.Kr. Det finns fynd, som antyder att hanteringen kan ha börjat redan några århundraden tidigare, det vill säga under bronsåldern. Studier kring järnhanteringens introduktion har gjorts av många och måste ses som en av de traditionella forskningsfrågorna. Under senare år har dessa studier i Norden främst behandlats av Eva Hjärtner-Holdar. Hon visar på ett rumsligt sammanhang mellan fyndplatserna för den äldsta järnhanteringen och bronsålderns boplatser. Ett intressant sammanhang, som antyder att järnhanteringen kan ha uppstått i metallurgiska miljöer kring bronshanteringen. Järnet «uppfanns» nog inte av en tillfällighet, utan är mer ett resultat av ett systematiskt sökande efter metallurgisk kunskap. En kunskap som formulerades på ett annat sätt än vad vi gör idag och de metallurgiska sambanden tolkades på för oss idag okända sätt.

Blästerugnshanteringen var tidigt ett komplett utvecklat tekniksystem, senast under 500-talet f.Kr. Redan då var tekniken utvecklad och merparten av de redskap, smidestänger, smideshamrar, släggor och andra smidesredskap var fullt utvecklade.

Nästa stora teknikutveckling skedde under medeltiden både på den europeiska kontinenten och i Skandinavien. Järnet producerades först i olika typer av blästerugnar - antingen höga schaktugnar med nedgrävd slaggrop, nedgrävda stenramsugnar eller den tredje typen - den kupolformade ugnen (Pleiner 2000: 163). Under 1200-talet utvecklas till exempel en rad olika typer av blästerugnar i Jämtland (Magnusson 1986: 257), då etablerades också masugnstekniken i Bergslagen (Magnusson 2003: 225) och från Halland har vi ett, även i ett europeiskt perspektiv, mycket tidigt belägg av vattendrivet hammarsmide och en blästerugn vid Tvååker (Strömberg 2004: 142; Magnusson 2004b: 216). Samtidigt växer det fram en betydande marknad runt Östersjön och Nordsjön, med ett flertal aktörer, men där den tyska hansan får ett allt större inflytande med tiden.

\section{Frågeställningar}

- Vilken teknik har man brukat och vad innebar teknikskiftena?

- Hur kan järnhanteringen i skogsområdena ha vart organiserad?

- Vilken betydelse har naturresurserna och vem som ägt dem haft för järnhanteringen?

- Vilken roll har järnet haft för kolonisationen av skogsbygden?

\section{JÄRNHANTERINGENS FORSKNINGSBAK- GRUND I SVERIGE}

Den första gången vi möter historisk järnhantering $\mathrm{i}$ Sverige var i samband med Rannsakningar efter antikviteter på 1680-talet. I rapporten från Åby socken i Norra Möre, Kalmar län på Sveriges östkust talas det om sinnerskutor:

Antiquiteter ifrån Åby Finnes inga, der om någon weet göra någon berättelse, wndantagandess i Skougzbygden, åthskillighe höghar med sinderskutor eller Smidieslagg, Somblige store som laghom huus, Somblighe mindre, huar wthi äro fundne Tänger hambrar och annat sådant, finnes och ännu wnderstundom stora Jernstycken, der af göras bilder. Och således förmehnas der fordom warit Jernbruuk. Serdeles berättas rätta JerMästaren, huilken skall hafua kunnat med med store tractamenter wppehålla i någre dagher, konungen och hela hans hoff, hafua bodt widh ett kärr, kallas Brunnsskiärr, icke longt ifrån Capellet, huarest och finnes till wedermähle, en Öfuermåttom stoor Sinderhögh, och synes ännu, tå Solen skin, nedre wthi wattnet, lijka som Jern (Stahre 1992: 166).

Länge levde berättelser som denna i de småländska skogstrakterna, men det skulle dröja till 1920-talet innan arkeologen John Nihlén genomförde de första omfattande moderna fornminnesinventeringarna av den äldre järnhanteringens lämningar i södra Sverige i landskapen Småland, Skåne, Halland och Gotland. Dessa tidiga undersökningar från 1920- och 1930-talen av den småländska järnhanteringen var banbrytande (Nihlén 1932), och som under 1990-talet följdes upp med nya studier inom projektet Småländsk järnhantering under 1000 år (Berglund 2000). Nihléns studier och sammanställningar har blivit klassiska för den arkeologiska 
forskningen. En stor del av hans arbete bestod i att intervjua lokalbefolkningen, men Nihlén inventerade också själv. Sammanlagt registrerade han drygt 150 järnframställningsplatser. Viktigt var också att han till medhjälpare valde Karl-Alfred Gustawsson, sedermera överantikvarie vid Riksantikvarieämbetet. Gustawsson verkade senare för att slaggvarpen skulle registreras i samband med fornminnesinventeringen för den ekonomiska kartan. Dock redovisades dessa lämningar inte med en R-markering på kartan, då man var osäker på deras ålder. Fornminneslagen ställde som krav att lämningarna skulle vara från forna tider. En som ställde sig bakom de båda unga forskarna, och som också bedrev egen forskning, var Carl Sahlin, då ordförande i Jernkontoret. Här kan man säga att grunden lades till Jernkontorets engagemang för den egna branschens historia. Sahlin gjorde själv insatser för att lyfta fram bergshanteringens historia och finansierade också annan forskning inom området till exempel historikerna Sven Tunbergs och Tom Söderbergs betydande arbeten. John Nihléns klassiska studie om den äldre blästbrukshanteringen i östra Småland publicerades i Jernkontorets bergshistoriska skriftserie (Nihlén 1932). Nihlén fullföljde sedan sitt arbete med ytterligare en volym om den äldre järnhanteringen i Sydsverige (Nihlén 1939).

År 1968, långt efter Carl Sahlins död, skapades ett bergshistoriskt utskott vid Jernkontoret, som sedan dess har varit en mötesplats för industrifolk och kulturmiljövårdare. Den första arbetsuppgiften som man tog sig an var frågan om den medeltida osmunden. En «osmundgrupp» bildades och 1974 lades en slutrapport fram, som egentligen inte gav några direkta svar på vad begreppet stod för, men där ett antal tydliga frågor formulerades. Efter att i stort sett arbetat med samma historiska källor som den tidigare 1900-talsforskningen, underströk man betydelsen av att ta fram nytt källmaterial. I gruppen ingick bland andra arkeologerna Inga Serning och Åke Hyenstrand, som framhöll de bevarade fornlämningarnas betydelse för att belysa olika forskningsfrågor. Alltsedan John Nihléns arbeten i Småland på 1920-talet, hade slagghögar registrerats i samband med den ordinarie fornminnesinventeringen för den ekonomiska kartan. Först på 1960-talet började de betraktas de som fasta fornlämningar och undersökas som arkeologiska objekt. Här hade Inga Sernings undersökningar av några blästerugnar i Dalarna, och det faktum att hon lyckades att datera dem till vikingatid med hjälp av ${ }^{14} \mathrm{C}$-teknik, stor betydelse.

Den moderna forskningen kring järnhanteringens historia inleddes på 1950-talet med kemisten

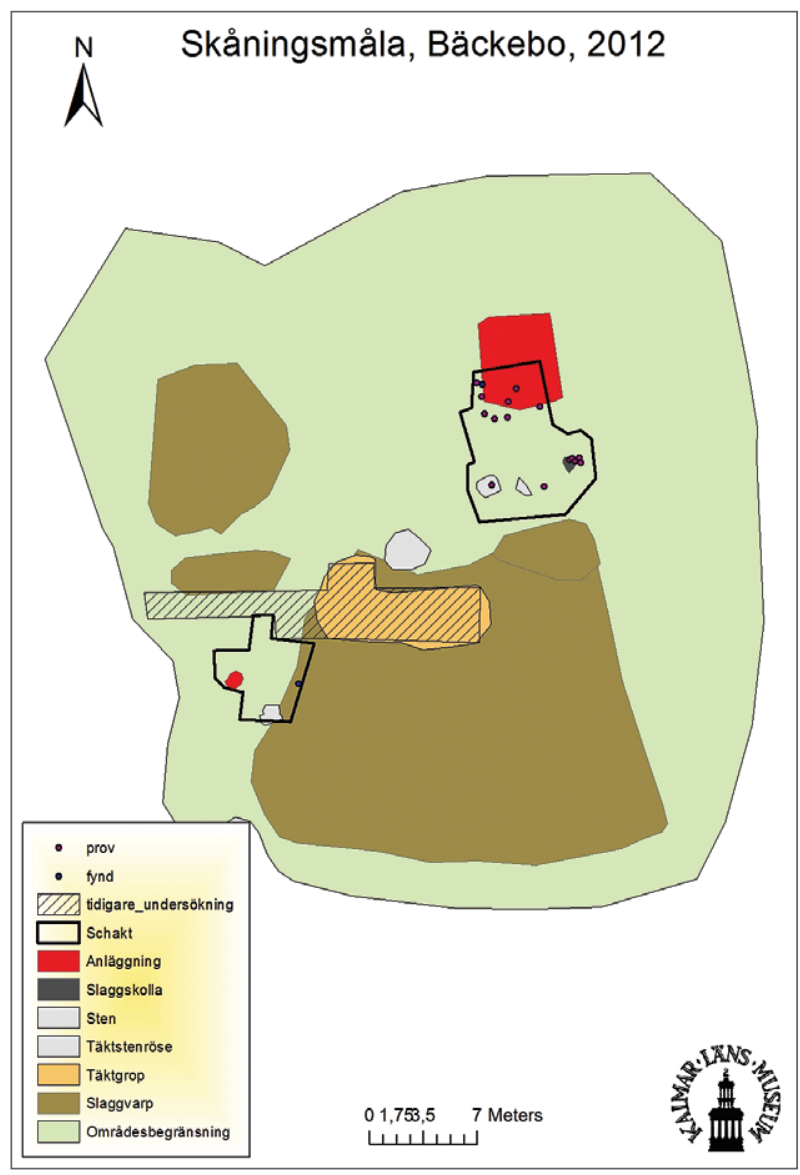

Figur 1a: Karta över järnframställningsplatsen vid Skåningsmåla i Bäckebo socken utanför Kalmar. Platsen är känd sedan 1600-talet som platsen för «den rätte järnmästaren» och är en plats med hela kedjan från malm till färdigt järn för försäljning $i$ Kalmar eller någon annan plats vid Kalmarsundskusten. Platsen är daterad till 1200-talet.

Figure 1a: Plan of bloomery site at Skåningsmåla in Bäckebo $N W$ of the town of Kalmar. The site has been known since the 17 th century as the forge of the "privileged iron master". The site has been radiocarbon dated to the 13th century, and contains remains of every step of iron production from ore to iron bars, to be sold in the medieval town of Kalmar or other trading sites along the coast of Kalmarsund.

Olof Arrhenius studie kring fosforhalten i en stor mängd fornsaker i Statens historiska museums samlingar. Arrhenius menade att den höga fosforhalten berodde på att man redan under forntiden brukat fosforrika bergmalmer (Arrhenius 1959). Ett tiotal år senare bidrog Arrhenius med ytterligare ett inlägg om vilka malmer man hade använt, som tog utgångspunkt i 1940-talets fornminnesinventeringar i Möre (Arrhenius 1968). Detta blev startpunkten för en rad nya studier, bland annat Inga Sernings undersökningar i Dalarna. Tillsammans med Åke Hyenstrands inventeringsmaterial också främst från Dalarna, bidrog Sernings studie med helt nya resultat. 


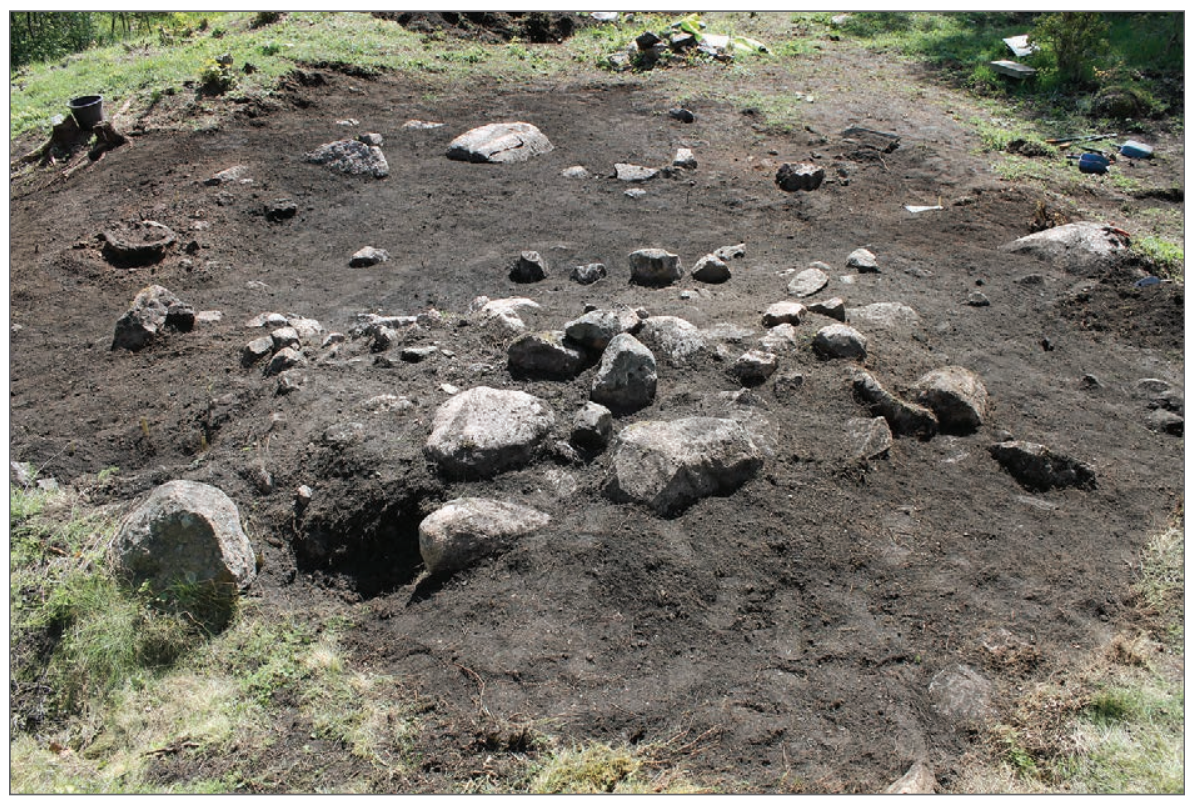

Figur 1b: Översikt av «den rätte järnmästarens plats» vid Skåningsmåla i Bäckebo socken $i$ Småland. Platsen har lämningar av hela processen frän malm till färdiga ämnesjärn. I förgrunden ses ässjan under utgrärning. Foto: $G$. Magnusson.

Figure 1b: Overview of «the iron master's site» at Skainingsmåla, in Bäckebo parish in the county of Smailand. In the foreground is the smithy. Photo: G. Magnusson.
En serie regionala studier kring blästbruket genomfördes under 1970-talet i Dalarna, Västergötland, Jämtland, Härjedalen och Hälsingland. Under det påföljande decenniet tillkom studier i Skåne och Halland. Stora delar av landet blev således inventerat under den här tiden och över sammanlagt 7000 platser med blästbruk registrerades. I mitten av 1970-talet hade Åke Hyenstrand publicerat sitt arbete Hyttor och järnframställningsplatser, där han särskilt visade på betydelsen av bergsbrukets lämningar i Bergslagen (Hyenstrand 1977). Något år senare initierade Hyenstrand undersökningarna av Lapphyttan utanför Norberg. Lapphyttan, var mycket välbevarad och visade hur en medeltida hyttplats sett ut med alla sina kringanläggningar, masugn, rostbås, malmtorg, färskningshärdar och bostadshus och stall (Magnusson 2003). För att förstå tekniken har en rekonstruktion och en försöksanläggning byggts. Nya Lapphyttan är en fullskaleanläggning, där man har gjort årliga försök sedan 1994 och just 2010 lyckades man få processen framgångsrik och tappade tackjärn för första gången. Försöken ger kunskap kring de problem och svårigheter som var förknippade med medeltidens masugnshantering, men också de motgångar, som var förknippade med den nya tekniken i Bergslagen under medeltiden.

Under 1980-talet genomfördes en rad studier av den medeltida svenska järnhanteringen. Inga Serning fortsatte sina studier i Dalarna, men var nu mer inriktad på frågan om masugnens etablering $\mathrm{i}$ Bergslagen genom grävningar av Vinarhyttan och Harhyttan. Revideringen av fornminnesinventeringen för den ekonomiska kartan gick nu åter över
Bergslagen och de bergshistoriska lämningarna blev systematiskt inventerade. Inventeringsresultaten tillsammans med arkivstudier har publicerats i 23 volymer av Atlas över Sveriges bergslag fr.o.m. 1994 (Pettersson 1994). Här har ett material om 700 medeltida hyttor och 10000 gruvor dokumenterats. Samtidigt som Lapphyttan utanför Norberg grävdes, genomfördes undersökningar även i Västergötland. I Tranemo leddes dessa undersökningar av Lars Erik Englund (Englund 2002) och i Skara-/Skövdeområdetav Per Olof Millberg och Gert Magnusson (Jonsson et al. 2001). Englunds avhandling bearbetade tekniska frågor kring arkeologiskt undersökta järnframställningsplatser och hur 1700-talets beskrivningar kan hjälpa till med tolkningen och detaljerna förstås med hjälp av systematiska försök. I nära samarbete med en grupp tranemobor lyckades man rekonstruera blästerugnsprocessen och tillverka ett smidbart järn.

Den jämtländska järnhanteringen bearbetades och presenterades $\mathrm{i}$ en avhandling 1986 (Magnusson1986). Här var det möjligt att se minst två kronologiska horisonter, en förhistorisk och en medeltida, samt att det under 1200-talet skedde en betydande utveckling av blästbruket med minst fem olika nya typer av blästerugnar (Magnusson 1986: 257). Blästerugnshantering spred sig till nya områden, men frågan är i vilken utsträckning man producerat järn för en exportmarknad över Norge och/eller i Östersjöområdet, eller om produktionen främst inriktat sig på en lokal marknad.

Under 1990-talet utvecklades studierna av den sydsvenska järnhanteringen genom fyra betydande 
forskningsprojekt. Projektet Småländsk järnhantering genom 1000 ar leddes av ekonomhistorikern Bengt Berglund och historikern Lars-Olof Larsson. De vidgade de äldre studierna och gav en ny bild av den småländska järnhanteringen, bland annat kunde en tydlig senmedeltida industriell fas i västra Småland beläggas. Där John Nihlén redovisat 150 blästbruksplatser, hade man nu identifierat drygt 2000 platser, huvudsakligen daterade till vikingatid och äldre medeltid (Larsson och Rubensson 2000: 271).

Ett andra projekt Vittsjö - en socken $i$ dansk järnbruksbygd drevs av medeltidsarkeologen Anders Ödman i norra Skåne. Det visade på ett tydligt samband mellan de tidigmedeltida borgarna och järnhanteringen med drag av feodalisering (Ödman 2001; 2005). Järnhanteringen var en utmarksnäring, men uppenbarligen knuten till borgarna, som låg utmed den gamla riksgränsen mellan Sverige/ Småland och Danmark/Skåne.

I Halland, slutligen, drevs ett gemensamt nordiskt projekt kring den äldsta i skrift kända järnmöllan, som länge hade setts som ett exempel på hur cisterciensermunkarna spred teknik över Europa. Med utgångspunkt från Sorö klosters jordebok undersöktes en tidigmedeltida järnmölla som sannolikt var den i de medeltida dokumenten omnämnda järnmöllan. Undersökningen visade att järnhanteringen istället lades ner när munkarna fick kontroll över området. Sannolikt satsade de på någon annan av de verksamheter, såsom saltframställning, trävaror eller svinavel, som omnämns i de medeltida dokument som rör ärkebiskop Absalons donation (Olsen 2004). Det råder däremot inget tvivel om det redan under 1100-talet fanns en vattendriven hammare vid Ugglehult i Tvååkers socken i Halland (Magnusson 2004: 217-218; Strömberg 2004: 154,161).

I samband med de stora vägbyggen, framför allt E4:an, som genomfördes i södra Småland och norra Skåne på 1990-talet och de första åren på 2000-talet, undersöktes flera fornlämningar efter den äldre järnhanteringen (Lagerås 2007: 110 ff.; Strömberg 2008: 148, Åstrand 2006; 2008: 65 ff.). Undersökningarna omfattade bland annat en skogsgård i utmarksläge, som gav väsentlig ny kunskap kring en perifer bebyggelse och dess försörjningssystem. På motsvarande sätt har forskning bedrivits kring flera järnframställningsplatser i Närke, Uppland, Halland, Småland och Skåne. Med hjälp av bl. a. noggranna laboratoriestudier har medeltida blästerugnar rekonstruerats.
NATURFÖRUTSÄTTNINGARNA - MALMERNA

Råvaran till blästerugnarna i Sverige har vanligen varit olika typer av limonitmalmer. Det kan ha varit sjö- eller myrmalmer, men även så kallad rödjord har i vissa delar av Sverige varit en betydande råvara och i Dalarna finns det exempel på att man använt vittrad magnetit. Malmen har grävts fram på somrarna ur myrarna, under det att sjömalmen har man samlat upp från sjöbottnarna under vintern, då man kunde arbeta från isen. I Ängersjö socken i Hälsingland, som har ett antal blästerugnar från senmedeltiden, finns främst bara myrmalm. Det har visat sig att de flesta myrarna runt om i socknen har varit utsatta för omfattande omgrävningar. Bilden verkar vara densamma även i grannsocknarna Älvros, Sveg i Härjedalen och Fågelsjö i Dalarna. Samtliga blästerugnar i Ängersjö, Älvros, Sveg och Ytterhogdals socknar ligger i direkt anslutning till malmförande myrar. Redan här krävdes kunskap. All malm, som fanns i socknens myrar var inte användbar för järnhantering, utan ett urval skedde för att finna den rätta kvaliteten. Enligt flera författare på 1700-talet kontrollerades malmkvaliteten redan i samband att man påträffade malmen ute i myren (Schoultze 1732; Rinman 1997 [1794]).

I Möre i sydöst finns omfattande sjö- och myrmalmsförekomster, men även här har så kalllad rödjord varit utgångsmaterial. Myrmalmen var under hela medeltiden en resurs, tillgänglig för de som brukade myren och först senare blev det vanligt med inmutningar och försvar av malmförekomsterna. Omfattningen av sjömalmförekomsterna inventerades ännu på 1920-talet, då sjömalmerna fortfarande utgjorde råvara för flera småländska järnbruk (Arrhenius 1968: 68 ff.).

Från slutet av vikingatiden utvecklades bergsbruket och gruvdriften i de mellansvenska bergslagerna. Det verkar som att den kan ha börjat vid Kopparberget i Falun för att senare sprida sig till de omgivande järnbergslagerna. Det var ju en till stora delar annan teknik. Troligen följer de här det betydande teknikskiftet i samband med att masugnen etableras (Segerström et al. 2010).

\section{NATURFÖRUTSÄTTNINGARNA \\ - SKOGEN SOM RESURS}

Förutom malm var ved och träkol avgörande resurser. I de flesta metallframställningssammanhang världen över har det oftast varit tillgången på skog till ved och kol som varit den begränsande faktorn. Endast undantagsvis har malmen tagit slut.

Det är svårt att uppskatta mängden träkol som har behövts. Frågan har varit aktuell för att 
man ska få en uppfattning om den mängd arbete, som vi faktiskt inte ser mer än mycket begränsade spår av i det arkeologiska materialet i form av järnframställningsplatser.

En engelsk arkeolog, Peter Crew, har genom praktiska försök i järnframställning i blästerugn och smide försökt att beräkna hur mycket ett ton slagg på en järnframställningsplats representerar $i$ ved och träkolsförbrukning. Ett ton slagg motsvarar ca. $75 \mathrm{~kg}$ färdiga utsmidda ämnesjärn. För detta har det åtgått ca. 375 ton torr ved. För att omsätta detta i en yta av avverkad skog har SLU, Sveriges lantbruksuniversitet, i Umeå brukat följande beräkningsgrund;

Fukthalt i lufttorkad ved $=18 \%(375 / 1,18=318$ ton ved torrsubstans)

Densitet torrsubstans ved $=0,5 \mathrm{~kg} / \mathrm{dm}^{3}$ ( $=$ ton $/$ $\mathrm{m} 3 ; 318 / 0,5=636 \mathrm{~m}^{3}$ skogskubik eller fast kubik) ger $8,5 \mathrm{~m}^{3}$ ved $/ \mathrm{kg}$ järn.

Besparingsskogarna i Orsa, Hamra och Älvdalen hade på 1880 -talet $90-130 \mathrm{~m}^{3} /$ ha (totalt). Det betyder att 5 - 10 ha skog för produktion av $75 \mathrm{~kg}$ järn eller $600-1300 \mathrm{~m}^{2}$ skog för produktion av ett $\mathrm{kg}$ ämnesjärn.

Det betyder att för den genom fornminnesinventeringen kända omfattningen av blästerugnshanteringen i Ängersjö som omfattar ca. 22 ton slagg, vilket innebär att ett område av ca. 110 - 220 ha skog har gått åt för den senmedeltida järnhanteringen av Ängersjös $300 \mathrm{~km}^{2}$ produktiv skogsmark. Det har knappast inneburit några mer omfattande kalhyggen. T. ex. det samlade uttaget av skogsråvara från de jämtska skogarna för Jämtlands 600 kända järnframställningsplatser, om alla dessa varit i bruk samtidigt, skulle det ändå bara betyda att man inte ens utnyttjade den årliga tillväxten i landskapets skogar. Detta är litet av en lek med siffror, men det ger en anvisning om att för forna tiders järnframställare i de svenska skogsbygderna har inte skogen uppfattats som en ändlig resurs. Det skulle komma först med bergsbruket i Bergslagen, då det under vissa perioder uppstod skogsbrist.

Merparten av arbetet med järnhanteringen bestod av kolning och huggning av ved till rostbäddar och blästerugnar. Innan man kunde sätta upp malm i blästerugnen var man tvungen att värma den med ved. Vissa blästerugnar under medeltiden förefaller ha varit helt drivna av ved. Man har inte använt träkol i en senare del av arbetet, utan reduktionen av malmen har skett med hjälp av det kol som bildats av veden i samband med uppvärmningen av blästerugnen.

\section{DEN MEDELTIDA OCH YNGRE MYRJÄRNSHANTERINGEN}

I mellersta Sverige - Södra Norrlands inland, från Dalarna, Värmland, Härjedalen, Jämtland och Hälsingland har vi ett betydande område med över 2000 kända järnframställningsplatser. Inom området finns flera kronologiska horisonter i järnhanteringen, dels en äldre horisont med dateringar till vendel och vikingatid, dels en senmedeltida horisont med en tyngdpunkt i dateringarna till 1400- och 1500-talen. I delar av dessa områden har det funnits blästerugnar i drift så sent som under 1700- och 1800-talen (Hyenstrand 1977; Magnusson 1986).

I de NV delarna av Dalarna kom hanteringen att vara betydande ännu in på 1700-talet. Det är främst från socknar som Älvdalen, Lima, Transtrand et al. som vi har de viktiga beskrivningarna från 1700-talet över myrjärnshanteringen av författare som Schoultze, Swedenborg, Hülphers och Carl Rinman et al. I de SÖ delarna av Dalarna kom en betydande förändring redan under den äldre medeltiden - introduktionen av masugnen och den äldsta färskningsmetoden osmundsmidet. Dock förefaller det som om denna innovation i stort sett inte påverkat järnhanteringen alls i området norr om sjön Siljan i Dalarna förrän på 1700-talet i samband med att järnbruket i Los anlades.

Det kan tyckas att en sådan innovation helt skulle ersätta tidigare teknik. Så skedde inte, utan den direkta järnhanteringen producerade tillräckliga mängder järn för en lokal marknad. Det förefaller, som om det först under 1500-talet kom att ske en betydande nedgång i blästerbruket, som sedan skulle komma att vara fram till början av 1800-talet. Den sista gången vi har uppgifter om att man gjort järn med direkt järnframställning är i mitten av 1800-talet från Storsjö socken i norra Härjedalen. Småland, Halland, Västergötland, Dalarna, Härjedalen, Hälsingland, Jämtland var de stora områdena för järnhanteringen under medeltiden, men en hög produktion under 1200- till 1400-talen. Under denna tid är det vanligt att järnet i de skriftliga källorna ofta anges med ursprungsområde, t,ex. jemptejern, härdalsjern och calmarejern.

\section{VÄLBEVARADE}

\section{JÄRNFRAMSTÄLLNINGSPLATSER}

Älvros, Ängersjö, Ytterhogdal och Svegs socknar är sedan länge kända som några av de mer betydande järnproducerande socknarna i gränsbygderna mellan Härjedalen och Hälsingland, vilket ju även före 1645 var riksgräns mellan Sverige och Norge. Socknarna har ett osedvanligt stort antal blästerugnar för Sverige 


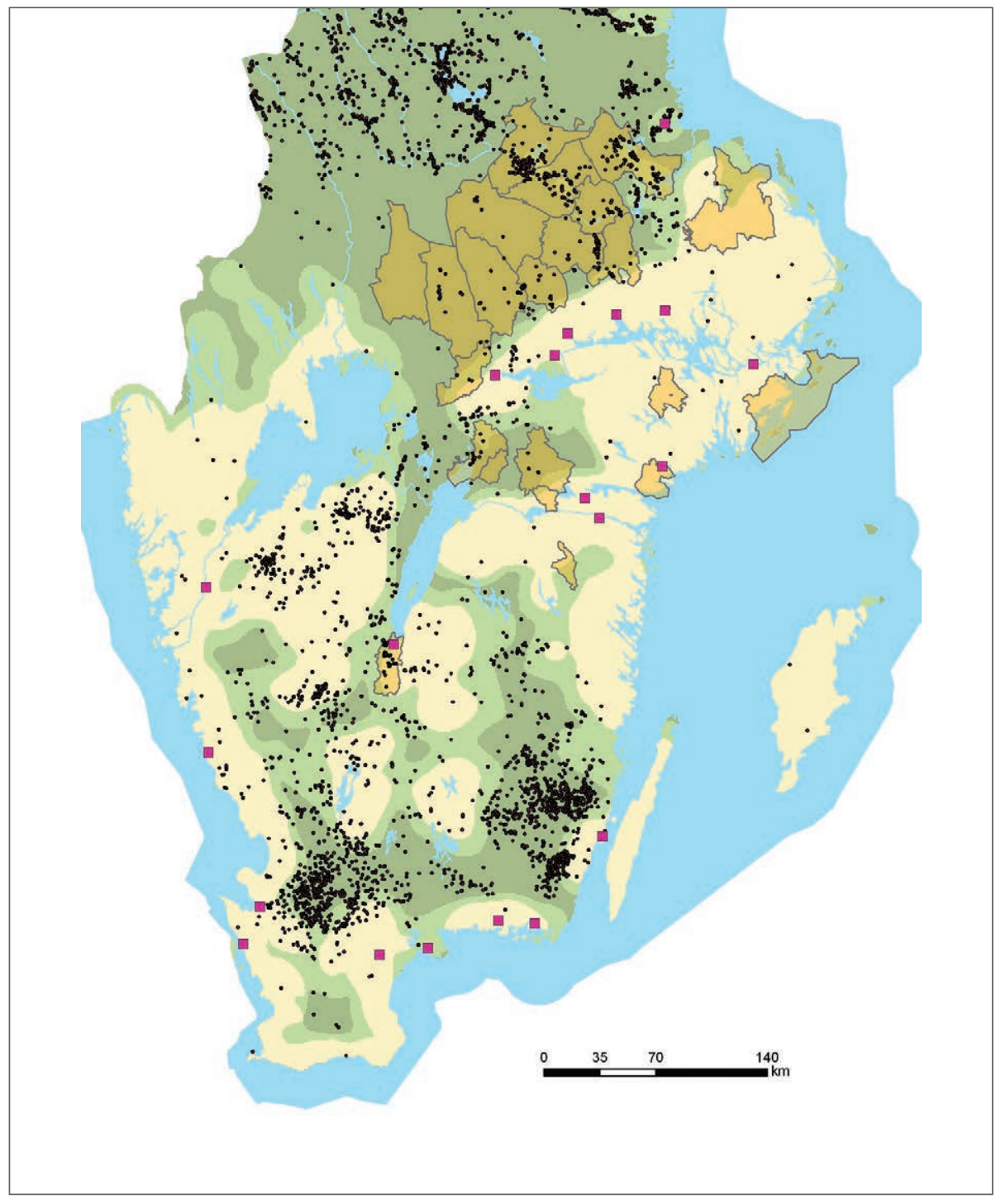

Figur 2: Karta över Sveriges medeltida järnframställningsplatser och områden. De gula områdena visar bebyggelsens utbredning och $i$ de med grönt redovisade skogarna ligger tusentals blästbruksplatser, redovisade med svarta prickar. Med orange fält redovisas de medeltida bergslagerna. Vi kan se att stora delar av det medeltida Sverige var på ett eller annat sätt indragna $i$ järnframställningen.

Figure 2: Map of medieval bloomery sites and mining areas of Sweden. The yellow areas are the Viking Age settled land and the green areas are medieval forested land, with thousands of bloomery sites represented as black dots. The orange areas are mining areas. It can be seen that most of medieval Sweden was involved in iron production. och kanske ett av de finast bevarade blästerugnsmaterialen i Europa. Det har också visat sig att de flesta blästerugnarna har varit möjliga att knyta till olika byar. Man kan inom området se att varje by och sannolikt varje enskild gård har haft en eller flera blästerugnar. Det är notabelt att ugnarna ligger på ömse sidor av den riksgräns, som drogs upp mellan Sverige och Norge och som finns i ett belagd i ett gränsläggningsdokument från 1270-talet. Det kan finnas en möjlighet det funnits tvister om järnhanteringen $\mathrm{i}$ skogarna eller lämpliga myrar, som drivit fram denna medeltida gränsläggning. Situationen är likartad vid den sydöstra gränsen mellan Småland och Blekinge.

Järnframställningsplatsen i området tillhör en mycket typisk kategori av väldigt välbevarade järnframställningsplatser. Ofta är de komplett bevarade med ugn, slaggvarp, fällsten, kollager och spår av malmrostningen. Bilden gäller merparten av alla kända järnframställningsplatser i Ängersjö,
Ytterhogdal, Älvros, Sveg och Överhogdals socknar. Bilden är även den samma i de sydjämtska socknarna Rätan, Åsarna, Berg och Klövsjö samt Haverö i Medelpad (Magnusson 1986: 131). Detta ger området speciella förutsättningar för att studera järnhanteringen sociala och tekniska kvaliteter. Till platsernas rikedom hör även det faktum att de nästan aldrig har blivit återanvända utan legat kvar orörda i skogsmarken sedan de var i bruk.

Möre längs Kalmarsundskusten är ett av de småland, som under medeltiden blev en del av landskapet Småland. Det omnämns redan på 800-talet av den engelske resenären Wulfstan under hans resa från Hedeby i Schleswig till Truso i nuvarande Polen (Lund 1983: 24-25). Wulfstan skrev att Möre, Öland, Gotland och Blekinge tillhörde svearna. Detta är första gången vi möter begreppet Möre i skrift. Området låg i en periferi till det Sverige, som växte fram under 1100- och 1200-talen, men 


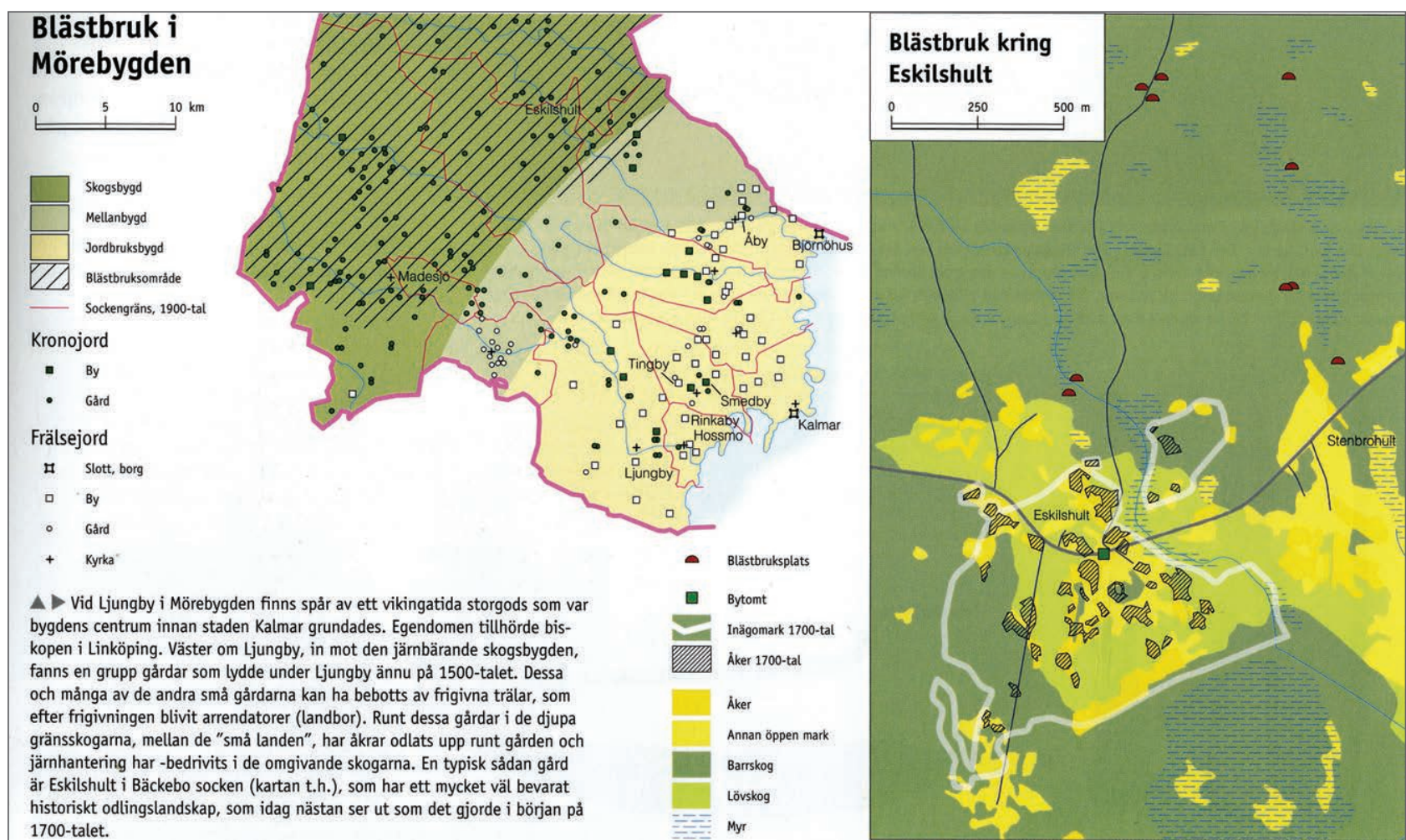

Figur 3: Möre med förhistoriska bygder och området med järnframställning. Efter Sveriges Nationalatlas.

Figure 3: Möre's medieval settled country and its iron production districts. National Atlas of Sweden.

hade således sedan 800-talet räknats till svearnas land. Först med freden i Roskilde 1658, upphörde Möre att vara en gränsbygd. I öster gränsar Möre mot Kalmarsund och i väster mot ett annat av de små landen, Värend. I norr gränsar Möre mot Stranda och i söder mot den gamla riksgränsen mot Blekinge och Danmark.

I ett tillägg till äldre Västgötalagen, det så kallade landameri, berättas hur gränsen vid Landabäcken drogs upp av tolv män från Danmark och tolv män från Sverige, utsända av den danske kungen Sven respektive den svenske kungen Anund Jakob. Detta skulle ha skett någon gång under 1000-talet. Att de båda kungarna som omnämns inte var samtida har av Peter Sawyer tagits som intäkt för att dokumentet upprättats långt senare, sannolikt $\mathrm{i}$ nära anslutning till att äldre Västgötalagen nedtecknades på 1220-talet (Sawyer 1991: 64 ff.). Det kan sannolikt också kopplas till att Danmark då definierade sina gränser och definitivt inkorporerade Blekinge i riket. Senast i början av 1200-talet var Möres gränser bestämda och smålandet inordnat i ett svenskt rike. Den gamla riksgränsen mellan Sverige och Danmark har senast behandlats av Mats Mogren i Landskap bortom traditionen (Mogren 2008: 221).
Redan under vikingatiden kan det i Möre ha bildats storgårdar efter europeiska förebilder, till exempel Ljungby och Hossmo. De kan ha ingått i en tidig förvaltning av området och utgjort en bakgrund till Wulfstans uppgifter om att det tillhörde svearna. De första kyrkorna byggdes i början av 1100-talet, såsom de båda systerkyrkorna Hossmo och Ljungby. Hossmo kyrka är dendrodaterad till 1119. Trots att den norske kungen Sigurd Jorsalafare hävdade att Möre kristnades i samband med hans korståg, det så kallade Kalmare ledung 1124, har Hossmo kyrka daterats genom dendrodateringar av stockar som finns inmurade i kyrkan till år 1119 (Blomkvist 1979: 169; Sturlasson 1993: 208). På 1100-talet ingick som tidigare nämnts Ljungby i Linköpingsbiskopens godsmassa (Ericsson 2001: 383). Ljungby ligger på gränsen mellan södra och norra Möre härader och utgör ett naturligt centrum för ett äldre småland. Ortnamn som Tingby, Rinkaby och Husaby kring Ljungby pekar också ut platsen som en möjlig centralpunkt i det gamla smålandet (Hellberg 1979: 134 ff.; Vikstrand 1993: 48 ff.). I anslutning till kyrkan i Hossmo har rester av ett stort antal tidiga kristna gravmonument, så kallade Eskilstunakistor, påträffats, vilket tolkats 
som att kyrkan tidigt varit en gravplats för en politisk eller religiös elit. I närheten av Ljungby låg också Smedby. Frågan är om det innebär att järnhanteringen här haft en roll och i så fall vilken den kan ha varit.

Under 1100-talet byggdes de första delarna av Kalmar slott och i omedelbar anslutning anlades staden, bland annat med en Smedjegata. Kalmar blev under medeltiden en av de mest betydelsefulla städerna i dåtidens Sverige (Blomkvist 1979: 174). Härifrån exporterades under 1200-talet ett järn under namnet calmarejern. Innanför den av frälset dominerade slättbygden, fanns stora gränsskogar mot Värend i väster och det danska Blekinge i söder. Alltsedan 1600-talet har man omtalat en forntida storhetstid för järnhanteringen i dessa skogsbygder och den «rätte jermästaren», som kunde försörja konungen och hela hans hov. I Rannsakningar efter Antiquiteter rapporteras som vi sett om de många sinnerskutekullarna, slagghögarna. I skogsbygderna var frälsets ägande inte lika stort, där dominerade skattebönder. Vad representerade då «den rätte Jermästaren»? Var det en ovanligt tekniskt kunnig person med avseende på järnhantering eller stod han snarast för en stor och omfattande produktion?

\section{MÖRES MEDELTIDA MYRJÄRNSHANTERING}

Johan Nihlén avgränsade området med medeltida järnproduktion i östra Småland till socknarna väster om Kalmar, Bäckebo, Kråksmåla, Madesjö, Karlslunda, Torsås och Gullabo (Nihlén 1932: 15 ff.). I samband med fornminnesinventeringen på 1970-talet visade det sig möjligt att förtäta, men inte att på något mer betydande sätt utvidga detta område. Skillnaden är däremot betydande om man ser till antalet järnframställningsplatser. Nihlén hade drygt 150 registrerade platser (Nihlén 1932: 171 ff.), medan fornminnesinventeringen, figur 5 , registrerade över 600. I samband med inventeringen genomfördes även ett försök att datera området med hjälp av ${ }^{14} \mathrm{C}$. Det är värt att notera att även detta resultat i stort sett verifierade Nihléns datering 1986: 187. Inom projektet Småländsk järnbantering genom 1000 år fann man att det år 2000 fanns 2193 kända järnframställningsplatser i Småland (Larsson och Rubensson 2000: 271). Men då ska man veta att de enda socknar som kan sägas vara välinventerade i östra Småland är Kalslunda med 105 platser och Madesjö med 70 platser. Bäckebo med så många som 101 kända platser har däremot aldrig blivit föremål för en noggrann inventering (Larsson och Rubensson 2000: 322).

Under medeltiden utvecklades ett storskaligt blästbruk med tyngdpunkten i skogstrakterna mel-

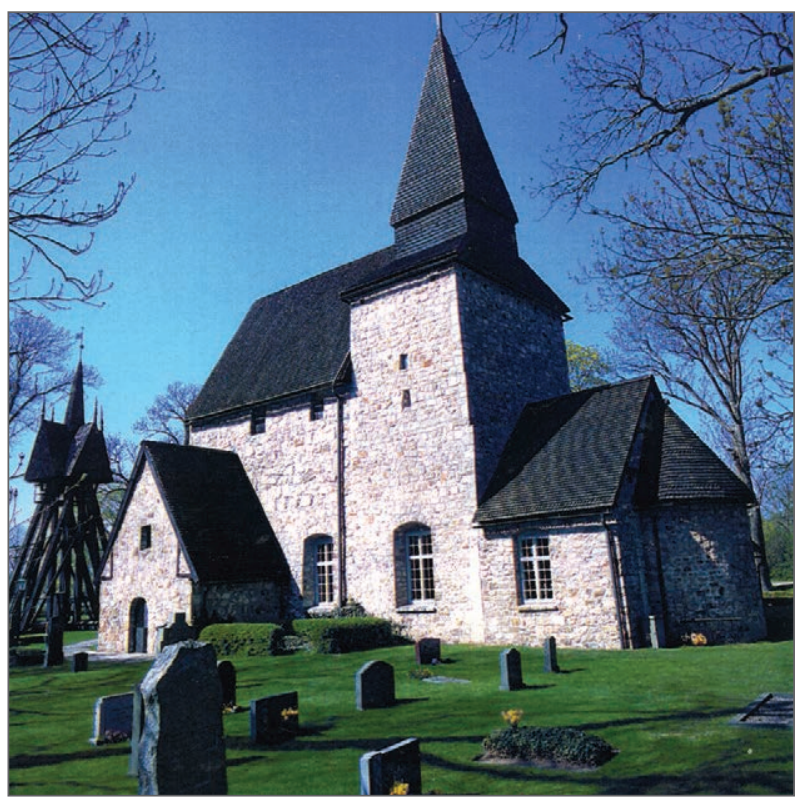

Figur 4: Hossmo kyrka byggd 1119, men anfallen av Sigurd Jorsalafare 1124 med motiveringen att människorna i Möre skulle kristnas, något som de ju redan var. Foto: G. Magnusson. Figure 4: Hossmo church was build in 1119 and attacked by the Norwegian king Sigurd Jorsalafare and his crusaders in 1124. He forced Christianity on the inhabitants of Möre, but they were already believers. Photo: G. Magnusson.

lan Möre och Värend samt längs den gamla riksgränsen mellan Sverige och Danmark. Expansion in mot de stora skogstrakterna tycks ha skett under 1100och 1200-talen och järnet var tveklöst varit en av de resurser som varit målet för bebyggelseexpansionen.

I Ljungby fanns som redan nämnts under 1100-talet en curia, ett storgods, som tillhörde Linköpingsbiskopen. I den västliga delen av socknen in mot de järnbärande skogarna fanns en grupp gårdar, som lydde under Ljungby och skattade till Linköpingsbiskopen ännu på 1500-talet. Denna bebyggelse kan ha bebotts av frigivna trälar, som blivit landbor, arrendatorer, och fătt en möjlighet att odla upp en bit mark och bruka skogen till kolning (Ericsson 2001: 384).

Årsringarna i det småländska kulturlandskapet är mycket välbevarade och småskaliga. Det är fullt möjligt att rekonstruera ett medeltida blästbrukslandskap. Gårdarna inne i de djupa skogarna mellan de små landen i Småland låg oftast isolerat. Med hjälp av 1600-talets geometriska jordeböcker är det möjligt att se hur jordbrukets och boskapsskötselns landskap då såg ut. Sannolikt speglar det även en medeltida bild. Runt gården låg små åkrar och i de omgivande skogarna finns de talrika spåren av järnhanteringen i form av slaggvarp. För järnhan- 


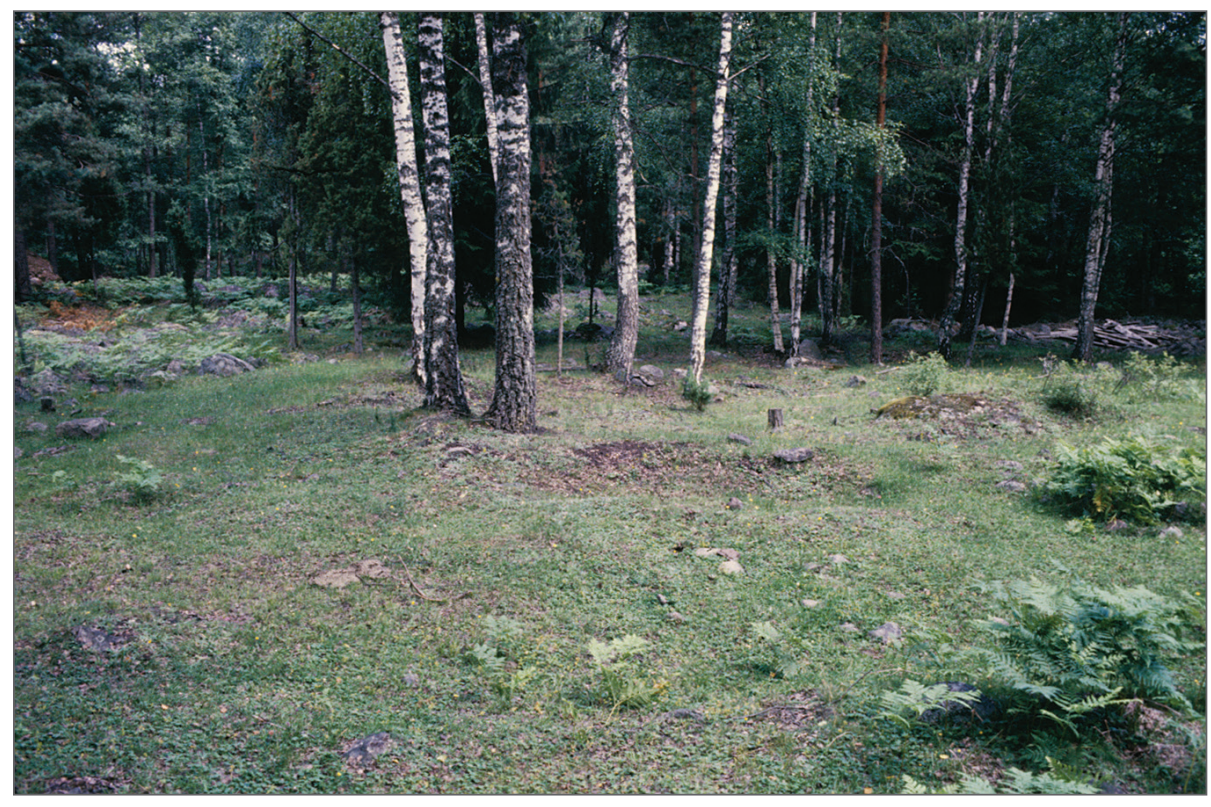

Figur 5: En typisk järnframställningsplats i Möre. Foto: G. Magnusson. Figure 5: A typical iron production site in Möre. Photo: G. Magnusson. teringen krävdes ved och gläntorna som öppnades i skogen blev värdefull betesmark för gårdens kreatur. Typiska exempel på sådana gårdar är Eskilshult och Århultemåla i Bäckebo socken. Kolonisationen har studerats i ortnamnsskicket och dess relation till järnframställningen (Strid 2006: 138). ${ }^{1}$ Några av de centrala åarna i Möre är Ljungbyån, Alsterån, Snärjebäcken och Hagbyån, vilka alla rinner från områden med rikliga slagghögar och utmynnar i flera fall vid några av de mer betydande godsen i Möre Ljungbyholm, Strömsrum, Björnö och Värnanäs. Finns här ett samband mellan de järnproducerande områdena, kommunikationerna längs åarna och godsen. Hade frälset kontroll av kommunikationerna och eller handeln med järnet? Vad betydde det att under 1100-talet anlades Kalmar och bl a uppfördes en exporthamn för järnhanteringens produkter i området och den statliga närvaron i form av slottet?

I början av 1200-talet dyker det upp järn i handelsordningen för staden Flensburg, under beteckning calmarejern och blekingejern. Det kan tyckas att en sådan innovation som masugnen och bergsbruket helt skulle ersätta tidigare teknik. Så skedde inte, utan blästbruket fortsatte att producera stora mängder järn. Småland, Halland, Västergötland, Dalarna, Härjedalen, Hälsingland och Jämtland var betydande områden för järnhanteringen under medeltiden, med en hög produktion under 1200- till 1400-talen. Helt uppenbart även för export. Under

1 Strid diskuterar här - måla namnens betydelse i samband med uppdelning av land på äldre allmänningar. medeltiden angavs järnet i de skriftliga dokumenten ofta med ursprungsområde, t.ex. jemptejern, bärdalsjern eller just calmarejern. De så kallade lieformiga ämnesjärnen har huvudsakligen påträffats längs Kalmarkusten samt på Öland och Gotland. Detta kan tyda på att marknaden för dessa ämnesjärn framför allt var de stora öarna, där de smitts ut till vapen, redskap eller praktfulla dekorationer på medeltida kyrkdörrar och kistor.

\section{FRÅGAN OM TEKNIKEN}

Vikingatiden var en dynamisk period i järnhanteringens historia. Järnkonsumtionen ökade på ett sätt den inte gjort tidigare. En förklaring kan vara att jordbrukredskapen blev större och tyngre, vilket fordrade ökad tillgång på metall (Myrdal 1999: 53). En annan faktor var utvecklingen inom den militära sektorn. Den ökade efterfrågan på smide, som avspeglas i det arkeologiska materialet, åtföljdes av ett allt större tekniskt kunnande kring järnets olika egenskaper.

Smidet utvecklades på ett intressant sätt. De berömda «äkta ulfbertsvärden» visar på betydande teknisk skicklighet och förmåga att framställa olika kvaliteter av smidbart järn med mycket olika hårdhet och på ett skickligt sätt smida samman dem. Det har även varit möjligt att urskilja dåliga «falska» kopior av de riktiga svärden (Williams 2007). På senare år har man föreslagit att ulfbertsvärden kan ha smitts i Östersjöområdet, istället för en äldre tolkning, att detta kvalitetssmide skedde i Frankerriket. Damaskerade spjutspetsar har tillverkats i speciella smedjor och verkstäder runt hela Östersjön. Spjutspetsarna är exempel på den förfinade teknik 


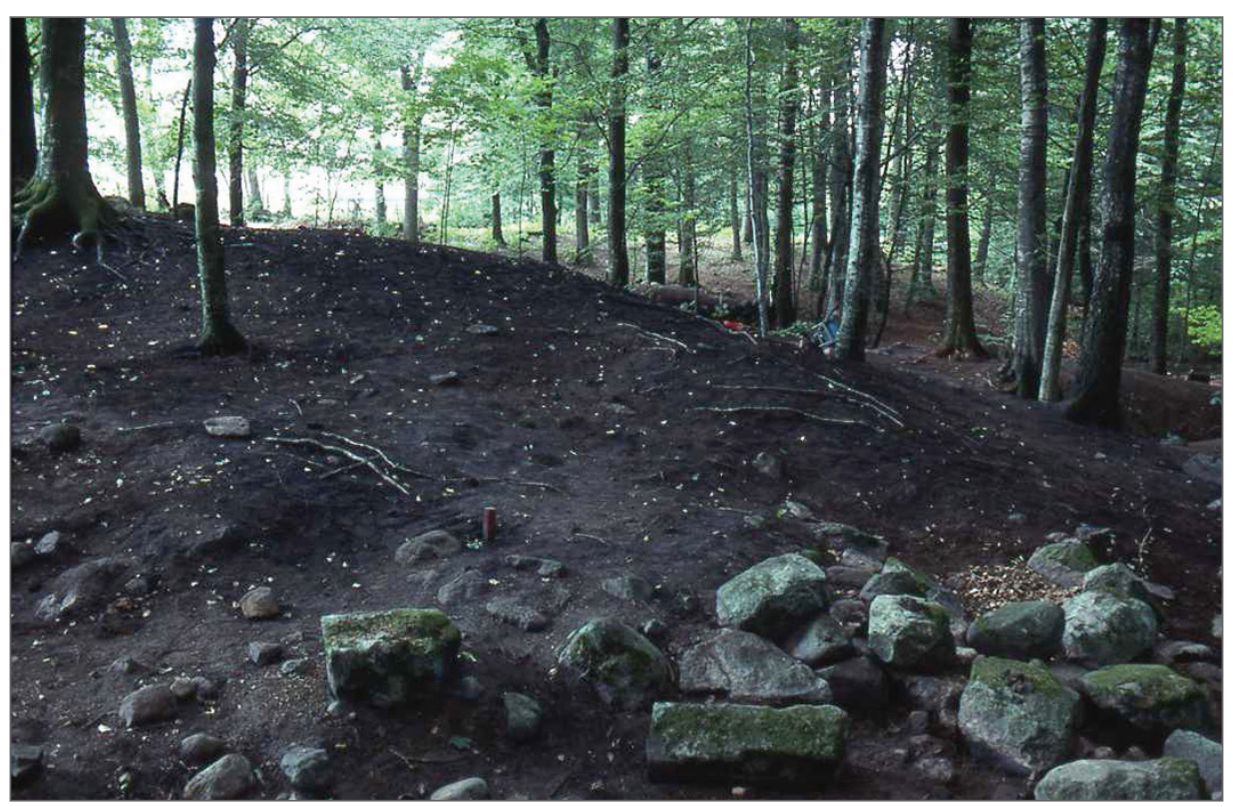

Figur 6: Järnmöllan vid Tvååker i Halland är nämnd i biskop Absalons donation till Sorö kloster 1197 och är ett av de äldsta beläggen for en vattendriven järnanläggning $i$ Europa. På platsen har man både smitt och framställt järn ur malm. Foto: G. Magnusson. Figure 6: The iron mill at Tvaakker in the county of Halland, mentioned in Archbishop Absalon's donation to Sorö monastery 1197, is one of the earliest written mentions of a water-powered forge in Europe. At this site the old smiths produced bloomery iron from bog ore and forged it. Photo: G. Magnusson.

som det vikingatida smidet kunde uppvisa (Creutz 2003). En särställning tycks ha intagits av Gotland och Saaremaa (Ösel). Det är möjligt att man i ortnamnsskicket än idag kan se spåren av detta. Hälften av alla orter i Sverige, som har ortnamnet Smedby eller Smiss eller liknande finns på Gotland. Antyder det Gotlands särställning och som en provins som sedan länge har pekats ut där exceptionella kvalitativa föremål har tillverkats?

Den vikingatida järnframställningen var så vitt vi vet, helt baserad på blästerugnar. De rika blästerugnsområdena som utvecklades i Dalarna och Gästrikland har tolkats som ett resultat av Mälarbygdens stora järnbehov (Hyenstrand 1974; Ambrosiani 1980). Det ökade järnbehovet möttes med fler små anläggningar, där man utvecklade befintlig teknik eller introducerade nya blästbrukstekniker. Den vikingatida järnhanteringen i Möre är ännu bara känd i ett fåtal blästerugnar, som legat överplöjda ute i jordbruksbygderna vid Hossmo och Binga. I samband med grävningarna för väg E22 påträffades flera blästerugnar i slättbygden, vilka kunde dateras till järnåldern (Karlsson 2001: 345). Den bäst bevarade låg i Söderåkra och hade en datering till århundradena före Kristus (Karlsson 2001: 348). I Ljungbyområdet påträffades mindre rester av vikingatida blästerugnar. Den stora ökningen av järnhanteringen i Möre skedde under 1100-talet, men fick större betydelse inom exporthandeln i Östersjöområdet redan på 1200-talet. Möjligen kan Möre ha varit järnleverantör till Gotland redan under 1100-talet.

Blästerugnstekniken förnyades under 1200-talet med ett flertal nya ugnskonstruktioner (Magnusson
1986: 228, 256 ff.; Englund 2002: 228). Flera av ugnstyperna hade direkta motsvarigheter utomlands, bland annat i Ruhrområdet (Pleiner 2000). Vissa blästerugnar kan ha varit specialiserade för att tillverka de olika kvaliteter som det avancerade vapensmidet krävde, men också vardagsverktyg som t.ex. stenhuggarmejslar. Blästerugnar krävde lite kapital för att anläggas och kunde drivas inom ett familjekollektiv. I södra Sverige blev blästbruket omfattande med hundratals blästerugnar, inte minst i östra Småland. Här utvecklades en «bergslag», där råvaran var sjömalm och tekniken en blästerugn $\mathrm{i}$ närmaste torrbacke. Järnhanteringen i Möre hade sin stora period under 1100- till 1400-talen, för att sedan avklinga (Magnusson 1986: 188). Trots att östra Småland varit föremål för studier sedan 1920-talet, har man inte påträffat några välbevarade medeltida blästerugnar. Man vet därför inte hur de varit konstruerade och var de har haft sina närmaste motsvarigheter. Leif Rubensson grävde en järnframställningsplats vid Århultemåla gård i Bäckebo socken på 1990-talet, där enligt det ovan citerade 1600-talstexten var platsen för «de rätte jermästren». Ingen blästerugn påträffades, däremot ett flertal värdefulla järnfynd, bland annat ett blästermunstycke till en blästerugn. Frågan om den medeltida tekniken i Möre återstår således att besvara.

\section{Vattenhjulet}

De stora förändringarna kom i samband med att vattenkraften introducerades $\mathrm{i}$ järnhanteringen under 1000- eller 1100-talen. Det äldsta skriftliga belägget är Järnmöllan i Halland, som utgjorde ett gränsmär- 
ke för en donation av en skog vid Tvååker av ärkebiskop Absalon i Lund till Sorö kloster 1197 (Olsen 2004: 29). Anläggning har inte tillhört biskopen eller klostret, utan får ses som ett uttryck för teknisk kunskap inom bondesamhället. Dokumentet har varit centralt i diskussionen kring cisterciensernas roll inom järnhanteringen och i förlängningen klostrens roll som ägare och intressenter $\mathrm{i}$ järnhanteringen under 1200- och 1300-talen (Lindroth 1955: 81). ${ }^{2}$ I Tvååker har funnits en vattendriven hammare och vattendrivna bälgar, som sannolikt använts till rennverkshärdar, en ugnstyp som framför allt hade sin utbredning i bl. a. Oberpfalz i Tyskland (Magnusson 2004: 217). Anläggningarna representerade ett nytt tekniskt komplex i ett område som haft en tradition med blästerugnar sedan vikingatiden. Lars-Olof Larsson har uppmärksammat att det i Sunnerbo härad i västra Småland fanns ca. 70 vattendriva smedjor under 1400- och 1500-talen (Larsson och Rubensson 2000: 26). Under 1400-talet fanns smedjor i Älghults socken, som bland andra ägdes av Arvid Trolle (Larsson och Rubensson 2000: 24). Vid Kurrö ström i Älghults socken finns tydliga rester av en vattendriven smedja, som kan ha tillhört Arvid Trolle på 1400-talet. Redan på 1100-talet fanns vattendrivna hamrar vid Tvååker i Halland, men även i Frankrike och Tyskland.

Den tredje stora innovationen efter de många blästerugnstyperna och de vattendrivna hamrarna under 1100-talet, var masugnen i den mellansvenska Bergslagen och den avancerade bergmalmsbrytningen. Med masugnen följde större teknokomplex, som omfattade bergmalmsbrytning, specialiserat jordbruk, hyttdrift, utvecklade kommunikationer, lönearbetare, specialiserade arbetare m.m. Verksamheten var så omfattande att den skapade sina egna bebyggelseformer. Från de flesta bergslager har vi dateringar som visar att driften varit igång senast omkring år 1200. Vid de äldsta masugnarna bedrevs färskningen i smedjor, där hammare och bälgar hanterades med handkraft. Först mot slutet av medeltiden, då masugnar och vattendrivna hamrar kopplades samman, förändrades villkoren för järnhanteringen i grunden och hanteringen utvecklades mycket snabbt under 1500-talet till att bli Sveriges viktigaste exportindustri. I Möre skulle det dock dröja in på 1600-talet innan det skedde någon etablering av masugnar.

2 Lindroth argumenterar med hjälp av historiska texter från Frankrike att den term, som använts i dokumentet tyder på att det varit en hammarsmedja.

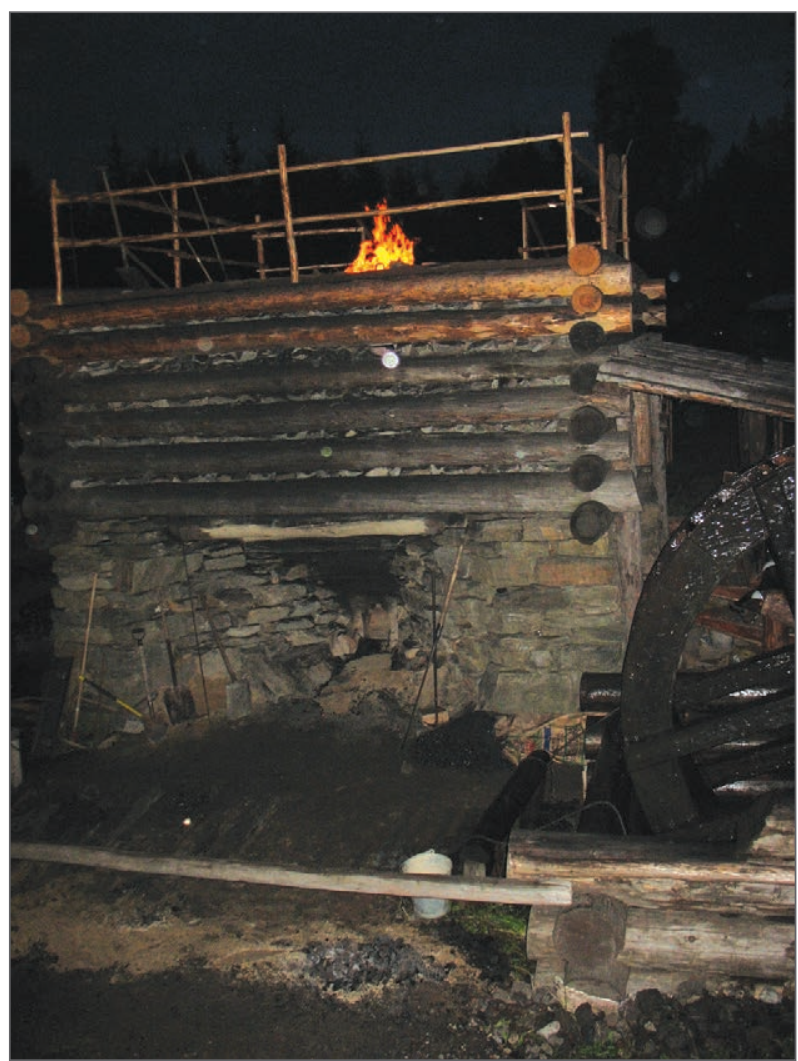

Figur 7: Nya Lapphyttan är en rekonstruktion av den påträffade masugnsruinen vid Lapphyttan. Den ger en bild av bur det en gång på medeltiden kan ha sett ut $i$ de svenska bergslagerna. Foto: G. Magnusson.

Figure 7: Nya Lapphyttan is a reconstruction based on the remains of the medieval blast furnace at Lapphyttan. It gives an impression of medieval iron working in the mining areas of Sweden. Photo: G. Magnusson.

\section{JÄRNHANTERINGENS BETYDELSE UTANFÖR DE JÄRNPRODUCERANDE OMRÅDENA}

När järnet kunde massproduceras blev det en produkt som kunde gå som handelsvara över Östersjön. Det utgjorde basen för en betydande smidesverksamhet i medeltida städer såsom Lödöse, Kalmar, Söderköping och Visby. Omfattande smedkvarter fanns på motsvarande sätt i Lübeck och Gdansk, där delar av det svenska järnet under 1300-, 1400- och 1500-talen förädlades till olika smidesprodukter.

I samband med att man lade ned vattenledningar i Visby på 1920-talet, genomförde den unge arkeologen John Nihlén några banbrytande undersökningar, vilka på ett nytt sätt belyste stadens äldsta historia. I området runt Smedjegatan i norra delen av Visby påträffades omfattande slagglager, vilka huvudsakligen utgjordes av smidesslagger som uppskattades omfatta ca. 7500 kubikmeter (Nihlén 1927: 682). Nihlén daterade slagglagret till i huvudsak tiden före 


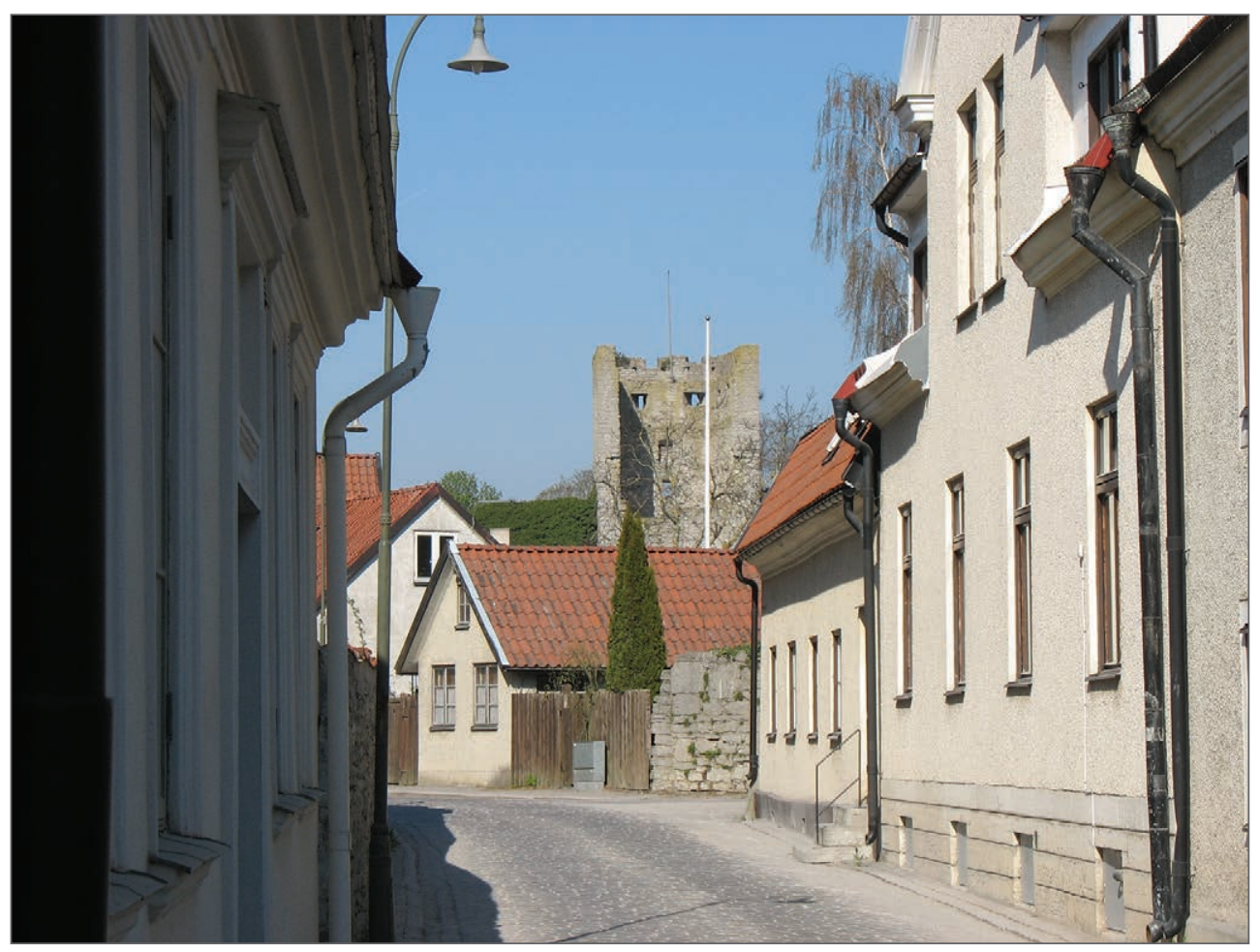

Figur 8: Smedjegatan $i$ Visby var en gaing en av de mest betydande smidesplatserna i Östersjön. Hanteringen minskade $i$ betydelse på 1200-talet, men här har tusentals ton järn smitts ut för marknaderna i Östersjön.

Foto: G. Magnusson.

Figure 8: During the

Middle Ages, Smedjegatan (The Smith's Street) in the town of Visby was one of the most important forging sites in the Baltic. Though the iron production declined during the 13th century, thousands of tonnes of iron were forged here for the markets around the Baltic.

Photo: G. Magnusson.

1250, med hänvisning till Johnny Roosvals datering av Helgeandskyrkan (Nihlén 1927: 684). Han diskuterade slagglagrens betydelse och framhöll särskilt några stycken av Utömalm (Nihlén 1927: 688). Nihlén framlade en hypotes om att malm importerats från Utö till Visby, där den sedan skulle ha reducerats till järn. Samtidigt noterade han att slaggen egentligen inte talade för reduktion av malm, utan smidesverksamhet (Nihlén 1927: 693).

Den mesta slaggen i samband med smide uppkom då man hettade upp järnet. För att minska ytspänningen på det upphettade järnet kastade man på sand då man skulle välla samman två eller flera järnstycken. Den andra väsentliga komponenten i smidesslagg var så kallat glödskal, vilket är oxiderat järn. Mest smidesslagg bildades i samband med avancerat klingsmide, t.ex. liar eller vapen, medan det vid spiksmide knappt blev någon slagg alls.

En uppskattning av mängden slagg ger vid handen att man i Visby har bearbetat minst 30000 ton järn och förbrukat ca. 2,5 miljoner ton träkol. Det innebär att en mycket stor del av Gotlands befolkning måste ha varit direkt beroende av denna hantering. Pollendiagrammen från tidigmedeltid visar att det då sker en mycket omfattande uthuggning av de gotländska skogarna. Tidigare har detta tolkats som en nyodlingsfas för det gotländska jordbruket, men sannolikt hör det snarare samman med kolningen för smedjorna i Visby. Smidet i staden var föremål för flera påvebrev under 1220- och 1230-talen. Påven vände sig till biskopen i Linköping, abboten i Roma kloster och prosten i Visby för att de skulle stoppa gutarnas illegala handel med vapen, skepp, hästar och livsmedel med de hedniska folken i Baltikum. Handeln hotade enligt påven «Kristi vingårdar» där (Magnusson 1995: 69).

\section{KONSUMTION OCH DISTRIBUTION AVJÄRN}

Järnkonsumtionen ökade på ett betydande sätt under vikingatiden och den äldre medeltiden. Detta ska nog snarast ses som ett uttryck för en allmän trend i samhället under denna tid. Skeppsbyggeriet ökade och fartygen blev större, ett stort antal kyrkor uppfördes och senare även ett stort antal borgar, jordbruket utvecklades med allt tyngre plogar och militärväsendet förändrades med bland annat ett bepansrat rytteri osv. Det är troligen denna generella konsumtionsökning och högkonjunktur i hela samhället som återspeglas i en högre järnproduktion och alltmer avancerad bearbetningsteknik.

Merparten av det vid masugnarna i Bergslagen producerade järnet exporterades över främst mälarstäderna, där Stockholm kanske redan mot slutet av 1200-talet spelade en framträdande roll som exporthamn för järnet. Men all järnproduktion var inte baserad på masugnsteknik från och med 1100-talet. En betydande ökning av järnproduktionen under senare delen av vikingatiden och den äldre medeltiden 
skedde också inom blästbrukshanteringen. Även det direktframställda järnet förekommer i de medeltida skriftliga källorna i form av calmarejern, blekingejern och dylika. Det dröjde fram till mitten av 1500-talet innan blästjärnet i större omfattning ersattes av färskat tackjärn. Räkenskaperna från Kalmar under 1500-talet visar hur calmarejernet under medeltiden efterhand alltmer spelat ut sin roll (Larsson och Rubensson 2000: 27). Någon järnhantering i Möre efter 1400-talet har inte kunnat beläggas arkeologiskt. Det är i detta sammanhang intressant att påpeka, att man på 1600-talet ansåg att slagghögarna var från forntiden och att de blev en del av de antikvariska berättelserna. Ändå hade den medeltida järnhanteringen varit så omfattande i området att det närmast kan räknas som en «bergslag». Några medeltida masugnar är inte kända. Snarare liknade Möre de kontinentala blästerugnsområdena i västra Tyskland och centrala Frankrike samt områdena på östra sidan av Östersjön, exempelvis Saaremaa och norra Estland. Möre är i själva verket ett av de områden, där fortsatta studier skulle kunna bidra till att ge svar på frågor om hur medeltida storskaligt blästbruk anpassats till befintliga naturresurser och påverkat landskapet.

Järnhanteringen inom det nuvarande Sverige rymmer många frågor kring hur man tekniskt har utformat ugnarna, men egentligen speglar ugnar och föremål människornas tekniska kunnande. En kunskap som aldrig var statisk utan under ständig förändring, anpassning och utveckling. Det är väl så vi egentligen kan se ett studium av ugnarnas utformning och som arkeologiska typer. Med konstruktioner i stort och i detaljer möter vi de forntida och medeltida smederna och deras idéer hur de löste metallurgiska problem. Det är väl detta som är det egentliga målet med våra studier kring den äldre järnhanteringen.

\section{SUMMARY}

In the history of mankind, iron production, smelting and forging have been a well-developed technical system since the introduction of iron. The techniques seem to have been used for centuries, but at some periods great innovations occur. Such a period of great changes and of introduction of new techniques was the $12^{\text {th }}$ and $13^{\text {th }}$ centuries. Many new techniques were introduced, such as different types of bloomery furnaces, the high bloomery, the blast furnace for mass production of pig iron and, finally, the use of water-power for forges and blast furnaces. This shift in technology raises several questions:

- Which technique was used in different regions and when did a shift in technology occur?

- How was the iron production organized locally?
- How was the ownership of the natural resources, like bogs or lakes for the limonite ore and forest for wood and charcoal production, organized?

- What was the role of iron production in the colonization of forests in Sweden?

Iron production has been the subject of historical studies since the $17^{\text {th }}$ century. In one of the earliest records, from 1680, «the leading iron master» and his iron production site at Skåningsmåla, outside Kalmar in south east Sweden, is mentioned. Modern research started in the 1920s on the initiative of Jernkontoret, (The Swedish iron master's association), when historical studies of Swedish iron production were organized in Bergshistoriska utskottet, a meeting place for historians and modern steel producers. Different local studies of Swedish iron production have been undertaken and published, such as Iron production in Småland during 1000 years, Järnmöllan - an iron mill from the $12^{\text {th }}$ century - and Lapphyttan, a medieval blast furnace. Another research area is the development of $20^{\text {th }}$ century industrial history and industrial heritage.

I have for some years been studying issues concerning the technology shift in the iron production around Kalmar. Already during the $9^{\text {th }}$ century the area was referred to as the land of Möre. More than 1000 sites with remains of bloomery iron production are known in the forest land, most of which seem to be from the $12^{\text {th }}$ and $13^{\text {th }}$ centuries. We can see a division of the landscape into two regions: the coastal plain with the large farms owned by the high nobility, with their castles situated by every little river from the forests, and strongholds to control the iron production before exporting the iron. Here we can see the existence of the king at his site at Hossmo and the early administrative center of Möre, with a curia for the bishop of Linköping and a ting (assembly) at Tingby. It is possible to see that a lot of farmers paid their taxes to the bishop, while in the forests most farmers paid their taxes to the state or to the king. Only a few farmers paid their taxes to the nobility. Natural resources seem to be used in commons, i.e. not owned by individuals in the same way as arable land. The taxes were not paid in iron as one might expect, but in agricultural products like butter. However, the iron from the district is known from tariff lists from several of the major medieval harbors of the Baltic and the North Sea as Calmar iron, i.e. a regional quality of iron.

In the $12^{\text {th }}$ century we can see traces of some major steps in the technical development, among them the introduction of water power. This inven- 
tion seems to occur within the farming society. At Tvååker, in Halland in the southwest of Sweden, we have a very early written source which mentions a water-wheel, as well as an excavated iron production site powered by water from the $12^{\text {th }}$ century located along a small stream. The same situation occurs at Lapphyttan, in the mining districts of Bergslagen, $170 \mathrm{~km} \mathrm{NW}$ of Stockholm. Both sites are located in areas dominated by farmers and with only little influence by the nobility. Here the farmers probably had a drive to develop new technical inventions such as water power and blast furnaces.

\section{LITTERATUR}

Ambrosiani, B. 1980. «Båtgravarnas bakgrund i Mälardalen». I Sandwall, A. (red.). Vendeltid. Stockholm: Statens historiska museum.

Arrhenius, O. 1959. Die grundlagen unserer älteren eiserherstellung. Antikvariskt arkiv: Stockholm.

Arrhenius, O. 1968. «Smålands malmtrakt och järnframställning». Dedalus. Tekniska museets årsskrift: Stockholm.

Baudou, E. 1963. «Arkeologiska undersökningar på gravfältet vid Årsunda». Från Gästrikland. Gävle.

Berglund, B. 2000. «Järn i Småland». Småländskjärnhantering under 1000 år. Del 1. Jernkontorets Bergshistoriska skriftserie nr 34. Stockholm: Jernkontoret.

Blomkvist, N. 1979. «Kalmar uppkomst och äldsta tid». Kalmar stads historia del 1 (utg. I. Hammarström). Kalmar: Kulturnämnden i Kalmar.

Creutz, K. 2003. Tension and Tradition. A study of the late ironage Spearheads around the Baltic Sea. Stockholm Studies in Archaeology. Stockholm.

Englund,L.-E. 2002. Blästbruk. Myrjärnshanteringens förändringar i ett långtidsperspektiv. Jernkontorets Bergshistoriska Skriftserie nr 40. Stockholm: Jernkontoret.

Ericsson, A. 2001. «Möre mellan järnålder och medeltid - omvandlingen av ett agrarlandskap». I Magnusson, G. och S. Selling (red.). Möre - bistorien om ett småland. Kalmar.

Hellberg, L. 1979. «Forn-Kalmar. Ortnamnen och stadens förhistoria». Kalmar stads historia del I. Kalmar: Kulturnämnden i Kalmar.

Hyenstrand, Å.1974. Centralbygd-Randbygd. Stockholm university Thesis and papers in Archaeology. Stockholm: Universitetet i Stockholm.

Hyenstrand, Å. 1977. Hyttor och järnframställningsplatser. Nagra sammanfattningar kring inventerat material . Jernkontorets Bergshistoriska utskott, serie H 14. Stockholm: Jernkontoret.

Jonsson, K., G. Magnusson och P.-O. Millberg 2001. Järnhantering i Norra Västergötland. Arkeologiska undersökningar i Essunga, Främmestad, Istrum, Ledsjö
Lerdala, Vättlösa och Älgarås socknar. Jernkontorets Bergshistoriska utskott H71.Stockholm:Jernkontoret. Karlsson, L. 1985. «Cistercian Iron Production». I Magnusson, G. (red.). Medieval Iron in Society. Vol I. Jernkontorets Bergshistoriska utskott, serie H 34. Stockholm: Jernkontoret.

Karlsson,C. 2001. «Möre, järnet och människan». I Magnusson, G. och S. Selling (red.). Möre - bistorien om ett småland. Kalmar.

Lagerås, P. 2007. The Ecology of Expansion and Abandonment. Medieval and Post-Medieval land-use and Settlement Dynamics in a Landscape Perspective. Stockholm: Riksantikvarieämbetet.

Larsson, L.-O. och L. Rubensson, 2000. «Från blästbruk till bruksdöd». Småländskjärnhantering under 1000 år. Del 2. Jernkontorets Bergshistoriska skriftserie nr 35. Stockholm: Jernkontoret.

Lindroth, S. 1955. Gruvbrytning och kopparhanteringen vid Stora Kopparberget intill 1800-talets början Vol. I-II. Uppsala.

Lund, N. 1983. «Ottar og Wulfstan». Ottar og Wulfstan to rejsebeskrivelser fra vikingetiden. Roskilde.

Magnusson, G.1986. Lågtekniskjärnhantering i Jämtlands län. Jernkontorets bergshistoriska skriftserie 22. Stockholm: Jernkontoret.

Magnusson, G. 1995. «Iron production, smithing and iron trade in the Baltic during the late Iron age and the early Middel Ages (c. $5^{\text {th }}-13^{\text {th }}$ centuries)». I Jansson, I. (red.). Archaeology East and West of the Baltic Stockholm: Stockholms universitet.

Magnusson, G. 2003. «Att gräva en industrilämning». I Avango, D. och B. Lundström (red.). Industrins avtryck. Perspektiv på ett forskningsområde. Stockholm: Brutus Östlings Bokförlag Symposion.

Magnusson, G. 2004a. «Järnmöllan i Tvååker. Inledning och projektets bakgrund». I Vellev, J. (red.). Jernmollan $i$ Halland. Jernkontorets Bergshistoriska Skriftserie nr 43. Stockholm: Jernkontoret.

Magnusson, G. 2004b. «Järnhantering i Tvååkersområdet i Halland. En avslutande diskussion kring Järnmöllan». I Vellev, J. (red.). Jernmøllan i Halland. Jernkontorets Bergshistoriska Skriftserie nr 43. Stockholm: Jernkontoret.

Mogren, M. 2008. «Riksgränsen». I Angelert, M. (red.). Landskap bortom traditionen. Historisk arkeologi i nordvästra Skåne. Stockholm: Riksantikvarieämbetet.

Myrdal, J. 1999. Jordbruket under feodalismen. Det svenska jordbrukets historia del 2. Stockholm: Natur och kultur.

Nihlén, J. 1927. Äldre järnhantering på Gotland. Jernkontorets annaler. Stockholm: Jernkontoret.

Nihlén, J. 1932. Studier rörande äldre svensk järntillverkning med särskild bänsyn till Småland. Jernkontorets Bergshistorisk skriftserie nr 2. Stockholm:Jernkontoret. 
Nihlén, J. 1939. Äldre järntillverkning $i$ Sydsverige. Studier rörande den primitiva järnhanteringen i Halland och Skåne. Jernkontorets Bergshistoriska skriftserie nr 9. Stockholm: Jernkontoret.

Pettersson, I-M. 1994. Norbergs bergslag. Jernkontorets forskning Serie H 101, Stockholm: Jernkontoret.

Olsen, R. A. 2004. «Sorö i Tvååker». I Vellev, J. (red.). Jernmollan $i$ Halland. Jernkontorets Bergshistoriska Skriftserie nr 43. Stockholm: Jernkontoret.

Pleiner, R. 2000: Iron in Archaeology. The European Bloomery Smelters. Praha: Archeologický ústav AVČR.

Sönnecken, M. 1985. «Die Mitelalterliche - frühneuzeitliche Eisenerzeugung in Märkischen Sauerland». Der Märker. Bochum.

Rinman, C. [1794]1997. Korrt underrättelse om sättet att smälta sjö- och myrmalmer uti blästerugnar. Jernkontorets Bergshistoriska utskott H 66. Stockholm: Jernkontoret.

Segerström, U., A. Berg, I.-M. Pettesson Jensen, R. Bindler och I. Renberg 2010. «Det tidiga bergsbruket i Norberg - Nu ännu tidigare. Skogshistoria och föroreningshistoria kastar nytt ljus över utvecklingen». Med Hammare och Fackla XLI. Stockholm.

Schoultze, L. T. 1982 [1732]. Kort berättelse, om myr-ugnar eller så kallade bläster-werk uti Östra- och wästra Dahle- orterna brukelige. 1732, I. Pettersson, J.-E. (red.). Lima och Transtrand. Ur två socknars historia 1. Malung: Kommunen.

Sawyer, P. 1991. När Sverige blev Sverige. Alingsås: Viktoria.
Stahre, N.- G.1992. Rannsakningar efter antikviteter. Band 3. Stockholm.

Strid, J. P. 2006. Från Mumsmålen till Duvemåla. Den svenska måla-kolonisationeen under medeltiden: en topolingvistisk studie. Stockholm: Runica et mediaevalia

Strömberg, B. 2004. Arkeologiska undersökningar av järnhanteringsplatser i Tvååkersområdet. I Vellev, J. (red.). Jernmollan i Halland. Jernkontorets Bergshistoriska Skriftserie nr 43. Stockholm: Jernkontoret.

Strömberg, B. 2008. Detförlorande järnet. Danskprotoindustriell järnhantering. Stockholm: Riksantikvarieämbetet.

Sturlasson,S.1993.Nordiska kungasagor»Magnussönernas saga. Stockholm: Fabel.

White 1978. «The Expansion of Technology 500-1500». I Cipolla, C. M (red.). The Fontana Economic History of Europe I. The Middle Ages. Glasgow: Collins/Fontana.

Williams, A. 2007. "The Ulfberth swords a high eutectoid steel». Paper at the Aquileia conference. Milano.

Åstrand, J. 2006. «Utmarksbruk och arkeologi i Sydvästra Skåne. Utmarker, gårdar och människor». Om järnålder och medeltid i Sydvästra Småland. Växjö.

Åstrand, J. 2008. Rapport del I. Järn Lundströms plats. Jönköping: Jönköpings läns museum.

Ödman, A. 2001. Vittsjö. En socken i dansk järnbruksbygd. Norra Skånes Medeltid 2. Report series nr 76. Lund: Arkeologiska institutionen. Lunds universitet. Ödman, A. 2005. Skeingeborg, borgen som Saxo glömde. Norra Skånes Medeltid 4. Report series nr 90. Lund: Arkeologiska institutionen. Lunds universitet. 


\title{
EVENSTAD-PROSESSEN I TID OG ROM MED EN METALLURGISK ANALYSE
}

\author{
Arne Espelund
}

\section{MANUSKRIPTET OG MILJØET}

Ole Evenstads manuskript Afhandling om jernmalmen som fins i myrene og Moradeser og Omgangsmåden med å foredle dem til Jern og Stål om jernframstilling, som var på cirka 60 sider, ble sendt til Det Kongelige Danske Landhuusholdnings Selskab i 1782. Forfatteren, som levde fra 1739 til 1806, var bonde og lensmann i Aamodts prestegjeld, nå Stor-Elvdal kommune. Han fikk selskapets 2. gullmedalje som belønning for sin innsats. Evenstads manuskript forelå i trykt utgave i 1790 (Evenstad 1790/1960). Manuskriptet er translitterert og supplert med kommentarer av meg (Espelund 2008).

Evenstads manuskript er et enestående kildeskrift fordi det beskriver praksisen ved den jernframstillinga som ennå ble drevet i Nord-Østerdalen. Evenstad hadde åpenbart lært av dem som ennå smelta i nabosognet, det vil si Sollia (Sollia er preget av tallrike funn og jernvinneanlegg fra alle tre perioder). I europeisk sammenheng er manuskriptet bare sammenlignbart med litteratur fra 1830-tallet om den halvindustrielle Catalan-prosessen i Pyreneene. Evenstad skriver til sambygdinger som en kyndig legmann, mens de franske bidragene ble skrevet av vitenskapsmenn for en akademisk leserkrets.

Evenstad var et aktivt medlem av Det Aamodtske patriotiske Selskab, som fikk i gang en skole med en liten fabrikk for moderne tekstilbehandling. Skolen ble kalt Enighed, og den lå ved bredden av Glåma. Alt vitner om opplysningstida på sitt beste og innspurten før 1814. Det samme gjelder Evenstads manuskript om bruk av myse og koking av brunost, et manuskript han fikk sølvmedalje for i 1805 (Espelund 2009). Der beskriver han også hvordan store bukjeler ble laget av garkobber.

I året 1782 fikk Sven Rinman også trykt sitt monumentale verk om jernets historie i Stockholm, noe som vitner om at Sverige på den tida hadde en akademisk elite knyttet til en stor jernindustri (Rinman 1782).

Tyskfødte Blumhof berømmer den faglige kvaliteten i skriftet etter at det ble utgitt på tysk $\mathrm{i}$ Göttingen i 1801:

Es ist immer die Mühe werth, die fast allerälteste Methode, das Eisen aus seinen Erzen zu schmelzen, kennen zu lernen, besonders da noch jetzt jährlich viele 1000 Centner Eisen auf diese Art in Schweden und Norwegen producirt werden ... keiner von diesen Schriftstellern [Swedenborg, Rinman, Agander] hat, meines Erachtens, die Sache so deutlich gemacht.

Daraus lernen können wir für unsern Deutschen Eisenhütten-Haushalt freylich nichts, allein man sieht doch das Verfahren, und die dadurch für jene Länder und gegenden erwachsenen ansehnlichen Vortheile, welches für die Geschichte des Eisenhüttenwesens in Europa nicht unwichtig ist.

Som vi ser, sier Blumhof at metoden neppe er aktuell i Tyskland. Manuskriptet, bortsett fra den siste delen om kostnader, ble også oversatt og utgitt på engelsk i 1968 (Evenstad/Jensen).

At skriftet om jernvinna er så nøyaktig, henger sammen med at Evenstad sammen med fetteren Ole Furuseth planla å bygge ei hammersmie ved fossen Kløvet i Neta, som er ei bielv til Glåma. Han ønsket å få sambygdinger til å lage blåsterjern for utsmiing. Med innføringen av oppgangssaga og overgangen til bruk av plank og reisverk ved husbygging økte behovet for blant annet spiker. Nagler og spiker i konstruksjoner hadde før så å si bare blitt brukt i båter, slik som i vikingskipene. Evenstad viser i siste del av boka at det kan lønne seg å lage slikt «blåsterjern» sjøl når man bare skal betale for arbeidshjelp og har egen tilgang på både myrmalm og ved. For kjøpejern fra jernverkene regner han med store transportomkostninger.

Det er ingen tegn som tyder på at noen fulgte rådet hans. Da boka ble utgitt, var jernverkene, slik som Eidsvoll, Odal, Næs og så videre, i full drift, og de leverte blant annet godt stangjern. Heller ikke østerdøler som flytta til Målselv og Bardu, begynte med slik smelting, trass i funn av lokal myrmalm. Hans beregninger er også veldig optimistiske. Blant annet er utbyttet av jern ved smeltinga satt altfor høyt, og han oppgir opptil fem smeltinger per dag, mens to er mer realistisk etter vår erfaring.

Men at kildeskriftet er gyldig som dokumentasjon av smeltepraksis, er bevist ved noen hundre smelteforsøk, i først rekke ved Ivar Berre i Skogn og på Stiklestad, og ved Norsk Skogmuseum på Elverum. 


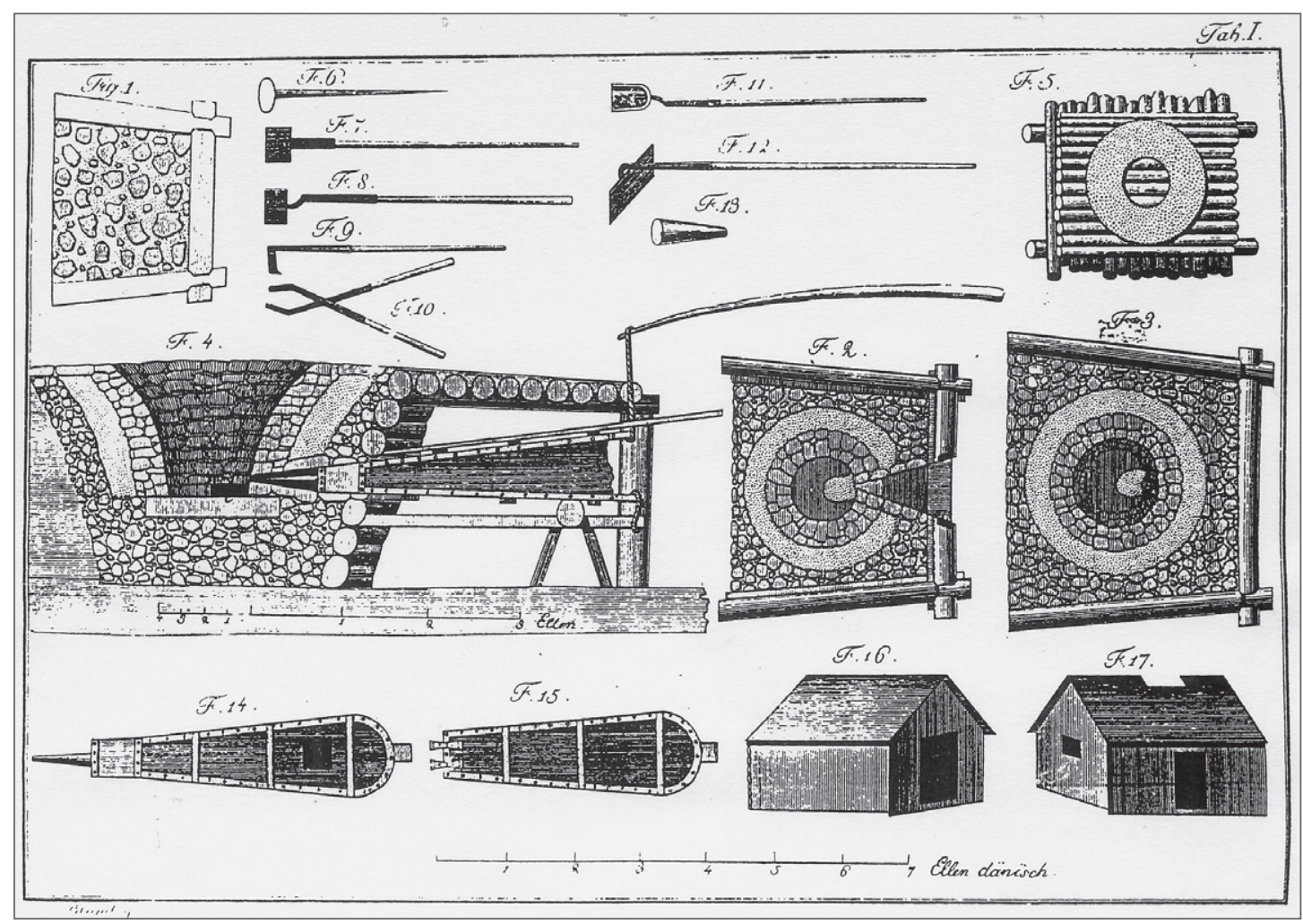

Figur 1: Den forste av tegningene i manuskriptet. Den viser ovnen med blåseutstyr i vertikalsnitt, to horisontalsnitt, bläsebelgene, handredskap og to små hus, alt med referanse til teksten. Også rosting er tatt med. Legg merke til at det er to stokker i nederste skift for å slippe til rikelig med luft. På mange tegninger ligger stokkene tett $i$ botnen. Det stemmer ikke overens med virkeligheten.

Figure 1: The first drawing in the manuscript. The furnace with bellows is shown in section and also in two plane drawings, along with the bellows, utensils and two small huts, everything with reference to the text. Roasting is also included. Note that there are only two logs in the bottom. On some other drawings many logs are erroneusly placed next to each other.

Jeg sitter med et inntrykk av at den seine jernvinna ble drevet som attåtnæring i opptil et par uker rundt månedsskiftet oktober-november, og at jernet som ble framstilt, var til eget bruk. Bare fra Folldalen hører vi om utsmiing og salg av ljåer som var laget av blåsterjern. Det finnes nesten ikke rettsdokumenter om denne virksomheten, bortsett fra et brudd på helligdagsloven ved malmtransport fra fjellet og en strid om retten til malmtak (Espelund 2008).

\section{HVA ER TYPISK FOR ET EVENSTADANLEGG?}

I dette tilfellet kan vi med god grunn bygge på manuskriptet. Boka inneholder to svært gode tegninger som støtte for utførlig tekst (figur 1).

På Grindflek i Unset har det blitt funnet et malmspyd som er merket B(erger) G(jermundsen), etter en mann som levde fra 1702-1755. Et slikt malmspyd ser vi i figur 1 , nr. F 6 .

Det er slagghaugene som forteller oss at det har foregått smelting. Ovnene ble etter endt smelting tømt ved bruk av spade. Bare jernet ble behandla på ambolt, mens resten, som var en blanding av slagg, trekol og halvt redusert malm, havna i slagghaugen. I Sollia ligger det en ferdigbygd ovn som aldri har vært tatt $i$ bruk. På vanlige funnsteder er treverket rundt ovnen råtna opp. Vanlig treverk holder i 20 år. Som vi kan vente, har forsida derfor ikke lenger støtte i forkant, slik at stein forskyver seg og ovnen blir oval. Rester av hus er ikke funnet ved noen av ovnene, bortsett fra ei kvilebu ved Sandnesbekken i Tolga (figur 2). I Norge er det bare tre kjente anlegg som vitner om vassdrift: Sandnesbekken i Tolga, Fjellbudalbekken i Alvdal og Vollablesteren ved Storsjøen i Rendalen. I Sverige er det flere, og mange av ovnene har navn etter eieren.

Ovnene ligger nesten alltid i tørt terreng som skråner cirka $1: 10$. På den måten var det bare nødvendig å lafte på tre sider, bakken dannet den fjerde veggen, som vist på figur 1 . Det lettet adkomsten og gjorde det greit å ferdes rundt ovnskransen. 
Slagghaugen er så å si alltid på høyre side, sett forfra. Det betyr at smelteren når han tømte ovnen, sto på oppsida, og det betyr også at han var høyrehendt, som de fleste. I noen få tilfelle er det slagg på venstre side eller på begge sider. Slagghaug på venstre side forteller at det var en bestemt mann som drev smeltinga. Slagghaugene varierer i størrelse fra 0,5 kubikkmeter til 10 kubikkmeter.

I Sverige er det skrevet flere artikler som beskriver ovner på flat mark, lafta på alle fire sider og med stige som adkomst. Den eneste ovnen i nokså flatt lende hos oss er funnet på Eidsmoen i Tolga, men også den er svakt oval. Schultzes ovn fra 1734 blir av gode grunner ofte trukket fram:

1. Schultzes ovn er en ovn med et innvendig volum som er cirka tre ganger større enn Evenstadovnens. Samtidig skal driftstida ha vært på fire til fem timer, som for Evenstadovnen, noe som for øvrig er høyst usannsynlig at den var.

2. Ovnen har form som et åpent kremmerhus, og den må følgelig ha hatt så stort varmetap oppover at det er utenkelig at man klarte å oppnå flytende slagg.

3. Ovnen er ikke vist med slaggavtapping. Slagg kan ikke tappes gjennom en trevegg, så dette må være fri fantasi. Til og med Nils Björkenstam, tidligere leder av Bergshistoriska utskottet ved Jernkontoret - en mann som er meget opptatt av svensk autonomi - sier at noen slik ovn som Schultzes ikke er påtruffet.

Ovnene er «gardsnære», oftest ikke over et par kilometer unna. Evenstad trekker fram at man i forbindelse med smelting ikke skulle bruke opp vinterved i nærheten av garden, samtidig var det naturlig å gå heim til garden etter endt arbeidsdag. Vi må forestille oss at kanskje tre personer dro sammen til anlegget tidlig om morgenen. De hadde med seg hest, som bar de to blåsebelgene sammen med røsta malm i sekker. Ved var stablet opp ved anlegget. Smeltinga tok gjerne fem timer. Det ville svare seg å smelte to ganger i løpet av en lang dag og deretter dra tilbake til garden med ferdig jern, kanskje også med de kostbare belgene.

På figur 3 og 4 ser vi rester av to anlegg: ovnen i Stalltomtdalen i Kåsa, som er usedvanlig godt bevart, og ovnen på Eidsmoen, begge i Tolga kommune. Den siste ligger i nesten flatt terreng, og slagghaugen ved ovnen er enorm, den er på minst 10 kubikkmeter.
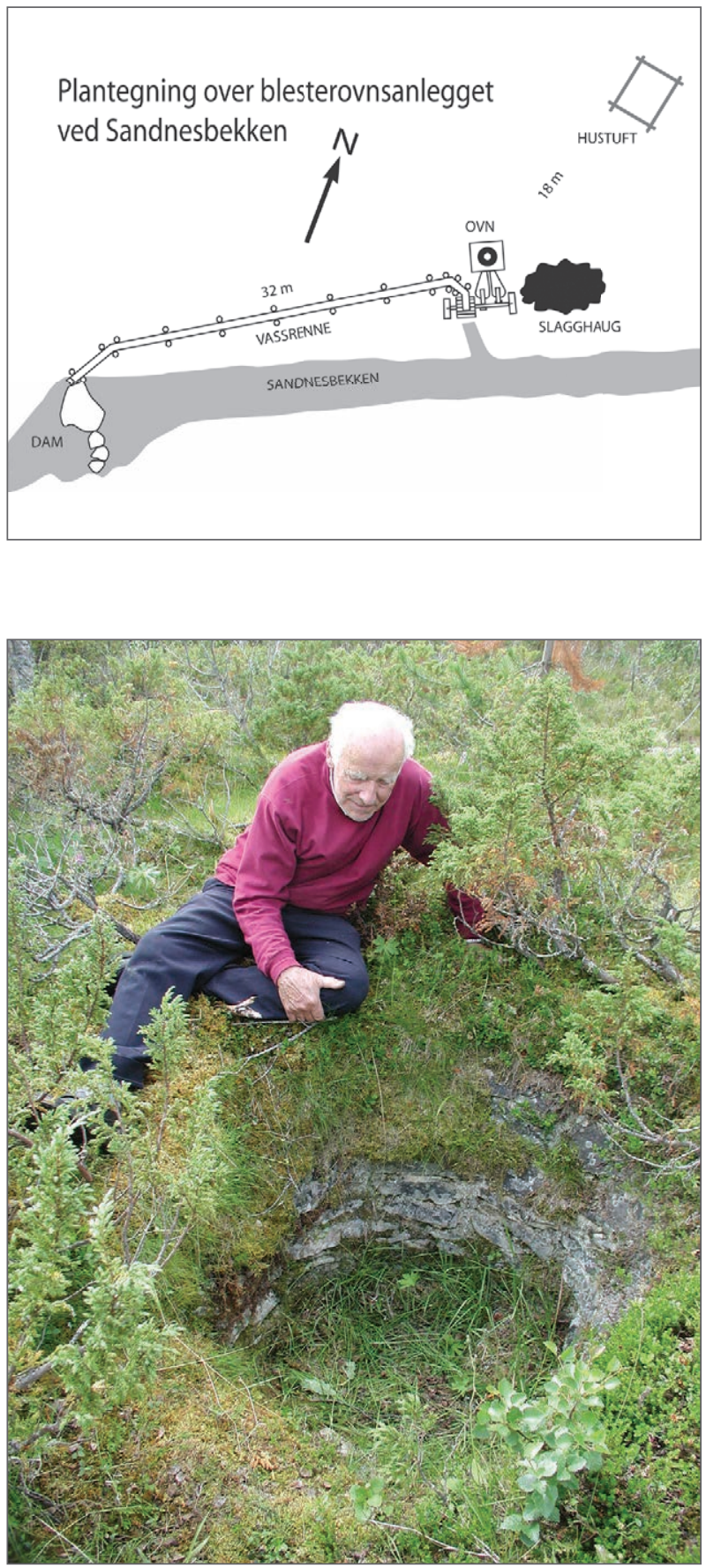

Figur 2 og 3: Ovnen i Stalltomtdalen og anlegget på Eidsmoen. Den overste er uvanlig fint murt med heller, og den nederste er murt med rund stein. Begge ovenene er murt uten bruk av leire i fugene. Slagghaugen på Eidsmoen er av de storste som er kjent, og den ligger på grunn som tilhorer Vingelen. Foto: figur 2 S. Nygaard og figur 3 A. Espelund.

Figure 2 and 3: The furnaces in Stalltomtdalen, Kåsa and at Eidsmoen, near the center of the municipality of Tolga. The first is exceptionally well built using flag stones, while in the second rounded stones have been used. The slag heap at Eidsmoen is very large. It lies on land belonging to the community of Vingelen. Photo: figure 2. S. Nygaard/figure 3. A. Espelund. 


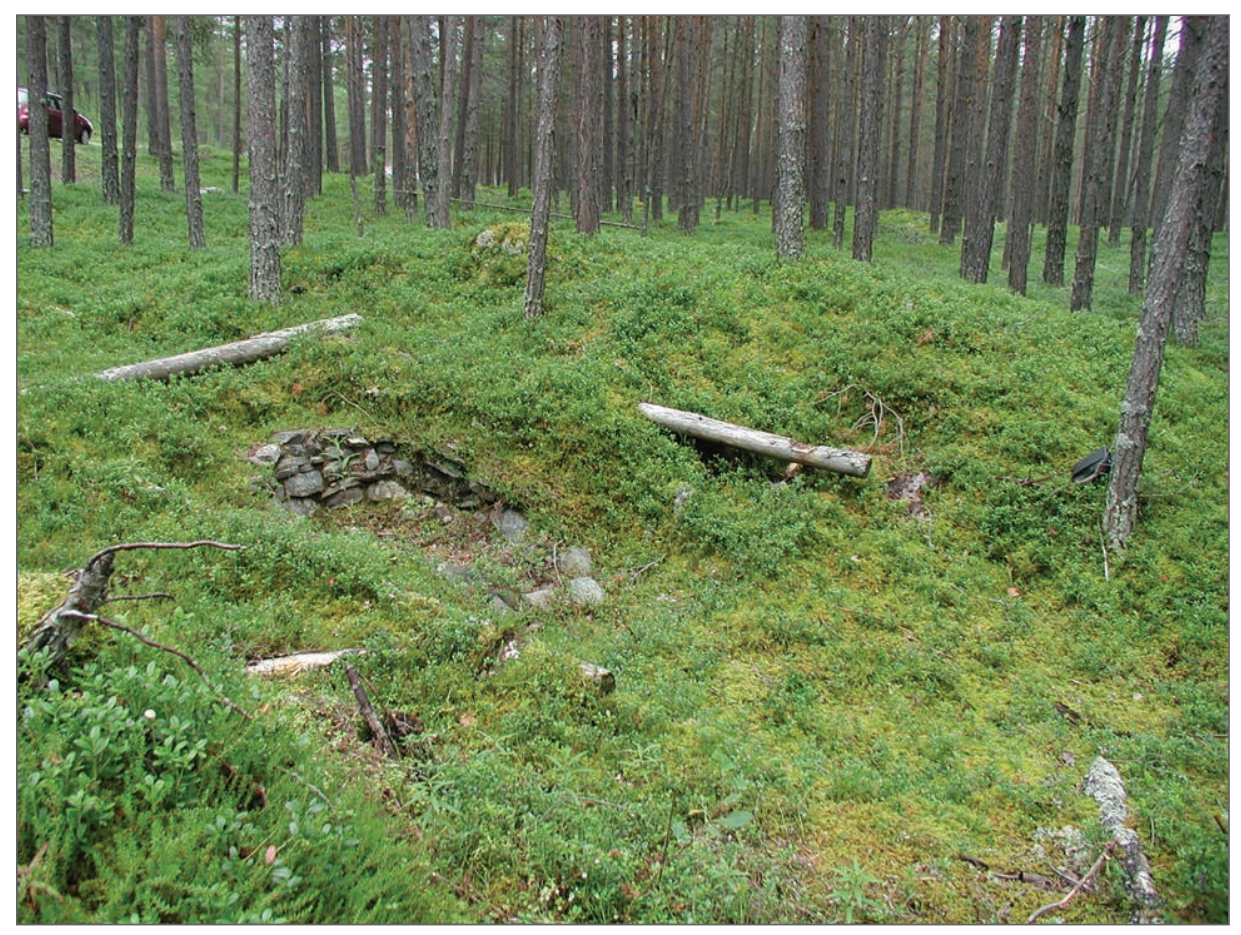

Figur 4: Anlegget ved Sandnesbekken. Det som ble funnet, er bekken med damsted, ovnen med slagghaug og hustufta, mens vassrenna og overfallshjulet med blåsebelger er tilfoyd og stär for egen tolkning. Illustrasjon: H. Ness.

Figure 4: The work site at Sandnesbekken. It comprises the small river, the furnace with its slag heap and the house area. The duct for water and the overshot water wheel have been added by the present author. Drawing: H. Ness.

\section{EVENSTADOVNENS UTBREDELSE}

De øvrige ovnene finner vi bare spredte tilfeller av, så de må være knyttet til omreisende «mestere» (figur 5). Både på Voss og i Oppdal henger funnene sammen med navngitte innvandrede svensker fra Jämtland, som kjente teknikken og åpenbart ønsket å bli i Danmark-Norge etter at Jämtland ble svensk i 1645 (Espelund 2008). Det største mysteriet er ovnen som ble funnet i Holmevika ved strandkanten av Sunndalsfjorden i Hol kommune. Der er det blokkmark, slik at malmen må ha blitt frakta med båt eller på isen. Ovnen har en svært tidlig datering (1310-1430), noe som kan komme av at det daterte materialet var av gammel furu. Det finnes ingen tradisjon for slik smelting $\mathrm{i}$ området, mens smelting på Voss ble omtalt i Bergen av presten Meldal (1768).

Jeg har sjøl vært på Voss og prøvd å finne rester etter den smeltinga som Meldal fortalte om i 1768 , uten å finne noe. Vi må stole på Meldal. Jeg synes det virker sannsynlig at blestersmeder innvan- dret til Norge da Jämtland ble svensk ved freden i Brømsebro (var det i 1645). Det kom også en blestersmed til Oppdal i Trøndelag. Slike enkeltpersoner som har hatt med seg teknikken, uten at det har blitt noen tradisjon, preger også Nord-Norge, riktignok for de to eldre periodene (Jørgensen 2011).

\section{DATERING}

Det var forventet et flertall av dateringer på 1600-1700-tallet, men snart kom dateringer helt tilbake til år 1400. Nesten alle dateringene - i alt rundt 30 stykker - er basert på trekol av furu og har et tyngdepunkt på 1500-1600-tallet (Espelund 1997). Men for et anlegg i Mølmannsdalen på Røros lyktes det å datere trekolbiter av bjørk - disse ble datert til AD 1415-1445. I den siste boka mi, Jernvinna $i$ Tolga og Os, har jeg mange dateringer som peker mot 1400-tallet. Mest betegnende er to dateringer fra anlegget Sandnesbekken, den ene fra slaggvarp, den andre fra hustuft, med bare 10 års forskjell i verdiene for begynnelse og slutt. Det gir et

\begin{tabular}{|l|l|l|l|l|}
\hline Lab. referanse & Kontekst & Prøvetidspunkt & Journalnr. & Datering kalibrert \\
\hline T-6246 & Sandnesbekken, slaggvarp & 14.02 .1986 & DF 1433 & AD 1170 \pm 00 \\
\hline T-9729 & » Trekol furu, slaggvarp & 21.03 .1990 & DF 1433 & AD 1320-1445 \\
\hline T-9269 & » Trekol furu, ildsted i hustuft & 05.03 .1991 & DF 1433 & AD 1310-1435 \\
\hline
\end{tabular}

Tabell 1: ${ }^{14} \mathrm{C}$ dateringer fra Evenstadanlegget ved Sandnesbekken.

Table 1: ${ }^{14} C$ dates from the Evenstadsite at Sandnesbekken. 


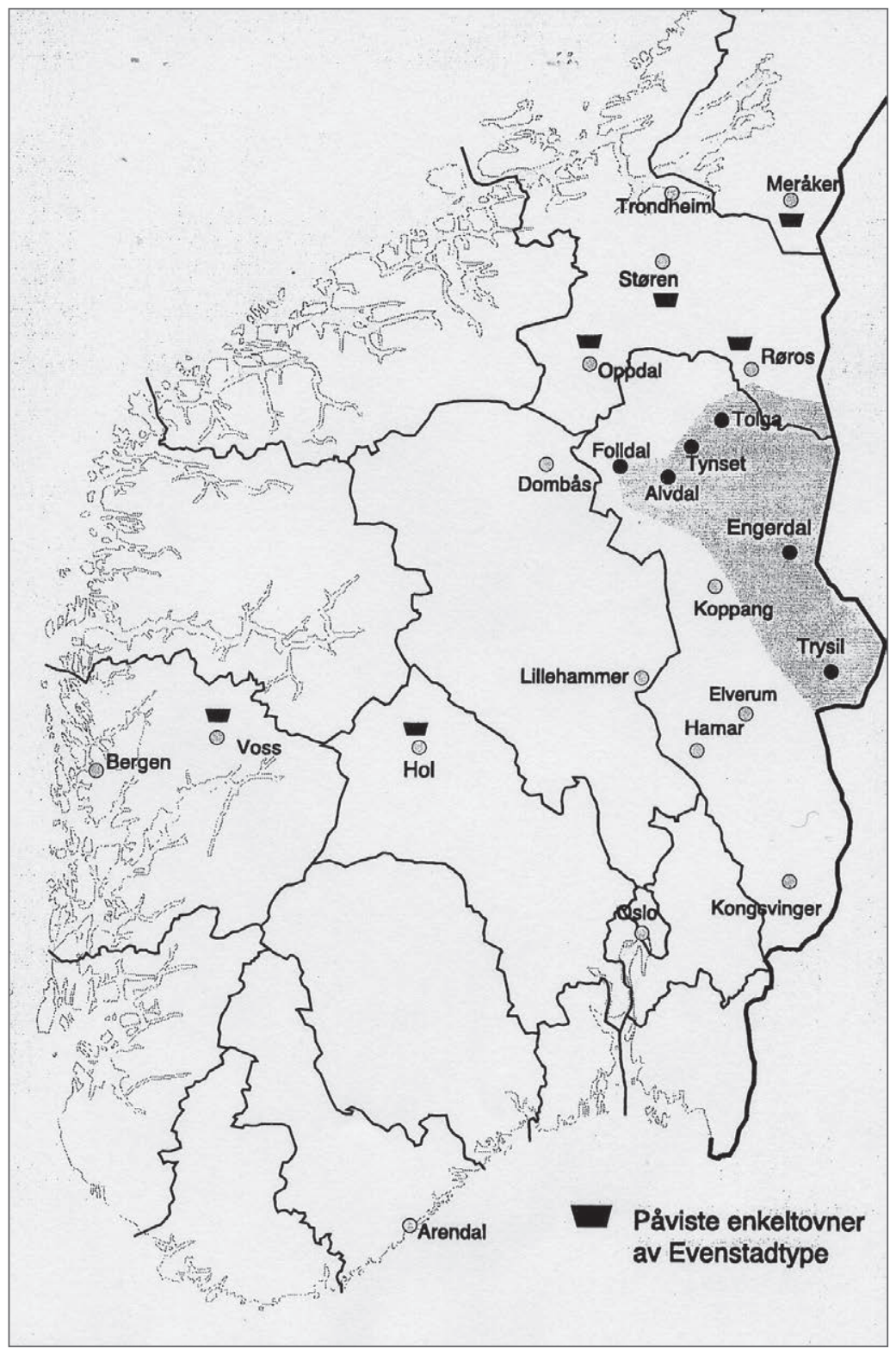

Figur 5: Fordeling av ovner i Norge. Det er et solid tradisjonsomrade fra Trysil i sør over til Folldalen $i$ vest og opp mot Roros i nord. Området henger sammen med et tilsvarende område i Härjedalen, på svensk side av grensen. Alvdal, med funn av cirka 140 ovner, ser ut til a vare et tyngdepunkt.

Figure 5: The distribution of this type of technology in Norway. It was a part of normal seasonal activities from Trysil in the south, Folldal in the west and to Roros in the north, as well as in the adjoining part of Härjedalen in Sweden. In Norway some 140 slag heaps have been recorded in the municipality of Alvdal. ganske sikkert resultat innenfor et tidsrom på 30 år.

Dateringene ved Sandnesbekken i Tolga 11'34' $62^{\circ} 11^{\prime}$ var meget illustrerende for ${ }^{14} \mathrm{C}$-teknikken og dens begrensninger (tabell 1).

Av tre dateringer er de to siste sikkert basert på trekol fra fersk furu, mens den første, fra cirka år 1200, må være basert på trekol fra tørrfuru, som har en høy egenalder. På 1200-tallet var teknikken helt annerledes, med småsjaktovner og slaggtapping. Disse dateringene er dermed de første som påviser at Evenstad-teknikken ble tatt i bruk rundt år 1400 . Det gode samsvaret mellom datering av trekol fra slagghaugen og fra kvilebua er ganske overbevisende.

Det er dermed klart at metoden ble tatt i bruk rundt år 1400, bare 50 år etter svartedauden. Det betyr at mange anlegg er fra før reformasjonen i 1537, og de forvaltes som fornminner etter kultur- minnelovens bestemmelser, uten at det røpes ved ytre trekk.

\section{OPPHAV}

Retterboten til Håkon VI Magnusson, skrevet 22. februar 1358 da han var i Nes på Romerike, indikerer at det var en ny situasjon etter svartedauden. Bøndene i Østerdalen fikk rett til å ta malm og skog til jernbrenning i kongens allmenning og smelte, slik det hadde vært gjort tidligere. Det er som om han hilser den nye metoden velkommen:

Fyrst at per skulur engha skatta ne tolla gera. meiri en per eighur at forno oss at gera. ok ydrir forældrar hafua vaarom forældrum ok oss gort her till, skulu per ok heðan af ok allir adrir peir sem jarnwinnu vilja plægha $\mathrm{j}$ almænningom varom her frealslegha 


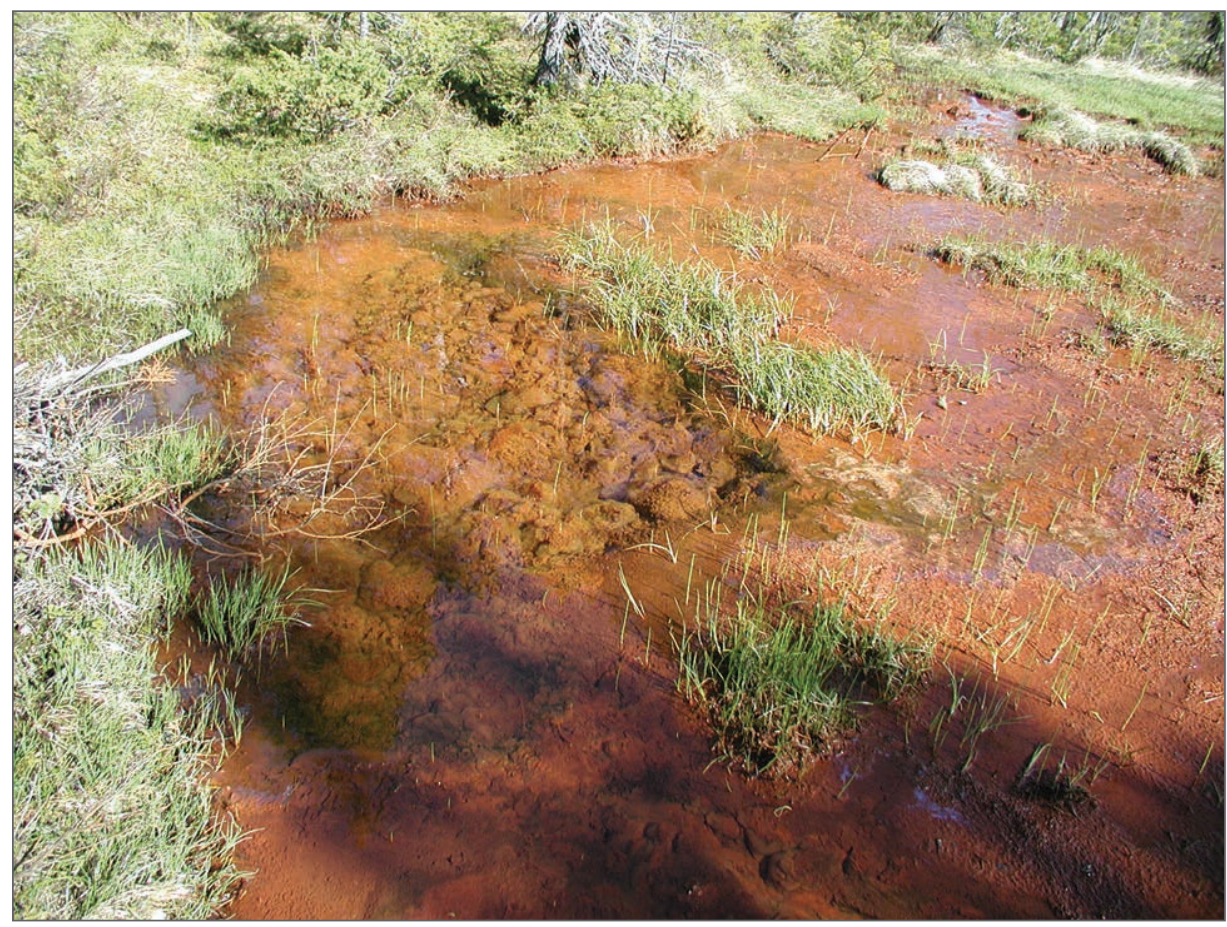

Figur 6: Raudvella ved Namlåmyra i Singsås. Her er det mulig a hente myrmalm med gravemaskin. Foto: $A$. Espelund.

Figure 6: The ore well at Namlamyra in the community of Singsås. Here large amounts of pigment-like ore can be picked up. Photo: A. Espelund.

niotande verða sinnar orko ok malmss eftir peim siðuana sem aat forno hefuir veret her $\mathrm{j}$ dalenum, swa skulut per ok frealslaga fæyra ydarn varnengh a Heidmork ok j aðra staðe fæyra ok skipta j pan varnengh sem peim likar, vten hindran ok talman vaarra vmboðs manna (DN VI: 238).

I retterboten kommer ordet jernvinna på «trykk» for første gang. Mens vinne opprinnelig sto for arbeid generelt, har det gått over til å stå for onnearbeid. Den andre vinna i Østerdalen er slåttonna.

Det er grunn til å tro at den nyinnsatte kongen ved å gi rettigheter ville sikre seg lojalitet.

Det er ingen kjente paralleller til Evenstadovnen og dens kremmerhusform. Riktignok har Ivar Berre, Skogn, hevdet at også romertidsovnen i Trøndelag hadde en slik form, og han har utført eksperimenter med direkte tilsats av ved. Men det er ikke allment godtatt at dette stemmer. I hvert fall er det stor avstand i tid mellom ovnstypen fra romertida og Evenstadovnen. Bortsett fra materialstrømmen er det ingen tegn til at det er noen overforing fra middelalderens ovnstype til Evenstadovnen, heller ikke er det gjort funn som vitner om eksperimenterer som kunne lede fram til en vellykket løsning.

Men kanskje dekket den nye ovnen et behov: Etter hvert hadde det i Øst-Norge og i Sverige blitt stor mangel på klump- eller grusformet myrmalm, som hadde vært råstoff $\mathrm{i}$ eldre og yngre jernalder. På en del steder i Norge - sjøl kjenner jeg til et tjuetalls steder - finnes det raudveller, som er store oppkommer der jernholdig grunnvatn møter luft. Ved oksidasjon felles oker med sammensetningen $\mathrm{FeOOH}$ ut. Etter tørking og en eventuell røsting er den som pigment. I en trang ovn vil slikt «støv» bli blåst ut, mens i en kremmerhusformet ovn vil gassen strømme langsommere. Det finnes beretninger i Sverige om bruk av «gyttja», altså nærmest «søle», men Ole Evenstad omtaler bare den andre, klumpformede malmtypen, som trolig ble dannet i høyvarmetida for cirka 5000 år siden. En ganske kjent raudvelle ved Namlåmyra i Singsås er vist på figur 6. Malm fra en annen raudvelle, som den ved Ingstadnes i Hegra, inneholder derimot mye fosfor.

Kjemisk analyse av malmen etter tørking og røsting ved $600^{\circ} \mathrm{C}$ vises i tabell 2 .

\begin{tabular}{|l|l|l|l|l|l|l|l|l|l|l|l|l|}
\hline $\mathrm{FeO}$ & $\mathrm{Fe}_{2} \mathrm{O}_{3}$ & $\mathrm{MnO}$ & $\mathrm{SiO}_{2}$ & $\mathrm{Al}_{2} \mathrm{O}_{3}$ & $\mathrm{P}_{2} \mathrm{O}_{5}$ & $\mathrm{CaO}$ & $\mathrm{MgO}$ & $\mathrm{BaO}$ & $\mathrm{TiO}_{2}$ & $\mathrm{~K}_{2} \mathrm{O}$ & $\mathrm{Sum}$ & $\mathrm{R}$ \\
\hline & 76.86 & 3.36 & 15.9 & 0.01 & 0.055 & 3.1 & 0.01 & 0.2 & 0.01 & 0.01 & 99.5 & 3.8 \\
\hline
\end{tabular}

Tabell 2: Kjemisk analyse fra Raudvella ved Namlåmyra i Singsås. Table 2: Chemical analysis of the ore well at Namlamyra in Singsås. 


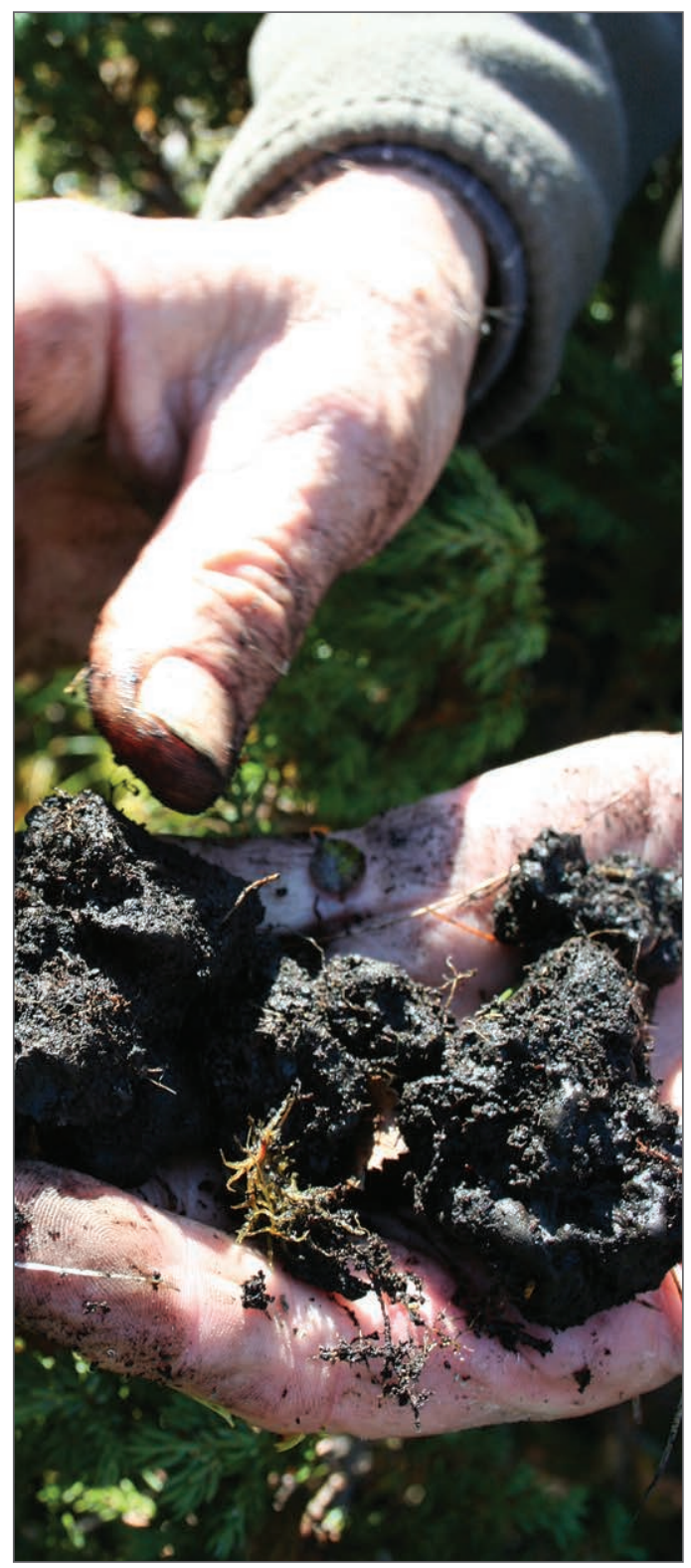

Figur 7: Slagg fra Evenstad-anlegget ved Kjerklehaugen i Hodalen, Tolga. Foto: G. Jortveit. Figure 7: Slag from the slag heap at Kjerklehaugen in Hodalen. Notice the porosity. Photo: G. Jortveit.

«Fayalittbrøken» R står for $(\% \mathrm{FeO}+\% \mathrm{MnO}) /$ $\% \mathrm{SiO}_{2}$ (med molverdier). Verdien 2.0 svarer til fayalitt $(\mathrm{Fe}, \mathrm{Mn})_{2} \mathrm{SiO}_{4}$, som er hovedandelen i avfallet - slagg fra vellykket smelting. Det er derfor verdier av $R$ vesentlig høyere enn 2 som kan gi et godt jernutbytte. 3.8 er lavt, og vi kan spørre oss om smelting ville lønne seg. Men innholdet av skadelig fosfor er lavt.

I Norge er det en stor, kjent forekomst av myrmalm i lia mot øst ved Dokkfløyvatn, der det er store grasmyrer. Malmen er som kaffegrut, og den ble brukt til smelting i eldre og yngre jernalder, slik
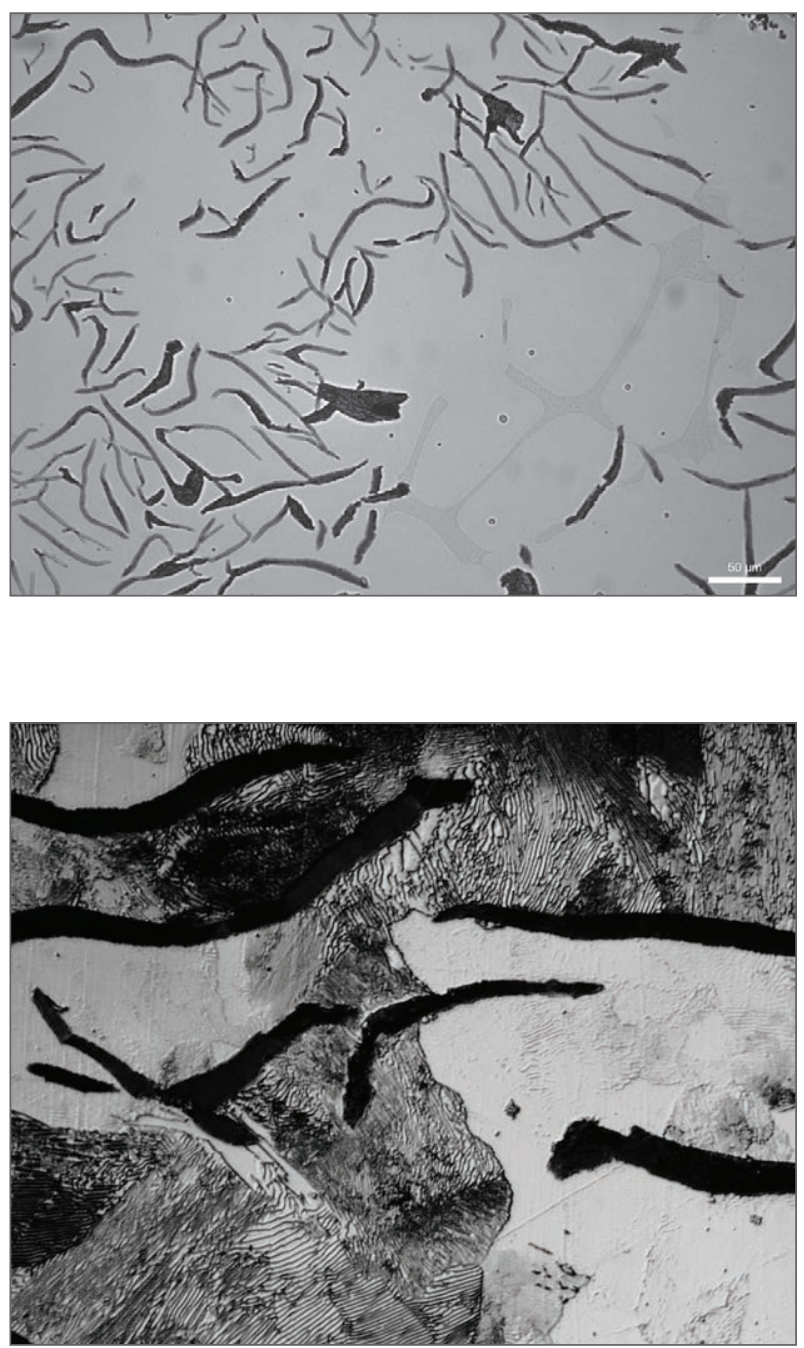

Figur 8 og 9: Jernbit funnet i slagghaugen $i$ Stalltomtdalen. Det ovre bildet er uetset, med tydelige grafittlameller, og det nedre bildet viser de samme lamellene $i$ en masse av perlitt og ferritt etter etsing med nital $2 \%$. Metallografi: P. Ulseth.

Figure 8 and 9: Micrographs of a piece of iron from the slag. heap in Stalltomtdalen. Upper picture unetched, lower picture etched. Notice worms of graphite and pearlite. Metallography: P. Ulseth.

det er dokumentert etter de store utgravingene ved Dokkfløy (og dessuten i forbindelse med gassrensing i Christiania rundt år 1900). Smelting av malm etter svartedauden er ikke påvist ved Dokkfløy. I det hele tatt er ingen ovner av Evenstad-typen funnet i Gudbrandsdalen, Valdres, Numedal eller Telemark. I Hallingdal er bare den ene ovnen påvist i Hol kommune. Vi kan lure på hvordan bønder på storparten av Østlandet fikk dekket sitt jernbehov etter middelalderen. Våre eldste jernverk kom i drift på 1500-tallet, men masovnen ble tatt i bruk på 1600-tallet. Fikk vi dekket jernbehovet 


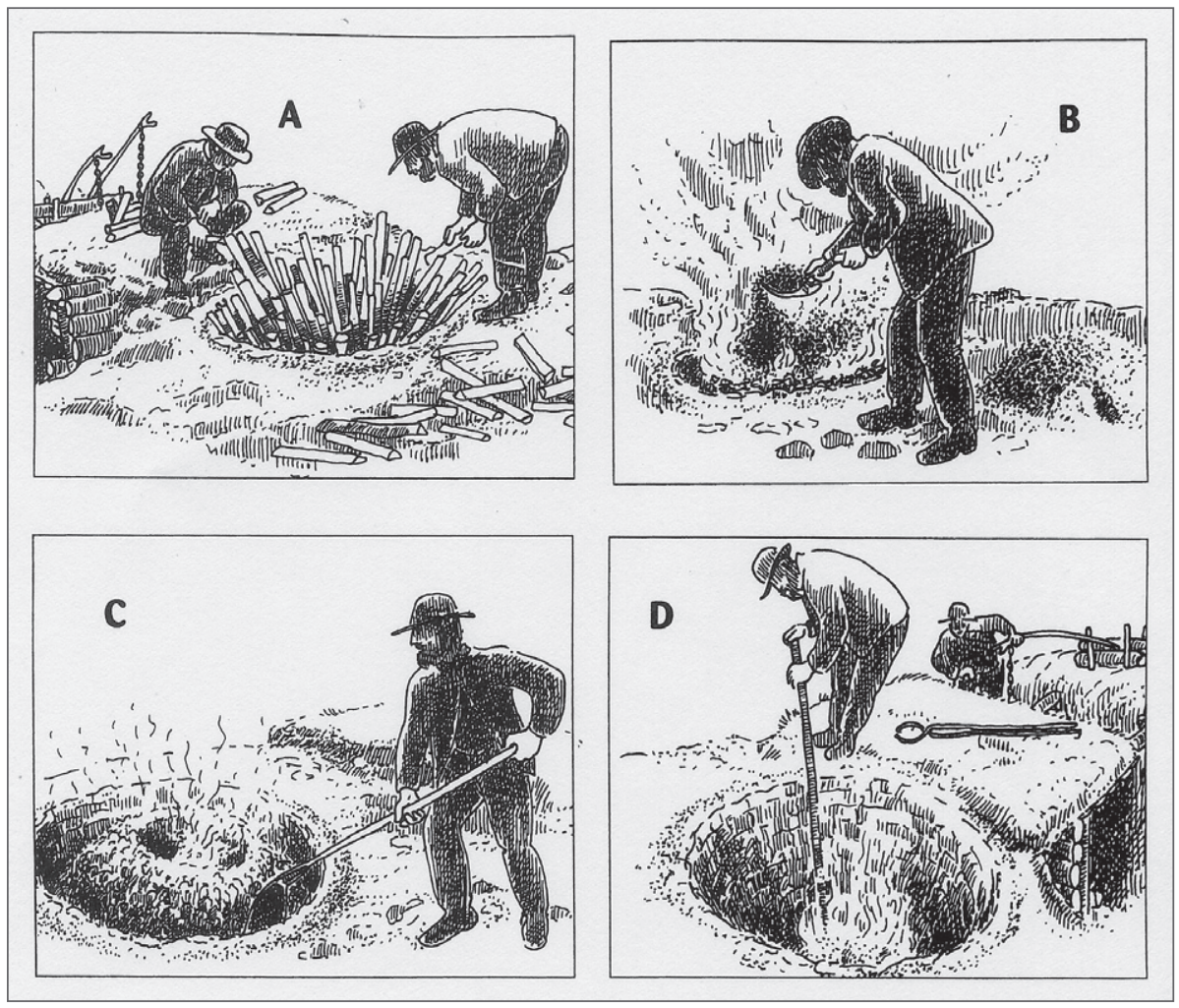

Figur 10: Smelting rundt 1990 på Dolmotunet i Tolga. Illustrasjon: H. Ness (etter lysbilder).

Figure 10: Smelting circa 1990 at Dølmotunet in Tolga. Drawing: H. Ness (based upon slides). fra Sverige, der industriell framstilling begynte på 1300 -tallet?

\section{PRODUKTER}

Slagget fra Evenstadtradisjonen har ikke noen orientering, i motsetning til slagg fra middelalderen, som hadde en oppside og en nedside. En stor del av slagget er porøst, slik som vist i figur 7 , men det finnes også nokså faste slaggklumper. Porene henger sammen med gassutvikling $\mathrm{i}$ siste fase av smeltinga, noe som blir tatt opp i en diskusjon om smelteteknikken.

Noe blåsterjern fra denne tida er ikke kjent. For å avgjøre kvaliteten på jernet burde vi undersøke utsmidd jern fra denne perioden. En stor del av de små jernbitene vi finner i slagghaugene, er karbonrikt jern, og er derfor knapt smibart metall. Figur 8 og 9 viser funn av jern ved Stalltomtdalen i Tolga den ene viser slipt og polert jern uten etsing, og den andre viser samme bit etter etsing. Vi ser primær utskilling av grafitt, i en særdeles heterogen masse av perlitt og ferritt. Bildet forteller at temperaturen har vært over $1145^{\circ} \mathrm{C}$, og at den ønskede ferskinga ikke har blitt fullført.

\section{DRIFT}

Uten Evenstads manuskript hadde vi stått hjelpeløse foran ovnen når det gjelder tolking av drifta. Hans store manuskript inneholder følgende kapitler:

\section{Forerindring.}

1. Om nogle Kiendemerker, der alminnelig vise de Myrer, som have Jern-Malm i sig.

2. Om Maaden at eftersoge Malmen, samt om de dertil behrvende Redskaber.

3. Om Myr-Malmarternes forskiellige Egenskaber og Kiendemerker, som haves deels af. Farven, deels af Skikkelsen, og ellers af andre Omstandigheder.

4. Om Myr-Malmens Opgravning. Røstning, Bevaring og hvad som horer dertil af Redskaber og andet.

5. Om Blasterens (Smelte-Ovnens) Bygning, samt de Redskaber og den Veed, som behoves til Malmens Smeltning i Blesteren.

6. Om Maaden at blande de forskiellige Myr-MalmArter, som ikke sarskilt samlede give gotJern, item om den rostede Malms Smeltning i Blesteren til Rue-Jern.

7. Om Maaden at smelte den rostede Malm til Staal i Blesteren.

8. Om Blaster- eller Rue-Jerns Omsmeltning $i$ Smidden til finere Jern.

9. Om fint Jerns Omsmeltning til Staal.

10. Om Blester-Bygningen og dertil horende andre Bygningers, samt Redskabers Bekostning.

11. Beregninger over de Omkostninger, som udfordres 


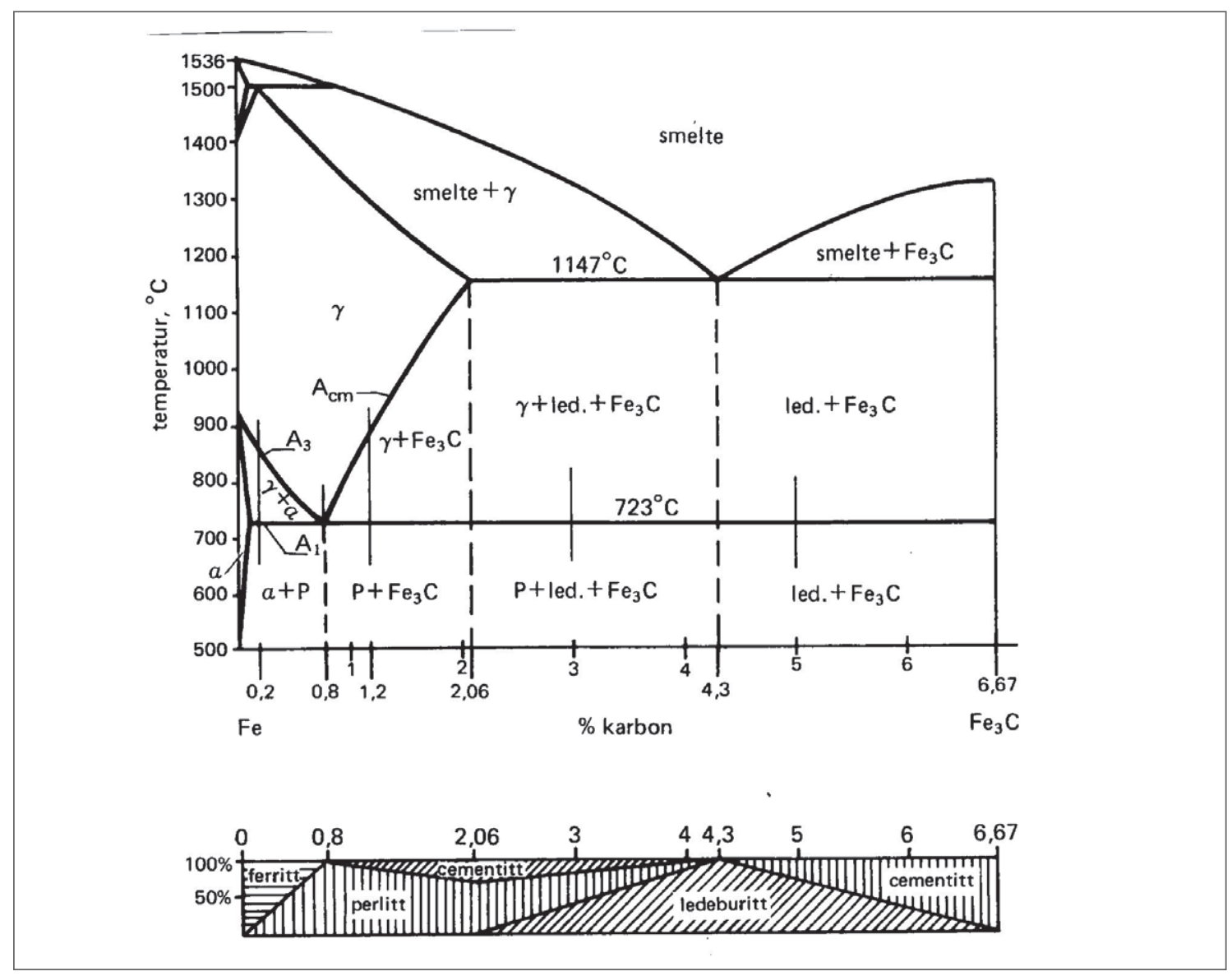

Figur 11: Jern-karbon-diagrammet. Linja Acm viser at metall som dannes ved 1100oC $i$ kontakt med karbon (trekol) eller en tilsvarende CO-rik gass, vil ta inntil $2 \%$ C i fast losning.

Figure 11: The iron-carbon diagram. The line marked Acm shows that metal created at 1100oC in the presence of carbon (charcoal) or the corresponding CO-rich gas will take up to $4 \% \mathrm{C}$ in solid solution.

paa Malmen, indtil den er smeltet til Blaster-Jern, og hoad Blester-Brug derimod kaster af sig.

12. Beregning over Omkostninger paa et Skippund Blester-Jerns Omsmeltning til finere Jern, og bva deraf udkommer til Fordeel.

Ved smelting i ovnen på Dølmotunet i Tolga rundt 1990 ble det tatt bilder som er brukt som grunnlag for tegninger Helge Ness har laget. Vi ser først hvordan ovnen blir fylt med ved, deretter hvordan malmtilsatsen skjer, så hvordan massen blir omfordelt på toppen, og til slutt hvordan luppen av jern blir forsøkt skilt fra slagg og trekol (figur 10).

For sjølve smeltinga er en del av kapittel 6 av særlig interesse:

Naar Veeden er forbrændt saa nær til Kul, at der ikkun findes endeel Brande til overs, da trykker man Kullene tilsammen med Bagen af Blæster-Spaden, først i Midten og siden uden omkring, dog ikke gandske ud til Blæster-Muuren, men saa mange af Brandene, som kan faaes fat paa, lægges rundt omkring oven paa Kullene. Derpaa drysses 12 Potter smaa banket Malm gandske sagte af en Træ Skuffe op i Blæsteren rundt omkring oven paa Kul-Ilden, dog lader man i Midten en Aabning frie for Malm...

Naar nu Malmen er bleven rød, maae man med Røgespaden føre Kullene og Malmen fra alle Sider af Blæsteren henimod Midten, saa at der bliver en Forhøining, som helder udover til alle Kanter, derpaa drysses igien 8 Potter Malm paa lige Maade, som forhen, rundt omkring, men ei midt paa. Efterat denne Malm ligesom den forrige, er bleven rød, begynder en Karl at træde Bælgene langsom ..., Da Kullene nu ere omtrent halv opbrændte, saa drysser man tredie og sidste Gang Malm paa ligesom forhen, men ikkun ungefær 4 Potter. Man blæser nu sagte igien indtil Malmen bliver rød.... Saa hastig det derefter begynder at skiære sig, blæser man sagte, optager Kullene fra Formen, støder den Malm-Krave, som sætter sig omkring Formen 
løs, og fører det alt op paa Malm-Fælden (den smeltede Jern-Klump)... I al den Tid, indtil Kullene ere gandske opbrændte, og Jern-Fælden ligger blot, blæses sagte med Bælgerne, og derefter vender man Jern-Klumpen op med Blæster-Krogen, saa at den kan faaes fat, og optages med Tangen af Blæsteren. Man har da en stor Steen ved Haanden, hvorpaa en Karl lægger eller holder Jern-Klumpen paa Kanten imedens en anden Karl med en Øxe kløver den næsten i 2 Deele...

Naar Jernet er smidigt og got, da falder Klumpen tynd og fladagtig, men er det haardt, da falder den høi og tyk, eller utæt og fuld af Huller. Haardheden er en Mangel i Blandingen, men Hullerne ere Følger af Mangel i Smeltningen. Man kan og prøve Jernet saavel varmt, som koldt, ved det at man paa de kløvede Sider af Jern-Klumpen afhugger nogle smaa Splintre. Ellers falder det af sig selv, at Jernet ved Omsmeltning bliver mere smidigt.

Midt i en løpende tekst kan vi lese om tilsats av 12, 8 og 4 potter røsta malm (uthevet her). 1 pott svarer til 1 liter (i 1683 lik 0,986 liter)?. Siste tilsats skjer «naar kullene er halvt opbrændte». Det er dette trekket som møter de metallurgiske kravene til vellykket jernframstilling, nemlig mot slutten en nødvendig fersking av det karbonrike jernet som har oppstått inne $\mathrm{i}$ ovnen.

I samsvar med jern-karbon-diagrammet, som er vist $\mathrm{i}$ figur 11, må vi forvente at jernet som dannes i blesterovnen, vil inneholde inntil 2 prosent karbon. Slikt jern er sprødt som støpejern, og det blir vraket av smeden. Tilsatsen av røsta malm med mye $\mathrm{Fe}_{2} \mathrm{O}_{3}$ skal tvinge karboninnholdet ned, helst til cirka 0,2 prosent $\mathrm{C}$ gjennom reaksjonen

$\mathrm{Fe}_{2} \mathrm{O}_{3}+\underline{\mathrm{C}}=2 \mathrm{FeO}+\mathrm{CO}$, eventuelt $\mathrm{FeO}+\underline{\mathrm{C}}=\mathrm{Fe}+$ $\mathrm{CO}$,

der $\underline{\mathrm{C}}$ står for karbon oppløst i jernet. $\mathrm{CO}$ er som kjent en gass, og den kommer til uttrykk som porer i slagget, slik som vist i figur 7. I beste fall vil dannet $\mathrm{FeO}$ reagere videre med $\mathrm{SiO}_{2}$ til fayalitt i flytende slagg.

Men vi risikerer at tilsatt malm i stedet reagerer med trekol, etter ligninga

$\mathrm{Fe}_{2} \mathrm{O}_{3}+\mathrm{C}=2 \mathrm{FeO}+\mathrm{CO}$, eventuelt $\mathrm{FeO}+\mathrm{C}=\mathrm{Fe}+$ $\mathrm{CO}$,

der C står for trekol. Dette sier oss at forholdene mot slutten av smeltinga er ganske komplekse, og utbyttet av eller kvaliteten på det ferdige jernet vil som ventet variere mye. Dette blir tydelig dokumentert i slagg- og metallanalyser ved anleggene.

Denne store spredningen står i kontrast til smel- tinga i middelalderovn nummer II, der slagget er kompakt og har en ganske enhetlig analyse, og der metallet har veldig gode egenskaper.

\section{UTPRØVNING}

Den best dokumenterte smeltinga i Evenstadovnen ble utført under Budalseminaret i 1991 (Espelund 1993). Materialet var ikke lett smibart, men det ble smidd ut en liten barre av godt jern ved tilsats av boraks.

\section{OPPSUMMERING}

Evenstad-prosessen, som var i bruk fra cirka år 1400-1800, var en utmarksnæring i kombinasjon med fjelljordbruket i Nord-Østerdalen, og var tilpasset garder med husdyrhold og utnytting av utmark. Om høsten hadde folk ledig tid som kunne brukes til å lage jern til eget bruk.

For denne prosessen befinner vi oss i en enestående situasjon, fordi vi har et detaljert kildeskrift fra 1790, som dekker bøndenes jernproduksjon i ØstNorge tilbake til cikra år 1400, tallrike funn, som svarer til kildeskriftet, og en vellykket etterprøving ved praktisk smelting, på en skala som er overkommelig.

Kildeskriftet forteller om en satsvis prosess som tilfredsstiller metallurgens krav om smibarhet. Om vi bare hadde hatt ovnsrester å gå ut fra, eventuelt tegninga i Evenstads bok, ville vi aldri ha kommet på at prosessen hadde to perioder, nemlig først reduksjon og deretter fersking ved tilsats av ekstra malm. Dette sier oss noe om at morfologi ikke alltid forteller alt. Reduksjon fulgt av fersking er også mønsteret i dagens industrielle framstilling. Men i dag foregår periodene $\mathrm{i}$ to ulike reaktorer, mens de hos Evenstad foregikk i én ovn.

Mange forsøk med de eldre ovnstypene bygger ensidig på morfologien. Morfologi kan bare avdekke helheten for en kontinuerlig prosess. Evenstads manuskript forteller om en kompleks, men ikke komplisert, prosess. En som har deltatt i slik smelting et par ganger, vil ha lært seg kunsten. De strenge kravene som smeden setter til det jernet han skal smi, kan neppe møtes ved enkleste form for framstilling fra myrmalm og trekol, som mange forsøker seg på.

Vi kan også tenke kontrafaktisk: Ville Evenstadprosessen ha oppstått dersom slik smelting hadde vært enkel? Hvorfor er skiftet i teknologi så totalt ved overgangen fra forste til andre periode, og fra andre til tredje periode? Hvorfor tok det 1000 år fra starten i Lilleasia til kunsten ble tatt i bruk i Norge? 


\section{SUMMARY}

Bloomery iron smelting in Norway during the period AD 1400-1800 took place in dug-in shaft furnaces without slag tapping. There are some 500 slag heaps and remains of such furnaces in the northern part of Østerdalen and in nearby Härjedalen in Sweden. The process is very specific, described by many authors. However, the sherriff and farmer Ole Evenstad made a very detailed account of the construction and the operation of the furnace in the year 1782 , so that in the literature the process is named after him. He received a price for the manuscript in Copenhagen. It was translated to German and printed in Göttingen in the year 1805.

The furnace was a truncated cone, placed on sloping terrain and put into a frame of logs.

Smelting, which lasted some four or five hours, was initiated by filling the furnace with split wood, which was allowed to burn to charcoal. Roasted ore was added in amounts 121,81 and 41 , the last addition being made when everything had burnt down to a mixture of charcoal, slag, half reduced ore and metallic iron, clearly in order to refine the primary, carbon-rich iron and also to consolidate it. Such smelting has been re-enacted in recent years. Normal output is a bloom weighing some 5 to $8 \mathrm{~kg}$.

Iron making by this process was a seasonal activity in a barter economy. There are no known parallels to this process. How it came into being is a mystery.

\section{LITTERATUR}

Espelund, A. 1993. "The value of a tradition». A. Espelund (red). Bloomery ironmaking during 2000 years III. Trondheim.

Espelund, A. 1997. «Ole Evenstad og den yngre jernvinna i Norge». Viking: 109-132.
Espelund, A. 2008. Bondejern i Norge. Trondheim: Arketype.

Espelund, A. 2009. Brunosten. Historien om et godt naringsemne gjennom $300 \mathrm{a}$. Trondheim: Arketype.

Espelund, A. 2011. Jernvinna i Tolga og Os. Smiarbeid. Trondheim: Arketype.

Evenstad, O. 1790. Afhandling om Jern-Malm, som findes $i$ Myrer og Moradser i Norge, og Omgangsmaaden med at forvandle den til Jern og Staal. København.

Evenstad, O. Praktische Abhandlung von den Sumpf- und Morast-Eisensteinen in Norwegen und von der Methode solche in so genannten Bauer-oder Blaseöfen in Eisen und Stabl zu verwandeln. Aus dem Dänischen übersetzt und mit Anmerkungen begleitet von Joh. Georg Lud. Blumhof. Göttingen.

Evenstad, O. 1968. «A treatise on iron ore, as found in the bogs and swamps in Norway and the process of turning it into iron and steel». Translation from Danish of chapters 1-9 by Niels L. Jensen. Bulletin of the Historical Metallurgy Society. Hist. Met. 2. London.

François, J. 1843. Recherches sur le gisement et le traitement direct des minerais de fer dans les Pyrénées, particulièrement dans $l=$ Ariége. . Paris.

Meldal, E. 1768. «Underretning om den Jern-Jord eller Malm, som udi forige Aargang af de bergenske Adresse-Efterretninger No. 35 til No. 37 er anmelded, at Bønderne paa Vaas opgrave og smelte Jern af, samt deres Berednings og Smeltnings Maade, indhented deels af Bøndernes Forklaring, deels af egen Tilskuelse». Efterretninger fra Addresse-Contoiret i Bergen i No 1768 No. 28-30, 32, 34-36. Bergen.

Richard,T.1838. Études sur l'art d'extraire immédiatement le fer de ses minerais. Paris.

Rinman, S. 1782. Försök till Järnets Historia, med Tillämpning för Slögder och Handtwerk. Stockholm. 


\title{
OPPSUMMERING OG VEIEN VIDERE
}

\author{
Tom H. Borse Haraldsen
}

\section{SEMINARET - EN OPPSUMMERING}

Nå har vi for første gang gjort opp en samlet nordisk forskningsstatus med hensyn til hva vi egentlig vet om jernvinnas mest påaktede komponent, blesterovnen. Når jeg skriver for forste gang, er det ikke ment som noen påstand om at vi ikke snakker sammen, men at mange forskere og kollegaer fra hele det nordiske området først $n a ̊$, har møttes for å diskutere denne komponenten. Den første samlingen om skandinavisk tilnærmingen til blestring av jern kom til syne gjennom utstillingen «När Järnet Kom» i 1976 ved Göteborgs Arkeologiska Museum (Cullberg 1976). For oss som opplevet den, var utstillingen en skjellsettende opplevelse, ikke bare fordi den søkte å vise jernalderens introduksjon, men også fordi den eksponerte jernvinna i et Kattegat- og Polenperspektiv. Allerede på 1880-tallet var Ingvald Undset (1881) pådriver for erkjennelse av den førromerske jernalders eksistens og jernalderens kronologiske aspekter. Grensen mellom bronsealderen og den funksjonelle jernalder er for så vidt ikke endelig trukket. Utstillingen den gang eksponerte også på en god måte ovnenes form og bruk, og ikke minst ga den oss innsyn i fremstillingsprosessene.

Det synes fortsatt å være usikkerhet om når Nordens tidligste jernfremstilling fant sted, en oppfatning Carl-Axel Moberg også flagget for snart tredve år siden (Moberg 1979: 33). Det finnes åpenbart som vi har hørt, produksjonslokaliteter for jern som ligger i bronsealderen med de konsekvenser det kan få for vår forestillingsverden.

Det virker også som om de sørnorske fjell- og lavfjellsområdene, sammen med Mellom-Sverige inklusive bergslagene, danner et nesten massivt aktivitetsbelte. Trøndelag og ikke minst Jylland utpeker seg stedvis med konsentrerte produksjonsområder. Den tidlige jernproduksjonen viser seg å ha vært like tidlig i Finland som ellers i Skandinavia. Seminaret har med tydelighet vist at jernvinna i løpet av yngre jernalder er tilstede $i$ hele Norden om den i intensitet $\mathrm{i}$ de forskjellige geografiske rom finnes i svært varierende mengde.

De forskjellige innleggene under seminaret viser som forventet at forskningsstatus i Norden er mangefasettert, med hensyn til både mengden empirisk materiale og interpretasjonen, tolkningen av

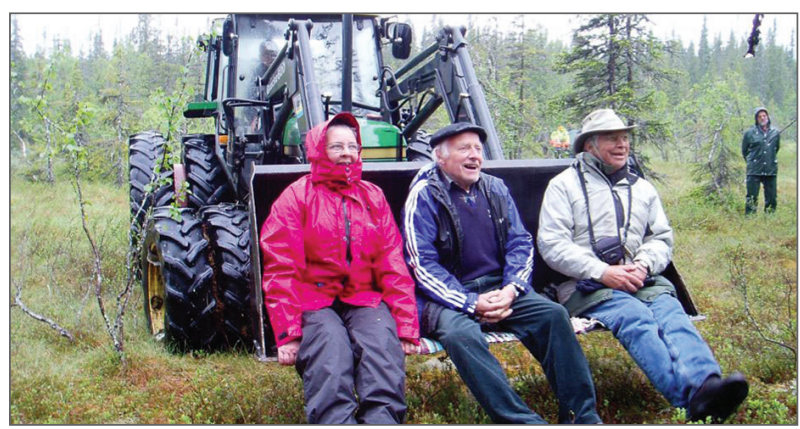

Figur 1: «Faglige pilarer» $i$ nordisk jernforskning blir her er transportert i traktorskuffen til Per Kristenstuen over tunggåtte myrstrekninger under seminarets besøk i Snertingdal, Gjøvik kommune, Eva Hjärthner-Holdar, Arne Espelund og Olfert Voss. Foto: L. Grandin.

Figure 1: "Academic pillars» of the Nordic Iron research here being transported in a tractor tray by Per Kristenstuen, through the boggy marshland during the seminar inspection in Snertingdal, Gjøvik Municipality, Eva Hjärthner-Holdar, Arne Espelund, Olfert Voss. Photo: L. Gradin.

materialet. Ikke minst har innleggene synliggjort forskningsmiljøenes forstålse av jernvinna som et landskapsbundet fenomen i et økonomisk og økologisk samfunnsperspektiv. Noe overraskende fremstår jernvinna på grunnlag av innleggene slik:

- I norsk og dansk sammenheng er det utviklingstrekk som viser at blesterovnen endrer seg over tid, og at den kan grupperes morfologisk i tidsspesifikke typer. Det virker umiddelbart sannsynlig at det kan etableres en felles typologi.

- Det svenske materialet, som er formidabelt i mengde, tegner på grunnlag av innleggene et veldig variert inntrykk av jernvinna som i seg selv, eller på en selvforklarende måte, ikke umiddelbart passer inn i «det dansk-norske mønsteret».

\section{JERNVINNA I OPPLAND}

Museenei Oppland hari fellesskap gjennom tredveår drevet nettverksorganisasjonen «Opplandsarkivet». Det var følgelig naturlig for museene å etablere nok et felles forpliktende nettverk, som har fătt navnet «Opplandsjern». Et nettverk som er tiltenkt å kunne understøtte det enkelte museum i tilfeller hvor fagkunnskapen på feltet jernvinne og forhistorisk 
jern for museenes del er utilstrekkelig og/eller ikke til stede. Prosjektet «Jernvinna i Oppland» er derfor et prosjekt som skal avløses av nettverket «Opplandsjern» $\mathrm{i}$ et forpliktende, likeverdig og tverrfaglig samarbeid, med de utfordringene det innebærer.

Prosjektarbeid har det ved seg at det er et godt verktøy for å løse definerte oppgaver utenfor den enkelte virksomhets fortløpende arbeid (Johansen et al. 1979). For å lykkes med prosjektarbeid krever samhandlingen generøsitet, gjensidig vilje til innsats og integritet (Dahl 1970). Ikke minst må institusjonene erkjenne at enkelte oppgaver som faller inn under prosjektet, verken kan eller skal løses av alle. Prosjekt som arbeidsform er ikke nødvendigvis en «utdanningsarena», men et målstyrt resultatfokusert forskings- og utviklingsverksted. Gode samarbeidsog samhandlingsløsninger er nødvendig om nettverket samlet og på en robust måte skal oppnå de tilsiktete mål.

Mulighetene er mange, men fallhøyden er stor. Resultatet av prosjektet vil være direkte avhengig av museenes vilje og evne til å bære nettverket på en god måte.

\section{VEIEN VIDERE}

Museene i Oppland kan ikke ta ansvar for å tilrettelegge og bære en forskningsarena for Norden. Men vi kan bidra med å la også de andre landene i Norden, delta på og bruke våre arrangementer $\mathrm{i}$ løpet av prosjektperioden. Vi håper at arrangementene i sin tur vil medvirke til å skape engasjement som er egnet til å bære et nordisk forskningsnettverk på en god og fruktbar måte. Kunnskap er ikke noe som finnes a priori - den ligger ikke der ferdig til å bli funnet og plukket opp -, men kunnskap må skapes (Johansen 2011: 24).
Kittilbu er tenkt å skulle bli og være feltstasjon og forskningsarena. Jernvinneplassene finnes der i et landskap med en rik bestand av natur og kulturmiljøer. Kulturmiljøene speiler på en god måte den omfattende norske og nordiske jernproduksjonen i forhistorisk tid. Ikke minst kan den enkelte besøkende og den enkelte forsker på en oversiktlig måte forstå og oppleve sammenhengen mellom kulturminnene og naturens potensiale i Dokkfløyområdets lett «lesbare» topografi.

I løpet av prosjektperioden er det meningen at det skal gjennomføres fire seminarer/symposier med en åpen nordisk/skandinavisk forskningsprofil. Det første symposiet - «Ovnskronologi og ovnstypologi i den nordiske jernvinna» - er nå avsluttet. Videre vil det være nærliggende å belyse vår fortolkning av ovnens konstruksjon og fremstillingsprosessen gjennom forsøk knyttet til ovnsbygging, søke å belyse problemkomplekset fra lupp til smibart jern, og invitere til en bred nordisk forskningskonferanse. Tanken er at det som skjer i løpet av prosjektet, skal rapporteres skriftlig i samhandling med Kulturhistorisk museum, $\mathrm{UiO}$.

\section{LITTERATUR}

Dahl, O. 1970. Om årsaksproblemer $i$ historisk forskning. Oslo: Universitetsforlaget.

Johansen, A.B. et al. 1979. Prosjekthåndbok for humanistisk forskning. Oslo: NAVF.

Johansen, A.B. 2011. «Kvalitet og avkastning i norsk forskning». Forskning nr 3/11, årgang 19: 24.

Moberg, C.-A. 1976. «Väster-Öster-Söder». K. Cullberg (red). När Järnet kom. Gøteborg: Göteborgs Arkeologiska Museum.

Undset, I. 1881. Jernalderens begyndelse i Nord-Europa: en studie $i$ sammenlignende forbistorisk arkcologi. Christiania: Cammermeyer. 


\section{JERNVINNA I OPPLAND}

Symposium: «Ovnskronologi og ovnstypologi i den nordiske jernvinna» $16-18$. juni 2009 på Kittilbu

Hjemmeside: www.oppland.no/opplandsjern

\section{PROGRAM}

TIRSDAG 16. JUNI

14.00 Avreise Lillehammer - Kittilbu med buss. Det er togforbindelse Gardermoen - Lillehammer hver time (www.nsb.no)

15.00-16.20 Innlosjering og lunch

Velkomst

16.20 - 16.25 v/ Direktør Per Morset Randsfjordsmuseene

16.25 -16.35 Praktiske opplysninger v/museumsleder Charlotte Kirk

16.35 -16.45 Kulturhistorisk bakteppe v/ 1.amanuensis Jan H. Larsen

16.45 -16.55 Kittilbu som formidlings og eksperimentarena v/museumsleder Charlotte Kirk

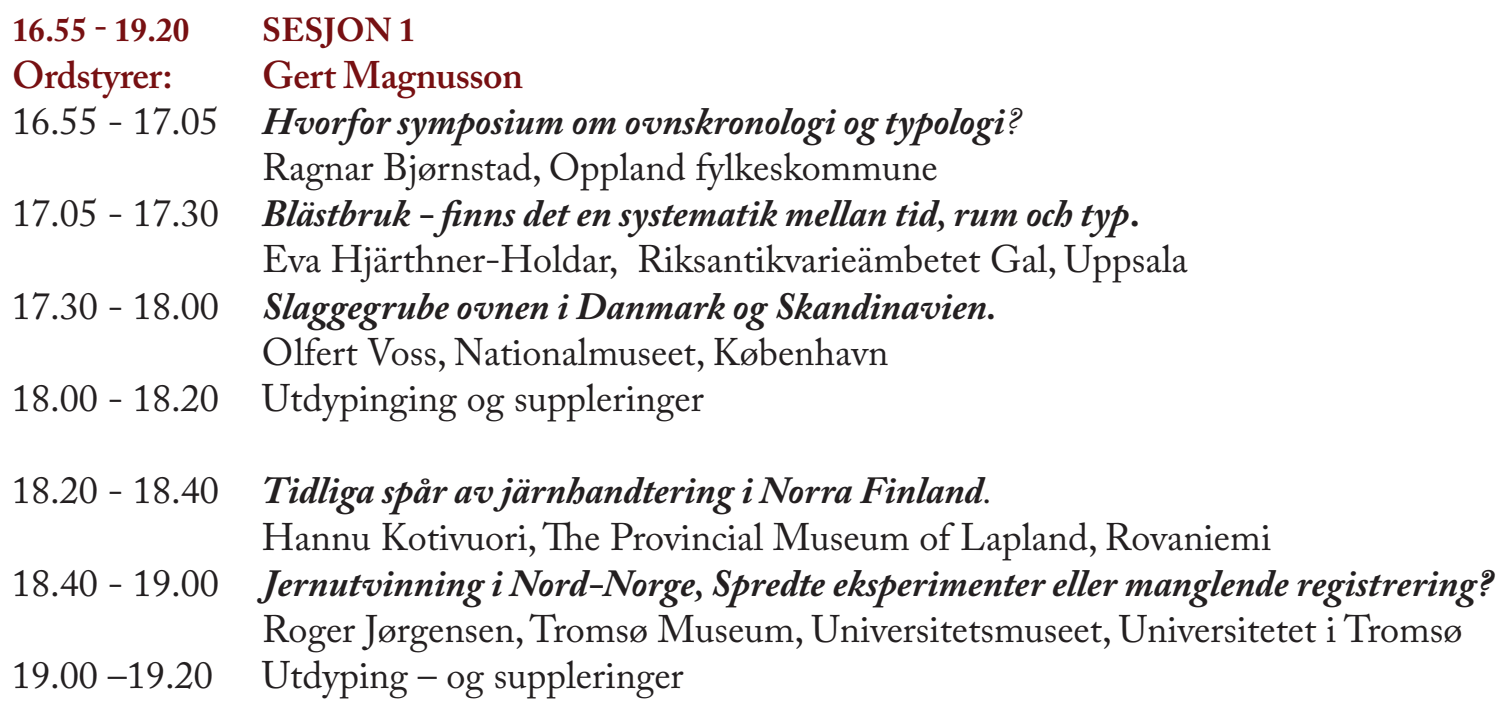


10.00 -10.20 Tidigjärnproduktion i södra och östa Finland - några synpunkter av järnproduktionens historia under järnåldern.

Mika Lavento, Institute for Cultural Research, Dept. of Archaeology, University of Helsinki

10.20 -10.40 De aldste jernudvindingsovne I Danmark.

Arne Jouttijärvi, Heimdal-archaeometry \& Olfert Voss, nationalmuseet, København

$10.40-11.00$ Evenstadprosessen $i$ tid og rom, med en metallurgisk analyse.

Arne Espelund, NTNU

10.00 - $11.20 \quad$ Utdyping - og suppleringer

$11.20-11.40 \quad$ Kaffe

11.40-13.20 SESJON 3

Ordstyrer: Mika Lavento

$11.40-12.00 \quad$ En brytningstid för järnhanteringen. Kring teknik och social organisation $i$ det medeltida sambället 1000-1350.

Gert Magnusson, Riksantikvarieämbetet

12.00 -12.20 Slaggeaftapningsovne i Danmark, udgravninger og forsog.

Henriette Lyngstrøm, Forhistorisk Arkæologi ved Københavns Universitet

$12.20-12.40 \quad$ Utdyping og supplering

$12.40-13.00$ Bevis om jernproduktion fra landnamstiden.

Ragnar Edvardsson, Regional Archaeologist at The Archaeological Heritage Agency of Iceland

13.00 - 13.20 Jernfremstillingsplasser med kullgroper i samling-tilbakeblikkpå et bruksmonster

i jernvinna 20 år etter.

Lars Erik Narmo, - Lofotr - Vikingemuseet på Borg

14.30-16.00 SESJON 4

Ordstyrer: Tom H. Borse Haraldsen

14.30 - 14.50 Jernvinna i Gråfiell, en metode i grenseland.

$\begin{array}{ll} & \text { Bernt Rundberget, Kult } \\ 14.50-15.10 & \text { Utdyping og supplering }\end{array}$

$15.10-15.50 \quad$ Diskusjon

$15.50-16.00 \quad$ Oppsummering - veien videre.

Tom H. Borse Haraldsen, Mjøsmuseet

$16.00-16.30 \quad$ Kaffe og noe å bite $\mathrm{i}$

$16.30-17.30 \quad$ Befaring i kulturmiljøet i Kittilbu - Kultursti (Ta med godt med tøy)

$17.30-19.30 \quad$ Blestring i rekonstruert middelalderovn fra Dokkfløy

19.30 Middag på blestringsplassen

TORSDAG 18.JUNI

08.00 Frokost. NB: Smør med matpakke til lunch!

$09.00-14.30 \quad$ Ekskursjon Snertingdal

15.30 Avreise med tog fra Moelv til Gardermoen/Oslo/Lillehammer/Trondheim 


\section{DELTAKERLISTE}

\section{Danmark}

Olfert Voss, olfert.voss@gmail.com

Arne Jouttijärvi, heimdal@archaeomerty.dk

Henriette Lyngstrøm, lyngst@hum.ku.dk

\section{Finland}

Hannu Kotivuori, Hannu.Kotivuori@rovaniemi.fi Mika Lavento, lavento@mappi.helsinki.fi

\section{Island}

Ragnar Edvardsson, ragnar.edvardsson@gmail.com Vala Björk Gardarsdóttir, valabg@hi.is

Norge

Arne Espelund, arne.espelund@nt.ntnu.no

Bernt Rundberget, bernt.rundberget@khm.uio.no Jan Henning Larsen, j.h.larsen@khm.uio.no

Lars Erik Narmo, le@narmo-arkeologitjenester.no

Lars Stenvik, Lars.Stenvik@vm.ntnu.no

Joakim Wintervoll, joakimwintervoll@hotmail.com

Ole Tveiten, Ole.Tveiten@oppland.org

Roger Jørgensen, Roger.Jorgensen@uit.no

\section{Sverige}

Eva Hjärthner-Holdar, ehh@raa.se

Gert Magnusson, gert.magnusson@raa.se

Lena Grandin, lena.grandin@raa.se

Svante Forenius, svante.forenius@raa.se

\section{Vertskap}

Charlotte Kirk, kittibu@randsfjordmuseene.no

Finn Audun Grøndahl, fag@randsfjordmuseene.no Per Kristenstuen, pe-arnul@online.no

Ragnar Bjørnstad, ragnar.bjornstad@vegvesen.no

Tom H. Borse Haraldsen, t-hharal@online.no

Torill Tømt, torill.thomt@valdres.museum.no

Kjetil Loftsgarden, Kjetil.Loftsgarden@ahkr.uib.no 


\section{ARTIKKELFORFATTERE}

Bjørnstad, Ragnar

Statens vegvesen

ragnar.bjornstad@vegvesen.no

\section{Espelund, Arne}

Institutt for materialteknologi

Norges teknisk-naturvitenskapelige universitet

arne.espelund@material.ntnu.no

\section{Forenius, Svante}

Geoarkeologiskt Laboratorium (GAL)

svante.forenius@raa.se

\section{Grandin, Lena}

Geoarkeologiskt Laboratorium (GAL)

lena.grandin@raa.se

\section{Haraldsen, Tom H. Borse}

Mjøsmuseet, Kapp

t-hharal@online.no

\section{Hjärthner-Holdar, Eva}

Geoarkeologiskt Laboratorium (GAL)

ehh@raa.se

\section{Jouttijärvi, Arne}

Heimdal-archaeometry

heimdal@archaeometry.dk

Jørgensen, Roger

Tromsø Museum, Universitetsmuseet

Universitetet i Tromsø

roger.jorgensen@uit.no

\section{Kotivuori, Hannu}

Lapplands landskapsmuseum

Hannu.Kotivuori@rovaniemi.fi

\section{Larsen, Jan Henning}

Kulturhistorisk museum, Universitetet i Oslo

j.h.larsen@khm.uio.no

\section{Lavento, Mika}

Institutionen för filosofi, historia, kultur- och konstforskning

Helsingfors universitet

mika.lavento@helsinki.fi

Lyngstrøm, Henriette

Forhistorisk Arkæologi, SAXO-instituttet

Københavns Universitet

lyngst@hum.ku.dk

Magnusson, Gert

Riksantikvarieämbetet

gert.magnusson@raa.se

Mjærum, Axel

Kulturhistorisk museum, Universitetet i Oslo

a.j.mjarum@khm.uio.no

\section{Rundberget, Bernt}

Kulturhistorisk museum, Universitetet i Oslo bernt.rundberget@khm.uio.no

\section{Stenvik, Lars F.}

Vitenskapsmuseet

Norges teknisk-naturvitenskapelige universitet Lars.Stenvik@vm.ntnu.no

\section{Voss, Olfert}

Nationalmuseet, København

olfert.voss@gmail.com 